\title{
Archeological Significance Testing at 41BX17/271, the Granberg Site: A Multi-Component Site along the Salado Creek in Bexar County, Texas
}

Cynthia Moore Munoz

Center for Archeological Research, University of Texas at San Antonio

Raymond P. Mauldin

Center for Archeological Research, University of Texas at San Antonio

Jennifer L. Thompson

S. Christopher Caran

Linda Scott Cummings

See next page for additional authors

Follow this and additional works at: https://scholarworks.sfasu.edu/ita

Part of the American Material Culture Commons, Archaeological Anthropology Commons, Environmental Studies Commons, Other American Studies Commons, Other Arts and Humanities Commons, Other History of Art, Architecture, and Archaeology Commons, and the United States History Commons

Tell us how this article helped you.

This Article is brought to you for free and open access by the Center for Regional Heritage Research at SFA ScholarWorks. It has been accepted for inclusion in Index of Texas Archaeology: Open Access Gray Literature from the Lone Star State by an authorized editor of SFA ScholarWorks. For more information, please contact cdsscholarworks@sfasu.edu. 


\title{
Archeological Significance Testing at 41BX17/271, the Granberg Site: A Multi- Component Site along the Salado Creek in Bexar County, Texas
}

\author{
Authors \\ Cynthia Moore Munoz, Raymond P. Mauldin, Jennifer L. Thompson, S. Christopher Caran, Linda Scott \\ Cummings, J. Philip Dering, Mary E. Malainey, Al McGraw, Tom McKern, Manuel Palacios-Fest, Barbara \\ Meissner, Barbara Winsborough, and Chad Yost

\section{Licensing Statement} \\ This is a work for hire produced for the Texas Department of Transportation (TxDOT), which owns all \\ rights, title, and interest in and to all data and other information developed for this project under its \\ contract with the report producer. The report may be cited and brief passages from this publication may \\ be reproduced without permission provided that credit is given to TxDOT and the firm that produced it. \\ Permission to reprint an entire chapter, section, figures or tables must be obtained in advance from the \\ Supervisor of the Archeological Studies Branch, Environmental Affairs Division, Texas Department of \\ Transportation, 125 East 11th Street, Austin, Texas, 78701
}




\title{
Archeological Significance Testing at \\ 41BX17/271, the Granberg Site: \\ A Multi-Component Site along the Salado Creek \\ in Bexar County, Texas
}

\author{
by \\ Cynthia M. Munoz, Raymond P. Mauldin, Jennifer L. Thompson, and S. Christopher Caran \\ with contributions by \\ Linda Scott Cummings, J. Philip Dering, Mary E. Malainey, Al McGraw, Tom McKern, Manuel \\ Palacios-Fest, Barbara Meissner, Barbara Winsborough, and Chad Yost
}

Texas Antiquities Committee Permit No. 4010

Steve A. Tomka

Principal Investigator

Work Authorization \#57-904SA001

TxDOT Statewide Contract \#57-9XXSA001

CSJ: 0521-04-187

Texas Department of Transportation

Environmental Affairs Division

Archeological Studies Program, Report No. 140

Austin

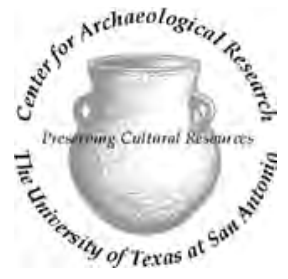

Center for Archaeological Research The University of Texas at San Antonio Archaeological Report No. 393 
Copyright $(\mathrm{C} 2011$

by the Texas Department of Transportation

This is a work for hire produced for the Texas Department of Transportation (TxDOT), which owns all rights, title, and interest in and to all data and other information developed for this project under contract [\#57-9XXSA001]. brief passages of this publication may be reproduced without permission provided that credit is given to TxDOT. Permission to reprint an entire chapter or section must be obtained in advance from the Supervisor of the Archeological Studies Program, Environmental Affairs Division, Texas Department of Transportation, 125 East $11^{\text {th }}$ Street, Austin, Texas, 78701. Copies of this publication have been deposited with the Texas State Library in compliance with the State Depository Compliance.

printed by:

Blue Tape

San Antonio, Texas

published by:

Texas Department of Transportation

Environmental Affairs Division

Archeological Studies Program

Scott Pletka, Ph.D., Supervisor

Archeological Studies Program Report No.140

A. McGraw, Series Editor

ISBN: 978-1-935545-08-8 


\begin{abstract}
:
The Center for Archaeological Research (CAR) of The University of Texas at San Antonio conducted archeological significance testing at 41BX17, the Granberg Site, from January to March 2006. The testing was conducted for the Texas Department of Transportation, Environmental Affairs Division (TxDOT-ENV). The Granberg Site sits on the eastern flood terrace of the Salado Creek south of Loop 410 in San Antonio, Bexar County, Texas. Planned road improvements including installation of a storm sewer line and a water main prompted the need to assess whether (1) cultural deposits including human remains still exist after previous testing and (2) if the deposits contribute to the site's National Register of Historic Places eligibility. The archeological work was conducted under Texas Antiquities Permit No. 4010. Steve A. Tomka served as Principal Investigator and Jennifer Thompson served as Project Archeologist.
\end{abstract}

Fieldwork included mechanical auger boring and backhoe trenching to determine the horizontal extent of the site boundaries within the median of Loop 410 eastbound. Sixteen 1-x-1-m units were excavated to determine the distribution and integrity of the cultural deposits and to locate any possible burials that may still exist at the site. Materials recovered included burned rock features, chipped stone artifacts, animal bone, snail and mussel shell and charred plant remains. The distribution of the artifacts, the geomorphic investigations, the radiocarbon assays, and temporally diagnostic artifacts indicate the presence of Middle and Late Archaic archeological materials with good stratigraphic integrity. The Granberg Site was determined to be ineligible for the National Register of Historic Places. Following the completion of eligibility testing efforts, the TxDOT directed the CAR to develop a research design linking the data recovered from the various excavations at the Granberg Site with research goals. The CAR developed the research design (Munoz et al. 2007) under Work Authorization No. 57513SA005 with Cynthia M. Munoz serving as Project Archeologist.

At roughly the time of the research design implementation, the CAR was the recipient of a donation of a collection of commingled human skeletal remains recovered from the Granberg Site. These remains were recovered from 41BX17/271 in 1962 by Harvey Kohnitz, an avocational archeologist, without knowledge or permission from the Texas Highway Department. The remains were stored at the Kohnitz home until his son, Mark Kohnitz, donated them to the CAR in 2007. An osteological analysis was conducted at the CAR laboratory during February 2008 for TxDOT, under Work Authorization No. 57513SA005 Supplemental Work Authorization No. 4. The results of this analysis are reported in Appendix H of this report. The commingled remains will be curated the CAR and all required documents, including an inventory, will be submitted to the National Park Service National NAGPRA Program to fulfill all obligations pertaining to the NAGPRA laws.

All artifacts collected during this project and all project-associated documentation are permanently curated at the CAR according to Texas Historical Commission guidelines. 



\section{Table of Contents:}

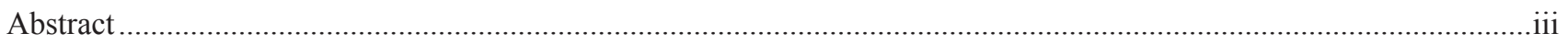

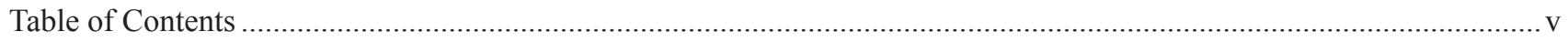

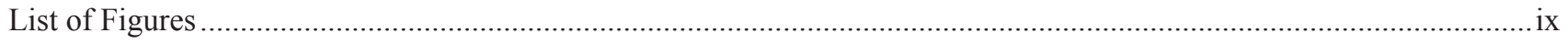

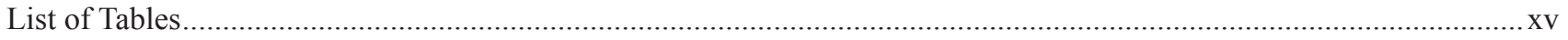

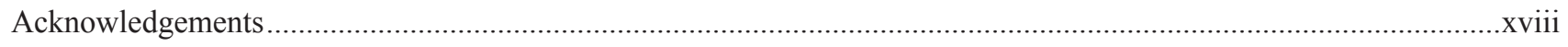

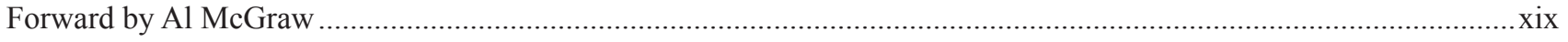

Chapter 1: Project Overview by Cynthia M. Munoz ……............................................................................................ 1

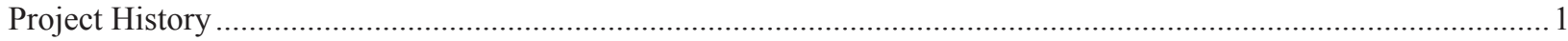

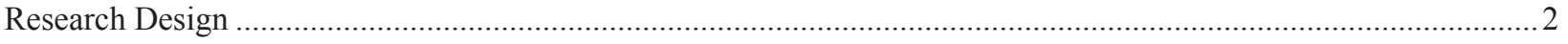

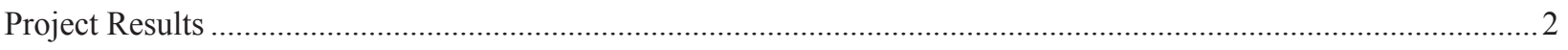

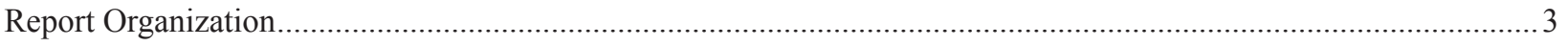

Chapter 2: Environmental Setting by Cynthia M. Munoz ………...............................................................................

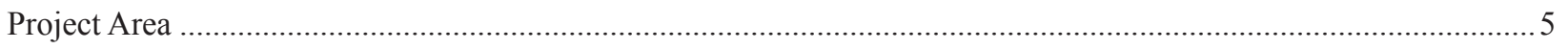

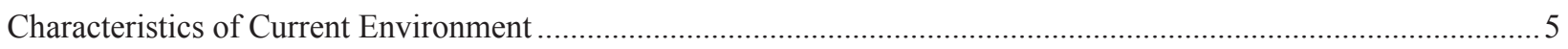

Climate

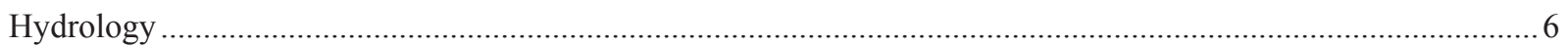

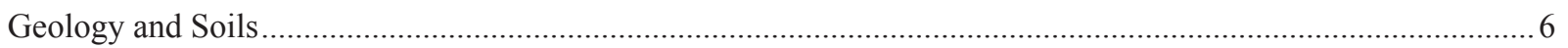

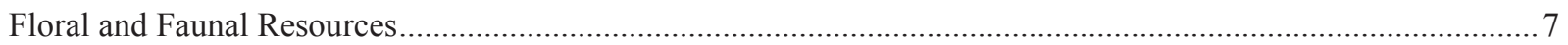

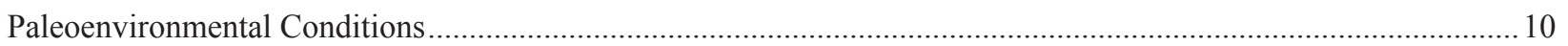

Chapter 3: Previous Research and Archeological Background by Cynthia M. Munoz .........................................................13

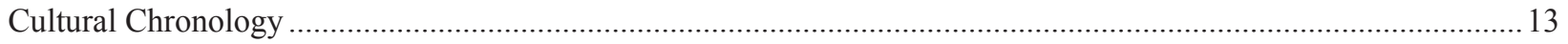

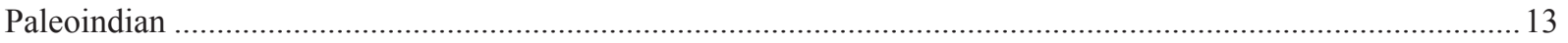

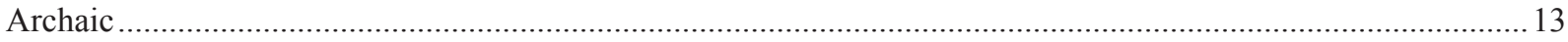

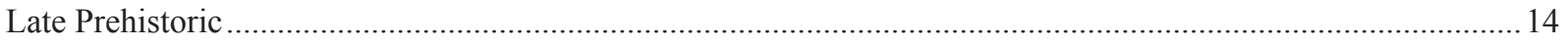

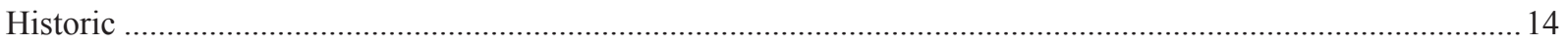

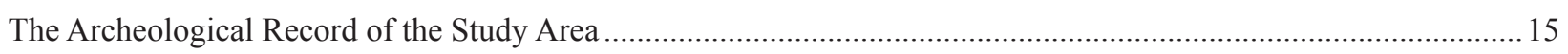

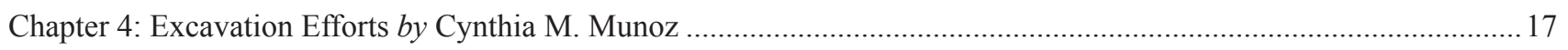

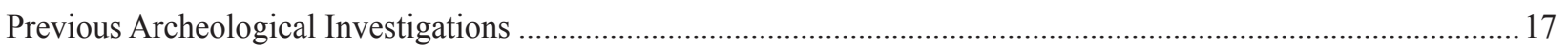

1962 Schuetz Excavation of Granberg I (41BX17) - Witte Museum .................................................................... 18

STAA 1973-1974 Excavations at Granberg II (41B X271) …………………………………….......................22

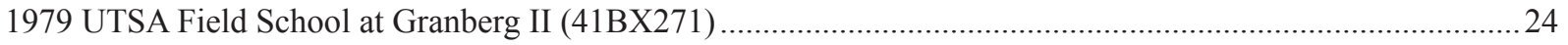

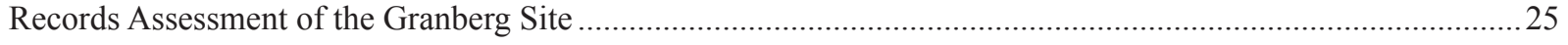

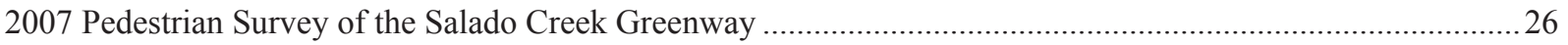


CAR-UTSA Significance Testing Excavations of the Granberg Site .....................................................................22

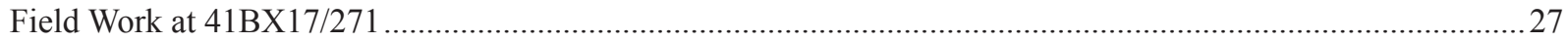

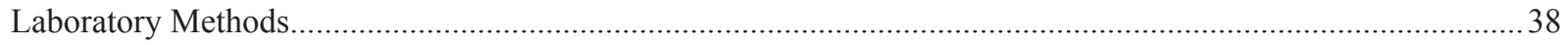

Chapter 5: Materials Recovered by Cynthia M. Munoz and Jennifer Thompson...........................................................41

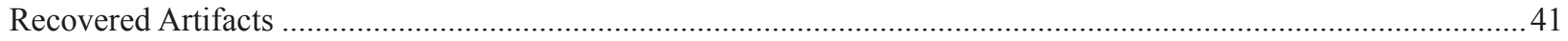

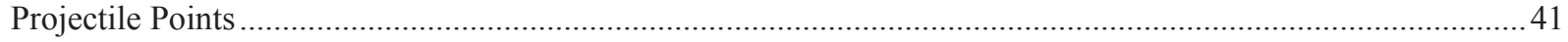

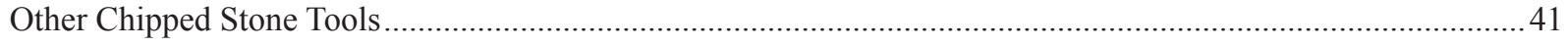

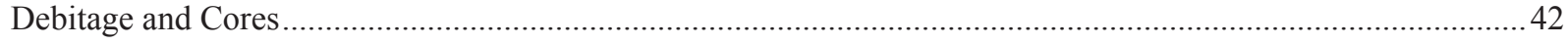

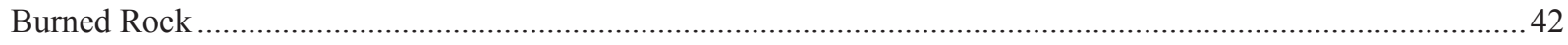

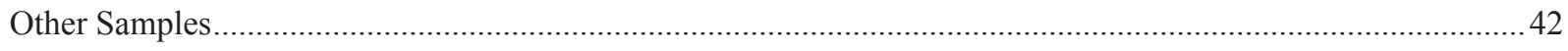

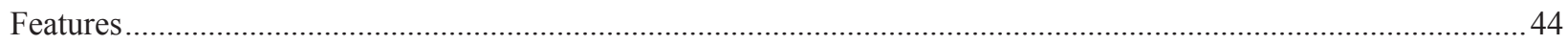

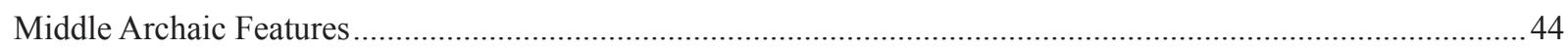

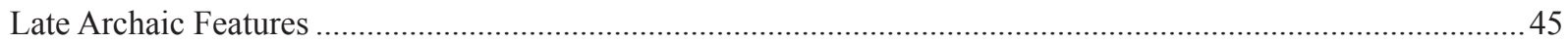

Artifact Review from Previous Excavations at the Granberg Site ……………...................................................... 47

Chapter 6: Geoarcheology by S. Christopher Caran, Jennifer Thompson, and Cynthia M. Munoz.....................................53

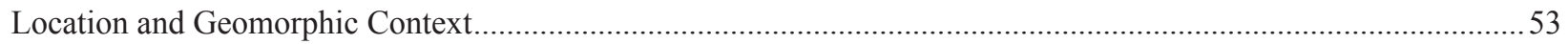

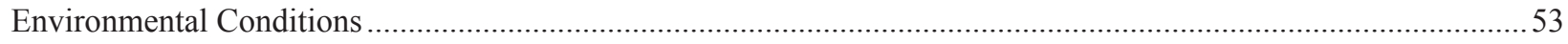

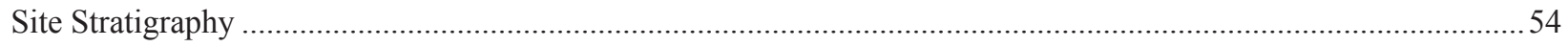

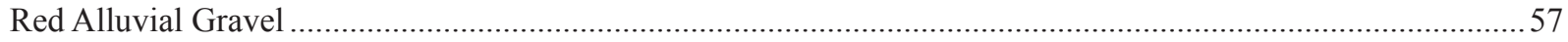

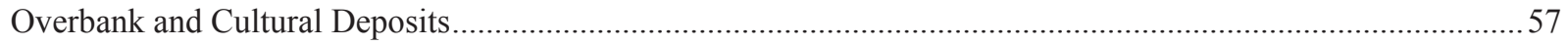

Modern Flood Deposits and Artificial Fill .....................................................................................................

Summary, Geomorphic Evolution and Cultural-Resource Potential .....................................................................6 60

Chapter 7: Defining Analytical Units by Cynthia M. Munoz ......................................................................................63

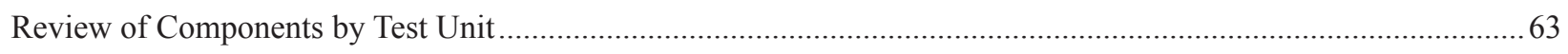

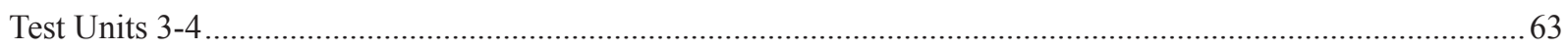

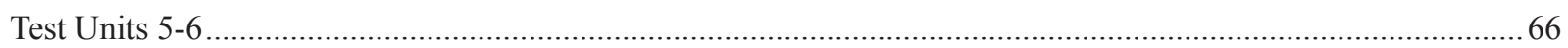

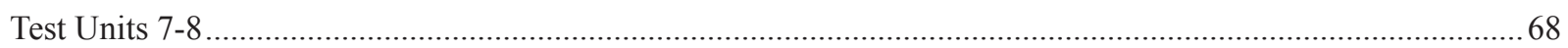

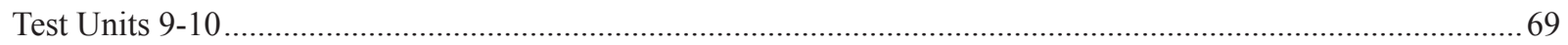

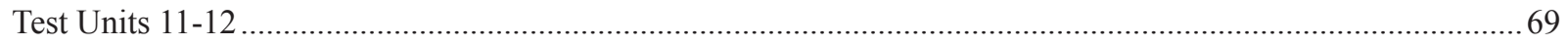

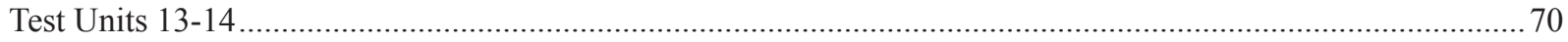

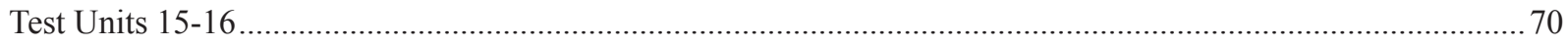

Summary of the Middle Archaic Deposits (6000-4000 BP) ...................................................................................... 70

Summary of the Late Archaic Deposits (4000-1200 BP) …….............................................................................

Chapter 8: Theoretical Perspective by Raymond P. Mauldin, Jennifer L. Thompson, and Cynthia M. Munoz..................73

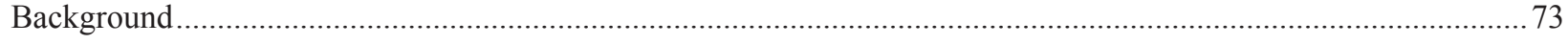

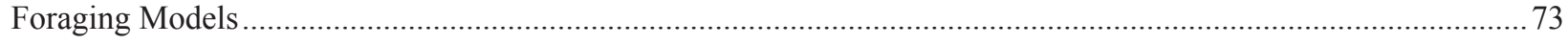


Summary

Chapter 9: Modeling Hunter-Gatherer Adaptations and Archeological Expectations by Raymond P. Mauldin and Cynthia M. Munoz. . .79

Estimating Bison and Deer Availability in the Middle and Late Archaic................................................................79

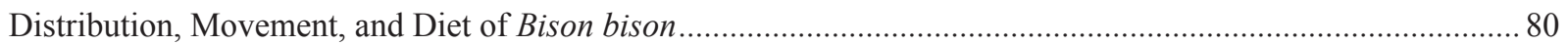

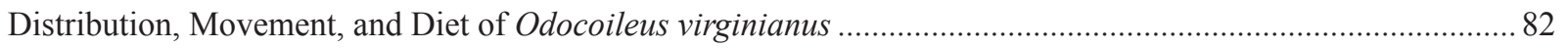

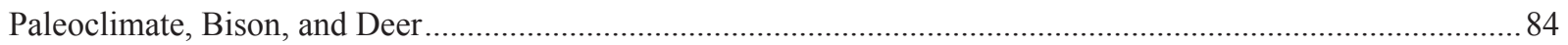

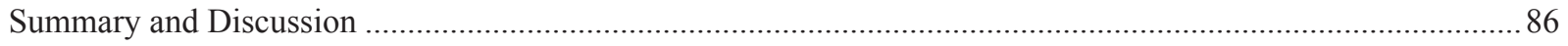

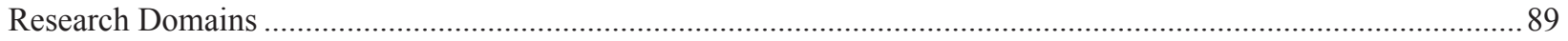

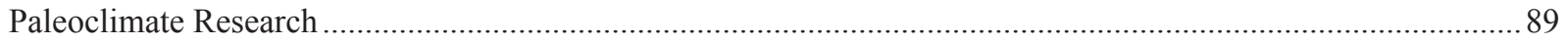

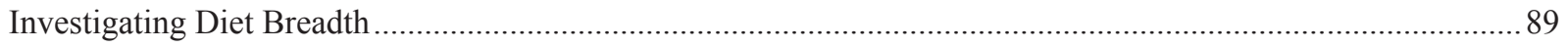

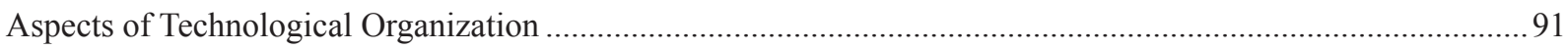

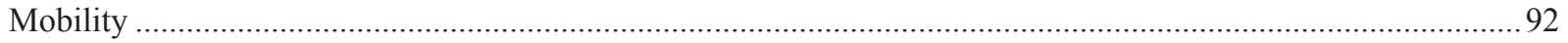

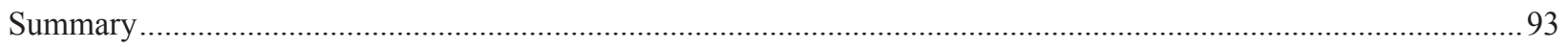

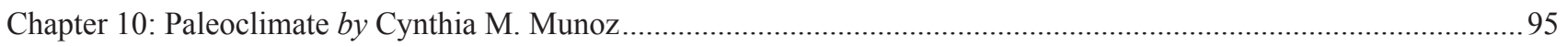

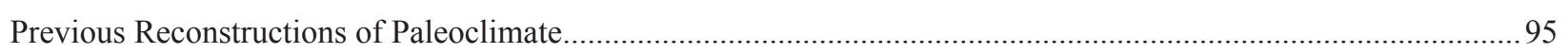

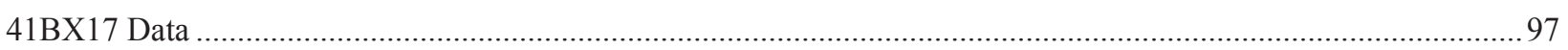

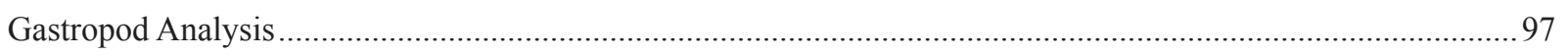

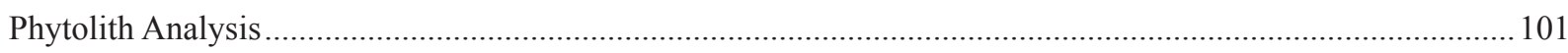

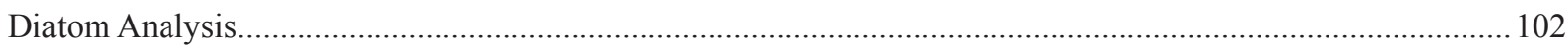

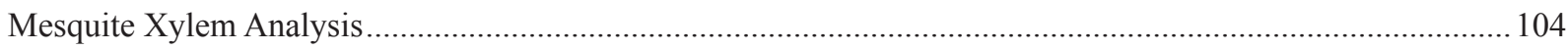

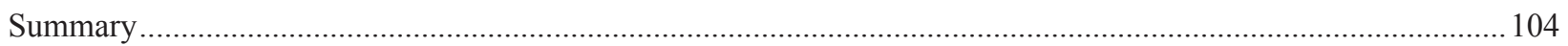

Chapter 11: Subsistence Strategies by Cynthia M. Munoz and Raymond P. Mauldin ..................................................... 105

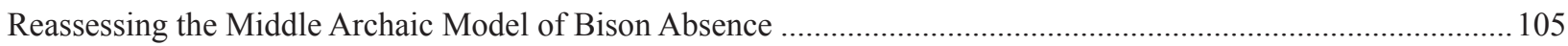

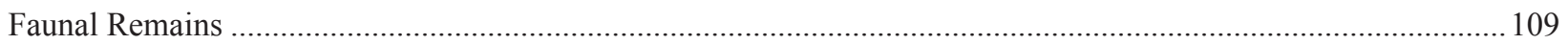

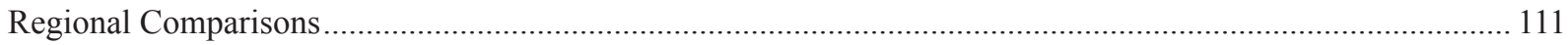

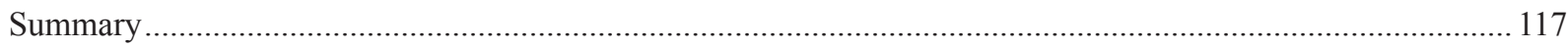

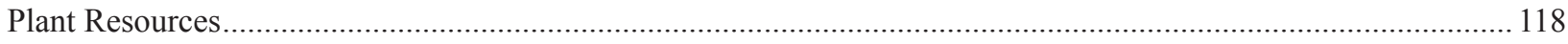

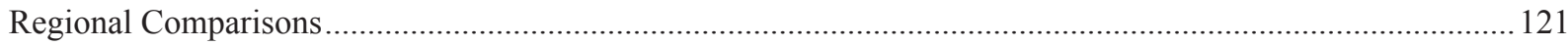

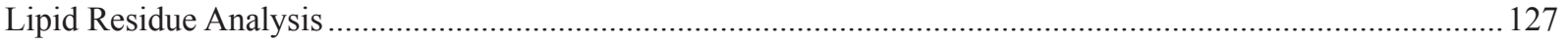

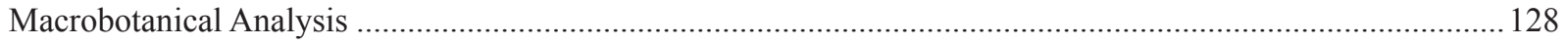

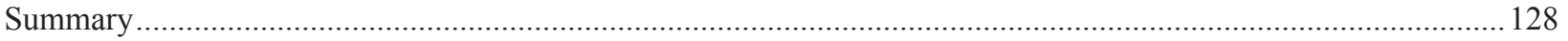

Chapter 12: Assessing Changes in Technological Organization by Cynthia M. Munoz and Raymond P. Mauldin..........131

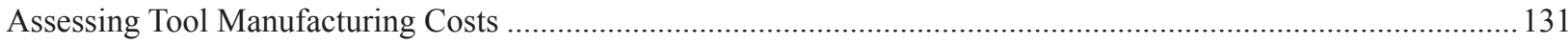

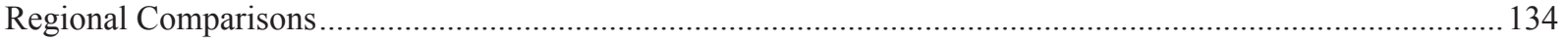

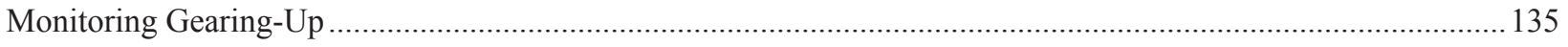


Regional Comparisons.

Summary

Chapter 13: Assessing Changes in the Scale of Mobility by Cynthia M. Munoz and Raymond P. Mauldin

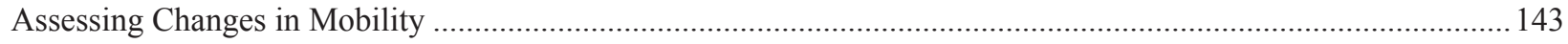

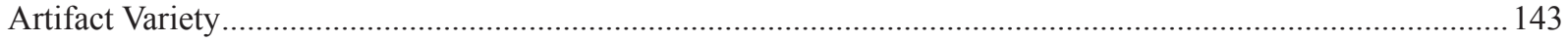

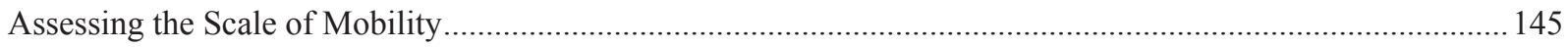

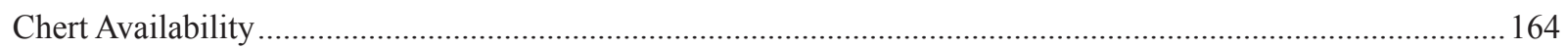

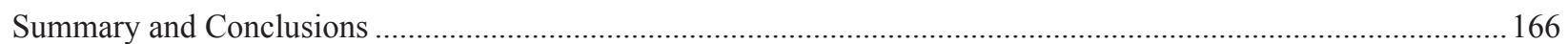

Chapter 14: Summary and Conclusions by Cynthia M. Munoz and Raymond P. Mauldin............................................. 167

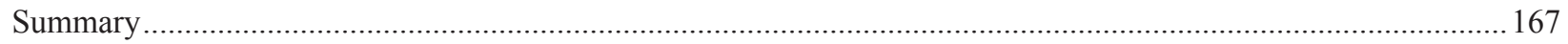

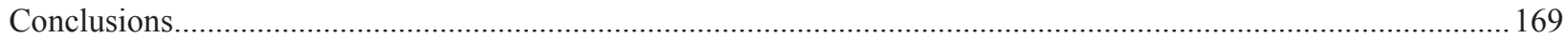

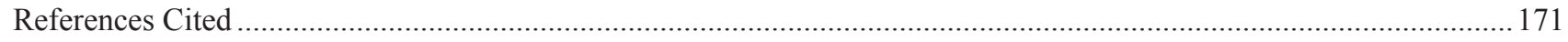

Appendix A: Land Snails of the Granberg Site (41BX17), Bexar County, Texas: The Paleoenvironmental History by Manuel R. Palacios-Fest.....

Appendix B: Analysis of the Fatty Acid Compositions of Burned Rock Residues from the Granberg Site, 41BX17

by Mary E. Malainey .....

Appendix C: Diatom Paleoenvironmental Analysis of Middle and Late Archaic Material from the Granberg

Archeological Site (41BX17), Bexar County, Texas by Barbara M. Winsborough .....

Appendix D: Phytolith Analysis of Feature and Stratigraphic Samples from the Granberg Site, 41BX17, Bexar

County, Texas by Chad Yost and Linda Scott Cummings..................................................................................229

Appendix E: Botanical Analysis of Flotation Samples from 41BX17 by J. Philip Dering ...........................................2239

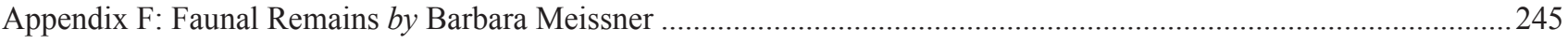

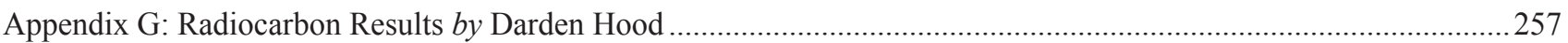

Appendix H: Bioarcheological Analysis of a Commingled Prehistoric Burial from the Granberg Site (41BX17/271),

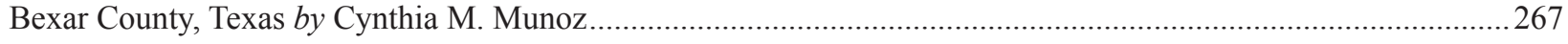

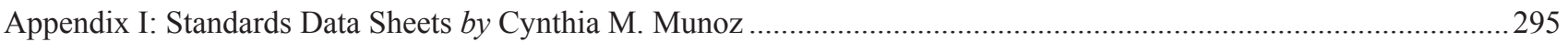

Appendix J: Granberg Burials by Tom McKern ……..........................................................................................

Appendix K: Selected Artifacts from the CAR-UTSA's 1973-74 Excavation Collection, the Witte Museum's 1962

Excavation Collection, and the October 1962 excavation of the water trench immediately prior to the Witte excavations

Appendix L: TxDOT Review of National Register Eligibility Recommendation for 41BX17/271, the Granberg Site

Loop 410 and the Salado Creek, San Antonio by Al McGraw

Appendix M: Summary of Archeological Monitoring, 41BX17/271 Along Storm Sewer Line Adjacent to Eastbound Access Road and East of Salado Creek Bridge by Al McGraw 


\section{List of Figures:}

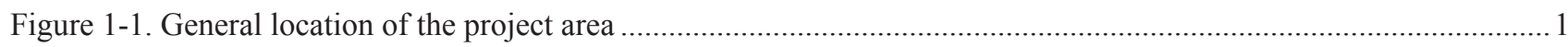

Figure 2-1. Average maximum and minimum temperatures for San Antonio, Texas (1971-2000)..................................5

Figure 2-2. Average monthly rainfall for San Antonio, Texas (1971-2000) .....................................................................6

Figure 2-3. Yearly rainfall for San Antonio, Texas (1871-2008) ……….......................................................................... 6

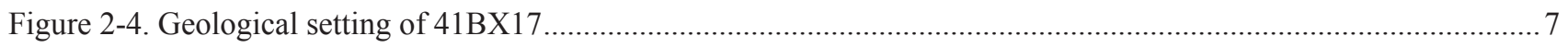

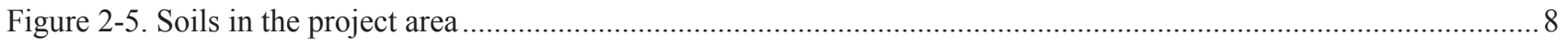

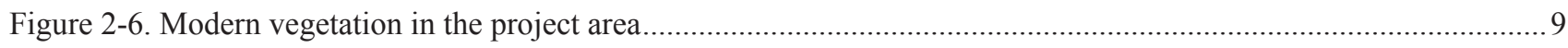

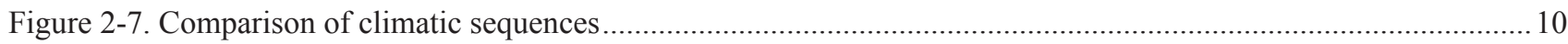

Figure 4-1. The 2001 aerial photograph shows the proximity of Granberg I, 41BX17, and Granberg II, 41BX271,

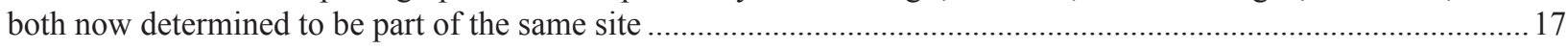

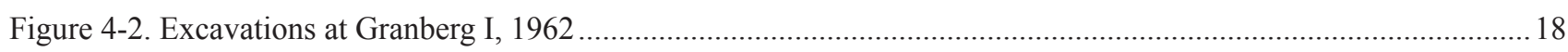

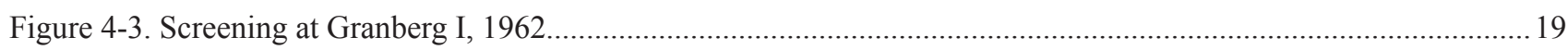

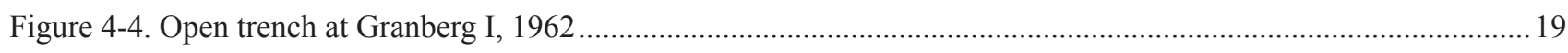

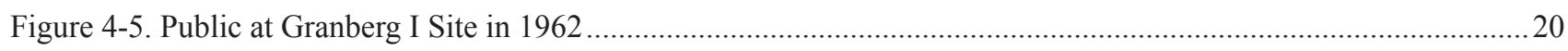

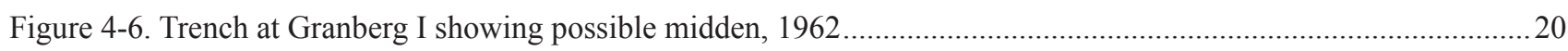

Figure 4-7. Granberg I (41BX17) showing location of midden and excavation units...................................................2

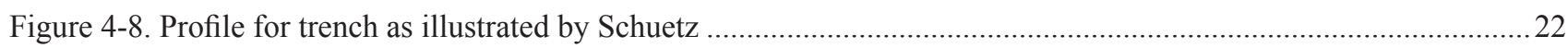

Figure 4-9. Map of 41BX271 adapted from H. Kohnitz sketch, 1973 .....................................................................2

Figure 4-10. Stratigraphy of 41BX271 as defined by Hester and Kohnitz (1975) ..........................................................24

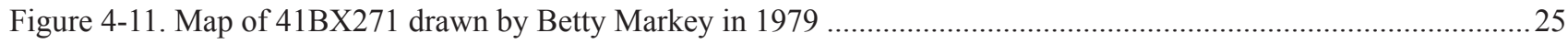

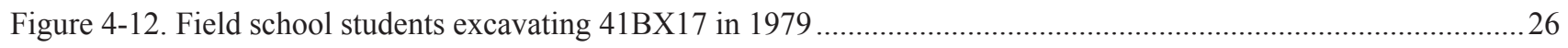

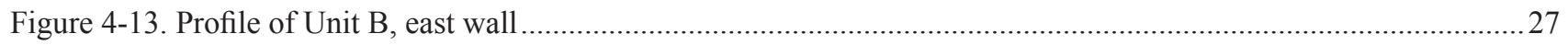

Figure 4-14. Sites 41BX17 and 41BX271 showing previous excavations and known improvements along Loop 410 …28

Figure 4-15. Location of testing in the vicinity of the trail head/parking lot to be constructed on the Granberg Site ........29

Figure 4-16. Location of areas of concentrated excavation of 41BX17 (Blocks I-IV) ............................................... 30

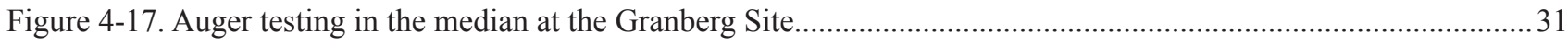

Figure 4-18. Site map showing the location of recently excavated auger tests in proximity to previous excavations ........31

Figure 4-19. Site map showing the location of recently excavated backhoe trenches in proximity to previous

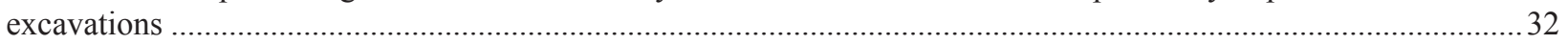

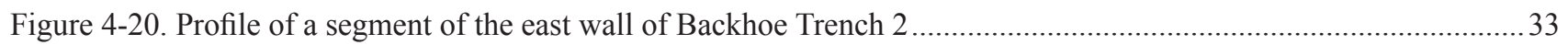

Figure 4-21. The south profile of Backhoe Trench 4 shows Middle and Late Archaic occupation zones between gravel

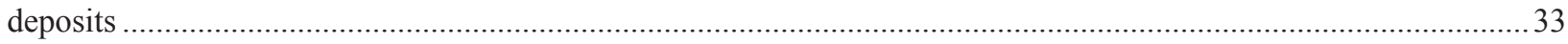

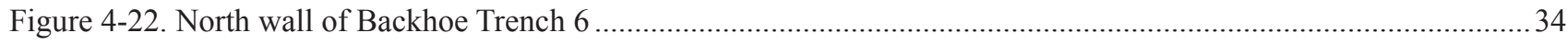

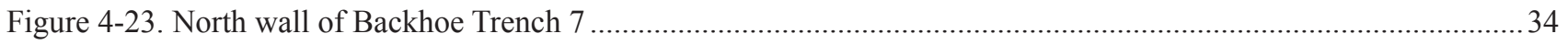


Figure 4-24. Site map showing the location of recently excavated test units in proximity to previous excavations ...........35

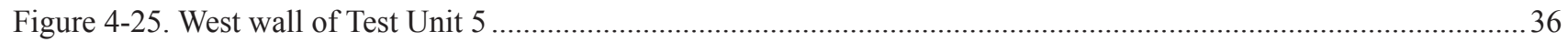

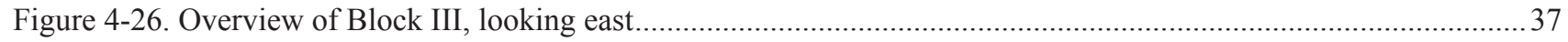

Figure 4-27. Overview of Block IV and Test Units 15 and 16, looking west-northwest.................................................38

Figure 4-28. Revised site boundary determined from research conducted by Córdova et al. 2005 and during the current

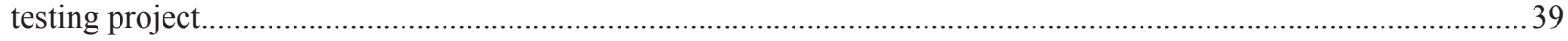

Figure 5-1. Projectile points recovered from 41BX17 include Middle Archaic forms: (a) Langtry; (b) Nolan.................42

Figure 5-2. Projectile points recovered from 41BX17 include Late Archaic forms: (a) Marcos; (b) Marshall; (c)

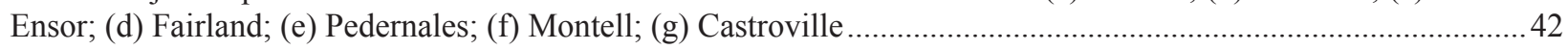

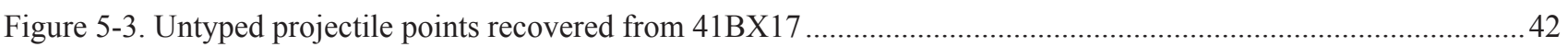

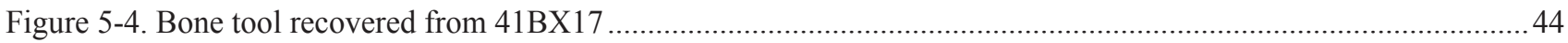

Figure 5-5. Map of the central portion of 41BX17 showing Middle Archaic features encountered during test excavations

Figure 5-6. Map of the central portion of 41BX17 showing Late Archaic features encountered during test excavations.. 45

Figure 5-7. Burned rock Feature 104 was uncovered aligned in the southwestern corner of the unit .............................46

Figure 5-8. Feature 107 is a small, burned rock hearth excavated within a gravel deposit in Test Unit 4 ........................47

Figure 5-9. Feature 109 was identified in the east wall of Backhoe Trench 9, shown here in profile ................................47

Figure 5-10. Feature 100 is a concentration of burned rock with associated artifacts dating to the Late Archaic ..............48

Figure 5-11. Feature 101 is a burned rock cluster directly beneath Feature 100 in the bottom of Zone 1 of Test Unit $6 \ldots 48$

Figure 5-12. Feature 102 is a burned rock cluster with many associated artifacts. Note Pedernales projectile point near the southern wall

Figure 5-13. Feature 103 is a hearth in Test Unit 4 with numerous associated artifacts. This feature was originally

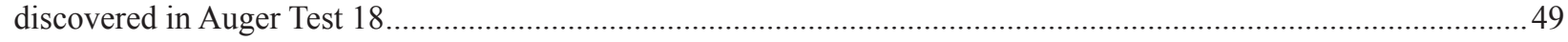

Figure 5-14. Feature 105 is a hearth discovered at the bottom of the Late Archaic deposit............................................50

Figure 5-15. Feature 106 shows the concentration of burned rock in the midden deposit of Test Units 7-8 ...................50

Figure 5-16. Feature 108 is a small scatter of burned rock at $69-81 \mathrm{cmbd}$ in Test Unit 10 ............................................51

Figure 6-1. Stratigraphic synthesis, Backhoe Trench 4, site 41BX17 ……...............................................................54

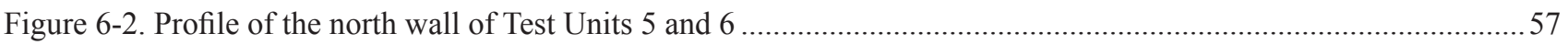

Figure 6-3. West to east geologic cross-section through site 41BX17 ……………................................................... 60

Figure 6-4. North wall of Backhoe Trench 8, similar to Figure 4-23, north wall of Backhoe Trench 7 ...........................61

Figure 7-1. Profile of the south wall of Test Units 3 and 4 showing depth of projectile points, features, and radiocarbon

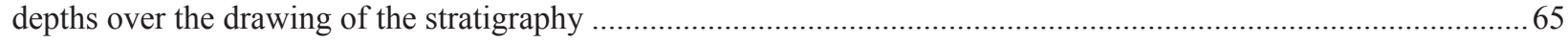

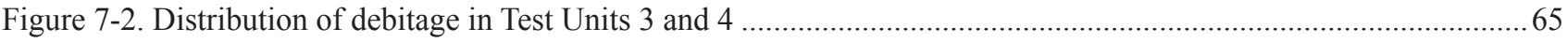

Figure 7-3. Boxplot comparing size of debitage $\left(\mathrm{mm}^{2}\right)$ by artifact peak for Test Unit 4 ..............................................66

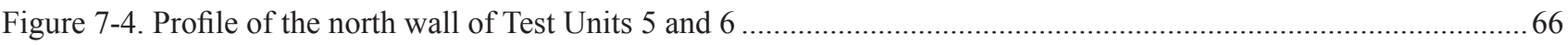

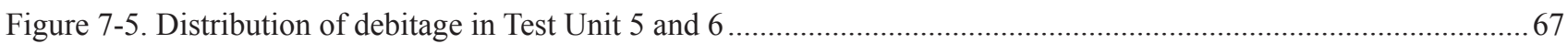

Figure 7-6. Boxplot comparing size of debitage $\left(\mathrm{mm}^{2}\right)$ by artifact peak for Test Unit 6 ..............................................67

Figure 7-7. Profile of the north wall of Test Units 7 and 8 showing depth of projectile points recorded during excavation of the units compared to the drawing of the stratigraphy in the north wall ...........................................68 
Figure 7-8. Distribution of debitage in Test Units 9 and 10

Figure 7-9. Profile of the north wall of Test Units 9 and 10 showing depth of projectile points recorded during excavation of the units compared to the drawing of the stratigraphy in the north wall .69

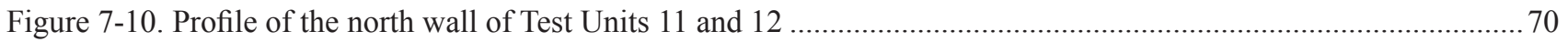

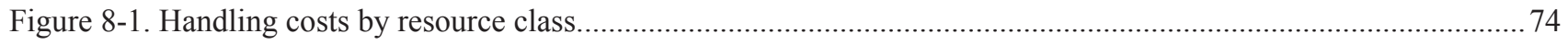

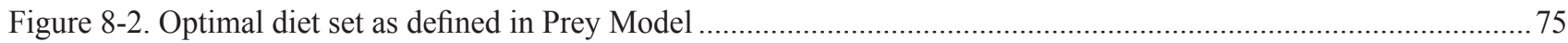

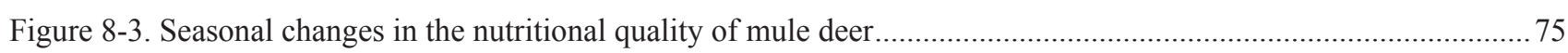

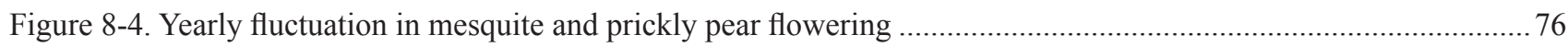

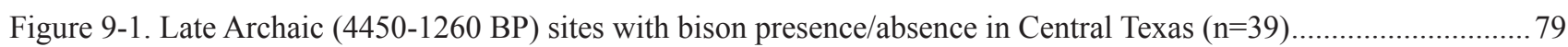

Figure 9-2. Radiocarbon dates associated with bison remains, with Texas latitudes highlighted .................................. 80

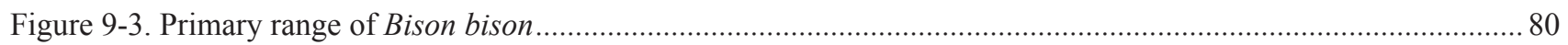

Figure 9-4. Season of bison encounters by Spanish expeditions into Central Texas from 1675 through $1767 \ldots \ldots \ldots \ldots \ldots . . . .81$

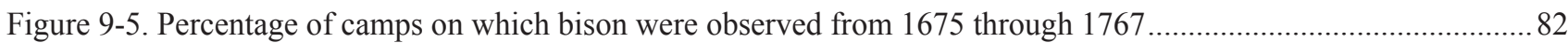

Figure 9-6. Seasonal changes in the forage consumed by White-tailed Deer........................................................... 83

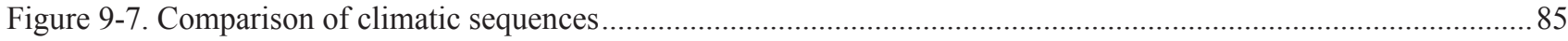

Figure 10-1. Distribution of wooded habitat and open habitat snail species in Test Unit 5/6 by level ...........................99

Figure 10-2. Distribution of the three most common snail species in Test Unit $5 / 6$ by level...................................... 100

Figure 10-3. Percentages of open habitat (top) and wooded habitat (bottom) snail species in Test Unit 5/6 by level...... 101

Figure 10-4. Percentages of the three major phytolith classes by level ............................................................... 101

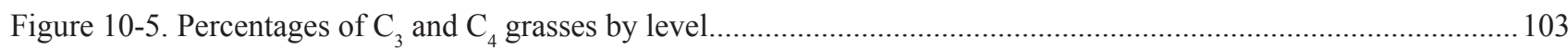

Figure 11-1. Middle ( $\mathrm{n}=22)$ and Late Archaic $(\mathrm{n}=39)$ sites with bison presence/absence in Central Texas ................... 106

Figure 11-2. Percentage of Middle and Late Archaic components in Central Texas with bison ................................... 106

Figure 11-3. Volume of bone recovered from 41BX17 by time period .............................................................. 109

Figure 11-4. Taxa combined by size-class from 41BX17 by time period........................................................... 109

Figure 11-5. Location of archeological sites mentioned in the comparative faunal analysis discussion........................ 111

Figure 11-6. Taxa richness for comparative faunal assemblages by time period ................................................. 117

Figure 11-7. Percentage of fauna by size-class in each time period for Granberg and comparative sites....................... 118

Figure 11-8. Mean ratio of unidentified bone to identified bone by time period................................................... 118

Figure 11-9. Ethnographically reported cooking time for meat (top) and plants (bottom). Bars show the interquartile range

Figure 11-10. Frequency of burned rock weights in Late Middle Archaic features at 41BX17 ................................ 120

Figure 11-11. Frequency of burned rock weights in Initial Late Archaic features at 41BX17 .................................. 121

Figure 11-12. Frequency of burned rock weights in Middle Late Archaic features at 41BX17 ...................................125

Figure 11-13. Frequency of burned rock weights in Terminal Late Archaic features at 41BX17 .............................. 125

Figure 11-14. Location of archeological sites mentioned in the comparative feature analysis .................................. 125

Figure 11-15. Percentage of each component devoted to burned rock features ................................................... 127

Figure 11-16. Number of burned rock features per 100 square meters per 100 years .............................................127 
Figure 11-17. Mean density (gm/cm2) per 100 years

Figure 12-1. Percentage of formal tools from 41BX17 by analytical units (see also Table 12-2) .....

Figure 12-2. Location of archeological sites mentioned in the manufacturing cost analysis .....

Figure 12-3. Percentages of formal tools from 41BX17 and comparative components by temporal units (see also Table 12-4)

Figure 12-4. Proposed relationship between manufacture-failed and use-related items for locations in two (on-demand vs. gearing-up) stategies

Figure 12-5. The relationship between manufacture-failed and use-related tools from each site dating to the Early Middle and Late Middle Archaic from 41BX17 and comparative components

Figure 12-6. The relationship between manufacture-failed and use-related tools from each site dating to the Initial Late Archaic from 41BX17 and comparative components.

Figure 12-7. The relationship between manufacture-failed and use-related tools from each site dating to the Middle Late Archaic and the Terminal Late Archaic from 41BX17 and comparative components.....

Figure 13-1. Expected relationship between the number of artifact types and sample size for residential and special purpose sites.

Figure 13-2. The relationship between number of artifact types and sample size for $41 \mathrm{BX} 17$ and comparative components by time period.

Figure 13-3. Proposed relationship between the number of raw material types present and mobility

Figure 13-4. An example of debitage photos for material collected during testing at 41BX17

Figure 13-5. An example of the impact of a Gaussian Blur highlighted within the black circle.

Figure 13-6. An example of RGB colors on debitage for the Gaussian Blur portion of the flake, identified within the dark circle

Figure 13-7. Plot of green vs. blue values for Late Archaic (top) and Middle Archaic (bottom) debitage from 41BX17.

Figure 13-8. Plot of red vs. blue values for Late Archaic (top) and Middle Archaic (bottom) debitage from 41BX17.... 151

Figure 13-9. Plot of red vs. green values for Late Archaic (top) and Middle Archaic (bottom) debitage from 41BX17.. 152

Figure 13-10. Histogram of blue values for Late Archaic (top) and Middle Archaic (bottom) debitage from 41BX17... 155

Figure 13-11. Plot of red and green values for debitage (top) and "expensive" tools (bottom) from 41TV163 ............. 160

Figure 13-12. Plot of red and blue values for debitage (top) and "expensive" tools (bottom) from 41TV163 .............. 161

Figure 13-13. Plot of green and blue values for debitage (top) and "expensive" tools (bottom) from 41 TV163 ............ 162

Figure 13-14. Boxplots for red, green, and blue values at 41CM111 .................................................................. 164

Figure A-1. Paleoenvironmental reconstruction of Test Units 5 and 6, Block 1 at Granberg Site 41BX17, Bexar County, Texas.

Figure A-2. Paleoenvironmental reconstruction of Test Unit 3, Block 1 at Granberg Site 41BX17, Bexar County, Texas.

Figure D-1. Phytolith diagram for site 41BX17, Bexar County, Texas

Figure D-2. Major phytolith class and $\mathrm{C}_{4} / \mathrm{C}_{3}$ ratio diagram for site $41 \mathrm{BX} 17$.

Figure H-1. Sketch by Harvey Kohnitz of Montell point and Feature 1 burial location

Figure H-2. Estimate of the location of Feature 1 and revised location per Kohnitz sketch map

Figure H-3. Montell point associated with Feature 1 burial 
Figure H-4. Adapted from a sketch by Harvey Kohnitz of the City water main trench detailing burial and associated artifacts ...... .271

Figure H-5. Clam shell gorget from Feature 1 .272

Figure H-6. Gorget associated with Feature 1 burial .272

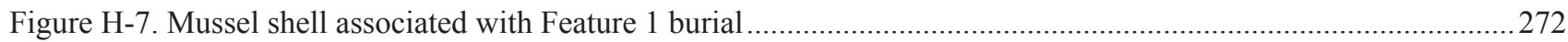

Figure H-8. Tar ball and worked bone associated with Feature 1 burial ....................................................................22

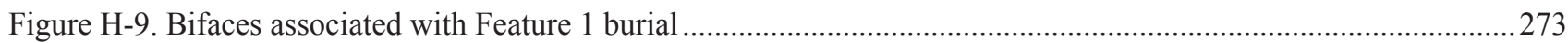

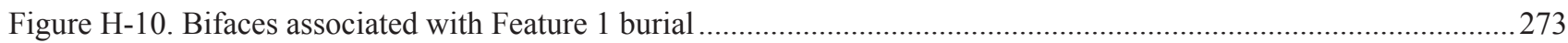

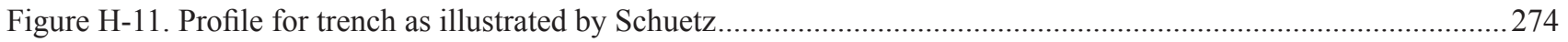

Figure H-12. Stone gorget from Burials 1 and 2 from Feature 2 ….......................................................................2274

Figure H-13. Sketch map by H. Kohnitz showing the location of Feature 5 in relationship to Loop 410, 1963 .............275

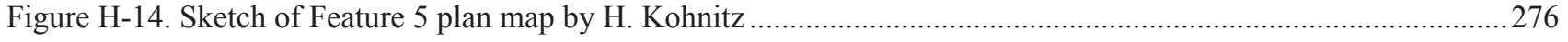

Figure H-15. Right ulna. Inset shows healed fracture on the distal diaphysis..............................................................2 279

Figure H-16. Mortuary sites in Bexar County discussed in this report .......................................................................282

Figure K-1. Projectile points from the 1974 work at 41BX271 including Terminal Late Archaic forms (a-d), Montell (e), Abasalo (g), Bulverde (h), and Late Archaic Perdenales (i-k).............................................................323

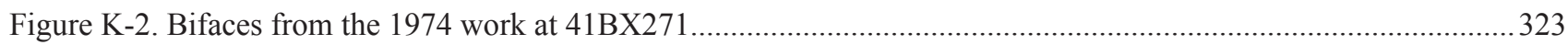

Figure K-3. "Clear Fork" tools from the 1974 work at 41BX271 …............................................................................... 324

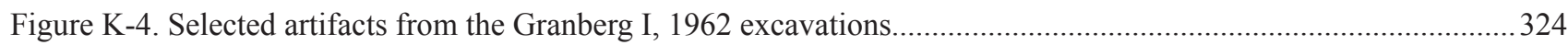

Figure K-5. Pedernales dart point from the Granberg I, 1962 excavations ................................................................325

Figure K-6. Selected artifacts from the Granberg I, 1962 excavations......................................................................325

Figure K-7. Selected artifacts from the Granberg I, 1962 excavations....................................................................325

Figure K-8. Selected artifacts from the Granberg I, 1962 excavations.......................................................................325

Figure K-9. Selected artifacts from the Granberg I, 1962 excavations.......................................................................326

Figure K-10. Selected artifacts from the Granberg I, 1962 excavations.........................................................................326

Figure K-11. Selected artifacts from the Granberg I, 1962 excavations..........................................................................326

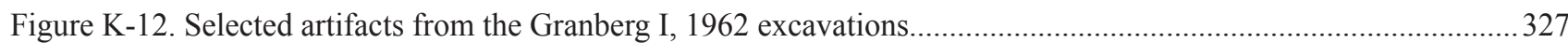

Figure K-13. Selected artifacts from the Granberg I, 1962 excavations......................................................................327

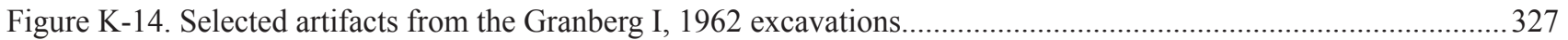

Figure K-15. Selected artifacts from the Granberg I, 1962 excavations.................................................................... 328

Figure K-16. Scan of photograph of selected artifacts from the October 1962 excavation of the water trench immediately prior to the Witte 1962 excavations.....

Figure K-17. Scan of photograph of selected artifacts from the October 1962 excavation of the water trench immediately prior to the Witte 1962 excavations

Figure K-18. Scan of photograph of selected artifacts from the October 1962 excavation of the water trench immediately prior to the Witte 1962 excavations

Figure K-19. Scan of photograph of selected artifacts from the October 1962 excavation of the water trench immediately prior to the Witte 1962 excavations..... 
Figure K-20. Scan of photograph of selected artifacts from the October 1962 excavation of the water trench immediately prior to the Witte 1962 excavations

Figure K-21. Scan of photograph of selected artifacts from the October 1962 excavation of the water trench immediately prior to the Witte 1962 excavations

Figure K-22. Scan of photograph of selected artifacts from the October 1962 excavation of the water trench immediately prior to the Witte 1962 excavations

Figure K-23. Scan of photograph of selected artifacts from the October 1962 excavation of the water trench immediately prior to the Witte 1962 excavations

Figure K-24. Scan of photograph of selected artifacts from the October 1962 excavation of the water trench immediately prior to the Witte 1962 excavations

Figure K-25. Scan of photograph of selected artifacts from the October 1962 excavation of the water trench immediately prior to the Witte 1962 excavations

Figure K-26. Scan of photograph of selected artifacts from the October 1962 excavation of the water trench immediately prior to the Witte 1962 excavations

Figure L-1. Synoptic archeological and environmental sequence for Central Texas (modified from Collins 1995) ........346

Figure L-2. Radiocarbon assays from the Granberg Site, Loop 410

Figure M-1. North wall profile of two segments of storm sewer line excavated parallel to the south ROW of the existing eastbound access of Loop 410 


\section{List of Tables:}

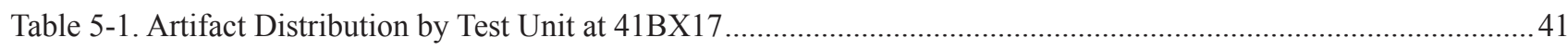

Table 5-2. Distribution of Typed Projectile Points by Block, 41BX17 ….....................................................................43

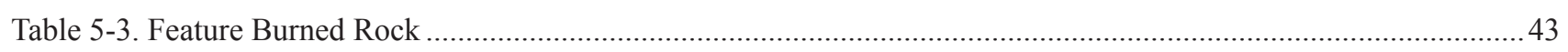

Table 5-4. Radiocarbon Samples from 41BX17 Significance Testing Phase ............................................................... 44

Table 5-5. Features Recorded at 41BX17 during Significance Testing ........................................................................46

Table 5-6. Artifacts Housed at the CAR from the 1973-1974 and 1979 Excavations at the Granberg Site .......................51

Table 6-1. Stratigraphy of Trench and Unit Profiles at Site 41BX17: Summary and Interpretation .................................55

Table 6-2. Stratigraphic Profile Exposed in the Southern Wall of Backhoe Trench 4 ......................................................56

Table 6-3. Stratigraphic Profile Exposed in the Western Walls of Block 1 and Test Unit 5 .............................................58

Table 6-4. Relationship of Radiocarbon Dates to Geological Strata ............................................................................5

Table 7-1. Summary of Test Units with Diagnostic Artifacts and/or Features ................................................................. 64

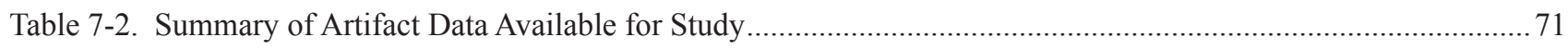

Table 9-1. Early Middle Archaic Sites with Isolable Components ................................................................................ 87

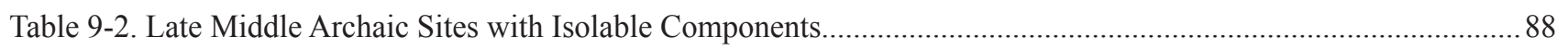

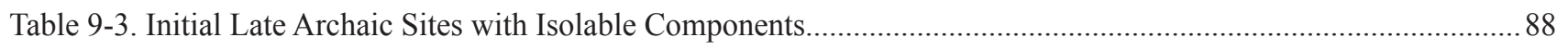

Table 9-4. Middle Late Archaic Sites with Isolable Components.................................................................................. 88

Table 10-1. Breakdown of Snail Species and Densities from Test Unit 5/6 by Level.....................................................98

Table 10-2. Breakdown of Snail Species and Densities from Test Unit 3 by Level ........................................................98

Table 10-3. Distribution of Phytolith Classes by Test Unit and Level......................................................................... 102

Table 10-4. Distribution of Identified Diatom Species by Unit and Level ................................................................. 103

Table 10-5. Distribution of Features with Wood Samples by Time Period ................................................................... 104

Table 11-1. Bison Presence/Absence in Central Texas Late Archaic Components ............................................................ 107

Table 11-2. Bison Presence/Absence in Central Texas Middle Archaic Components.................................................... 108

Table 11-3. Weight and Volume of Taxa by Time Period from 41BX17 …................................................................ 110

Table 11-4. Breakdown of Faunal Assemblage by Taxa and Analytical Unit from 41BX17 ....................................... 112

Table 11-5. Breakdown of Unidentified Fragments by Class and Analytical Unit from 41BX17.................................. 113

Table 11-6. Archeological Components Reviewed for Faunal Regional Comparison ................................................... 113

Table 11-7. Number of Genera Identified by Component within the Comparative Faunal Assemblages ........................ 114

Table 11-8. Comparison of Middle Archaic Faunal Assemblage Richness between Granberg and Selected Central

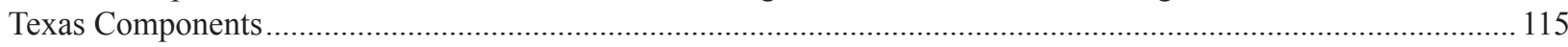

Table 11-9. Comparison of Late Archaic Faunal Assemblage Richness between Granberg and Selected Central Texas Components

Table 11-10. Comparison of Unidentified and Identified Fragment Weights (gm) from 41BX17 and Selected Central Texas Components 
Table 11-11. Size, Weight, and Shape of 41BX17 Features 120

Table 11-12. Middle Archaic Feature Data from 41BX17 and Selected Central Texas Components ..... .122

Table 11-13. Initial Late Archaic Feature Data from 41BX17 and Selected Central Texas Components 123

Table 11-14. Middle Late Archaic Feature Data from 41BX17 and Selected Central Texas Components 124

Table 11-15. Terminal Late Archaic Feature Data from 41BX17 and Selected Central Texas Components 126

Table 11-16. Burned Rock Feature Data for 41BX17 and Comparative Sites 128

Table 11-17. Identification of Lipid Residues from 41BX17 129

Table 12-1. Estimation of Utilized Flakes from Debitage from Comparative Components. 132

Table 12-2. 41BX17 Tool Manufacturing Costs by Analytical Unit 133

Table 12-3. Tool Manufacturing Costs by Temporal Period for 41BX17 and Comparative Collections 134

Table 12-4. Summary of Tool Manufacturing Costs by Temporal Period .........................................................................135

Table 12-5. Failure Cause for 41BX17 Tool Groups ................................................................................................. 137

Table 12-6. Failure Cause for Early and Late Middle Archaic Comparative Assemblages.............................................138

Table 12-7. Failure Cause for Initial, Middle, and Terminal Late Archaic Comparative Assemblages ........................... 139

Table 13-1. Artifact Variety at 41BX17 and in Comparative Assemblages ....................................................................145

Table 13-2. Comparison of RGB Values for Late and Middle Archaic Debitage from 41BX17 ...................................154

Table 13-3. Comparison of RGB Values for Middle Archaic Debitage/Tools and Samples of Late Archaic

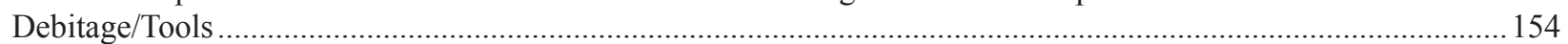

Table 13-4. Means, Standard Deviations, and CV for Red, Green, and Blue Values of Debitage .................................. 156

Table 13-5. Means, Standard Deviations, and CV for Red, Green, and Blue Values of Tools .........................................156

Table 13-6. T-Test Results for RGB Values for Middle Archaic Debitage and Tools from 41BX228, 41CM111, 41BX300, and 41TV163.....

Table 13-7. T-Test Results for RGB Values for Late Archaic Debitage and Tools from 41MM340 and 41KM69.....

Table 13-8. Mann-Whitney Test Results for RGB Values for Debitage and Tools at 41BX228, 41CM111, 41BX300, and 41TV163

Table 13-9. Chert Bearing Deposits within a 30 km Radius. 165

Table A-1. Ecological Requirements of Mollusk Species Identified from 41BX17, Bexar County, Texas.

Table A-2. Total and Relative Abundance, and Adulthood (A/J) Ratios of Gastropods Identified from 41BX17, Bexar County, Texas

Table B-1. Summary of Average Fatty Acids Compositions of Modern Food Groups Generated by Hierarchical Cluster Analysis .

Table B-2. Criteria for the Identification of Archeological Residues Based on the Decomposition Patterns of Experimental Cooking Residues Prepared in Pottery Vessels....

Table B-3. List of Burned Rock Samples Analyzed from Site 41BX17.

Table B-4. Fatty Acid Composition and Identification of Residues from Site 41BX17

Table C-1. List of Samples Analyzed from the Granberg Site, 41BX17

Table C-2. List of Diatoms Found in Sediment Samples from 41BX17

Table C-3. Ecological Characteristics of Diatoms in Samples from 41BX17 
Table D-1. Provenience Data for Samples from Site 41BX17 …....................................................................23

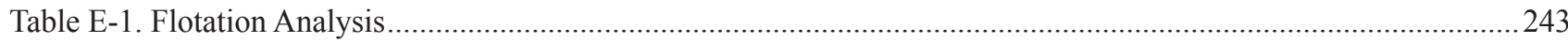

Table F-1. Faunal Bone Recovered from the Middle and Late Archaic Components of 41BX17 ..............................247

Table H-1. Artifacts Donated to the CAR in 2010 Associated with Feature 1 Burial ..............................................272

Table H-2. Settings and Time Periods of Bexar County Prehistoric Burials .............................................................286

Table H-3. In Situ Placement of Bexar County Prehistoric Burials......................................................................28

Table H-4. Evidence of Pathology and Violence in Bexar County Prehistoric Burials ................................................289 


\section{Acknowledgements:}

The author would like to acknowledge a number of individuals whose help was instrumental in the successful completion of this manuscript. The successful completion of this project is due to the cooperation and hard work of the CAR field crew, lab, and office staff. The CAR field personnel included Brian Davis-Brothers, Amanda Cargill, Jon Dowling, Leonard Kemp, Lindy Martinez, Jason Perez, Bryant Saner, and Joseph Thompson. Cynthia Munoz served as the project osteologist, supervised the lab processing of artifacts, and created the artifact database. Cathy Stacy and Bryant Saner washed and sorted artifacts. Billy Blackman of CESA Contractors, Inc. excavated backhoe trenches; Alamo Backhoe Services, Inc. provided equipment and several operators for the excavation of trenches, and auger bores. Bruce Moses served as the site surveyor and created the many figures in this report with the help of Leonard Kemp. Jennifer Thompson edited the text with the help of Bruce Moses who also compiled the final document. Dr. Raymond P. Mauldin advised us throughout fieldwork, analysis, and report production. Jennifer Thompson served as Project Archeologist during the fieldwork. The Witte Memorial Museum graciously allowed the CAR access to collections, site records, and photographs. Eric Salazar from TxDOT District office in San Antonio helped coordinate safety precautions related to traffic and provided specific construction plans integral to the assessment of the site.

S. C. Caran who conducted the geomorphic investigations and produced drawings and a chapter of this report, wishes to acknowledge the project archeologists who drew the stratigraphic profiles that were instrumental to the geoarcheological investigation. Several of the exposures had been filled, completely or in part, by the time S. C. Caran visited the site. The profile drawings provided a record of those exposures no longer accessible and served as a convenient point of departure for detailed stratigraphic examinations. He particularly acknowledges a debt to Mardith K. Schuetz and other participants in the original 1962 excavation of the Granberg Site. As an eleven year-old child living in San Antonio at the time, he was privileged to visit the site, which afforded his first exposure to an ongoing archeological investigation, which stimulated a lifelong interest in geoarcheology.

In addition to serving as Principle Investigator during testing of the site, Dr. Steve Tomka assisted with field excavations, equipped us with field supplies, provided logistical support, and coordinated communication between CAR, TxDOT, and the Texas Historical Commission. Raymond P. Mauldin acted as Principle Investigator during the creation of the Research Design, the analysis phase, and report production and provided helpful insight and comments. Al McGraw served as the primary liaison from TxDOT-ENV.

The specialized analyses referred to in the body of the text have been carried out by a distinguished group of scientists including in alphabetical order: Linda Scott Cummings, J. Philip Dering, Mary E. Malainey, Barbara Meissner, Manuel Palacios-Fest, Barbara Winsborough, and Chad Yost. Many thanks to each of them for completing the analyses and providing drafts in a timely fashion. The success of the color analysis of lithic tools and debitage from 41BX17 and comparative collections is largely due to the hard work of Jason Perez and Leonard Kemp. They both spent many many hours photographing the material followed by setting up Gaussian blurs on each specimen. Thank you both.

The author would like to acknowledge the archeological staff at TxDOT, Al McGraw, Dr. Jim Abbott, and Dr. Scott Pletka, who facilitated the complete and proper analysis of the individuals making up the Kohnitz donation. The author thanks Mark Kohnitz for his donation of the remains and for his availability and willingness to discuss his knowledge of his father's excavations at the Granberg Site. Bryant Saner is thanked for his assistance with the inventory of the remains. The help of everyone is greatly appreciated.

Cynthia M. Munoz

Center for Archaeological Research, UTSA

June 2011 


\section{Forward:}

This report presents a description of archeological investigations at the Granberg Site, a prehistoric Indian encampment along the east bank of Salado Creek in north-central Bexar County, Texas. Although periodically revisited for thousands of years by Native Americans seasonally exploiting the natural resources of the oak-lined creek, the campsite would not be recognized today by its former inhabitants. The modern setting consists of extensive residential neighborhoods and businesses associated with the City of San Antonio's expansive urbanization of north-central Bexar County.

A part of the modern development -the construction of utility lines and the major thoroughfare of Loop 410 -led to the discovery of the site in the 1960s. The discovery predated the emergence and the requirements of current federal and state historic preservation laws. As a result, early archeological investigations were conducted by the Witte Museum with the approval of the highway department. In subsequent decades additional work was conducted in the locale by the Southern Texas Archaeological Association, the Center for Archaeological Research at the University of Texas at San Antonio, and more recently, by TxDOT.

In addition, although the site's discovery preceded historic preservation laws, the threat of relic collecting and looting at the Granberg Site and on highway rights-of-way resulted in the department's support of Senate Bill No. 242 of the $58^{\text {th }}$ Texas Congress. The bill enacted a law for the preservation and protection of cultural material on lands owned or controlled by the state. The law's regulations that include criminal penalties for the vandalism, damage or destruction of resources has evolved today into V.T.C.A. Penal Code, Title 7, Section 28.03, 28.04 and Natural Resources Code Title 9, Sec.s 191.171-174.

Extensive archeological investigations of Bexar County in the last two decades have shown that the Granberg Site was one of a series of relatively large prehistoric campsites along the Salado Creek just south of the Balcones Escarpment. The Granberg Site like many others in the area has been severely impacted by the disturbances of modern development both within highway right-of-way and on adjacent private properties.

As a result because most of the previous multi-decade investigations at the Granberg Site have never been fully described or published, three primary purposes of this current report are to present: an updated site description; a cumulative summation of its collected material for comparison with other sites, and; interpretations of its place in the local archeological record. To that end, the staff of the Center for Archeological Research, The University of Texas at San Antonio, sponsored by TxDOT have labored under sometimes difficult conditions and with fragmentary archeological data to produce the following report.

\section{Al McGraw}

TxDOT Archeologist, 2011 



\title{
Chapter 1: Project Overview
}

\author{
Cynthia M. Munoz
}

The Center for Archaeological Research (CAR) of The University of Texas at San Antonio (UTSA) was contracted by The Texas Department of Transportation, Austin (TxDOT; Work Authorization No. 57904SA001), to conduct archeological significance testing on 41BX17, a previously recorded prehistoric archeological site in Bexar County, Texas. The investigations were conducted under Texas Antiquities Permit Number 4010, with Dr. Steve Tomka, CAR Director, serving as Principal Investigator. The work described in this report was conducted in the context of planned improvements to N.E. Loop 410 in the vicinity of 41BX17 by TxDOT and the Federal Highway Administration. The archeological work was necessary to address the requirements of Section 106 of the National Historic Preservation Antiquities Code of 1966, as amended, the implementing regulations of 36 CFR Part 800, and the Texas Antiquities Code. The construction impacts land owned by the State of Texas and is partially funded by the Federal Highways Administration (FHWA).

Excavations occurred between January 23 and April 8, 2006, in advance of proposed construction within the current rightof-way (ROW) south of N.E. Loop 410 on the east bank of Salado Creek. Site 41BX17, a multi-component site in north-eastern San Antonio, is transected by the eastbound lanes of N.E. Loop 410 and its access road. Figure 1-1 displays the general location of the project area. A separately recorded site, 41BX271, located to the immediate south of $41 \mathrm{BX} 17$ and a more accurate plotting of 41BX17 indicate that both sites are part of one prehistoric site once located on a small knoll overlooking the east bank of Salado Creek.

\section{Project History}

The western margin of the site known as 41BX17 originally extended at least $15 \mathrm{~m}$ (50 ft.) into the highway ROW where it was first identified by Harvey Kohnitz in the early 1960s (Córdova et al. 2005). Mardith Schuetz of the Witte Memorial Museum (Schuetz 1966; Córdova et al. 2005) subsequently tested the site in 1962. Hester and Kohnitz tested 41BX271 in 1973-1974. Hester also conducted testing of 41BX271 in 1979 in association with a CARUTSA field school (Córdova et al. 2005). In 1984, a burned rock midden deposit and at least one burial were uncovered as a result of ditching activities performed by the South Texas Construction Co. in the access road ROW adjacent to 41BX271 (Hester 1984; Córdova et al. 2005). The majority of the Granberg Site (41BX17 and 41BX271) appears to extend for an unknown distance southward of the access road ROW onto property owned by the City of San Antonio. Based on the styles of projectile points uncovered from these early excavations, Córdova et al. (2005) concluded that the total span of occupations at the site encompassed a period from about 4000 BC to AD 1200 (Schuetz 1966; Thompson 2006b).

Based on these preliminary investigations, the TxDOT issued Work Authorization No. 57510SA005 to the CAR to conduct testing at 41BX17. The testing was designed to determine the extent and nature of archeological deposits that may be impacted by construction, to ascertain whether these deposits contribute to the National Register of Historic Places (NRHP) eligibility of the site, and to determine if $41 \mathrm{BX} 17$ warranted formal designation as a State Archeological Landmark (SAL). Testing of 41BX17 was undertaken in the context of

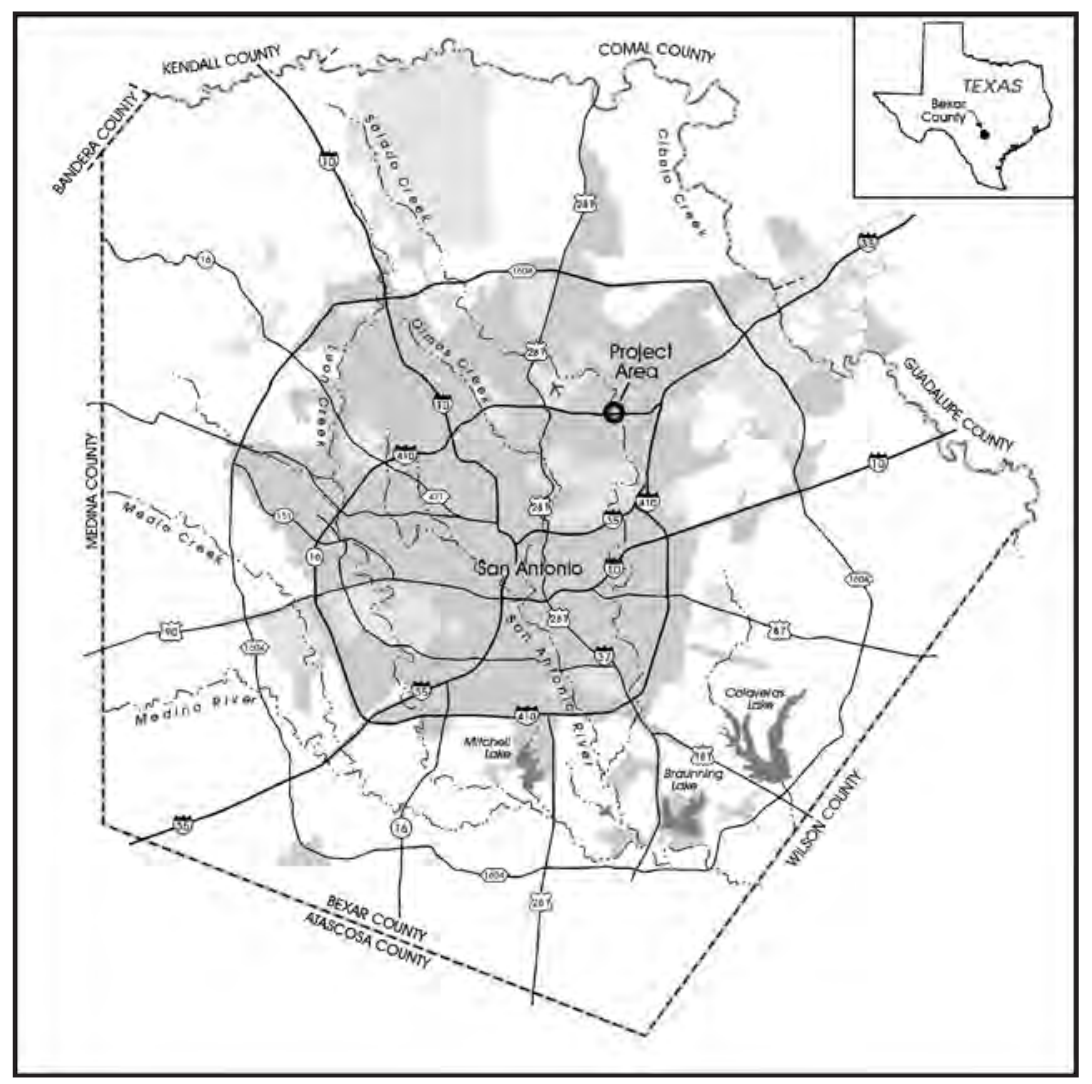

Figure 1-1. General location of the project area. 
anticipated road improvements to N.E. Loop 410 including proposed construction within the current ROW south of N.E. Loop 410 and on the east bank of Salado Creek. Dr. Steve A. Tomka served as Principle Investigator and Jennifer Thompson served as Project Archeologist during the testing of the site.

The testing undertaken by the CAR demonstrated the presence of Middle and Late Archaic deposits in the ROW. Temporally diagnostic material recovered in test unit excavations included 29 Middle and Late Archaic projectile points. Prehistoric features found during this phase of field excavation included seven hearths, one burned rock cluster, and one burned rock midden (Thompson 2006b). Schuetz (1966) previously documented the burned rock midden. Three of the hearth features contained charcoal samples that returned radiocarbon dates falling within the Late Archaic. A fourth burned rock feature returned a date from the Middle Archaic. The remaining features were dated using artifact association and proximity to dated materials or features. No historic materials were found below the modern zones mechanically removed before hand excavation of test units (Thompson 2006b).

It was the CAR's assessment, based on a preliminary review of the distribution of material, that the integrity of deposits dating to the Middle and Late Archaic occupations at the Granberg Site was good. That material included, but was not limited to, Middle and Late Archaic hearth features with ethnobotanical remains, faunal material, and chipped stone tools. The 2006 project recovered no human interments; however, the stratigraphic zones in which previous excavators recovered human remains lies undisturbed and likely contain additional burials. Based on these results, the CAR recommended that the site was eligible for inclusion to the NRHP under criterion $d$ of 36CFR 60.4, in that the site has and is likely to yield information significant in prehistory. In addition, the CAR suggested that the site warranted designation as a SAL. TxDOT did not concur with the CAR's recommendations. TxDOT argued that due to extensive disturbances throughout much of the site area within the ROW, the portion of the prehistoric archeological site within the area of potential effect (APE) lacked sufficient integrity to warrant eligibility to the NRHP under criterion d. The Texas Historical Commission (THC) concurred with the TxDOT recommendation. Appendix L presents TxDOT's review of the National Register Eligibility Recommendation for the Granberg site.

\section{Research Design}

Following the completion of eligibility testing efforts, the TxDOT directed the CAR to develop a research design linking the data recovered from the various excavations at the Granberg Site with research goals. The CAR developed the research design (Munoz et al. 2007) under Work Authorization No. 57513SA005 with Cynthia M. Munoz serving as Project Archeologist. The research design, developed as a collaborative effort between the CAR and the TxDOT Environmental Affairs Division, focuses on the interpretation of data made available by the archeological testing of 41BX17 (Munoz et al. 2007). Using principals derived from optimal foraging theory, we developed a general model of hunter-gatherer subsistence practices and technological organization. Next, we defined a series of sitespecific expectations with temporal and spatial elements that could be pursued with site data. To test these expectations, we proposed to study several data types recovered from 41BX17 and compare trends within them to data types from a number of previously excavated sites from South-Central and Central Texas. Chapters 10, 11, 12, and 13 describe the analyses of this data.

\section{Project Results}

The excavation and analytical work summarized in this report from the Granberg Site has resulted in a number of contributions toward understanding aspects of Central and South-Central Texas archeology. Briefly, the results presented here suggest that 1) site level paleoenvironmental conditions during the Middle and Late Archaic occupations at 41BX17 correlate relatively well with the larger overall pattern apparent from pollen and soil carbonate sequences (see Bousman 1998; Cooke 2005; Nickels and Mauldin 2001; Nordth et al. 2002); 2) contrary to the findings of Dillehay (1974) and Collins (1995) suggesting that bison were absent in Central Texas during some or all of the Middle Archaic period, bison were present throughout both the Middle and Late Archaic period; 3) at odds with our expectations (based on patterns of $\mathrm{C}_{4}$ grasses) of a generally narrow diet breadth throughout the occupations at $41 \mathrm{BX} 17$ with a gradual widening during the latter years of the Late Archaic and probable variances in the Middle Archaic, when bison are expected to have gradually emerged in Central Texas, our assessment of faunal and floral materials from 41BX17 suggests that variation rather than homogeneity in subsistence characterized any given period; 4) although anticipated changes in technological organization in response to shifts in bison density over time (i.e., a more specialized tool kit as a response to decreasing bison, or a more generalized tool kit in response to increasing bison availability) were not supported, the counter argument, that formal tools, which are more likely to reflect task specific requirements, are correlated directly with increases or decreases in bison, was marginally supported, suggesting that certain types of expensive tools may be designed specifically for bison; 5) "gearing-up" behavior, anticipated when bison is present, especially in the later portions of the Late Archaic 
as bison declined in availability, was not supported with the 41BX17 data; 6) anticipated shifts in bison density, based on grassland density fluctuations, resulted in a decline in logistical forms of mobility organization from the Middle into the Initial Late Archaic, followed by a gradual increase into the Terminal Late Archaic, suggesting that an uneven distribution of bison in the early years of the Middle Archaic and the latter years of the Late Archaic caused a heavier reliance on logistical strategies as the large mammal became more difficult to locate; and 7) as logistical strategies increased in the latter Late Archaic a more diverse raw material assemblage, evident from color variability in lithic material from 41BX17 and comparable components, points to an increasing scale of mobility.

\section{Report Organization}

This report is divided into 14 chapters with 11 appendices. Following this introduction, Chapter 2 outlines the environmental setting of the site, including information on paleoenvironmental conditions. Chapter 3 provides an overview of cultural history concerns. Chapter 4 discusses the field methods and laboratory methods employed in the 1960s and 1970s excavations as well as the 2006 CAR significance testing. Chapter 5 outlines the data recovered and includes a discussion of the features identified on the site. Chapter 6 presents a detailed description of the geology of the site area. Chapter 7 identifies several analytical units that contain data from specific time periods that are used in subsequent chapters. Chapters 8 and 9 present the theoretical perspective used for developing a model for hunter-gatherer adaptations and the resultant archeological expectations. Chapter 10 presents the results of our investigation into site level paleoclimate at the Granberg Site. Chapter 11 describes the results of our investigation into subsistence change between the Middle and Late Archaic periods at 41BX17. Included in this chapter is comparative data on several other Middle and Late Archaic sites. Chapter 12 discusses changes in the lithic assemblages at the site from the Late Middle Archaic to the Terminal Late Archaic. Chapter 13 discussed changes in mobility based on artifact variety and chert colors. Finally, Chapter 14 provides a summary of the report.

The analyses conducted in Chapters 10,11, 12, and 13 are supported by a number of appendices. Appendix A, by Dr. Manuel Palacios-Fest, presents an analysis of gastropods. Appendix B, by Dr. Mary Malainey presents a discussion of lipid residues on selected samples. Details on diatoms, by Barbara Winsborough, are discussed in Appendix C. Appendix D, by Dr. Linda Scott Cummings, contains the results of an analysis of phytolyths. Dr. J. Philip Dering presents a discussion of the macrobotanical assemblage and the results of a mesquite xylem analysis from the site in Appendix E. Appendix F provides the vertebrate faunal data collected at 41BX17. Appendix G presents details on the radiocarbon dates associated with the project. A history and description of the Granberg Site burial features and an analysis of comparative skeletal assemblages is reported in Appendix H. Appendix I provides Standard data sheets (Buikstra and Ubelaker 1994) associated with the donated remains. Appendix J presents the 1966 osteology report from Witte Museum. Finally, Appendix K provides scans of selected points, bifaces, and unifaces in the CAR collection and samples of the scans from the collections permanently curated at the Witte Museum. Appendix L presents TxDOT's review of the National Register Eligibility Recommendation for 41BX21/271. Appendix $M$ provides the TxDOT monitoring report for a storm sewer line excavated parallel to the south ROW of the existing Loop 410 access road. 



\section{Chapter 2: Environmental Setting}

\section{Cynthia M. Munoz}

This chapter presents an overview of the environment of the project area including a brief discussion of the physiographic setting, climate, soils, flora, and fauna. The chapter closes with a summary of paleoenvironmental conditions during the Late Holocene.

\section{Project Area}

The Granberg Site is located within the Salado watershed in northeast San Antonio in Bexar County, Texas. The land to the north, east, and west of the site has been commercially developed. Residential neighborhoods lie to the southeast. Salado Creek runs immediately west of the site and is an undeveloped greenbelt in this part of the city. The site is transected by the eastbound lanes of N. E. Loop 410 and its access road. Large oak trees are located south of the access road where the previous property owner capped the site with fill to level the terrain. This southern section was recently developed. A cancer center was constructed on the privately owned southeastern portion whereas the southwestern portion was partially paved over for the construction of a City of San Antonio hike and bike trail parking lot and trailhead (see Munoz 2008).

\section{Characteristics of the Current Environment}

Situated approximately $213 \mathrm{~m}$ (700 ft.) AMSL, the project area is located at the boundary of the Tamaulipan and Balconian biotic provinces (Blair 1950). The Tamaulipan province, ranging from the east-west portion of the Balcones Escarpment in southern Texas to the east of the eastern Sierra Madre in northeastern Mexico, is made up of a mix of plants and animals typical of neotropical Mexico, the semiarid southern Plains, and the humid southeastern United States. Presently this subhumid to semi-arid land is dominated by thorny brush. The Balconian province covers most of the Edwards Plateau, an uplifted, limestone-dominated region, and is characterized by a semiarid climatic regime and relatively denser vegetation. The province is dominated by oak, juniper and mesquite often underlain by a variety of grasses (Blair 1950, Hester et al. 1989). The project area lies in a setting where these two very different biotic provinces merge.

\section{Climate}

Climate in this general area is classified as humid subtropical with hot, humid summers and mild, dry winters. The mean annual temperature for the region is $70^{\circ} \mathrm{F}$ (Southern Regional Climate Center [SRCC] 2009). The length of the growing season in Bexar County is roughly 270 days per year. Rainfall averages approximately 30 inches a year. Figure 2-1 presents the average minimum and maximum monthly temperatures in San Antonio, Texas between 1971 and 2000 (SRCC 2009). Throughout these three decades the coolest months occurred in December and January and the warmest in July and August.

Figure 2-1. Average maximum and minimum temperatures for San Antonio, Texas (1971-2000).

Between 1971 and 2000 the average annual precipitation in San Antonio was 32.93 inches. Rainfall peaks in May and June with a smaller peak in October, indicating a bimodal pattern (Figure 2-2). The driest periods fall in the winter to early spring with December, January, February and March having an average of 1.81 inches of rain each (SRCC 2009). Figure 2-3 illustrates year-to-year variability in rainfall using data from 1871 through 2008 (Southern Region Headquarters National Oceanic and Atmospheric Administration 2009). The driest year was 1917, with less than 10.11 inches of precipitation, while the wettest year during this period was 1973, with over 52.28 inches of precipitation recorded. 


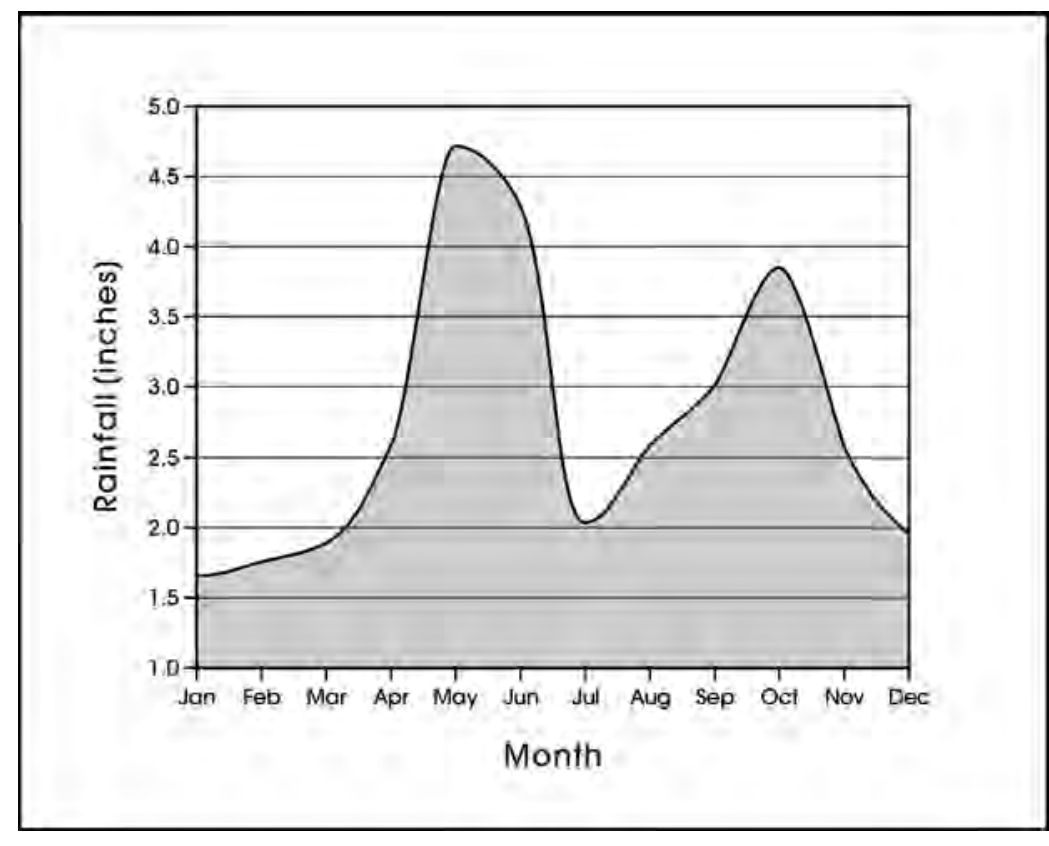

Figure 2-2. Average monthly rainfall for San Antonio, Texas (1971-2000).

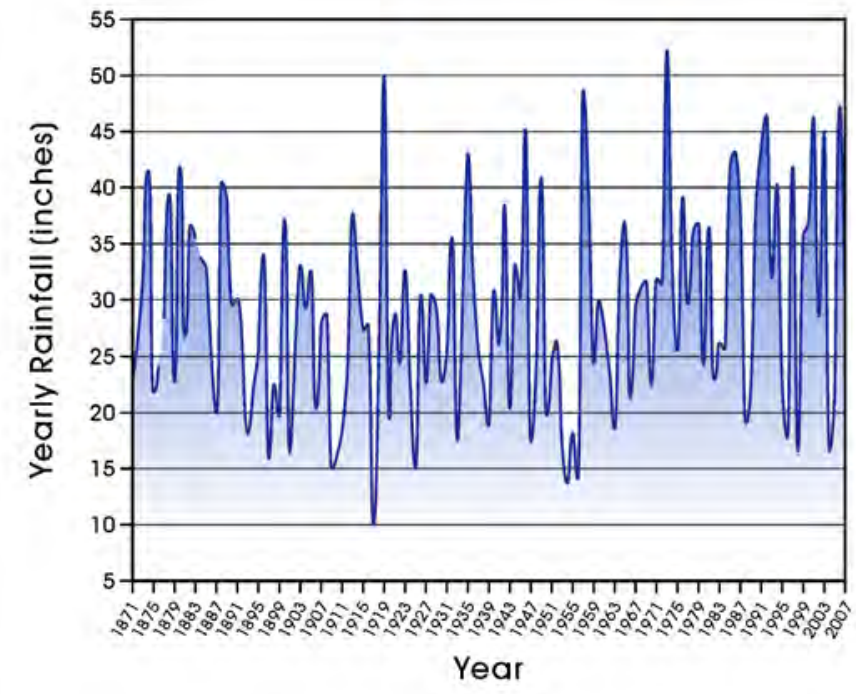

Figure 2-3. Yearly rainfall for San Antonio, Texas (1871-2008).

\section{Hydrology}

The edge of the Balcones Escarpment contains numerous springs, seeps, and drainages. The major river system in Bexar County is the San Antonio system consisting of the San Antonio River and a number of smaller streams that flow into it, including the Medina River and Medio, Leon, Helotes, Salado, and Calaveras creeks (Long 2009). The immediate project area is located in what Potter et al. (1995) terms the Middle Salado watershed. The Middle Salado consists of approximately 25 linear $\mathrm{km}$ of drainage from the confluence of Panther Springs Creek and Salado Creek to roughly $20 \mathrm{~km}$ above the Salado/San Antonio River confluence. The Middle Salado stream gradient decreases significantly in comparison to the Upper Salado gradient. This decrease is accompanied by broadening floodplain and terrace landforms, deeper alluvial deposits and significantly increased stream meandering in comparison to the linear aspects of the Upper Salado (Potter et al. 1995). Chapter 6 addresses the hydrology in the project area in detail.

\section{Geology and Soils}

Adapted from the San Antonio (Barnes 1983) sheet of the Geological Atlas of Texas, Figure 2-4 shows the geology of the general project area. The project area is contained within Pliocene/Pleistocene age deposits of fluviatile terrace deposits $(\mathrm{Qt})$ that are associated with the Edwards Plateau. These deposits often contain chert gravels. Large deposits of Pecan Gap Chalk (Kpg) and smaller pockets of Austin Chalk (Kau) and Navarro Group and Marlbrook Marl (Kknm), all dating to the Upper Cretaceous, are located within a $5 \mathrm{~km}$ radius of the project area. Kpg, Kau, and $\mathrm{Kknm}$ formations are all devoid of chert, but $\mathrm{Kknm}$ is noted to contain sandstone. A deposit of Pliocene/Pleistocene age Uvalde gravels (Q-Tu) is located on the far southern edge of the $5 \mathrm{~km}$ radius. Uvalde Gravel is known to contain well-rounded cobbles of chert, as well as quartz and limestone (Barnes 1983). The projects area's setting on fluviatile terrace deposits and its close proximity to a deposit of Uvalde gravels would have allowed the inhabitants of the Granberg Site easy access to material well suited to tool manufacture.

The soils in the immediate vicinity of the active channel, presented in Figure 2-5 (Taylor et al. 1962:12, Sheet Number 37) are described as frequently flooded Trinity and Frio Soils (Tf). These soils occur as narrow, irregularly shaped areas on the flood plains of small streams and larger drainage ways. Trinity/Frio soils range from one to one and one half meters deep and consist of a surface layer of clay loam and a subsurface layer of clay with pockets of thin loamy strata (Taylor et al. 1991). The soils abutting the active channel are identified as Lewisville silty clays (Lv), Patrick soils (Pa), and Tarrant association 
(Ta). The Lewisville series consists of moderately deep, dark colored, alluvial soils. Patrick soils contain shallow, calcareous clay loam. The Tarrant series is characterized by gently undulating, stony, clay loam overlying shallow bedrock (Taylor et al. 1991).

\section{Floral and Faunal Resources}

The Middle Salado meanders through the Blackland Prairie region of Texas, a biotic zone running west to east across most of central Bexar County. The Blackland Prairie is

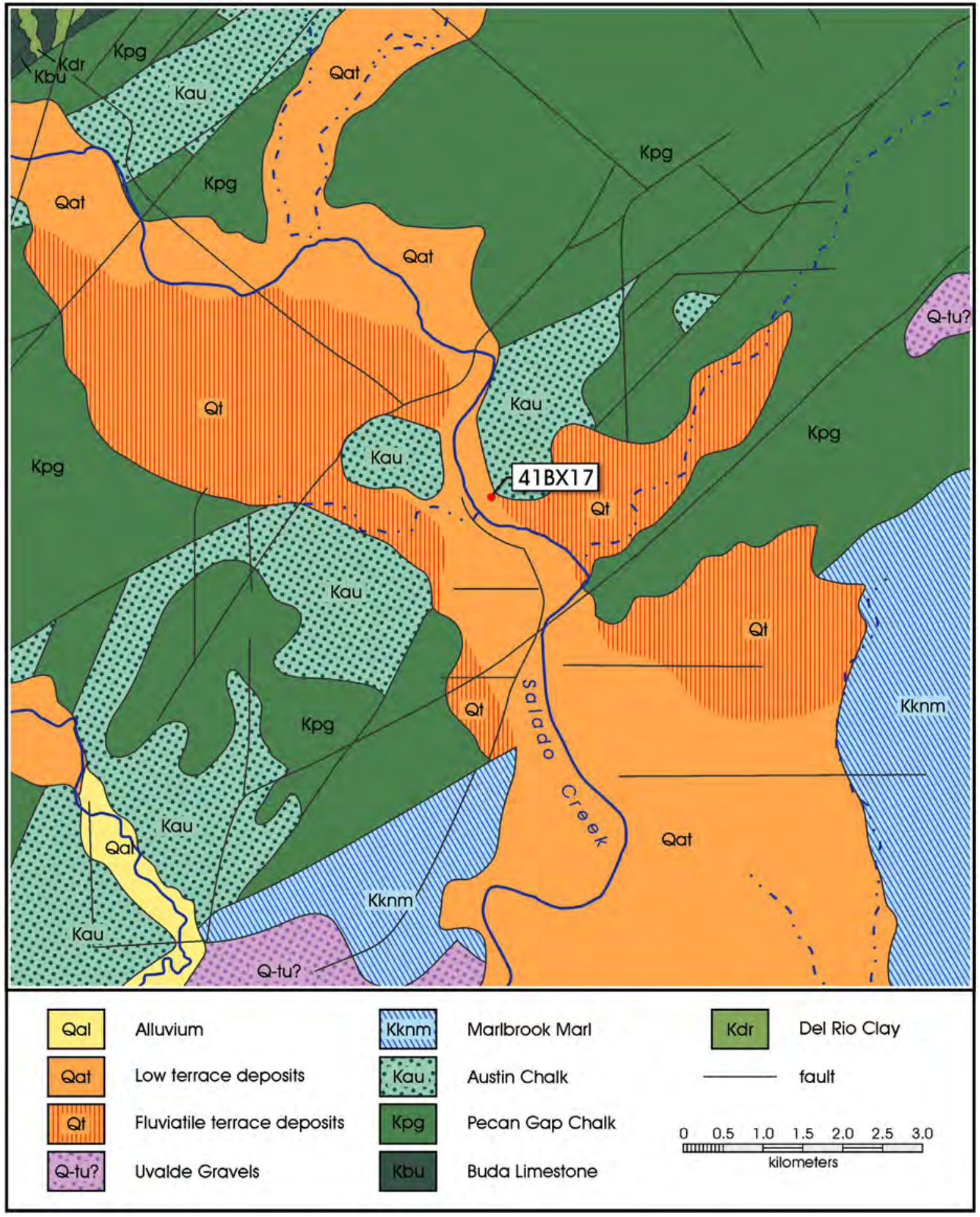

Figure 2-4. Geological setting of $41 B X 17$. 


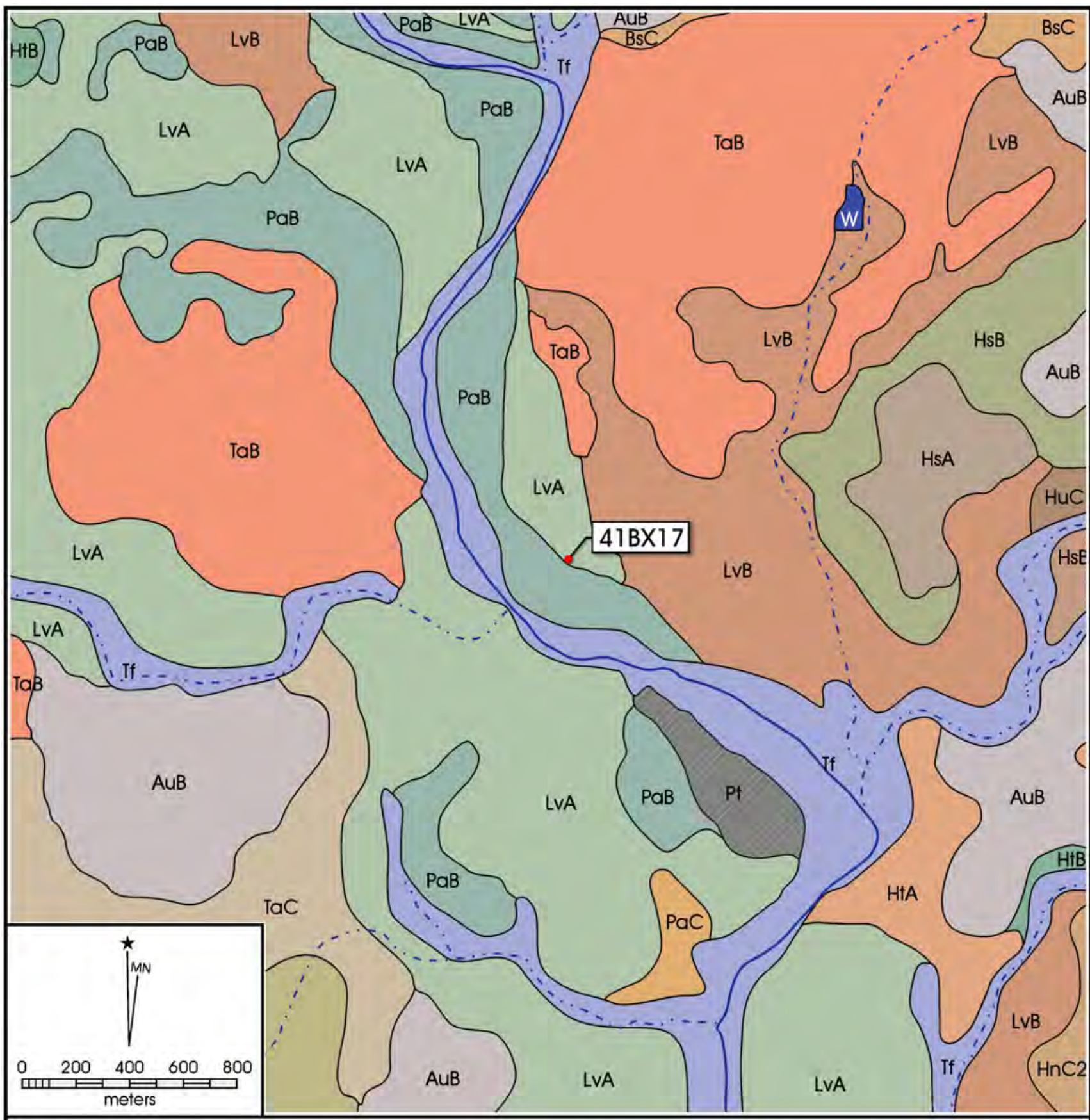

AuB - Austin silty clay, 1 to 3 percent slopes BsC - Whitewright-Austin complex, 1 to 5 percent slopes Fr - Loire clay loam, 0 to 2 percent slopes, occasionally flooded HnC2 - Heiden clay, 3 to 5 percent slopes, eroded HsA - Houston Black clay, 0 to 1 percent slopes HsB - Houston Black clay, 1 to 3 percent slopes HtA - Branyon clay, 0 to 1 percent slopes $\mathrm{H}+\mathrm{B}$ - Branyon clay, 1 to 3 percent slopes HuC - Houston Black gravelly clay, 3 to 5 percent slopes LVA - Lewisville silty clay, 0 to 1 percent slopes
LvB - Lewisville silty clay, 1 to 3 percent slopes

$\underline{\mathrm{PaB}}$ - Patrick soils, 1 to 3 percent slopes, rarely flooded PaC - Patrick soils, 3 to 5 percent slopes, rarely flooded Pt - Pits and Quarries, 1 to 90 percent slopes IaB - Eckrant cobbly clay, 1 to 5 percent slopes IaC-Eckrant cobbly clay, 5 to 15 percent slopes Ib - Eddy gravelly clay loam, 1 to 8 percent slopes If - Tinn and Frio soils, 0 to 1 percent slopes,frequently flooded $\underline{\text { W }}$ - water

Figure 2-5. Soils in the project area. 
characterized by low, rolling hills with gentle slopes (Diamond et al. 1987). This area supports a diverse assemblage of flora including a variety of oaks (Quercus sp.), pecan (Carya illinoiensis), cedar elm (Ulmus crassifolia), mesquite (Prosopis sp.), ashe juniper (Juniperus ashei), buffalo grass (Buchloe dactyloides), Texas grama (Bouteloua rigidiseta), big bluestem (Andropogon gerardi), little bluestem (Schizachyrium scoparium), Indiangrass (Sorghastrum nutans), switchgrass (Panicum virgarum), sideoats grama (Bouteloua curtipendula), hairy grama (Bouteloua hirsute), tall dropseed (Sporobolus asper), and Texas wintergrass (Stipa leucotricha; Vines 1960).

The modern vegetation in the project area is depicted in Figure 2-6 (Texas Parks and Wildlife Department [TPWD] 1984). The project area is located in an urban area. Currently, Live Oak-Ashe Juniper Woods, distributed chiefly on shallow limestone soils on the hills and escarpment of the Edwards Plateau, and Live Oak-Mesquite-Ashe Juniper Parks and Live Oak-Ashe Juniper Parks, found on level to gently rolling uplands and ridge tops of the Edwards Plateau, dominate the landscape to the north of San Antonio. Cropland with pockets of Mesquite-Live Oak-Bluewood Parks, primarily located in Uvalde, Medina and Bee Counties on the South Texas Plains, and Post Oak Woods/Forest and Post Oak Woods Forest with Grassland Mosaic, distributed mostly on the sandy soils of the Post Oak Savannah, covers most of the areas to the south, east and west (TPWD 2009). It is likely that prior to European settlement of the region in the mid-1800s, grassland was much more common and the juniper, mesquite, woody brush and shrubs that dominate the region today had a much more restricted distribution.

Present day fauna occupying the area include white-tailed deer (Odocoileus virginianus), coyote (Canis latrans), gray fox (Urocyon cinereoargenteus), bobcat (Lynx rufus), raccoon (Procyon lotor), striped skunk (Mephitis mephitis), fox squirrel (Sciurus niger), eastern cottontail rabbit (Sylvilagus floridanus), and turkey (Meleagris gallopavo), in addition to other mammals, snakes, and reptiles (Blair 1950). Prehistorically, important economic species in the area included bison (Bison bison), pronghorn antelope (Antilocapra americana), and black bear (Ursus americanus; Gerstle et al. 1978).

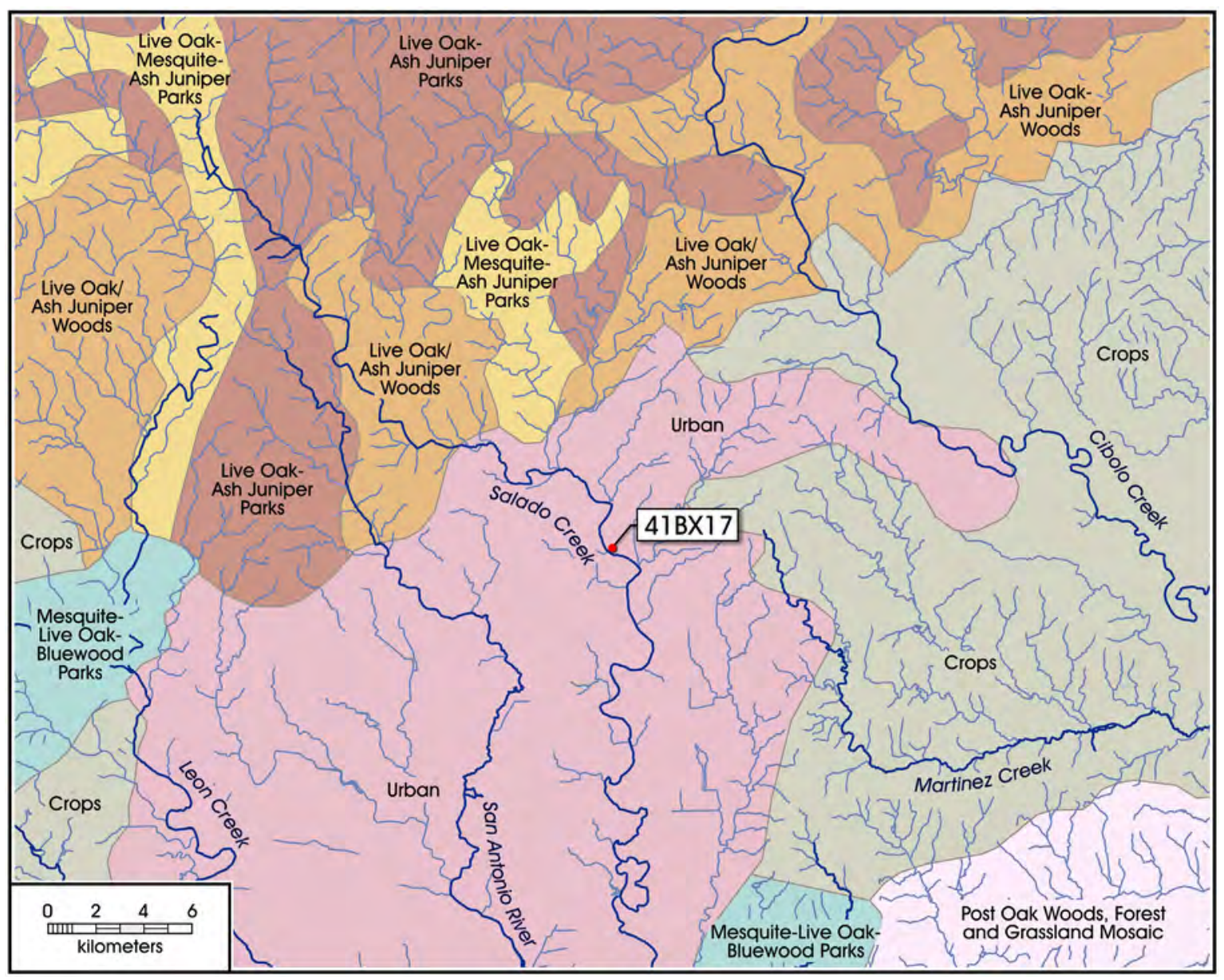

Figure 2-6. Modern vegetation in the project area. 


\section{Paleoenvironmental Conditions}

Most aspects of the environment described in the previous section were undoubtedly different from the conditions during the prehistoric occupation of the Granberg Site. The introduction of domestic livestock, fencing, and fire suppression, all related to European settlement, have altered the landscape significantly (Mauldin et al. 2004). Much of our current knowledge about paleoenvironmental conditions in Central Texas in the Late Holocene is derived from climate studies using various proxy measures including the presence/ absence of bison, pollen data, geomorphological shifts in alluvial deposition along major streams, cave humins, and fluctuations in shrew species in cave deposits (see Bousman 1998; Camper 1991; Collins 1995; Cooke 2005; Dillehay 1974; Johnson and Goode 1994; Mauldin and Kemp 2005; Nickels and Mauldin 2001; Nordt et al. 2002; Toomey 1993; Toomey et al. 1993).

We currently lack detailed information on paleoclimate at short temporal scales; the scale which would allow us to fully investigate the degree to which essentially modern fluctuations in grasslands may be characteristic of past vegetation regimes. However, the long-term data sets mentioned above can provide large-scale patterns of vegetation shifts at the community level. Figure 2-7 presents four long-term data sets. The Medina River data are from southern Bexar County, just to the south of $41 \mathrm{BX} 17$, and represent carbon isotopic signatures derived from a series of buried, dated soils (Nordt et al. 2002). The Hall's Cave carbon isotope data, also on buried sediments, are from an extremely welldated deposit in Kerr County (Cooke 2005) located roughly $100 \mathrm{~km}$ to the northwest of the Granberg Site. Boriack and Patschke bogs are located in Lee County, roughly $180 \mathrm{~km}$ to the northeast of the site. The Boriack arboreal pollen sequence, taken from Bousman's (1998) reanalysis of the original data, is poorly dated. The Patschke grass pollen sequence (Camper 1991), taken from a reanalysis of the original data by Nickels and Mauldin (2001), is supported by four radiocarbon dates. The Patschke cure reflects the relative frequency of poaceae pollen within a sample following the removal of taxa that are thought to reflect local conditions (Nickels and Mauldin 2001:34-35).

If the four sequences shown in Figure 2-7 are accurately monitoring shifts in vegetation at large spatial scales, comparisons of the patterns suggest some regional variability encompassed by similar overall trends. The two carbon

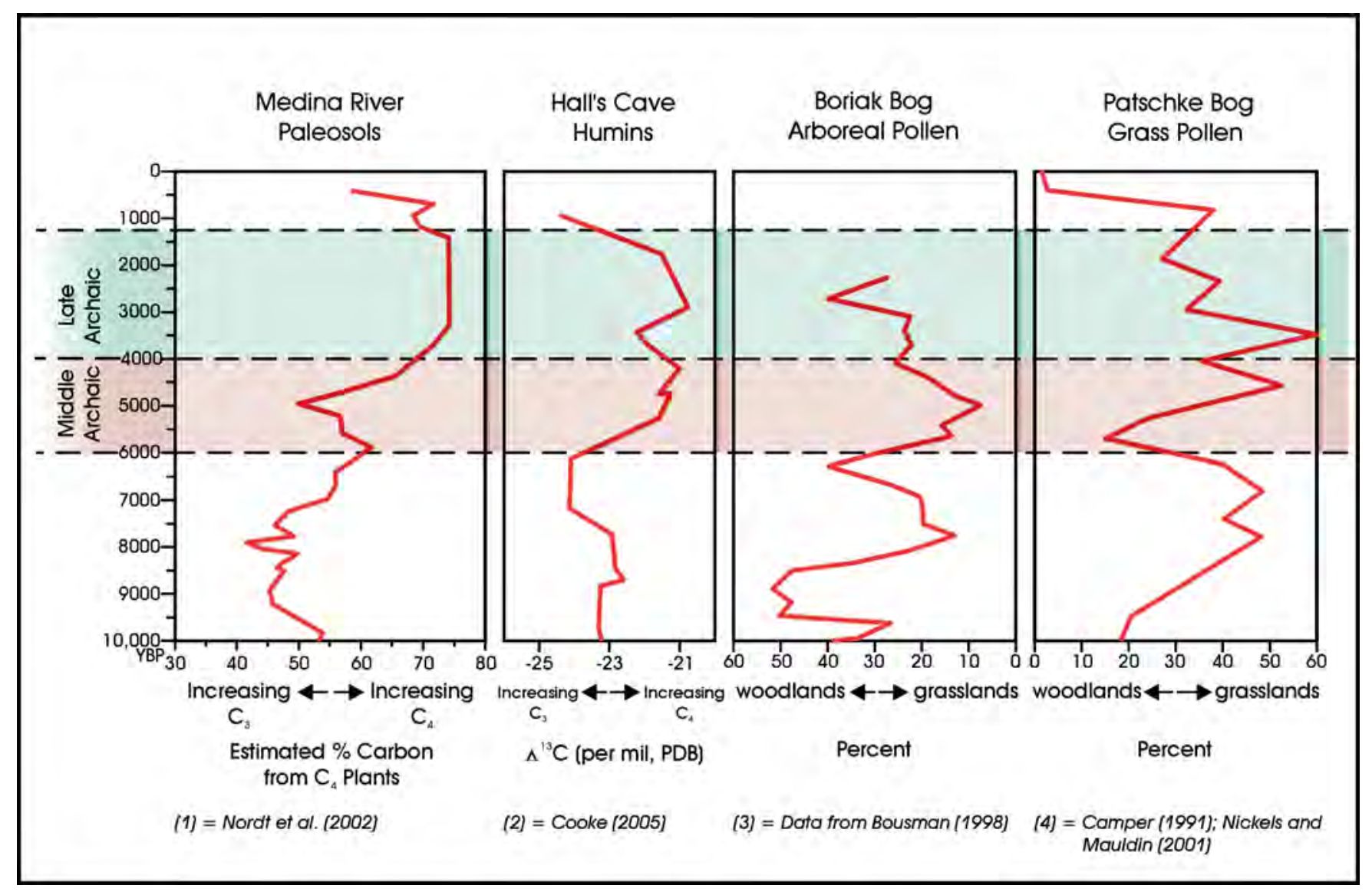

Figure 2-7. Comparison of climatic sequences. 
isotope data sets suggest a high frequency of $\mathrm{C}_{3}$ plants before about 6,000 years ago (6 Kya), with an increase in $\mathrm{C}_{4}$ at the beginning of the Middle Archaic. The curves differ slightly, with the Medina River sequence showing a decline in $\mathrm{C}_{4}$ plants to about $5 \mathrm{Kya}$, and then a rapid increase in $\mathrm{C}_{4}$ throughout the Late Archaic. The Hall's Cave sequence shows no such decline in $\mathrm{C}_{4}$ in the Middle Archaic, but does show a slight decrease in the early portion of the Late Archaic. Both sequences show a decline in $\mathrm{C}_{4}$ late, with the decline initiated at about 1200 BP in the Medina River area, and at about 2000 BP in the Hall's Cave sequence.

Data from the two pollen sequences located close together and to the northeast of the sediment sequences, suggest more variability then the isotope data. A high frequency of arboreal vegetation is present in both sequences at about $8500 \mathrm{BP}$, giving way to grasslands by around 7500 BP. The Boriak bog data shows a decline in grassland that culminates at around $6200 \mathrm{BP}$, with a rapid increase in grasslands in the Middle Archaic up to about 5000 BP. After that date, grasslands decline and the sequence terminates prior to $2 \mathrm{Kya}$. Conversely, the Patschke pollen data suggest an increase in woodland communities in the initial Middle Archaic, with a rapid increase in grasslands through the remaining portion of this period. Grass pollen, and by extension grasslands, reach a peak in the Patschke sequence at around 3,500 years ago, then begin a slow, though variable decline.

Overall, the long-term data sets in Figure 2-7 suggest a relatively mesic period with warmer temperatures as indicated by extensive grasslands $/ \mathrm{C}_{4}$ vegetation regimes during most of the Middle and Late Archaic. Grasslands seem to be at their peak in the early portion of the Late Archaic, and then began a slow, gradual decline until the close of that period. In addition, the data sets in Figure 2-7 suggest that a different pattern, one of rapidly declining grasslands, is characteristic of at least the last 1,000 years. 



\section{Chapter 3: Previous Research and Archeological Background}

\section{Cynthia M. Munoz}

This chapter provides background material on the archeological record of the general study area. A summary of the cultural history of Central Texas is presented followed by a short review of the history of research in the project area.

\section{Cultural Chronology}

The Granberg Site is situated at the intersection of two broad archeological regions, Central Texas and South Texas. Because archeological sites with long sequences of stratified deposits are sparse in South Texas, the prehistoric sequence developed for Central Texas is often relied on to frame the prehistory of South Texas. The following culture history emphasizes Central Texas although reference is made to trends in South Texas. The discussion is based primarily on the chronologies developed by Black (1989a), Collins (1995), and Johnson and Goode (1994) for Central Texas, with observations from Hester (1995) for South Texas. Four major time periods define South Central Texas: Paleoindian, Archaic, Late Prehistoric, and Historic. These periods are further divided into sub-periods that are based on particular subsistence strategies and material culture. A brief description of each period follows to illustrate the archeological potential of the region.

\section{Paleoindian}

The Paleoindian period, $11,500-8800 \mathrm{BP}$, is divided into early and late sub-periods, each characterized by particular projectile point styles and subsistence patterns (Collins 1995). The period begins at the close of the Pleistocene with the earliest evidence of humans in the Central Texas region. Projectile points include lanceolate-shaped, fluted forms such as Clovis, Plainview, and Folsom. In the past, Paleoindian populations have generally been characterized as huntergatherers ranging over wide areas in pursuit of now extinct megafauna, such as mammoth and Bison antiques. This view of Paleoindian peoples has recently been reassessed. Although exploiting Late Pleistocene megafauna may have constituted a part of Paleoindian subsistence, these peoples are perhaps better characterized as more generalized huntergatherers, exploiting a wide variety of plants and animals including large herbivores like deer and Bison bison and small animals such as turtles, alligators, rabbit, and raccoons (Collins 1995; Nickels 2000). Paleoindian artifacts are commonly recovered as isolated finds or from lithic scatters lacking good stratigraphic context including kill, quarry, cache, camp, ritual, and burial sites (Collins 1995).

\begin{abstract}
Archaic
The Archaic period, $8800-1200 \mathrm{BP}$, is marked by intensification of hunting and gathering of local resources, changes in projectile points, and by a broader array of material culture (Collins 1995; Prewitt 1981; Weir 1976). A change in food processing is evident from a widespread increase in hearth, oven and midden features. During this period, large cemeteries were formed indicating an increasing population and the subsequent establishment of territories (Black and McGraw 1985). Collins (1995) and Johnson and Goode (1994) subdivided the Archaic into Early, Middle, and Late sub-periods. These sub-periods are distinguished by variances in climate conditions, resource availability, subsistence practices, and diagnostic projectile point styles (Collins 1995; Hester 1995).
\end{abstract}

\section{Early Archaic}

In Central Texas, the Early Archaic dates from 8800 to 6000 BP (Collins 1995). Changing climate and the extinction of megafauna appear to have initiated a behavioral change by the Prehistoric peoples of Texas. Because of the necessary economic shift away from big game hunting, local resources in Central Texas, such as deer, fish, and plant bulbs were more intensively exploited. This behavioural change is indicated by greater densities of ground stone artifacts, burned rock cooking features, and more specialized tools such as Guadalupe bifaces and Clear Fork gouges (Turner and Hester 1993). Projectile point styles found in sites from this period include Angostura, Early Split Stem, and Martindale-Uvalde (Collins 1995). Open campsites, including Loeve, Richard Beene, Wilson-Leonard, Jetta Court, Sleeper, Camp Pearl Wheat, Youngsport, and Landslide, and a cave site, Hall's Cave, contain notable Early Archaic components (Collins 1995).

Weir (1976) concludes that the Early Archaic groups were highly mobile and small. He bases this inference on the fact that Early Archaic sites are thinly distributed and that projectile points are widely distributed across most of Texas and northern Mexico. The decline in bison numbers on the plains suggested to Hurt (1980) that the inhabitants were forced to broaden their diets to include animals and plants that produce equivalent amounts of calories and protein with the same or slightly more expended effort. Story (1985) concurs with Weir that population densities were low during the Early Archaic. She suggests that groups were made up of small bands of related individuals with "few constraints on 
their mobility" (Story 1985:39) subsisting on a broad range of resources, such as prickly pear, lechugilla, rodents, rabbits and deer.

\section{Middle Archaic}

The Middle Archaic, 6000 to 4000 BP (Collins 1995), appears to have been a period of increasing population, based on the large number of sites documented from this time in South and Central Texas (Story 1985; Weir 1976). Projectile point variation at the Jonas Terrace Site points to a period of "ethnic and cultural variety, as well as group movement and immigration" (Johnson 1995:285). Point styles from this period include Bell, Andice, Calf Creek, Taylor, Nolan and Travis (Collins 1995). Exploitation of broadly scattered, year-round resources such as prickly pear, deer and rabbit continued (Campbell and Campbell 1981) with the addition of seasonal nut harvests from the riverine settings of the Balcones Escarpment (Black 1989a; 1989b). Weir (1976) posits that the expansion of oak on the Edwards Plateau and Balcones Escarpment resulted in intensive plant gathering and acorn processing that may have been the catalyst for the merging of the widely scattered bands prevalent in the Early Archaic into larger groups. These larger groups likely shared the intensive labor involved with the gathering and processing of acorns. Some investigators believe burned rock middens resulted from acorn processing (Creel 1986; Weir 1976) although others (e.g., Black et al. 1997; Goode 1991) question this argument. Black et al. (1997) suggest that the burned rock middens of Central Texas accumulated as a result of the baking of a relatively broad range of resources in rock/earth ovens These resources potentially included carbohydrate laden nuts, bulbs, roots, and pads as well as various vertebrate and invertebrate animals.

\section{Late Archaic}

The final interval of the Archaic in Central Texas dates from 4000 to 1200 BP (Collins 1995). There is not a consensus among researchers as to population size in this sub-period. Prewitt (1985) posits an increase while Black (1989a) believes population remained the same or decreased. There is also disagreement as to the continuing use of burned rock middens. Prewitt (1981) suggests the near cessation of the midden construction, whereas excavations at a number of sites document large cooking features up to 15 meters in diameters (Houk and Lohse 1993; Johnson 1995; Mauldin et al. 2003). Bison reemerge during this sub-period in Central Texas (Mauldin and Kemp 2005) after evidence of a definitive decrease during the Middle Archaic (Dillehay 1974). Points from the Late Archaic sub-period are generally smaller than those of the Middle Archaic and include Bulverde, Pedernales, Kinney, Lange, Marshall, Marcos, Montell,
Castroville, Ensor, Frio and Darl types (Collins 1995; Turner and Hester 1993). During this period, large cemeteries were formed indicating an increasing population and the subsequent establishment of territories (Black and McGraw 1985). The earliest occurrences are at Loma Sandia (Taylor and Highley 1995), Ernest Witte (Hall 1981), Hitzfelder Cave (Givens 1968), and Olmos Dam (Lukowski 1988).

\section{Late Prehistoric}

The beginning of the Late Prehistoric period (1200-350 BP) in Central Texas is marked by the appearance of arrow points, indicative of bow and arrow technology, and pottery (Black 1989a; Collins 1995; Hester 1995; Story 1985). The Late Prehistoric is subdivided into early and late sub-periods termed Austin and Toyah Phases, respectively. Temporal diagnostics including Scallorn and Edwards arrow points define the Austin Phase (1200-650 BP; Prewitt 1981). It appears that the use of burned rock middens may have reached its peak during this phase (Black and Creel 1997). The subsequent Toyah Phase spans 650-350 BP and includes the first occurrence of pottery in South Texas. Characteristic artifacts of this phase include Perdiz and Cliffton arrow points (Black 1986). Material culture associated with the Late Prehistoric period points to increasing complexity in subsistence patterns and to very large prehistoric populations (Black 1989a; Collins 1995).

\section{Historic}

The Historic period in South Texas begins with the arrival of Europeans, theoretically with the shipwreck of the Narvaez expedition along the Texas coast (likely Galveston Island) in 1528. The treasurer of the expedition, Álvar Núñez Cabeza de Vaca, and three other survivors arrived in Vera Cruz, Mexico more than seven years after the shipwreck. Although the route of their wanderings is still in dispute, it appears that the first part of their trip was from the mainland near Galveston Island to the convergence of the lower Guadalupe River into San Antonio Bay. At this point de Vaca turned inland eventually arriving in Vera Cruz (Favata and Fernandez 1993; Thoms 2008).

From AD 1550 to the late 1600s, European forays into South and Central Texas were infrequent. René Robert Cavelier, Sieur de La Salle, established a French settlement, Fort St. Louis, along Matagorda Bay on the Texas coast in 1685. Hunger, disease, and escalating hostilities between the French and the Karankawas, subsequently destroyed the colony (Foster 1998). In 1690, as a result of the discovery of the remains of the La Salle colony, the Spanish began securing the northern border of New Spain, expanding their interests in East Texas to counter any French expansion across the Mississippi River. 
Europeans successfully settled in the region in early AD 1700 (Taylor 1996). The southward incursion of the Comanche and Apache and the northward expansion of Spanish influence led to the displacement of many of the area's indigenous groups. Some Native Americans moved to the protective environment of the various missions that were established in the area in the early eighteenth century. The move to the missions significantly impacted the hunter-gatherer way of life and the material culture.

Artifacts from the Historic period reflect European influences and include metal, glass, ceramics, including pre-Hispanic Goliad wares, lithic arrow points, tools, and gunflints (Taylor 1996).

\section{The Archeological Record of the Study Area}

Several recent summaries of archeological research in Central Texas are available, including overviews by Black (1989a), Collins (1995), and Johnson and Goode (1994). Thousands of sites have been documented in Central Texas, upwards of 11,000 as of 1995 (Collins 1995). The most common site types consist of debris accumulations, containing lithic debitage, burned rock, pottery sherds and assorted utilitarian objects. Camp sites are found in the open on bluff lines, in caves and in rockshelters. Notable sites documented in Central Texas include Kincaid Rockshelter (Hester 1980), Wilson-Leonard (Collins 1998), Gault (Collins 1999), Horn Shelter (Watt 1978), Pavo Real (Collins et al. 2003; Figueroa and Frederick 2008; Henderson and Goode 1991; Martinez et al. 1994), Loeve-Fox (Prewitt 1974, 1982), Richard Beene (Thoms and Mandel 2007), Jetta Court (Wesolowsky et al. 1976), Camp Pearl Wheat (Collins et al. 1990), Hall's Cave (Cooke 2005), Wounded Eye (Luke 1980), and Barton (Abbott 1994).

The immediate project area lies along the Middle Salado Creek watershed in Bexar County (Potter et al. 1995). The Salado drains into the San Antonio River and combined, the Salado Creek/San Antonio River system, is the primary drainage system in Bexar County. This drainage system includes Salado Creek and its tributaries along with the portion of the San Antonio River north of the Medina River.

An abundance of recorded prehistoric archeological sites are documented along the Middle Salado Creek watershed. A review of the Texas Historical Commission Site Atlas revealed that roughly 40 sites ( 31 prehistoric, 4 historic, and 5 multicomponent) are located on the Middle Watershed within the immediate vicinity of the Salado from the northern boundary at its confluence with Panther Springs Creek to the southern boundary, roughly $20 \mathrm{~km}$ above the Salado/San Antonio River confluence (THC 2008). Several projects have been undertaken along the Salado system, including a series of surveys, testing, and mitigation projects. These projects include mitigations of 41BX300 (Katz 1987) and the Panther Springs Site (41BX228, Black and McGraw 1985), testing at the Granberg Site (41BX17/271, Schuetz 1966; Thompson 2006b), the St. Mary's Hall Site (41BX229, Hester 1977), and the Dos Mujeres Site (41BX1764, Figueroa 2009), testing and survey of the Wurzbach Parkway (Potter et al. 1995), and Walker Ranch (Fox 1979; Hudson et al. 1974; Meissner 2000, 2006; Potter 1980; Scurlock and Hudson 1973; Tomka 1998; Weston and Greaves 2003), and surveys of the EW Parkway (THC 2009), Tobin Oakwell Farms (McGraw and Valdez 1977), and the Salado Greenway (Figueroa 2008, 2009; Figueroa and Ulrich 2006; Kemp and Moses 2008; Munoz 2008; Weston et al. 2004).

Ten archeological sites are located within 1000 meters of the Granberg Site, all directly adjacent to Salado Creek and all prehistoric. These sites are 41BX229 and 41BX1007, both north of the Granberg Site, 41BX473 - 41BX479, and 41BX482, all south of the site. 41BX229 contains deposits situated on a colluvial downslope of Salado Creek, about 35 meters east of the present channel. This site, the St. Mary's Hall site, was recorded in 1974 by Kohnitz and Hester. No subsurface testing was noted but observed cultural material included debitage, scattered burned rock, points, native ceramics, and a midden (THC 2008). The site was excavated in 1974 by the Southern Texas Archaeological Association. Multicomponent occupational materials were revealed including an extensive midden with remains dating from the Middle Archaic through the Late Prehistoric. Below the midden (60-75 cmbs) evidence of a Paleoindian component was documented. In 1977, a University of Texas at San Antonio field school resumed the excavations with the intent of exposing two large areas, Area A and Area B, containing Plainview and Folsom artifacts, respectively (Hester 1977, Texas handbook online 2007).

Site 41BX1007, located to the immediate west of the present channel, was recorded in 1994 by C. K. Chandler. This Late Prehistoric occupation site contained a midden, burned rock, Scallorn points and one triangular point. No subsurface testing was conducted but the depth of cultural deposits was estimated to be as much as one meter. No recommendations as to National Register of Historic Places (NRHP) status were noted (THC 2008).

The remaining eight sites within 1000 meters of the Granberg Site were documented as part of a 1977 UTSA archeological survey along the Salado Creek as part of the Tobins Oakwell Farm project (McGraw and Valdez 1977). That survey documented 10 prehistoric sites including 41BX473, 41BX474, 41BX475, 41BX476, 41BX477, 41BX478, 41BX479, and 41BX482. Six of the sites were considered 
lithic scatters, one a lithic scatter with a possible deflated midden (41BX476), and one a quarry (41BX479). Of the eight sites, six were deemed ineligible and two potentially eligible (41BX476 and 41BX479) for the NRHP. No subsurface tested was conducted (McGraw and Valdez 1977; Munoz 2008; THC 2008).

As a final component of our investigation into the archeological remains associated with the current project, we conducted a review of the Texas Archeological Sites Atlas database in early 2009 (THC 2009). The review, focused on Bexar County, found 1,994 archeological sites listed. Of these 1,994, 17 lacked temporal information, 480 (24\%) are recorded as Historic, and 1,393 (70\%) are recorded as Prehistoric. The majority of the sites were designated as Archaic, Neoamerican, or unknown. Because the majority of the Archaic sites had no information on subdivisions and most of the sites with unknown temporal designations listed material collected as lithic materials, we grouped these sites into the prehistoric category. The remaining 104 sites contain both prehistoric and historic materials. 


\section{Chapter 4: Excavation Efforts}

\section{Cynthia M. Munoz}

The Granberg Site was once located on a small knoll overlooking the east bank of Salado Creek. Though exact site boundaries are unknown, the eastbound lanes of N.E. Loop 410 and its access road transect the site. The western margin of the site originally extended at least $15 \mathrm{~m}$ (50 ft.) into the highway ROW where Harvey Kohnitz first identified it in 1962 (Córdova et al. 2005). The original landform has been transformed. Fill associated with the construction of N.E. Loop 410 and fill brought in by a private landowner to level the grade south of the access road now covers the area. An Archaic period site remains buried underneath. The site appears to extend for an unknown distance southward from N. E. Loop 410 into property partly privately owned and partly owned by the City of San Antonio. The site is well known to artifact collectors and has been looted as recently as 2006. This chapter presents a summary of the history of excavations at 41BX17 as well as 41BX271. Following the history, the CAR's 2006 excavation efforts are presented in detail.

\section{Previous Archeological Investigations}

Two sites, Granberg I (41BX17) and Granberg II (41BX271), were individually recorded though excavation data suggest that they are two parts of the same site (Figure 4-1). Mardith Schuetz recorded Granberg I in 1962; Thomas Hester and

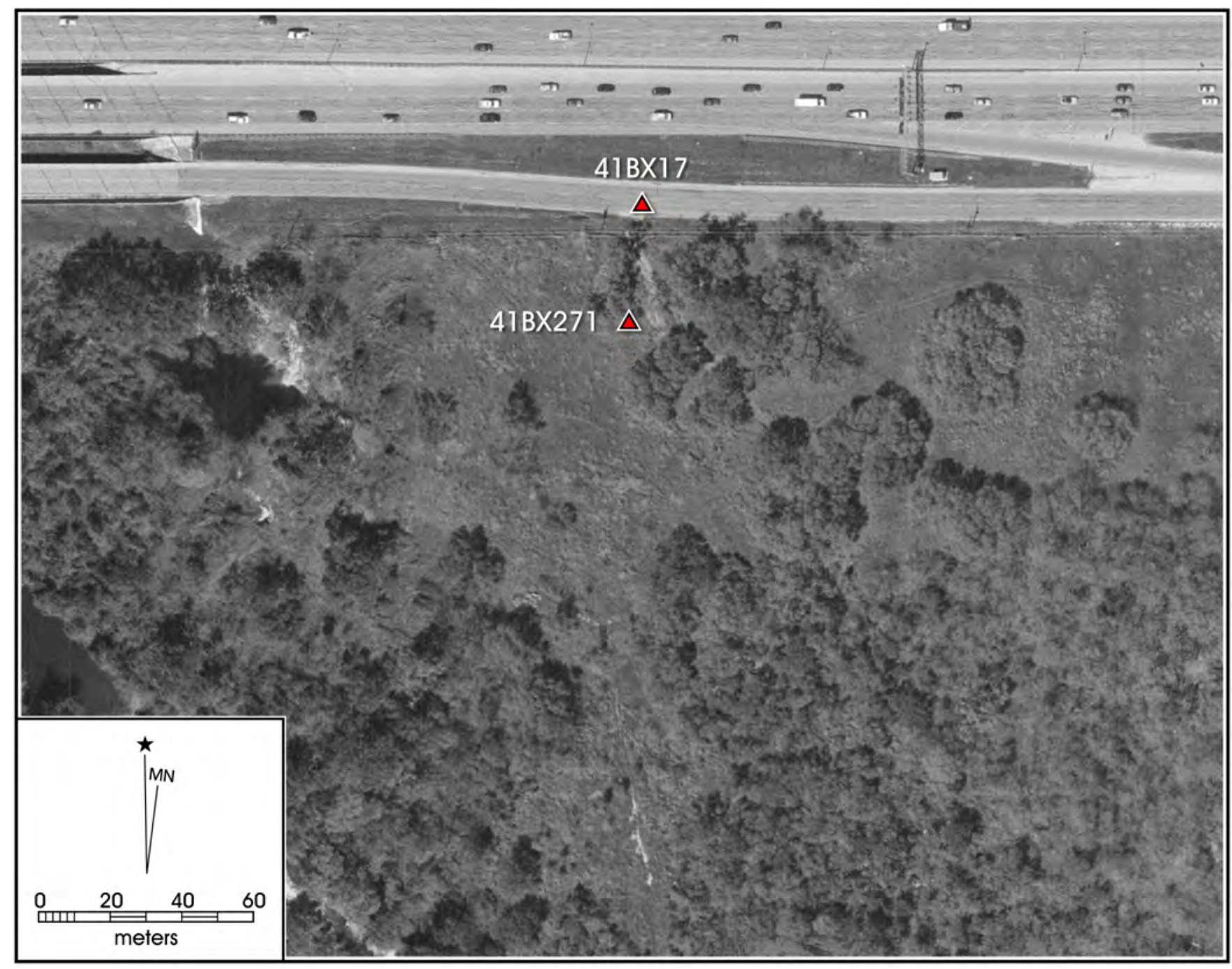

Figure 4-1. The 2001 aerial photograph shows the proximity of Granberg I, 41BX17, and Granberg II, 41BX271, both now determined to be part of the same site. 
Harvey Kohnitz recorded 41BX271 in December 1974. The terms Granberg I and Granberg II are used in this discussion of the previous excavations for consistency with any previous documentation. Any mention of the "Granberg Site" refers to both as a single site.

The Granberg Site has a history of unexpected discoveries during construction projects that have prompted archeological investigations. The archeological excavation that occurred there in 1962 was a salvage effort, designed to mitigate the impacts of road construction after discovery of prehistoric human remains (Schuetz 1966). City utility installation disturbed Granberg deposits again in 1973, prompting another salvage excavation effort by the Southern Texas Archaeological Association (STAA). Thomas Hester reported further unexpected discoveries in 1984 when a construction company began excavations within the ROW adjacent to 41BX271 without notifying the highway department. The description of the location of the ditch states that it began $1.5 \mathrm{~m}$ (5 ft.) east of the gate into the site area, on the south side of Loop 410 and east of Salado Creek. It extended from that point $9.8 \mathrm{~m}(32 \mathrm{ft}$.) toward the east about $3.05 \mathrm{~m}(10$

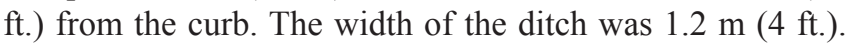
Along with burned rock midden deposits, one burial was found in the area and another possible burial was reported by a workman. According to Hester (1984), these burials were located roughly in the same area where the human remains were documented in 1962. No emergency archeological excavation was reported for this incident. Apparently the human remains were disposed of and no action was taken to prevent or document the situation. Most recently a private contractor erroneously excavated a utility trench over three meters deep across the Granberg Site to connect new construction, adjacent on a privately owned lot, to the City sewer main. Upon visual inspection of the entire length of this trench it was determined that segments of the trench appeared similar to Middle Archaic deposits previously excavated at the Granberg Site. Personnel from the CAR were not able to enter the trench due to OSHA regulations; however, an unprovenienced bone tool, recovered from the trench wall by a City of San Antonio employee, was given to the CAR. The CAR was unable to inspect the backdirt. The utilities were completed and the trench was filled in within a few days of the CAR's inspection due to the threat of heavy rains (Munoz 2008).

Planned excavations, not salvage efforts, included a 1979 UTSA fieldschool, the 2006
CAR significance testing of the Granberg Site in advance of construction to widen N. E. Loop 410 (the subject of this report; Thompson 2006b), and the 2007 CAR pedestrian survey in advance of installation of a portion of the Salado Creek Greenways Hike and Bike trail system for the City of San Antonio (Munoz 2008).

The following sections present brief summaries of previous investigations at the Granberg Site from Kohnitz's excavation in 1962 to the pedestrian survey of the Salado Creek Greenway.

\section{Schuetz Excavation of Granberg I (41BX17) - Witte Museum}

In 1962, Harvey Kohnitz discovered human remains while monitoring the excavation of a City of San Antonio water main trench. Kohnitz identified three burials within this trench and expanded the excavation to explore the extent of the cultural deposits. At this time, the Texas Highway Department recognized the importance of this extensive stratified site and allowed the Witte Museum, under the direction of Mardith Schuetz, to excavate (Figures 4-2 and 4-3). No funding was available on such short notice, so all work and equipment was donated. Schuetz's (1966) report discusses the results of this excavation.

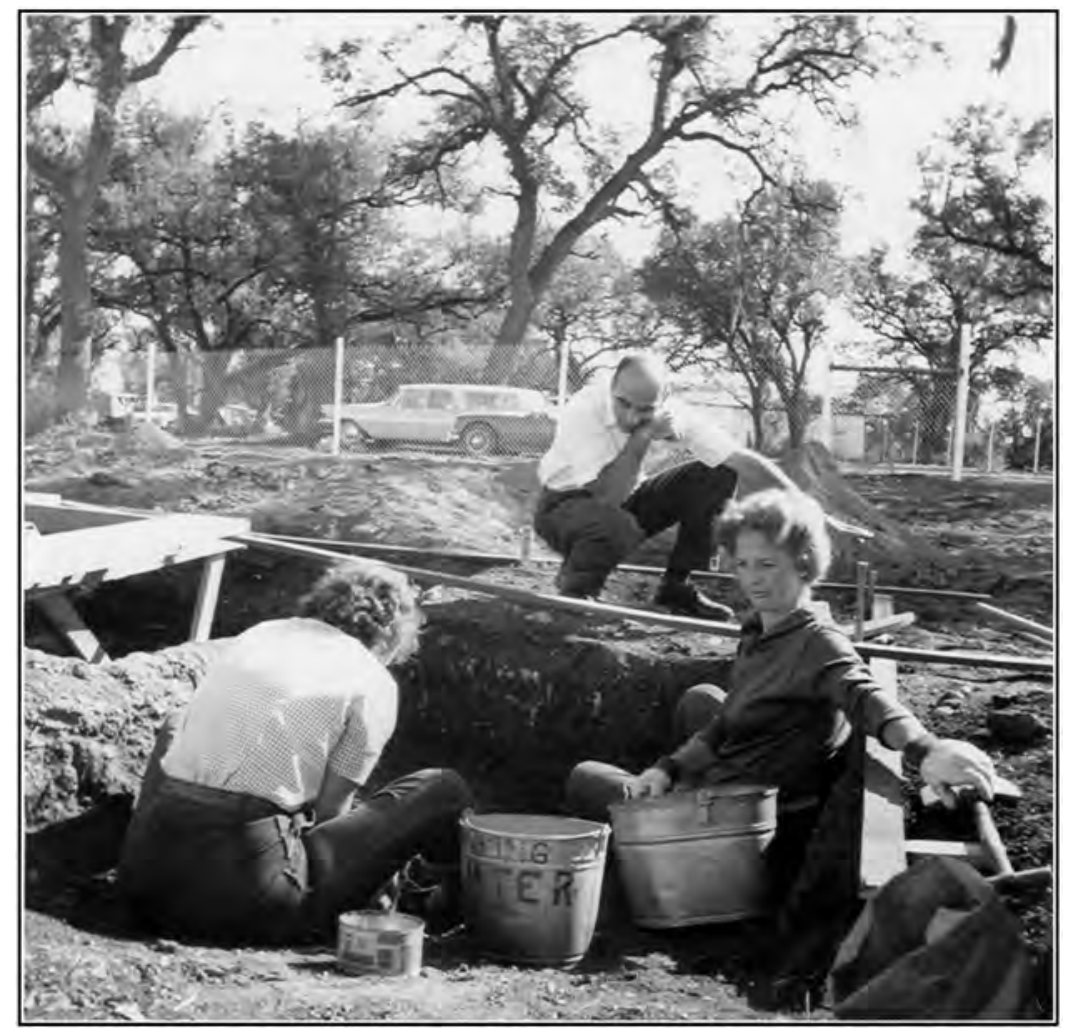

Figure 4-2. Excavations at Granberg I, 1962. 


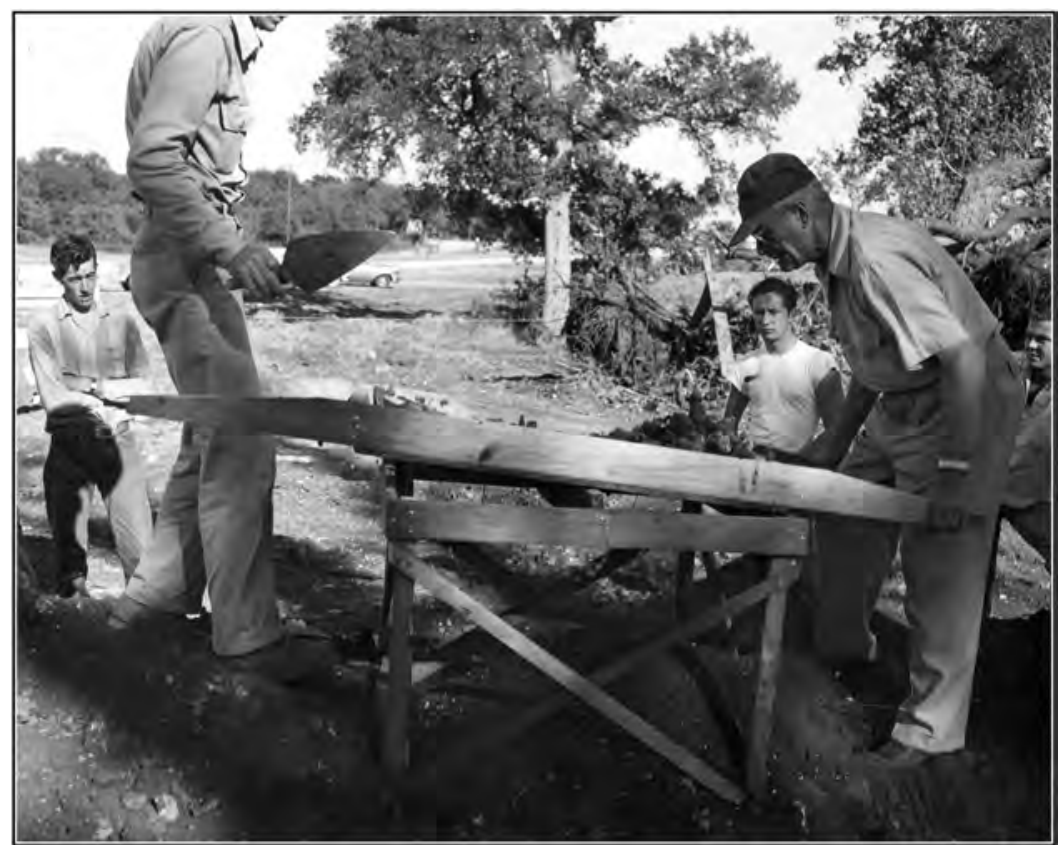

Figure 4-3. Screening at Granberg I, 1962.
The original water main trench that exposed the human remains extended approximately 9-12 m (30-40 ft.) in length and $4 \mathrm{~m}$ (13 ft.) in width along a northwest axis (Figure 4-4). The depth of the trench is unknown but thought to be up to $1.8 \mathrm{~m}$ (6 ft.) (Córdova et al. 2005). Schuetz extended this trench another $16.7 \mathrm{~m}$ (55 ft.) from the northwest end of Kohnitz's original trench with a narrower two-foot wide trench she labeled the North Lateral. The North Lateral trench exposed the northern edge of the cultural deposit. Apparently, this narrow trench was set aside for public digging in order to keep visitors outside of Schuetz's excavation area (Figure 4-5). Schuetz continued excavations at other locations east of the Kohnitz trench. A West Lateral trench was placed perpendicular to the Kohnitz trench to locate the site boundaries in other areas but did not find the limits of the site (Scheutz 1966). This trench measured $9 \mathrm{~m}$ (30.5 ft.) in length and was $2.3 \mathrm{~m}$ (7.5 ft.) wide. Its terminal depth is not known. Midden deposits were present the entire length of this trench (Figure 4-6).

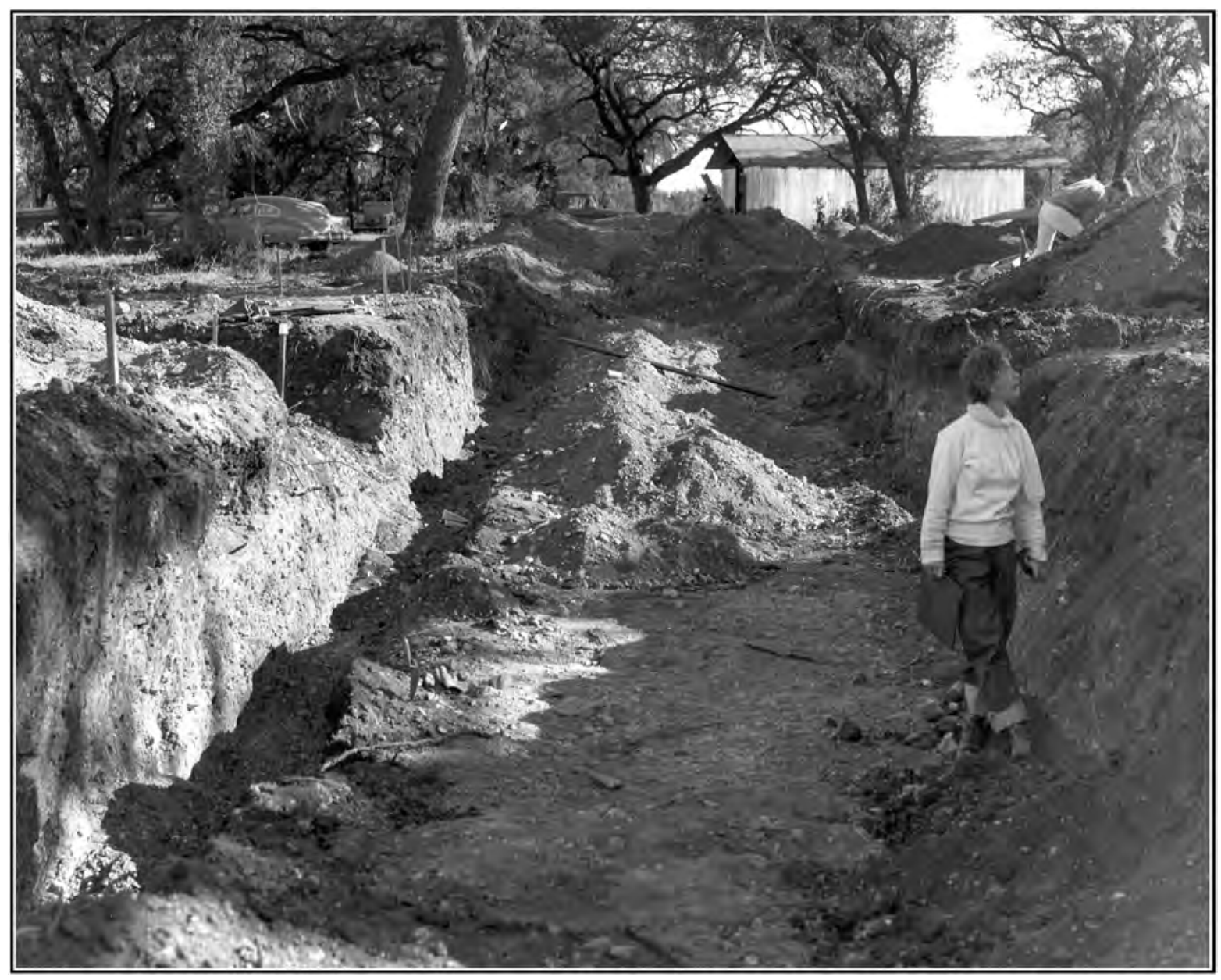

Figure 4-4. Open trench at Granberg I, 1962. 


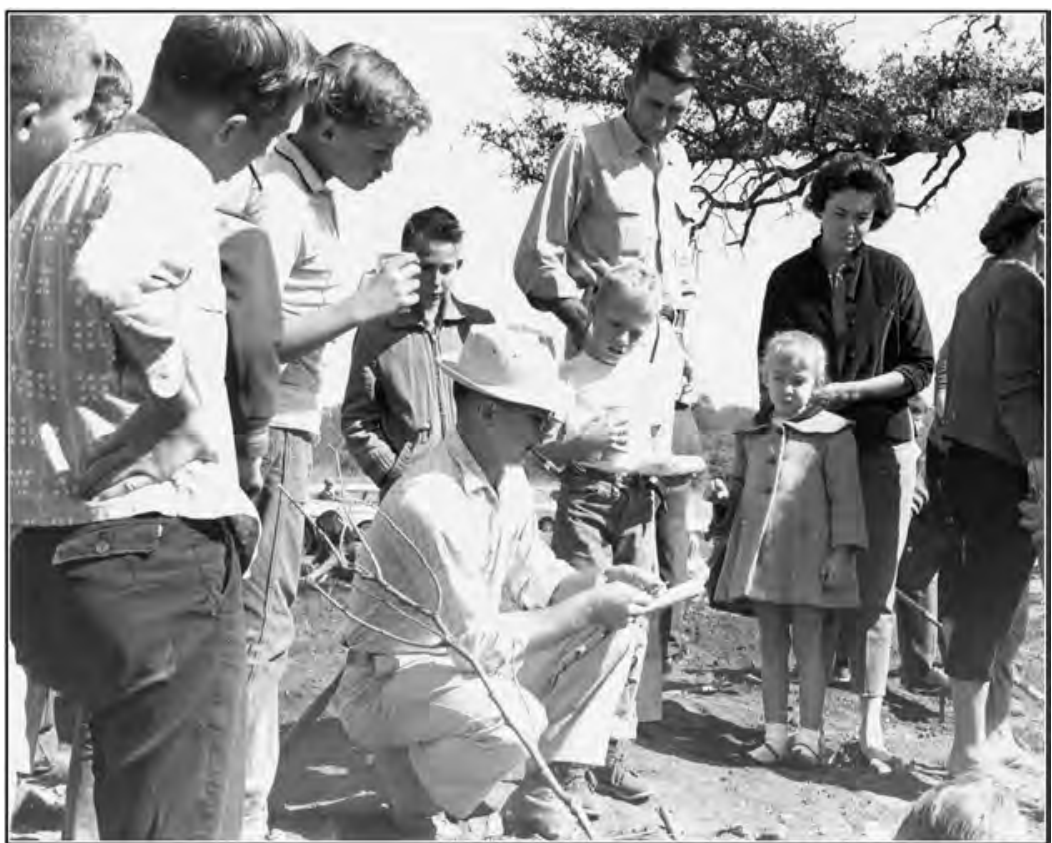

Figure 4-5. Public at Granberg I Site in 1962.
Schuetz set up a block of nine 1.5-x-1.5-m. hand-excavated units west of the Kohnitz trench (Figure 4-7). Eight units were in a contiguous block while the ninth unit was located $3.05 \mathrm{~m}$ (10 ft.) to the east. Apparently midden deposits were not identified in this isolated unit because the eastern boundary of the midden is drawn just east of the water main trench rather than extending to the isolated unit. Two units were also placed south of the larger block, one measuring $1.5-\mathrm{x}-1.5-\mathrm{m}$, the other $2.4-\mathrm{x}-1.8-\mathrm{m}$, but these were only partially excavated before backfilling. The majority of the archeological information comes from the hand excavation of the first nine units (Schuetz 1966). At the beginning of the salvage work, the soil matrix excavated from the trenches and units was screened using $0.64 \mathrm{~cm}$ (0.25 in.) hardware mesh. When it appeared that there were no small artifacts present, the screen size was changed to $1.27 \mathrm{~cm}$ (0.5 in.) mesh.

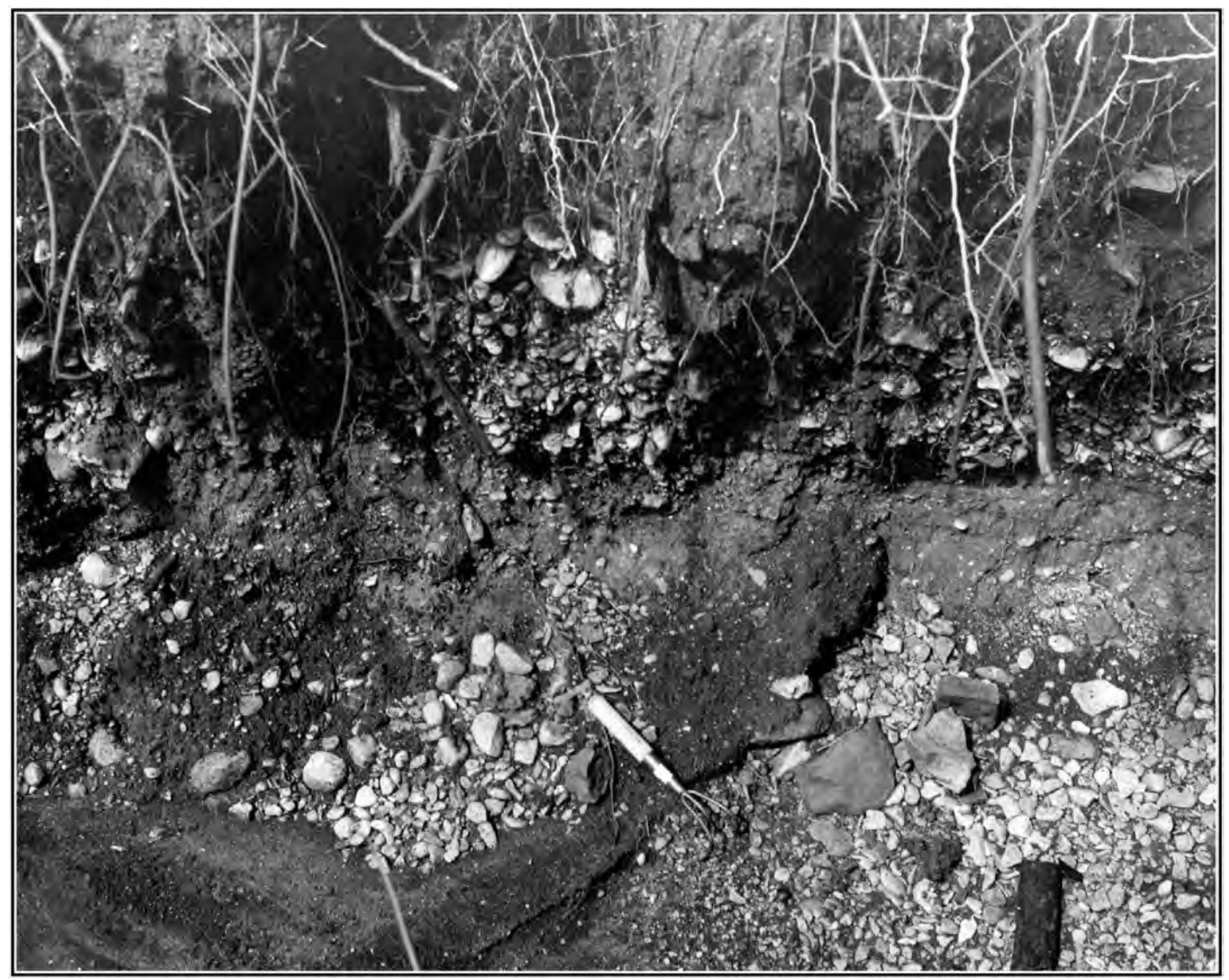

Figure 4-6. Trench at Granberg I showing possible midden, 1962. 


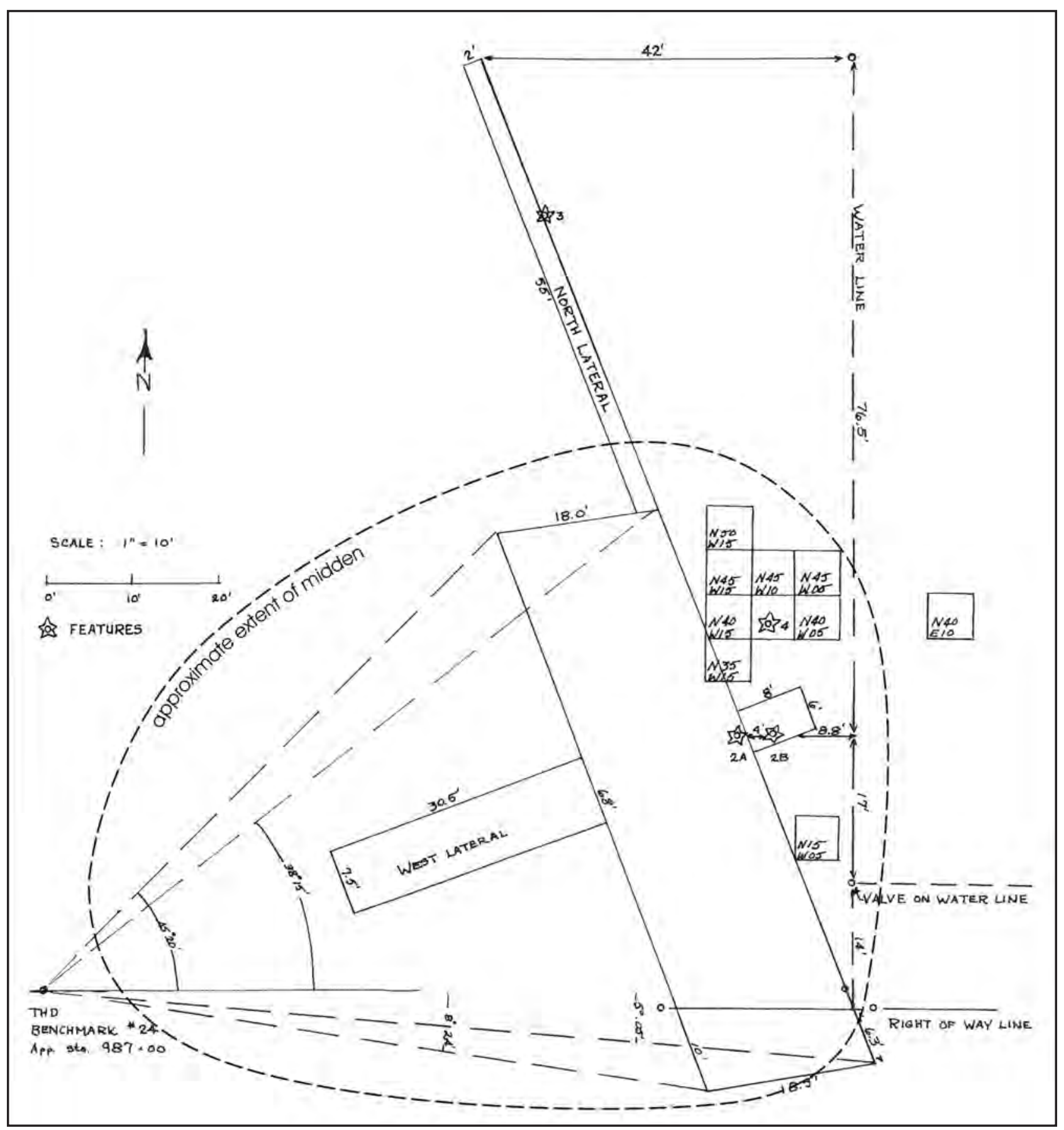

Figure 4-7. Granberg I (41BX17) showing location of midden and excavation units.

Schuetz recorded two general strata: an upper humic zone and a lower burned rock and "midden" fill zone (Figure 4-8). Below the midden fill layer, Schuetz noted a "red alluvial gravel" zone that was essentially sterile. The upper zone contained over fifty dart points from the Terminal Late Archaic (e.g., Ensor, Edgewood, Shumla), Middle Late Archaic (e.g., Castroville, Montell, Williams), and Early Late Archaic (e.g., Pedernales, Bulverde, Langtry). The lower zone contained over sixty dart points from the Middle Archaic (e.g., Nolan and Travis, $\mathrm{n}=21$, $32 \%$ ) and Early Late Archaic (e.g., Pedernales, Bulverde, Kinney, Langtry, Marshall, Lange, and Castroville). In addition to the points recovered from the controlled excavations, Schuetz reports a variety of other points either associated with the trenching or presented for identification as a result of the public dig. These appear to reflect the same general temporal range as seen in the controlled excavation, with the exception of the recovery of six 


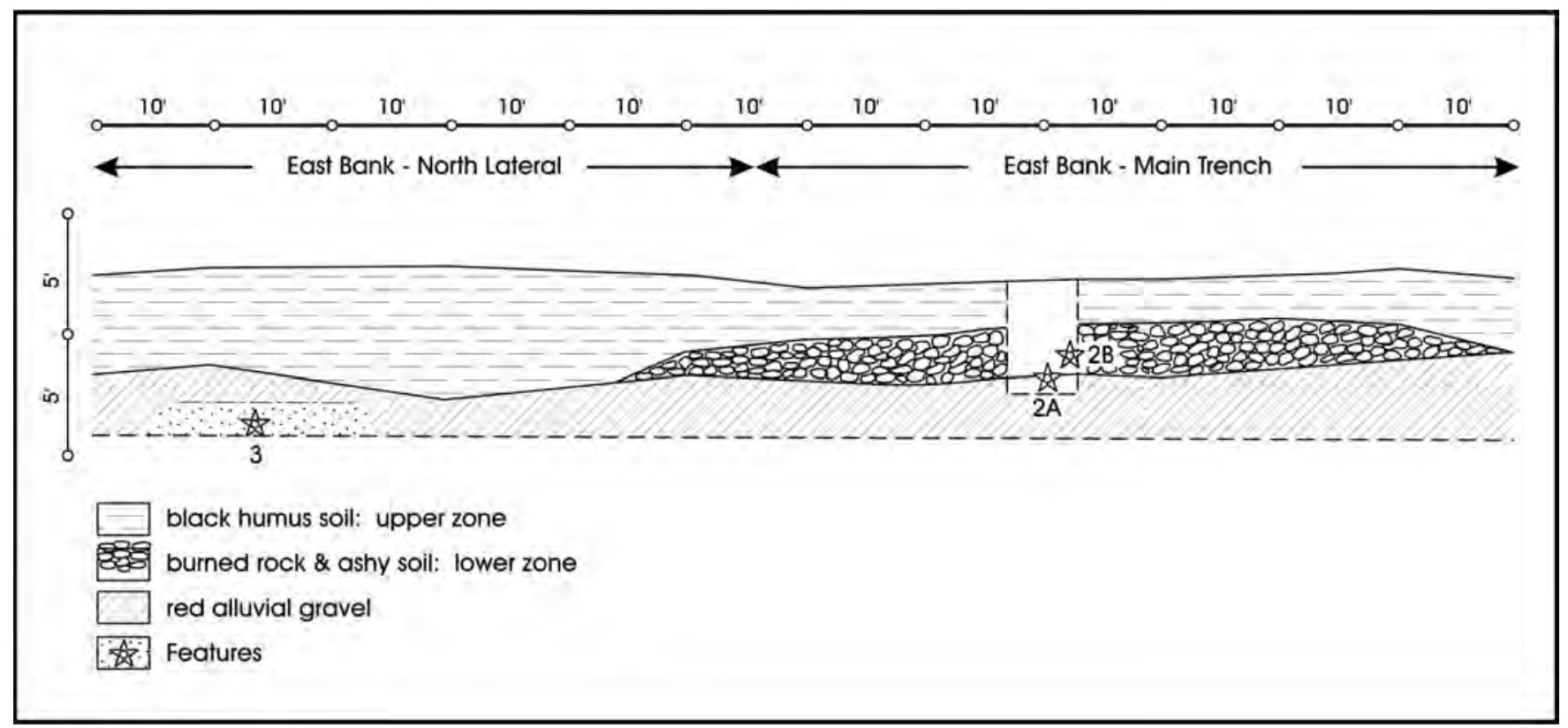

Figure 4-8. Profile for trench as illustrated by Schuetz.

Late Prehistoric points, several of which appear to be Edwards in form. No provenience is available for these arrow points. Varieties of other stone tools were also found in both zones including bifaces, unifaces, scrapers, hand axes, cores, and drills. Faunal material included both deer and bison bone fragments in both the upper and lower zones. (Schuetz 1966).

The excavations uncovered five features including hearths and burials. Feature 1 is the burial identified by Kohnitz in the first utility trench excavation. None of the materials from this feature were returned to the Witte Museum after excavation and the locations of the burials were not recorded (Schuetz 1966). In the spring of 2007 Mark Kohnitz donated the remains from Feature 1 to the CAR (see Appendices H, I, and J for a discussion and details of this donation). A double burial (Feature 2A) and an additional burial (Feature 2B) were located southeast of the water main trench. These were damaged by the construction as well as root action and the pressure of overlying rock. Feature 3 was a limestone slab hearth located 1.5 $\mathrm{m}(5 \mathrm{ft}$.) below ground surface during the excavation of the north lateral trench. Feature 4 was a fire pit encountered in one of the grid units and Feature 5 was another burial found one year later, $0.6 \mathrm{~m}$ (2 $\mathrm{ft}$.) below surface, approximately 15 to $23 \mathrm{~m}$ (50 to $75 \mathrm{ft}$.) southwest of the previously recorded midden (Schuetz 1966).

\section{STAA 1973-1974 Excavations at Granberg II (41BX271)}

In 1973 more artifacts were revealed when the City of San Antonio returned to the area to install a sewer line along the ROW of N.E. Loop 410. This discovery prompted the STAA to commence excavations that continued into 1974 (Córdova et al. 2005). Because a site report was not produced, details of the excavations remain unknown. Thomas Hester holds the field documentation, maps, most of the diagnostic artifacts, bone, and $\mathrm{C} 14$ samples from this excavation. Hester would not release any of the project materials to the CAR during any stage of the records assessment (2005) or significance testing project (2006). Dr. Hester plans to publish the data associated with the 1973-1974 STAA excavation in addition to data from the 1979 excavations also conducted under his direction (see next section). However, two brief articles, Hester (1980) and Hester and Kohnitz (1975), provide some insight into the STAA findings. The CAR retains copies of two brief student manuscripts, Kelly (1975) and Griffin (n.d.), and some artifacts including debitage, bifaces, unifaces, a few projectile points, cores, snails, burned rock, and small quantities of bone. Additionally, the 2007 Kohnitz skeletal donation (see Appendix $\mathrm{H}$ ) included rough sketch maps of the 1973-1974 excavations.

Based on the curation records referencing the Granberg II artifacts held by the CAR, the Kohnitz maps, and personal communication with Tom Hester, it appears that the STAA hand-excavated 26 units to depths of up to $3.7 \mathrm{~m}$ (12 ft.) below surface (Figure 4-9). Some units measured 1.5-x-1.5-m and were excavated in $15 \mathrm{~cm}$ (6 in.) and $61 \mathrm{~cm}$ (24 in.) levels. A description of the stratigraphy is included in Hester (1980) and Hester and Kohnitz (1975; Figure 4-10). The stratigraphy is similar to Schuetz's (1966) findings but described in greater detail. The upper $55 \mathrm{~cm}$ of the deposits included two strata consisting of recent fill (Stratum I) and a burned rock midden (Stratum II). Projectile points associated with the burned rock midden included Late Archaic point forms such as Montell and Pedernales (Hester and Kohnitz 1975). 


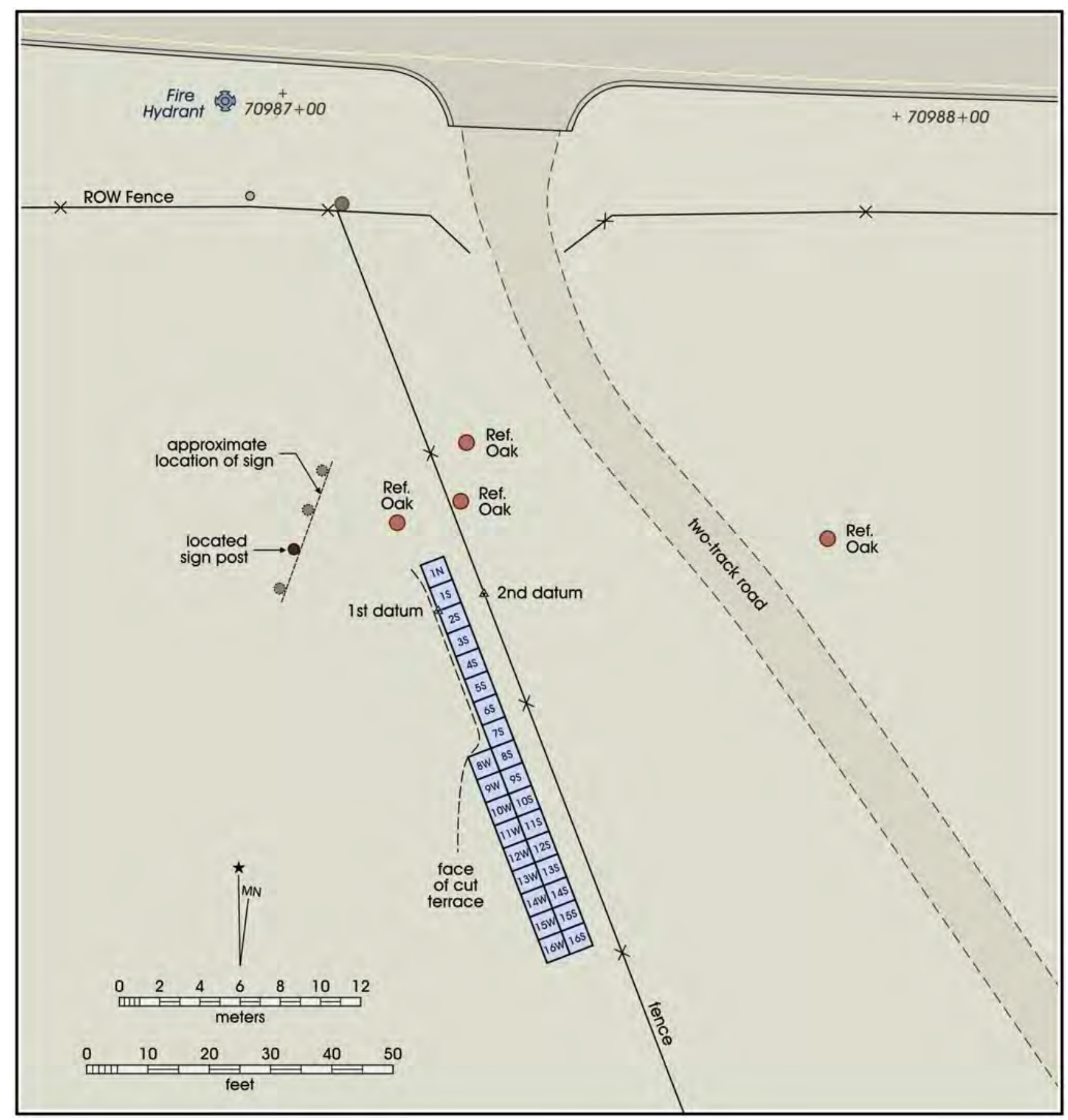

Figure 4-9. Map of 41BX271 adapted from H. Kohnitz sketch, 1973.

Hester and Kohnitz (1975) describe a thick transitional stratum (III) of burned rock and ash-stained midden soil containing Pedernales points above alluvial gravel deposits that extended from an average of $60 \mathrm{~cm}$ to $360 \mathrm{~cm}$. These gravel deposits were separated into eight additional strata of alternating gravel and sand. Stratum IV consisted of small gravels in a yellow-red clay matrix containing diagnostic artifacts including Bell, Early Corner Notched, Early Triangular, and Gower points; Clear Fork and Guadalupe tools; cores; and lithic debitage. Stratum V also contained coarse gravels deposited above Strata VI and VII, both made up of fine sand and gravel deposits. Stratum VIII was a compact, charcoal-stained, distinctive surface exposed at 2.45 meters that contained lithics, snail shell, burned rocks, and Guadalupe tools. Below the surface, additional layers of sand and gravel were exposed. The deepest excavated deposit, Stratum XI, contained large, heavy gravels and one core (Hester and Kohnitz 1975). 


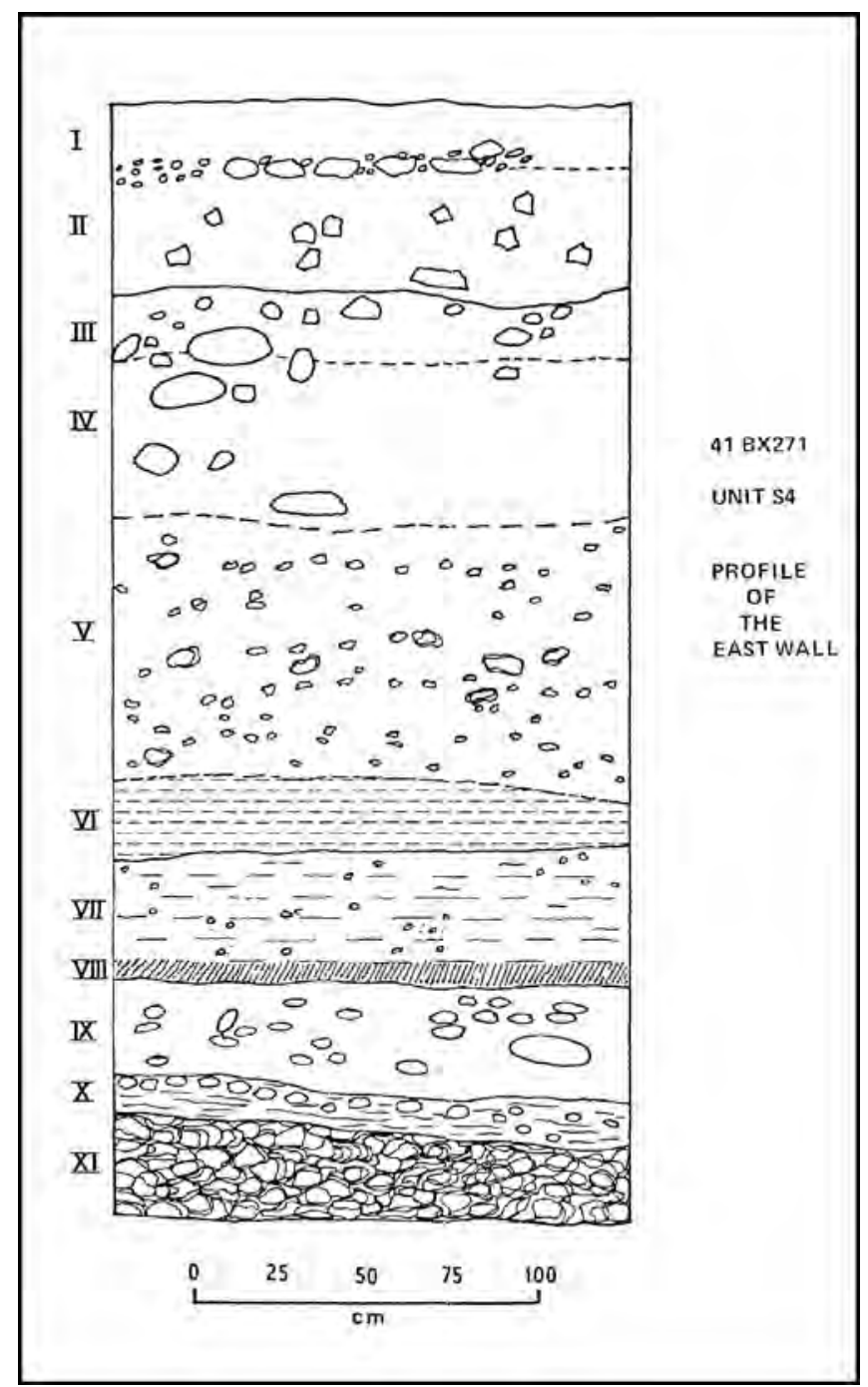

Figure 4-10. Stratigraphy of $41 B X 271$ as defined by Hester and Kohnitz (1975).

\section{UTSA Field School at Granberg II (41BX271)}

In 1979 a UTSA field school directed by Thomas Hester continued work at the Granberg II Site to further target the archaic deposits uncovered in 1973-1974. No site report of the excavations is currently available but three student papers are archived at the CAR and discuss the excavation strategy (Markey 1979), the debitage (Jones et al. 1979), and the gastropod assemblage (Galin 1979). The following paragraphs summarize these papers.

Field school students excavated four 2-x-2-m blocks consisting of $161-\mathrm{x}-1-\mathrm{m}$ test units in $15 \mathrm{~cm}$ levels (Figures 4-11 and 4-12). Based on an examination of artifacts housed at the CAR (primarily debitage) and a review of the student papers, Córdova et al. (2005) determined that some of the field school excavations reached terminal depths of $285 \mathrm{~cm}$ below surface (cmbs). Terminal depth appeared to vary from unit to unit. It appears that the NW and SW quadrants of Unit A were excavated to a terminal depth of at least $210 \mathrm{cmbs}$, with the SE and NE quadrants terminating at $150 \mathrm{cmbs}$. The NE and NW quadrants of Unit C were terminated at 90 cmbs, with the SE and SW excavated to $105 \mathrm{cmbs}$. In Unit $\mathrm{D}$, the NE and NW quadrants were excavated to $195 \mathrm{cmbs}$, with the SE quadrant terminating at $165 \mathrm{cmbs}$, and the SW quadrant terminating at $150 \mathrm{cmbs}$. Finally, it appears that all four quadrants of Unit B were initially excavated to a depth of about $150 \mathrm{cmbs}$. From that point, the excavation of Unit B continued down to at least $285 \mathrm{cmbs}$ (Markey 1979), although artifacts within the CAR collections are recorded as coming from as deep as Level 21, a depth that would translate into a maximum depth of $310 \mathrm{cmbs}$. Markey (1979) notes that "the walls of unit B were sloped to help prevent any cave-in and the bottom of the unit measured $1 \mathrm{~m}^{2}$ rather than the 2 $\mathrm{m}^{2}$ we began with..." Figure $4-13$ presents a profile of the east wall of Unit B, taken from Markey (1979). Using the scale provided by Markey, the terminal depth appears to be roughly $320 \mathrm{cmbs}$. However, the same scale suggests that the east wall was roughly $140 \mathrm{~cm}$ in width, rather than $100 \mathrm{~cm}$ (Córdova et al. 2005). Because of conflicting documentation among the three reports, drawings, and artifact inventories, resolution of provenience was complicated.

Markey's profile (Figure 4-13) details stratigraphy that is similar to the stratigraphy reported in the 1973-1974 work, although precise correlations are difficult to make (Córdova et al. 2005). Markey (1979) describes Stratum I as a grayish brown loamy soil with a high organic content containing projectile points characteristic of the Late Archaic, including Ensor, Castroville, and Fairland. Stratum II is presented as a "burned rock midden" with gray to black midden soil and abundant fire-cracked rock. Markey reported that the gravels at the base of this stratum were rounded and reflect flood deposits. Stratum III was largely the same deposit as Stratum II, but lacked the organic staining characteristic of midden deposits. Markey noted that a radiocarbon sample (TX 3603) was recovered from Unit D from Stratum III at $70 \mathrm{cmbs}$, however, the radiocarbon specimen sheet recorded the sample number as TX 3606 and the location as the northwest quadrant of Unit A. Provenience issues aside, the sample returned an uncorrected date of $4770+/-110$ years $\mathrm{BP}$, calibrated to $3650-3370 \mathrm{BC}$ using the Oxcal calibration program (Ramsey 2003). The radiocarbon sample was reported in association with a Bell projectile point. Turner and Hester (1999) note that Bell projectile points range from 6000 to $3500 \mathrm{BC}$, though Collins (1995) suggests a more restricted temporal range of roughly 4000 to $3000 \mathrm{BC}$ Markey mentioned several additional diagnostic projectile 


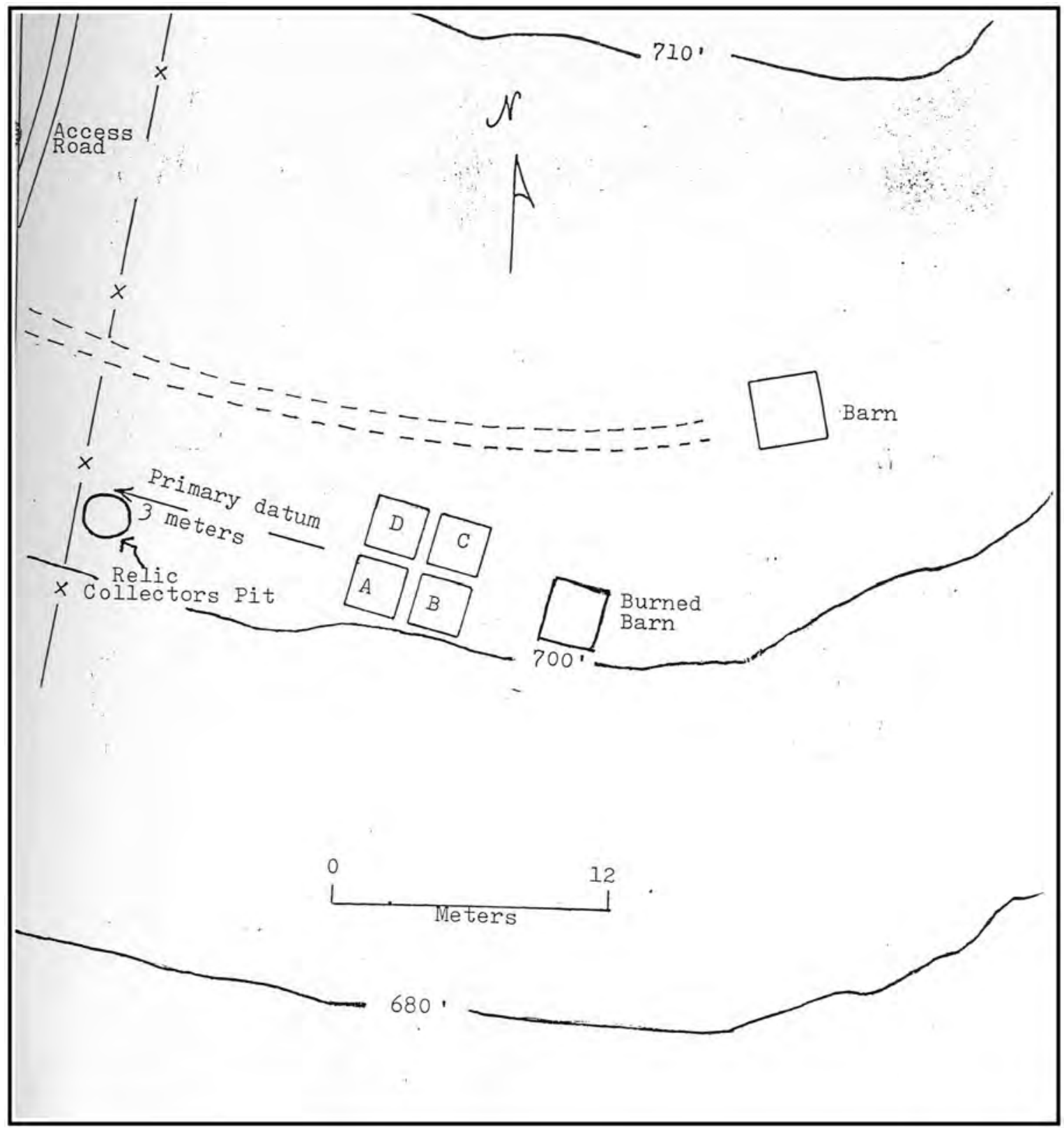

Figure 4-11. Map of 41BX271 drawn by Betty Markey in 1979.

points from the Strata II and III interface, including two Early Triangular and two Early Corner Notched forms. Although artifacts continued throughout the deposits, no temporally diagnostic artifacts are mentioned below Stratum III. Stratum IV is described as a sandy yellowish brown deposit, while Stratum V was dominated by medium-coarse gravels intermixed with lenses of sand and clay. Stratum VI was sand with small, fine gravels while Stratum VII consisted of a compact layer of coarse gravels and cobbles, some of which range up to $25 \mathrm{~cm}$ in maximum diameter (Markey 1979). The 1979 work does not mention the "living floor" identified by Hester in the 1973-1974 work as Stratum VIII.
Artifact bags from the 1979 field school reference features. Feature 2 appears to have been in Unit D. There is also a reference to F7 which may be Feature 7. No information is available documenting these features (Córdova et al. 2005).

\section{Records Assessment of the Granberg Site}

From January to July 2005, the CAR conducted a review of all available collections and records associated with sites 41BX17 and 41BX271 (Córdova et al. 2005). The purpose of the assessment was to find all available data pertaining to the Granberg Site in order to make an informed decision 


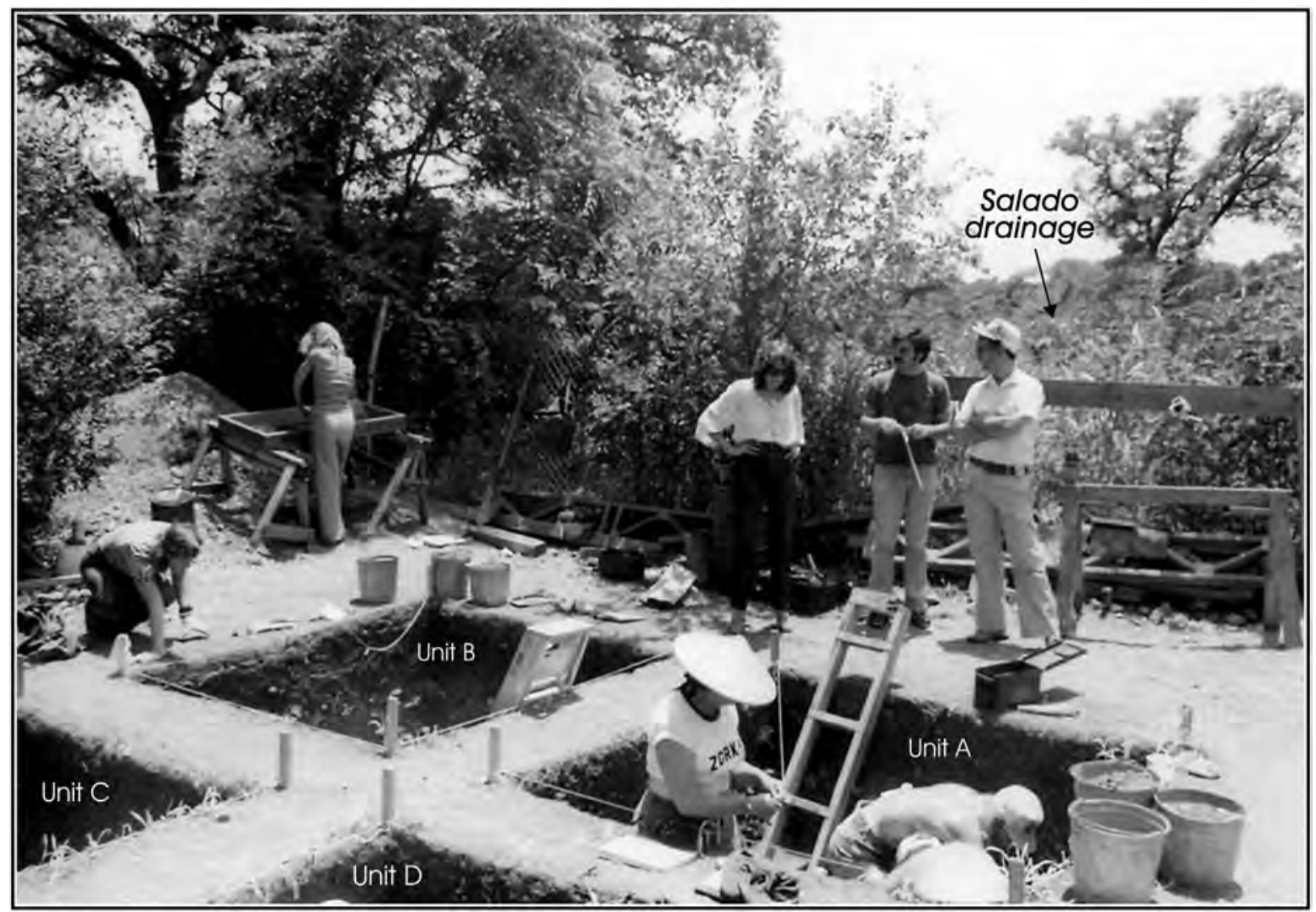

Figure 4-12. Field school students excavating 41BX17 in 1979.

about the management of sites that were in immediate danger of impact by road construction. Museum collections and curation repository collections were thoroughly investigated and persons associated with the various excavation projects were contacted. Personnel from the CAR visited 41BX17 and $41 \mathrm{BX} 271$ to inspect site condition and aid in the reconstruction of site boundaries.

Documentation was compiled from the Texas Archeological Research Laboratory (TARL), the CAR, the Witte Museum, and former UTSA staff and students. Inventories were created of Granberg artifacts housed at the Witte Museum and the CAR, and of those specimens on loan to Thomas Hester (the loaned specimens were not available for study). Collections housed at the Witte included skeletal remains consisting of at least eight individuals. All artifacts that were available for study were reviewed and a selection scanned.

Based on the artifacts and documentation, the CAR redrew the site boundaries, and attempted to plot all previous excavation units, features, and burials (Figure 4-14). The data from 41BX17 and 41BX271 suggest that the deposits probably represent a single site, some of which remained under the ROW of N.E. Loop 410 East. The deposits, primarily within the upper $90 \mathrm{~cm}$ of the site, likely occurred principally during the Middle Archaic and Late Archaic periods. A single radiocarbon date (1979 excavation) from a depth of $70 \mathrm{cmbs}$ dates to the Middle Archaic period.

Córdova et al. (2005) reported that the deposits remaining within the ROW, between the surface and approximately 105 $\mathrm{cm}$ below ground surface, likely retained integrity and were expected to yield a variety of data sets, including features, chipped stone tools, lithic debitage, charcoal, and faunal and ethnobotanical remains. Córdova concluded that these data sets could yield significant information on both the Late Archaic and Middle Archaic periods in South-Central Texas. The results of this archival research prompted Phase II Significance Testing at the Granberg Site in early 2006.

\section{Pedestrian Survey of the Salado Creek Greenway}

The most recent professional excavations of the Granberg Site occurred in 2007, when the CAR completed an intensive pedestrian survey for the installation of a portion of the Salado Creek Greenways Hike and Bike trail system for the City of San Antonio (Munoz 2008). A proposed trailhead/ parking lot for a section of the hike and bike was planned for 


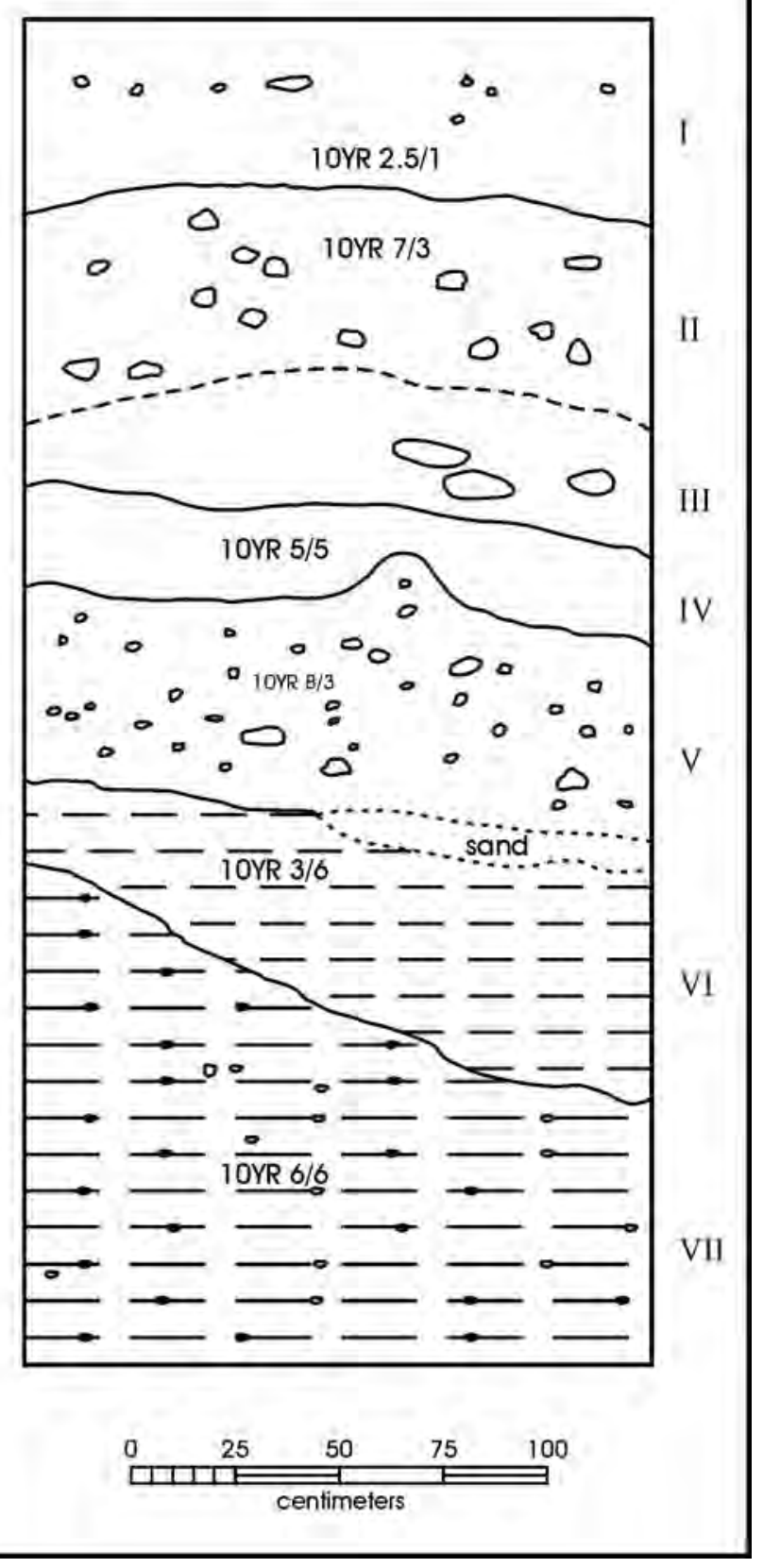

Figure 4-13. Profile of Unit B, east wall.

the western portion of the Granberg Site immediately south of the east bound N.E. Loop 410 access road (Figure 4-15).

The archeological investigation of the trailhead consisted of a pedestrian survey accompanied by shovel testing and the mechanical excavation of three backhoe trenches (BHT, Munoz 2008). No artifacts were noted on the surface. Shovel testing of this area resulted in the excavation of construction fill reaching a minimum of $60 \mathrm{cmbs}$. Based on the results of the shovel tests, three backhoe trenches were excavated to expose stratigraphic profiles and potential features, further define the depth of the fill, and to define the horizontal and vertical distribution of cultural materials remaining on the Granberg Site. Both BHT 2 and 3 revealed construction fill to $160 \mathrm{cmbs}$. BHT 1 consisted of fill to $100 \mathrm{cmbs}$ on the western end of the trench and to $50 \mathrm{cmbs}$ on the eastern end. Below the fill, intact sediments consisted of dark yellowish brown, firm, silty clay. Dark yellowish brown, loose, sandy loam alluvium was evident at the base of the trench, approximately 140-144 cmbs. No features or artifacts were identified in the walls of the trench but two specimens of debitage were observed in the backdirt (Munoz 2008).

\section{CAR-UTSA Significance Testing Excavations of the Granberg Site}

Significance testing was conducted for TxDOT in advance of road construction along N.E. Loop 410. The CAR designed the archeological testing specifically to delineate site boundaries within the ROW, evaluate the integrity, depth, and nature of the deposits at the site, and to conduct the requisite analytical and interpretive investigations necessary to assess the site's National Register of Historic Places and State Archeological Landmark eligibility status. The fieldwork was conducted in 2006 under the direction of Jennifer L. Thompson.

\section{Field Work at 41BX17/271}

Although Córdova et al. (2005) suggested that sites 41BX17 and 41BX271 represent a single site extending an unknown distance to the south of Loop 410, the CAR's 2006 excavations remained within the current ROW, which includes the area between the eastbound Loop 410 lanes and the overhead power lines south of the access road. Utility poles, buried utility lines, and road construction have impacted the project area. In the document review (Córdova et al. 2005), the CAR suggested that the area within the ROW could still contain intact Late Archaic and Middle Archaic deposits to a depth of at least 90 centimeters below surface (cmbs) including prehistoric human burials.

Excavations commenced with auger tests in January 2006 (Thompson 2006b). Excavation results confirmed Córdova's 2005 assessment that portions of the site within the ROW remained intact. These deposits were much deeper than Córdova estimated with several layers of road fill covering the original ground surface. Though our methodology changed during the course of this project as we received information, the CAR employed traditional field methods in order to address some of our specific concerns. We employed mechanical augers, backhoes, and hand excavation to address 


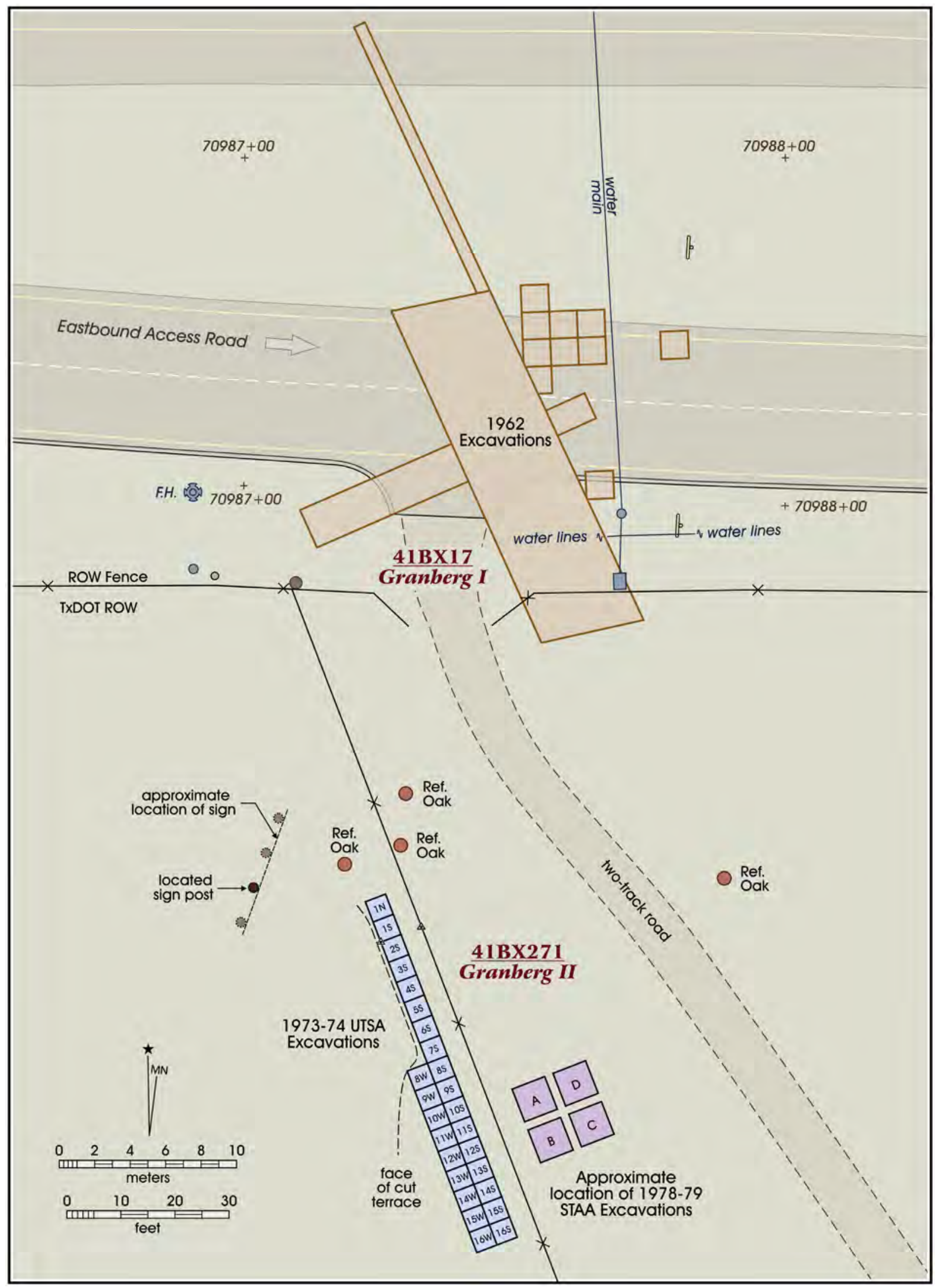

Figure 4-14. Sites $41 B X 17$ and $41 B X 271$ showing previous excavations and known improvements along Loop 410. 


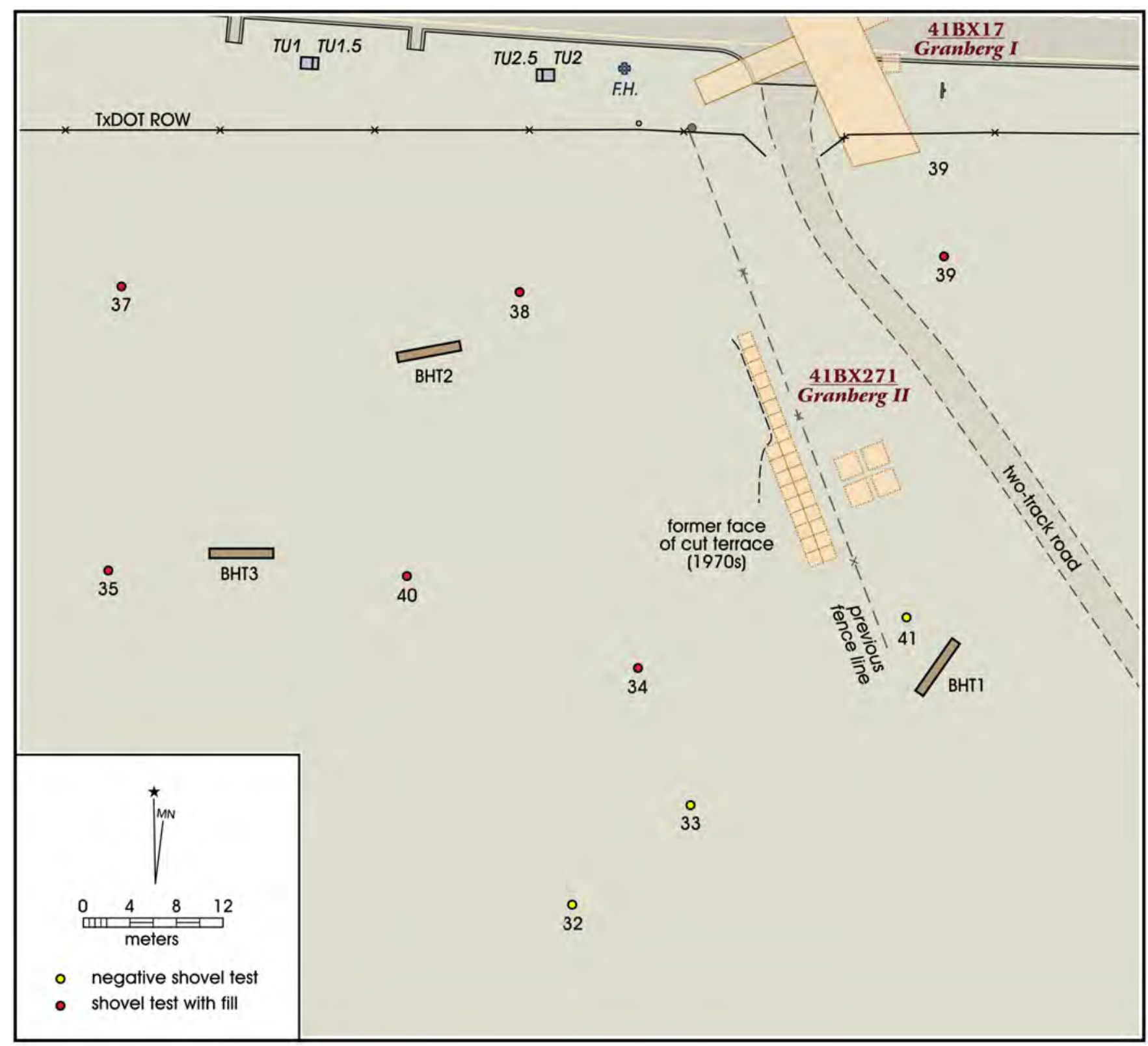

Figure 4-15. Location of testing in the vicinity of the trail head/parking lot to be constructed on the Granberg Site.

the location of the site boundary, the location of any human remains, the depth and content of Late and Middle Archaic deposits, and the NRHP eligibility. Excavations included 68 mechanical auger tests, $161-\mathrm{x}-1-\mathrm{m}$ hand-excavated test units within 4 excavation areas, 9 backhoe trenches, and a geomorphic analysis. Auger tests were excavated to $150 \mathrm{cmbs}$ to identify horizontal artifact concentrations and define the general vertical distribution of buried archeological deposits. The results of these auger tests helped determine the placement of test units. Backhoe trenches exposed long profiles for geomorphic documentation of the Salado Creek stream terrace and site boundary delineation. Within these trenches, the CAR identified Late and Middle Archaic cultural-bearing strata extending to $3 \mathrm{~m}$ below surface (mbs). For a more controlled examination of the vertical extent of artifacts, 16 1-x-1-m test units were excavated after mechanically removing the upper 80-100 $\mathrm{cm}$ of modern fill (Figure 4-16). The depths of these units spanned approximately 0.8 to $3 \mathrm{mbs}$ (Thompson 2006b). Intact prehistoric features were exposed to the extent necessary for sampling and characterization. Field excavation methods included excavation in $10-\mathrm{cm}$ levels, pedestalling, plan view illustration, and photography. When available, a 2.0-liter soil sample was collected from within the boundaries of each feature. All burned or firecracked rock was collected from burned rock features with some specimens reserved for potential lipid analysis. 


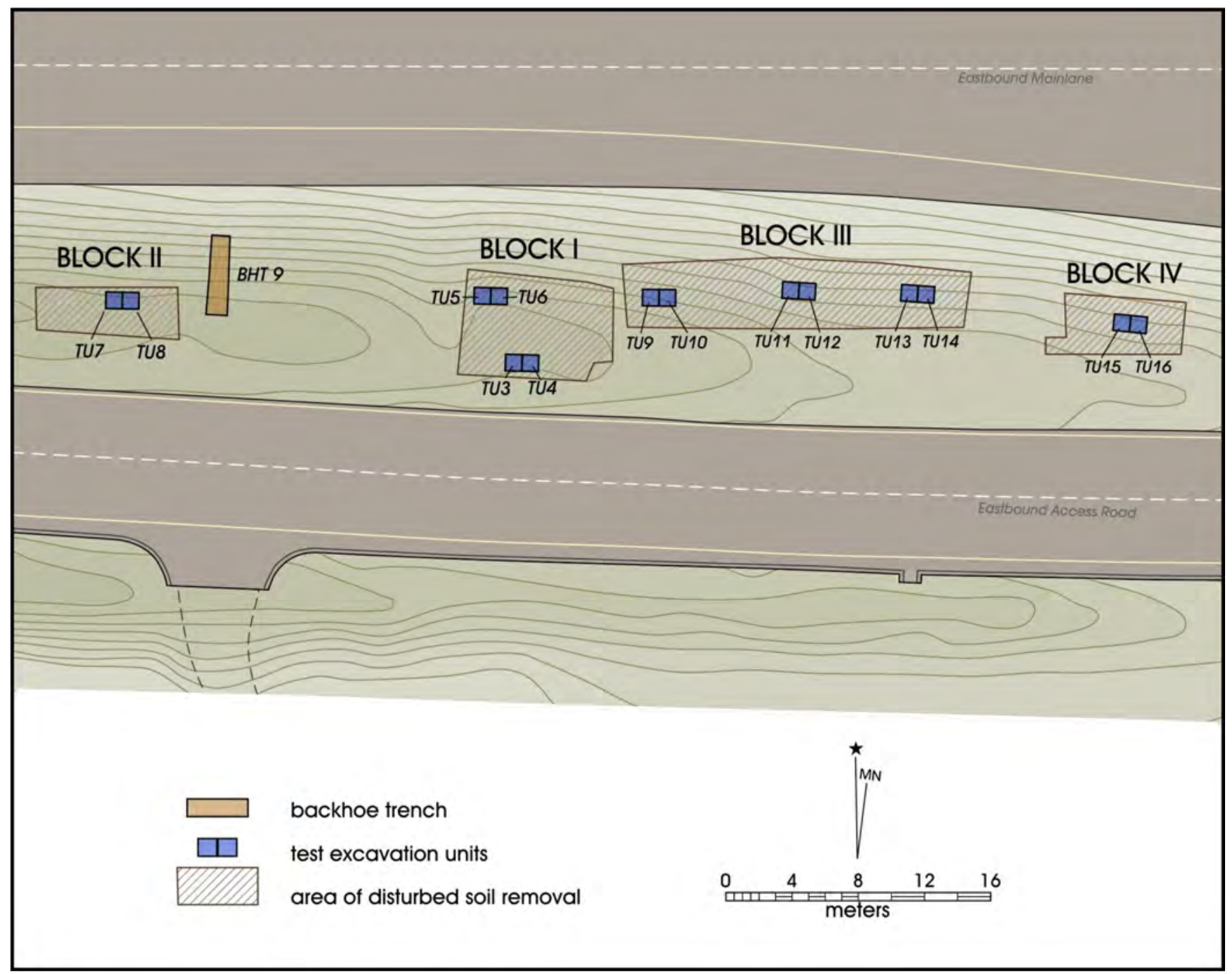

Figure 4-16. Location of areas of concentrated excavation of 41 BX17 (Blocks I-IV).

Radiocarbon dates and preliminary artifact analysis suggest that prehistoric human occupation at the Granberg Site spanned 3000 years from the Middle Archaic to the Late Archaic. Temporally diagnostic material recovered in test unit excavations included 29 Middle and Late Archaic projectile points (Thompson 2006b). Prehistoric features uncovered by Thompson (2006b) included seven hearths, one burned rock cluster, and one burned rock midden. Schuetz (1966) previously documented the burned rock midden. Three of the hearth features contained charcoal samples that returned radiocarbon dates falling within the Late Archaic. A fourth burned rock feature returned a date from the Middle Archaic. The remaining features were dated according to associated artifacts and proximity to dated materials or features. No historic material was found below the mechanically removed modern zones. Thompson (2006b) concluded that the excavations at the Granberg Site revealed what appeared to be an intact archeological deposit, including 10 thermal features extending below the roadbed up to $3.05 \mathrm{~m}(10 \mathrm{ft}$.) below the current ground surface.
During block excavation, the site was vandalized at least two times. Looters did the most damage to Feature 106 but also destroyed archeological deposits in the test units of Block I and Block II. Personnel from the CAR staff drove out to the project several times during late evening hours hoping to spot the individual(s) responsible. UTSA also filed a police report on the issue. Because of delays in getting a contract supplemental in place to cover the cost of security, the site continued to be potted well after the first notification by CAR. Upon initiation of the contract supplemental the TxDOT paid for the hiring of outside contractor site security (the UTSA Police Department).

In the opinion of the CAR the excavations revealed what appears to be an intact archeological deposit, including 10 thermal features extending below the roadbed up to $3.05 \mathrm{~m}$ (10 ft.) below the current ground surface. Over 12,000 pieces of debitage and 200 tools were roughly sorted for the interim significance excavation report. 


\section{Auger Test Excavation}

Auger tests were excavated to determine the horizontal limits of artifact distribution and the depth of disturbances across the median. Placement of handexcavated test units were based on auger test results. The CAR excavated 68 auger tests within the median between the eastbound access road and the main lanes of Loop 410 (Figure 4-17). In general, auger tests (ATs) were $30.5 \mathrm{~cm}$ (12 in.) in diameter and were excavated to $150 \mathrm{cmbs}$ or until they reached an impenetrable level. Underlying road base, compacted clay, and gravel deposits prevented the mechanical auger from reaching the target depth in some instances. Auger tests were placed on a $5.0-\mathrm{m}$ grid with three rows of 14 tests offset by two rows of 13 tests across the median (Figure 4-18). To avoid potential impact to three buried water lines systematic auger tests in the shoulder of the access road were cancelled and with TxDOT-ENV concurrence replaced with two hand-excavated test units (TUs 1 and 2). To assess the depth of disturbance in the

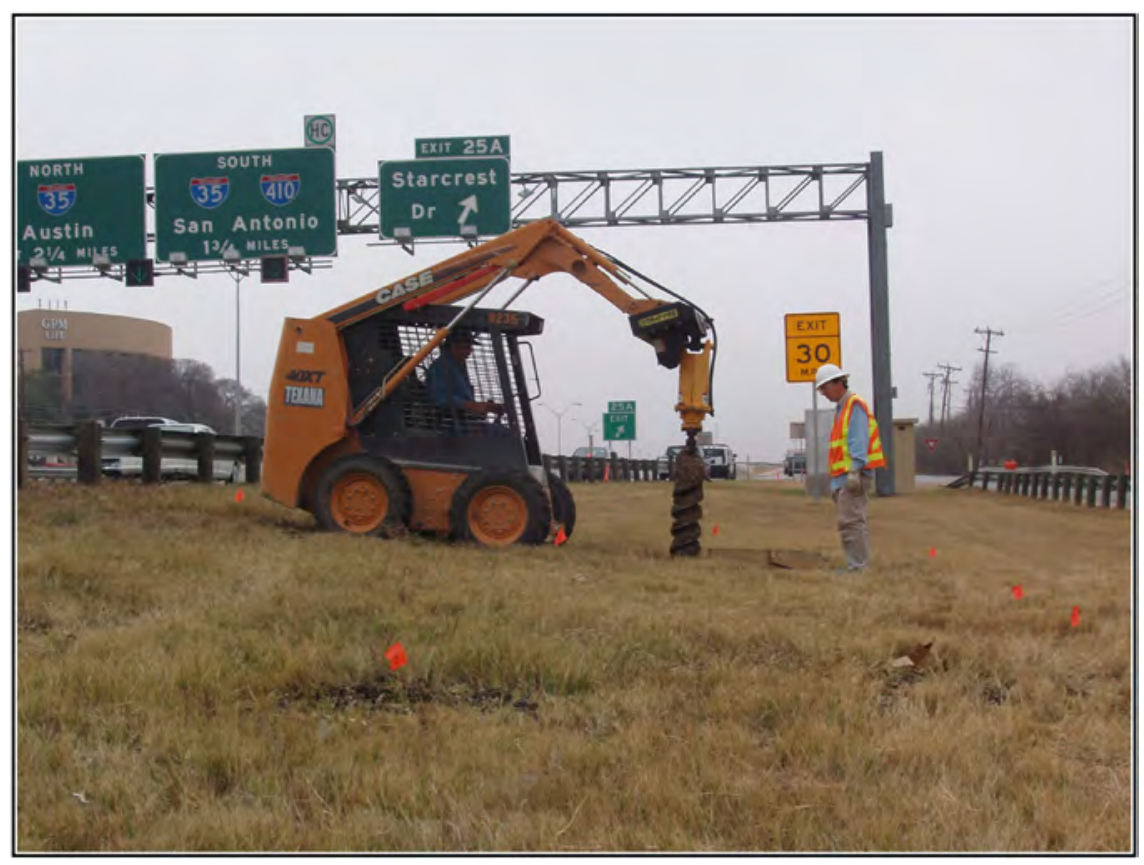

Figure 4-17. Auger testing in the median at the Granberg Site.

shoulder, one auger bore was placed within one of the two test units at its terminal depth $(110 \mathrm{cmbs})$. These test units are discussed in a following section.

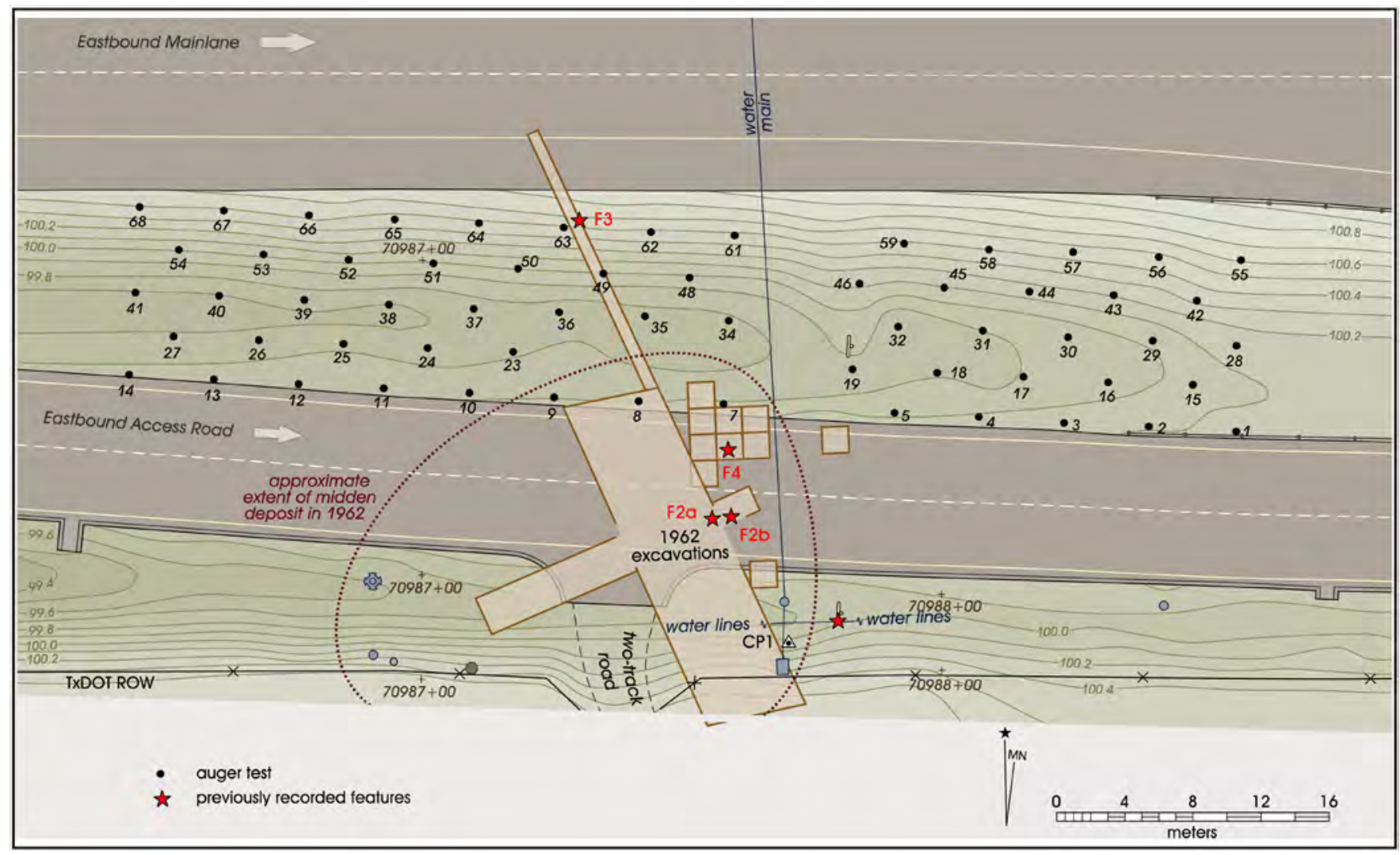

Figure 4-18. Site map showing the location of recently excavated auger tests in proximity to previous excavations. 
Auger tests west of the water line revealed highly disturbed deposits with modern materials and road base fill present to varying depths, some up to $100 \mathrm{cmbs}$ (Figure 4-18). The northern line of auger tests (ATs 55-59 and 61-68) adjacent to the main lane produced only road fill materials. These auger tests likely did not reach the cultural deposits due to the amount of overburden adjacent to the main lanes of the highway. Two of the auger tests excavated immediately adjacent to the access road (ATs 4 and 5) were positive. Auger Test 4 contained burned rock and charcoal (120$135 \mathrm{cmbs}$ ) under construction fill. One unidentifiable bone fragment was recovered in disturbed context from AT 5 (120-150 cmbs). Cultural material was recovered in seemingly undisturbed context from ATs 18, 19, 32, 36, 37, 45, and 46. Auger Test 18 returned fire-cracked rock and a possible ash lens. Auger Tests 1, 3, 8, 15, 16, 28 and 29 were impenetrable at varying depths from 40 to $120 \mathrm{cmbs}$ due to roadbed materials and compact clays.

Results of the auger testing suggested that a large concentration of intact deposits was likely present in a 5-x-5-m area, approximately $75-80 \mathrm{cmbs}$, immediately east of the water main. In addition, smaller pockets of possibly intact cultural deposits appeared present approximately 90 $\mathrm{cmbs}$ in a 2.5-x-5-m area west of the water main.

Auger tests revealed that the depth of disturbance from road construction varied within the project area as the engineered topography of the median changed. The depth of disturbance was much deeper along the northern row of auger tests adjacent to the main lanes than in the tests placed in the center of the median since more road fill was required to raise the elevation of the main lanes. Elevations at the center of the median were lower to facilitate drainage. Because the engineered topography caused starting elevations to vary, some auger tests could not reach intact materials below the road base. Because ground surface along the main lanes is approximately $80 \mathrm{~cm}$ higher than ground surface in the center of the median, intact archeological deposits were further below the surface near the main lanes.

\section{Backhoe Trench Excavation}

Nine backhoe trenches (BHT; 1.0-2.5 m wide) were excavated to aid in the delineation of site boundaries and site formation analysis (Figure 4-19). A backhoe with a smooth bucket excavated these in 10-cm levels until uncovering the red, alluvial gravels described in the Schuetz (1966) profile. Because the site sits in the Salado Creek floodplain, these gravels were located as deep as $3.0 \mathrm{mbs}$. A geologist examined all trenches to determine site formation and preservation status. His findings are presented in Chapter 6.

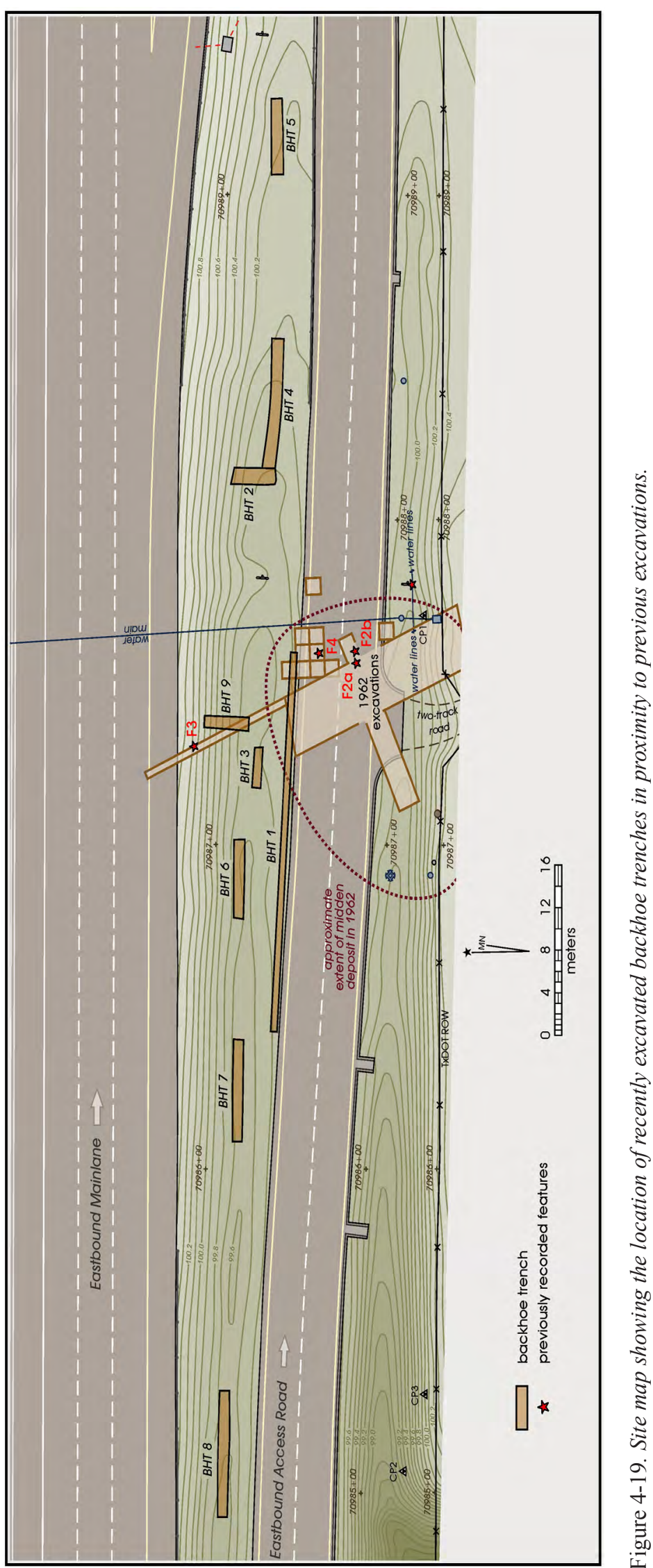


Backhoe Trench 1 extended from AT 7 to AT 14. The trench contained a thick stratum of deep calcareous clayey soils in old alluvium (45-140 cmbs) beneath road base materials. The targeted red, alluvial gravels commenced at $140 \mathrm{cmbs}$. The clayey soil contained dense pockets of rock, likely representing the zone of burned rock seen elsewhere and documented in the Schuetz (1966) profile. The narrow width of this trench $(1.0 \mathrm{~m})$ made examination difficult; however, modern materials were noted within the upper meter of the trench.

To determine the depth of disturbance in areas slated for hand excavation (Blocks I and II, see next section) two backhoe trenches were excavated. Backhoe Trench 2 (5.0 $\mathrm{m}$ long and $3.7 \mathrm{~m}$ deep), was oriented north-south at the eastern edge of Block I and BHT $3(4.0 \mathrm{~m}$ long and 3.3 $\mathrm{m}$ deep) was oriented east-west along the southern edge of Block II. Backhoe Trench 2 revealed a thick midden deposit (150-280 cmbs) above a Middle Holocene overbank deposit and below modern fill and Late Holocene overbank deposits. Approximately $60 \mathrm{~cm}$ of the profile consisted of modern road base materials and fill. The modern flood deposit lies directly below the road construction. Backdirt from the 1962 excavation was evident in the profile as compact clay containing mixed modern and prehistoric artifacts below the modern flood deposit (Zone 5). Below the zone of backdirt lie alternating zones of silt, clay, sand, and gravel. Two lower gravel zones (7 and 8) separated Late Archaic (Zone 6) and Middle Archaic (Zone 9) cultural occupations, both dense with artifacts. The stratigraphy of BHT 2 is shown in Figure 4-20.

Backhoe Trench 3 uncovered approximately $1.9 \mathrm{~m}$ of modern road base materials and modern flood deposits. Burned rock and a midden deposit (Zone 5) were detected in the eastern wall of the trench, also evident in the eastern and northern walls of Block II. This zone is likely analogous to the burned rock, ashy soil drawn in the Schuetz's north lateral profile (see Figure 4-8). The targeted red alluvial gravels were relatively shallow in this trench.

Six additional backhoe trenches (BHTs 4-9) were excavated after block excavations began to delineate site boundaries within the median. Backhoe Trench 4, extending $12 \mathrm{~m}$ east from Block I, contained two zones ( 5 and 7 ) of intact cultural deposits separated by a gravel horizon, Zones 6 (Figure 4-21). Middle Archaic cultural deposits overlie Middle Holocene channel deposits (Zone 8). These cultural deposits are overlain with Late Holocene overbank deposits and backdirt from previous archeological excavations. Modern chute-channel deposits (Zone 2) overlie the backdirt (Zone 3). The trench was excavated to $2.75 \mathrm{mbs}$.

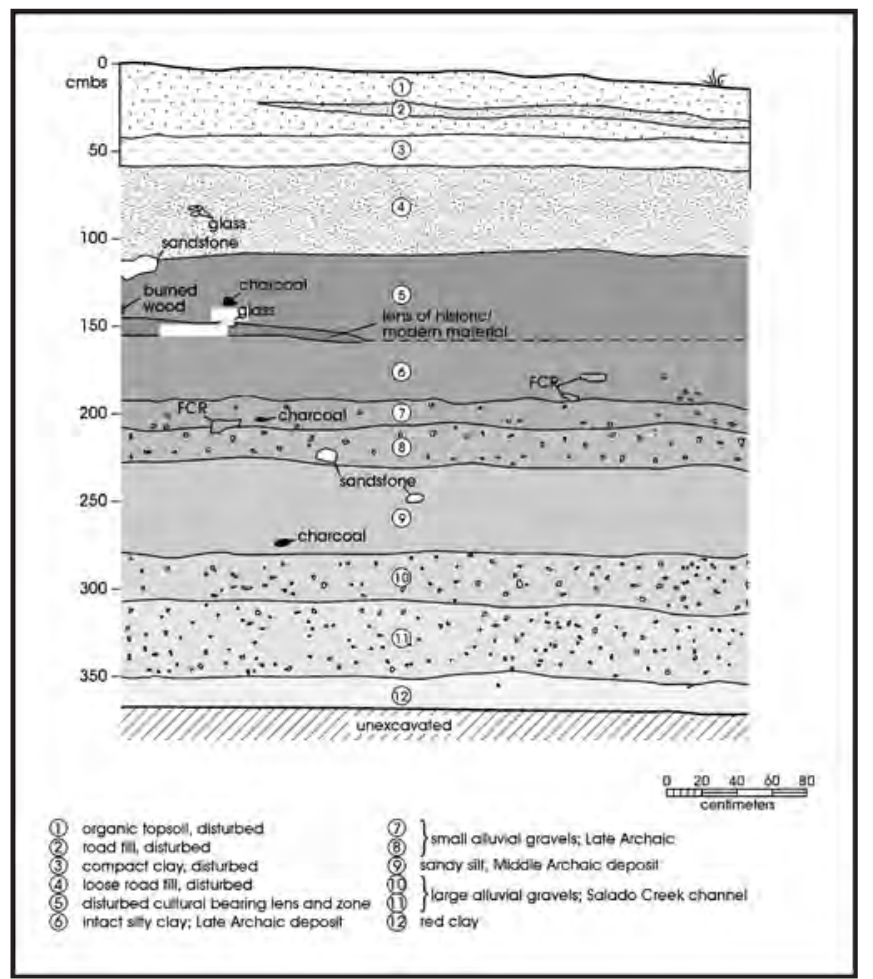

Figure 4-20. Profile of a segment of the east wall of Backhoe Trench 2.

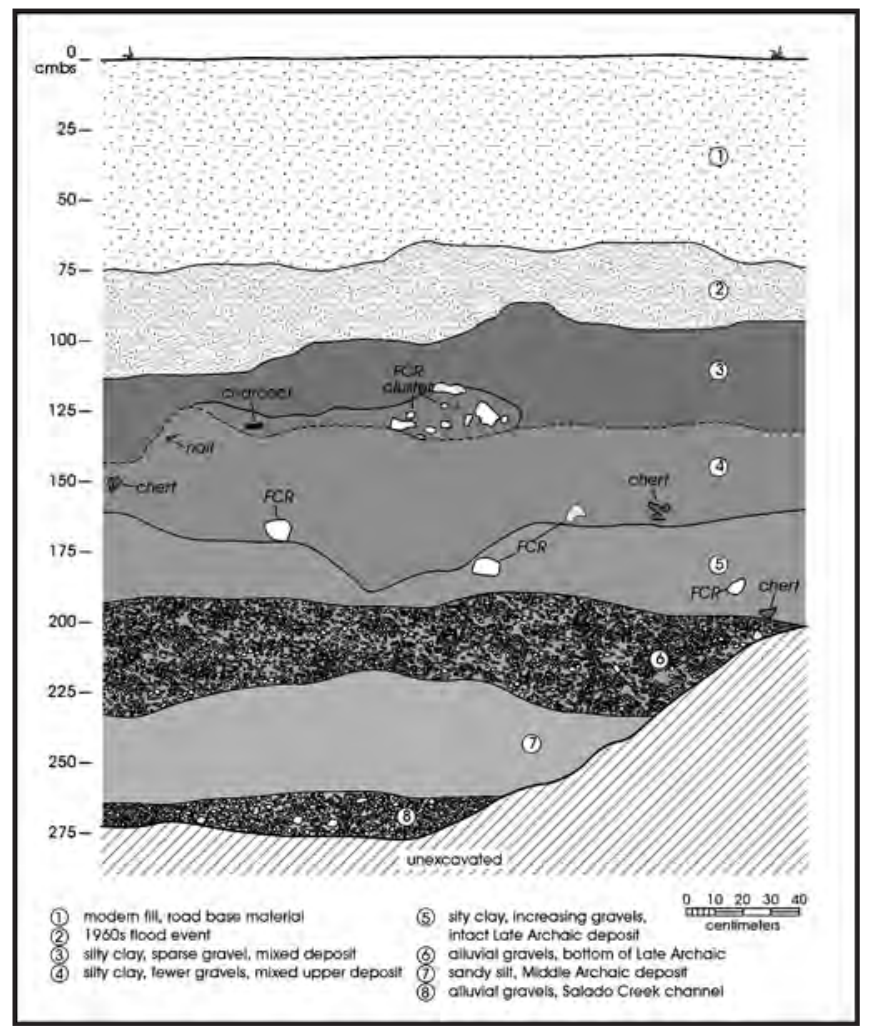

Figure 4-21. The south profile of Backhoe Trench 4 shows Middle and Late Archaic occupation zones between gravel deposits. 
The stratigraphy evident in BHTs 2, 3 and 4 was not seen in BHTs 5 (7 m, $2.59 \mathrm{mbs}), 6$ (7 m, $2.2 \mathrm{mbs}), 7$ (15 m, 2.0 $\mathrm{mbs})$, or 8 (11 m, $2.43 \mathrm{mbs})$. Backhoe Trench 5 consisted of construction and modern fill over a modern overbank deposit. These zones were above modern fill, a Holocene overbank, colluvial deposits, and finally a Holocene channel deposit. Backhoe Trench 6 (Figure 4-22) contained modern fill and roadbase material over Middle Holocene channel deposits. Backhoe Trench 7 (Figure 4-23) uncovered modern fill from the 1962 excavation backdirt covering channel and overbank deposits. Backhoe Trench 8 consisted of entirely modern fill and roadbase materials above the red alluvial channel deposit gravels.

Backhoe Trench 9 (5 m, $1.9 \mathrm{mbs})$ was placed perpendicular to the highway, $2 \mathrm{~m}$ from the eastern wall of Block II. This trench revealed Middle Holocene channel deposits overlain by Middle Archaic midden or midden related deposits. These zones were capped with midden derived channel deposits, modern fill dirt and roadbase materials. A hearth feature (Feature 109), located near the bottom of this trench $(1.6 \mathrm{mbs})$, returned a radiocarbon date of $3890 \pm 50 \mathrm{BP}$.

\section{Unit Excavation}

Fourteen 1-x-1-m test units (TUs) were excavated within the median in four excavation areas, identified as Blocks I-IV, to explore the vertical extent, artifact distribution,

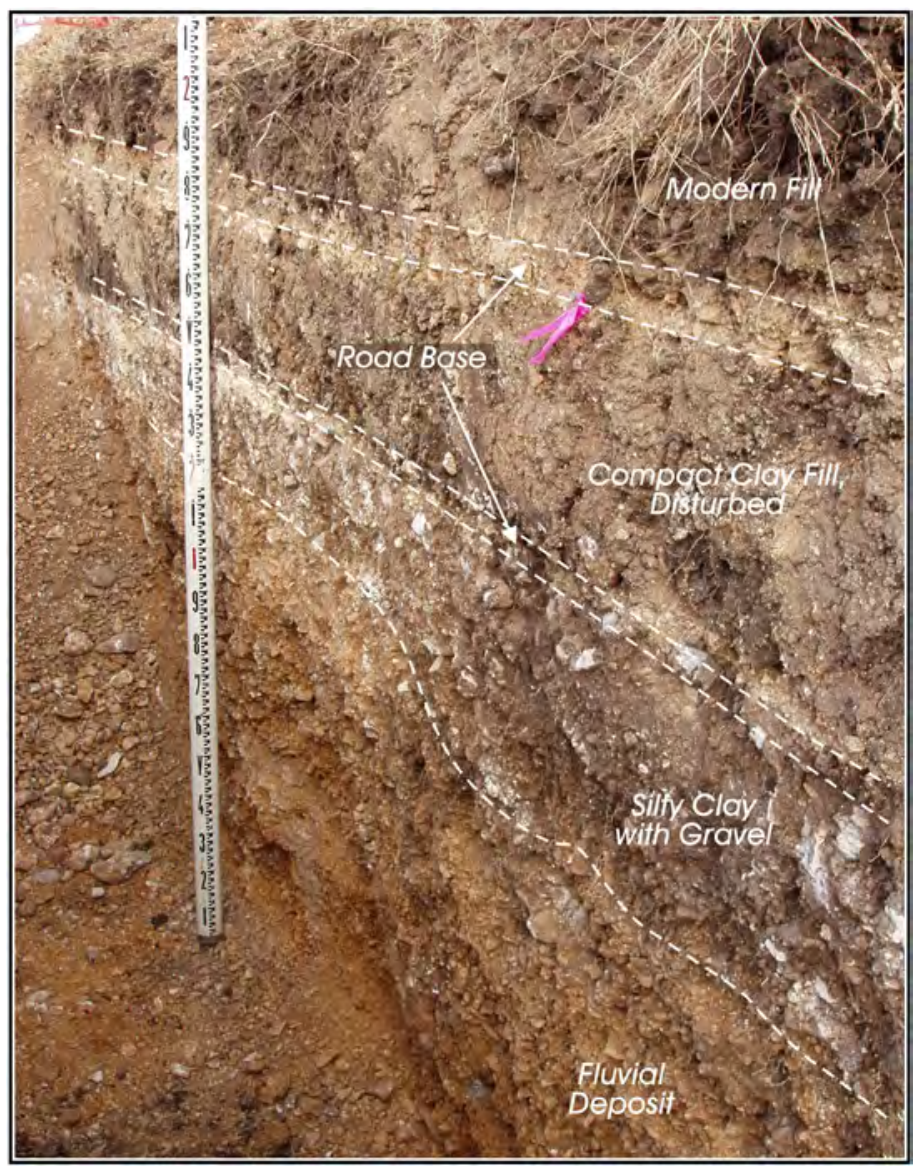

Figure 4-22. North wall of Backhoe Trench 6. and integrity of the cultural material recovered from the auger tests. Two units were placed south of the access road (Figure 4-24). Several factors determined test unit placement including existing utilities, safety regulations, construction plans, and results of auger test data and backhoe trench profiles. The excavation blocks were scraped to an elevation below any modern disturbance to enable hand excavation to begin in undisturbed prehistoric deposits. The modern over-burden was removed by backhoe.

All 1-x-1-m test units were excavated in $10 \mathrm{~cm}$ levels (Figure 4-24). Because the ground surface elevation in the median varied greatly across short distances, $100.2 \mathrm{~m}$ near the main lanes, 99.6 $\mathrm{m}$ at median center, elevations below ground surface was not

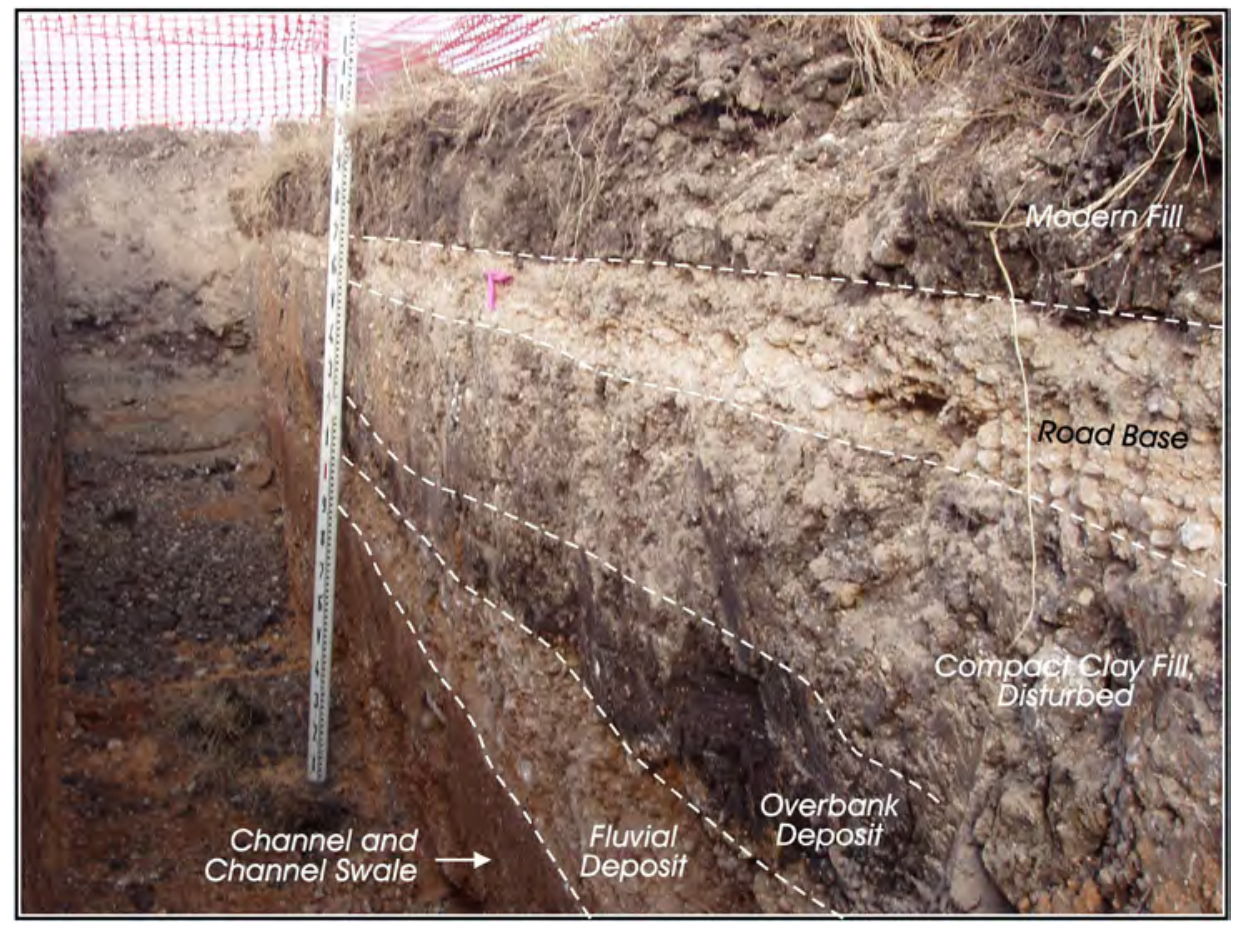

Figure 4-23. North wall of Backhoe Trench 7. 
straightforward. In general, the ground surface elevation increases from Salado Creek to the project area. Test unit elevations below ground surface were measured from the northern walls of the blocks except in TUs 3 and 4, where surface measurements were taken from the southern wall. Matrix from each level was sifted through 1/4 in. hardware cloth. Artifacts found in the screen were collected in bags and labeled by provenience. Some artifacts were plotted in situ when discovered. All prehistoric artifacts, faunal, and charred organic material encountered in test units was collected. Soil, two to three $100 \mathrm{~g}$ matrix samples, was bagged from undisturbed contexts in each level of TUs 3, 5, 7, 9, 11, 13, and 15 (see Figure 4-24). A total of $17.1 \mathrm{~m}^{3}$ of matrix was excavated from within the median.

\section{Access Road Units}

Test Units 1 and 2, each 1-x-1.5-m, were excavated in the easement of the access road in place of auger testing. Road base was encountered in TU 1 at $110 \mathrm{cmbs}$. A mechanical auger, used to remove deposits below the road base, revealed fill continuing to the terminal depth of $150 \mathrm{cmbs}$. Excavations in TU 2 uncovered road construction material to $100 \mathrm{cmbs}$. No auger test was placed in this unit. Because no intact soils were uncovered, sediments were not screened.

\section{Block I Test Units}

The CAR excavated four test units in Block I, a 9-x-6 block east of the water line (see Figure 4-16). Based on auger bore results, the upper $70 \mathrm{~cm}$ of disturbed soils were mechanically removed prior to handexcavation. Because the disturbance continued at $70 \mathrm{cmbs}$, a north-south oriented backhoe trench (BHT 2) was dug along the eastern edge of

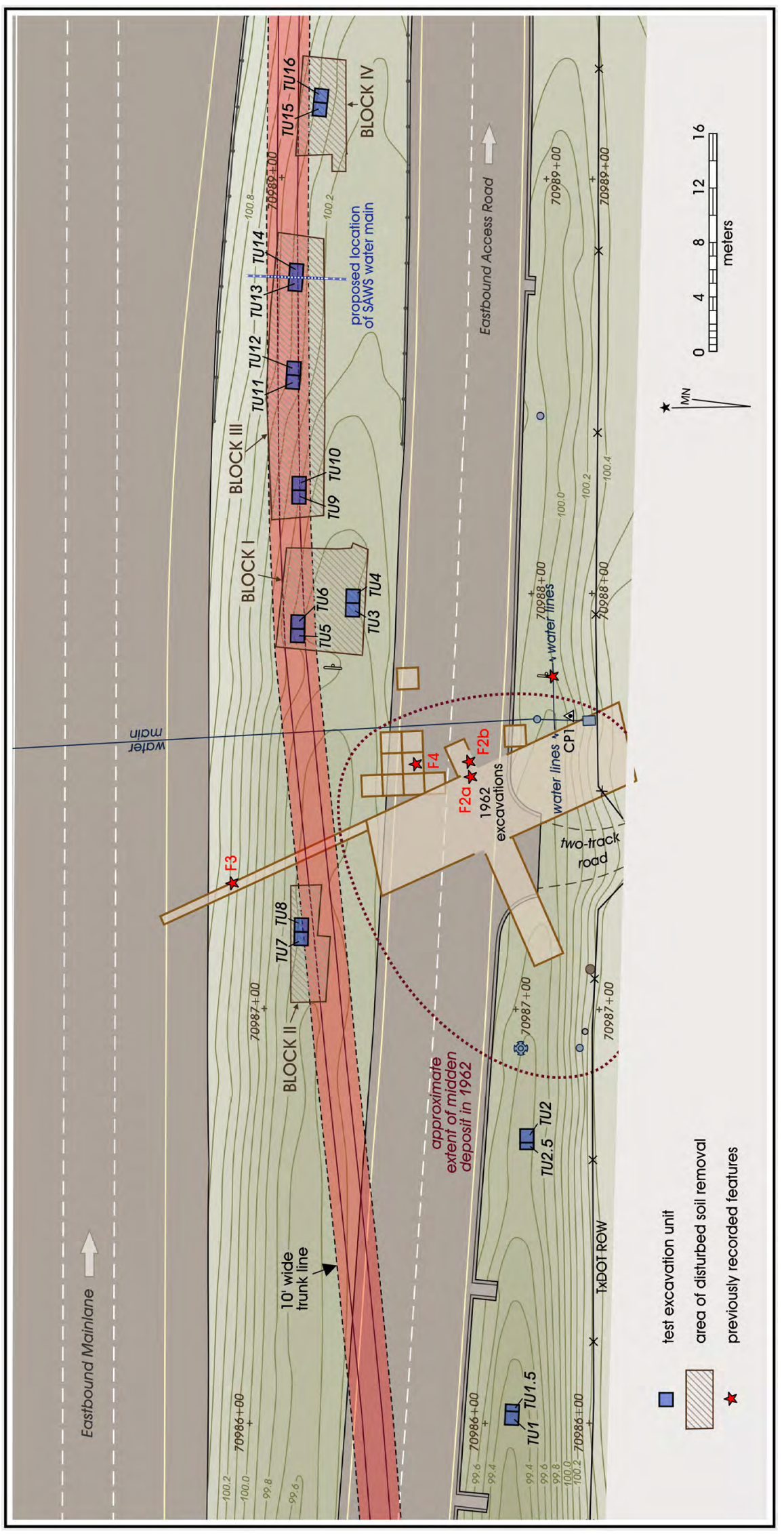

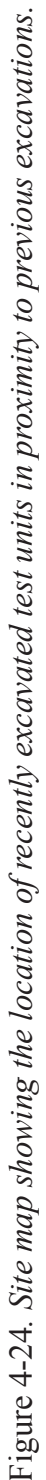


the stripped area to provide a clear stratigraphic exposure of the deposits. Backhoe Trench 2 was excavated to the sterile red gravel zone identified by Schuetz (1966). The stratigraphy revealed that the horizon below the disturbed soils was a modern flood deposit, which occurred sometime after the Schuetz excavations but before the construction of Loop 410. Major flooding of the Salado Creek occurred in May 1965 and December 1966. Construction of Loop 410 at its intersection with Salado Creek occurred in 1967 (Slade and Patton 2006a, 2006b). Based on this stratigraphy, handexcavations commenced at the layer of dark clay beneath this flood zone.

Test Units 3 and 4 formed a 1-x-2-m unit along the southern wall of Block I. Test Unit 4 was placed over AT 18, which had revealed a possible burned rock feature. The units began at a benched elevation of $1.0 \mathrm{~m}$ below the ground surface and terminated $1.9 \mathrm{~m}$ below opening hand excavations ( $2.9 \mathrm{mbs})$. The CAR removed $3.8 \mathrm{~m}^{3}$ of deposits from these two units.

Test Units 5 and 6 formed a second $1-x-2-m$ unit in the northwest corner of Block I (Figure 4-25). Hand excavation of this unit began at $1.2 \mathrm{mbs}$, below what appeared to be 1962 excavation backdirt. Hand excavation stopped at $1.6 \mathrm{~m}$ below opening hand excavation $(2.8 \mathrm{mbs}) . \quad 3.2$ $\mathrm{m}^{3}$ of deposits was excavated from these two units.

\section{Block II Test Units}

Two test units in Block II, an 8-x-3-m area to the west of the water line, were excavated. Based on auger bores, the upper $80 \mathrm{~cm}$ of disturbed deposits were mechanically removed. A short eastwest-running backhoe trench (BHT 3) was excavated along the southeastern corner of the block to a depth of 180 cmbs (a zone of gravels) to expose the stratigraphy. Test Units 7 and 8 (1-x-2-m), were placed along the northern wall of Block II (see Figure 4-16). This position was chosen because a small, dark cultural lens was noted in the eastern and northern walls of the block but was absent from the southern wall. This lens was dense with artifacts and burned rock likely representing an extension of the burned rock midden noted by Schuetz in 1962.
Excavation in these test units began at $80 \mathrm{cmbs}(10 \mathrm{cmbd})$, immediately below disturbed strata, and stopped in the red alluvial gravels below the burned rock midden, $80 \mathrm{cmbd}$ in TU 7 and $60 \mathrm{cmbd}$ in TU 8. The CAR excavated a total of 1.2 $\mathrm{m}^{3}$ of deposits from these two units.

\section{Block III Test Units}

Because a storm sewer trunk line trench, $3.05 \mathrm{~m}(10 \mathrm{ft}$.) wide and $3.05 \mathrm{~m}$ (10 ft.) deep, and a new water line, perpendicular to Loop 410, were planned to impact the site within the median (see Figure 4-24), a large area (Block III) containing six test units (TUs 9-14) was started in the trunk line's footprint (Figure 4-26). The CAR mechanically removed overburden through the modern flood deposit prior to test unit hand-excavation. Block

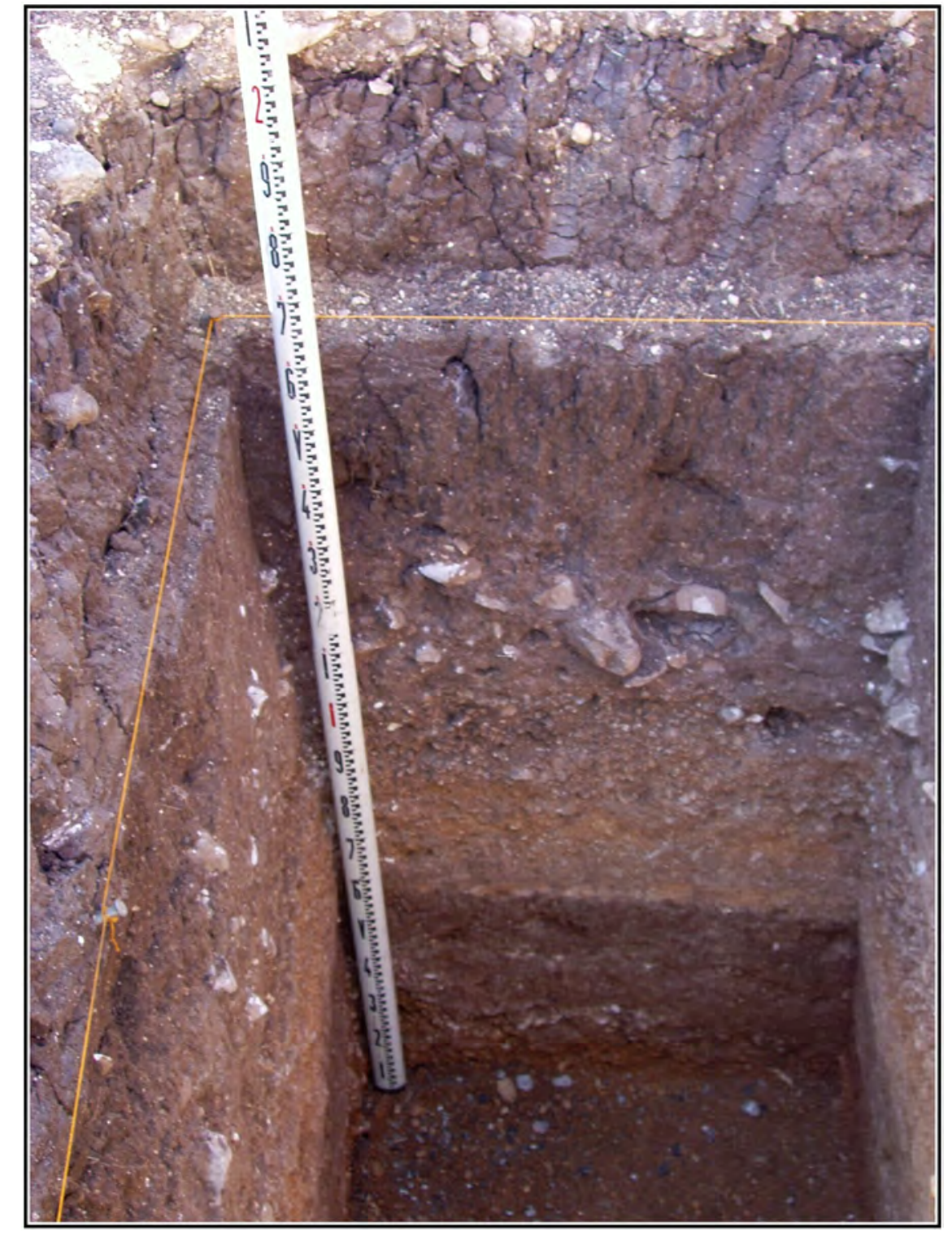

Figure 4-25. West wall of Test Unit 5. 


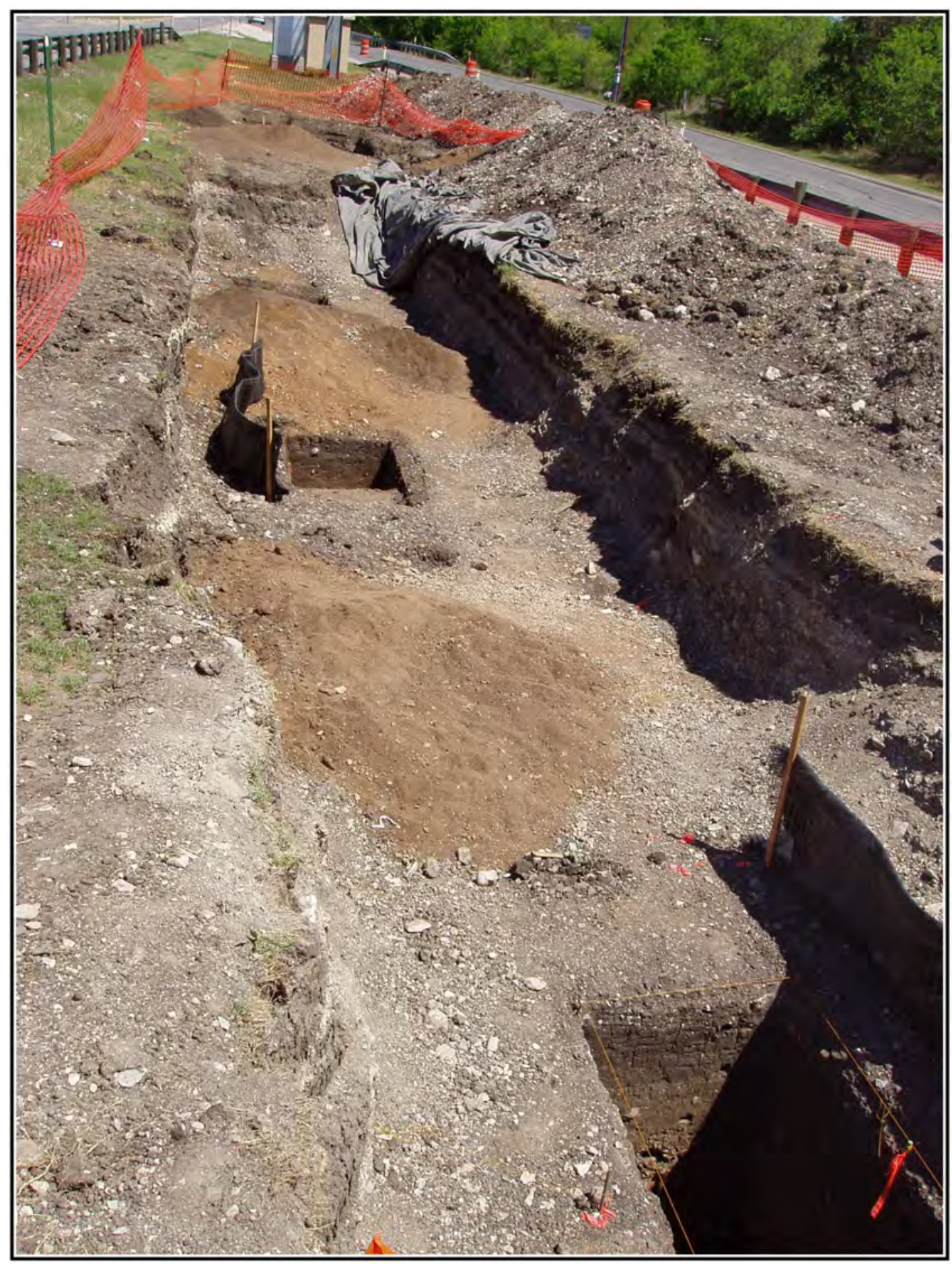

Figure 4-26. Overview of Block III, looking east.

III test units were tied to a single datum elevation also used in TUs 3 and 4 (Block I). Test Units 9 and 10 formed a 1-x-2-m unit with a starting elevation of $30 \mathrm{cmbd}$. The terminal depths in TUs 9 and 10 were $180 \mathrm{cmbd}$ and $190 \mathrm{cmbd}$, respectively. The CAR removed a total of $3.1 \mathrm{~m}^{3}$ of matrix from these two units. The stratigraphy and artifact distribution in TUs 9 and 10 resembled that of TUs 5 and 6 (Block I).
Test Units 11 and $12(1-\mathrm{x}-2-\mathrm{m})$ were set approximately 6.0 m east of TUs 9 and 10 . Both units commenced at $30 \mathrm{cmbd}$, but due to an inundation after heavy rains TU 11 terminated in at $40 \mathrm{cmbd}$. After several days of dry weather TU12 was continued. The unit was terminated at $100 \mathrm{cmbd}$, upon evidence of the upper gravel deposit. These units did not reach planned 3.05 
$m$ depth of the planned storm sewer. Archeological deposits may remain in the unexcavated levels of these units. The combined total volume excavated in TUs 11 and 12 is $0.8 \mathrm{~m}^{3}$.

Test Units 13 and 14, 1-x-2-m, were located at the eastern end of Block III. These units both started at 30 cmbd and terminated at $180 \mathrm{cmbd}$, reaching the bottom of the proposed area of impact. The CAR removed 3.0 $\mathrm{m}^{3}$ of matrix from the units.

\section{Block IV Test Units}

Block IV, containing TUs 15-16, was intended for the eastern portion of the storm sewer footprint (Figure 4-27). Because safety standards dictate a one to one ratio from the main lanes of Loop 410, test units could only be excavated $3.0 \mathrm{~m}$ deep when located a minimum of $3.0 \mathrm{~m}$ from the roadway. Therefore, excavations within the eastern portions of the trunk line were not feasible. Block IV test units were excavated slightly south of the proposed trunk line. Test Units 15 and 16 began approximately $10 \mathrm{cmbd}$ and terminated at a gravel zone, $110 \mathrm{cmbd}$. A total of $2.0 \mathrm{~m}^{3}$ of deposits were removed from these units.

\section{Summary}

The archeological testing of the Granberg Site was designed in part to delineate site boundaries within the project ROW. After examining the series of auger tests, backhoe trenches, and test units, the site boundaries were revised within the current project area. Geological analysis conducted during the archeological excavation supports these revisions (see Chapter 6). Excavations recovered artifacts down to $3.05 \mathrm{~m}$ (10 ft.) below surface from TUs 3, 4, 5, 6, 9, 10, 13, and 14. The target depth of this project, the maximum depth of impact proposed by installation of the storm sewer line along the median, was $3.05 \mathrm{~m}$ (10 ft.) below surface. Archeological excavation was terminated at this depth regardless of the density of cultural deposits. Artifacts were present from BHT 7 in the west to BHT 5 in the east. Block I and the western half of Block III contained the densest and deepest cultural deposits. The burned rock midden uncovered by Schuetz (1966) was partially excavated in Block II. The density of artifact recovery at similar depths dropped to the east and west from Blocks I and II. Therefore, the site boundary was revised to include the entire ROW within the median from the western end of BHT 7 to the eastern edge of BHT 5. Beneath the road and modern flood gravels, which end at roughly 80$100 \mathrm{cmbs}$, the upper portions of the undisturbed archeological deposits was preserved. It is possible that the archeological deposits extend

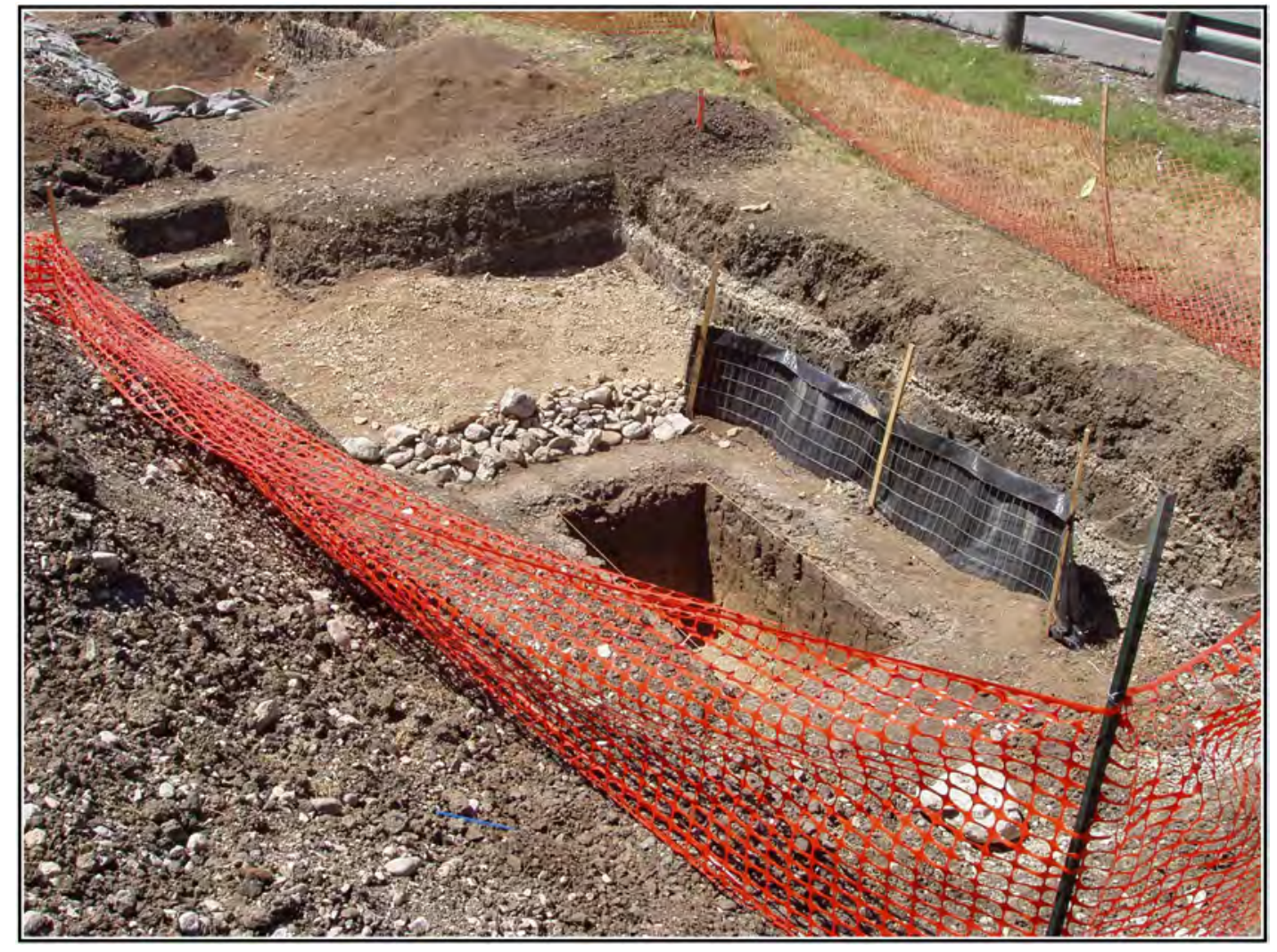

Figure 4-27. Overview of Block IV and Test Units 15 and 16, looking west-northwest. beneath both the main lanes of Loop 410 (Figure 4-28).

\section{Laboratory Methods}

Cultural materials and records obtained and/ or generated during the project were prepared in accordance with federal regulation 36 CFR part 79, and THC requirements for State Held-inTrust collections. Additionally, the materials were curated in accordance with current guidelines of the Texas Archaeological Laboratory. Artifacts processed in the CAR laboratory were washed, air-dried and stored 
in 4-mm zip locking archival-quality bags. Materials needing extra support were double-bagged. Acid-free labels were placed in all artifact bags. Each label contained provenience information and a corresponding lot number written in archival ink, with pencil or laser printed. Tools were labeled with permanent ink over a clear coat of acrylic and covered by another acrylic coat. Artifacts were separated by class and stored in acid-free boxes. Boxes were labeled with standard labels. Digital photographs were printed on acid-free paper and labeled with archivally appropriate materials and placed in archivalquality sleeves. All field forms were completed with pencil. Field notes, forms, photographs, and drawings were printed on acidfree paper and placed in archival folders. A copy of the survey report and all computer disks pertaining to the investigations were stored in an archival box and curated with the field notes and documents. Upon completion of the project all cultural materials and records will be permanently curated at the CAR facility.

Subsequent to proper analyses and quantification, artifacts associated with this project possessing little scientific value will be discarded pursuant to Chapter 26.27(g) (2) of the Antiquities Code of Texas and in consultation with the Texas Historical Commission. Artifact classes to be discarded specific to this project may include, but are not limited to the following: snail shell, burned rock, and soil samples. In all instances, discarded materials will be documented and their counts included in the final report and curation documentation. Discarded materials will be disposed of using suitable disposal procedures.

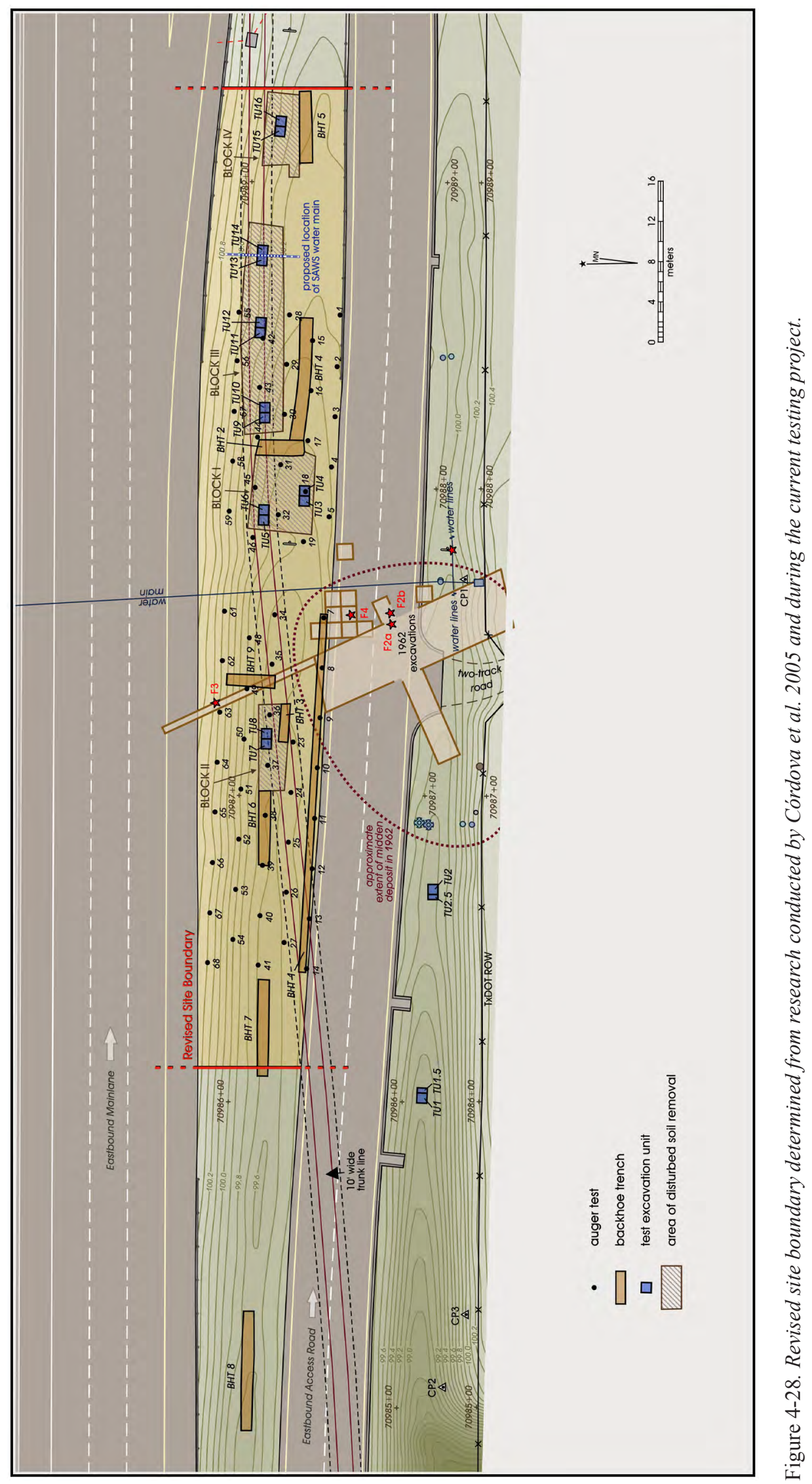





\section{Chapter 5: Materials Recovered}

\section{Cynthia M. Munoz and Jennifer Thompson}

During the 2006 CAR significance testing of the 41BX17, a variety of data types were recovered, including chipped stone debitage, cores, projectile points and other chipped stone tools, vertebrate faunal remains, mussel and snail shell, charcoal samples, soil samples, lipid samples, and burned rock. In addition, the CAR recorded information on ten hearths and burned rock cluster features. A total of 17 cubic meters of soil deposits were hand excavated and 572.3 cubic meters were mechanically excavated. This section provides a short review of the materials recovered. The review is followed by a brief description of artifacts available for study from previous excavations.

\section{Recovered Artifacts}

Table 5-1 provides counts of the major artifact classes present in the 2006 collection. The artifact classes are presented by each excavation block (i.e., I, II, III, and IV). In addition, auger test materials along with a small number of items identified as "surface" are included in the table. Artifacts recovered from testing included over 12,000 pieces of debitage and over 250 lithic tools, points, and cores. Blocks I and II had the highest densities of recovered artifacts. Lithic debitage, the largest dataset collected, comprise over 60 percent of the artifact assemblage, . Lithic tools and cores include all chipped stone with characteristics associated with use (i.e., edge modification from sharpening, reshaping, and wear) and falling into various morphological and functional categories including cores, unifaces, bifaces, and projectile points. Each of these primary artifact classes is briefly discussed.

\section{Projectile Points}

Testing produced 33 projectile points. As can be seen in Table 5-1, 15 (45\%) of the points came from Block III, 12 (36\%) from Block I, 4 (12\%) from Block II, and none from Block IV. Block II had the highest density of points with 3.3 projectile points recovered per cubic meter of fill.
Block I had the lowest density with only 1.7 points per cubic meter of excavations. The dart points found were typed by Dr. Steve Tomka according to cultural-historical definitions to aid in a preliminary assessment of site integrity (Turner and Hester 1999). Of the 33 points, 31 (94\%) could be assigned to a recognized type with the remaining items being too fragmentary to type, reflecting untyped and untypable dart points and dart point performs. Projectile point forms recovered from the site include Middle Archaic types Langtry, Nolan (Figure 5-1) and a possible Travis, and Late Archaic types Bulverde, Castroville, Ensor, Fairland, Marcos, Marshall, Montell, and Pedernales (Figures 5-2). Other untyped projectile points were also collected (Figure 5-3). Table 5-2 provides a list of the diagnostic points grouped by types and by excavation block. Projectile points from 41BX17 reflect the Archaic periods with diagnostic points suggesting some level of use from the Middle Archaic (6000-4000 BP) through the Late Archaic (4000-1250 BP). Points dating to the Late Archaic are the most common $(n=24,77 \%)$. Several locations within selected blocks can be isolated that allow consideration of period level assemblages. Those assemblages are discussed in subsequent chapters.

\section{Other Chipped Stone Tools}

In addition to projectile points, a variety of other chipped stone tools are present in the Granberg testing collection. Over 200 of these other tool types were recovered from the site. These include more than 60 bifaces, 10 unifaces, and 80 edge-modified flakes. Although classification by artifact categories, tool production cost, and by failure cause was not attempted on the entire tool assemblage, all tools that could be assigned to an analytical unit (defined in Chapter 7) were classified according to these categories (see Chapter 12). One hundred and forty-one (64\%) of the chipped stone tools came from Block I. Block IV had the fewest number of items, 1 (< $1 \%)$ and the lowest density ( 0.5 tools per cubic meter). The highest density of tools was recovered from Block II with 35 tools recovered per cubic meter of fill.

Table 5-1. Artifact Distribution by Test Unit at 41BX17

\begin{tabular}{|c|c|c|c|c|c|c|c|c|c|c|c|}
\hline \multirow{2}{*}{ Artifact Class } & \multicolumn{2}{|c|}{ Block I } & \multicolumn{2}{|c|}{ Block II } & \multicolumn{2}{|c|}{ Block III } & \multicolumn{2}{|c|}{ Block IV } & \multirow{2}{*}{ Auger Tests } & \multirow{2}{*}{ Surface } & \multirow[t]{2}{*}{ Total } \\
\hline & \# & $\# / \mathbf{m}^{3}$ & \# & $\# / \mathbf{m}^{3}$ & \# & $\# / \mathbf{m}^{3}$ & \# & $\# / \mathbf{m}^{3}$ & & & \\
\hline Projectile Points & 12 & 1.7 & 4 & 3.3 & 15 & 2.2 & 0 & 0 & 0 & 2 & 33 \\
\hline Lithic Tools/ Cores & 141 & 20.1 & 42 & 35 & 30 & 4.4 & 1 & 0.5 & 2 & 5 & 221 \\
\hline Debitage & 7665 & 1095 & 1431 & 1192.5 & 2804 & 406.4 & 218 & 109 & 110 & 5 & 12233 \\
\hline Bone (gm) & 1465 & 209.3 & 87 & 72.5 & 385 & 55.8 & 0 & 0 & 4 & 47 & 1988 \\
\hline Mussel Shell (gm) & 18 & 2.6 & 0 & 0 & 1 & 0.15 & 0 & 0 & 0 & 2 & 21 \\
\hline Snail Shell (gm) & 3863 & 551.9 & 426 & 355 & 2349 & 340.4 & 259 & 129.5 & 0 & 0 & 6897 \\
\hline
\end{tabular}




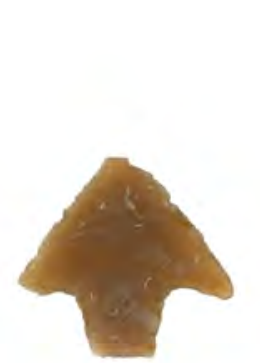

a

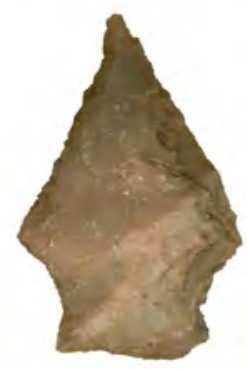

b

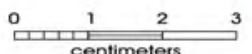

Figure 5-1. Projectile points recovered from 41BX17 include Middle Archaic forms: (a) Langtry; (b) Nolan.

\section{Debitage and Cores}

The most common item recovered during testing of 41BX17 was chipped stone debitage (see Table 5-1). The debitage appears to vary in size and cortex coverage. Chert is by far the most common raw material, represented by a wide range of colors. Of the over 12,000 specimens of debitage in the collection, roughly $63 \%$ were associated with the excavations in Block I. However, Block II contained the highest overall density of debitage with approximately 1193 pieces of debitage per cubic meter of fill. In contrast, both Blocks III and IV had low debitage densities with densities of 406 and 109 items per cubic meter, respectively. Over 30 cores were
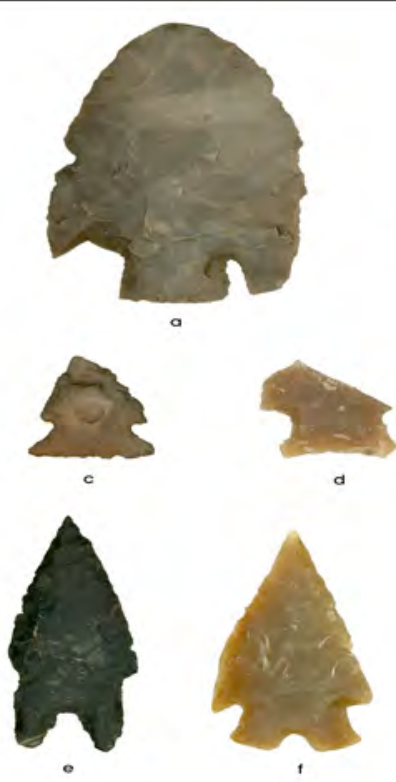
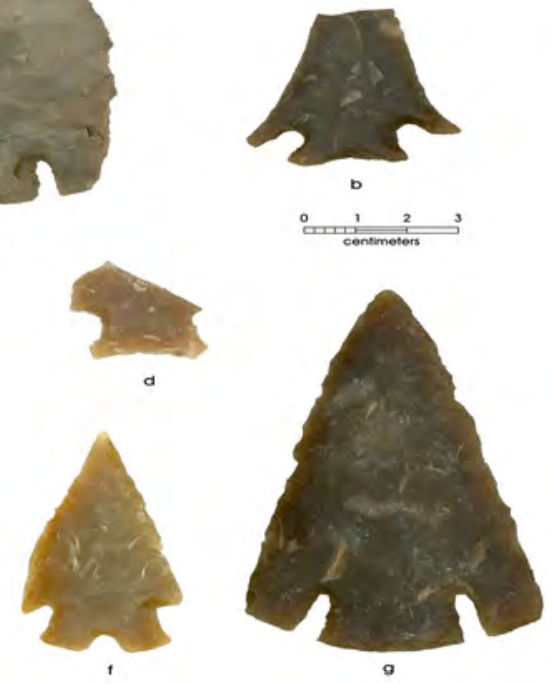

Figure 5-2. Projectile points recovered from 41BX17 include Late Archaic forms: (a) Marcos; (b) Marshall; (c) Ensor; (d) Fairland; (e) Pedernales; (f) Montell; (g) Castroville. recovered from the 2006 testing. Although approximately $58 \%$ of the cores were associated with Block I, the highest density was recovered from Block II with roughly 6 cores per cubic meter of matrix.

\section{Burned Rock}

Along with chipped stone material, burned rock was recovered during the testing phase of the CAR's work at 41BX17. Over 6600 specimens of burned rock were recorded comprising over 30 percent of artifact counts. Burned rock was present in all hand-excavated test units with the majority removed from test units in Blocks I and II. The burned rock was recovered from most levels of hand-excavated units generally peaking around $100 \mathrm{cmbd}$. All 10 of the recorded features were burned rock features. The total weight of the excavated feature burned rock was over 265,000 gm (Table 5-3). Most of this rock appears to be limestone.
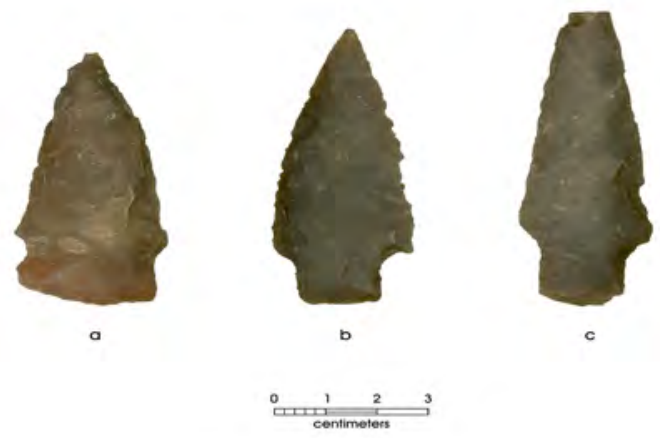

Figure 5-3. Untyped projectile points recovered from $41 B X 17$.

\section{Other Samples}

A variety of other samples, including vertebrate faunal material, snail and mussel shells, sediment samples, charcoal samples, and lipid samples were collected during testing of 41BX17. These are briefly discussed in the following paragraphs. The weights of faunal bone, snail shell and mussel shell recovered from each excavation block are presented in Table 5-1.

\section{Vertebrate Faunal Remains}

Animal bone was recovered from all units at the site except Test Units 15 and 16 (Block IV). During testing, over 1900 gm of bone were collected (see Appendix F for the raw data). The bone is in good condition. As shown in Table 5-1, bone recovery was highest in Block I (74\%), which showed two peaks in weights, one in Levels 4 and 5, and another in Level 12. This block also had the highest overall density, 
Table 5-2. Distribution of Typed Projectile Points by Block, 41BX17

\begin{tabular}{|c|c|c|c|c|c|}
\hline & \multicolumn{4}{|c|}{ Blocks } & \multirow[b]{2}{*}{ Total } \\
\hline Point Type & I & II & III & IV & \\
\hline \multicolumn{6}{|l|}{ Late Archaic } \\
\hline Bulverde & 0 & 0 & 2 & 0 & 2 \\
\hline Castroville & 1 & 0 & 2 & 0 & 3 \\
\hline Ensor & 2 & 0 & 1 & 0 & 3 \\
\hline Fairland & 0 & 0 & 1 & 0 & 1 \\
\hline Marcos & 0 & 1 & 1 & 0 & 2 \\
\hline Marshall & 2 & 0 & 2 & 0 & 4 \\
\hline Montell & 0 & 2 & 0 & 0 & 2 \\
\hline Pedernales & 3 & 0 & 4 & 0 & 7 \\
\hline \multicolumn{6}{|l|}{$\begin{array}{l}\text { Middle } \\
\text { Archaic }\end{array}$} \\
\hline Langtry & 2 & 0 & 0 & 0 & 2 \\
\hline $\begin{array}{l}\text { Langtry or } \\
\text { reworked } \\
\text { Montell }\end{array}$ & 0 & 1 & 0 & 0 & 1 \\
\hline Nolan & 1 & 1 & 0 & 0 & 2 \\
\hline Possible Nolan & 0 & 0 & 1 & 0 & 1 \\
\hline Possible Travis & 0 & 0 & 1 & 0 & 1 \\
\hline Total & 11 & 5 & 15 & 0 & 31 \\
\hline
\end{tabular}

with almost 209 grams of bone per cubic meter of matrix. In contrast, Block III had the lowest density with 56 grams of bone per cubic meter. Most bone represents large mammals such as deer $(57 \%)$ and bison $(26 \%)$. One bone tool was recovered. This tool appears to be the distal end of an awl or perforator (Figure 5-4).

\section{Mussel and Snail Shell}

A small amount of mussel shell (Bivalve) was recovered during testing, roughly 21 grams. All fragments of mussels were recovered from units in Block I $\left(2.6 \mathrm{gm} / \mathrm{m}^{3}\right)$ and Block III $\left(0.2 \mathrm{gm} / \mathrm{m}^{3}\right)$. All is highly fragmentary. The mussel shell may represent natural deposits associated with the proximity of Salado Creek. Snail shells (Gastropod) were also collected. Roughly 183 complete and fragmentary specimens (over $6500 \mathrm{gm})$ were recovered from screening during testing. Rabdotus dominates the assemblage. The relative density of snail shells was highest in Block I $\left(552 \mathrm{gm} / \mathrm{m}^{3}\right)$ and the lowest densities were in Block IV $\left(130 \mathrm{gm} / \mathrm{m}^{3}\right)$. Complete snail from Block I recovered from screening was submitted to Dr. Manuel Palacios-Fest of Earth Sciences Research in Tuscon, Arizona, for Gastropod analysis. Microsnail, from soil samples, were also submitted and are discussed in the following section. The results of the gastropod analysis are discussed in Chapter 10 and Appendix A.

\section{Charcoal, Sediment, and Lipid Samples}

Charcoal, soil, and burned rock lipid samples were collected because of their potential to provide information about the age and environmental setting of the site. Sixty-eight charcoal samples were collected in aluminum foil packets and reserved for potential dating and/or paleoethnobotanical analyses. Of these over 30 charcoal samples were piece-plotted. Nine of the recorded features had charcoal samples within the feature boundaries (Features 100-107, 109). Six samples were submitted to Beta Analytic Radiocarbon Dating Laboratory (Table 5-4), five from Block I and one from Backhoe Trench 9. The corrected dates for the samples range in age from 4830 to 1860 BP. Details of these dates are presented in Appendix G. Chapter 7 discusses the dates as they pertain to analytical units chosen for analysis. In addition to the charcoal samples submitted for radiocarbon dating, six charred samples from Block I were submitted to Dr. J. Philip Dering of Shumla Archeobotanical Services in Comstock, Texas, for mesquite xylem analysis (see Chapter 10 and Appendix E).

Ninety-nine soil samples were collected from the testing effort at 41BX17. These samples consisted of approximately two liters of soil each. The majority of these samples were derived from general excavation levels, taken each $10 \mathrm{~cm}$ level from all test units, although a large number were also feature associated. One sample each from Features 100-108 (seven from Block I, one from Block II, and one from Block III), were floated at the CAR, and the light fraction submitted to Dr. J. Philip Dering of Shumla Archeobotanical Services for macrobotanical analysis. The results of this analysis are discussed in Chapter 11. Additional information can be found in Appendix E. Eighteen soil samples representing Levels

Table 5-3. Feature Burned Rock

\begin{tabular}{|c|c|c|}
\hline Feature & Count & Weight (gm) \\
\hline 100 & 417 & 44547 \\
\hline 101 & 210 & 17819 \\
\hline 102 & 343 & 41648 \\
\hline 103 & 174 & 17961 \\
\hline 104 & 113 & 7519 \\
\hline 105 & 20 & 4776 \\
\hline 106 & 805 & 109443 \\
\hline 107 & 22 & 7387 \\
\hline 108 & 113 & 14332 \\
\hline Total & 2217 & 265432 \\
\hline
\end{tabular}




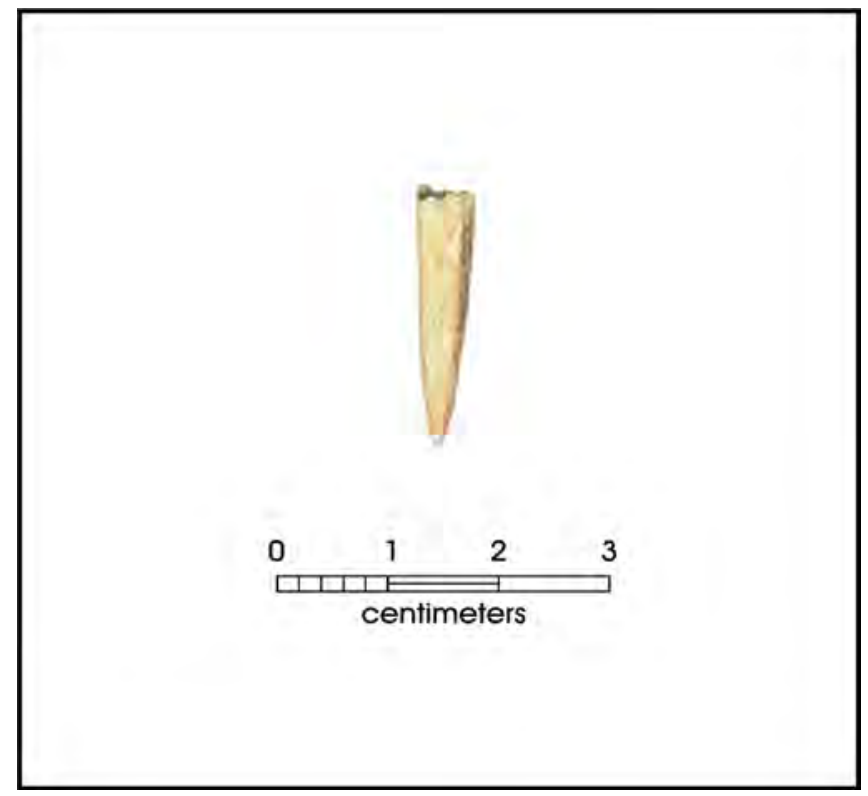

Figure 5-4. Bone tool recovered from 41BX17.

1-16 of Block I, each subsampled into two portions of $5.0 \mathrm{gm}$ and $130.0 \mathrm{gm}$, were submitted to Dr. Barbara Winsborough of Leander, Texas, for diatom analysis and to Dr. Linda Scott Cummings of Paleo Research Institute in Golden, Colorado, for phytolyth analysis, respectively. The results of these analyses are discussed in Chapter 10 with additional information in Appendices C and D. Finally, 18 soil samples from Levels 1-17 of Block I were floated at the CAR, and the light fraction submitted to Dr. Manuel Palacios-Fest of Earth Sciences Research in Tucson, Arizona, for microsnail Gastropod analysis. Chapter 10 presents the results of this analysis with further detail in Appendix A.

Burned rock from nine features at the Granberg Site was collected and set aside for lipid residue analysis. In all, 39 specimens were recovered. These samples represented features 100-108. Twenty-seven samples, three from each feature, were sent to Dr. Mary Malainey in Winnepeg, Manitoba, for lipid residue analysis. The results are discussed in Chapter 11. Appendix B presents further details.

\section{Features}

Ten features were defined during the 2006 excavations at 41BX17. Recorded cultural features all consisted of some arrangement of burned rock. These features were of two types: hearths and burned rock clusters. Hearth features exhibited deliberate placement of rock whereas burned rock cluster features appeared to consist of randomly placed burned rock in a concentrated area. White (1980) refers to these features as "spillage". He describes "spillage" as a blanket of cobbles and gravel with mixed placement and an unknown shape. Hearths, as described by White, exhibit even placement of rock in a tightly laid saucer shaped arrangement. Six rock hearths and three burned rock clusters were excavated during testing. The project archeologist documented a tenth rock hearth (Feature 109) in the bottom of BHT 9. The feature was not excavated although a radiocarbon sample was obtained from it. Three of the features were temporally assigned to the Middle Archaic, two based on radiocarbon dates and one based on point typology (Figure 5-5). The remaining seven features dated to the Late Archaic three based on radiocarbon dates, two on point typology, and two based on proximity to other dated features (Figure 5-6). Table 5-5 contains a summary of feature data.

\section{Middle Archaic Features}

Feature 104 was a burned rock scatter located $70 \mathrm{cmbd}$ in Test Unit 5 (Figure 5-7). The feature was characterized by an area of increased gravels (Zone 2) and contained bone, lithic debitage, lithic tools, lithic cores, burned rock, and large charcoal samples. Burned rock was uncovered aligned in the southwestern corner of the unit and was scattered throughout the unit along with chipped stone tools and cores. One of the two radiocarbon samples collected from Feature 104 dates to 3800 BP (cal 4290-4080 BP; Beta no. 215738), placing the feature and the top of the gravel deposit in the Middle Archaic.

Feature 107 was a small burned rock hearth $(70-\mathrm{x}-60-\mathrm{cm})$ in Test Unit 4 excavated from a gravel deposit $98 \mathrm{cmbd}$

Table 5-4. Radiocarbon Samples from 41BX17 Significance Testing Phase

\begin{tabular}{|c|c|c|c|c|c|}
\hline Unit & Feature & Date cal BP & Period & Sample No. & FS No. \\
\hline 6 & 100 & $2010-1860$ & Late Archaic & 41BX17F100 & $50-5$ \\
\hline 4 & 103 & $2740-2450 ; 2410-2380$ & Late Archaic & 41BX17F103 & $60-19$ \\
\hline 5 & 104 & $4290-4080$ & late Middle Archaic & 41BX17F104 & $75-3$ \\
\hline 3 & 105 & $3980-3820$ & early Late Archaic & 41BX17F105 & $93-2$ \\
\hline BHT 9 & 109 & $4430-4160$ & Middle Archaic & 41BX17BHT9 & 58 \\
\hline 5 & n/a & $4830-4520$ & Middle Archaic & 41BX17TU5L13 & $99-2$ \\
\hline
\end{tabular}




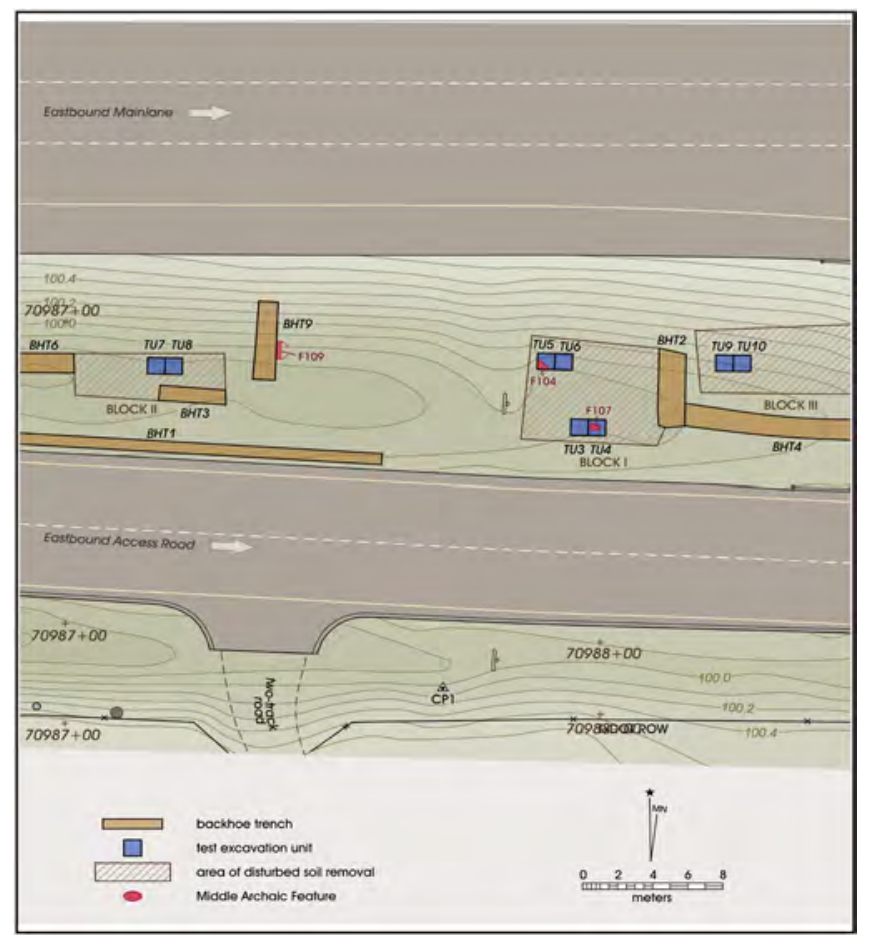

Figure 5-5. Map of the central portion of 41BX17 showing Middle Archaic features encountered during test excavations.

(Figure 5-8). This feature, consisting of a loose collection of burned rocks, was located in an area of sandy clay and increasing gravel (Zone 4). Bone, lithic debitage, and lithic tools were collected at the same elevation in the adjoining test unit (TU 5). CAR archeologists collected burned rock for lipid residue analysis. No charred material was available for dating. Based on its depth and its stratigraphic placement below Langtry and Pedernales points, this feature is likely a Middle Archaic hearth.

Feature 109 was located in an area of alluvial gravels (Zone 6) overlain with silty clay containing a high density of artifacts (Zone 5). This feature was identified $160 \mathrm{cmbd}$ in the east wall of Backhoe Trench 9, a short trench placed between Blocks I and II, west of the existing water main (Figure 5-9). The feature appears to be a hearth approximately $50 \mathrm{~cm}$ across. No artifacts were collected from the feature, but a charcoal sample was submitted and returned a Middle Archaic date of 3890 BP (cal 4430-4160 BP; Beta no. 215735).

\section{Late Archaic Features}

Feature 100 was a concentration of burned rock located in Test Units 5 and 6 between 23 and $39 \mathrm{cmbd}$ in an area of very hard blocky clay (Zone 1). Because the dimensions of the burned rock scatter reach beyond the boundary of the test units, the exact measurements of the rock scatter associated with this hearth are unknown. However, within the scatter of burned rock a formal hearth remains intact (Figure $5-10)$. The hearth measures approximately $60-\mathrm{x}-60-\mathrm{cm}$.
Feature 100 occupies a surface that also contains bone, lithic debitage, and projectile points. Projectile point types recovered from this feature include Castroville and Pedernales. However, a charcoal sample taken from 31 cmbd was submitted and returned a date of 1990 BP (cal 2010-1860 BP; Beta no. 215736), over 1000 years more recent than dates associated with Pedernales points (35003150 BP) (Turner and Hester 1999).

Feature 101 was a burned rock cluster (possibly including two remnant features) located directly beneath Feature 100 in Test Units 5 and 6, 40-50 cmbd, in the bottom of Zone 1 (Figure 5-11). The burned rock concentrated in the southwest corner of TU 6 appeared to be a possible hearth. A semi-circular pattern possibly a remnant hearth in the west wall of Test Unit 5 was also visible. Feature 101 was sitting on a silt zone of increased gravels and burned rock. Stone tools and faunal material were discovered at the same depth and among the burned rock. No charred material was recovered for dating. However, based on its association with Feature 100 and 102, its proximity to both Castroville and Pedernales points, and its location above Feature 104, radiocarbon dated to $3800 \mathrm{BP}$ (cal 4290-4080 BP; Beta no. 215738; see previous section), the feature is relatively dated to the Late Archaic. The extent of the burned rock extended beyond the boundaries of Test Units 5 and 6 . The visible dimensions are $180-\mathrm{x}-100-\mathrm{cm}$.

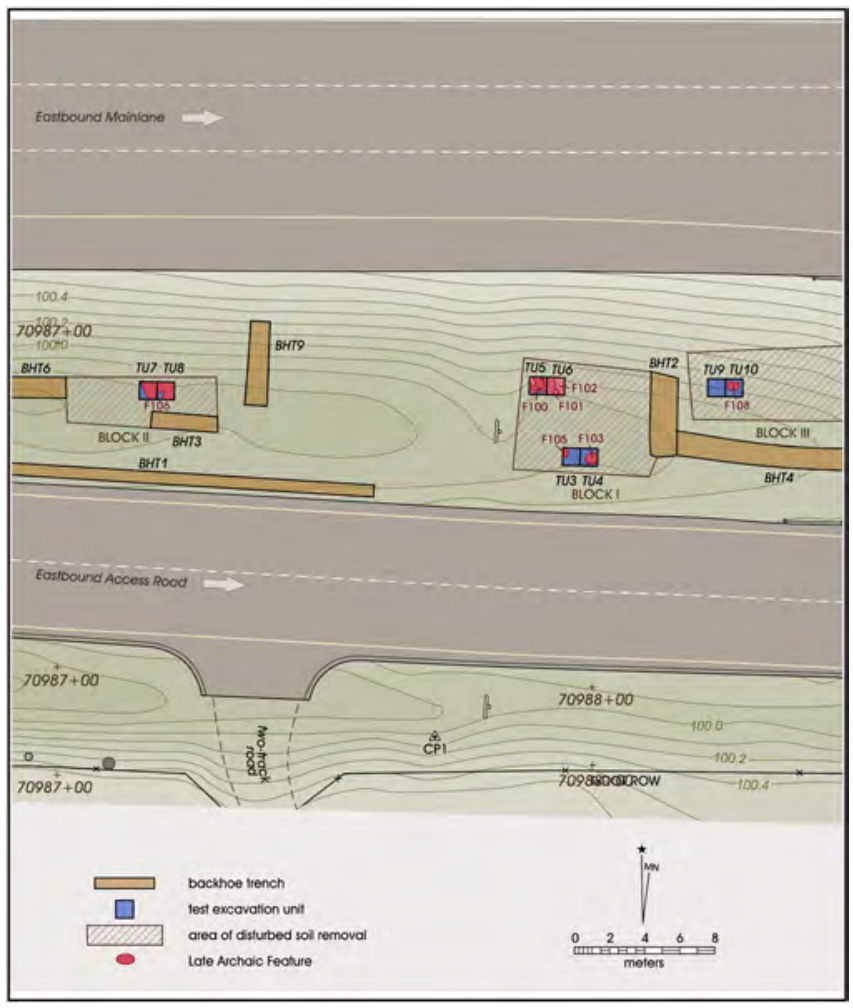

Figure 5-6. Map of the central portion of $41 B X 17$ showing Late Archaic features encountered during test excavations. 
Table 5-5. Features Recorded at 41BX17 during Significance Testing

\begin{tabular}{|c|c|c|c|c|c|c|}
\hline Fea No. & Unit & Lvl & Type & Dimension (cm) & $\begin{array}{c}\text { Radiocarbon Date } \\
\text { (cal BP)/Relative Date }\end{array}$ & Period \\
\hline 100 & 5,6 & 3 & Large Burned Rock Cluster/Hearth & unknown & $2010-1860$ & Late Archaic \\
\hline 101 & 6 & 5 & Burned Rock Cluster/Hearth & 180 -x-unknown & Castroville/Pedernaeles & Late Archaic \\
\hline 102 & 5,6 & 6 & Hearth & Unknown & Castroville & Late Archaic \\
\hline 103 & 4 & 5 & Hearth & $64-x-45$ & $2740-2450 ; 2410-2380$ & middle Late Archaic \\
\hline 104 & 5 & 7 & Burned Rock Scatter & 20 -x-36 & $4290-4080$ & late Middle Archaic \\
\hline 105 & 3 & 7 & Hearth & Unknown & $3980-3820$ & early Late Archaic \\
\hline 106 & 7,8 & 3 & Burned Rock Cluster/Midden & Unknown & Sample available for & early Late Archaic \\
\hline 107 & 3,4 & 10 & Hearth & 70 -x-60 & Lagtry & Middle Archaic \\
\hline 108 & 10 & 7 & Burned Rock Scatter & $47-x-93$ & Association & Late Archaic \\
\hline 109 & BHT 9 & n/a & Hearth & 50 -x-unknown & 4430-4160 & Middle Archaic \\
\hline
\end{tabular}

The burned rock in Feature 102 appeared purposefully stacked in the western half of Test Unit 5 as a hearth, though burned rock was scattered across both Test Units 5 and 6 (Figure 5-12). Feature 102 was located 50-60 cmbd on a zone of increased gravel concentration at the interface of Zones 1 and 2. No charred material was recovered for dating but the feature's association with Pedernales projectile points excavated from Test Unit 5 from 30-40 cmbd and Test Unit 6 at $54 \mathrm{cmbd}$, along with its placement below Feature 100 (1990 BP; cal 2010-1860 BP; Beta no. 215736), and above Feature 104 (3800 BP; cal 4290-4080 BP; Beta no. 215738) suggest a relative date in the Late Archaic.
Feature 103 was originally discovered in Auger Test 18. Burned and cracked rock measuring 64-X-45-cm was concentrated $42-55 \mathrm{cmbd}$ in the eastern part of Test Unit 3 in an area of silty clay (Zone 2). Burned rock was scattered across this unit and extended into the walls and into adjacent Test Unit 4 (Figure 5-13). Large pieces of debitage and bone lay at the perimeter of the concentrated burned and cracked rock. Burned rock samples were collected for lipid residue analysis. Stone tools also lay within the boundaries of this feature. A charcoal sample recovered was submitted and returned a date of $2510 \mathrm{BP}$ (cal 2740-2380 BP; Beta no. 215737).

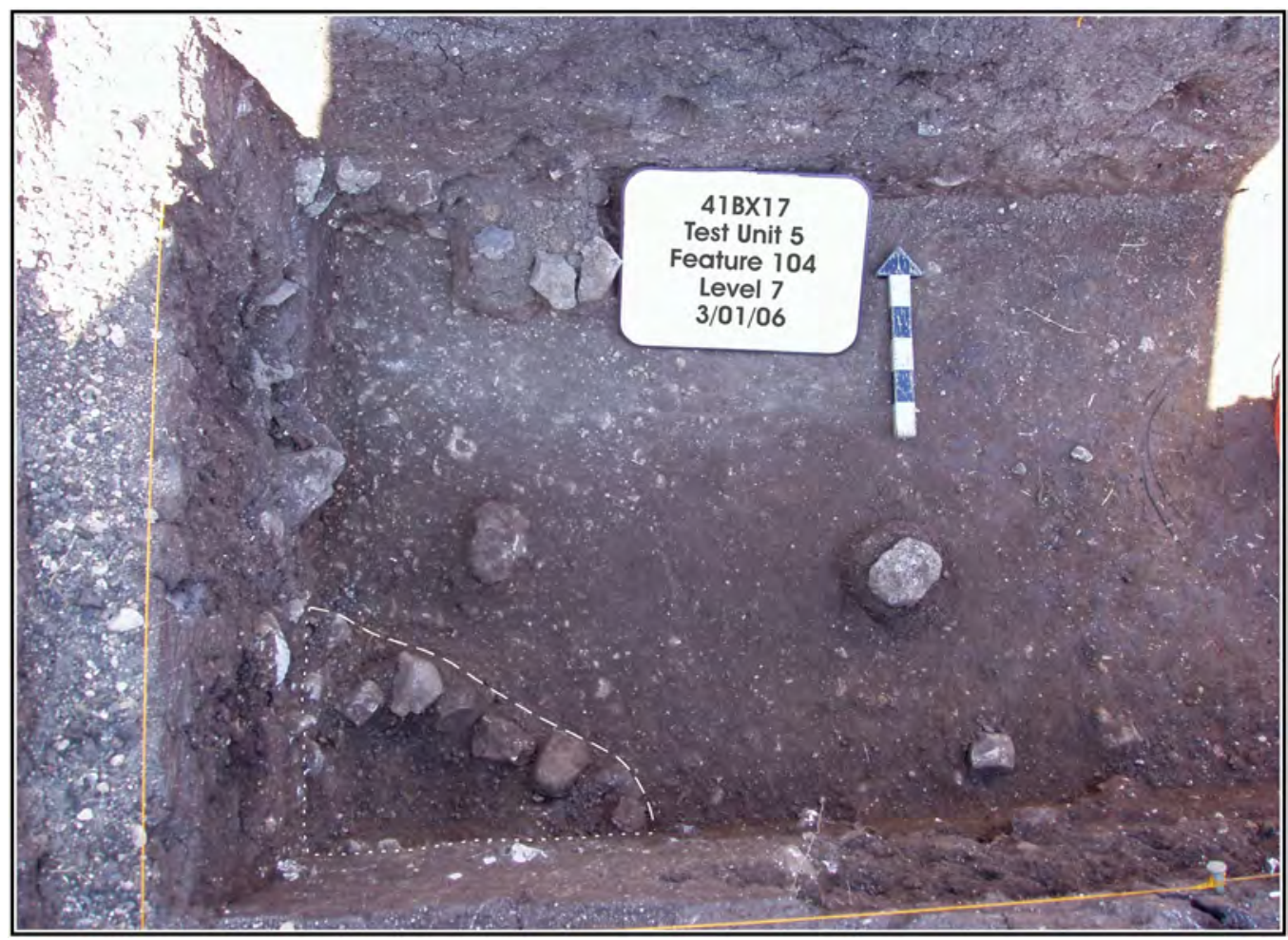

Figure 5-7. Burned rock Feature 104 was uncovered aligned in the southwestern corner of the unit. 
Feature 105 (Figure 5-14) was a small hearth remnant uncovered in Test Unit 3, 70-80 cmbd at the interface of Zones 2 and 3 (silty clay to silty clay with increasing gravels). Debitage, stone tools, and bone were excavated in association with the burned rock. Because the burned rock extended into the western and northern walls of Test Unit 3, the dimensions of the feature are unknown. Visible dimensions were $60-\mathrm{x}-30-\mathrm{cm}$. Burned rock was collected for future lipid residue analysis. Charred material was submitted and returned a date of $3620 \mathrm{BP}$ (cal 3980-3820 BP; Beta no. 215739) placing the feature near the beginning of the Late Archaic.

Partially exposed in Test Units 7 and 8, Feature 106 may represent an extension of the midden discovered by Schuetz in 1962. The feature (Figure 5-15), dense with burned rock and artifacts, was located in zones of silty clay changing to silty clay with increasing sand (Zones 5 and 6 ). The midden was also observed in Block II after several instances of looting activities during the fieldwork exposed additional rocks and artifacts in the east wall of that block. The midden sits within the main Salado Creek channel deposit between the modern flood deposit and an ancient rubified flood deposit. The burned rock was approximately $40 \mathrm{~cm}$ thick and contained bone, debitage, and stone tools. Because it sits on the surface of rubified gravels, it likely dates to the Late Archaic.

Feature 108 consisted of a small collection of burned rock measuring 47-x-93-cm (Figure 5-16). The feature was located 69-81 cmbd in Test Unit 10. Most of the rock was cracked in situ and was collected for lipid residue analysis. A thin biface was collected from this feature. No charred materials

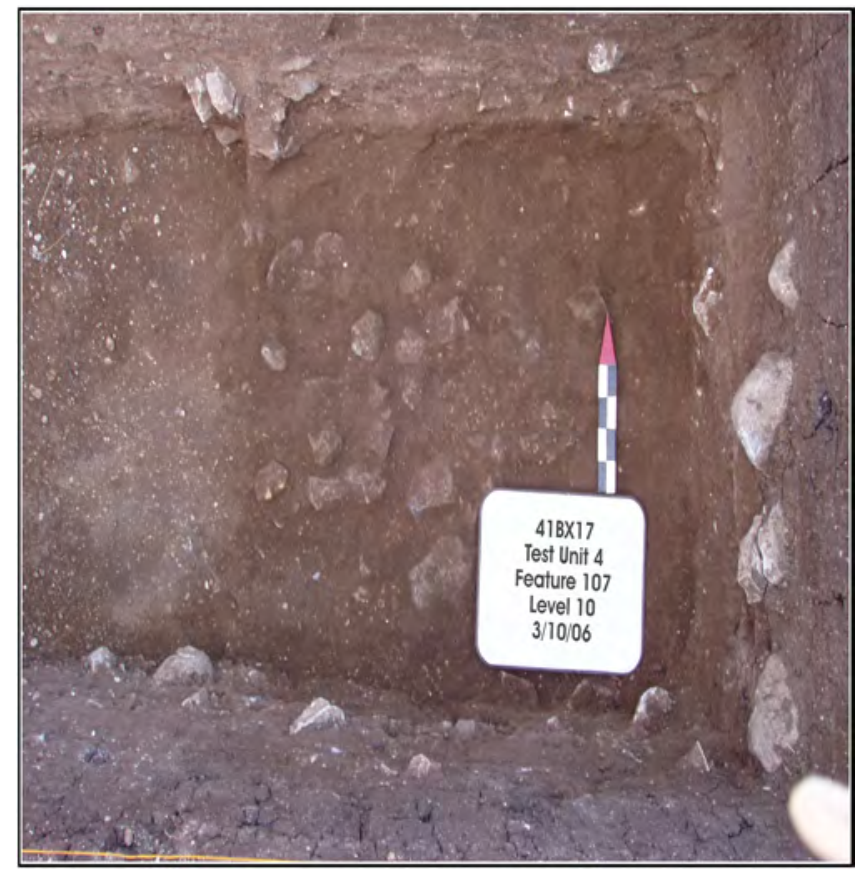

Figure 5-8. Feature 107 is a small, burned rock hearth excavated within a gravel deposit in Test Unit 4.

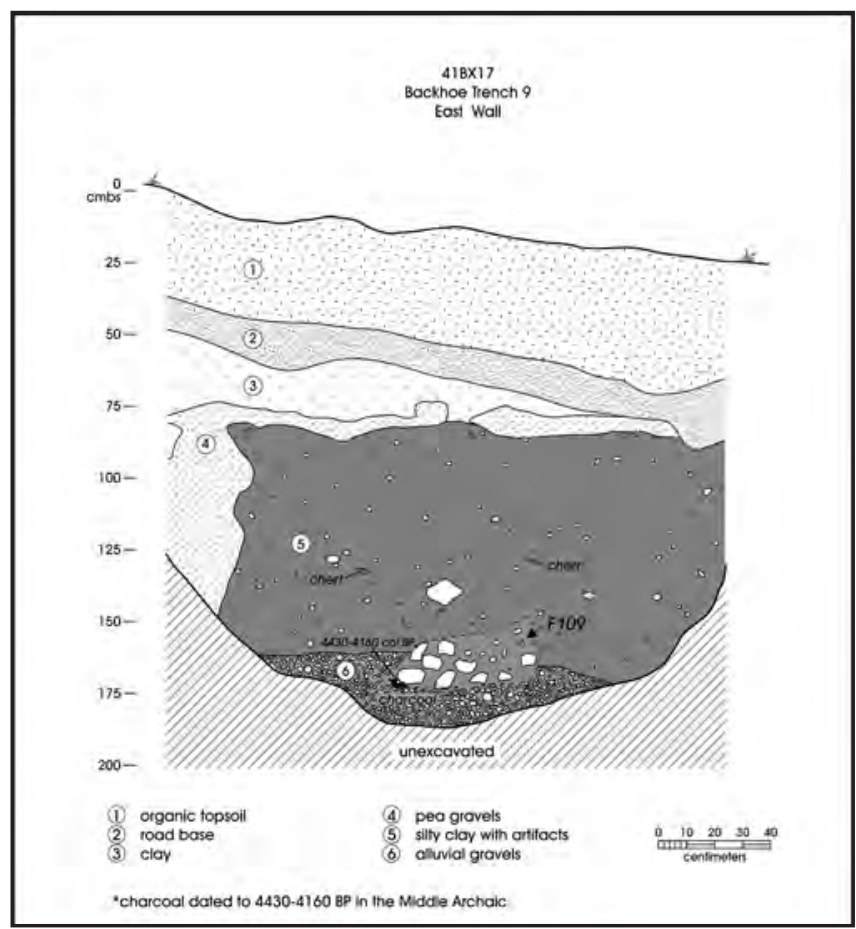

Figure 5-9. Feature 109 was identified in the east wall of Backhoe Trench 9, shown here in profile.

were available for dating. The feature was relatively dated to the Late Archaic because of its proximity to Castroville and Pedernales points.

\section{Artifact Review from Previous Excavations at the Granberg Site}

This chapter concludes with a brief discussion of artifacts available for study from previous excavations of the Granberg Site. Córdova et al. (2005) reviewed the entirety of the collection of artifacts available for study at the CAR's curation facility and constructed a preliminary catalog of all artifact categories available for study. The CAR houses portions of the 1973-1974 collection and the 1979 UTSA field school collection. The diagnostic artifacts from 1979 are in the possession of Dr. Thomas Hester (personal communication 2005). The artifact categories include snails, soil samples, modern debris, lithic debitage, and a small collection of lithic tools. Table 5-6 summarizes the artifacts housed at the CAR. Appendix K presents scans of selected points, bifaces, and unifaces in the CAR collection. The review of the materials available at CAR showed that the 1973-1974 materials included roughly 5,300 pieces of debitage, 76 bifaces, 8 unifaces, 11 projectile points, 1 edge modified flake, 63 cores, snails, burned rock, and small quantities of bone. Note that, based on comparison with the paper by Griffin (n.d.) which describes the 1973-1974 tools, several of the tools are missing. In addition, Kelly's 1975 summary of debitage from the 1973-1974 work suggests that roughly 1,400 pieces of 


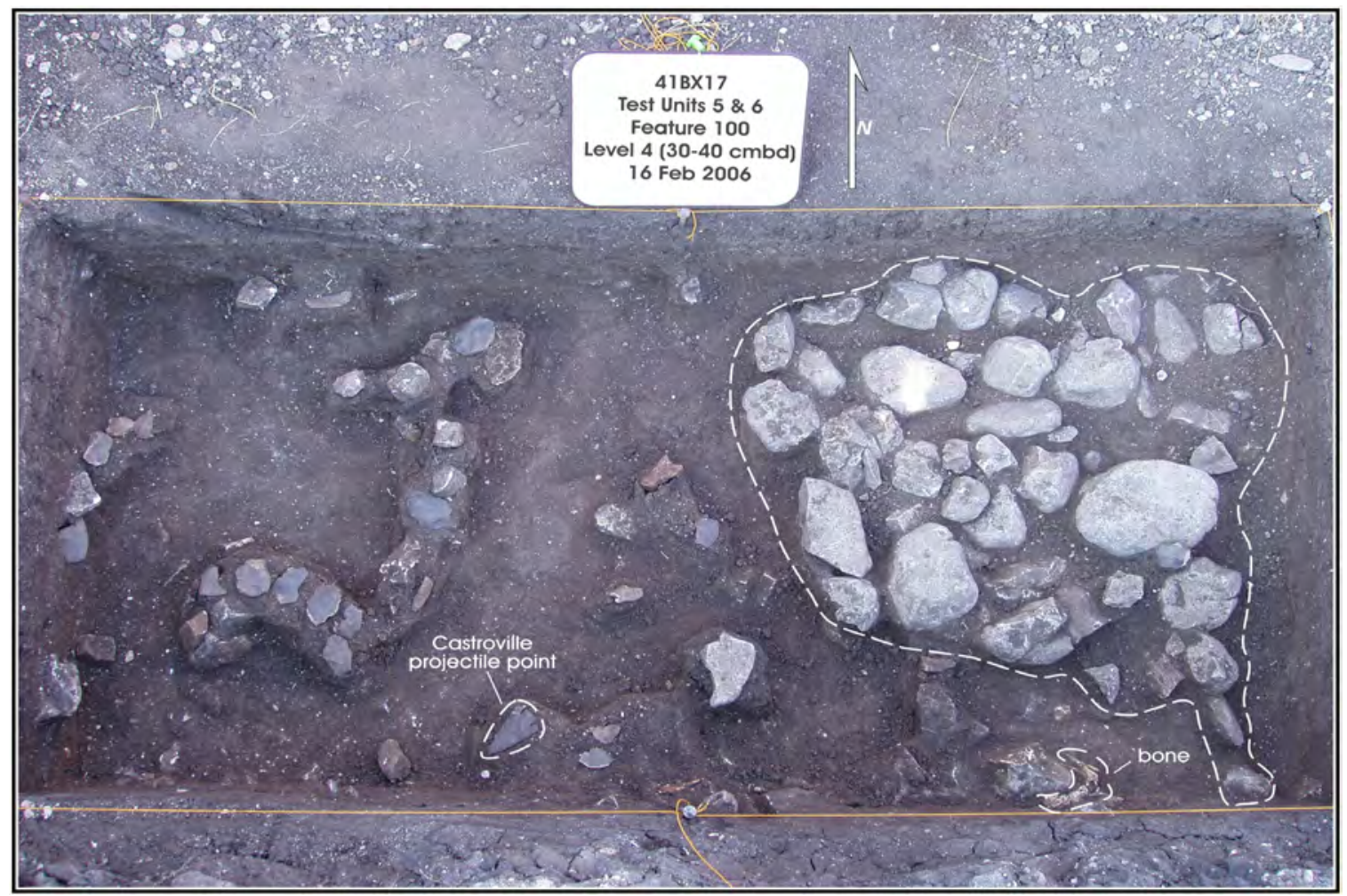

Figure 5-10. Feature 100 is a concentration of burned rock with associated artifacts dating to the Late Archaic.

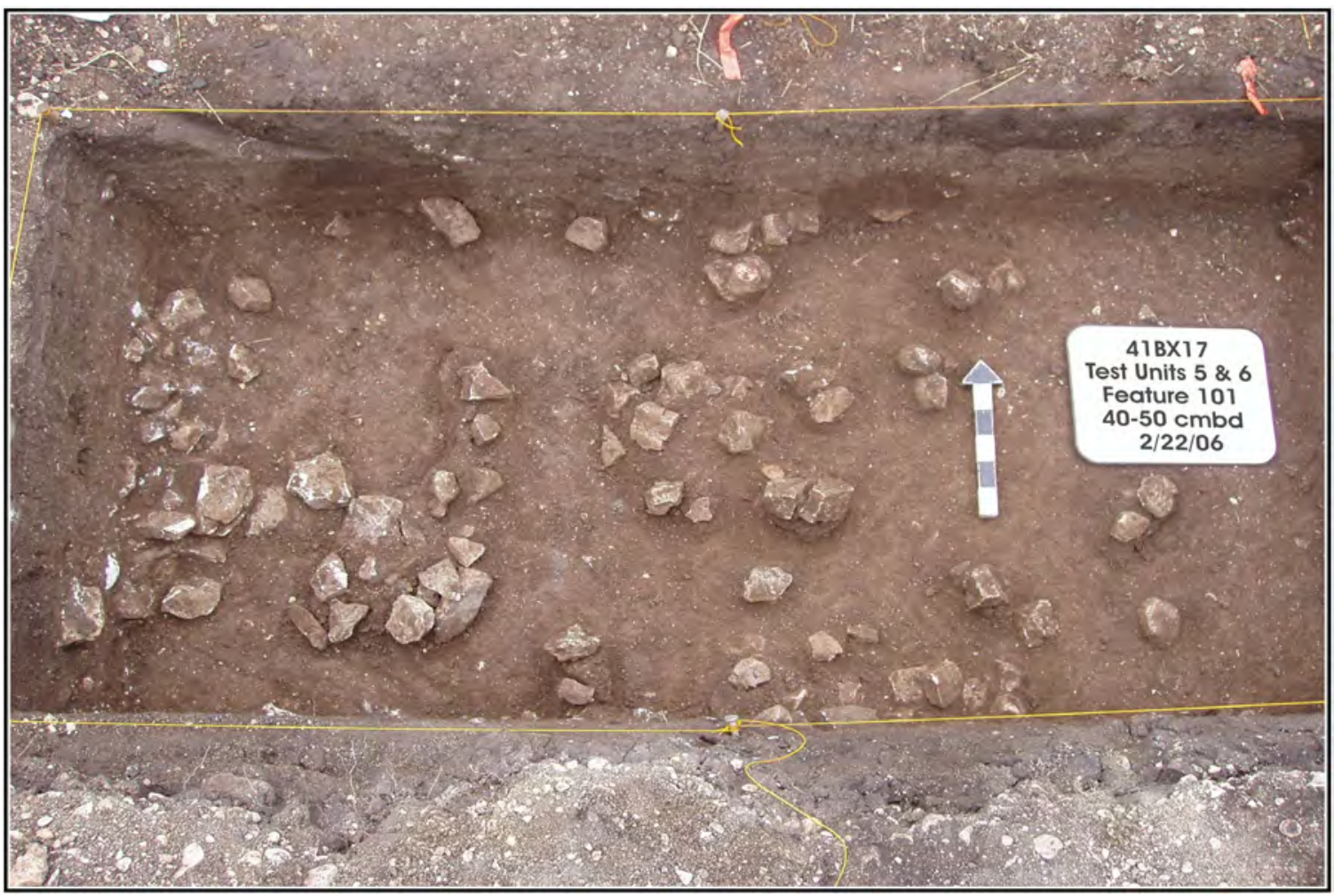

Figure 5-11. Feature 101 is a burned rock cluster directly beneath Feature 100 in the bottom of Zone 1 of Test Unit 6. 


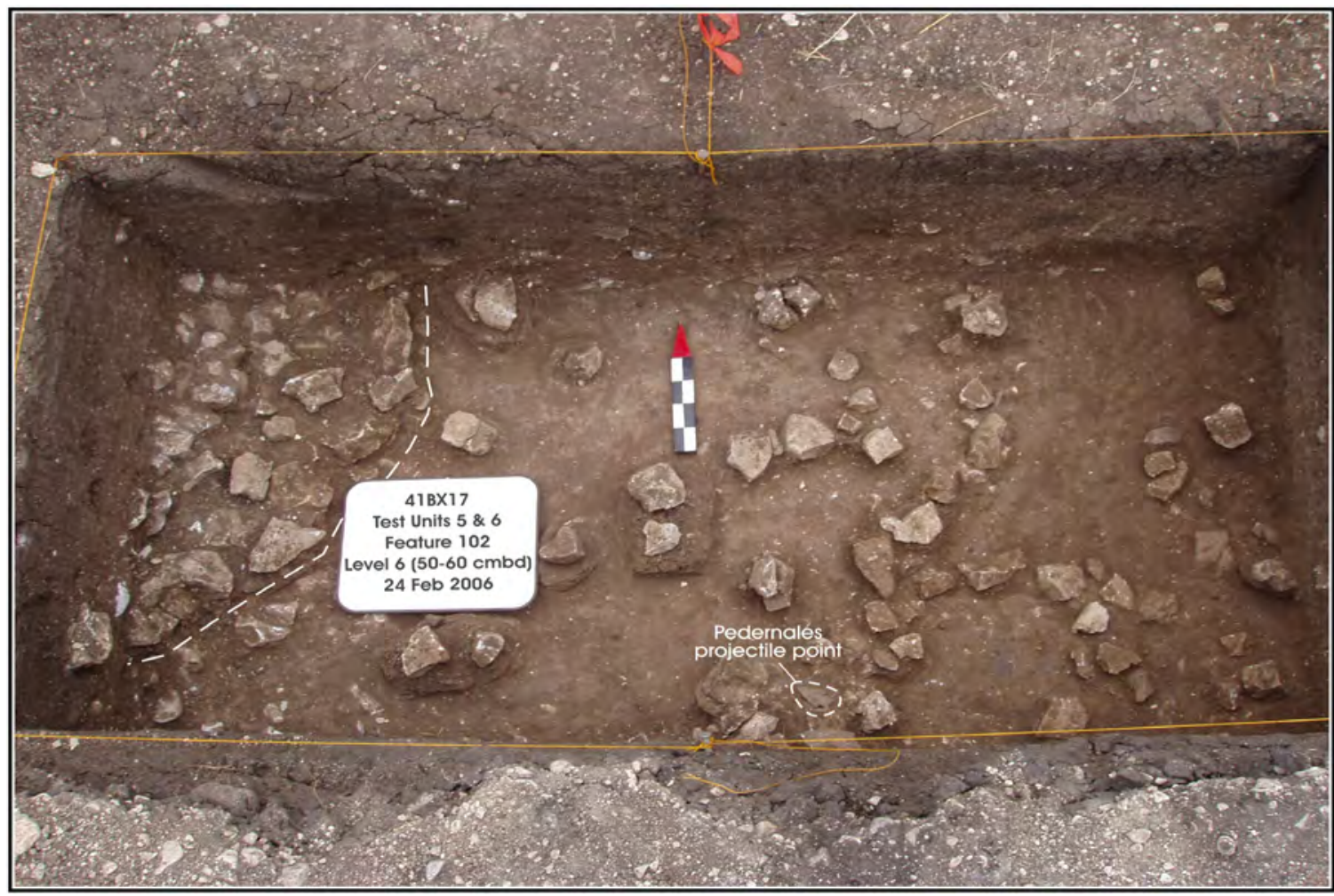

Figure 5-12. Feature 102 is a burned rock cluster with many associated artifacts. Note Pedernales projectile point near the southern wall.

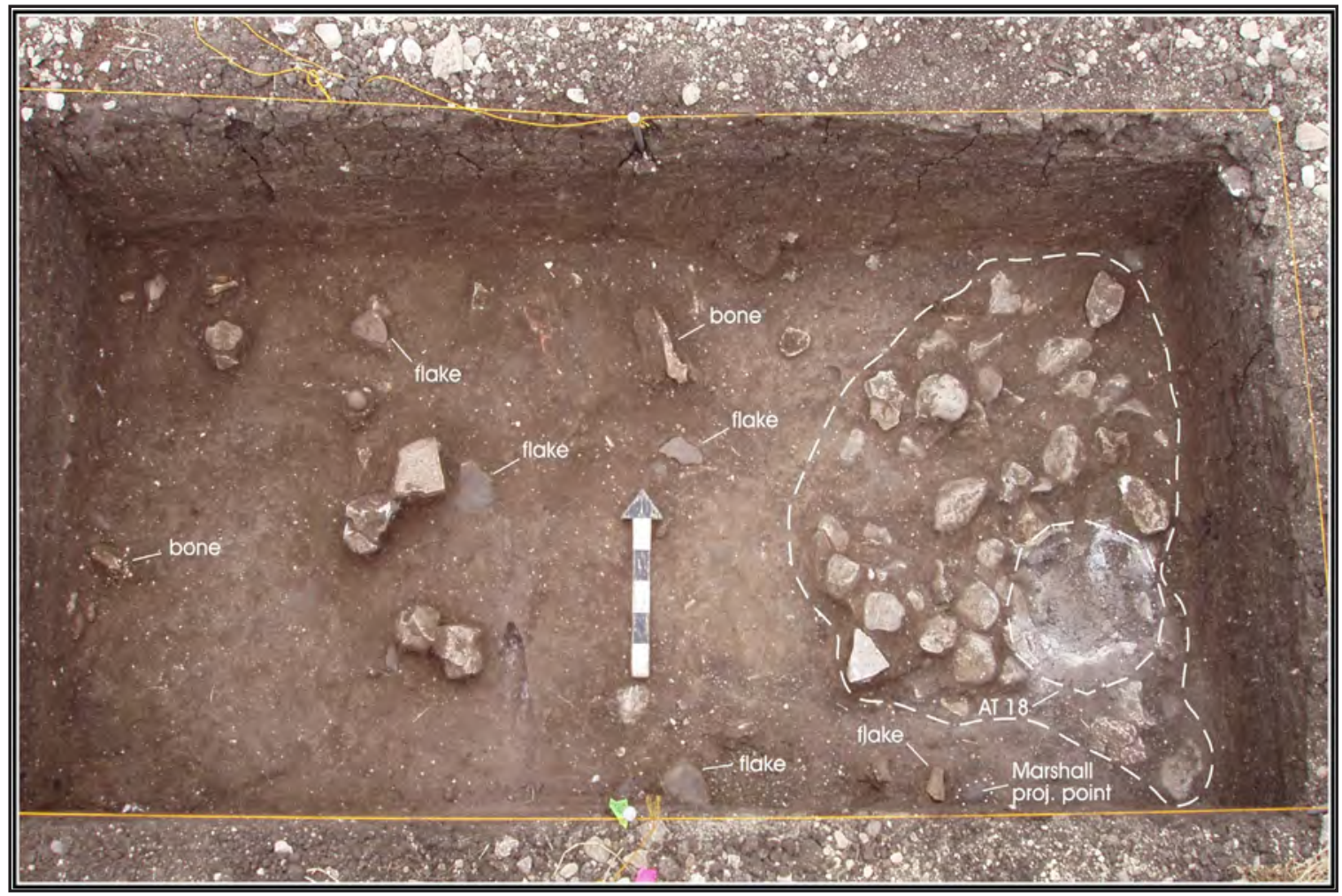

Figure 5-13. Feature 103 is a hearth in Test Unit 4 with numerous associated artifacts. This feature was originally discovered in Auger Test 18. 


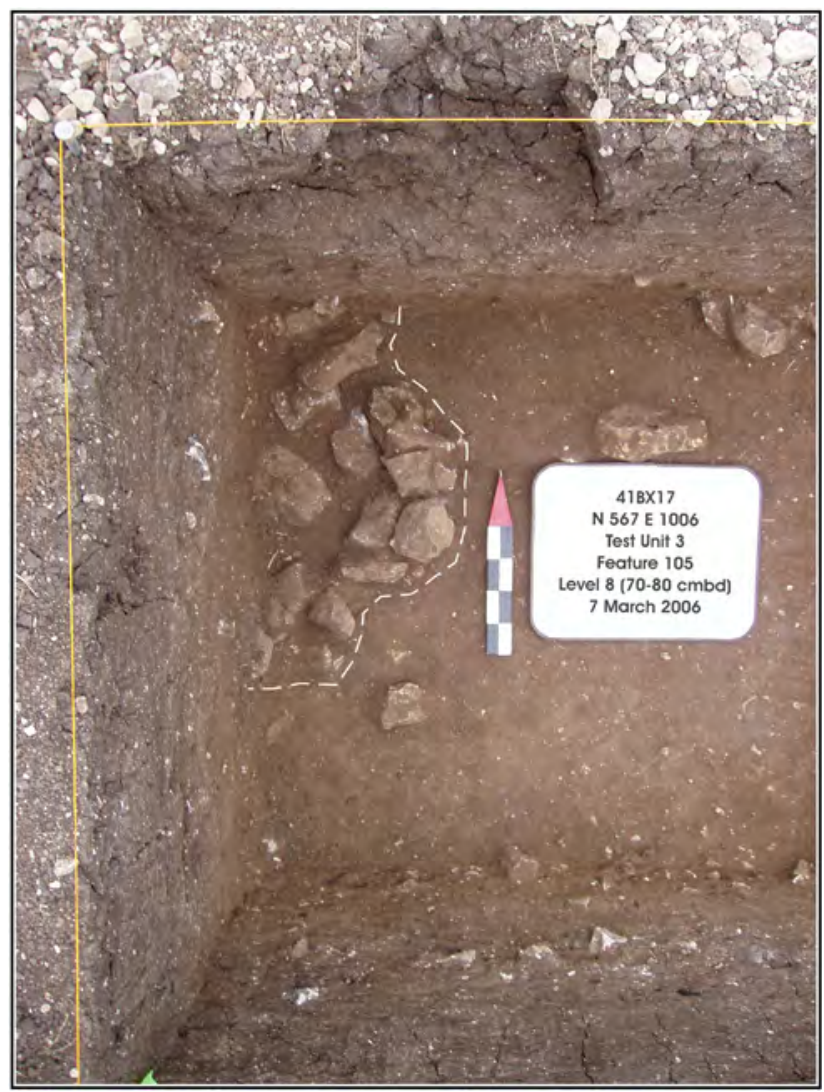

Figure 5-14. Feature 105 is a hearth discovered at the bottom of the Late Archaic deposit.

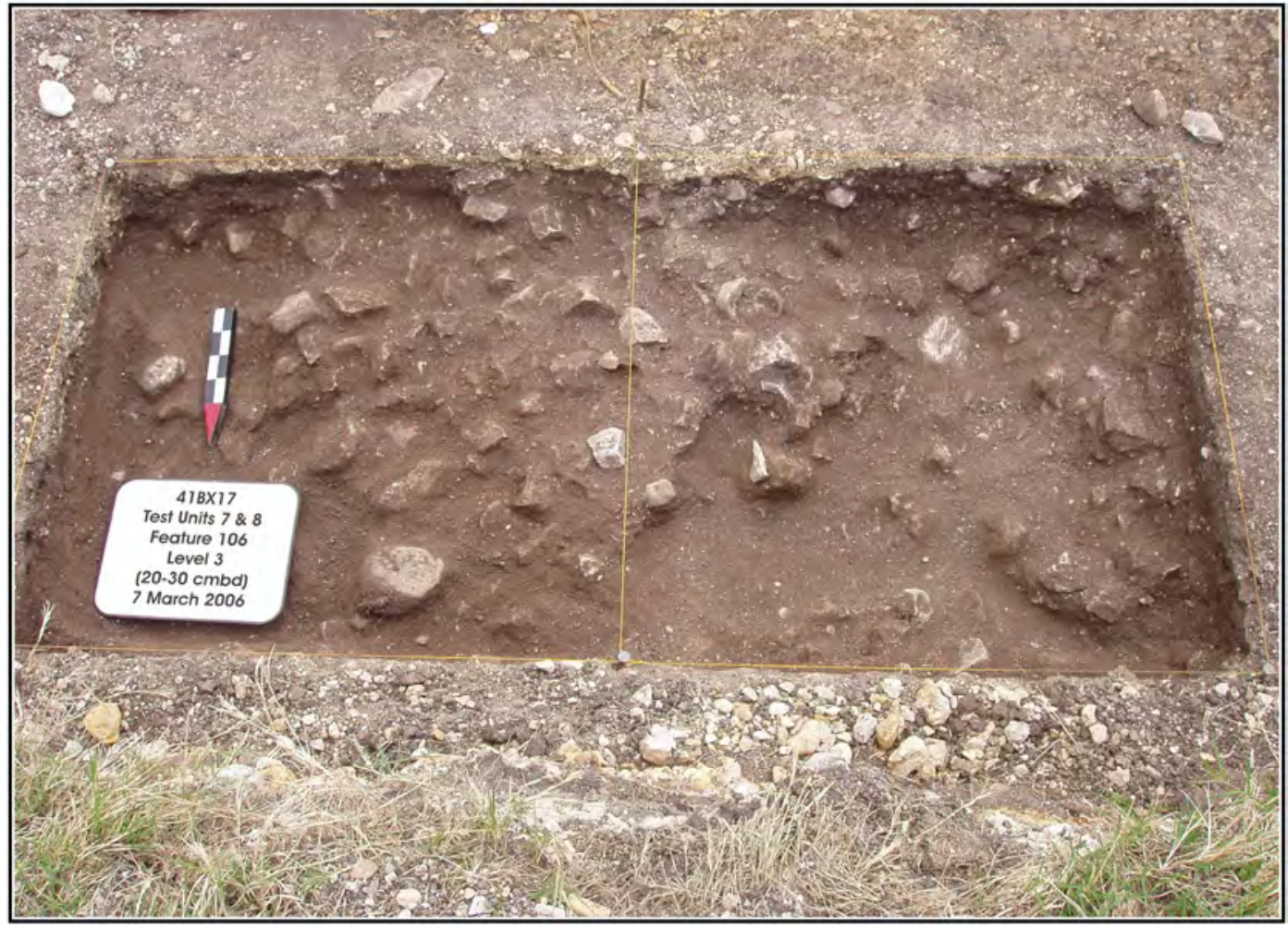

Figure 5-15. Feature 106 shows the concentration of burned rock in the midden deposit of Test Units 7-8. 


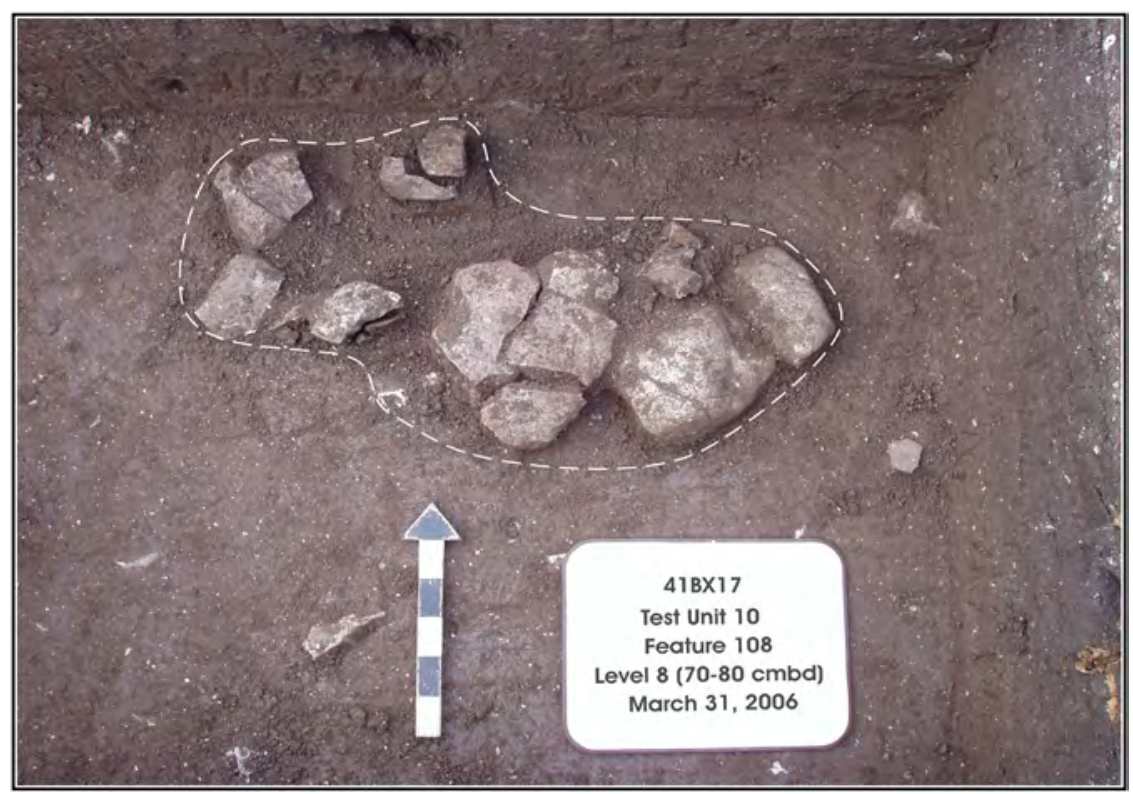

Figure 5-16. Feature 108 is a small scatter of burned rock at 69-81 cmbd in Test Unit 10.

debitage that were in the 1973-1974 collection are no longer present in the collections.

The 1979 material curated at CAR included just over 10,000 flakes, 19 bifaces, four unifaces, a point base, four edge modified flakes, 63 cores, and other miscellaneous material. Comparison with summaries by Markey (1979) and Jones et al. (1979) suggest that while much of the 1979 debitage is still present at CAR, all of the projectile points and many of the formal tools described in the 1979 summaries are no longer present in the collections.
In addition to the review of the CAR's collections Córdova et al. (2005) visited the Witte Museum to assess the extent of the artifact collections from the 1962 Schuetz excavation. The Witte Museum collection includes five drawers of lithic tools, cores, and debitage. A representative sample of diagnostic artifacts, selected to include artifacts from the different areas or units excavated during 1962, were scanned. Samples of the scans from the collections permanently curated at the Witte Museum are presented in Appendix K. All of the diagnostic projectile points recovered during the 1962 excavations are shown as line drawings in Schuetz's 1966 report.

Table 5-6. Artifacts Housed at the CAR from the 1973-1974 and 1979 Excavations at the Granberg Site

\begin{tabular}{|c|c|c|}
\hline Artifact Class & $\mathbf{1 9 7 3 - 1 9 7 4}$ & $\mathbf{1 9 7 9}$ \\
\hline Debitage & $5300+$ & $10000+$ \\
\hline Biface & 76 & 19 \\
\hline Uniface & 8 & 4 \\
\hline Projectile Points & 11 & 4 \\
\hline Edge Modified Flakes & 1 & 63 \\
\hline Cores & 63 & 18 \\
\hline CVS Samples & 0 & Present \\
\hline Soil Samples & Present & Present \\
\hline Snail Shell & 0 & Present \\
\hline Historic Artifacts & 0 & 0 \\
\hline Burned Rock & Present & 0 \\
\hline Bone & Present & \\
\hline
\end{tabular}





\section{Chapter 6: Geoarcheology}

\section{S. Christopher Caran, Jennifer Thompson, and Cynthia M. Munoz}

\section{Location and Geomorphic Context}

Archeological site 41BX17 is located in northeastern San Antonio, Bexar County, Texas, on the left-bank (eastern) flood terrace of Salado Creek (Geological Survey 1973). The site lies approximately $250 \mathrm{~m}$ east of the stream channel, immediately south of N. E. Loop 410 (Córdova et al. 2005:Figure 4-9; Taylor et al. 1962:Sheet Number 37). Salado Creek is a major tributary of the San Antonio River in the West Gulf Coastal Plain physiographic region (Fenneman 1946; Geological Survey 1980). This reach of Salado Creek is perennial, but streamflow is highly variable both seasonally and annually (Buckner and Shelby 1991:272; Geological Survey 1973). Although brief periods with no measurable flow are recorded in some years, baseflow is generally maintained by discharge from a series of small springs. Salado Springs, the largest in the area, are located $1.6 \mathrm{~km}$ downstream from site 41BX17 (Brune 1981:75-76; Geological Survey 1973; Hill and Vaughn 1988).

Within the project area, streamflow is primarily affected by rainfall and runoff from upstream. Southern Texas is one of the most flood-prone areas in the United States, and episodic heavy rains have produced severe flooding many times over the period of record (Buckner and Shelby 1991:272; Caran and Baker 1986:1; Griffiths and Bryan 1987:12-13, 49-50; Slade and Patton 2006b). Flooding can cause erosion, which may damage or even destroy archeological sites; but floodwaters likewise transport large quantities of suspended organic sediment and fine-grained inorganic sediment, which are deposited as the waters recede. This process, known as overbank sedimentation, causes rapid burial, thus preserving archeological sites on flood plains and flood terraces.

\section{Environmental Conditions}

Previous investigations of environmental conditions in the project area provide insights regarding the geoarcheology of site 41BX17. The principal published geological map identifies the deposits within and immediately adjacent to Salado Creek as Holocene "low terrace deposits above flood level" (Brown et al. 1983). This indicates that the terrace is an inactive relict landform on which there is little potential for burial and preservation of cultural resources. Based on published information and data collected during the present inquiry, however, this interpretation is clearly erroneous.
At site 41BX17, Salado Creek need rise only 3 to $4 \mathrm{~m}$ to overtop its bank (Geological Survey 1973). Stages of this and greater magnitudes have been recorded several times since gauging began at this location in 1960 (Buckner and Shelby 1991:272). The highest directly recorded stage was $6.8 \mathrm{~m}$ in 1998, but there are indirect records of even greater floods from as early as 1853 (Slade and Patton 2006a, 2006b). Maximum water level over the entire period was 7.0 to $7.3 \mathrm{~m}$ in 1913 (Buckner and Shelby 1991:272). In this region, where major floods occur frequently, historical records are often good indicators of flooding potential and approximate flood frequency throughout middle to late Holocene prehistory.

Because it is subject to flooding, the broad, flat landform adjacent to the bank of Salado Creek is analogous to a flood plain but has the morphologic expression of a stream terrace: prominent vertical separation from the channel. This landform is, therefore, a flood terrace. Taylor et al. (1962:25, Sheet Number 37) mapped the soils of Bexar County, including site 41BX17. Their findings provide further evidence that the strata underlying the flood terrace are, in part, the product of Holocene overbank deposition. The nominal soil of this area is the Lewisville silty clay. The Lewisville series is a Typic Calciustoll consisting of fine-grained alluvial deposits (Soil Survey Staff 1997). It is found primarily on low-relief terraces of large streams. A Typic Calciustoll is a calcic soil with a dark epipedon (A and B horizons) and at least moderate horizonation. Such soils are common on Holocene flood terraces throughout the region and have significant potential for archeological site preservation.

The upper watershed of Salado Creek remains partly undeveloped but has undergone rapid urbanization over the past 50 years (Geological Survey 1992; Taylor et al.:1962, Sheet Number 37). Site 41BX17 was affected directly, primarily by archeological excavations in 1962, 19731974, and 1979 (Córdova et al. 2005:1). Highway and other road and utility construction at the site required localized trenching and extensive filling to raise the ground level. Consequently, much of the site was disturbed, whereas intact remnants were buried beneath a variable thickness and composition of layered fill dirt. Yet even then, the site was not immune to the effects of stream flooding, which scoured both ancient and modern strata and deposited additional sediment on a number of occasions. Following the excavations of 1962, but prior to filling and construction 


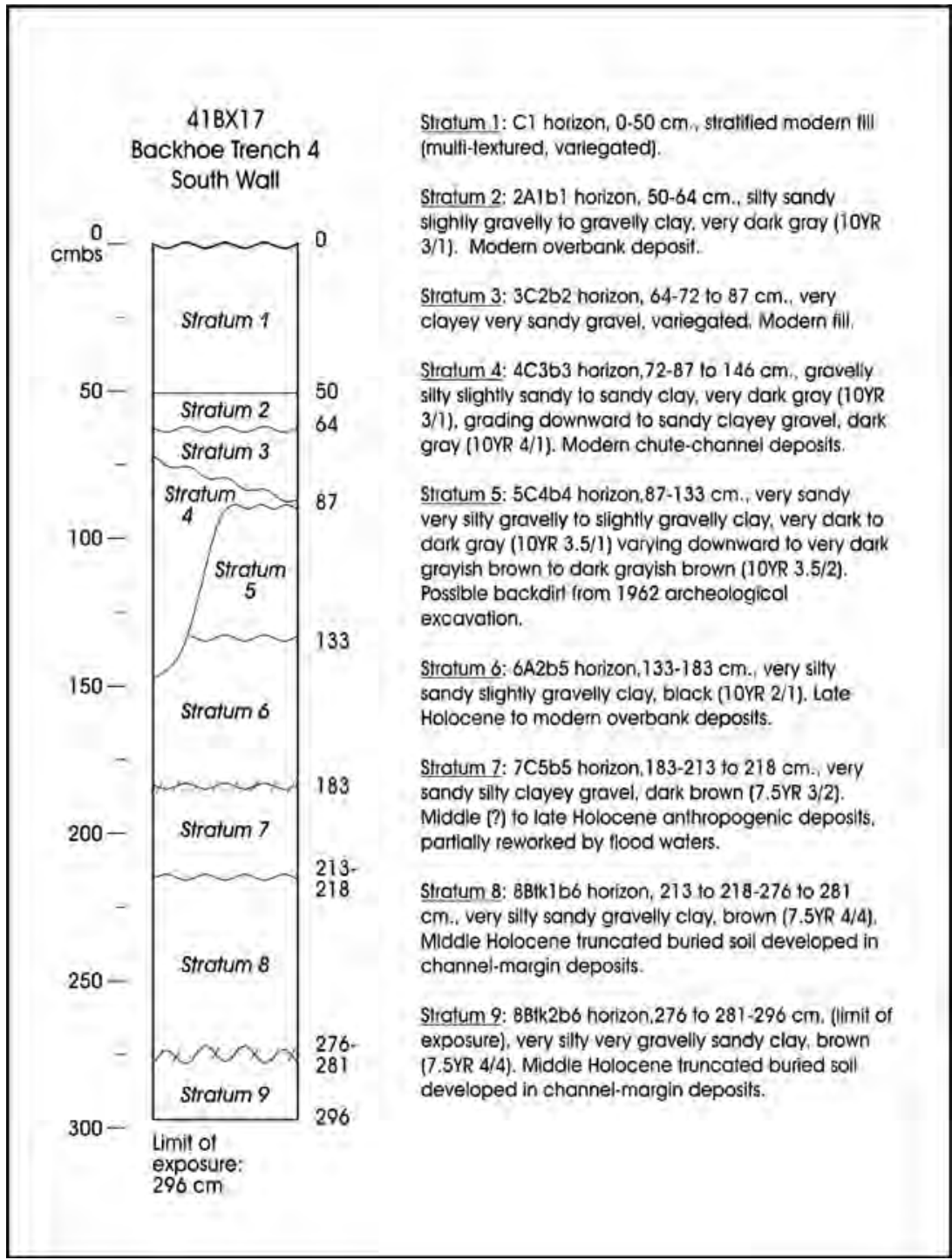

Figure 6-1. Stratigraphic synthesis, Backhoe Trench 4, site 41BX17.

of the adjacent segment of N. E. Loop 410 in 1967, the site was partly inundated three times in 1964 and twice in 1965 (Slade and Patton 2006b). Later floods also affected the site to varying degrees. The stratigraphy of site $41 \mathrm{BX} 17$ reflects each of these impacts and is, therefore, somewhat complex.

\section{Site Stratigraphy}

As stated previously, site 41BX17 was discovered during road construction in 1962. At that time, archeologists recovered abundant Middle Archaic to Late Prehistoric cultural materials from a 2-m thick sequence of anthropogenic (midden and related deposits) and noncultural deposits, including three human burials (Schuetz 1966). Following this initial investigation, both the excavated and remaining intact portions of the site were reburied and covered by a meter or more of fill dirt and compacted roadbase. Additional archeological testing in the 1970s revealed other parts of the site and increased the maximum depth of exposure to more than $3 \mathrm{~m}$. These later studies largely corroborated the original conclusions, but neither they nor the initial inquiry disclosed detailed information regarding the site's stratigraphy and geomorphic history.

The present investigation provides further confirmation of earlier findings, as well as a coherent artifact assemblage and radiocarbon chronology. Project archeologists prepared a series of profile drawings illustrating the stratigraphy at a number of new backhoe trenches and test-excavation units. Most of these exposures were left open for geoarcheological review; the results of which are described here. Table 6-1 summarizes the stratigraphy of individual trench and unit profiles. Backhoe Trench 4 afforded the longest continuous 
Table 6-1. Stratigraphy of Trench and Unit Profiles at Site 41BX17: Summary and Interpretation

\begin{tabular}{|c|c|c|c|}
\hline $\begin{array}{l}\text { Trench or } \\
\text { Unit No. }\end{array}$ & Profile & $\begin{array}{l}\text { Depth (meters } \\
\text { below ground) }\end{array}$ & Genetic Stratigraphy and Inferred Chronology \\
\hline BHT 8 & Stratified fill dirt & $0-1.43$ & Modern fill and roadbase deposits \\
\hline BHT 7 & $\begin{array}{l}\text { Modern fill dirt - fill dirt composed of } \\
\text { backdirt from previous archeological } \\
\text { excavation - overbank deposit - channel } \\
\text { deposit }\end{array}$ & $0-2$ & $\begin{array}{l}\text { Middle Holocene channel and overbank deposits overlain by modern fill dirt } \\
\text { (imported and locally derived) and roadbase material. }\end{array}$ \\
\hline BHT 6 & $\begin{array}{l}\text { Modern fill dirt - fill dirt composed of } \\
\text { backdirt from previous archeological } \\
\quad \text { excavation - channel deposit }\end{array}$ & $0-2.2$ & $\begin{array}{l}\text { Middle Holocene channel deposit overlain by modern fill dirt (imported and } \\
\text { locally derived) and roadbase material. }\end{array}$ \\
\hline BHT 3 & Modern fill dirt - channel deposit & $0-1.8$ & $\begin{array}{l}\text { Middle Holocene channel deposit overlain by modern fill dirt and roadbase } \\
\text { material. }\end{array}$ \\
\hline BHT 9 & $\begin{array}{l}\text { Modern fill dirt - midden and/or midden- } \\
\text { derived deposit - channel deposit }\end{array}$ & $0-1.9$ & $\begin{array}{l}\text { Middle Holocene channel deposit overlain by Middle Archaic midden or } \\
\text { midden-related deposit overlain by modern fill dirt and roadbase material; } \\
\text { radiocarbon age } 3890+/-50 \mathrm{BP} \text {. }\end{array}$ \\
\hline TU 5 & $\begin{array}{l}\text { Modern fill dirt, overbank, and/or slope- } \\
\text { wash (A) - modern fill dirt (2C1b1) - } \\
\text { 3C1b2 - midden and/or slope-wash deposit } \\
\text { (4Acb3) - midden deposit (5ABb4) - 6C3b5 } \\
\text { - 7C4b6 - 7CB1b7 - 8CB2b7 }\end{array}$ & $0-3.3$ & $\begin{array}{c}\text { Middle Holocene overbank deposit overlain by middle Holocene channel- } \\
\text { margin deposits overlain by middle Holocene channel deposit overlain by } \\
\text { middle Holocene midden deposit overlain by middle to Late Holocene midden } \\
\text { and/or slope-wash deposit overlain by modern chute-channel deposit overlain } \\
\text { by modern fill dirt overlain by modern fill dirt, overbank, and/or slope-wash } \\
\text { deposit; radiocarbon ages Cal 4290-4080 BP; Cal 4830-4520 BP. }\end{array}$ \\
\hline TU 6 & $\begin{array}{l}\text { Modern fill dirt (stripped) - slope wash } \\
\text { deposit-midden deposit-channel deposit- } \\
\text { channel margin deposit - overbank deposit }\end{array}$ & $0-3.4$ & $\begin{array}{l}\text { Middle Holocene overbank deposit overlain by middle Holocene channel- } \\
\text { margin deposits overlain by middle Holocene channel deposit overlain by } \\
\text { middle Holocene midden deposit overlain by middle to Late Holocene midden } \\
\text { and/or slope-wash deposit overlain by modern chute-channel deposit overlain } \\
\text { by modern overbank deposit; radiocarbon ages Cal 2010-1860 BP. }\end{array}$ \\
\hline TU3 & $\begin{array}{l}\text { Modern fill dirt (stripped) - overbank } \\
\text { deposit - midden deposit - channel deposit }\end{array}$ & $0-3.5$ & $\begin{array}{c}\text { Middle Holocene channel deposits overlain by Middle Archaic midden } \\
\text { deposits overlain by Late Holocene overbank deposits - overlain by modern fill } \\
\text { dirt; radiocarbon age } 3590+/-40 \text { BP. }\end{array}$ \\
\hline TU4 & $\begin{array}{l}\text { Modern fill dirt (stripped) - overbank } \\
\text { deposit - midden deposit - channel deposit }\end{array}$ & $0-3.5$ & $\begin{array}{c}\text { Middle Holocene channel deposits overlain by Middle Archaic midden } \\
\text { deposits overlain by Late Holocene overbank deposits - overlain by modern fill } \\
\text { dirt; radiocarbon age } 2510+/-40 \text { BP }(134 \mathrm{~cm}) .\end{array}$ \\
\hline BHT 2 & $\begin{array}{l}\text { Modern fill dirt - backdirt - overbank } \\
\text { deposit - midden deposit - channel deposit; } \\
\text { overbank deposit }\end{array}$ & 3.6 & $\begin{array}{l}\text { Middle Holocene channel and overbank deposits overlain by Middle Archaic } \\
\text { midden deposits overlain by late Holocene overbank deposits overlain by } \\
\text { modern fill dirt. }\end{array}$ \\
\hline BHT 4 & $\begin{array}{l}\text { Modern fill dirt (C1) - 2A1b1 - modern fill } \\
\text { dirt (3C2b2) - 4C3b3 - backdirt (5C4b4) - } \\
\text { 6A2b5 - 7C5b5 - 8Btk1b6 - 8Btk2b6 }\end{array}$ & $0-2.96$ & $\begin{array}{l}\text { Middle Holocene channel deposits overlain by disturbed Middle Archaic } \\
\text { cultural deposits overlain by late Holocene overbank deposits overlain by } \\
\text { backdirt from previous archeological excavation overlain by modern chute- } \\
\text { channel deposits overlain by modern fill dirt overlain by modern overbank } \\
\text { deposits overlain by modern fill dirt. }\end{array}$ \\
\hline BHT 5 & $\begin{array}{l}\text { Modern fill dirt (C1) - 2A1b1 - modern fill } \\
\text { dirt (3C2b2) - 4A2b3 - 5Btb4) - 5Btk1b4 - } \\
\text { 5BTk2b4 }\end{array}$ & $0-2.59$ & $\begin{array}{l}\text { Middle Holocene channel deposits overlain by middle Holocene overbank and } \\
\text { colluvial deposits overlain by modern fill dirt overlain by modern overbank } \\
\text { deposits overlain by modern fill dirt. }\end{array}$ \\
\hline
\end{tabular}

Exposures examined by the author are listed in sequence from west to east across the project area. Exposures that provided key stratigraphic information regarding the site are described in detail. The profile is described from ground surface downward, whereas the genetic information is from base of exposure to ground surface.

exposure and the greatest range of stratigraphic variation. Figure 6-1 and Table 6-2 illustrate and describe in detail profile in BHT 4, which is representative of much of the site. The profile in Test Unit 5 was also described because it yielded two radiocarbon samples, affording good chronological control (Figure 6-2, Table 6-3). An additional radiocarbon sample was collected from Test Unit 6, immediately east of Test Unit 5, further constraining the site's chronostratigraphy (Figure 6-2; Table 6-3). The radiocarbon dates, analytical units, and profile strata are summarized in 6-4. Overall stratigraphy of the site is shown in Figure 6-3, a geological cross-section. Data collected and evaluated during the geoarcheological study provide the basis for a genetic model of site development and post-occupational history. 
Table 6-2. Stratigraphic Profile Exposed in the Southern Wall of Backhoe Trench 4

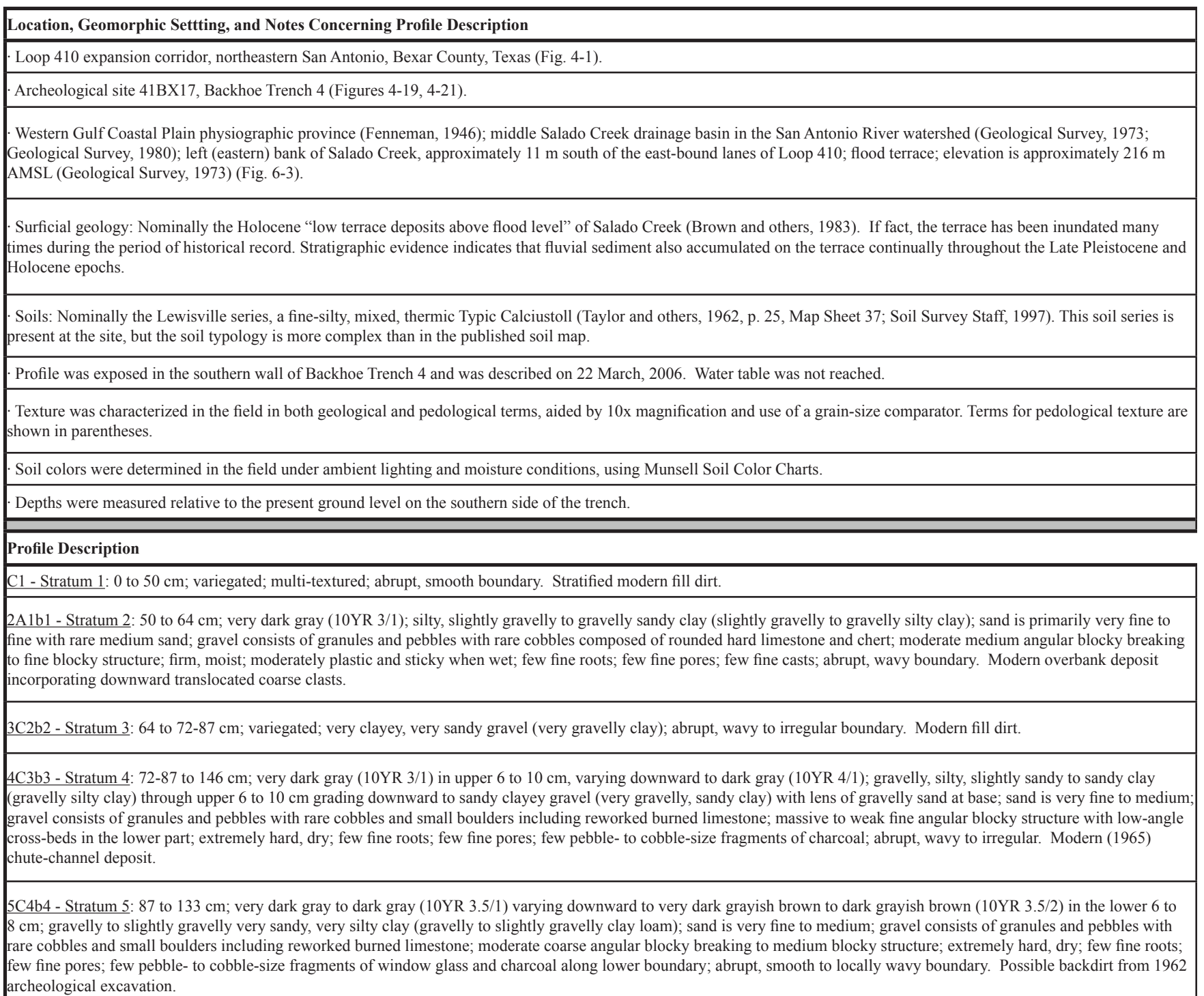
archeological excavation.

6A2b5 - Stratum 6: 133 to $183 \mathrm{~cm}$; black (10YR 2/1); very silty, sandy, slightly gravelly clay (slightly gravelly, silty clay); sand is primarily very fine to fine with rare medium sand; gravel consists of isolated granules, pebbles, cobbles, and rare small boulders composed of rounded hard limestone including reworked burned limestone and chert flakes; strong coarse angular blocky (upper $20 \mathrm{~cm}$ ) to strong coarse angular prismatic breaking to fine to medium blocky structure; extremely hard, dry; moderately plastic and sticky when wet; many fine pressure faces; few fine and medium roots; common fine pores, most with clay linings; few fine casts; many whole and fragmented landsnail shells; clear, wavy boundary. Late Holocene to modern overbank deposit.

7C5b5 - Stratum 7: 183 to 213-218 cm; dark brown (7.5YR 3/2); very sandy, silty, clayey gravel (very gravelly, silty clay loam); sand is very fine to very coarse; gravel consists of granules and pebbles with few cobbles of rounded hard limestone including reworked burned limestone; massive structure; clast-supported and imbricated; slightly hard, dry; many fine pressure faces; few fine roots; few fine pores; abrupt, wavy boundary. Middle Holocene anthropogenic (midden-margin) deposits partly reworked by floodwaters.

8Btk1b6 - Stratum 8: 213-218 to 276-281 cm; brown (7.5YR 4/4); very silty, sandy, gravelly to slightly gravelly clay (gravelly to slightly gravelly, silty clay); sand is very fine to medium; gravel consists of granules and pebbles of rounded hard limestone with rare chert flakes; moderate fine to medium angular prismatic breaking to fine blocky structure; firm, moist; many calcareous filaments and few thin incomplete calcareous films; few to common pebble-size hard spherical to oblong calcareous nodules with septarian interiors; thin to moderately thick nearly complete argillans; few fine roots; many fine pores; many fine casts; common whole and fragmented landsnail shells; gradual, wavy boundary. Middle Holocene channel-margin deposits with a well-developed truncated buried soil.

8Btk2b6 - Stratum 9: 276-281 to $296 \mathrm{~cm}$ (limit of exposure); brown (7.5YR 4/4); very silty very gravelly sandy clay (very gravelly, silty clay); sand is very fine to medium; gravel consists of granules and pebbles of rounded hard limestone; moderate fine to medium angular prismatic breaking to fine blocky structure; firm, moist; many calcareous filaments and few thin incomplete calcareous films; few to common pebble-size hard spherical to oblong calcareous nodules with septarian interiors; thin to moderately thick nearly complete argillans; few fine roots; many fine pores; many fine casts; common whole and fragmented landsnail shells. Middle Holocene channel-margin deposits with a well-developed buried soil. 


\section{Red Alluvial Gravel}

In general, the stratigraphy of site $41 \mathrm{BX} 17$ is relatively consistent across most of the site, although some lateral variation is evident and the depths of individual strata differ from place to place (Figure 6-3). At the base of the deepest profiles, from 2.3-2.6 $\mathrm{m}$ depth to below the maximum depth of exposure, 3.3-3.6 m, there is a rubified (reddened through concentration of iron oxide) sandy gravel locally grading upward to a silty clay (for examples, see BHT 8 Figure 6-4 and TU 5 Figure 6-2). This Middle Holocene channel deposit is the "red alluvial gravel" of Schuetz (1966). A shallow grave was excavated into this stratum, which contains other features and isolated Middle Archaic artifacts in its the upper $0.5 \mathrm{~m}$. Charcoal from $2.3 \mathrm{~m}$ depth in Test Unit 5 yielded a conventional radiocarbon age of 4150 +/-40 BP (calibrated 4830-4520 BP, Beta-215740). Total thickness and maximum age of this bed are unknown. The sandy gravel may represent the basal fill of the terrace, lying on an eroded bedrock surface, and probably was deposited as the main channel of Salado Creek migrated across its valley bottom.

\section{Overbank and Cultural Deposits}

Overlying the basal gravel is a laterally variable, 0.4 to 1 $\mathrm{m}$ thick, brown, gravelly clay or sandy gravel with a light gray to dark brown, fine-grained matrix (see Strata 7 and 8 in BHT 4, Figure 6-1, Table 6-2). A moderately mature,

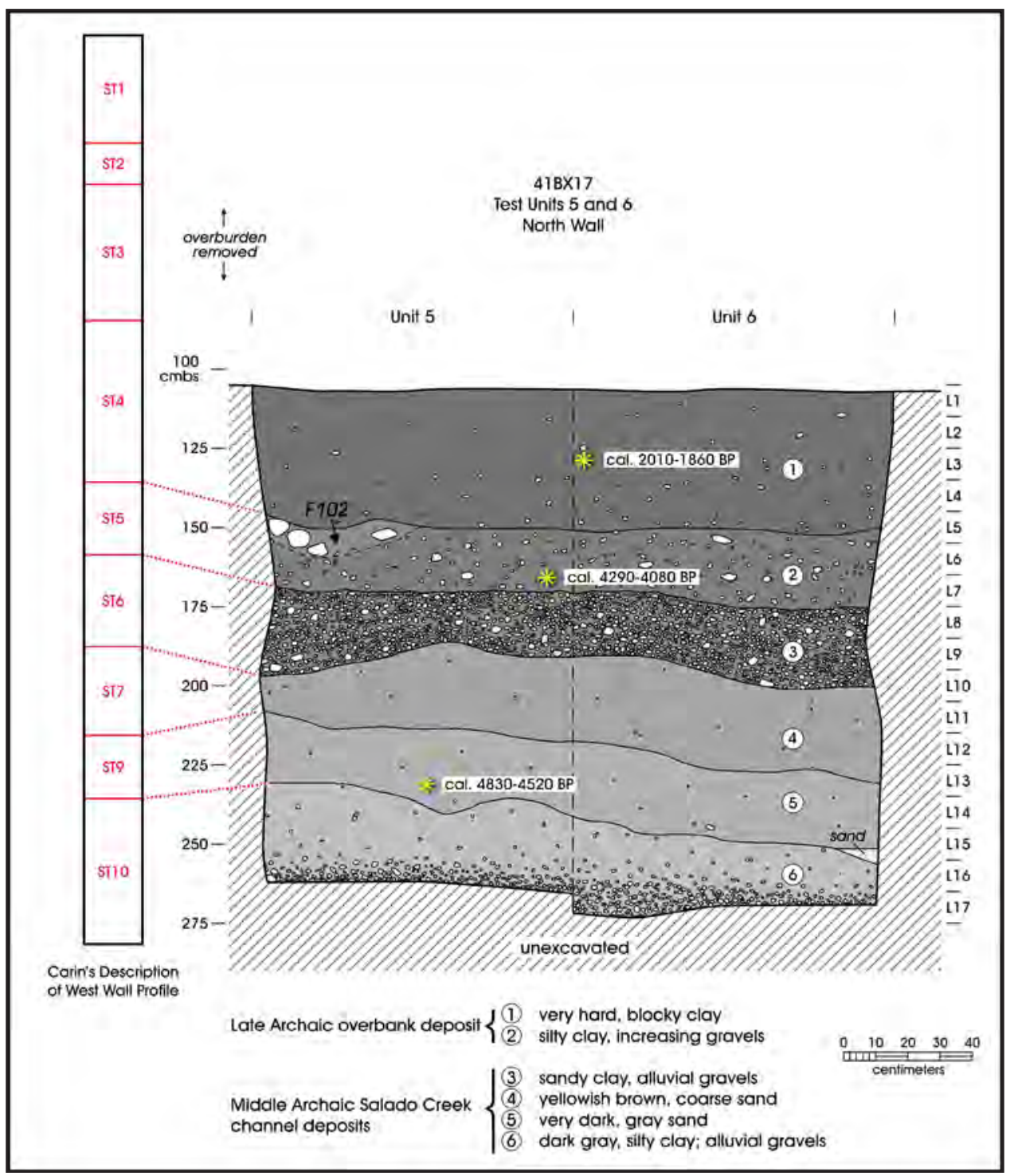

Figure 6-2. Profile of the north wall of Test Units 5 and 6. 
Table 6-3. Stratigraphic Profile Exposed in the Western Walls of Block 1 and Test Unit 5

\section{Location, Geomorphic Setting, and Notes Concerning Profile Description}

- Loop 410 expansion corridor, northeastern San Antonio, Bexar County, Texas (Figure 4-1)

- Archeological site 41BX17, Block 1 and Test Unit 5 within Block 1 (Fig. 4-16).

Western Gulf Coastal Plain physiographic province (Fenneman, 1946); upper Salado Creek drainage basin in the San Antonio River watershed (Geological Survey, 1973; Geological Survey, 1980); left (eastern) bank of Salado Creek, approximately $7 \mathrm{~m}$ south of the east-bound lanes of Loop 410 ; flood terrace; elevation is approximately $216 \mathrm{~m}$ AMSL (Geological Survey, 1973).

Surficial geology: Nominally the Holocene "low terrace deposits above flood level" of Salado Creek (Brown and others, 1983). If fact, floods have inundated this terrace many times during the period of historical record. Stratigraphic evidence indicates that fluvial sediment accumulated on the terrace continually throughout the Late Pleistocene and Holocene epochs.

Soils: Nominally the Lewisville series, a fine-silty, mixed, thermic Typic Calciustoll (Taylor and others, 1962, p. 25, Map Sheet 37; Soil Survey Staff, 1997). This soil series is present at the site, but the soil typology is more complex than in the published soil map.

The upper $\sim 1 \mathrm{~m}$ of deposits within Block 1 had been scraped prior to commencement of the geoarcheological investigation; however, the upper part of the profile remained intact in the western wall of Block 1 immediately adjacent to Test-excavation Unit 5 . The lower part of the profile was exposed in the western wall of Test-excavation Unit 5 . The composite profile was described on 03 April, 2006. Water table was not reached, but the lower walls of contiguous of Test-excavation Unit 6 were wet.

Texture was characterized in the field in both geological and pedological terms, aided by 10x magnification and use of a grain-size comparator. Terms for pedological texture are shown in parentheses.

Soil colors were determined in the field under ambient lighting and moisture conditions, using Munsell Soil Color Charts

Depths were measured relative to the present ground level on the western side of the trench.

\section{Profile Description}

A - Stratum 1: 0 to $34 \mathrm{~cm}$; very dark gray (10YR 3/1); silty, slightly gravelly to gravelly sandy clay (slightly gravelly to gravelly, silty clay); sand is primarily very fine to fine with rare medium sand; gravel consists of rounded granules and pebbles with rare cobbles composed of hard limestone and chert; moderate medium angular blocky breaking to fine blocky structure; firm, moist; moderately plastic and sticky when wet; few fine roots; few fine pores; few fine casts; abrupt, wavy boundary. Modern fill, fluvial overbank, and/or slope-wash deposits incorporating coarse clasts (from fill).

2C1b1 - Stratum 2: 34 to $47 \mathrm{~cm}$; variegated; very clayey, very sandy gravel (very gravelly clay); abrupt, wavy to irregular boundary. Modern fill dirt.

3C2b2 - Stratum 3: 47 to $90 \mathrm{~cm}$; from 47 to $78 \mathrm{~cm}$, very dark gray (10YR 3/1), varying downward to dark gray $(10 \mathrm{YR} 4 / 1)$ from 78 to $90 \mathrm{~cm}$; from 47 to $78 \mathrm{~cm}$, gravelly, silty, slightly sandy to sandy clay (gravelly silty clay), grading downward to sandy, clayey gravel (very gravelly, sandy clay) from 78 to $90 \mathrm{~cm}$; sand is very fine to medium; gravel consists of granules and pebbles with rare cobbles and small boulders including reworked burned limestone; massive to weak fine angular blocky structure with low-angle cross-beds in the lower part; extremely hard, dry; few fine roots; few fine pores; few pebble-size fragments of charcoal; abrupt, wavy to irregular boundary. Lower boundary is approximately $20 \mathrm{~cm}$ above the site datum. Modern (1965) fluvial chute-channel deposit.

4ACb3 - Stratum 4: 90 to $141 \mathrm{~cm}$; dark gray (10YR 4/1); silty, slightly sandy, slightly gravelly clay (slightly gravelly clay); sand is very fine to medium; gravel consists of rounded and subangular granules and pebbles with rare cobbles including reworked burned limestone; moderate coarse angular blocky breaking to medium blocky structure; extremely hard, dry; few fine roots; few fine pores; few whole landsnail shells (Rabdotus sp.); abrupt, wavy boundary. Middle Holocene anthropogenic deposit (midden) and/or slope-washed sediment derived from midden (see Stratum 5, below). Radiocarbon sample (charcoal) collected from Feature 100, $31 \mathrm{~cm}$ below the site datum: Cal 2010-1860 BP, $\mathrm{d}^{13} \mathrm{C}-24.9 \%$ (Beta-215736)

5ABb4 - Stratum 5: 141 to $164 \mathrm{~cm}$; dark gray to gray (10YR 4.5/1); very silty, very sandy, gravelly clay (gravelly, clay loam); sand is primarily very fine to fine with rare medium sand; gravel consists of both clustered and isolated rounded to subangular granules, pebbles, cobbles, and rare small boulders composed of hard limestone including burned limestone with chert flakes, tools, and projectile points; strong coarse angular blocky structure; extremely hard, dry; moderately plastic and sticky when wet; few fine and medium roots; common fine pores, most with clay linings; few fine casts; many whole and fragmented landsnail shells (Rabdotus sp.); abrupt, wavy boundary. Lower boundary is 54 cm below the site datum. Middle Holocene anthropogenic deposit (midden) containing intact burned-rock features. Radiocarbon sample (charcoal) collected from Feature $104,67 \mathrm{~cm}$ below the site datum: Cal 4290-4080, $\mathrm{d}^{13} \mathrm{C}-25.2 \%$ (Beta-215738)

6C3b5 - Stratum 6: 164 to $193 \mathrm{~cm}$; fine-grained matrix is light gray (10YR 7/1); very sandy, silty, clayey gravel (very gravelly, clay loam); sand is very fine to very coarse; gravel consists of rounded granules and pebbles with rare cobbles of hard limestone; massive structure with low-angle cross-beds; clast-supported and imbricated; slightly hard, dry; few fine roots; few fine pores; gradual, wavy boundary. Middle Holocene fluvial channel deposit.

7C4b6 - Stratum 7: 193 to $221 \mathrm{~cm}$; reddish yellow (7.5YR 6/6); slightly gravelly to locally gravelly, silty sand (slightly gravelly to gravelly sand); sand is fine to very coarse; gravel consists of rounded granules and pebbles of hard limestone with rare chert flakes; weak fine to medium angular blocky structure; firm, moist; few fine roots; few fine pores gradual, wavy boundary. Middle Holocene fluvial channel-margin deposit.

7CB1b7 - Stratum 9: 221 to $241 \mathrm{~cm}$; very dark grayish brown (10YR 3/2); very silty, slightly gravelly sand (slightly gravelly, loamy sand); sand is fine to coarse; gravel consists of rounded granules and pebbles of hard limestone with few chert flakes; moderate fine to medium angular blocky structure; firm, moist; few fine roots; many fine pores. Middle Holocene fluvial channel-margin deposit with a weakly developed buried soil. Radiocarbon sample (charcoal) collected from matrix, $126 \mathrm{~cm}$ below the site datum: Cal 4830 $4520 \mathrm{BP}, \mathrm{d}^{13} \mathrm{C}-26.3 \%$ (Beta-215740).

8CB2b7 - Stratum 10: 241 to $287 \mathrm{~cm}$ (limit of exposure); dark gray (10YR 4/1); upward-fining sequence, grading from silty, sandy gravel (very gravelly, sandy loam) to silty clay (silty clay); sand is fine to coarse; gravel consists of rounded granules and pebbles of hard limestone with few chert flakes; reportedly contains burned-rock features; moderate fine to medium angular blocky structure; firm, moist; few fine roots; many fine pores. Middle Holocene fluvial channel-margin deposit with a weakly developed buried soil. 
Table 6-4. Relationship of Radiocarbon Dates to Geological Strata

\begin{tabular}{|c|c|c|c|c|c|c|c|}
\hline Date cal BP & $\mathbf{A U}$ & Feature & Provenience & & $\begin{array}{l}\text { Geological Strata } \\
\text { (Caran) }^{\mathrm{a}}\end{array}$ & Table & Strata Description \\
\hline $2010-1860$ & Late Archaic & 100 & TU 6 & $23-30 \mathrm{cmbd}$ & $\left|\begin{array}{c}\text { Stratum } 4 \text { (Block } 1 \\
\text { and TU } 5 \text { sequence) }\end{array}\right|$ & $6-3$ & $\begin{array}{l}\text { dark gray (10YR4/1), silty, slightly sandy } \\
\text { slightly gravelly clay, Middle Holocene } \\
\text { anthropogenic deposit and/or slope-washed } \\
\text { sediment derived from midden. }\end{array}$ \\
\hline $\begin{array}{l}2740-2450 \\
2410-2380\end{array}$ & Late Archaic & 103 & TU 4 & $42-55 \mathrm{cmbd}$ & $\begin{array}{l}\text { Stratum } 7 \text { (BHT } 4 \\
\text { sequence) }\end{array}$ & $6-2$ & $\begin{array}{c}\text { dark brown (7.5YR3/2), very sandy, silty, } \\
\text { clayey gravel, Middle Holocene anthropogenic } \\
\text { (midden-margin) deposits partly reworked by } \\
\text { floodwaters. }\end{array}$ \\
\hline $3980-3820$ & Late Archaic & 105 & TU 3 & $60-70 \mathrm{cmbd}$ & $\begin{array}{c}\text { Stratum } 8(\mathrm{BHT} 4 \\
\text { sequence })\end{array}$ & $6-2$ & $\begin{array}{c}\text { brown (7.5YR4/4), very silty, sandy gravelly } \\
\text { to slightly gravelly clay, Middle Holocene } \\
\text { channel-margin deposits with a well- } \\
\text { developed truncated buried soil. }\end{array}$ \\
\hline $4290-4080$ & Middle Archaic & 104 & TU 5 & $67 \mathrm{cmbd}$ & $\left|\begin{array}{c}\text { Stratum } 4 \\
\text { termination (Block 1 } \\
\text { and TU } 5 \text { sequence) }\end{array}\right|$ & $6-3$ & $\begin{array}{l}\text { dark gray (10YR4/1), silty, slightly sandy } \\
\text { slightly gravelly clay, Middle Holocene } \\
\text { anthropogenic deposit and/or slope-washed } \\
\text { sediment derived from midden. }\end{array}$ \\
\hline $4430-4160$ & Middle Archaic & 109 & BHT 9 & $160 \mathrm{cmbd}$ & $\begin{array}{c}\text { Stratum } 8 / 9 \text { (BHT } 4 \\
\text { sequence) }\end{array}$ & $6-1$ & $\begin{array}{c}\text { Middle Holocene anthropogenic (midden } \\
\text { and/or midden-derived) deposit over Middle } \\
\text { Holocene fluvial channel-margin deposit with } \\
\text { a weakly developed buried soil. }\end{array}$ \\
\hline $4830-4520$ & Middle Archaic & $\mathrm{n} / \mathrm{a}$ & TU 5 & $146 \mathrm{cmbd}$ & $\begin{array}{c}\text { Stratum } 9 \text { (Block } 1 \\
\text { and TU } 5 \text { sequence) }\end{array}$ & $6-3$ & $\begin{array}{c}\text { very dark grayish brown (10YR3/2), very } \\
\text { silty, slightly gravelly sand, Midden Holocene } \\
\text { fluvial channel-margin deposit with a weakly } \\
\text { developed buried soil. }\end{array}$ \\
\hline
\end{tabular}

${ }^{\text {a }}$ Caran's strata numbers from Block 1/TU 5 and BHT 4 do not correspond and should be considered seperately. Therefore, Strata 7 and 8 from BHT 4 are located, sequentially, above Strata 5 of Block 1/TU 5.

calcic and/or argillic soil developed in these deposits, which contain scattered burned rock and chert artifacts. The deposits are Middle Holocene in age and appear to consist of mixed overbank and colluvial sediment. In part, they derived from and horizontally interfinger with a 0.5 to $1 \mathrm{~m}$ thick, dark brown, gravelly clay midden deposits containing a much higher concentration of burned rock and artifacts (see Test Units 5 and 6, Figure 6-2). Schuetz (1966) found two graves within the midden, but no additional gravesites were discovered during the present investigation. Diagnostic artifacts and radiocarbon analyses indicate that the site was occupied from at least 4100 to less than $2000 \mathrm{BP}$.

Both the midden and the gravelly soil are overlain by a 0.5 to $0.6 \mathrm{~m}$ thick, dense, black, silty, slightly gravelly clay containing few to locally numerous artifacts (see Test Units 5 and 6, Figure 6-2). The black clay consists of overbank and anthropogenic sediment. Anthropogenic deposits are often black, dark gray, or dark brown in color, reflecting the high concentration of burned and unburned organic matter associated with human activity. Across portions of the site, the black clay is overlain by a disturbed, dark gray, gravelly clay containing displaced burned rock and artifacts (see
Layer 5 in BHT 2, Figure 4-20; Stratum 5 in BHT 4; Figure 4-21; Figure 6-1; Table 6-2). These disturbed deposits may be the backdirt produced during the original archeological investigations. The deposits are clearly modern because they contain or overlie fragments of window glass, metallic debris, and other twentieth century refuse (see profile drawings of BHTs 2 and 4, Figures 4-20 and 4-21).

\section{Modern Flood Deposits and Artificial Fill}

Soon after the 1962 excavations, an ephemeral chute channel diverged eastward from the main channel of Salado Creek during a major flood, probably the flood of December 1965 , when the stream reached a stage of $3.5 \mathrm{~m}$ (Slade and Patton 2006b). This flood would have barely overtopped the stream bank adjacent to the site but apparently breached a lower point on the left (east) bank somewhere upstream. The floodwaters then continued southeastward, carving an ephemeral chute channel through the central part of the site. Flow through the chute channel was not gauged, and there are no records of the stage it attained. Traces of what may be that chute channel are, however, evident on the USGS 7.5-minute topographic map covering the site and vicinity, 
as a series of elongate closed depressions and offsets in contour lines extending from northwest to southeast across the site (Geological Survey 1973).

A flood in 1972 reached a gauge height of $4.6 \mathrm{~m}$ on the main channel just west of site 41BX17 (Buckner and Shelby 1991:272). This flood may have affected parts of the site, but much of the unexcavated portion was by then covered with a thick layer of fill and pavement. In contrast, the 1965 flood pre-dated construction of this segment of N. E. Loop 410, which was completed in 1967. The 1965 flood appears to have incised the layer of backdirt from the 1962 excavations and the underlying black clay locally. The resulting channelform is filled with a lens of gravel $0.6 \mathrm{~m}$ thick (see Stratum 4 in BHT 4, Figure 6-1 and Table 6-2). This lens is poorly exposed in the eastern part of the site, but thins and ultimately pinches out westward. In the center of the channelform, the gravel is capped by a $0.1 \mathrm{~m}$ thick bed of gravelly clay representing the final stage of deposition in the chute channel. Construction activities appear to have truncated the gravelly clay farther east.

Across the entire site, the upper part of the stratigraphic profile consists of a 1-m thick sequence of modern (twentieth century) layered and compacted fill dirt and, in places, thin layers of fine-grained sediment that may represent very recent overbank deposits and slope wash (Figure 6-2). Backhoe Trench 8 , located west of the site in the area of low elevation nearest the present stream channel, exposed $1.5 \mathrm{~m}$ of artificial fill without penetrating natural deposits. Placement of fill for road construction had the unintentional benefit of mantling intact portions of the site. The present investigation has demonstrated the integrity of these remaining cultural deposits.

\section{Summary, Geomorphic Evolution and Cultural-Resource Potential}

At site 41BX17, the sequence of depositional and erosional events and both ancient and modern anthropic activities have produced a complex stratigraphic record. Natural processes dominated until road and utility construction began in 1962 and continued intermittently thereafter. Archeological studies in the 1960s and 1970s also left their mark, as did modern flooding. Despite this history of disturbance, burial, and erosion, parts of the site are intact.

The present study has also revealed part of the Late Pleistocene/Holocene history of Salado Creek and its flood terrace. Salado Creek is a very dynamic stream with a history

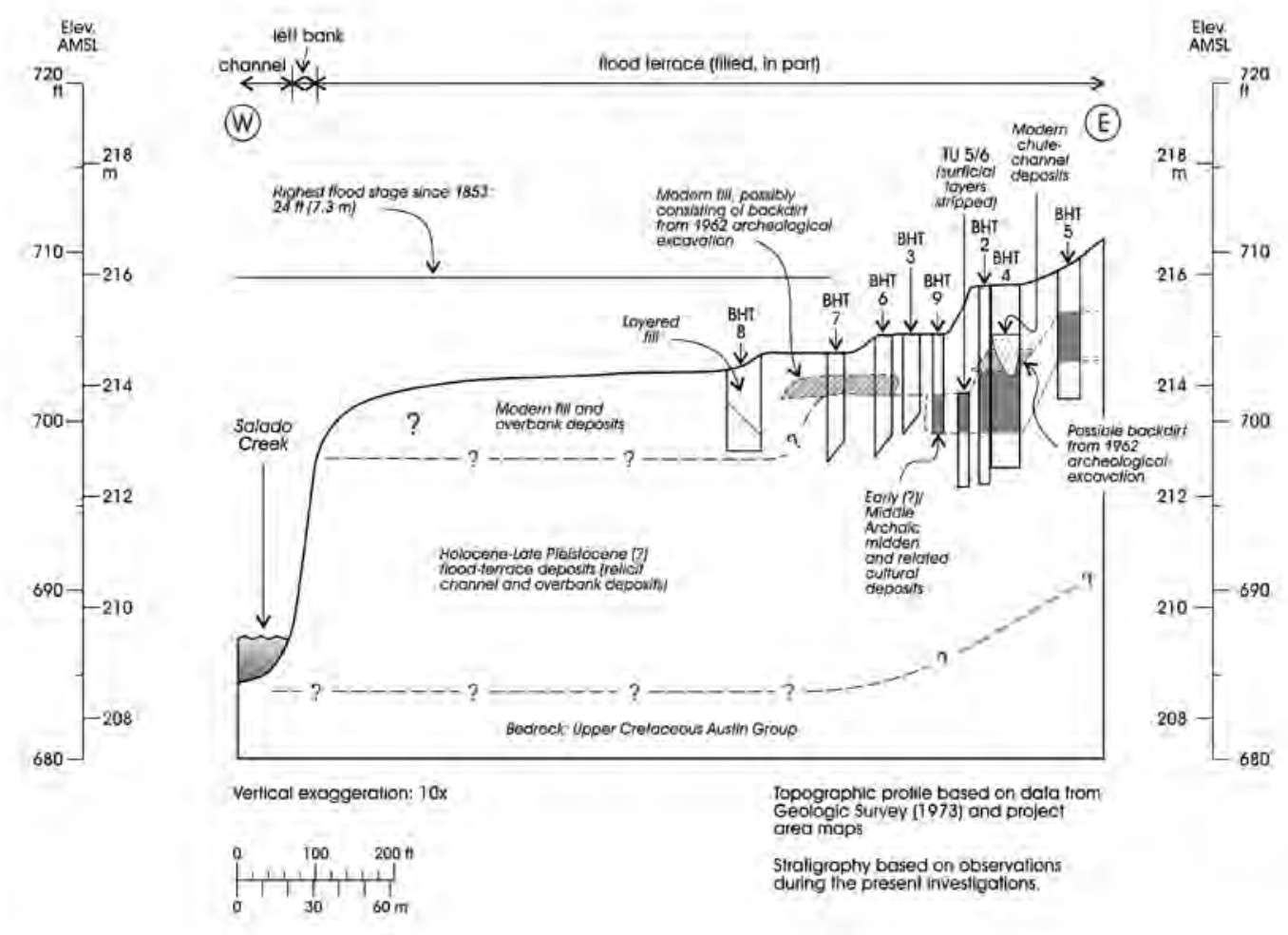

Figure 6-3. West to east geologic cross-section through site $41 B X 17$. 


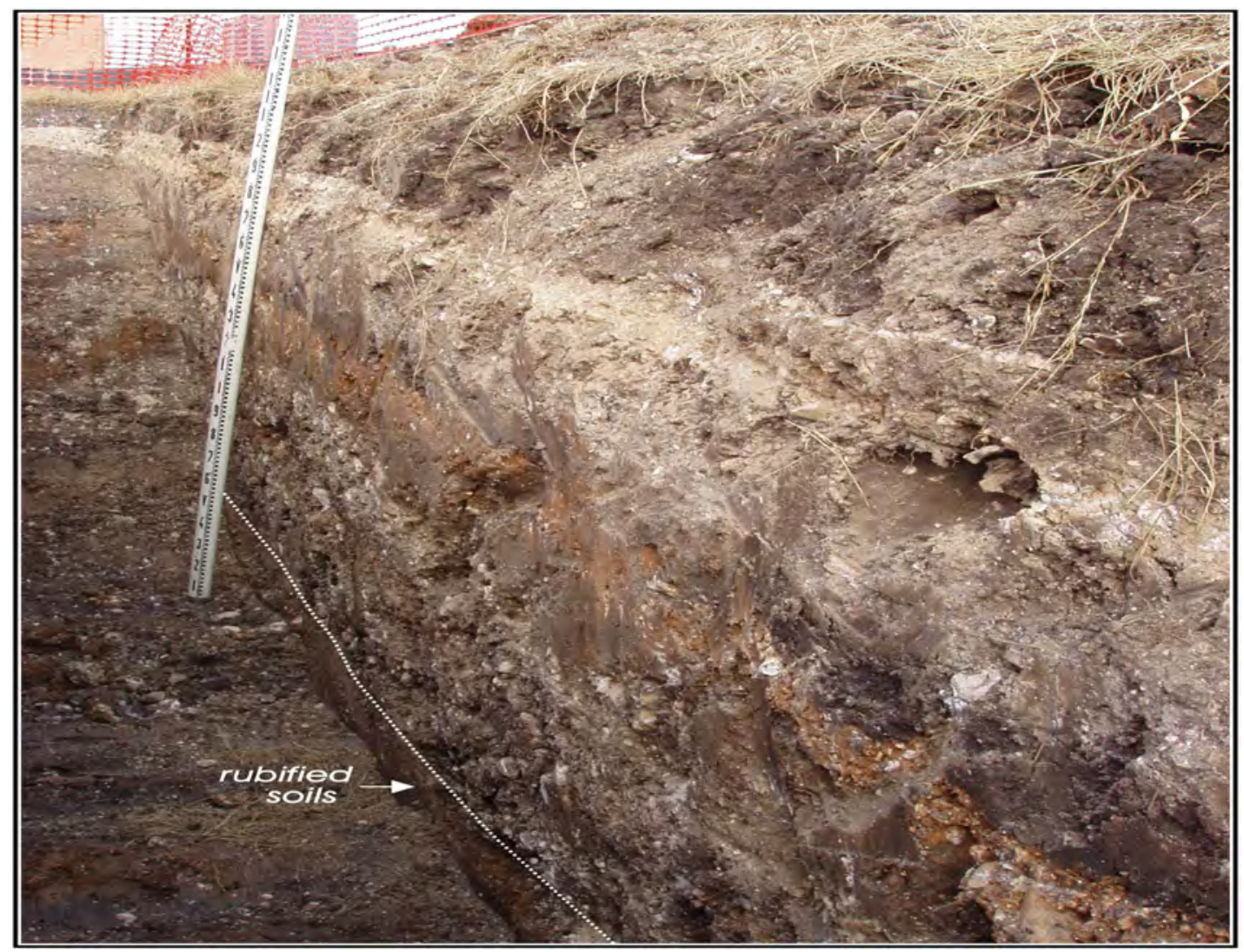

Figure 6-4. North wall of Backhoe Trench 8, similar to Figure 4-23, north wall of Backhoe Trench 7.

of severe flooding. The creek has a large watershed in the steep bedrock terrain north of the site. Major rainstorms are frequent in this region and combine with landscape characteristics to yield high rates of stream flow. Because the nearby bedrock is also an aquifer, springs discharge at points along the stream channel, sustaining flow during dry periods. Recurrent floods have continually reshaped the local environment and defined the geomorphic evolution of this area.

Evidence of these conditions can be found at site 41BX17. Relict channel and overbank deposits older than 4100 radiocarbon years $\mathrm{BP}$ underlie the site and probably compose the majority of the terrace fill. Salado Creek appears to have incised its channel very quickly until reaching a resistant layer of bedrock. The stream then carved a broad valley as its channel meandered atop the resistant bed, producing cutbanks in the softer overlying bedrock strata and in previously deposited channel sediment. As the cutbanks eroded, they retreated ever farther from the valley axis, widening the valley. The dynamic stream simultaneously deposited coarse channel gravels on the inside of each meander bend as the stream migrated across the valley floor. The resulting lateral-accretion deposits vary in age both horizontally and vertically.

By the middle Holocene Epoch, valley width had increased sufficiently, such that large areas of older valley-fill deposits remained relatively stable. The resulting stream terraces and adjacent spring-fed channel became ideal habitats for a wide variety of plants and animals. A high water table promoted growth of rich riparian woodlands offering abundant resources. Humans utilized these resources and from an early date occupied the terraces continually. Floods occurred often, but because the valley had widened, flow was less confined and more likely to spread over the terraces without causing erosion. The floodwaters deposited fine-grained sediment, which buried the occupation sites and kept their cultural materials intact. Overbank flooding was common enough to ensure rapid site burial and to separate the cultural history into discrete episodes of occupation. These processes are ideal for securing an important archeological record. Site 41BX17 owes its existence to the attractive local resource base, perennial water source, and conditions favorable to site preservation. 



\section{Chapter 7: Defining Analytical Units}

\author{
Cynthia M. Munoz
}

The artifacts, features, and other samples summarized in Chapter 5 reflect the total data set available for consideration. This section defines the analytical units that will be used to structure the analysis. The goal is to isolate deposits that date to the Middle Archaic and the Late Archaic periods. All of the projectile point types recovered from the CAR's testing of 41BX17 are diagnostic of these two periods. In addition, the date ranges of three of the six radiocarbon samples fit into the Late Archaic, while the other three fit into the Middle Archaic period.

\section{Review of Components by Test Unit}

As noted in Chapter 4, the CAR's excavations at 41BX17 were concentrated along the south ROW between the eastbound frontage road and the west-bound main lane of Loop 410 on the east bank of Salado Creek. Work focused on four areas identified as Blocks I-IV (see Figure 4-16). The project target depth was $3.05 \mathrm{~m}$ (10 ft.) below surface, the maximum depth of impact proposed by installation of the storm sewer line along the median. Excavation stopped at this depth when reached, regardless of the density of cultural deposits. Artifacts were recovered to $3.05 \mathrm{~m}$ (10 ft.) below surface from TUs 3, 4, 5, 6, 9, 10, 13, and 14 (see Figure 4-16). The areas of densest and deepest cultural deposits were within Block I and Block III (western half). The burned rock midden recorded by Schuetz (1966; see Chapter 4) was partially excavated in Block II. The density of artifact recovery at similar depths dropped to the east and west from Blocks I and II. Beneath the road fill and modern flood gravels, which ended at about $80-100 \mathrm{cmbs}$, the upper portions of the undisturbed archeological deposits were preserved.

The 2006 excavations and geomorphic analysis, supported with radiocarbon dates, determined that Middle and Late Archaic deposits existed within the median of the project area. The components are identified as distinct peaks in artifact quantities that correspond with stratigraphic zones. Projectile point types, radiocarbon dates, and geological strata aid in their identification and age. A general discussion of the depth of the deposits at a broad scale is problematic because of the complex stratigraphy across the site and because the depth below surface is so variable due to the engineered design of the median above the archeological deposits. Table 7-1 provides summary information on the Middle and Late Archaic components including information on the depth below surface of the temporally diagnostic artifacts collected during testing and feature dates for each excavation block.

\section{Test Units 3-4}

Test Units 3 and 4 contained two peaks in artifacts corresponding to thermal features, which contained preserved surfaces within the Late Archaic and the Middle Archaic. Figure 7-1 is a profile of the south wall of TUs 3 and 4 showing the depth of points, features, and radiocarbon dates. These include Feature 103 in Levels 5 and 6, Feature 105 in Level 8, and Feature 107 in Level 10.

The Late Archaic component was located between Levels 1 and 7 , from zero to $70 \mathrm{cmbd}$, with the peak in artifacts occurring between 50 and $60 \mathrm{cmbd}$ (Figure 7-2). These Late Archaic deposits occurred in the upper two soil horizons illustrated in the profile drawing. Based on a radiocarbon sample submitted from Feature 105 at $71 \mathrm{cmbd}$, the deposits in Zones 1 and 2 date no earlier than $3981 \mathrm{cal} \mathrm{BP}$. The relative placement of temporally diagnostic artifacts and radiocarbon dates was generally good in these units with some minor displacement. The Late Archaic radiocarbon dates from Level 6 of Feature 103 in TU 4 are 2740-2450 cal BP and 2410-2380 cal BP. An Ensor projectile point was found above the dated feature in Level 4. Ensor projectile points have been radiocarbon dated at 41LK67 to 370-210 BC (2320 -2160 BP) (Brown et al. 1983:167). A Marshall projectile point associated with the Late Archaic (2600-1050 BP) was found in Level 5 slightly above the charcoal sample near the transition between Zones 1 and 2. These are Late Archaic projectile points, often found associated with Pedernales points, thought to have a longer temporal span. Marshall dart points recovered from the Panther Springs Creek Site (41BX228) were recovered from a depth dating around 650 BC (2600 BP) (Black and McGraw 1985:325).

The Middle Archaic deposit in TUs 3 and 4 occurred from 70 to $200 \mathrm{cmbd}$. At the upper end of this deposit, at the interface of Zones 2 and 3 (71 cmbd), Feature 105 was recorded with charcoal material dating to 3980-3820 cal BP. Thus, Feature 105 and the top of Zone 3 date to the beginning of the Late Archaic and the end of Middle Archaic. Two Langtry projectile points, one from Level 8 and one from Level 9, and one Pedernales projectile point from Level 9 were collected within the peak of artifacts surrounding Feature 105. Langtry forms are generally associated with the Middle Archaic in the Pecos Region of Texas. Both types were two of the common Middle Archaic projectile points types found at the Devil's Mouth site (41VV7) in deposits dating to 2000-3000 BC (3950-4950 BP) (Johnson 1962:123, Figure 25). In South- 
Table 7-1. Summary of Test Units with Diagnostic Artifacts and/or Features

\begin{tabular}{|c|c|c|c|c|c|c|c|c|c|}
\hline Unit & Block & $\underset{\text { Unit }}{\text { Analytical }}$ & $\begin{array}{l}\text { Component Level } \\
\text { (Depth) }\end{array}$ & Diagnostics & $\begin{array}{l}\text { Diagnostic Level } \\
\text { (Depth) }\end{array}$ & $\left|\begin{array}{c}\text { Point } \\
\text { Comments }\end{array}\right|$ & Feature & $\begin{array}{l}\text { Feature Level } \\
\text { (Depth) }\end{array}$ & Method of Dating \\
\hline Test Unit 3-4 & I & Late Archaic & Level 1-7 (0-70 cmbd) & Ensor & Level 4 (39cmbd) & & 103 & $\begin{array}{l}\text { Level } 5 \text { and } 6 \\
(42-55 \mathrm{cmbd})\end{array}$ & C-14 (cal 2740-2380 BP) \\
\hline Test Unit 3-4 & 1 & Late Archaic & Level 1-7 (0-70 cmbd) & Marshall & Level 5 (47 cmbd) & & 105 & Level $7(60-70 \mathrm{cmbd})$ & C-14 (cal 3980-3820 BP) \\
\hline Test Unit 3-4 & 1 & $\begin{array}{l}\text { Middle } \\
\text { Archaic }\end{array}$ & Level 8-20 $(70-200 \mathrm{cmbd})$ & Langtry & Level $8(70-80 \mathrm{cmbd})$ & & 107 & Level 10 (98 cmbd) & Point Association \\
\hline Test Unit 3-4 & 1 & $\begin{array}{l}\text { Middle } \\
\text { Archaic }\end{array}$ & Level 8-20 (70-200 cmbd) & Pedernales & Level $9(80-90 \mathrm{cmbd})$ & & & & \\
\hline Test Unit 3-4 & 1 & $\begin{array}{l}\text { Middle } \\
\text { Archaic }\end{array}$ & Level 8-20 (70-200 cmbd) & Langtry & Level 9 ( 85 cmbd) & & & & \\
\hline Test Unit 3-4 & 1 & $\begin{array}{l}\text { Middle } \\
\text { Archaic }\end{array}$ & Level 8-20 (70-200 cmbd) & Nolan & Level $15(140 \mathrm{cmbd})$ & & & & \\
\hline Test Unit 5-6 & 1 & Late Archaic & Level 1-7 (0-67 cmbd) & Ensor & Level $3(20-30 \mathrm{cmbd})$ & & 100 & Level $3(23-30 \mathrm{cmbd})$ & C-14 (cal 2010-1860 BP) \\
\hline Test Unit 5-6 & 1 & Late Archaic & Level 1-7 (0-67 cmbd) & Castroville & Level 4 (34 cmbd) & & 101 & Level $5(40-50 \mathrm{cmbd})$ & Point Association \\
\hline Test Unit 5-6 & 1 & Late Archaic & Level 1-7 (0-67 cmbd) & Pedernales & Level $4(30-40 \mathrm{cmbd})$ & & 102 & Level $6(50-60 \mathrm{cmbd})$ & Point Association \\
\hline Test Unit 5-6 & 1 & Late Archaic & Level 1-7 (0-67 cmbd) & Pedernales & Level 6 (54 cmbd) & & & & \\
\hline Test Unit 5-6 & 1 & $\begin{array}{l}\text { Middle } \\
\text { Archaic }\end{array}$ & Level 7-17 $(67-170 \mathrm{cmbd})$ & Marshall & Level $8(70-80 \mathrm{cmbd})$ & & 104 & Level 7 (67cmbd) & C-14 (cal 4290-4080 BP) \\
\hline Test Unit 5-6 & 1 & $\begin{array}{l}\text { Middle } \\
\text { Archaic }\end{array}$ & Level 7-17 $(67-170 \mathrm{cmbd})$ & & & & N/A & Level $13(126 \mathrm{cmbd})$ & C-14 (cal 4830-4520 BP) \\
\hline Test Unit 7-8 & II & Late Archaic & Level 1-8 (0-80 cmbd) & Montell & Level $2(10-20 \mathrm{cmbd})$ & & 106 & Level $3(20-30 \mathrm{cmbd})$ & Point Association \\
\hline Test Unit 7-8 & II & Late Archaic & Level 1-8 (0-80 cmbd) & Montell & Level $2(10-20 \mathrm{cmbd})$ & & & & \\
\hline Test Unit 7-8 & II & Late Archaic & Level 1-8 (0-80 cmbd) & $\begin{array}{l}\text { Langtry or } \\
\text { Montell }\end{array}$ & Level $2(10-20 \mathrm{cmbd})$ & & & & \\
\hline Test Unit 7-8 & II & Late Archaic & Level 1-8 (0-80 cmbd) & Nolan & Level $3(20-30 \mathrm{cmbd})$ & See Note 1 & & & \\
\hline Test Unit 9-10 & III & & Level 3-12 (20-115 cmbd) & Ensor & Level $3(22-30 \mathrm{cmbd})$ & & 108 & $\begin{array}{c}\text { Level } 10 \\
(69-81 \mathrm{cmbd})\end{array}$ & Point Association \\
\hline Test Unit 9-10 & III & Late Archaic & Level 3-12 (20-115 cmbd) & Bulverde & Level $4(30-40 \mathrm{cmbd})$ & & & & \\
\hline Test Unit 9-10 & III & Late Archaic & Level 3-12 (20-115 cmbd) & Marshall & Level 5 (41 cmbd) & & & & \\
\hline Test Unit 9-10 & III & Late Archaic & Level 3-12 (20-115 cmbd) & Fairland & Level $6(50-60 \mathrm{cmbd})$ & & & & \\
\hline Test Unit 9-10 & III & Late Archaic & Level 3-12 (20-115 cmbd) & Marshall & Level 7 (60 cmbd) & & & & \\
\hline Test Unit 9-10 & III & Late Archaic & Level 3-12 (20-115 cmbd) & Castroville & Level $8(70-80 \mathrm{cmbd})$ & See Note 2 & & & \\
\hline Test Unit 9-10 & III & Late Archaic & Level 3-12 (20-115 cmbd) & Pedernales & Level 9 ( 85 cmbd $)$ & & & & \\
\hline Test Unit 9-10 & III & Late Archaic & Level 3-12 (20-115 cmbd) & Pedernales & Level 10 ( $97 \mathrm{cmbd})$ & & & & \\
\hline Test Unit 9-10 & III & Late Archaic & Level 3-12 $(20-115 \mathrm{cmbd})$ & Pedernales & Level $11(101 \mathrm{cmbd})$ & & & & \\
\hline Test Unit 9-10 & III & $\begin{array}{l}\text { Middle } \\
\text { Archaic } \\
\end{array}$ & $\begin{array}{c}\text { Level 12-19 } \\
(115-190 \mathrm{cmbd}) \\
\end{array}$ & Possible Travis & Level $16(154 \mathrm{cmbd})$ & & & & \\
\hline Test Unit 11-12 & III & Late Archaic & Level 1-8 (0-80 cmbd) & Castroville & Level $5(40-50 \mathrm{cmbd})$ & & & & \\
\hline Test Unit 11-12 & III & Late Archaic & Level 1-8 (0-80 cmbd) & Marcos & Level 5 (49 cmbd) & & & & \\
\hline Test Unit 11-12 & III & Late Archaic & Level 1-8 (0-80 cmbd) & Bulverde & Level $6(50-60 \mathrm{cmbd})$ & & & & \\
\hline $\begin{array}{l}\text { Back Hoe } \\
\text { Trench } 9\end{array}$ & N/A & $\begin{array}{l}\text { Middle } \\
\text { Archaic }\end{array}$ & N/A & N/A & N/A & See Note 3 & 109 & $\mathrm{~N} / \mathrm{A}$ & C-14 (4430-4160 BP) \\
\hline
\end{tabular}

Note 1: Along the Salado Creek Nolan represent the Early Archaic, Clear Fork Phase (Black and McGraw 1985). At 41BX1 Nolan were associated with C-14 of 1950-1920 BC, a Middle Archaic date; (Assad 1979). Nolin are dominant during the Late Archaic on the Edwards Plateau (Johnson and Goode 1994)

Note 2: The relative sequence of Castroville-Marshall-Bulverde is reversed. The points all come from the top of Zone 7 and the bottom of Zone 6, possibly backdirt from Schuetz 1962 trenching. Note 3: A hearth feature was discovered at the bottom of BHT 9. The feature was not excavated but was documented by the project archaeologist.

Central Texas Langtry points are associated with Pedernales points. At 41BX228, Pedernales and Langtry projectile points were associated with a Middle Archaic component that also contained a burned rock midden dating to $800 \mathrm{BC}$ (2750 BP) (Black and McGraw 1985:325). Slightly lower, at $98 \mathrm{cmbd}$, we unearthed Feature 107 near the interface of Zones 3 and 4. Though we were not able to radiocarbon date materials from the feature, its position between the Langtry projectile points in Level 9 and the Nolan projectile point in Level 15 suggest it was a Middle Archaic feature.
There was not a dramatic soil change separating the Middle and Late Archaic components; however, there was a drop in debitage density from over 800 to less than 200 specimens before an increase to nearly 600 specimens of debitage between 80 and $90 \mathrm{cmbd}$ (see Figure 7-2). Postburial disturbances can disrupt the context of a buried site. Floralturbation and faunalturbation, as well as other postburial biogenic and physiogenic processes, cause cultural material to shift position in the matrix and may cause differential sorting resulting in concentrations of artifacts into artificial layers (Waters 1992). 


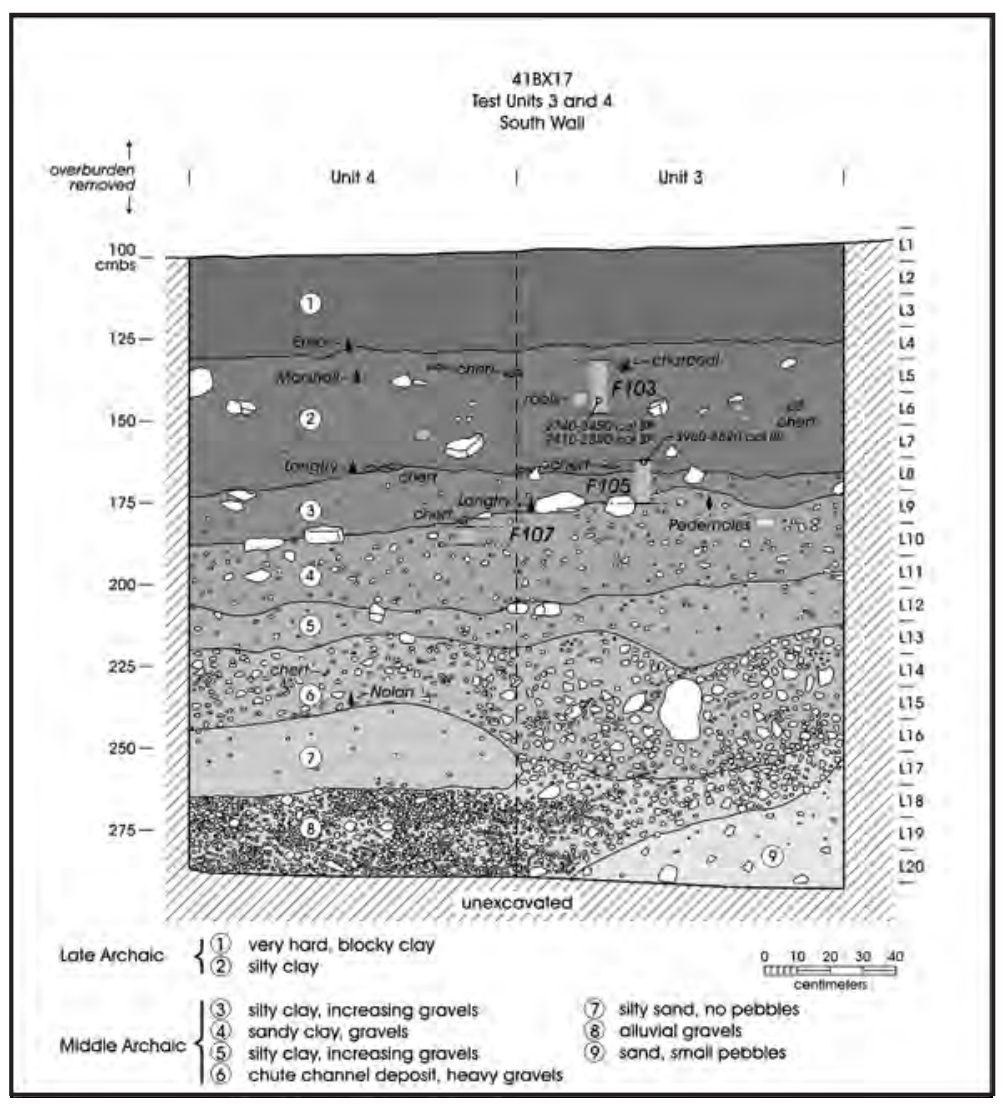

Figure 7-1. Profile of the south wall of Test Units 3 and 4 showing depth of projectile points, features, and radiocarbon depths over the drawing of the stratigraphy.

Burrowing animals with a fossorial lifestyle, e.g., pocket gophers and moles, perform all activities, i.e. sleeping, foraging, mating, and raising offspring, underground. To accomplish this they dig an extensive system of dens and tunnels (Wilkins 1989). Burrowing most frequently displaces small objects. As a tunnel is excavated small material ( 0.6 to 2.5-5.0 $\mathrm{cm}$ ) is hauled to the surface and placed in backdirt mounds (Dalquist and Sheffer 1942; Hansen and Morris 1968; Murray 1967:101). Most fossorial animals dig under items larger than $5 \mathrm{~cm}$ eventually undermining the object (Dalquist and Scheffer 1942; Grinnell 1923; Murray 1967). This process results in the deposit of small material on the surface and large objects below the animal zone, eventually creating artificial layers of artifacts (Bocek 1986).

To explore the possibility that the two artifact peaks in Test Units 3 and 4 (see Figure 7-2) are the result of displacement from rodent activity, maximum length, maximum width (perpendicular to maximum length), and area were calculated for all the debitage removed from Test Unit 4. To increase the speed and accuracy of these measurements, JPEGs of the debitage were processed by SigmaScan Pro 5.0, an image analysis application with the ability to capture and measure digital images. Disproportionate numbers of small specimens in the top concentration (Level 6) and large pieces in the lower concentration (Levels 9 and 10) would suggest faunalturbation (see Figure $7-2)$. Small items $(\leq 2.5 \mathrm{~cm})$ make up $79 \%$ of the upper peak and $64 \%$ of the lower peak, whereas large specimens $(\geq 5.0 \mathrm{~cm})$ account for $3 \%$ and $5 \%$, respectively. A boxplot of the area data for the peaks is presented in Figure 7-3. Mann-Whitney $U$ test $(Z=-6.744 ; p<0.001)$ and an

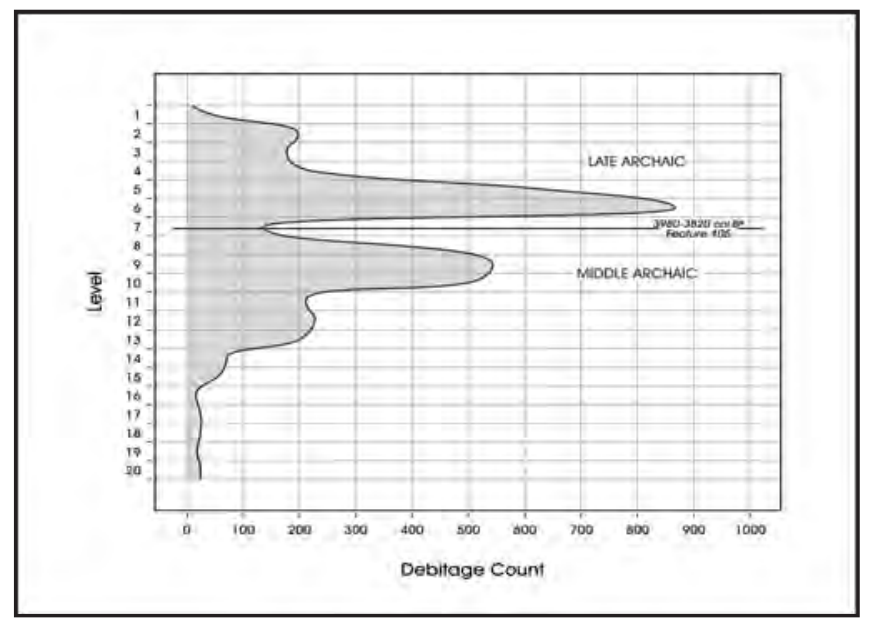

Figure 7-2. Distribution of debitage in Test Units 3 and 4. 


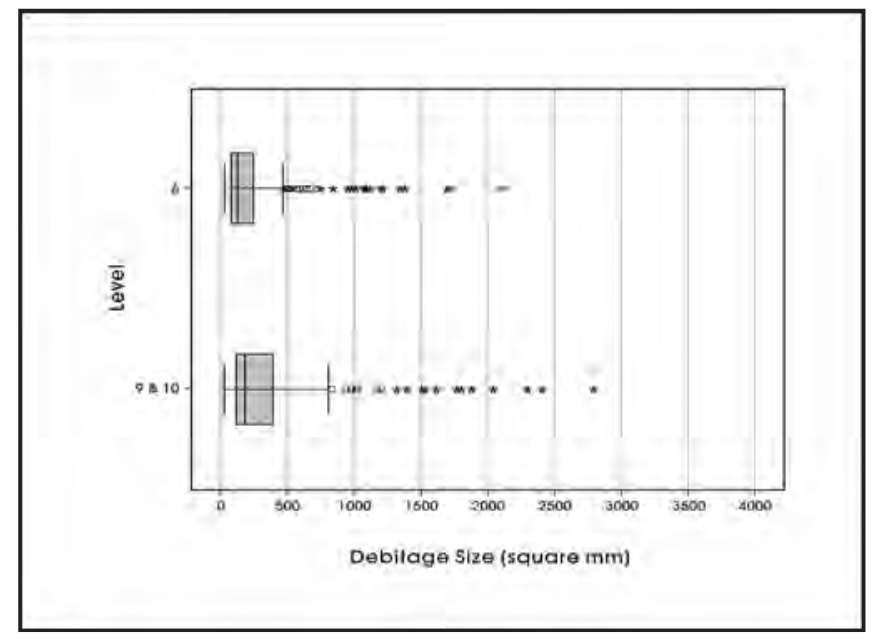

Figure 7-3. Boxplot comparing size of debitage $\left(\mathrm{mm}^{2}\right)$ by artifact peak for Test Unit 4.

Independent Samples Median test $(\mathrm{p}<0.001)$ run on the data suggest that the differences in debitage size between the upper and lower peaks are statistically significant.

Although this data supports the possibility that the debitage pattern revealed in Test Units 3 and 4 is the result of burrowing activity, other evidence does not. High levels of burrowing activities leave an abundance of subsurface krotovina and bones (Bocek 1986; Erlandson 1984). No evidence of rodent burrows were noted during the 2006 CAR excavations of TUs 3 and 4 . Of the 566 gm of bone recovered from TUs 3 and 4 , only $0.31 \mathrm{gm}$ were identified as rodentia. Fossorial rodent population size is directly related to ground cover with the greatest impact on grassland environments, followed by forests, and least on agricultural fields (Coupland 1979; Davis et al. 1938; Golley et al. 1975). The extent of burrowing at the Granberg site, located in a riparian zone adjacent to the perineally flowing Salado Creek, should not have been excessive enough to result in artificial layers of artifacts. It is also unlikely that size sorting of material from rodent activity could result in rocks aligned as hearths containing charred material (see Figures 5-13 and 5-14).

Test Units 3 and 4 have matched artifact distribution with soil stratigraphy, dated features at the same surface as multiple artifacts (including temporally diagnostic artifacts), and temporally diagnostic projectile points in good relative chronological order. This is supported by radiocarbon dates. The pattern may be the result of multiple episodes during the Middle or Late Archaic occupations at the site. In the opinion of the CAR, the prehistoric archeological components in the Middle and Late Archaic were still intact in these units.

\section{Test Units 5-6}

Test Units 5 and 6 contained two artifact peaks and four burned rock features in deposits dating to the Middle and Late Archaic (Figure 7-4). These included Features 100, 101, 102, and 104. Deposits above Zone 3 to $67 \mathrm{cmbd}$ were Late Archaic in age. Deposits between 67 and $170 \mathrm{cmbd}$ represented the Middle Archaic. A dense gravel stratum (Zone 3) divided the Middle and Late Archaic deposits. Two of the features were dated. Feature 100 dates the middle of Zone 1 to 2010-1860 cal BP. Feature 104 was uncovered at $67 \mathrm{cmbd}$ near the interface of Zones 2 and 3 with dated charcoal placing the bottom of the Late Archaic deposit to a transitional Middle to Late Archaic period of 4290-4080 cal

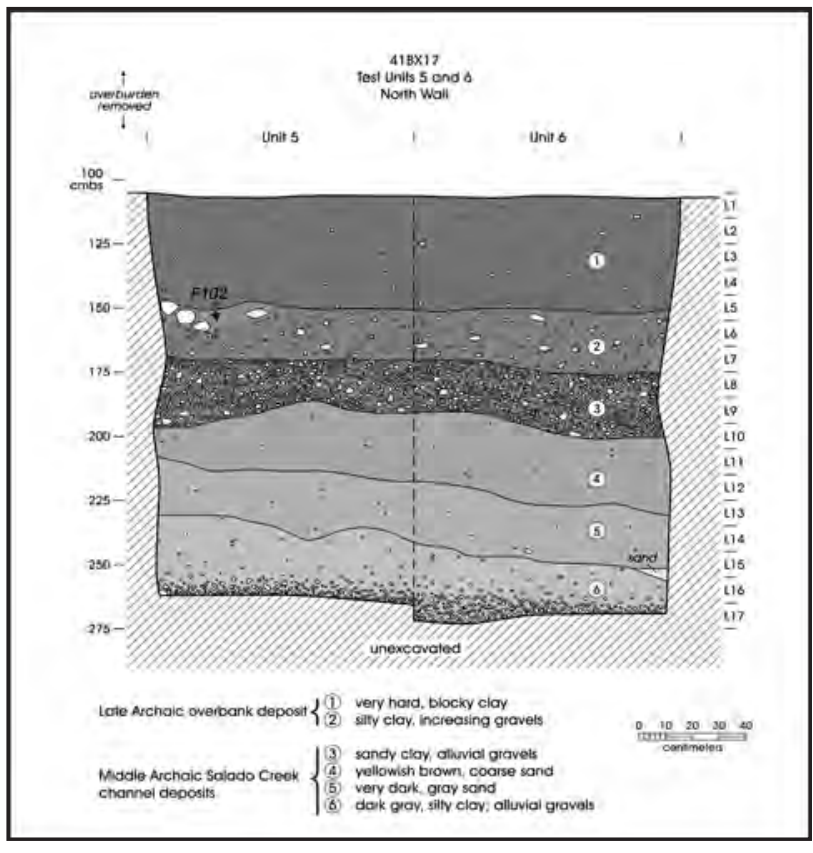

Figure 7-4. Profile of the north wall of Test Units 5 and 6. 


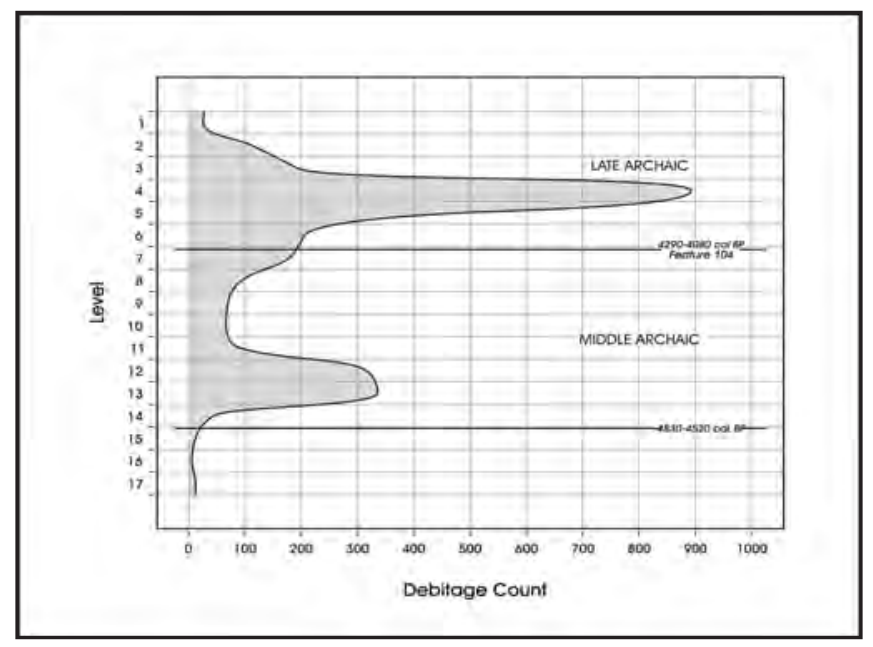

Figure 7-5. Distribution of debitage in Test Unit 5 and 6.

BP. A Pedernales point was uncovered in Zone 2 in the same level as Feature 4. Pedernales points are dated to 3950-3150 BP in Turner and Hester (1999) and to about 3320-2400 BP in Collins (1995). At 1-sigma, the Feature 104 radiocarbon date predates the point. At 2-sigmas, there is an overlap with the Turner and Hester range. The Pedernales point was not part of Feature 104 but was east of the feature in the adjoining unit, TU 6.

A charcoal sample from Zone 5 dated to $4830-4250 \mathrm{BP}$ (see Figure 7-4). This sample was uncovered $126 \mathrm{cmbd}$ in Middle Archaic deposits. A dense gravel stratum representing a depositional event separated this C-14 date and the C-14 date associated with Feature 104. The dates were vertically separated by $50 \mathrm{~cm}$. A depositional event, probably a flood, could have occurred very rapidly resulting in a chronological difference of 500 years between Feature 104 and this charcoal sample. Different rates of deposition occur across a site, especially in watershed contexts. The vertical distribution of artifacts in these units increases at surfaces associated with soil changes and features. The density of debitage peaked between 30 and $50 \mathrm{cmbd}$ and between 120 and $130 \mathrm{cmbd}$ (Figure 7-5). Debitage was evenly distributed across both units, each producing approximately 1,500 pieces.

To explore the possibility that the two artifact peaks in Test Units 5 and 6 (see Figure 7-5) are the result of displacement from rodent activity, maximum length, maximum width (perpendicular to maximum length), and area were calculated, using SigmaScan Pro 5.0, for all the debitage removed from Test Unit 6. As discussed in the previous section, disproportionate numbers of small specimens in the top concentration (Level 4) and large pieces in the lower concentration (Levels 12 and 13) would suggest faunalturbation (see Figure 7-5). Small items $(\leq 2.5 \mathrm{~cm})$ make up $75 \%$ of the upper peak and $68 \%$ of the lower peak, whereas large specimens $(\geq 5.0 \mathrm{~cm})$ account for $2 \%$ and $4 \%$, respectively Figure 7-6 presents a boxplot of the area data for the artifact peaks. A Mann-Whitney U test ( $\mathrm{Z}$ $=4.202 ; \mathrm{p}<0.001)$ and an Independent Samples Median test $(\mathrm{p}=0.057)$ run on the data indicates that the differences in the distribution of debitage size between the upper and lower peaks is statistically significant, whereas, the difference in medians between the peaks is not significant. These tests suggest that the difference in debitage size in the two peaks is not significant, but it is trending in that direction.

No other signs of faunalturbation were evident in Test Units 5 and 6 . The average terminal depth for gopher chambers is approximately $50 \mathrm{~cm}$ while ground squirrel and mole tunnels are slightly closer to the surface (Grinnell 1923; Ingles 1952; Linsdale 1946; Miller 1964; Scheffer 1931). In Test Units 5 and 6 the artifact peaks are about $70 \mathrm{~cm}$ apart (see Figure

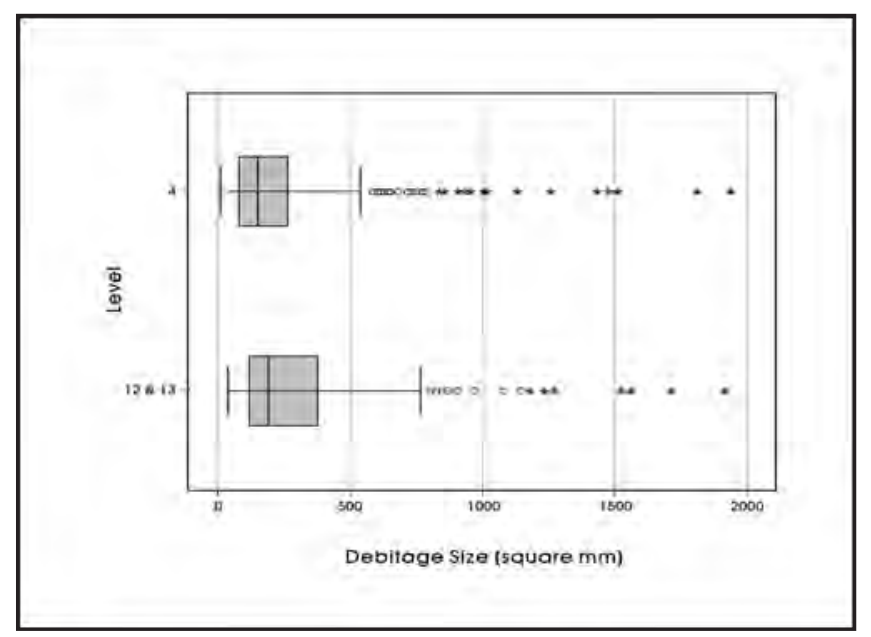

Figure 7-6. . Boxplot comparing size of debitage $\left(\mathrm{mm}^{2}\right)$ by artifact peak for Test Unit 6. 


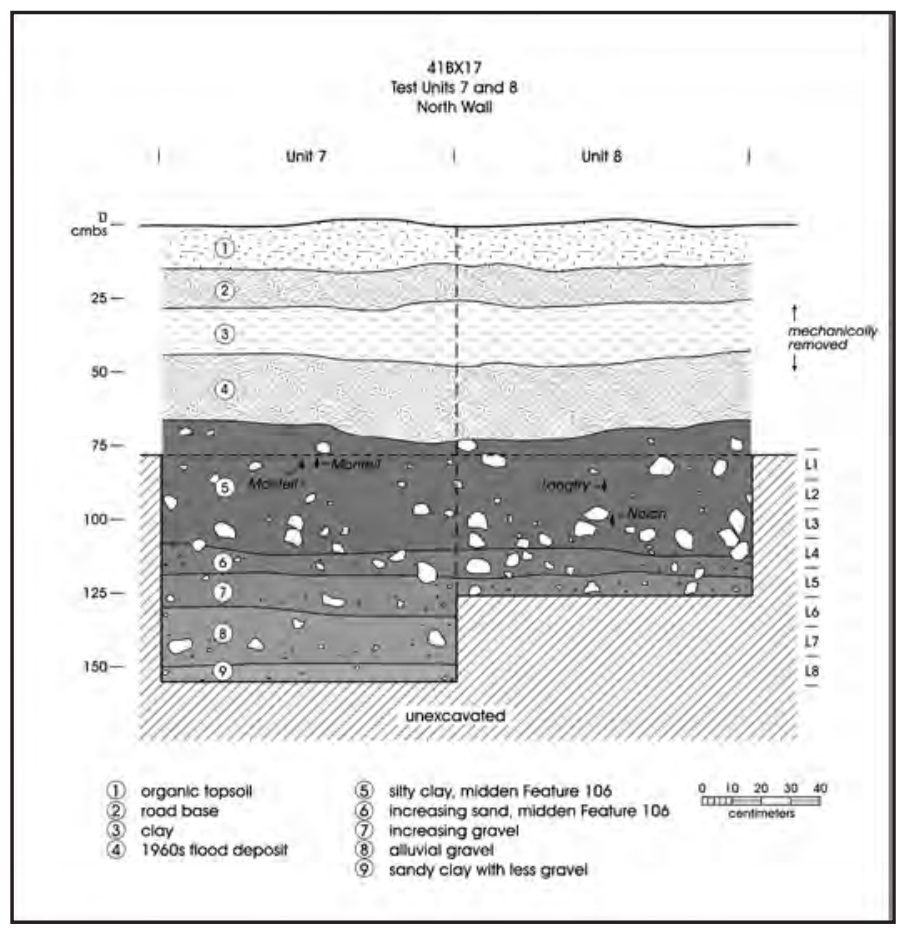

Figure 7-7. Profile of the north wall of Test Units 7 and 8 showing depth of projectile points recorded during excavation of the units compared to the drawing of the stratigraphy in the north wall.

7-5), slightly larger than most burrowing systems. There were no indications of krotovina. Of the $797 \mathrm{gm}$ of bone excavated from TUs 5 and 6 , only 1.3 gm were identified as rodentia. It is also doubtful that hearth rock alignments with charred material would be caused by rodent size sorting (see Figures 5-7 and 5-10). As in TUs 3-4, TUs 5-6 have matched artifact distribution with stratigraphic soil, dated features at the same surface as multiple artifacts (including temporally diagnostic artifacts), and temporally diagnostic projectile points in good relative chronological position supported with radiocarbon dates. In the opinion of the CAR, archeological components in the Middle and Late Archaic were intact in TUs 5-6.

\section{Test Units 7-8}

Near the western end of the site in TUs 7-8, part of the midden deposit documented by Schuetz in 1962 was exposed. The black matrix contained dense burned rock, chipped stone artifacts, and bone from $0-40 \mathrm{cmbd}$ in TU 7. Artifacts were present to $80 \mathrm{cmbd}$ where the main channel of Salado Creek was encountered. The profile drawing illustrates the thick deposit between modern and prehistoric flood deposits (Figure 7-7). The excavation of TUs 7-8 uncovered Late Archaic period deposits. These units contained Feature 106, which was a large burned rock feature that spanned beyond the perimeter of the units and sat above a thick channel deposit of rubified gravels. Excavation efforts recovered over 1,000 pieces of debitage. These counts peaked in Level $2(10-20 \mathrm{cmbd})$ returning over 800 pieces at the surface of the feature. Two Montell projectile points were excavated from Level $2(10-20 \mathrm{cmbd})$. These are mid-Late Archaic dart points with technological similarities to Marshall and Pedernales dart points. One Langtry came out of Level $2(10-20 \mathrm{cmbd})$ and as mentioned previously, has been associated with the Middle Archaic in the Pecos region of Texas and in later Pedernales components in South-Central Texas. One Nolan point was unearthed in Level 3 (20-30 cmbs). Elsewhere along the Salado Creek Nolan projectile points represent the Early Archaic, Clear Fork Phase (3000-2000 BC; Black and McGraw 1985:117). At 41BX1 Travis and Nolan points found associated with dated charcoal (1950-1920 BC) indicate that they may have been used during the Middle Archaic (Assad 1979:21). Johnson and Goode (1994:27) suggest that the points are more likely representative of the mid-Middle Archaic than the Early Archaic but are dominant during the Late Archaic on the Edwards Plateau ending in 2300 BC.

Test Units 7 and 8 contained a midden deposit with numerous artifacts and burned rock. Though the 1965 flood deposit impacted the cultural deposit here, the lower $70-80 \mathrm{~cm}$ beneath that deposit was intact (Thompson 2006b). This deposit extended beyond the test units to the north and east for an unknown distance. It thinned and disappeared within a few meters to the west and south, as seen in the walls of Block II and BHTs 3 and 6. 


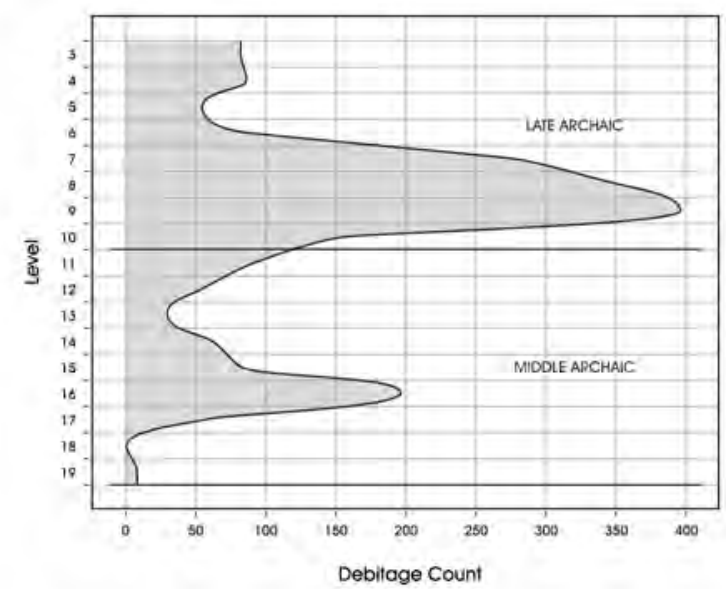

Figure 7-8. Distribution of debitage in Test Units 9 and 10.

\section{Test Units 9-10}

Test Units 9 and 10 also contained two artifact peaks, one Middle Archaic and one Late Archaic. The Late Archaic deposit continued from the starting excavation level at 20 cmbd to $115 \mathrm{cmbd}$, where the upper dense gravel stratum (Zone 9) was encountered. The Late Archaic component contained over 1,000 specimens of debitage, peaking in Level 9, just above stratigraphic Zone 8 (Figure 7-8). The
Middle Archaic component was also present in TUs 9 and 10, though at a slightly lower level than the previously discussed test units. Based on the date returned from Feature 104 in TU 5, the upper boundary of Zone 9, the dense gravel zone in TUs 9 and 10, dates to $4290-4080$ cal BP, marking the top of the Middle Archaic in these units at approximately 115 cmbd. Test Unit 9 was excavated to $180 \mathrm{cmbd}$ and TU 10 to $190 \mathrm{cmbd}$ (Figure 7-9).

The relative sequence of Castroville-Marshall-Bulverde in the upper levels of TU 9 is reversed (see Table 7-1). The Bulverde dart point would be expected much lower than, near, or below the Pedernales dart points. The Marshall points should be closely associated with Pedernales projectile points, but slightly later in time (Black and McGraw 1985:111). The seemingly displaced projectile points come from the top of Zone 7 and the bottom of Zone 6 . This zone may be backdirt from Schuetz's 1962 trenching, though a distinction was not made in the profile. While there is some question about the integrity of the Late Archaic deposits in TUs 9 and 10, the Middle Archaic components are well-preserved.

\section{Test Units 11-12}

Persistent flooding temporarily prevented excavation of TUs 11 and 12. Despite delays, $80 \mathrm{~cm}$ of the Late Archaic component in TU 12 and $20 \mathrm{~cm}$ of the Late Archaic component in TU 11 were excavated. No radiocarbon dates

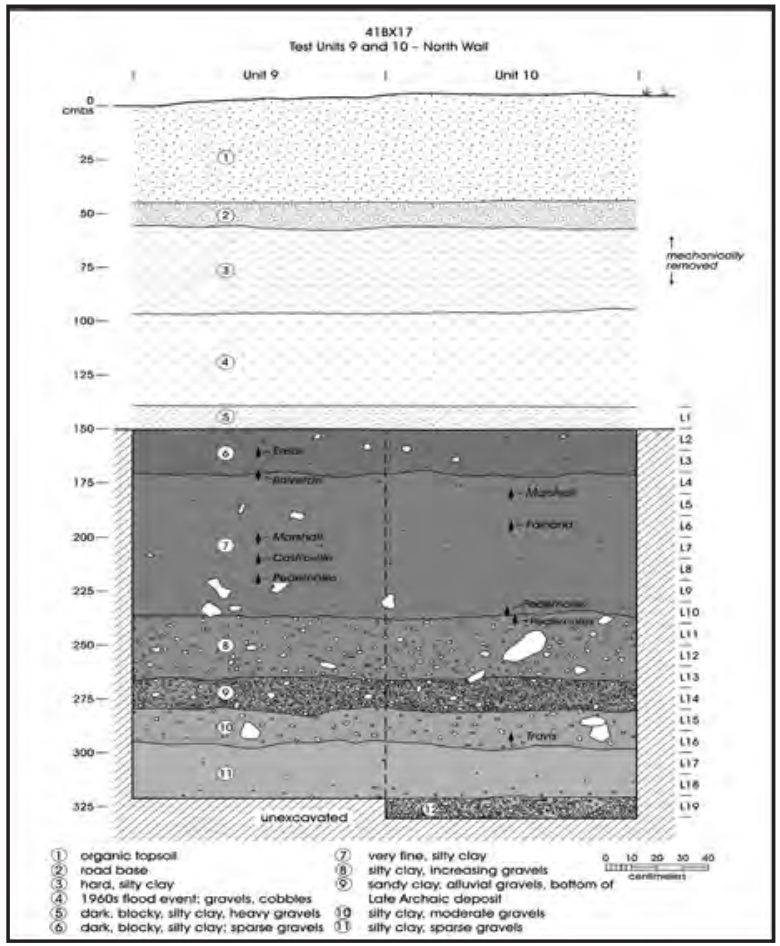

Figure 7-9. Profile of the north wall of Test Units 9 and 10 showing depth of projectile points recorded during excavation of the units compared to the drawing of the stratigraphy in the north wall. 


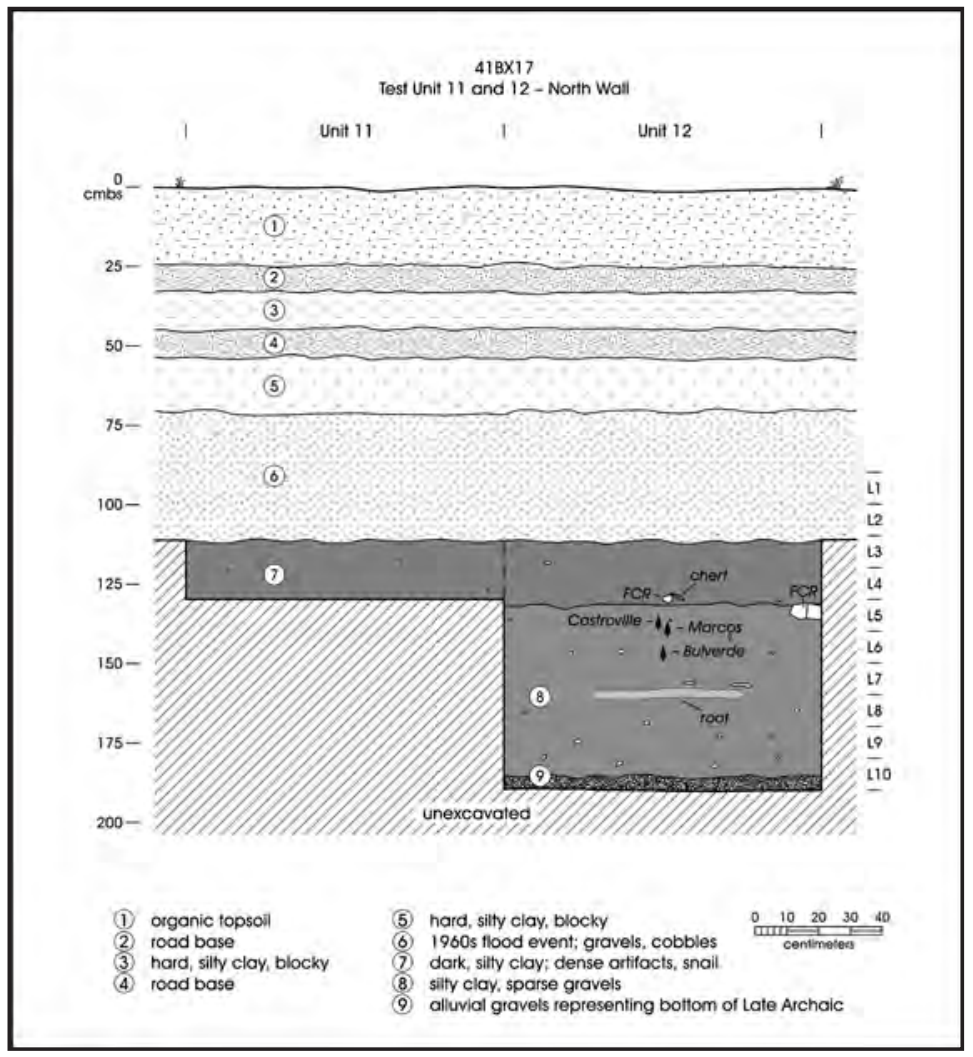

Figure 7-10. Profile of the north wall of Test Units 11 and 12.

were recovered from these units. The component dating was based on the stratigraphy in other units (TUs 4, 5, 9, and 10), specifically on the dense gravel stratum separating the Late and Middle Archaic components. In TU 12 this dividing soil change was unearthed in Zone 9. In addition, a handful of Late Archaic dart points were recovered in TU 12 (Figure 7-10), one Castroville and one Marcos in Level 5 and one Bulverde in Level 6. Black and McGraw (1985) place Marcos, Castroville and Montell dart points within the Late Archaic (between 1700-2600 BP) at 41BX228. This is consistent with the other units containing artifacts as these dart points lie above the gravel stratum noted in these units as Zone 9. No features were recorded within TUs 11 and 12.

The limited excavation within TUs 11 and 12 indicated intact archeological deposits within the Late Archaic time period below a modern (1965) flood horizon. Middle Archaic deposits likely exist below these as the same gravel strata seen in TUs 5, 6, 9, and 10 .

\section{Test Units 13-14}

Late Archaic deposits were also present in TUs 13 and 14. The upper $20 \mathrm{~cm}$ contained the majority of the artifacts within a very dark, midden-like matrix, though artifacts were present through $190 \mathrm{cmbs}$. A second peak in artifacts occurred in Level 12, 110-120 cmbd, where amounts of debitage increased substantially. No discernable soil change corresponded with this change in distribution. A sandy horizon with river pebbles was in place at approximately $155 \mathrm{cmbd}$. Though it was deep enough to date to the Middle Archaic, it did not resemble the lower alluvial gravels in other units. These Middle Archaic levels were rubified, whereas the others were dark. No features were recorded.

\section{Test Units 15-16}

Although TUs 15 and 16 contained minimal artifacts compared to the units in Block I, in the opinion of the CAR they were in good context. It is likely that all the artifacts recovered from these units are from the Late Archaic. The units were excavated to $110 \mathrm{cmbd}$ and did not reach Middle Archaic depths.

\section{Summary of the Middle Archaic Deposits (6000-4000 BP)}

Middle Archaic archeological deposits were present in six of the test units (TUs 3-6, 9, and 10) excavated during the 2006 significance testing of 41BX17. In four units, Middle 
Table 7-2. Summary of Artifact Data Available for Study

\begin{tabular}{|c|c|c|}
\hline Artifact Class & Middle Archaic & Late Archaic \\
\hline Vol. $\left(\mathrm{m}^{3}\right)$ & 6.2 & 10.4 \\
\hline Debitage & 4000 & 7200 \\
\hline Stone Tools & 100 & 115 \\
\hline Projectile Points & 6 & 21 \\
\hline Bone $(\mathrm{g})$ & 512.15 & 1298.6 \\
\hline Bone Tool & 1 & 0 \\
\hline Snail Shell $(\mathrm{g})$ & 1695.5 & 4506.88 \\
\hline Mussell Shell $(\mathrm{g})$ & 18.22 & 0.1 \\
\hline Lipid residue samples & 6 & 23 \\
\hline Soils Samples & 30 & 34 \\
\hline
\end{tabular}

Archaic deposits were located between two gravel strata with radiocarbon dates placing them in the late Middle Archaic. In two of the units, the deposits peaked beneath an upper Late Archaic zone separated by a dramatic drop in artifact counts.

Although TUs 11 and 12 were not excavated to a depth beneath the Late Archaic, they likely also contained Middle Archaic deposits. The Middle Archaic component was not present in TUs 13 and 14, which were excavated to 3.05 mbs. In TUs 7 and 8, excavations stopped upon exposing a thick alluvial gravel strata, seemingly void of artifacts. The Middle Archaic component may have been present beneath these alluvial gravels but was not seen in the adjacent BHT 6 . However, a radiocarbon date submitted from an unexcavated thermal feature (Feature 109) in BHT 9 (roughly 5 m east of TU 8) returned a Middle Archaic date of 4430-4160 cal BP. This was removed from $160 \mathrm{~cm}$ below ground surface above red, alluvial gravels.

The Middle Archaic component extends north and south from TUs 5, 6, 9 and 10, and for unknown distances beyond its exposure in TUs 3 and 4 . The adjacent BHT 4 contained deeply buried deposits resembling the Middle Archaic stratigraphy seen in the test units. Therefore, the extent of the Middle Archaic component on the site could span up to $40 \mathrm{~m}$ from BHT 9 to a point between TUs 12 and 13 and at least $5.0 \mathrm{~m}$ from BHT 4 to the northern wall of TUs 9 and 10 . No evidence of disturbance post-dating the period was seen in any of the Middle Archaic deposits.

Based on the above, the Middle Archaic analytical units chosen for the analysis consists of $6.2 \mathrm{~m}^{3}$ of deposits from TUs 3, 4, 5, 6, 9, and 10. These levels contained a variety of data, including more than 100 tools and cores, 4,000 pieces of debitage, roughly $500 \mathrm{gm}$ of bone, and over 14,900 gm of feature burned rock. The size and type of the data available for study from the Middle Archaic deposits are summarized in Table 7-2.

\section{Summary of the Late Archaic Deposits (4000-1200 BP)}

The Late Archaic deposits at the Granberg Site were present across the upper portion of the site in all 14 test units and 6 backhoe trenches. This cultural horizon was thickest in Block I and thinnest in Block IV. Block II contained a Late Archaic burned rock feature and midden deposit. The deposit was identified as a peak in artifact distribution above a gravel stratum or above a drop in artifact density in Blocks I, III, and IV. Test Units 9 and 10 contained the deepest deposits and largest quantities of Late Archaic artifacts in Block III. The depth and quantity of artifacts decreased to the east but the thickness of the deposit increased and was thickest in TUs 13 and 14. Although TUs 15 and 16 in Block IV contained minimal artifacts compared to the units in Blocks I, II, and III, they were in good context. Because a thin layer of Middle Archaic material overlies the Late Archaic deposits in TUs 9 and 10, these deposits were not included as part of the Late Archaic analytical unit.

The Late Archaic analytical unit picked for the analysis consisted of $10.4 \mathrm{~m}^{3}$ of deposits from TUs 3-8 and 11-16. The Late Archaic component in these units contained more than 130 tools and cores, over 7,000 pieces of debitage, more than $1,000 \mathrm{gm}$ of bone, and over 250,500 gm of feature burned rock. The size and type of the data types available for study from the Late Archaic deposits are summarized in Table 7-2 . 



\title{
Chapter 8: Theoretical Persepective
}

\author{
Raymond P. Mauldin, Jennifer Thompson, and Cynthia M. Munoz
}

The previous chapters reviewed the history of work at the Granberg Site, including a discussion of the materials recovered from the CAR's most recent effort, and a short discussion of the analytical units present at $41 \mathrm{BX} 17$. This chapter provides a general overview of the theoretical position that will guide the analysis of the material collected from the testing of the Granberg Site.

\section{Background}

At a general level, our interpretive scheme comes from a theoretical position that can be broadly classified as cultural ecology. We view cultural systems as both adaptive and differentiated. By adaptive, we mean that cultural systems are continually responding to changes in the physical and social environment. Of particular concern for us are the responses, including technology, that are involved with procurement and processing of food, fuel, and raw materials from the environment. By differentiated, we mean that different activities are conducted at different times and locations depending on specific circumstances. As activities conducted by a group vary in space and through time, the material remains generated by those activities and the tools and facilities used to conduct those activities, will also vary. Consequently, individuals and groups operating within a cultural system potentially will generate radically different sets of material at various points on the landscape. Variations in material culture, both at the level of individual artifact forms and at an assemblage level, primarily reflect adaptive responses. This position contrasts with that frequently used in Texas archeology where variations in certain artifact forms (e.g., projectile points), and in assemblages, are commonly seen to reflect historical relationships and normative, cultural constraints.

From our perspective, then, changes in cultural systems, including changes in material culture, are principally the result of changing parameters in the physical and social environment in which systems operate and to which they must adapt, rather than reflecting movement of groups with a shared culture or influences diffused from other groups. This is not to suggest that diffusion or migration does not occur. Clearly, they do. However, we are interested in explaining why groups adopted traits or changed territories rather than simply tracing the historical connections through similarities in artifact form. We do not find notions such as the persistence of existing lifeways, or lack thereof, to be particularly useful in explanations. What were the conditions and mechanisms that caused the change? Why did the changes occur when and where they did? We suggest that, currently, our understanding of the mechanisms of change, as well as our methodology for monitoring those mechanisms in the social realm are not well developed. Clearly, social factors, such as territorial disputes and shifting alliances, can affect adaptive strategies, especially through altering access to resource areas. However, our current understanding of how to monitor these social factors with archeological data is all but non-existent. In addition, even the best archeological data probably has a temporal resolution of decades, while social alliances commonly operated on a much shorter temporal scale. Consequently, we currently have no effective way to monitor these social factors in an archeological setting. We focus here, then, on interactions between aspects of cultural adaptation and the natural realm. At this level, we have better developed methods. Especially critical in that interaction are strategies and tactics, including the organization of technology and mobility, which are used to acquire resources. It is in this realm, where cultural systems interact with the natural environment, that extant adaptive strategies are molded and modified. In addition, at least some of these interactions operate at longer temporal scales that have the potential to manifest themselves in the archeological record.

Resources, including food, water, and raw material, are not uniformly distributed in space nor are they of uniform quality or density through time. Among hunter-gatherers, problems created by spatial variation in resources are commonly solved by mobility strategies that involve positioning and changes in group composition. Mobility strategies have several components that can vary, including the frequency of moves, the distance moved, and the degree to which different types of organization (e.g., logistically organized task groups, higher residential mobility) are used. Temporal fluctuations in resources, including daily and seasonal changes in resource availability and quality, year-to-year fluctuations in resource density, and longer-term changes in resource structure, are commonly solved by shifts in mobility strategies, fluctuations in group composition, technological alterations, and, potentially, resource storage strategies.

\section{Foraging Models}

The responses initiated by hunters and gatherers to various scales of spatial and temporal fluctuations and change in resources can be productively investigated using a cost/benefit framework developed in evolutionary ecology. Two principal 


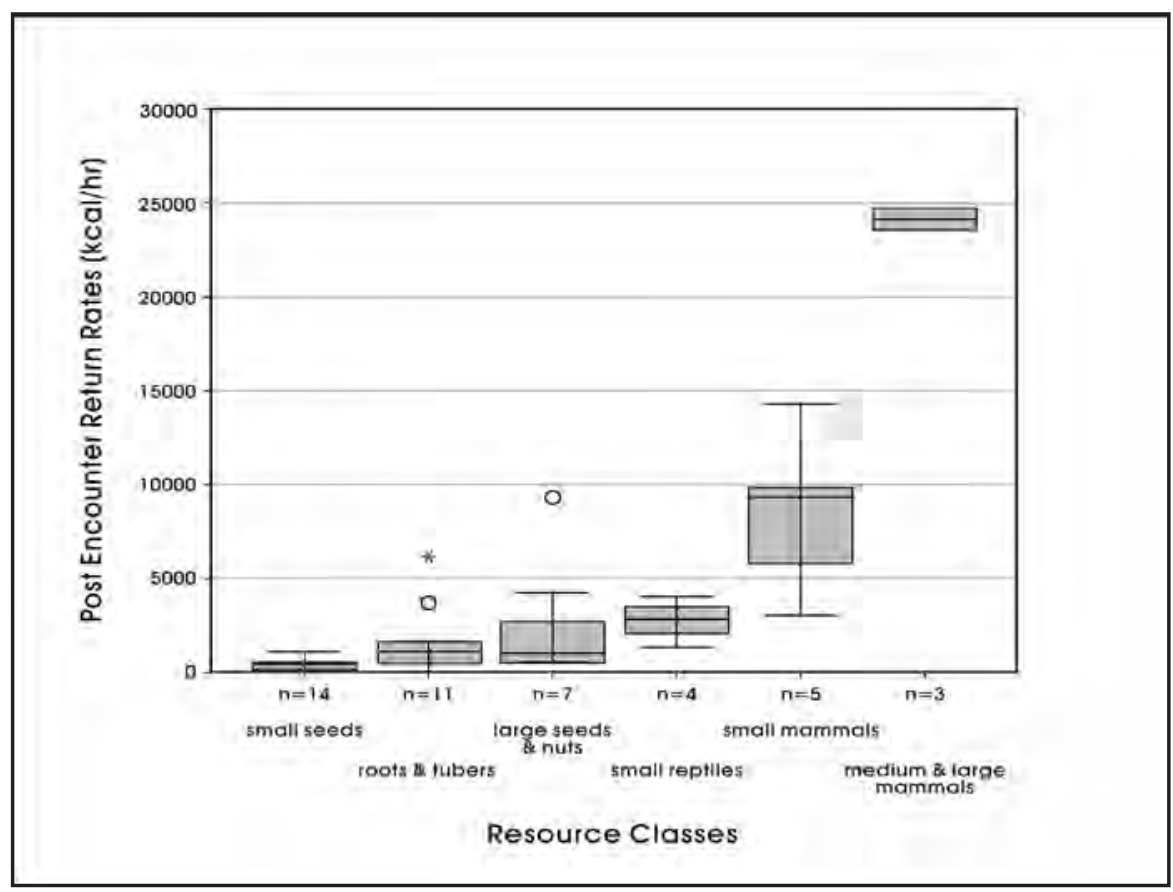

Figure 8-1. Handling costs by resource class.

models, a "Prey Model" which was explicitly developed for a single predator pursuing a single prey in a homogenous environment (Charnov et al. 1976; MacArther and Pianka 1966; Winterhalder 1981), and a "Patch Model," designed for situations where prey are clustered in a more heterogeneous setting (Charnov 1976; Kaplan and Hill 1992), have been developed to account for foraging behavior. While many assumptions of these foraging models are clearly violated by human hunter-gatherers and while parameters specified for analysis are often difficult to estimate in archeological situations, we find the models appealing as they provide an explicit cost/benefit framework for analysis.

Foraging models (see Stephens and Krebs 1986) frequently quantify returns (benefits) as energy (kilocalories [Kcal]) obtained from food (but see Jochim 1975; Speth and Spielmann 1983), and quantify costs as time expended on searching for, pursuing, capturing, and processing that food. They assume that foragers will attempt to maximize average return rates in the context of different cost/benefit ratios for different prey. Costs are usually broadly framed as search costs, the amount of time spent looking for game or resource patches, and handling costs, the amount of time required to pursue, capture, and process foods. For hunters and gatherers, we would also include in handling costs time associated with production of tools (e.g., raw material acquisition, tool shaping, maintenance, production of ceramics), and time associated with processing elements (e.g., preparation of hearths). While changes in technology can impact search costs (e.g., the use of dogs), most of the impacts of technology are on handling costs.

A critical element of prey foraging models is associated with ranking of prey alternatives. Potential prey items are ranked in terms of handling costs and benefits. This ranking often reflects body size with larger-bodied animals (e.g., mammoths, bison) being more profitable (higher returns relative to handling costs) than smaller-sized animals (e.g., rabbit, deer). Plants usually rank below animals. This pattern can be seen in Figure 8-1, which presents boxplots for a series of return rates gathered from a variety of experimental and ethnographic sources (see Kelly 1995; Simms 1987). The rates have been grouped by body size for animals and roughly by seed size for plants. Clearly, the return rates on large mammals in this example are extremely high, while those on collecting and processing small seeds are extremely low.

An additional element that must be considered is success rate. While successful acquisition of most plants can be assumed once they are encountered, not all encounters and pursuits of animals result in a positive outcome for the pursuer. In fact, ethnographic accounts of hunting suggest that many pursuits of animals do not result in a successful kill. For example, Marks (1976:205-209) reports the number of kills 


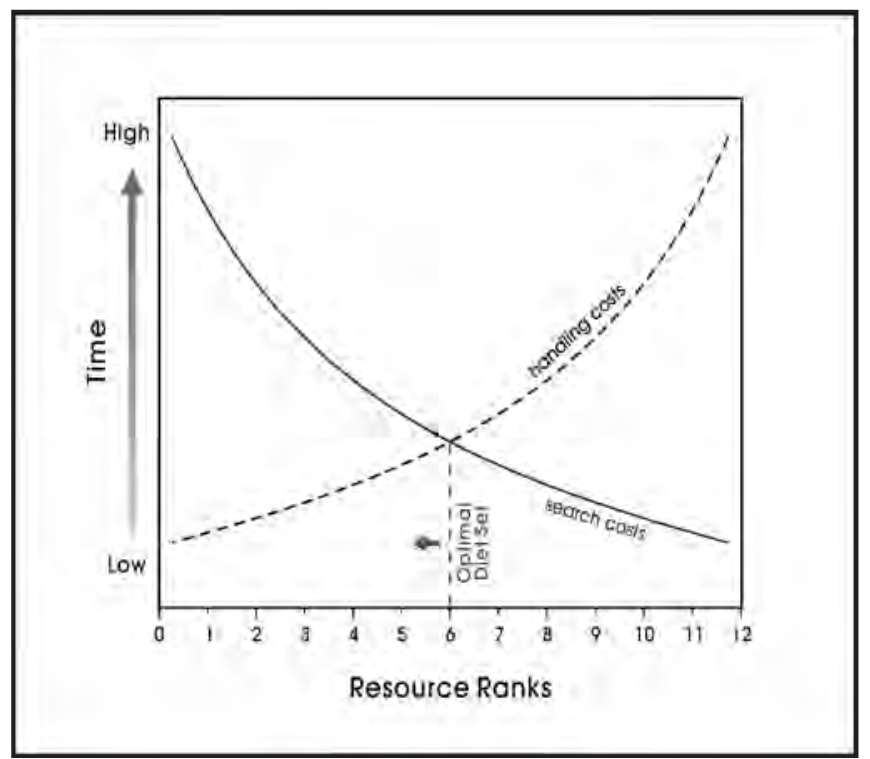

Figure 8-2. Optimal diet set as defined in Prey Model.

per stalking event for various types of large mammals by Valley Bisa hunters in Zambia. Using muskets, Bisa hunter kill rates per stalking event vary from a low of only $2.9 \%$ for impala to a high of $26 \%$ for buffalo. Success rates using more traditional technologies, such as bow and arrow, are probably much lower (see Hill and Hawkes 1983:164), though precise data could not be located. Consequently, the return rates on animals in the Figure 8-1 example are probably inflated given that unsuccessful stalking events would result in no return. A more realistic ranking strategy would involve the ratio of energy captured per attack to the handling time per attack. This "prey profitability" ranking of plants and animals (Stephens and Krebs 1986:17-23) would result in a reduction of rankings of animals, though it is likely, given the return rate disparity shown in Figure 8-1, that large-body sized animals would still be ranked higher than alternative food resources.
Search costs associated with a single resource type (e.g., large mammals) may be prohibitive. Search costs, though not involved in potential prey rankings, play a critical role in determining the actual diet, for as more resource types are added to the diet search costs decline because resources are more frequently encountered. These new resources, being lower ranked, have higher handling costs and/or lower benefits (lower profitability). Predator-Prey foraging models predict a tradeoff, then, between handling cost, benefits, and search costs that will maximize the average return and produce an optimal diet for the forager (Figure 8-2). These models predict that foragers will continue to add lowerranked prey to the diet, increasing the diet breadth, so long as the overall profitability of the diet, seen in terms of total costs and benefits, is increased. Furthermore, foragers should drop lower ranked resource types from the diet, reducing the diet breadth, when doing so would increase overall profitability.

Spatial or temporal fluctuations in resources are not explicitly incorporated into prey foraging models. However, we can incorporate temporal fluctuations and spatial differences, as well as long-term change in resource structure because of larger-scale climate change. For example, major shifts in the availability of bison in the prehistoric sequence of Texas have been suggested by several researchers (Collins 1995; Dillehay 1974). Bison is a highly ranked resource given the large body size, and their presence/absence, as well as changes in density, should have a dramatic impact on the inclusion or exclusion of other, lower-ranked resources, in hunter-gatherer diets. Note that while bison is currently the best documented case, especially in terms of potential long-term temporal changes in resources in Texas, other resources certainly experienced similar fluctuations, both in terms of density, which will impact search costs, and nutritional quality, which will impact return rates. Figure 8-3 presents an example of seasonal changes in nutritional quality of mule deer. While this example is from Colorado, we expect similar fluctuations, though perhaps not

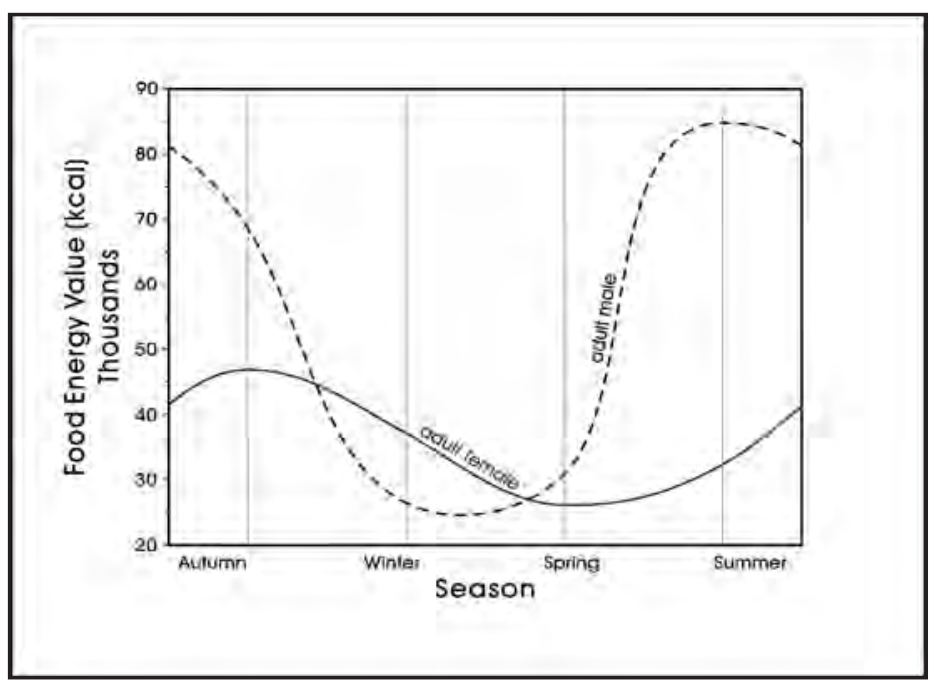

Figure 8-3. Seasonal changes in the nutritional quality of mule deer. 


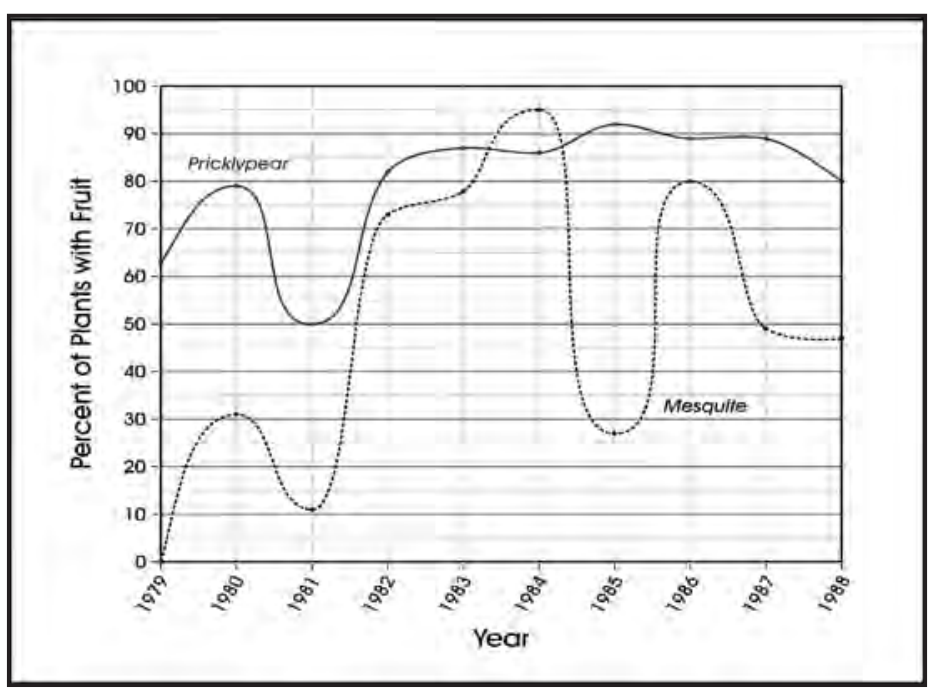

Figure 8-4. Yearly fluctuation in mesquite and prickly pear flowering.

as extreme, in deer, bison (Speth 1983: 120-131), and many other mammals in Texas. The fluctuating nutritional quality of deer in the Figure 8-3 example demonstrates that in this case, the post-encounter return rates differ by season with higher returns during the fall and summer months and lower returns during winter and spring. An example of yearly changes in availability in plants is presented in Figure 8-4. These data, from South Texas, demonstrate fluctuations in availability of prickly pear and mesquite over a 10-year period. Obviously, the search costs associated with mesquite in 1979,1980 , and 1981 would be considerably higher than the 1982 through 1984 years. Given the wide environmental differences across Texas, we can also anticipate dramatic differences in resource density and type across the state. For example, Central Texas will not only contain several different types of resources not present in East Texas (e.g., bison, agave, sotol), but environmental change will differentially impact the density of the resource types that the two areas share (e.g., deer). These changes in density, in turn, will translate into both different search costs and may, depending on resource ranking, impact overall diet breadth.

Technological change can also be effectively considered in this cost/benefit framework. As noted above, time associated with production of tools (e.g., raw material acquisition, tool shaping, and tool maintenance) and time associated with processing elements (e.g., preparation of hearths) can clearly be considered in determinations of handling costs associated with resource acquisition. Tools are potentially designed and used for a variety of different tasks, and the tasks required should impact the form of the tool. At a general level, we envision tools as ranging from generalized to specialized in form. Specialized tools tend to be more expensive to produce in that these formal tools require more time, are usually more complex, and in some cases may require specific raw materials that have limited distributions. As a group, these tool forms are frequently maintained, also increasing their overall costs. However, because of their specialized nature, they tend to be more efficient at the task for which they are designed and, thus, should reduce the time associated with a given processing event. Generalized tools, conversely, are less expensive to produce as they are often expediently made, tend to have fewer components, and may have more flexible raw material requirements. These tools often are designed to have short use lives; therefore, they have minimum associated maintenance costs. However, these tools, while less costly and potentially useful to perform a variety of tasks, will be less efficient at any given task.

When seen from this perspective, the decision to employ a more specialized or a more generalized technological solution in a given situation can be considered in the context of the overall costs associated with tool production and maintenance relative to the benefits derived from that tool. For example, in contexts where resources are processed in bulk, where they are available for a limited period of time, and where they are somewhat predictable in distribution, a solution that emphasizes a tool kit composed of more specialized tools would be favored as the greater cost investment in production and maintenance should be more than offset by an increased return (a greater processing rate) during the time when those resources are present. Conversely, more generalized tools would be favored in situations in which resources were not temporally restricted, are not processed in bulk, and where resources are somewhat less predictable in distribution. While both specialized and generalized tools can be present in any given system and could potentially be used in the processing of a range of resources with different ranks, the increased costs associated with the production of 
specialized tools would tend to suggest their use on higherranked resource types.

The final element considered in this section focuses on mobility systems. As noted above, mobility, in terms of search costs (travel time), plays a critical role in modeling diet breadth in Prey models. Mobility systems in archeological research on hunters and gatherers are increasingly discussed in terms of two broad organizational stances that Binford (1980) has termed "foragers" and logistically organized "collectors." Collector strategies are often characterized as having low residential mobility, with task-specific groups acquiring resources and moving those resources back to the residential location. Binford's "foragers," conversely, frequently move residential locations to acquire food. Binford (1980; see also Kelly 1995) broadly framed these two strategies as responding to different environmental conditions with "foragers" present in environments characterized by ubiquitous, low-density resources, and collectors present in settings with high temporal or spatial disparity in resources. In practice, these two strategies are frequently present within the same cultural system, with possible seasonal or resource-specific shifts in strategies. From the current cost/benefit perspective, we can suggest that logistical systems of resource procurement are a more specialized strategy relative to foraging-based systems. They are more costly in terms of distances covered, as well as requiring more planning and preparation time. Logistical strategies are used to gather resources in excess of immediate needs with that excess being returned to residential locations. It is likely, then, that when logistical strategies are used their targets will tend be higher-ranked resources. This is because the distance at which hunters and gatherers can effectively acquire resources in bulk is tied to the resources overall return rates, load-bearing abilities of the participants, and distance (e.g., Jones and Madsen 1989; Metcalfe and Barlow 1992). Hunters and gatherers should not exploit lowranked resources at great distances, as the longer travel time effectively negates any benefits. However, note that while logistical systems should always focus on higher return resources, the exploitation of higher return resources does not necessarily require a logistical system.

\section{Summary}

Using the cost/benefit framework provided by foraging theory, we have presented a number of general relationships that should be applicable to investigating aspects of diet, technology, and mobility in hunters and gatherers. We have suggested that human foragers can respond to short and long-term shifts in resource availability in complex ways. Those responses may involve various mixes or shifts in what resources are included and excluded from the diet, technological changes that alter handling costs and capture rates of dietary items, and shifts in mobility strategies that alter encounter rates.

The application of such a framework in an archeological setting is a daunting task. The archeological record is not generated at a temporal scale that is analogous to the ethnographic time frame (see Binford 1992; Dunnell 1992; Ebert 1992), the context where most human foraging cost/ benefit models have been developed and used. Even under exceptional conditions, the temporal scale at which we can define associated activities in archeological assemblages is on the order of decades. Events that happen on a daily, seasonal, or yearly scale are invisible in most assemblages. In an archeological setting, we lack quantitative data on what resources were available at various points in time, let alone detailed data on seasonal, yearly, or long-term fluctuations in the quality and density of those resources. We lack quantitative information on costs associated with various technological alternatives, as well as data on how those costs might change as the position of the forager on the landscape changes. We lack data on the costs associated with various alternative search strategies. We further realize that the responses of hunters and gatherers to different situations will be complex, and that factors other than simply maximizing average return rates will play a critical role in most circumstances.

Nevertheless, the models generated from foraging theory provide a coherent set of principles and an explicit analytical framework for investigating aspects of archeology. While strict quantitative modeling will probably always be beyond our reach, we have previously defined a series of expectations for several time periods within the Late Archaic and Late Prehistoric in South-Central Texas that were based on foraging theory using a more qualitative approach (Tomka et al. 2004a; see also Tomka et al. 2004b). We argued that the presence/absence of bison, a highly ranked resource given the large body size, should have a dramatic impact on subsistence, technology, and mobility. We suggested that the presence or absence of bison should result in a contraction or expansion of the diet with lower ranked plants and small animals being eliminated or added to the diet based on bison availability. We offered a series of specific expectations in technology and mobility for each of the time periods considered. The temporal periods of presence/absence we identified were initially taken from Dillehay's (1974; see also Collins 1995) model of bison within the state. In the following chapter, we begin to develop this model in more detail in the context of our recent work at 41BX17. That model development includes consideration of white tailed deer (Odocoileus virginianus), an animal that, based on body size, has return rates well below those of bison. However, when bison were absent from the region, such as has been suggested for the Middle Archaic (see Dillehay 1974), deer would have been among the highest ranked prey available. 



\section{Chapter 9: Modeling Hunter-Gatherer Adaptations and Archeological Expectations}

\section{Raymond P. Mauldin and Cynthia M. Munoz}

The cost/benefit framework provided by Foraging Theory suggests general relationships that should be applicable to investigating aspects of diet, technology, and mobility in hunters and gatherers. While Texas archeologists do not commonly conceptualize diet, technology, and mobility systems in strict cost/benefit terms and our ability to monitor aspects of these models in an archeological case are limited, components of Foraging Theory offer a coherent set of principals and an explicit analytical framework for investigating aspects of Texas archeology. In this chapter, we develop a general model based on bison and deer availability and argue that this particular framework can provide a context for investigating the Middle and Late Archaic material recovered from 41BX17.

\section{Estimating Bison and Deer Availability in the Middle and Late Archaic}

We designed our model in the context of the presence/ absence of bison and based it on Dillehay's (1974) early work on this issue. Dillehay argued that bison were absent in the state throughout the Middle Archaic, present throughout the Late Archaic and Initial Late Prehistoric, absent in the Late

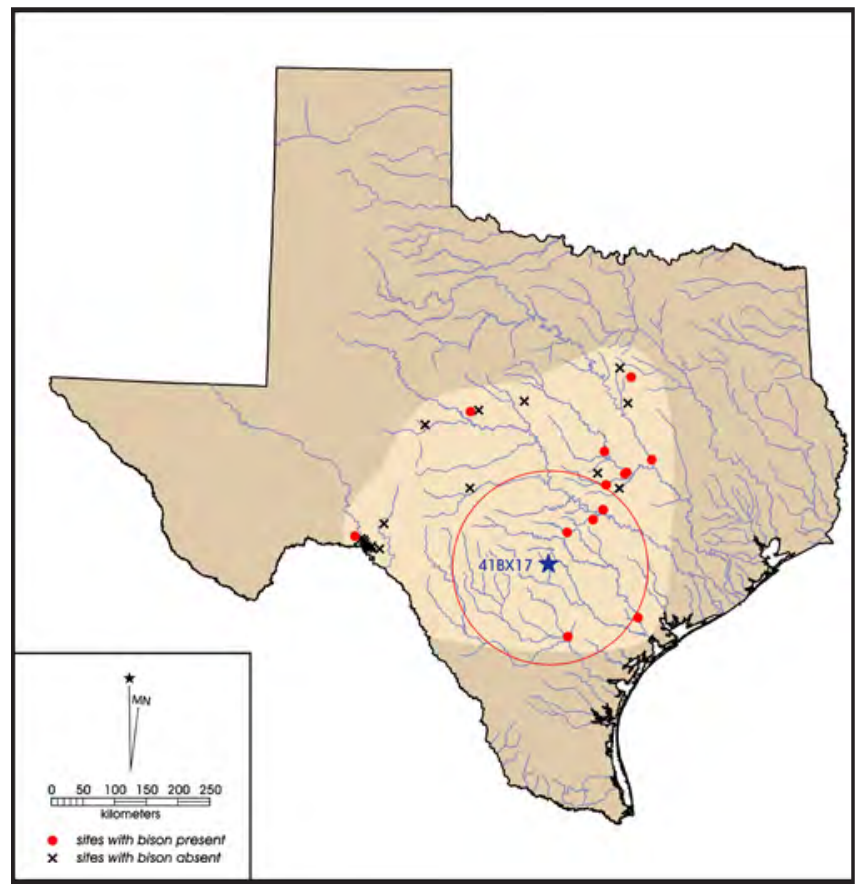

Figure 9-1. Late Archaic (4450-1260 BP) sites with bison presencelabsence in Central Texas $(n=39)$.
Prehistoric (Austin Phase) period, and present again in the Terminal Late Prehistoric (Toyah) period. Much of the Late Archaic as defined here (4000-1250 BP) corresponds closely to Dillehay's (1974; see also Huebner 1991) bison Presence Period II (4450-1450 BP), while much of the Middle Archaic (6000-4000 BP) is within his bison Absent Period I (ca. 7000-4450 BP). More recently Collins (1995:377, 2004; see also Huebner 1991) has suggested that after an absence from Texas in the Early Archaic bison were relatively abundant in the early portion of the Middle Archaic (ca. 6000-5000 BP) and, subsequently, were not common from the close of that period until roughly $3500 \mathrm{BP}$. Though the basis for this suggestion is unclear, it appears to come from climate data as well as from inferences derived from lithic tool forms.

Recently, Mauldin and Kemp (2005) reviewed data from over 180 components from Central and South Texas for the presence/absence of bison with good temporal association. Their analysis focused on the Late Archaic and the Late Prehistoric periods. Reviewing 67 components that could be confidently assigned to the Late Archaic and dividing the Late Archaic into smaller time periods, they found that bison were present in $28 \%$ of all Late Archaic components. Figure 9-1 presents the spatial distribution of the 39 Late Archaic sites that contained the 67 Late Archaic components that Mauldin and Kemp (2005) ultimately used in that study. These data are consistent with Dillehay's (1974) suggestions regarding bison presence throughout the Late Archaic. We cannot rule out the suggestion by Collins that bison were either absent or not abundant in Texas during the initial period of the Late Archaic until roughly 3500 BP (Collins 1995; 2004). However, data in Mauldin and Kemp (2005) demonstrate that bison are present on $38 \%$ of the 18 Late Archaic components that date between 4450 and $2500 \mathrm{BP}$, a temporal range that overlaps to some degree with the period of absence (5000 3500 BP) suggested by Collins.

The study by Mauldin and Kemp (2005) considered the Late Archaic and the Late Prehistoric periods in the central and southern portions of Texas. Consequently, we lack any recent data on bison presence in the Middle Archaic within the state. If, as suggested by Dillehay (1974), bison are absent during the entire Middle Archaic, then we would expect that this absence would dramatically influence the adaptations when we contrast those adaptations to the Late Archaic. In the central portion of Texas, deer would likely be the 


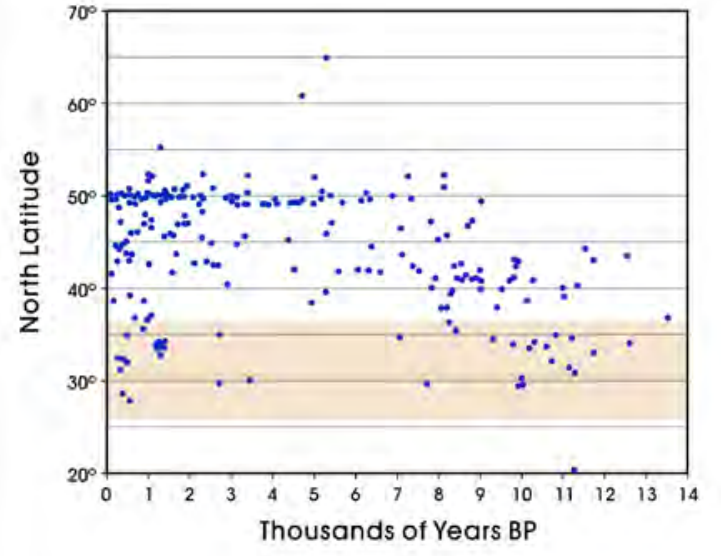

Figure 9-2. Radiocarbon dates associated with bison remains, with Texas latitudes highlighted.

highest ranked animal, and probably the focus of most large game hunting, when bison were absent. As we will discuss subsequently, deer provide a number of different challenges and opportunities for hunters. Similarly, the return of bison during the early portion of the Late Archaic should produce significant shifts in hunter-gatherer land use. Therefore, depending on the frequency of bison in the environment, hunters would take deer when they were encountered (i.e., deer would still be in the optimum diet), the presence of bison should influence the use of low ranked animals and plants. data to support Collin's (1995:377, 2004) suggestion that bison were relatively abundant in the early Middle Archaic within Texas.

\section{Distribution, Movement, and Diet of Bison bison}

While bison are clearly present in the state by the Late Archaic, the animal returning is a new species, the Plains bison (Bison bison). The species first appeared sometime after 6,000 BP and spread rapidly as grasslands replaced woodlands and forests during the Middle Holocene (McDonald 1981). Though certainly present at times in woodland settings, Figure 9-3, adapted from McDonald (1981:104), shows that the primary or core range of this animal was from Central Texas in the south to Alberta, Canada, in the north, an area consistent with the limits of the Great Plains grasslands.

Not surprisingly given this distribution, Plains bison are primarily grazers. Studies show that various grasses and sedges consistently comprise over $90 \%$ of their diet across all seasons (Coppedge et al. 1998; Peden 1976; Peden et al. 1974). Both cool $\left(\mathrm{C}_{3}\right)$ and warm $\left(\mathrm{C}_{4}\right)$ season grass species are used by bison, but there seems to be a slight preference for warm season grass species when both are present (see Peden et al. 1974). In the southern portion of the range shown in Figure 9-3, however, warm season grasses, those that grow primarily during the summer, will be dominant under most climate regimes. Both the relative frequency and overall productivity of cool season $\left(\mathrm{C}_{3}\right)$ and warm season $\left(\mathrm{C}_{4}\right)$ grasses are determined, to a large degree, by different mixes of precipitation and temperature in different soil regimes (see Bamforth 1988; Brown 1993; Epstein et al. 1997; Paruelo and Lauenroth 1996; Teeri and Stowe 1976). Productivity in cool

We constructed Figure 9-2 from large-scale research by McDonald (1981:257). The figure shows the pattern of bison finds that are associated with radiocarbon dates from throughout the Great Plains. The Texas latitudes have been highlighted in the figure. Focusing on those latitudes, McDonald's data clearly suggests that bison (Bison antiquus) were present in the state prior to $7000 \mathrm{BP}$. In addition, his data suggest that bison were absent in Texas during the period between about 7000 and $3500 \mathrm{BP}$, a period encompassing the Middle Archaic. During this time, bison ranges appeared to have shifted well to the north of Texas. Finally, and in accordance with the Figure 9-1 data, Figure 9-2 shows that bison returned to the state throughout much of the Late Archaic and Late Prehistoric periods. There is no evidence in McDonald's (1981)

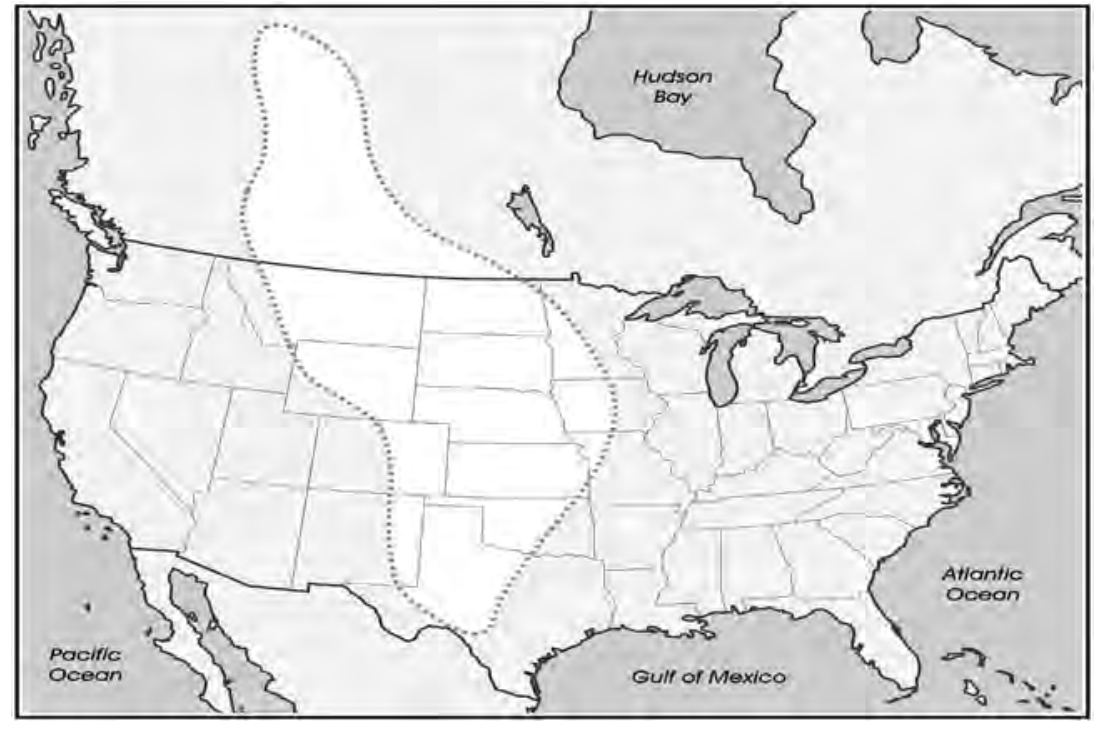

Figure 9-3. Primary range of Bison bison. 
season grasses has a significant, negative correlation with mean annual temperature and percentage of sand in soils and has a moderate positive correlation with mean annual precipitation (Epstein et al. 1997; Paruelo and Lauenroth 1996). Conversely, productivity in warm season $\left(\mathrm{C}_{4}\right)$ grass is highly correlated with mean annual precipitation, higher summer precipitation, sandy soils, and high mean annual temperatures (Epstein et al. 1997; Paruelo and Lauenroth 1996). These climate conditions produce a dominance of warm season grasses in the southern plains, both in terms of frequencies of species and in terms of overall forage production.

Several authors (e.g., Bamforth 1988; Speth 1983) have suggested that the amount of forage production for bison, the nutritional quality of that forage, and the location of that production in warm season grasses such as those that dominate the southern plains may be highly variable from year to year. Unlike their cool season counterparts, growth in warm season $\left(\mathrm{C}_{4}\right)$ species in the south frequently occurs in direct response to localized, unpredictable precipitation events during the summer months. Production pulses, shifts in the nutritional value of forage, and increased digestibility of grass by herbivores are all closely related to erratic summer precipitation (see Hart et al. 1983 Rauzi and Dobrenz 1970; Sala and Lauenroth 1982). The summer production pulse of warm season grasses, combined with the low frequency of cool season $\left(\mathrm{C}_{3}\right)$ grasses, results in seasonal

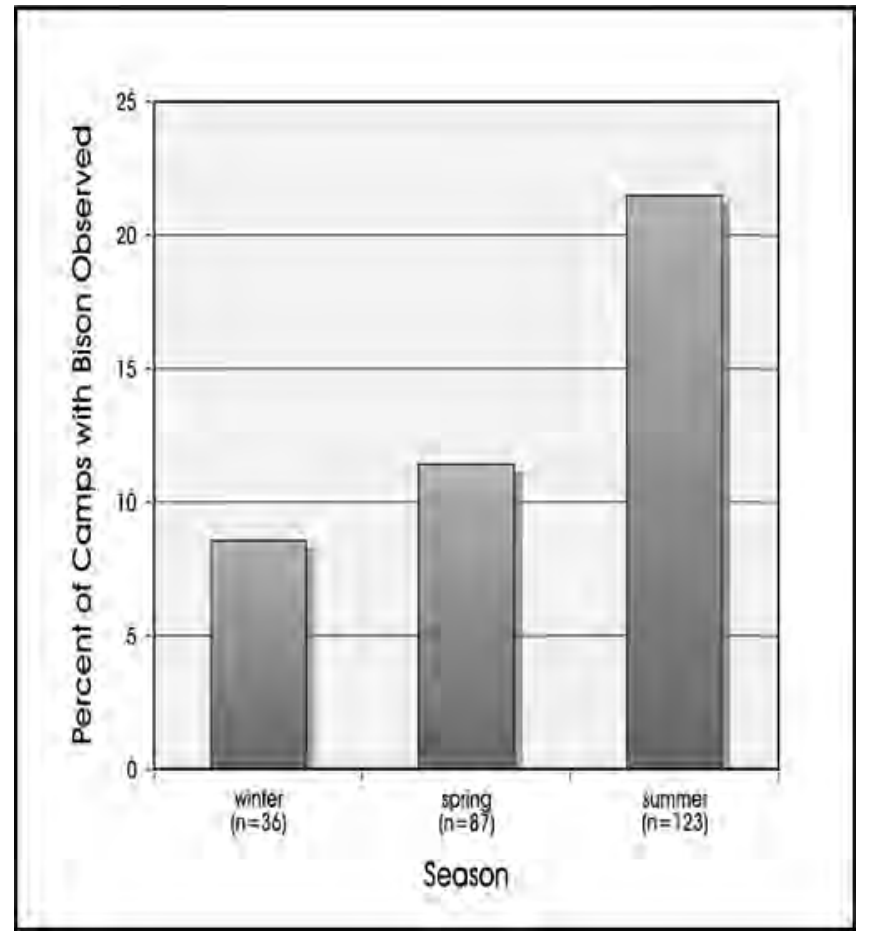

Figure 9-4. Season of bison encounters by Spanish expeditions into Central Texas from 1675 through 1767. shortages in forage production on the southern plains. In fact Speth (1983:119-131), looking at warm season grasses in southeastern New Mexico, suggests that bison in this region may have been operating below their maintenance threshold in crude protein and phosphorus levels from the late fall through the early spring.

Probably in response to these shifts in the quality and quantity of forage, along with the availability of water and climate extremes, bison populations certainly shifted locations, though both the scale and regularity of such movements are not clear (see Bamforth 1988; Chisholm et al. 1986:195; Doughty 1983: 45-48; Epp 1988; Gordon 1979; Morgan 1980; Roe 1951). Delta $(\delta){ }^{13} \mathrm{C}$ values on bison collagen collected from archeological deposits in the northern panhandle of Texas (Quigg 1997) demonstrate strong $\mathrm{C}_{4}$ signatures (values between -7.8 and $-8.6 \%$ ), and Huebner (1991) reports the analysis of collagen from 38 bison from throughout the state that have $\delta^{13} \mathrm{C}$ values ranging from -13.6 to $-7.8 \%$. These isotopic signatures are not consistent with extensive feeding in northerly $\mathrm{C}_{3}$ grasslands. Conversely, Chisholm et al. (1986) report a variety of bison collagen $\delta^{13} \mathrm{C}$ values from the northern end of the primary range (see Figure 9-3) that fall between -17.3 and $-20.6 \%$, suggesting a diet with little $C_{4}$ grass consumption.

Given these isotopic data, long distance migrations of bison herds on a short-term basis seem unlikely. Yet there is data that suggests that bison populations fluctuated in Texas, at least in the late seventeenth and eighteenth centuries. These data are from recent summaries of early Spanish expeditions onto the Edward's Plateau region of Texas (Wade 1998). One of the data sets compiled by Wade includes both probable camp locations and the Spaniards' observations on fauna, including bison. Overall, Wade provides detailed route and camp information on 10 different expeditions to the Plateau conducted from 1675 to 1767 and information on 246 camps used by these expeditions (Wade 1998: Appendix E). Figure 9-4, constructed from Wade's camp summaries (1998: Appendix E), provides information on the possible seasonal availability of bison in central and west Texas. Of 36 camp locations occupied during the winter months of December and January, the Spanish observed bison on only three camps (8.3\%). For the months of February, March, and April, there are 87 observations, 10 of which note bison (11.5\%). Finally, there are 133 observations during the months of May, June, July, and August. The Spanish noted bison in 26 instances (21\%). Interestingly, while the number of observations are small $(n=28)$, the late summer months of July and August do not have recordings of bison. This may suggest, then, that bison populations, at least in this portion of Texas and in the 


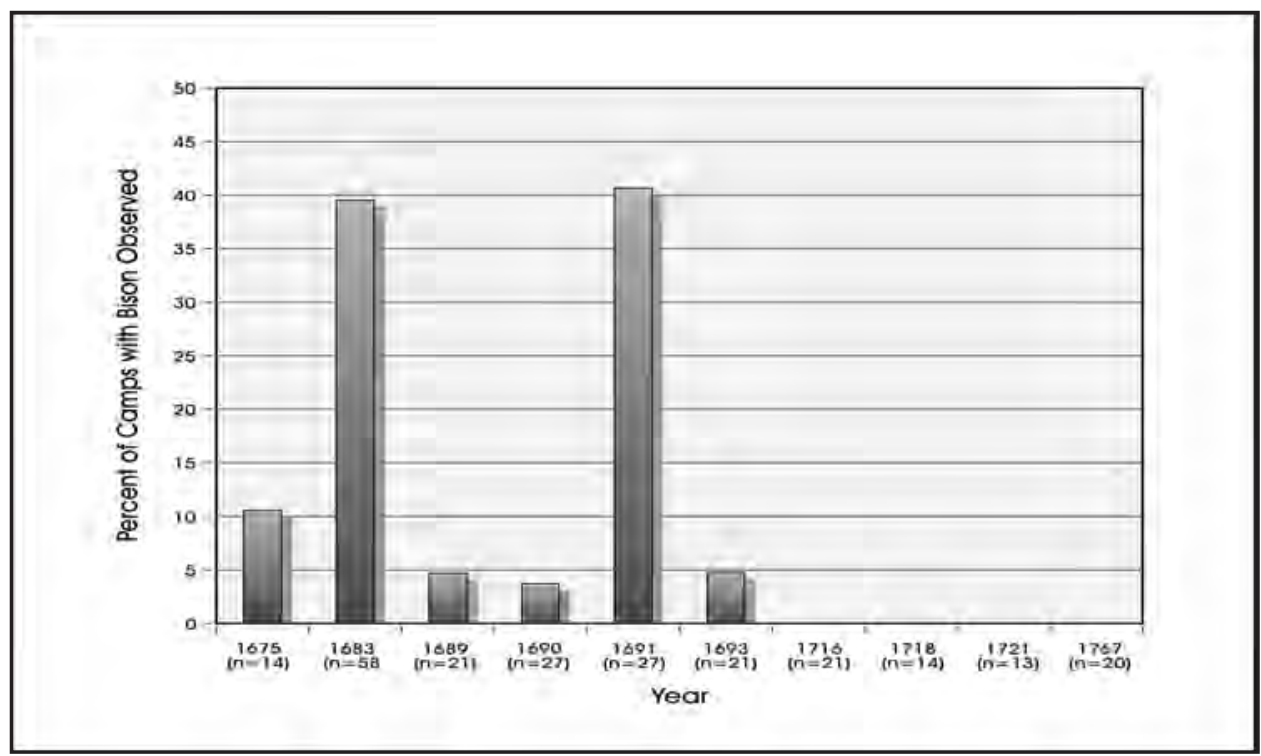

Figure 9-5. Percentage of camps on which bison were observed from 1675 through 1767.

late 1600 s and into the 1700 s, probably declined in the late summer and early fall, with a gradual increase in numbers throughout the spring, with peak populations present in the early summer months. This seasonal pattern of bison availability derived from Wade's (1998: Appendix E) data would be consistent with seasonal patterns in $\mathrm{C}_{4}$ grassland production in Texas discussed previously. We are suggesting, then, that levels of bison mobility and group size varied in response to seasonal availability of forage.

In Figure 9-5 we have grouped Wade's camp data (1988: Appendix E) at a yearly scale. Overall, these early expeditions noted bison on only 39 of the 246 camps. That is, roughly $85 \%$ of all camps lacked any mention of bison. As shown in the figure, there is extreme year-to-year variability in bison availability. In two out of the 10 years shown $(1683,1691)$, bison were observed on roughly $40 \%$ of camps. Four of the remaining eight years also note bison as present in the area, though the frequency is considerably lower. Finally, note that in four of the 10 years, members of these expeditions did not note any bison. While a variety of factors, including seasonality and camp location, could account for these apparent fluctuations in bison sightings, the fluctuations are consistent with our characterization of the southern plains as having variable forage production.

The seasonal and yearly fluctuations in bison availability within the state seen in the historic data are both consistent with our characterizations of the southern plains as less than optimal for bison populations. We based that characterization, in part, on modern patterns of variable precipitation and temperature data that produce distinct grass regimes. If these same regimes were present in the Middle and Late Archaic, it would have considerable importance for our model. There is currently minimal evidence for bison in the Middle Archaic; however, if these same patterns of seasonal and yearly fluctuations in bison populations were characteristic of the Late Archaic period, it would have important implications for our model. That is, the fluctuations, including possible seasonal absence of this high ranked resource, would result in short-term shifts in diet breadth at small temporal scales.

\section{Distribution, Movement, and Diet of Odocoileus virginianus}

While bison was the mammal with the highest return rate, periods of bison absence or diminishment would have caused an increase in procurement of other lower ranked animals in the diet. The second highest ranked prey choice in this portion of Texas, in terms of return rates, is the white-tailed deer, Odocoileus virginianus. Along with broadening the diet to include low ranked animals and plants, increased hunting of white-tailed deer would have been the logical choice when bison were scarce or unavailable, such as has been suggested for the Middle Archaic.

White-tailed deer are currently the most important big game animal in Texas. In 1991, deer populations in the state exceeded 3.1 million in spite of heavy hunting pressure. White-tailed deer are relatively small with a long broad tail, short ears, and a white underbelly. The male averages 1,800 $\mathrm{mm}$ in length, weighs an average of $30-70 \mathrm{~kg}$, and possesses antlers that are shed yearly after the rut followed by regrowth. 
The female usually lacks antlers and is slightly smaller than the male (Davis and Schmidly 1994).

White-tailed deer are found throughout Texas living in brushy or wooded areas, almost exclusively in hardwood environments. The highest deer production region, based on breeding numbers, is the Edwards Plateau (TPWD 2007). Populations are high with an average density of one deer per fifteen acres. Many pockets within this region report densities reaching one deer per three acres. The estimated deer population for the Edward Plateau in 1998 was 1,555,000 making up over 40 percent of the total number of white-tailed deer found in Texas (Armstrong and Young 2001).

White-tailed deer are nonmigratory mammals. They have a fairly small home range and foraging radius. Home range is defined as the area traversed by an animal annually during its normal activities of food gathering, mating, and caring for young. The deer's home range must be large enough to provide the essentials for survival and reproduction, yet small enough for familiarity which increases survival (Webb 2005). When food is adequate, deer tend to stay in one location for extended periods.

One study in the Edwards Plateau region noted deer remaining on an area of 259 ha (650 acres) for at least three years (Davis and Schmidly 1994). Research on movement and activity patterns of white-tail deer by Evans (1992) indicated a correlation between the distance of movement and month of the year. Movement was greatest in February and September and lowest in July and was negatively correlated with ambient temperature. Deer activity increases as the temperature decreases. Deer tend to forage over smaller areas in summer when plant material is abundant. In fall and winter as plant production decreases, the animals are forced to range over larger areas. In midsummer when the average temperature is the highest, mobility decreases significantly. Evans (1992) concluded that depleted summer range conditions and increased temperatures prevent deer from accessing enough quality forage to offset the energy directed towards foraging and heat dissipation. Thus, a reduction in movement/activity occurred to allow deer to maintain metabolic equilibrium.
Another factor influencing mobility is reproductive readiness and the beginning of the breeding season. Movement of does, during parturition and fawning, and bucks, from the onset of rut influences, varies greatly from the norm with both sexes frequently leaving and returning to established home ranges until the season is concluded (Kroll 1991). In addition, dominance or social position affects home range size with more dominant, older males using larger home ranges to maintain social position (Inglis et al. 1979). Home ranges are determined by competition between other deer and other species, predation, habitat availability, and deer social structure and density.

One other parameter, dispersal, influences deer population movement. Dispersal is the primary form of long-distance movement in a deer's lifetime. Yearling males, males under 2 years of age, often will leave their birth home ranges and establish new ranges. Male white-tailed deer establish stable home ranges by three or four years of age (Webb 2005).

In order for white-tailed deer to survive, their habitat must include adequate nutrition, water, and cover. Basic cover needs include low growing vegetation for hiding and for fawn protection, mid level vegetation for protection from predators, and overstory vegetation to shelter deer from weather extremes (Armstrong and Young 2001). Low and mid-level vegetation also provide food. Three broad categories of plants are important to deer: forbs, browse, and grass (Figure 9-6). The preferred foods of deer are forbs; broadleaf herbaceous plants. The abundance of forbs

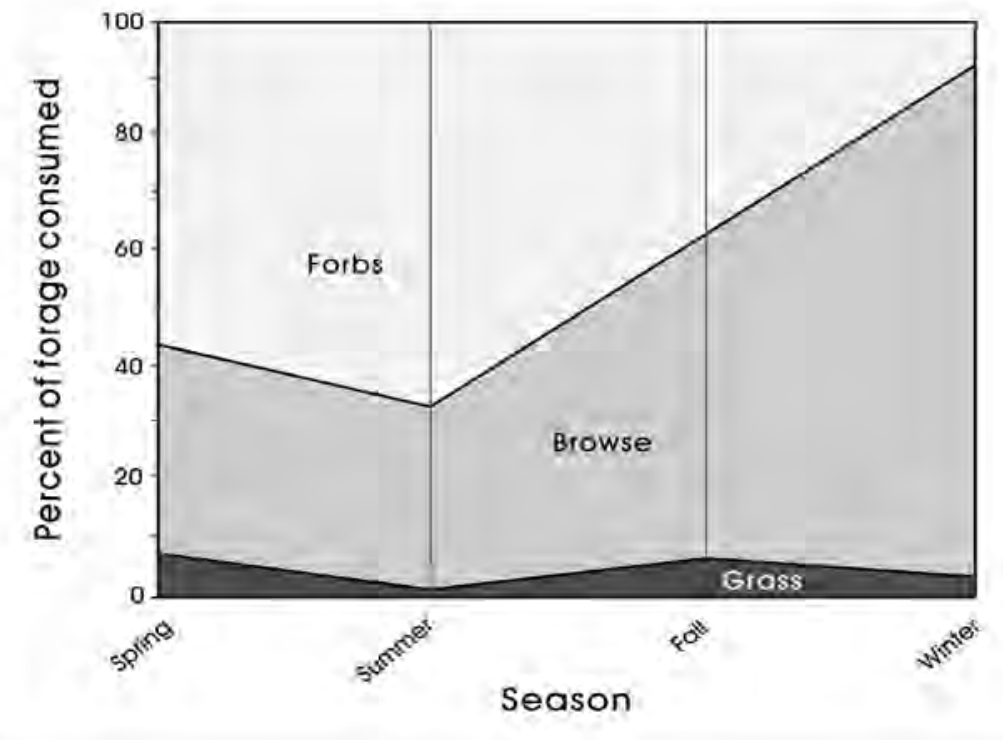

Figure 9-6. Seasonal changes in the forage consumed by White-tailed Deer. 
fluctuates with rainfall and season of the year. Equally important is browse, the leaves and twigs of woody plants. Preferred deer browse on the Edwards Plateau include post oak, Texas oak, blackjack oak, white shin oak, elm, hackberry, Lacey oak, and Texas kidneywood. Deer will eat less desirable, nutritionally poor plants such as cedar, persimmon, whitebrush, and mesquite during stress periods. White-tailed deer are not physiologically able to digest mature grasses and will only eat young grass in times of forb and browse scarcity. Seasonally, deer take advantage of mast, which contains the fruits, berries, and nuts of trees and shrubs. Because mast is dependent on rainfall amounts, it is not a reliable food source. However, during critical times of the year when forbs and browse are minimal, mast does become an important food source, allowing deer to increase fat for the winter and early spring (Armstrong and Young 2001).

Steuter and Wright (1980) investigated deer density on the Rio Grande Plain in habitats ranging from 10 to 97 percent brush cover (browse). Areas with less than 43 percent coverage had a maximum of 1.4 deer/ 40.5 ha ( 100 acres), 43 to 60 percent cover had 3.25 deer $/ 40.5$ ha, and coverage of 60 to 97 percent had 7.5 deer/40.5ha. The study concluded that shrub coverage was a good predictor of white-tailed deer numbers. Supporting this conclusion, a Texas Parks and Wildlife study found that the breeding rate of deer drops significantly during periods of drought. Along with the drop in pregnancy, fawn survival decreases when habitat declines due to inadequate forage (TPWD 2007). A combination of heat stress and drought is detrimental to deer survival,whereas above average rainfall produces excellent range conditions (increased browse) and contributes to higher survival. Widespread drought causing a lack of free-standing water is devastating to white-tailed deer. Deer will eat less and lose mass when deprived of water. They can survive approximately one month in starvation conditions, but white-tailed deer may die in as little as three days without water because they are not well-adapted to dehydration (Webb 2005).

White-tailed deer are polygamous and breed in the early fall through early winter. The commencement dates of the rut vary across Texas, but on average 92 percent of does are pregnant by early winter. Drought conditions decrease pregnancy rates (TPWD 2007). Following a gestation period of seven months one or two fawns are born. The fawns are hidden for ten days to two weeks, after which they follow the mother about. Fawns are born with bright grayish coats sprinkled with black. The spots are retained until the fawns molt in early fall which corresponds to the completion of weaning. Females normally reach sexual maturity the second year of life, however, when forage conditions are excellent they may mate and produce offspring the following spring when they are one year old (Davis and Schmidly 1994; TPWD 2007).

Prehistorically, bison was the mammal with the highest return rate, therefore, periods of bison absence or diminishment should have resulted in an increased use of other low ranked plants and animals into the diet, as well as intensification on other resources already in the diet. There is currently minimal evidence for bison in the Middle Archaic, and patterns of seasonal and yearly fluctuations in bison populations appear to be characteristic of the Late Archaic period. Bison fluctuations, including possible seasonal absence of this high ranked resource, should have resulted in short-term shifts in diet breadth at small temporal scales. While white-tailed deer were probably always in the diet set, this prey would have been of increased importance when bison were scarce or unavailable.

\section{Paleoclimate, Bison, and Deer}

We currently lack detailed information on paleoclimate at the short temporal scales required to fully investigate the degree to which essentially modern fluctuations in grasslands may be characteristic of past vegetation regimes. However, we do have several long-term data sets that can provide large-scale patterns of vegetation shifts at the community level. Figure 9-7 presents four such long-term data sets. The Medina River data are from southern Bexar County, just to the south of 41BX17, and represent carbon isotopic signatures derived from a series of buried, dated soils (Nordt et al. 2002). The Hall's Cave carbon isotope data, also on buried sediments, are from an extremely well-dated deposit in Kerr County (Cooke 2005) located roughly $100 \mathrm{~km}$ to the northwest of the Granberg Site. Boriack and Patschke bogs are located in Lee County, roughly $180 \mathrm{~km}$ to the northeast of the site. The Boriack arboreal pollen sequence, taken from Bousman's (1998) reanalysis of the original data, is poorly dated. The Patschke grass pollen sequence (Camper 1991), taken from a reanalysis of the original data by Nickels and Mauldin (2001), is supported by four radiocarbon dates. If the four sequences shown in Figure 9-7 are accurately monitoring shifts in vegetation at large spatial scales, comparisons of the patterns suggest some regional variability encompassed by similar overall trends. The two carbon isotope data sets suggest a high frequency of $\mathrm{C}_{3}$ plants before about $6 \mathrm{Kya}$, with an increase in $\mathrm{C}_{4}$ at the beginning of the Middle Archaic. The curves differ slightly with the Medina River sequence showing a decline in $\mathrm{C}_{4}$ plants to about $5 \mathrm{Kya}$ and then a rapid increase in $\mathrm{C}_{4}$ throughout the Late Archaic. The Hall's Cave sequence shows no such decline in $\mathrm{C}_{4}$ in the Middle Archaic 


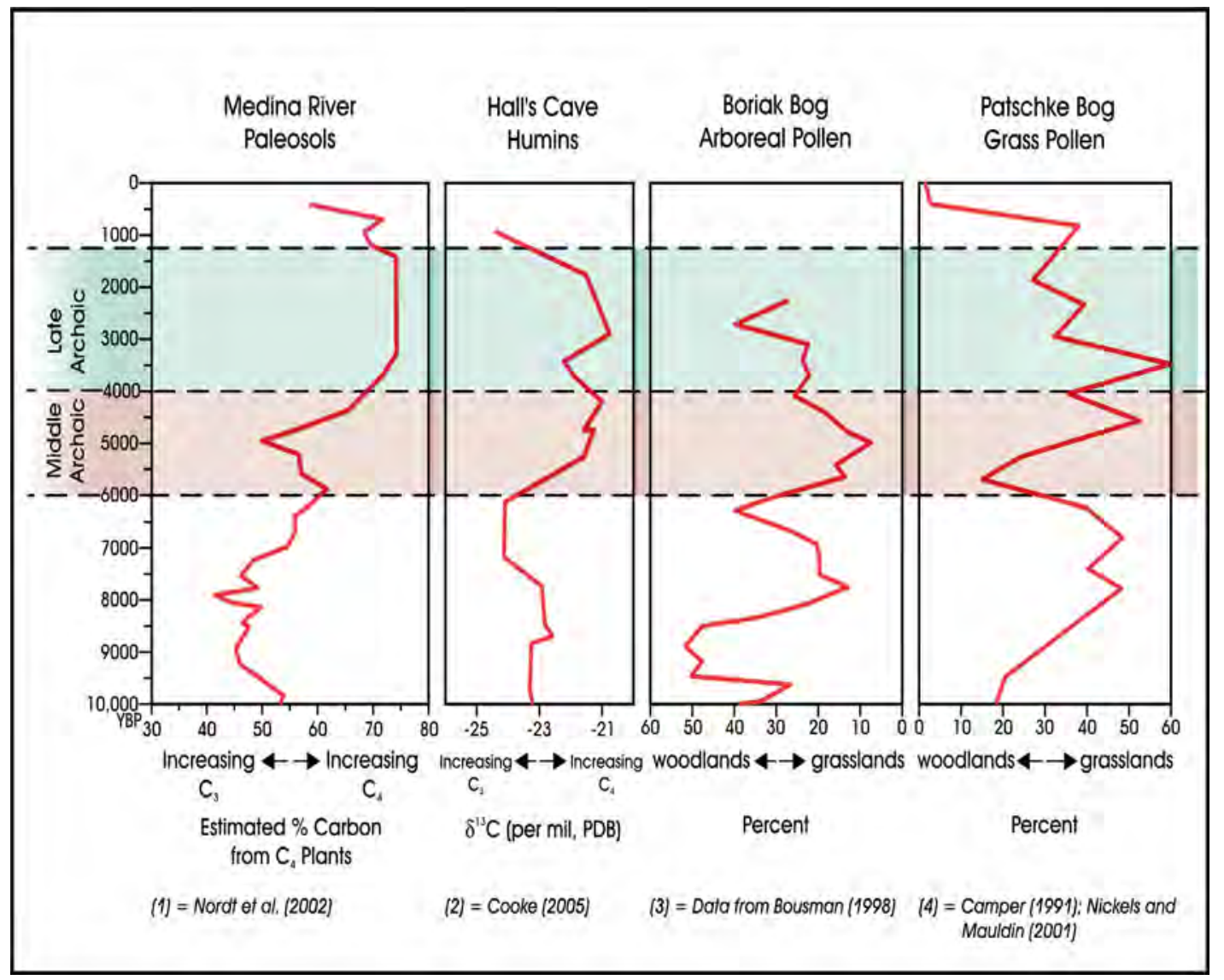

Figure 9-7. Comparison of climatic sequences.

but does show a slight decrease in the early portion of the Late Archaic. Both sequences show a decline in $\mathrm{C}_{4}$ late with the decline initiated at about $1200 \mathrm{BP}$ in the Medina River area and at about 2,000 BP in the Hall's Cave sequence. Data from the two pollen sequences, located close together and to the northeast of the sediment sequences, suggest more variability than the isotope data. A high frequency of arboreal vegetation is present in both sequences at about $8,500 \mathrm{BP}$, giving way to grasslands by around 7,500 BP. The Boriak bog data shows a decline in grassland that culminates at around 6,200 BP with a rapid increase in grasslands in the Middle Archaic up to about 5,000 BP. After that date, grasslands decline and the sequence terminates prior to $2 \mathrm{Kya}$. Conversely, the Patschke pollen data suggest an increase in woodland communities in the initial Middle Archaic with a rapid increase in grasslands through the remaining portion of this period. Grass pollen, and by extension grasslands, reach a peak in the Patschke sequence at around 3,500 years ago and begin a slow, though variable decline.

Overall, these long-term data sets (see Figure 9-7) suggest extensive grasslands $/ \mathrm{C}_{4}$ vegetation regimes during most of the Middle and Late Archaic. Grasslands seemed to have increased throughout the Middle Archaic, hitting their peak in the early portion of the Late Archaic, and then began a slow, gradual decline until the close of that period. In addition, the data sets in Figure 9-7 suggest that a different pattern, one of rapidly declining grasslands, is characteristic of at least the last 1,000 years, including the period during which early Spanish explorers noted seasonal and yearly fluctuations in bison. The fact that these observations were made under what appears to be a different climate/vegetation regime, one of rapidly declining grasslands, militates against the presence of such fluctuations during the relatively stable or expanding grasslands regimes of the Middle and early portions of the Late Archaic. Consequently, while the possible presence of bison early in the Middle Archaic, as suggested by Collins (1995), remains unresolved, as does the time frame for the return of bison to Texas in the Late Archaic, we will assume, based on the Figure 9-7 data, that bison availability during the period represented by the 41BX17 material considered in this report are not subject to the extreme fluctuations revealed in the historic data.

When we consider the impacts of the climate patterns suggested by the Figure 9-7 data sets in terms of bison and 
deer availability, it is clear that the two different classes of mammals would be impacted in different ways. The expansion of grasslands suggested by the Figure 9-7 data sets should have resulted in increased areas of bison forage and, possibly, an expanding, more consistently available population of bison in the region. At the same time, the Figure 9-7 data sets suggest that settings and food sources favored by white-tailed deer, settings dominated by $\mathrm{C}_{3}$ plants, were declining throughout much of the Middle and Late Archaic. Near the end of the Late Archaic, however, grasslands began to decline, a situation that would increase the availability of deer, while simultaneously reducing forage for grazers such as bison.

\section{Summary and Discussion}

Models derived from foraging theory provide a coherent set of concepts and an explicit analytical framework for investigating many aspects of hunter-gatherer adaptations. However, our ability to closely monitor several aspects of such models in archeological situations is problematic. In an archeological setting it is unlikely that we will ever obtain the detailed quantitative data necessary to apply foraging theory with the mathematical rigor that is characteristic of the more successful uses of foraging-based models in ethnography (see Binford 1992; Dunnell 1992; Ebert 1992). Yet, archeological investigations using an explicit cost/benefit framework have several advantages relative to the ethnographic time-scale. Primary among these advantages are the long temporal perspective provided by archeological research. After outlining some general principals of foraging theory and briefly discussing applications of those principals, this chapter initially focused on long-term changes in bison availability. While we lack information on kill rates, given their large body size it is likely that bison represented the highest ranked food resource, in terms of profitability, available in Texas during portions of the Paleoindian, Archaic, and Late Prehistoric periods. As such, changes in bison availability should have a major impact on the structure of the overall diet, as well as on technology and mobility strategies used by hunters and gatherers. While we have not established precisely when bison returned to the state following their apparent absence during the Middle Archaic or if they were absent during the early portion of that period, it is clear that these high return animals were present in the state sometime after 4,500 BP. Long-term climate data suggest that grasslands were fairly consistent and widespread between 4,500 BP and around $1,200 \mathrm{BP}$, a pattern that should promote lower levels of fluctuation in bison herds. Grasslands seem to have increased throughout the Middle Archaic, peaking in the early portion of the Late Archaic and slowly declining throughout the rest of the period.
Of course, varieties of other animals, as well as plants, are also present in Texas. If our review of the Middle Archaic supports Dillehay's (1974) suggestion that bison were absent from the region, we suggest that fluctuations in the relative abundance and profitability of lower-ranked resources, including whitetailed deer, should play a role in determining what set of responses are initiated in the context of maximizing the average return rate of the overall diet. While we lack detailed information on the availability of white-tailed deer, situations with declining $\mathrm{C}_{3}$ production should result in reduced food availability and reduced cover.

While modern data on the diversity of other mammals and some food plants at various spatial scales is available, we lack data on their density. Mauldin et al. (2006) reviewed both the plant and mammal data and suggested that there are important differences in diversity across the state, with areas of low net above-ground productivity (e.g., TransPecos) tending to have both a higher diversity of mammals in all size classes and a higher diversity of plants that are commonly used as food. Conversely, areas with high primary productivity (e.g., Pineywoods) tend to have a lower diversity of food plants and mammals. These differences in diversity may be related to environmental stress and/or differences in levels of disturbance with low levels of disturbance resulting in a homogenous landscape while higher levels of disturbance seem to produce a more varied habitat (Tilmon 1982, 1988, 1994). A consideration of both rainfall variability and temperature stress in Texas supported these suggestions (Mauldin et al. 2006). The structure of plant and animal resources, then, varies widely across the state with different sets of food plants and animals available for use by hunters and gatherers. In addition, seasonal fluctuations in resource quality and quantity should influence profitability.

Given that this variability in quality and quantity of resources certainly operated at a number of temporal and spatial scales and that these scales are not well defined, anticipating the detailed responses of hunters and gatherers to that variability is difficult. Clearly, a number of different responses are possible given alternative conditions. What might hunters and gatherers do when faced with alterations in high ranked resources, such as bison? They have a number of possible responses. What response they initiate should depend, in part, on the extant resource structure in the environment, as well as their existing subsistence, mobility, and technology mix. At present, we do not have sufficient data on past plant and animal densities, paleoenvironmental conditions, return rates and changes in those rates given various processing technologies, and technological costs to allow for specific, detailed modeling of responses in this case. However, we can gain some insights by considering an ethnographic example, 
the Nunamiut. Binford $(1977,1978,1979)$ notes that among the Nunamiut over $70 \%$ of the yearly supply of meat is gathered during two brief periods that correspond to the spring and fall migrations of highly ranked caribou through mountain passes. In preparation for those migrations, hunters invest significant time and effort in acquiring materials, repairing, stocking, and caching gear and in producing highly reliable tools that have a low potential for failure during the hunt. Upfront preparation, positioning of backup gear, and the over designing of tools are all costly practices, but practices that make sense in terms of the risk of food loss if, for example, a tool failed at a critical point (see discussions in Bleed 1986; Torrence 1989). Suppose, however, that caribou were suddenly available for six months of the year, rather than two brief periods, or that they were suddenly available year round. What impacts would that have on this costly strategy? Would Nunamiut hunters continue to make a significant investment in over designing tools if caribou were ubiquitous? Increasing investment under these conditions seems less likely. However, if caribou were suddenly available only once a year during their spring migration or the number of animals was significantly reduced, then even greater investment in costly hunting strategies and tactics may be expected along with other higher cost changes. Hunter gatherers should invest in more costly strategies under conditions of declining high return resources and choose less costly strategies under conditions of increasing high ranked resources.

Under conditions of increasing numbers of bison, Texas hunters and gatherers should narrow their diet by reducing dependence on lower ranked plants and animals that have higher handling costs. They may, correspondingly, reduce investments in more expensive processing technology. As bison are encountered more frequently, they may reduce dependence on specialized mobility strategies. As we noted in Chapter 8, while logistical systems should always be used to target high ranked resources, high ranked resources are not necessarily targeted through logistical systems. Logistical systems are initiated in response to scheduling conflicts between critical resources. When critical resources are increasing in frequency in the natural environment, scheduling conflicts will be reduced and potentially will result in less reliance on logistical organization. Under conditions of declining bison, Texas hunters and gatherers should broaden their diet to include lower-ranked resources with lower search costs but higher processing costs (e.g., mussels, nuts, small seeds). They may also develop or implement new technologies that are more expensive to produce and maintain (e.g., FCR oven features rather than non-rock hearths) in an attempt to reduce the processing (handling) time or improve the nutritional quality of lower-ranked resources in the diet. They may shift or reorganize their mobility or search strategies, with specialized task groups targeting shrinking grasslands in an attempt to increase encounter rates with bison. They may initiate all of these changes, as well as several others.

To investigate this perspective, we use a number of components that date to the Middle and Late Archaic occupations at 41BX17 and components from other sites in surrounding counties that are contemporary with those occupations. We have identified 46 components that can be used to begin our investigation into the impacts of fluctuations in diet breadth during the Middle and Late Archaic Periods. Tables 9-1, 9-2, 9-3, and 9-4 present site numbers and references

Table 9-1. Early Middle Archaic Sites with Isolable Components

\begin{tabular}{|c|c|c|}
\hline Site Name & Trinomial & Reference \\
\hline Olmos Dam Site & 41BX1 & Lukowski 1988 \\
\hline $41 \mathrm{BX} 47$ & 41BX47 & Tennis et al. 1996 \\
\hline Higgins Site & 41BX184 & Black et al. 1998 \\
\hline Panther Springs Creek Site & 41BX228 & Black and McGraw 1985 \\
\hline Cibolo Crossing Site & 41BX377 & Kibler and Gardner 1997; Kibler and Scott 2000 \\
\hline Richard Beene Site & 41BX831 & Thoms and Mandel 2007 \\
\hline Royal Coachman Site & 41CM111 & Mahoney et al. 2003 \\
\hline Smith Creek Bridge Site & 41DW270 & Hudler et al. 2002 \\
\hline 41GD21 & 41GD21 & Fox et al. 1979 \\
\hline $41 \mathrm{LK} 31 / 32$ & $41 \mathrm{LK} 31 / 32$ & Scott and Fox 1982 \\
\hline Jetta Court Site & $41 \mathrm{TV} 151$ & Wesolowsky et al. 1976 \\
\hline Vera Daniel Site & 41TV1364 & Ricklis et al. 1991 \\
\hline Shrew Site & $41 \mathrm{WN} 73$ & Labadie et al. 1988 \\
\hline
\end{tabular}


Table 9-2. Late Middle Archaic Sites with Isolable Components

\begin{tabular}{|c|c|c|}
\hline Site Name & Trinomial & Reference \\
\hline 41AT123 & 41AT123 & Robinson et al. 1995 \\
\hline Olmos Dam Site & 41BX1 & Lukowski 1988 \\
\hline 41BX47 & $41 \mathrm{BX} 47$ & Tennis et al. 1996 \\
\hline Culebra Creek Site & 41BX126 & Nickels et al. 2001 \\
\hline Higgins Site & 41BX184 & Black et al. 1998 \\
\hline Panther Springs Creek Site & 41BX228 & Black and McGraw 1985 \\
\hline $41 \mathrm{BX} 300$ & $41 \mathrm{BX} 300$ & Katz 1987 \\
\hline Richard Beene Site & 41BX831 & Thoms and Mandel 2007 \\
\hline Number 6 Site & 41BX996 & Potter and Black 1995; Potter et al. 1998 \\
\hline Royal Coachman Site & $41 \mathrm{CM} 111$ & Mahoney et al. 2003 \\
\hline Smith Creek Bridge Site & 41DW270 & Hudler et al. 2002 \\
\hline 41HY37 & 41HY37 & Godwin 2000 \\
\hline 41KR537 & 41KR537 & Cliff 2001 \\
\hline 41LK31/32 & 41LK31/32 & Scott and Fox 1982 \\
\hline Jonas Terrace Site & 41ME29 & Johnson 1995 \\
\hline Jetta Court Site & $41 \mathrm{TV} 151$ & Wesolowsky et al. 1976 \\
\hline Millican Bench Site & $41 \mathrm{TV} 163$ & Mauldin et al. 2004 \\
\hline 41UV45 & 41UV45 & Lukowski 1987 \\
\hline
\end{tabular}

Table 9-3. Initial Late Archaic Sites with Isolable Components

\begin{tabular}{|l|c|l|}
\hline \multicolumn{1}{|c|}{ Site Name } & Trinomial & \multicolumn{1}{c|}{ Reference } \\
\hline Coleto Creek & 41GD21 & Fox et al. 1979 \\
\hline 41LK201 & 41LK201 & Highley 1986 \\
\hline 41LK67 & 41LK67 & Brown et al. 1982 \\
\hline Little River Site & 41 MM340 & Mahoney et al. 2003 \\
\hline
\end{tabular}

Table 9-4. Middle Late Archaic Sites with Isolable Components

\begin{tabular}{|l|c|l|}
\hline \multicolumn{1}{|c|}{ Site Name } & Trinomial & \multicolumn{1}{c|}{ Reference } \\
\hline 41BX1032 & 41BX1032 & Wilder et al. 2003 \\
\hline 41CM211 & 41CM211 & Wilder et al. 2003 \\
\hline 41KM69 & 41KM69 & Thompson 2006a \\
\hline 41KR537 & 41KR537 & Cliff 2001 \\
\hline 41MC296 & 41 MC296 & Hall et al. 1986 \\
\hline Jonas Terrace Site & 41ME29 & Johnson 1995 \\
\hline Little River Site & 41 MM340 & Mahoney et al. 2003 \\
\hline 41RN3 & 41RN3 & Treece et al. 1993 \\
\hline East Levee Site & 41 TG91 & Creel 1990 \\
\hline Anthon Site & 41 UV60 & Goode 2002 \\
\hline Cervenka Site & 41 WM267 & Peter et al. 1982 \\
\hline
\end{tabular}


for these excavations. Because this set of 46 components was excavated between 1976 and 2007, the data will be of variable quality. Therefore, not all 46 will be used to assess all aspects of our model.

\section{Research Domains}

Using the cost/benefit framework provided by foraging theory, we have suggested a number of general relationships that should be applicable to investigating aspects of diet, technology, and mobility in hunters and gatherers. This section focuses on several broad research domains in light of the scenario summarized above. As discussed in earlier sections, 41BX17 was occupied from the Middle Archaic through the Late Archaic. We have suggested that during this period a number of adaptive changes were initiated as a response to changes in the availability of bison. Below, we discuss four research domains, including paleoclimate, and shifts in diet, technology, and mobility that we propose to explore with the Granberg data in light of these adaptive changes.

\section{Paleoclimate Research}

The suggestion that bison availability increased during the later part of the Middle Archaic and into the early portion of the Late Archaic periods is primarily based on presence/ absence data from archeological sites, as well as on climate proxy data (pollen and soil carbonates) that monitor shifts in vegetation communities at large temporal and spatial scales. The pollen samples come from bogs located in the easterncentral portion of the state. The carbon isotope samples come from Hall's cave in the northwestern portion of the area and from the Medina River region south of the site. While the pollen and carbon isotope data should reflect regional changes (see Bousman 1998; Cooke 2005; Nickels and Mauldin 2001; Nordt et al. 2002), the actual scale of these changes remains unknown. Independent measures of paleoenvironmental conditions at different scales of analysis can provide information regarding on-site conditions (i.e., snails) as well as site proximate conditions (i.e., vegetation communities exploited for firewood). The first general research domain investigated with the 41BX17 data focuses on paleoclimate. What were the paleoenvironmental conditions during the Middle and Late Archaic occupations of 41BX17? Is there evidence of climate change that is consistent, or inconsistent, with the proposed increase in grasslands suggested by the pollen and carbon isotope data?

The types of data needed to investigate this research topic include feature-specific charred samples from throughout the deposits, selected soil samples and selected samples of snails. These data were consistently recovered from our testing work. Analytical methods, including mesquite xylem analysis, gastropod analysis, phytolith analysis, and diatom analysis were implemented to address this research issue. In Chapter 10, we use patterns in the species composition of snail, phytolith and diatom samples to reconstruct paleoenvironmental conditions at the time of site occupation. Unfortunately no evidence of mesquite wood was recovered from the charred samples submitted for analysis. The snail, phytolith, and diatom data were analyzed to infer trends in paleotemperature and/or changes in rainfall seasonality.

\section{Investigating Diet Breadth}

The second research domain outlined in the research design (Munoz et al. 2007) focused on suggested changes in diet breadth initiated by the presence/absence of bison in the Middle and Late Archaic periods in Central and South Texas. When bison are present, we expect a narrowing of the diet with hunters and gatherers dropping low profitability animals and plants from their diet. Conversely, when bison are absent, we expect hunters and gatherers to increase their diet breadth by incorporating lower return plants and animals and focusing attention on high return animals such as deer. As we noted previously, Collins $(1995 ; 2004)$ has suggested that Dillehay's (1974) characterization of the Middle Archaic period as one that is lacking bison is incorrect, at least for the early portion of that period (ca 6,000-5,000 BP). Collins (1995; 2004) suggests that bison were absent in the latter portion of the Middle Archaic, returned to Texas sometime around 3,500 BP, and were present throughout the Late Archaic. Bison are present on $38 \%$ of 18 Late Archaic components that date between 4,450 and 2,500 BP and, as shown previously (see Figure 9-1), are frequent on later occupations in the Late Archaic Period (Mauldin and Kemp 2005; see also McDonald 1981). Initially, then, we need to establish if bison were present in the Middle Archaic in Central and South Texas and refine the date for their reentry into Texas after the Middle Archaic absence. We then explore two aspects of the archeological record to document actual trends in huntergatherer diet breadth, focusing on faunal remains and indirect measures of dependence on plant resources.

We use two measures to track diet breadth in faunal material. These are measures of taxa richness and shifts in the percentages of unclassified fragments in faunal assemblages. The simplest measure of diet breadth is taxa richness. We assume that an increase in species richness signals an increase in diet breadth while a decrease in number of species present in an assemblage signals a narrowing of the diet. That is, we assume that all recovered fauna reflect choices related to energy 
acquisition in diet. We acknowledge that this assumption is not always justified and that hunters and gatherers may pursue animals for non-dietary items (e.g., fur, tendons, bone tools). However, the assumption seems appropriate in the majority of cases. Recently, Tomka et al. (2004b) used taxa richness to identify some intriguing trends through time in a number of selected Central Texas assemblages dating from the Late Archaic through the terminal Late Prehistoric. The results are encouraging and suggest that researchers may be able to track broad shifts in hunter-gatherer subsistence through this simple measure. If bison availability in the Middle and Late Archaic periods follows the patterns we have suggested, as a group, taxa richness should be greater in the Middle Archaic, when bison are supposedly absent, and reduced in the Late Archaic, when bison are present. In addition, within the Late Archaic, taxa richness should be higher on sites without bison when contrasted with sites that have bison present. Finally, we anticipate that taxa richness should slowly increase throughout the Late Archaic as bison densities slowly decline thus resulting in the incorporation of lower ranked plants and animals and in an increased focus on deer.

Our second measure of diet breadth alterations in faunal assemblages focuses on differences in the relative frequencies of bone fragments in a faunal assemblage. Because of the intensive processing of skeletal remains for bone grease or marrow extraction, many faunal remains from archeological sites in Texas consist of fragmented, unidentified specimens. The fragmentation should be especially common during periods of dietary stress, such as the Middle Archaic when more intensive processing is anticipated, and less common under conditions of bison abundance. While researchers often ignore this class of remains, the weight of unidentifiable fragments relative to those that can be identified within an assemblage may provide a gross measure of processing and, indirectly, a measure of dietary stress. While complicated by the observation that larger animals are more likely to be involved with extensive processing for marrow and grease, we suggest that when a narrow diet breadth is present, the overall weight of fragments to identified items will be lower than under conditions of relatively wide diet breadth. We expect that on sites and during periods where bison are absent, the weight of fragments will account for a higher proportion of the total faunal assemblage weight. Conversely, when bison are present, the inverse should occur.

Gauging the contribution of plants to the diet is much more complicated than gauging the importance of animals. In part, this complication is related to the poor preservation of plant remains from open-air sites. Fewer plant taxa should be anticipated in the earlier periods simply as a function of preservation, and certain plants, such as nuts, should be over represented in any assemblage. In addition, flotation samples were not commonly collected prior to the mid 1970s, further complicating any direct comparisons of the number of plant taxa present. Currently, there simply are no well-established methodologies for assessing the importance of plants in archeological assemblages. However, using ethnographic data, we suggest that there is a strong relationship between the use of rock in thermal features and plant processing and that different types of rock thermal features are likely to be used to process different types of plants. We suggest that the frequency of thermal features with rock may serve as gross proxy indicator of the intensity of plant processing, while the variety of feature types, defined by feature size and rock weight, may provide an indirect measure of the variety of plants represented in the diet of Texas huntergatherers. Using these admittedly gross measures of plant dependence, we expect that as bison availability increased in the study area during the Late Archaic, the density and/or area devoted to rock hearths should decrease relative to sites dating to the Middle Archaic. In addition, as we anticipate that bison numbers will be slowly declining throughout the Late Archaic as grasslands slowly shrink and as fluctuations in bison densities are anticipated to be slowly increasing because of these same climatic processes, we expect that the density and/or area devoted to rock hearths should gradually increase within the Late Archaic period.

The types of data needed to address diet breadth include the vertebrate faunal remains from throughout the 41BX17 Middle and Late Archaic components and from comparative components within a restricted area adjacent to 41BX17, feature burned rock from 41BX17 and from literature on selected comparative components, and feature macrobotanical samples from 41BX17. Given the importance of bison in our model, we review literature for up to 30 Middle Archaic components within a restricted area adjacent to 41BX17. The goal of the review is to establish the pattern of bison presence in this Middle Archaic time frame. The study proceeds along the lines previously used by Mauldin and Kemp (2005). We divide the Middle Archaic into two intervals tied to projectile point types. The initial interval is from roughly 6000 to $5000 \mathrm{BP}$, corresponding to Collins' period of bison abundance and defined primarily by the presence of Bell, Andice, and Calf Creek style projectile points. We define the second interval by the presence of Nolan, Travis, or Taylor projectile point styles. This interval spans the remaining portions of the Middle Archaic Period (ca. 5000- 4000 BP). The literature review of up to 30 Middle Archaic components from Central and South Texas provides comparable data for comparison with the patterns already established by Mauldin and Kemp (2005) for later periods. We initially review sites 
of the appropriate age within Bexar county (e.g., Black and McGraw 1985) and proceed outside the county as necessary.

Analytical methods, including faunal analysis, macrobotanical analysis, lipid residue analysis, and burned rock analysis (feature size and burned rock counts) were implemented to address this research issue. The results of our investigations into this particular research topic are outlined in Chapter 11. We use the results of the analysis of animal bone, macrobotanical samples, lipid residue, feature size, and bison presence/absence to reconstruct Middle and Late Archaic subsistence strategies.

\section{Aspects of Technological Organization}

The third research domain focuses on tool organization. Changes in the availability of bison should affect tool design and the organization of tool manufacture and repair strategies. We suggest that shifts in bison availability during the Late Archaic should have resulted in a tool kit that was, overall, more specialized and consequently more expensive to produce and maintain. This would especially be the case late in the period, as bison are declining in numbers. While it is likely that specialized and generalized tools would have been present in any given system, it is our expectation that the increased costs associated with the production of specialized tools would tend to favor their use in situations where the exploitation of high-ranked resources was the primary focus. This would be particularly relevant if a group's annual subsistence is heavily dependent on a limited (e.g., seasonally restricted) resource set. Under these conditions, there is pressure on hunters and gatherers to assure that large quantities of a given resource are procured and processed during a limited period of availability (see Bamforth and Bleed 1997). We expect that more generalized tools that require less energy to manufacture (e.g., flakes with suitable working edges) would have been favored by hunter-gatherers during the Middle Archaic, when bison were absent, because resource acquisition and processing requirements were less likely to be temporally restricted, being dictated more by day-to-day needs. The acquisition of resources within a forager-oriented system does not normally lead to temporally constrained, intensive energy expenditures. Because roughly similar resource acquisition activities are carried out day after day, failure to acquire a particular resource is dampened by the potential to make up for a short-term shortage the following day. In addition, when resource acquisition is successful, immediate processing requirements are less strenuous due to the smaller quantities of resources needing processing. Therefore, within a foraging based system there is less of a premium on the careful scheduling of ancillary activities during the annual subsistence cycle because such activities will not compete substantially with time spent in resource acquisition activities.

Gearing up represents the manufacture of large numbers of tools in anticipation of future need. Because the artifacts being manufactured are to be used in bulk procurement activities and are often made to reduce in-field tool failure, gearing up involves the production of large numbers of tools at one location. Most importantly, the number of tools being made is in response to anticipated needs and failure rates rather than ongoing needs for tool replacement. This strategy of manufacturing tools for future needs (i.e., gearing up) can be contrasted with a strategy where tool manufacture is responsive to on-demand replacement of failed tools. Ondemand replacement involves the manufacture of specimens at the location where the tool failed, and has the effect of immediately reintroducing a needed implement into the systemic context. As a result, the manufacture of on-demand replacement tools results in the production of one replacement tool for each use-failed tool. Given the anticipated differences in manufacture rates between gearing-up and on-demand tool replacement, we suggest that comparisons of failure rates (i.e., manufacture versus use) within functionally specific tool classes can be profitably used to identify evidence of gearing up. We would expect that during the Middle Archaic when bison are absent resource procurement would occur on a day-to-day basis. Tool failure and tool manufacture will follow an on-demand model, and replacement will result in lower numbers of manufacture-failed items relative to usefailed specimens within functionally specific groups (e.g., use and manufacture broken points reflecting acquisition, knives reflecting processing, etc.). We expect that during the Late Archaic when bison are present there will be at least some bison procurement that is anticipated, and hunters will place some emphasis on tool manufacture for future use. This would especially be the case later in time, if bison are declining in numbers as suggested by the grassland paleoclimate data. This gearing up strategy will result in higher numbers of manufacture-failed items and fewer usefailed specimens within functionally specific groups.

As outcomes of these general principles, and in conjunction with variability in bison availability, we would expect to find fewer tools with high manufacture costs and little evidence of gearing up in assemblages dating to the Middle Archaic period. In contrast, we suggest that at least a portion of the tool kits associated with Late Archaic hunter-gatherers should consist of forms that have high manufacture costs. In addition, signs of gearing up should be more prevalent in Late Archaic assemblages compared to preceding components. Furthermore, these tendencies should have been exacerbated near the close of the Late Archaic when we anticipate increasing yearly and seasonal fluctuations in bison numbers. 
Data needed to address technological organization consist of the tools and debitage from the Middle and Late Archaic components at 41BX17 and from selected comparative components. To investigate the assumed relationship between energy expended in the manufacture of a tool and variance in bison availability, we categorize each tool specimen according to the level of energy that has been expended for its manufacture. Because utilized flakes are often underreported in archeological collections, we select a random sample of flakes from each selected assemblage and scan those flakes for macroscopic evidence of use wear. Once the total number of use-modified tools is known, total numbers of specimens within the collection is estimated by dividing the total number of debitage from the component/site by the count in each class. To monitor the frequency of gearing up demonstrated in the prehistoric assemblages, we differentiate use-broken from manufacture-failed specimens in each cost category. Once gathered, we array these data on bivariate plots. At the level of the entire assemblage, when we compare Middle Archaic assemblages with Late Archaic assemblages, we expect to find the patterns in tool manufacture costs outlined above. This pattern should be increasingly apparent near the end of the Late Archaic as bison decline in numbers.

The results of these analyses are presented in Chapter 12 . In summary, we expect, then, that under conditions of wide diet breadth, anticipated to occur when bison are absent, a generalized tool kit, characterized by less expensive tools, will dominate. In addition, as the structure of resource processing is unlikely to be conditioned by variable temporal availability and bulk processing, we anticipate that there will be little evidence for gearing up behavior. In contrast, when diet breadth narrows, we would expect that a more specialized tool kit would be in evidence with increasingly expensive tools and evidence for gearing up present at many components.

\section{Mobility}

The final research topic investigates shifts and changes in the scale of mobility as a result of the Late Archaic reemergence of bison. If Dillehay's (1974) model of bison absence in the Middle Archaic is supported in our review, we expect that the Middle Archaic material would be characterized by relatively small scale, foraging-based systems. Conversely, the Late Archaic occupations would be involved in a significantly larger-scale system, and a logistical form of organization would be increasingly reflected, especially near the close of the Late Archaic as bison decline in numbers and as fluctuations in bison become more pronounced as grasslands deteriorate. Here, we investigate the suggested changes in the organization of mobility between the Middle Archaic components relative to the Late Archaic components by initially focusing on measures of artifact variety as a method for distinguishing locations used in a residential manner from those used for more task-specific activities. We then further explore the scale of mobility reflected in archeological components dated to these time periods by focusing on diversity in chert types.

In his original discussion of collecting and foraging systems, Binford (1980; see also Kelly 1995) defined forager systems as having daily inputs of food to a residential camp. That food was gathered from within a short radius of the camp, and frequent residential moves occurred as resources within the foraging radius were exhausted. Foragers are characterized by no bulk storage and relatively small group size. In contrast, collectors were defined by a lower frequency of residential moves, larger group size, bulk inputs of food into the residential site generated by task groups, and bulk storage of food stuffs. For our discussion, we can envision foraging organizations as generating essentially one primary site type, a residential camp, though short-term processing sites may also be present under some conditions, while collectors minimally should generate two different types, residential camps and special-purpose sites. Below, we use the characteristics of the two systems to outline differences in artifact variety and in the scale of mobility.

At a general level, residential sites should be distinguishable from more limited activity sites by patterns in artifact variety (see Thomas 1983, 1989). A wider variety of activities are conducted at most collector and forager residential sites relative to special-purpose locations. Even relatively simple, foraging residential sites (e.g., Yellen 1977) have a wide variety of tasks conducted. While complicated by factors such as the length of occupation and use-life of tools (Schiffer 1975; Shott 1989), the number of diverse activities at residential sites should be reflected by a wider variety of artifact types when we compare residential locations with special-purpose locations. We expect that foraging based systems will be associated with wider diet breadth and narrower diet breadth will tend to be organized through logistical activities.

In addition to shifts in mobility strategies, we use data gathered from tools and debitage to investigate the scale of mobility. We have argued that mobility levels should be responding, in part, to alterations in diet. Specifically, when diet breadth is narrow, the scale of mobility should be increased as a function of increased search time associated with high-ranked animal prey. This should especially be the case near the close of the Late Archaic, if bison densities begin to fluctuate in response to a fluctuation in grasslands. 
Conversely, when diet breadth is wide and search costs are lower, we anticipate a greater component of mobility to be organized in a foraging mode. While the number of residential moves may increase in a foraging relative to a logistical organization, the scale covered by the entire mobility system will be drastically reduced with a foraging organization (see Kelly 1995). As the scale of the mobility increases, there should be concomitant increases in the range of tool stone encountered and used in tool production. A corollary of this expectation is that the greater the scale of mobility the more likely that some of the tool stone present on site arrived there from nonlocal resources in the form of staged, finished, or well worn tools and represents the debris from staged manufacture, rejuvenation, and reworking of tools.

Data necessary to explore the proposed relationship between artifact variety (i.e., richness and evenness) and different levels of activity consist of the tools from the Middle and Late Archaic components at $41 \mathrm{BX} 17$ and from selected comparative components. We require data on the number of different types of tools and other items present at dated components, as well as information on the sample size. Tool types are defined as broadly as possible in order to reflect a variety of behaviors at a location. We plot the number of different types of items against the total number of items in the sample to determine residential and special purpose sites. In order to investigate the relationships between raw material variety and different strategies of mobility, we compare raw material types defined by color within the debitage and expensive tools recovered from the Middle and
Late Archaic components of 41BX17. The patterns identified within the distinct components of the site are compared with patterns noted in a sample of debitage and tools from selected components of other sites. Because heat treating lithic material results in color and texture changes that would artificially raise the number of material types, heated specimens are not counted in this data set.

The results of these analyses are presented in Chapter 13. If our general model linking diet breadth changes and mobility is supported, then the assemblages from the Middle Archaic component should have fewer raw material types present in the debitage samples and fewer raw material types in the tools when compared to the Late Archaic component.

\section{Summary}

This chapter provided a review of the four research domains indentified in the research design (Munoz et al. 2007) for the analysis of material collected at 41BX17. These four domains involved paleoenvironmental reconstructions, investigations into subsistence strategies, technological organization, and shifts and scales of mobility. Associated with each domain were a series of data needs and analytical methods. As with most archeological investigations, only some of the proposed research topics were successfully investigated, the focus of several of the research topics were slightly altered, and there were changes in the analytical methods. Details regarding these changes are discussed in the appropriate chapters. 



\section{Chapter 10: Paleoclimate}

\author{
Cynthia M. Munoz
}

This chapter presents information relevant to the reconstruction of paleoenvironmental conditions during the time of occupation of 41BX17. In the research design, Munoz et al. (2007) suggested that bison availability and fluctuations during the Middle and Late Archaic periods would influence hunter-gatherer adaptations, including subsistence systems, lithic technology, and mobility. The suggestion that bison availability increased during the later part of Middle Archaic and into the Late Archaic periods is primarily based on presence/absence data from archeological sites, as well as on climate proxy data (pollen and soil carbonates) that monitor shifts in proxy data vegetation communities at large temporal and spatial scales. The pollen samples come from bogs located in the eastern-central portion of the state. The carbon isotope samples come from Hall's cave in the northwestern portion of the area and from the Medina River region south of the site. While the pollen and carbon isotope data should reflect regional changes (see Bousman 1998; Cooke 2005; Nickels and Mauldin 2001; Nordt et al. 2002), the actual scale of these changes remains unknown. What were the paleoenvironmental conditions during the Middle and Late Archaic occupations of 41BX17? Is there evidence of climate change that is consistent, or inconsistent, with the proposed increase in grasslands suggested by the pollen and carbon isotope data?

To address these questions, we compiled information from a diverse set of data including the composition of invertebrate assemblages (gastropod) and variation in vegetation as indicated by diatom and phytolith species. In addition we submitted charred plant remains and light fraction recovered from soil flotation for analysis of mesquite xylem as a proxy indicator of the paleoclimate at 41BX17.

Dering $(1994,2002)$ has argued that the anatomical characteristics of wood of the same species of tree may vary, partly, in response to local rainfall regimes. Plants growing in wetter environments should have fewer, larger vessels in the wood while the same species growing in dryer environments should have more numerous but smaller vessels. Dering (2002) has shown that modern mesquite in various areas of Texas have characteristics that are consistent with this expectation and has started to gather dated archeological samples that should eventually result in a useful paleoenvironmental record of rainfall variability. The results of the xylem analysis in conjunction with the feature dates should help document the rainfall variances at 41BX17 and perhaps allow a comparison between the paleoclimate pollen and carbon isotope data (see Figure 9-7) to the occupations on the Salado watershed at the Granberg Site. We submitted charred samples from five dated burned rock features (two Middle Archaic ranging from 4430-4080 BP and three Late Archaic ranging from 3980-1860 BP), one charcoal cluster from a non-feature context (Middle Archaic ranging from 4830-4520), and undated charred samples from three additional features to Dering for wood identification followed by xylem analysis of any identified mesquite samples. Unfortunately, although a small amount of mesquite was present in a single sample, the fragments were not large enough to conduct xylem analysis. Three very small mesquite charcoal fragments occurred in Feature 100, and three other fragments were attributable to the woody legume type. These six fragments weighed less than $0.1 \mathrm{gm}$ and do not provide an adequate sample for xylem analysis (see Appendix E).

These data types provide measures of paleoenvironmental conditions at different scales of analysis. For example, snail species identification and composition provide data regarding on-site conditions, whereas, macrobotanical species identification aids in the reconstruction of floodplain/ terrace vegetation in the proximity of the site.

\section{Previous Reconstructions of Paleoclimate}

Recently, several paleoclimate studies at large temporal and spatial scales have been published (e.g., Bousman 1998; Cooke 2005; Nickels and Mauldin 2001; Nordt et al. 2002). Chapter 2 presented a summary of this paleoenvironmental data consisting of pollen samples from bogs located in the eastern-central portion of the state (ca. $175 \mathrm{~km}$ and $325 \mathrm{~km}$ to the northeast of 41BX17) and carbon isotope samples from Hall's cave in the northwestern portion of the area (ca. 100 $\mathrm{km}$ to the northwest of 41BX17) and from the Medina River region south of the site (ca. $25 \mathrm{~km}$ ). These groups of data are all responses to changes in vegetation, although the exact spatial and temporal scale of the shifts in these climate proxy data sets relative to shifts in climate variables is uncertain. The overall pattern apparent from these sequences reflects a cooler, mesic climate, with a slight, gradual drying trend 
in the Early Holocene (ca. 10,000-8,000 BP). A warm and dry Middle Holocene (ca. 8000-4000 BP) follows, with an apparently brief mesic period sometime around 7000 to 6000 or 5000 BP. Xeric conditions resume between 5000 and $4000 \mathrm{BP}$ following the mesic interval. Although beyond the scope of the data set, the Late Holocene (ca. 4000 to 0 BP) is thought to be generally cooler and/or wetter with a return to more xeric conditions within the last few hundred years.

In addition to pollen and isotope data, data generated from gastropod analyses have been reported by Hudler et al. (2002) from the Smith Creek Bridge Site (41DW270) in De Witt County, Gadus et al. (2006) from the J. B. White Site (41MM341) in Milam County, Mahoney et al. (2003) from the Little River Site (41MM340) also in Milam County, Fullington and Fullington (1982) from 41WM53 and 41WM230 in Williamson County, and Amaral and Witter (1973) from 41WM118 and 41WM135 also in Williamson County. Fullington and Fullington suggested a shift from grasslands to more woodland settings on two Late Archaic sites in Williamson County based on a decrease over time in Rabdotus sp. corresponding with an increase in Helicina sp. Similar trends were noted at the Adamek (41WM135) and Dobias-Vitak (41WM118) sites (Amaral and Witter 1973).

Approximately 22,700 snails recovered from water-screening through $1 / 4$ and $1 / 8$ inch mesh from a single excavation unit, encompassing most of the site's stratigraphy, were analyzed from 41DW270 by Kenneth Brown (Hudler et al. 2002). This site, located roughly $150 \mathrm{~km}$ to the southeast of 41BX17, dates to the Middle and Late Archaic periods. Brown identified at least seven land taxa and six aquatic taxa. All were droughtresistant species suggesting an absence of heavy canopy cover from broadleaf deciduous trees and no indication of significant gallery woodland along Smith Creek. Brown concludes that the snail array hints at increasing environmental instability or stress after about 3000 BP. However, he considers the snail evidence inconclusive due to the lack of microscopic species in the collected population.

To assess the paleoenvironmental conditions at the J.B. White Site, 41MM341, gastropods collected from processed flotation samples from selected proveniences were analyzed by Karen Gardner (Gadus et al. 2006). Site 41MM341 is located approximately $200 \mathrm{~km}$ to the northeast of $41 \mathrm{BX} 17$ and dates to the Late Prehistoric. A total of 7,259 snails were analyzed representing 12 species. Based on changes in gastropod percentages over the span of occupation at 41MM341, Gadus et al. concluded that the site was relatively open during the initial occupation (AD 600), indicating relatively warm and dry climatic conditions, with increasing forest and woodland species, suggesting cooler, perhaps wetter conditions, in the later occupations (AD 1300).

Located less than a half kilometer from 41MM341, the Little River Site, 41MM340, was occupied in the Late Archaic from roughly 3050 to $2060 \mathrm{BP}$. Out of a total of 310 gastropod and bivalve shells recovered from a standard volume column, 11 snail species were identified by Richard Fullington (Mahoney et al. 2003). Based on habitat preference, the species were roughly divided into two principal groups: open/sparsely wooded and densely wooded species. The species suggest that the site area was heavily forested with a deep leaf litter floor with adjacent open grassy areas. Fullington concludes that the site was a benched terrace with a riparian woodland adjacent to a relatively slow moving stream. No clear climatic trends were evident. An additional 1,640 gastropod specimens, derived from a combination of flotation samples and $1 / 4$ inch screen samples suggested a definitive shift from open habitat to wooded habitat through time (Mahoney and Tomka 2001).

Another class of data, comprising phytolith and diatom species, is often used to determine variation in vegetation over time. The opal phytolith records from two Middle to Late Archaic period sites (41GD21 and 41GD21A) on Coleto Creek in South Texas, located approximately 130 $\mathrm{km}$ to the southeast of 41BX17, were analyzed by Ralph Robinson (Fox et al. 1979). Despite problematic dating for most of the sample contexts, Robinson's data suggest that sometime before $4850 \mathrm{BP}$ phytoliths from the deepest sample represent a well developed forest, however another sample dating sometime before $4850 \mathrm{BP}$ suggested an extremely dry period. Sometime between 5300 and $4400 \mathrm{BP}$ there appears to have been a brief mesic period, followed by a dry climate roughly between 4850 and $3350 \mathrm{BP}$. At around 2825 BP, phytoliths suggest a mesic interval, with a more xeric mixture of both wet and dry species present during the Late Prehistoric or Historic periods.

Additional phytolith work at Choke Canyon, approximately $125 \mathrm{~km}$ south of 41BX17, infers a cool, mesic climatic regime that shifts to a more arid period sometime prior to $5300 \mathrm{BP}$, continuing to roughly 4300 BP (Robinson 1982). By 3250 $\mathrm{BP}$ the climate resumed cooler and wetter conditions with mesic conditions by about $2540 \mathrm{BP}$. By $1000 \mathrm{BP}$, the climate once again shifted to more xeric patterns. Like the data from Coleto Creek, the Choke Canyon samples are poorly dated and underreported.

In 1985 and 1987, phytoliths were analyzed from two sites, 41BX228 and 41BX300, in Bexar County. These sites are located on the Salado Creek watershed and were each occupied 
from the Middle Archaic to the Late Prehistoric periods. To assess the paleoenvironmental conditions at the Panther Springs Site (41BX228), phytolith samples collected from sediment column samples from a selected provenience, Test Pit A, were analyzed by Ralph Robinson (Black and McGraw 1985). This test pit was chosen because it was collected from a burned rock midden in association with a Nolan projectile point, giving the column a tentative chronological value of 4000 to 3300 BP. Based on high frequencies of festucoid and panicoid phytolith types, Robinson speculates that between 4000 and $3300 \mathrm{BP}$ the environmental conditions at site 41BX228 were cooler and moister than present conditions, the burned rock midden was used during a cool season, and the Salado Creek was immediately adjacent to the site.

Twenty-nine soil samples recovered from site 41BX300, encompassing seven of the site's features and most of the site's stratigraphy, were analyzed by Ralph Robinson in 1987 (Katz 1987). The phytolith sequence suggests that the environment during the Middle Archaic occupations of 41BX300 was either wooded with tall grass on the uplands or presented a savanna-like setting with grassy areas amongst groves of trees. By the Late Archaic, roughly $3450 \mathrm{BP}$, the climate appears to have changed resulting in an ecosystem with fewer trees and a shorter species of grass. By about 2750 BP, the climate resumes a similar setting as in the Middle Archaic, with the return of tall grass and riverine forest trees.

Diatom content, the final proxy data type we address, was analyzed for burned clay material from radiocarbondated surface hearths at the J.B. White site (41MM341) in Milam County (Gadus et al. 2006). Barbara Winsborough recovered and analyzed 435 diatom cells from 7 clay samples representing 35 different taxa. The recovered diatoms may indicate climate changes and could be used to support the contention that the floodplain was drier during the early occupations of 41MM341 than during the later occupations. However, Gadus et al. suggest that the great variability in the percentage of aquatic species within the samples, the low counts of diatoms in most samples, and the uncertainty of how the diatoms were deposited in the hearth features are all reasons for treating the results with caution.

Four fired clay samples, four sediment samples, and three modern comparative samples from 41MM340, the Little River Site, were analyzed for diatom content by Barbara Winsborough (Mahoney and Tomka 2001). No diatoms were recovered from the sediment samples. The clay samples contained diatoms representing a mixture of aerophilic and benthic species, which are found attached to emergent vegetation and macroalgae. This assemblage suggests that the diatoms may have been transported to 41BX340 from a nearby stream, possibly attached to mussels or other edible material.

\section{BX17 Data}

Previous reconstructions of the paleoclimate using gastropod, diatom, and phytolith assemblages, with some exceptions, fit fairly well with the patterns apparent in the bog pollen and carbon isotope samples published by Bousman (1998), Cooke (2005), Nickels and Mauldin (2001), and Nordt et al. (2002) discussed at the commencement of the previous section. Below we present the results of these analyses on the data collected from 41BX17.

\section{Gastropod Analysis}

Prehistoric climate change is often extrapolated from the presence and numbers of certain snail species. These data generated from gastropod analysis can be used as a proxy of changes in site vegetation structure and composition. Different gastropod species prefer differing habitats. Thus a preponderance of a particular species in one zone or occupation level can indicate a particular habitat and can point to the climate that would have supported that habitat. For example, snail species that favor moist deeply wooded forests should indicate a mesic environment. Gastropod species that populate densely wooded forests with deep, moist leaf litter and fallen logs include: Strobilops texasiana, Helicodiscus parallelus, Hawaiia minuscule, Helicina orbiculata tropica, and Gastrocopta contracta. Species prevalent in open grassy areas to sparsely wooded areas include Rabdotus dealbatus dealbatus, Polygyra mooreana, Gastrocopta pellucida hordeacella, and Zonitoides arboreus. The habitat of Carychium mexicanum ranges from moss lying adjacent to flowing water to very moist forest floors (Cheatum and Fullington. 1971, 1973; Fullington and Pratt 1974).

Several snail species may represent samples biased by human selection. Rabdotus dealbatus dealbutus may represent food items that were consumed by indigenous groups; however, there is no direct evidence that either Rabdotus sp., Helicina sp., or any of the other macroscopic species of snails represent samples biased by human selection. Euglandina singleyan and possibly some of the Rabdotus mooreanus may be predatory and, thus, represent garbage-consuming activity by 
Table 10-1. Breakdown of Snail Species and Densities from Test Unit $5 / 6$ by Level

\begin{tabular}{|c|c|c|c|c|c|c|c|c|c|c|c|c|c|}
\hline \multicolumn{2}{|c|}{ 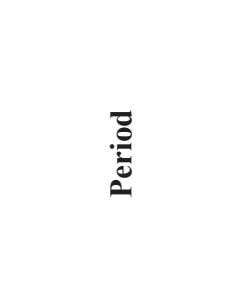 } & 离 & 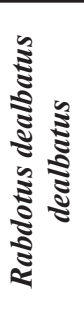 & 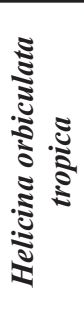 & 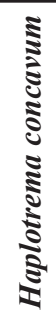 & 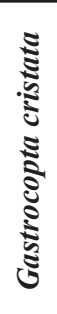 & 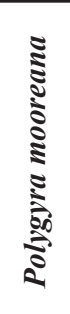 & 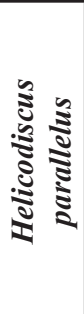 & 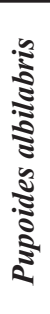 & 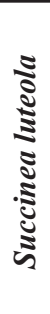 & 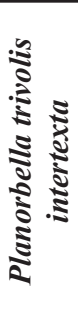 & 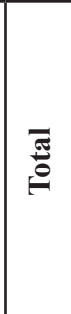 & 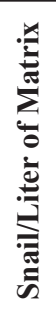 \\
\hline \multirow{6}{*}{$\begin{array}{l}\text { Late } \\
\text { Archaic }\end{array}$} & \multirow{3}{*}{ Terminal } & 1 & 0 & 1 & 34 & 4 & 0 & 0 & 0 & 0 & 0 & 39 & 28 \\
\hline & & 2 & 2 & 27 & 55 & 0 & 0 & 2 & 5 & 0 & 0 & 91 & 70 \\
\hline & & 3 & 47 & 326 & 46 & 0 & 14 & 1 & 0 & 0 & 0 & 434 & 289 \\
\hline & \begin{tabular}{|l|} 
Middle \\
\end{tabular} & 4 & 174 & 1232 & 0 & 0 & 76 & 0 & 3 & 0 & 0 & 1485 & $\mathrm{n} / \mathrm{a}$ \\
\hline & \multirow{2}{*}{ Initial } & 5 & 112 & 254 & 12 & 0 & 14 & 0 & 8 & 0 & 1 & 401 & 501 \\
\hline & & 6 & 38 & 7 & 69 & 0 & 2 & 6 & 6 & 0 & 0 & 128 & 91 \\
\hline \multirow{11}{*}{$\begin{array}{l}\text { Middle } \\
\text { Archaic }\end{array}$} & \multirow{11}{*}{ Late } & 7 & 29 & 1 & 22 & 0 & 0 & 6 & 8 & 0 & 0 & 66 & 44 \\
\hline & & 8 & 4 & 0 & 37 & 1 & 0 & 0 & 0 & 0 & 0 & 42 & 23 \\
\hline & & 9 & 1 & 0 & 40 & 1 & 0 & 0 & 0 & 0 & 0 & 42 & 25 \\
\hline & & 10 & 3 & 0 & 20 & 1 & 0 & 0 & 0 & 0 & 0 & 24 & 20 \\
\hline & & 11 & 4 & 0 & 52 & 5 & 0 & 0 & 0 & 0 & 0 & 61 & 36 \\
\hline & & 12 & 15 & 28 & 88 & 7 & 0 & 0 & 0 & 0 & 0 & 138 & 81 \\
\hline & & 13 & 30 & 0 & 0 & 0 & 0 & 0 & 0 & 0 & 0 & 30 & 16 \\
\hline & & 14 & 3 & 3 & 241 & 23 & 0 & 0 & 0 & 0 & 0 & 270 & 90 \\
\hline & & 15 & 25 & 9 & 83 & 15 & 0 & 0 & 0 & 1 & 0 & 133 & 55 \\
\hline & & 16 & 9 & 3 & 15 & 6 & 0 & 0 & 0 & 0 & 0 & 33 & 33 \\
\hline & & 17 & 10 & 2 & 0 & 0 & 0 & 0 & 0 & 0 & 0 & 12 & $\mathrm{n} / \mathrm{a}$ \\
\hline Total & & & 506 & 1893 & 814 & 63 & 106 & 15 & 30 & 1 & 1 & 3429 & \\
\hline
\end{tabular}

Table 10-2. Breakdown of Snail Species and Densities from Test Unit 3 by Level

\begin{tabular}{|c|c|c|c|c|c|c|c|c|c|c|c|}
\hline 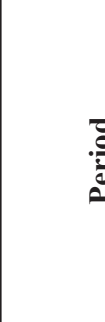 & & 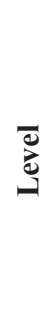 & 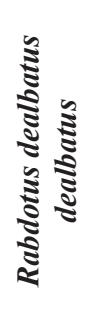 & 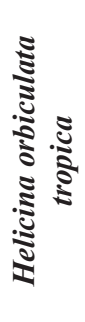 & 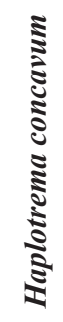 & 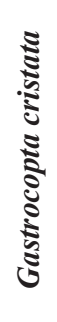 & 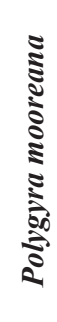 & 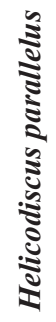 & 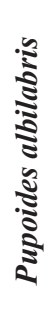 & ह⿱艹 & 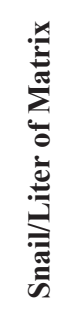 \\
\hline \multirow{3}{*}{$\begin{array}{l}\text { Late } \\
\text { Archaic }\end{array}$} & Middle & 5 & 152 & 334 & 101 & 0 & 19 & 0 & 10 & \begin{tabular}{|l|}
616 \\
\end{tabular} & 489 \\
\hline & \multirow{2}{*}{ Initial } & 6 & 112 & 614 & 0 & 0 & 30 & 3 & 4 & 763 & 636 \\
\hline & & 7 & 41 & 253 & 121 & 10 & 3 & 0 & 0 & \begin{tabular}{|l|}
428 \\
\end{tabular} & 259 \\
\hline Total & & & 305 & 1201 & 222 & 10 & 52 & 3 & 14 & 1807 & \\
\hline
\end{tabular}


snails attracted to organic remains of midden accumulations. Certain small-shelled aquatic snails such as Cincinnatia comalensis, Physella virgata, Micromenetus sampsoni, Biomphalaria havanensis, and Planorbella trivolvis may be introduced by human activities (Cheatum and Fullington. 1971, 1973; Fullington and Pratt 1974).

To attempt to determine climate using gastropods as our proxy, we submitted snail samples representing the Middle Archaic and the Late Archaic components at 41BX17 for species analysis to Manuel Palacios-Fest of Terra Nostra Earth Sciences Research in Tucson, Arizona. A snail was submitted from each level (Levels 1-17) of Test Unit 5/6, spanning the Terminal Late Archaic to the Late Middle Archaic periods (based on radiocarbon dates [1860-4830 BP] and diagnostic artifacts), and from Levels 5, 6, and 7 of Test Unit 3 dating from the Middle to the Initial Late Archaic period. Samples were derived from a combination of flotation samples and $1 / 4$ inch screen samples. Flotation of soil samples was necessary for microsnail recovery. Examples of microsnails too small to survive $1 / 4$ inch screening include Zonitoides arboeus, Carychium mexicanum, Strobilops texasiana, Gastrocopta contracta, Gastrocopta pellucida hordeacella, Hawaiia minuscula, and Helicodiscus parallelus (Tomka and Mauldin 2003).

The snail analysis performed by Palacios-Fest indicates that species richness ranged from one to seven species throughout the test unit levels. Based on habitat preference, the 5,236 gastropods identified by Palacios-Fest can be roughly divided into two principal groups: open/sparsely wooded and densely wooded species. Three of the recovered species, Rabdotus dealbatus dealbatus, Polygyra mooreana, and Pupoides albilabris, are classified in the first group, whereas the remaining six, Helicina orbiculata tropica, Helicodiscus parallelus, Haplotrema concavum, Gastrocopta cristata, Succinea luteola, and Planorbella trivolis intertexta, are of the densely wooded habitat type. The Late Archaic deposits contained eight species, seven in the Terminal, five in the Middle, and eight in the Initial Late Archaic, while the Late Middle Archaic deposits contained seven (Tables 10-1 and 10-2). The eight species recovered from the Late Archaic deposits included all three open/sparsely wooded types while the Middle Archaic deposits contained only one open/sparsely wooded species. Using species richness as a proxy for vegetation community diversity, the pattern identified above suggests that the plant community and vegetation structure of the floodplain in the vicinity of 41BX17 may have been more complex and heterogeneous in the Late Archaic with more species recovered of the open/sparsely wooded habit than found in the Late Middle Archaic deposits.

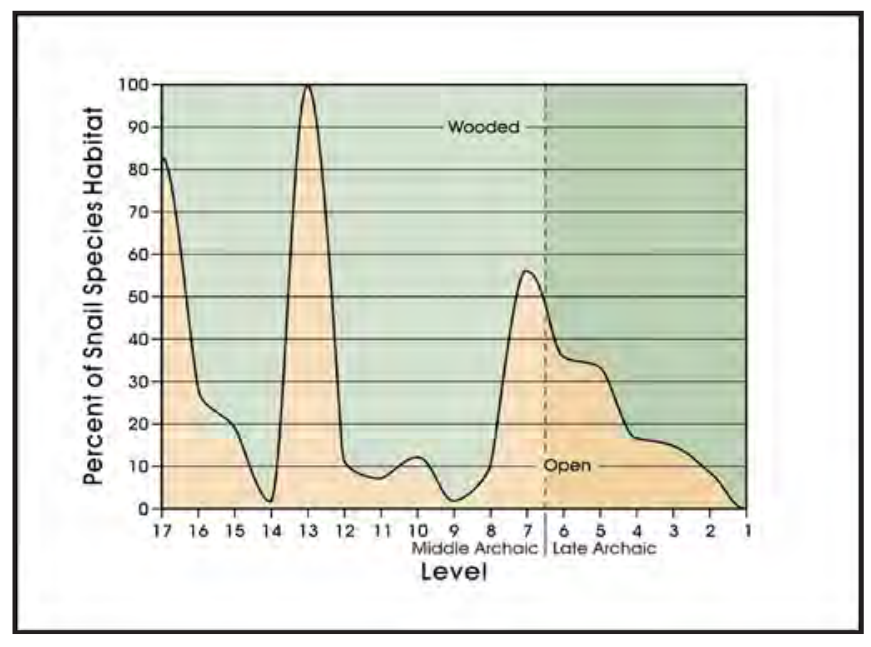

Figure 10-1. Distribution of wooded habitat and open habitat snail species in Test Unit 5/6 by level.

The snail assemblage from Test Unit 5/6 (Figure 10-1) illustrates that the densities of open habitat and wooded habitat species were roughly equal at the start of the Late Archaic with wooded species showing a gradual increase in dominance over time. The patterns in the Late Middle Archaic are more complex suggesting, in general, a snail assemblage indicative of a wooded habitat with the exception of Level 13. The period begins with a sharp decline in open habitat snails suggesting a change from an open/sparsely wooded setting to a more mesic densely wooded setting. However, the Level 13 assemblage points to a xeric interval, with a sharp decrease in wooded species suggesting a $\mathrm{C}_{4}$ dominated environment. Subsequently open habitat snails drop off, with more mesic species representing the bulk of the samples from Levels 12 through 8 dominating the period until the beginning of the Late Archaic. Three levels from the Initial and Middle Late Archaic in Test Unit 3 were also analyzed for snail diversity. These levels, containing an abundant population $(n=1,807)$ with high diversity (seven species), support the trend described for the Late Archaic in Test Unit 5/6 suggesting a habitat supporting both open and wooded species with a trend towards an increasingly mesic climate.

Tables 10-1 and 10-2 present the combined distribution and density of snail species by level and test unit. The levels with the highest density of snails per liter of matrix are Level 5 from Test Unit 5/6 and Level 6 from Test Unit 3, both representing the Initial Late Archaic. Levels 8, 10, and 13, all from Test Unit 5/6, representing the Late Middle Archaic have the lowest snail densities. Helicina orbiculata tropica, Haplotrema concavum, and Rabdotus dealbatus dealbatus have the largest samples while Planorbella trivolis intertexta, Succinea luteola, and Helicodiscus parallelus occur in very low numbers. The distribution of the three most prevalent 


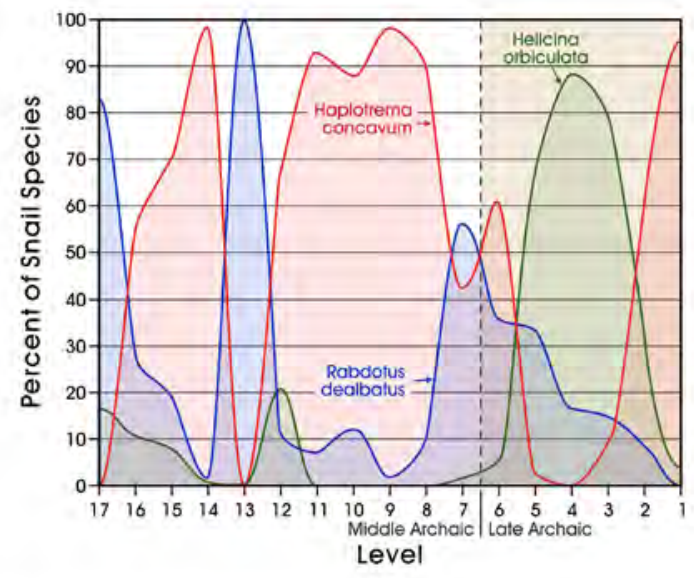

Figure 10-2. Distribution of the three most common snail species in Test Unit $5 / 6$ by level.

species by level in Test Unit 5/6 (Figure 10-2) indicates that Haplotrema concavum, a species preferring wooded habitats, dominates the Late Middle Archaic, with the exception of the spike in Level 13 in Rabdotus dealbatus dealbatus, a species prevalent in open/sparsely wooded settings. The third species, Helicina orbiculata, also a species from wooded habitats, is present in parts of the Middle Archaic but at a low density. This species shows a marked increase at the beginning of the Late Archaic as Hapltrema concavum declines; effectively, one wooded species appears to replace the other. Towards the end of the period this trend reverses with an increase in the Haplotrema sp. and a decline in the Helicina sp. Rabdotus dealbatus dealbatus begins to reemerge at the close of the Middle Archaic, but as the Initial Late Archaic commences this species declines steadily and is replaced by species thriving in wooded, mesic environments.

We charted the percentages of each individual snail species recovered from the Test Unit 5/6 samples by level to obtain a more detailed perspective on these ecological trends (Figure 10-3). The terminal depth of Test Unit 5/6, Level 17 , is represented by only two species, $R$. dealbatus dealbatus and $H$. orbiculata tropica. A changing environment is evident from the sharp decline of $R$. dealbatus dealbatus, slow decline in $H$. orbiculata, rapid increase in $H$. concavum, first occurrence of $G$. cristata, and the sole occurrence of S. luteola. Rabdotus dealbatus dealbatus is the only species of these five indicative of xeric condition, thus, its decrease and the increase and appearance of the latter four indicate a change to wetter conditions.

A sharply increasing Rabdotus dealbatus dealbatus population in conjunction with the disappearance of all other species (Level 13) supports the existence of a $\mathrm{C}_{4}$ dominated environment with xeric conditions resulting in a decline in mesic snails. Subsequently, $R$. dealbatus dealbatus rapidly decline as $H$. concavum become abundant. Palacios-Fest (see Appendix A) points to the possibility that the increase in $H$. concavum may be reflecting their role as a predator on $R$. dealbatus dealbatus. However, because no holes were visible on the Rabdotus dealbatus dealbatus shells, Palacios-Fest assumes that the increase in $H$. concavum is a response to ecological replacement due to a return to mesic conditions. Along with the decline in Rabdotus dealbatus dealbatus, a slight increase in G. cristata and the disappearance of $H$. orbiculata is evident. Palacios-Fest posits that the existence of G. cristata with low levels of Rabdotus dealbatus dealbatus may point to semi-arid, not fully mesic conditions.

Two species, $H$. parallelus and $P$. albilabris, first appearing in the stratigraphy at the end of the Middle Archaic period, indicate contrasting conditions. The former lives in swamp forests containing high levels of moss and bryophytes, while the latter prefers bare moist ground (Turgeon et al. 1998). The concurrent increase in Rabdotus dealbatus dealbatus and decrease in $H$. concavum indicate decreasing moisture. Palacios-Fest concludes that the gastropod assemblage indicates increasing aridity at the transition from the Middle to the Late Archaic period.

Following the transition, mesic conditions reemerge as evident by a significant increase in $H$. orbiculata tropica, the appearance of $P$. mooreana, and the decline of all other species. A mesic environment dominates much of the Late Archaic (Levels 3-6) evident by the maximum abundance of $H$. orbiculata tropica. Palacios-Fest suggests that such a high abundance of this species in an archeological setting points to human gathering and consumption, however, as no evidence of anthropogenic activity is evident on the shells, he infers that $H$. orbiculata tropica were abundant as a response to increasing effective moisture. The upper levels of Test Unit 5/6, Terminal Late Archaic, indicate a disappearance of Rabdotus dealbatus dealbatus, a sharp decline in $H$. orbiculata, and a rapid increase in $H$. concavum suggesting increasing mesic conditions.

The gastropod analysis correlates relatively well with the plant and pollen records discussed above. Shifts in $\mathrm{C}_{3}$ and $\mathrm{C}_{4}$ vegetation recorded from Hall's Cave (Cooke 2005), the Medina River (Nordt et al. 2002), and Boriak (Bousman 1998) and Patschke (Camper 1991; Nickels and Mauldin 2001) bogs point to trends that are supported in much of Palacios-Fest's snail analysis. However, it should be noted that the gastropod patterns discussed above could reflect shifting conditions at the microhabitat level. The relationship between that level and larger climate change is not really 
understood and microhabitat may certainly be determined by macrohabitat. An alternate method for determining paleoenvironmental change, the analysis of phytolith and diatom assemblages, is presented in the next section.
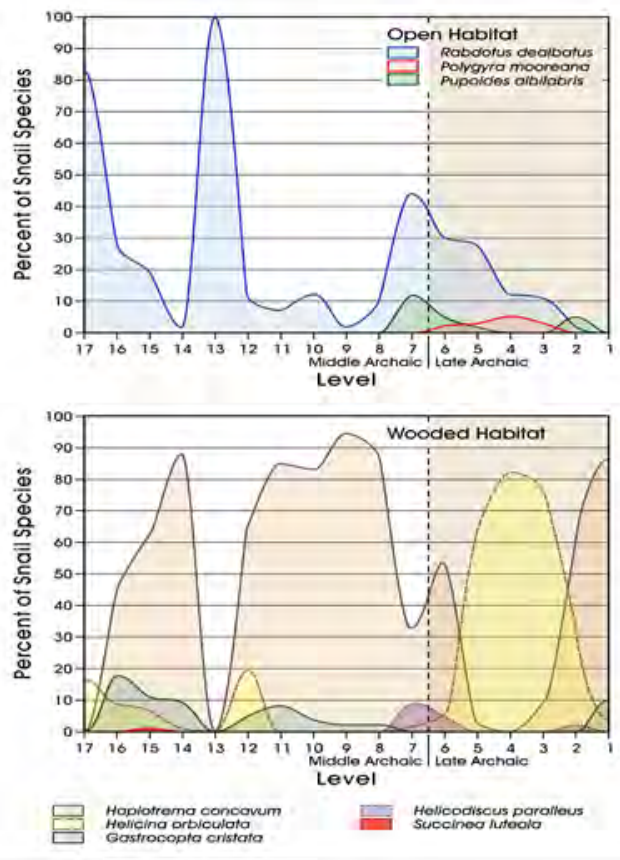

Figure 10-3. Percentages of open habitat (top) and wooded habitat (bottom) snail species in Test Unit 5/6 by level.

\section{Phytolith Analysis}

Phytolith and diatom species can be used as proxies to identify paleoenvironmental change in vegetation communities since the earliest occupation of a site. Plants produce silica bodies when soluble silica in the ground water is absorbed by the roots and carried up to the plant's vascular system. These silica bodies are termed phytoliths. When the ground water evaporates and is metabolized, silica precipitates in and around the cellular walls of the plant. As the plant dies, opal phytoliths, decay-resistant distinct plant remains, are deposited in the soil. Phytoliths are typically deposited directly into the soils into which the plants decay. However, transportation may occur through animal consumption and excretion, man's gathering of plants, or by transportation or erosion of soil by wind, ice, or water. Phytoliths are susceptible to erosion, deteriation, and mechanical breakage in high pH soils (Cummings 1994).

Phytoliths occur in members of the grass family, as well as in deciduous trees, sedges, rushes, palms, and conifers and take the shape of the cells in which they were deposited allowing an analyst the means to identify specific kinds of plants (Thomas and Kelly 2006). Three major types of grass short-cell phytoliths are festucoid, chloridoid, and panicoid. The fesucoid class, occurring most frequently in cool, moist environs, includes Kentucky bluegrass, fescue, junegrass, western wheatgrass, wild rye, and foxtail barley. Chloridoid phytoliths, abundant in the American Southwest, are found in warm-season grasses in arid to semi-arid areas with low levels of soil moisture. This class contains grama grass, buffalo grass, and plains muhly. Panicoid phytoliths are found in warm-season or tall grasses that often grow in humid conditions, including big bluestem, Indian grass, and switch grass (see Appendix D). Phytoliths have been recovered from several contexts within Bexar County (see Katz 1987; Robinson 1985) and have been useful for reconstructing general aspects of the environment.

An analysis of plant opal phytoliths extracted from 41BX17 test unit soil samples was performed by Chad Yost and Linda Scott Cummings of Paleo Research Institute, Inc. in Golden, Colorado (Table 10-3). Soil samples, collected in ten centimeter increments, were submitted from Test Unit 3 (Levels 5, 6, and 7) and Test Unit 5/6 (Levels 1-16). Figures 10-4 and 10-5 chart the frequencies of the major types of grass short-cell phytoliths and the percentage of warm season $\left(\mathrm{C}_{4}\right)$ verses cool season $\left(\mathrm{C}_{3}\right)$ grasses from the Late Middle Archaic through the Late Archaic periods at 41BX17, respectively. The most abundant class of phytolith throughout all levels represent warm season, arid to semi-arid $\mathrm{C}_{4}$ chloridoid grasses, ranging from 40 to 68 percent of the three major classes. The second most abundant phytolith class is representative of cool season $\mathrm{C}_{3}$ festucoid grasses. The lowest occurring phytolith, from tall grass warm-season $\mathrm{C}_{4}$ panicoids, are only slightly less abundant than the $\mathrm{C}_{3}$ festucoids. Yost and Cummings suggest that this mix of $\mathrm{C}_{3}$ and $\mathrm{C}_{4}$ grasses point to moderate moisture and temperatures that would have been hospitable

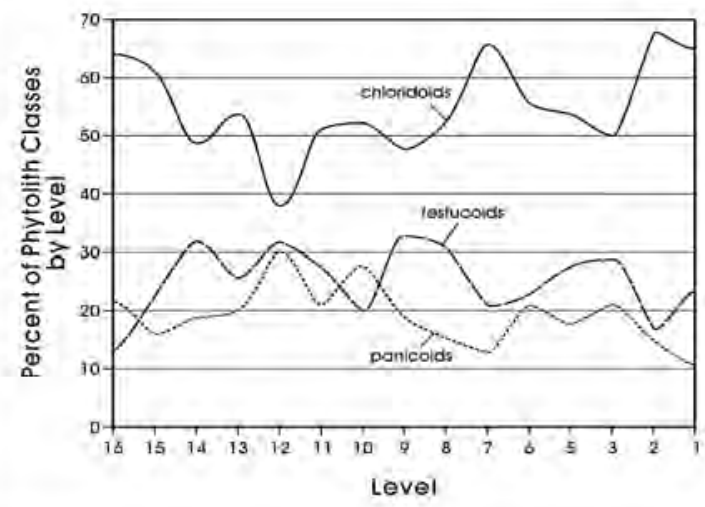

Figure 10-4. Percentages of the three major phytolith classes by level. 
Table 10-3. Distribution of Phytolith Classes by Test Unit and Level

\begin{tabular}{|c|c|c|c|c|c|c|c|c|c|c|c|c|c|c|c|c|c|c|}
\hline 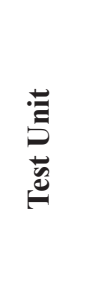 & 己 & 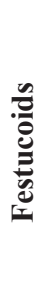 & $\begin{array}{l}\frac{n}{0} \\
\frac{0}{0} \\
\frac{0}{2} \\
\frac{0}{2}\end{array}$ & 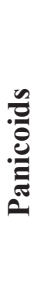 & 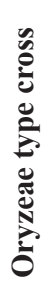 & 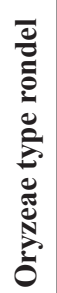 & 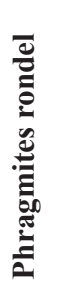 & 弟 & 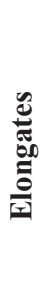 & 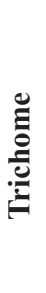 & 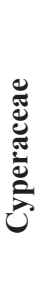 & 苞 & 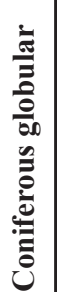 & 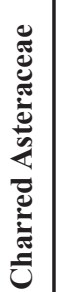 & 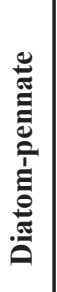 & 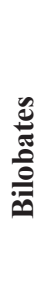 & 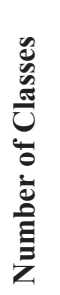 & 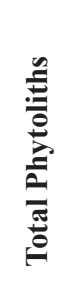 \\
\hline 3 & 5 & $\sqrt{ }$ & $\sqrt{ }$ & $\sqrt{ }$ & & & & $\sqrt{ }$ & $\sqrt{ }$ & $\sqrt{ }$ & & $\sqrt{ }$ & & & & $\sqrt{ }$ & 8 & 401 \\
\hline 3 & 6 & $\sqrt{ }$ & $\sqrt{ }$ & $\sqrt{ }$ & & & & $\sqrt{ }$ & $\sqrt{ }$ & $\sqrt{ }$ & $\sqrt{ }$ & $\sqrt{ }$ & & & & $\sqrt{ }$ & 9 & 401 \\
\hline 3 & 7 & $\sqrt{ }$ & $\sqrt{ }$ & $\sqrt{ }$ & & & & $\sqrt{ }$ & $\sqrt{ }$ & $\sqrt{ }$ & $\overline{\sqrt{ }}$ & $\sqrt{ }$ & & & & $\sqrt{ }$ & 9 & 401 \\
\hline $5 / 6$ & 1 & $\sqrt{ }$ & $\sqrt{ }$ & $\sqrt{ }$ & & & & $\sqrt{ }$ & $\sqrt{ }$ & $\sqrt{ }$ & $\sqrt{ }$ & & & $\sqrt{ }$ & & $\sqrt{ }$ & 9 & 401 \\
\hline $5 / 6$ & 2 & $\sqrt{ }$ & $\sqrt{ }$ & $\sqrt{ }$ & & & & $\sqrt{ }$ & $\sqrt{ }$ & $\sqrt{ }$ & $\sqrt{ }$ & & & $\sqrt{ }$ & & $\sqrt{ }$ & 9 & 401 \\
\hline $5 / 6$ & 3 & $\sqrt{ }$ & $\sqrt{ }$ & $\sqrt{ }$ & & & & $\sqrt{ }$ & $\sqrt{ }$ & $\sqrt{ }$ & $\sqrt{ }$ & $\sqrt{ }$ & & & & $\sqrt{ }$ & 9 & 301 \\
\hline $5 / 6$ & 5 & $\sqrt{ }$ & $\sqrt{ }$ & $\sqrt{ }$ & & & & $\sqrt{ }$ & $\sqrt{ }$ & $\sqrt{ }$ & $\sqrt{ }$ & & & & & $\sqrt{ }$ & 8 & 401 \\
\hline $5 / 6$ & 6 & $\sqrt{ }$ & $\sqrt{ }$ & $\sqrt{ }$ & & & & $\sqrt{ }$ & $\sqrt{ }$ & $\sqrt{ }$ & $\overline{\sqrt{ }}$ & & & & & $\sqrt{ }$ & 8 & 401 \\
\hline $5 / 6$ & 7 & $\sqrt{ }$ & $\sqrt{ }$ & $\sqrt{ }$ & & & & $\sqrt{ }$ & $\sqrt{ }$ & $\sqrt{ }$ & & & & & $\sqrt{ }$ & $\sqrt{ }$ & 8 & 401 \\
\hline $5 / 6$ & 8 & $\sqrt{ }$ & $\sqrt{ }$ & $\sqrt{ }$ & & & & $\sqrt{ }$ & $\sqrt{ }$ & $\sqrt{ }$ & $\sqrt{ }$ & $\sqrt{ }$ & & $\sqrt{ }$ & & $\sqrt{ }$ & 10 & 402 \\
\hline $5 / 6$ & 9 & $\sqrt{ }$ & $\sqrt{ }$ & $\sqrt{ }$ & & & & $\sqrt{ }$ & $\sqrt{ }$ & $\sqrt{ }$ & & $\sqrt{ }$ & & & & $\sqrt{ }$ & 8 & 300 \\
\hline $5 / 6$ & 10 & $\sqrt{ }$ & $\sqrt{ }$ & $\sqrt{ }$ & & & & $\sqrt{ }$ & $\sqrt{ }$ & $\sqrt{ }$ & $\sqrt{ }$ & $\sqrt{ }$ & & & & $\sqrt{ }$ & 9 & 301 \\
\hline $5 / 6$ & 11 & $\sqrt{ }$ & $\sqrt{ }$ & $\sqrt{ }$ & & & & $\sqrt{ }$ & $\sqrt{ }$ & $\sqrt{ }$ & $\sqrt{ }$ & $\sqrt{ }$ & & & & $\sqrt{ }$ & 9 & 301 \\
\hline $5 / 6$ & 12 & $\sqrt{ }$ & $\sqrt{ }$ & $\sqrt{ }$ & & $\sqrt{ }$ & & $\sqrt{ }$ & $\sqrt{ }$ & $\sqrt{ }$ & & $\sqrt{ }$ & & & & $\sqrt{ }$ & 9 & 301 \\
\hline $5 / 6$ & 13 & $\sqrt{ }$ & $\sqrt{ }$ & $\sqrt{ }$ & & & & $\sqrt{ }$ & $\sqrt{ }$ & $\sqrt{ }$ & $\overline{\sqrt{ }}$ & $\sqrt{ }$ & & & & $\sqrt{ }$ & 9 & 301 \\
\hline $5 / 6$ & 14 & $\sqrt{ }$ & $\sqrt{ }$ & $\sqrt{ }$ & & & & $\sqrt{ }$ & $\sqrt{ }$ & $\sqrt{ }$ & $\sqrt{ }$ & $\sqrt{ }$ & & $\sqrt{ }$ & & $\sqrt{ }$ & 10 & 301 \\
\hline $5 / 6$ & 15 & $\sqrt{ }$ & $\sqrt{ }$ & $\sqrt{ }$ & $\sqrt{ }$ & & $\sqrt{ }$ & $\sqrt{ }$ & $\sqrt{ }$ & $\sqrt{ }$ & $\sqrt{ }$ & & $\sqrt{ }$ & & & $\sqrt{ }$ & 11 & 301 \\
\hline $5 / 6$ & 16 & $\sqrt{ }$ & $\sqrt{ }$ & $\sqrt{ }$ & & & $\sqrt{ }$ & $\sqrt{ }$ & $\sqrt{ }$ & $\sqrt{ }$ & & $\sqrt{ }$ & & & & $\sqrt{ }$ & 9 & 301 \\
\hline Total & & & & & & & & & & & & & & & & & & 6318 \\
\hline
\end{tabular}

for both chloridoid grama grasses and tall grass panicoids. Throughout most of the Granberg stratigraphic record, the $\mathrm{C}_{3}$ festucoid values of roughly 20 to 30 percent suggest that cool-season grasses were an important part of the regional grass assemblage.

In addition to these three major classes of opal phytoliths, other types suggest subtle variations leading Yost and Cummings to conclude that an overall trend from mesic to more xeric conditions existed at the site. Rondel phytoliths, indicative of the wetland obligate common reed, and buliform phytoliths from wet habitats of floodplains were both found in Levels 15 and 16 of Test Unit 5/6. The buliform record gradually decreases from Level 14 to the surface. Yost and Cummings posit that the Granberg Site, at the time of its earliest occupation (Middle Archaic), was much closer to the floodplain. Overall, the phytolith record from 41BX17 represents a setting with moderate temperature and precipitation that was fairly stable throughout the entire occupation of the site indicating subtle to moderate shifts in the grass species composition with the $\mathrm{C}_{4}$ to $\mathrm{C}_{3}$ ratio responding to the seasonality and amount of precipitation.

\section{Diatom Analysis}

Diatoms are pigmented, photosynthetic, unicellular algae distinguished by a cell wall that is filled with silica. Diatoms live in a wide variety of aquatic and terrestrial habitats, including damp soil, springs, lakes and ponds, and streams. Water quality directly effects the overall composition of diatom species. Diatoms are usually found in large numbers and are easily identified to species. In addition, 


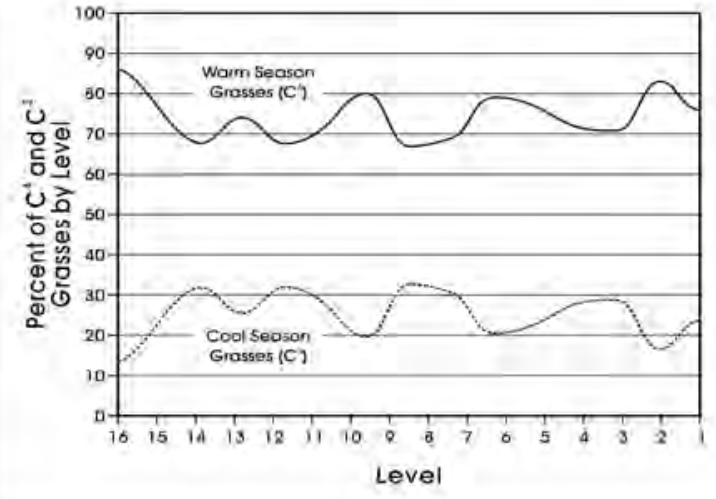

Figure 10-5. Percentages of $C 3$ and $C 4$ grasses by level.

they are resistant to most taphonomic processes and are sensitive indicators of habitat. They are well suited for use in paleoenvironment reconstruction (Winsborough 2001). Classes of diatoms include free-floating tychoplanktonic (associated with turbid periods) taxa and planktonic (lives suspended in water) taxa, and benthic species (associated with sediment, microbial mats, and vegetation near a body of water). We know of no previous work with diatoms within Bexar County (see Appendix C).
Barbara Winsborough of Winsborough Consulting in Leander, Texas, conducted an analysis of 18 soil samples from both Middle and Late Archaic intervals of the Granberg Site. Of the 18 samples, 6 were devoid of diatoms. The remaining 12 samples contained a total of 594 diatoms attributed to 26 soil and freshwater species and 7 brackish/marine species (Table 10-4). Aquatic benthic species, typically recovered from shallow streams and around the borders of ponds attached to vegetation, sand, pebbles or rocks, were the most abundant group of diatoms identified. Aerophilic species, found in soil and mud of marginal or occasionally wet habitats, were also well represented. Both benthic and aerophilic species live along the edges of streams and the upper margins of ponds and lakes, and they are often found together in very shallow habitats with fluctuating water levels. Winsborough observes that the benthic and aerophilic groups are typical of Central Texas, limestone spring-fed streams. The water may have been seasonal in flow-volume. One soil sample presented a very different diatom assemblage: estuarine-marine diatoms from shallow coastal areas. Winsborough suggests that the marine species may have been brought to the site as inclusions in salt used for meat preservation or as diatomaceous mats dried on the fur of large wading mammals, such as bison and migrating waterfowl. The diatoms recovered from 41BX17 could be suggestive of climate changes but are difficult to

Table 10-4. Distribution of Identified Diatom Species by Unit and Level

\begin{tabular}{|c|c|c|c|c|c|}
\hline $\begin{array}{l}\text { Test } \\
\text { Unit }\end{array}$ & Level & $\begin{array}{l}\text { Diatom } \\
\text { Class }\end{array}$ & Diatom Name & $\begin{array}{l}\text { Number of } \\
\text { Species }\end{array}$ & $\begin{array}{c}\text { Total } \\
\text { Diatoms }\end{array}$ \\
\hline 3 & 5 & Freshwater & Gomphonema angustatum, Hantzschia abundans, Nitzschia amphibia, Synedra ulna & 4 & 13 \\
\hline 3 & 6 & Freshwater & $\begin{array}{l}\text { Achnanthidium biasolettianum, Achnanthidium minutissimum, Amphora pediculus, } \\
\text { Brachysira vitrea, Cocconeis pediculus, Cymbella delicatula, Cymbella excisa, } \\
\text { Encyonema evergladianum, Encyonema silesiacum, Encyonopsis microcephala, } \\
\text { Eucocconeis flexella, Fragilaria nanana, Luticola goeppertiana, Navicula } \\
\text { cryptotenella, Navicula stroemii, Nitzschia amphibia, Nitzschia amphibioides, } \\
\text { Staurosirella (Fragilaria) pinnata, Synedra ulna }\end{array}$ & 19 & 500 \\
\hline 3 & 7 & Freshwater & Achnanthidium biasolettianum, Cocconeis placentula, Synedra ulna & 3 & 7 \\
\hline $5 / 6$ & 1 & Freshwater & $\begin{array}{l}\text { Cymbella delicatula, Denticula kuetzingii, Eunotia pectinalis, Fragilaria capucina, } \\
\text { Gomphonema angustatum, Hantzschia abundans, Luticola goeppertiana, Synedra } \\
\text { ulna }\end{array}$ & 8 & 27 \\
\hline $5 / 6$ & 2 & Freshwater & Hantzschia abundans, Luticola goeppertiana & 2 & 9 \\
\hline $5 / 6$ & 3 & Freshwater & Hantzschia abundans & 1 & 3 \\
\hline $5 / 6$ & 5 & Freshwater & Gomphonema angustatum, Hantzschia abundans & 2 & 4 \\
\hline $5 / 6$ & 7 & Freshwater & Hantzschia abundans, Surirella angusta & 2 & 3 \\
\hline $5 / 6$ & 9 & Freshwater & Nitzschia amphibia & 1 & 3 \\
\hline $5 / 6$ & 11 & Marine & $\begin{array}{l}\text { Chaetoceros sp., Cocconeis sp., Rouxia fusiformis, Synedra fasciculata, } \\
\text { Thalassionema nitzschioides, Thalassiosira oestrupii, Thalassiosira sp. }\end{array}$ & 7 & 19 \\
\hline $5 / 6$ & 12 & Freshwater & Achnanthidium biasolettianum, Hantzschia abundans & 2 & 4 \\
\hline $5 / 6$ & 16 & Freshwater & Achnanthidium biasolettianum, & 1 & 2 \\
\hline Total & & & & & 594 \\
\hline
\end{tabular}


Table 10-5. Distribution of Features with Wood Samples by Time Period

\begin{tabular}{|c|c|c|c|c|}
\hline Period & Interval & Feature Numbers & Taxon & Common Name \\
\hline Middle Archaic & Late & 104,107 & Quercus sp., Indeterminate & Oak \\
\hline \multirow{3}{*}{ Late Archaic } & Initial & $101,102,105,106,108$ & Quercus sp., Indeterminate & Oak \\
\cline { 2 - 6 } & Middle & 103 & Indeterminate & N/A \\
\cline { 2 - 5 } & Terminal & 100 & Prosopis glandulosa, Fabaceae, Quercus sp., Indeterminate & Mesquite, Woody legume, Oak \\
\hline
\end{tabular}

interpret. The relative frequencies of the aquatic benthic and aerophilic groups may be useful for addressing climate based on the assumptions that the aquatic species were deposited within the site sediments by flooding and that fluctuations in their numbers through time could relate to changes in the frequency or duration of flood episodes and thus, wet verses dry conditions.

\section{Mesquite Xylem Analysis}

As previously briefly discussed, we submitted charred plant remains and light fraction recovered from soil flotation for analysis of mesquite xylem as a proxy indicator of the paleoclimate at 41BX17. J. Philip Dering of Shumla Archeobotanical Services in Comstock, Texas, performed the macrobotanical analysis, but unfortunately, although a small amount of mesquite was present in a single sample, the fragments were not large enough to conduct xylem analysis (see Appendix E). Three very small mesquite charcoal fragments occurred in Feature 100, and three other fragments were attributable to the woody legume type. These six fragments weighed less than $0.1 \mathrm{gm}$ and do not provide an adequate sample for xylem analysis. No seeds, fruit, or geophyte/root fragments were identified in the samples. The total weight of wood charcoal contained in the samples is 9.2 $\mathrm{gm}$. Although a small amount of mesquite and woody legume were also identified, most of the wood is oak (Table 10-5), . The analysis suggests that the vegetation at $41 \mathrm{BX} 17$ during its occupation consisted primarily of oak. Dering concludes that the inhabitants of the site were either purposefully choosing oak over mesquite or the vegetation in the immediate vicinity of the Granberg Site was dominated by oak trees.

\section{Summary}

Climate proxy data (pollen and soil carbonates) monitor shifts in proxy data vegetation communities at large temporal and spatial scales. While this data should reflect regional changes (see Bousman 1998; Cooke 2005; Nickels and Mauldin 2001; Nordt et al. 2002), the actual scale of these changes remains unknown. This chapter addressed the paleoenvironmental conditions during the Middle and Late Archaic occupations at the site level at 41BX17. Using various data sets from the site, can we find evidence of climate change that is consistent, or inconsistent, with the proposed increase in grasslands suggested by the pollen and carbon isotope data?

The results of these various studies on data collected from the Granberg Site suggest that at the commencement of its occupation, in the Late Middle Archaic period, climatic conditions were relatively dry and that the forest or woodland canopy was moderately open. After this initial xeric period, conditions changed to become cooler, wetter, and more forested. Both the gastropod analysis and the phytolith analysis support this mesic interval with an increase in wooded habitat and a corresponding decrease in open habitat snail species in Levels 15-16 and the presence of Rondel and buliform phytoliths, both indicative of wetland plants, in Levels 15-16. Snail species drastically change to open habitat types in Level 13 followed by a mesic interval evident in Levels 8-11. At the transition from the Middle to Late Archaic, woodland and open habitat snail species are both abundant, suggesting a more xeric climate, but as the Late Archaic commences, the environment becomes increasing wetter and cooler. Wetland phytoliths gradually decrease from Level 14 up indicating an overall trend from mesic to more xeric conditions. The results of the diatom analysis point to a setting typical of limestone spring-fed streams with water that was likely seasonal in flow-volume.

These site level findings, specifically the results of the gastropod analysis, correlate relatively well with the overall pattern apparent in the Middle and Late Archaic portions of the pollen and soil carbonate sequences. Shifts in $\mathrm{C}_{3}$ and $\mathrm{C}_{4}$ ratios from the Medina River (Nordt et al 2002), Hall's Cave (Cooke 2005), and Boriak (Bousman 1998) and Patschke (Camper 1991; Nickels and Mauldin 2001) bogs show trends that, for the most part, agree with the interpretations presented in this chapter. The pollen and soil carbonate sequences reflect a warm and dry Middle Holocene (ca. 8000-4000 BP) with an apparently brief mesic period sometime around 7000 to 6000 or 5000 BP. Xeric conditions resume between 5000 and $4000 \mathrm{BP}$ following the mesic interval hitting a peak in the early portion of the Late Archaic. A slow gradual return to a generally cooler and/or wetter climate follows with a return to more xeric conditions within the last few hundred years. 


\section{Chapter 11: Subsistence Strategies}

\section{Cynthia M. Munoz and Raymond P. Mauldin}

In the previous chapter we attempted to define the characteristics of the immediate environs of the Granberg Site and the climatic conditions that prevailed during the history of the site's occupation. This chapter presents a reconstruction of the prehistoric subsistence practices of the site's inhabitants. The research design (Munoz et al. 2007) focused on suggested changes in diet breadth initiated by the presence/absence of bison in the Middle and Late Archaic periods in Central and South Texas. Because the site was repeatedly occupied over approximately 2500 years, and during that time the composition and structure of the resources changed, we are interested in identifying how subsistence and land-use strategies may have changed in response to changes in the resource base, specifically in response to the presence/ absence of bison.

Several topics, defined in the research design (Munoz et al. 2007), were identified to direct and focus this study. In addition to identifying the vertebrate remains that served as food sources for the site's inhabitants, we also needed to identify the principal plant foods consumed. Upon obtaining this information, we were able to commence reconstructing subsistence strategies and diachronic changes in subsistence. We expect a narrowing of diet breadth when bison are present with hunters and gatherers dropping low profitability animals and plants from their diet. Conversely, when bison are absent, we expect an increase in diet breadth due to the incorporation of lower return plants and animals and the focus of attention on high return animals such as deer.

To address diet breadth change over the occupations of the site we relied on the analysis of data from five principal sources: 1) published literature containing bison presence/ absence data obtained in the vicinity of the Granberg Site; 2) vertebrate faunal remains; 3 ) burned rock features; 4) macrobotanical identifications of charred nuts and seed fragments; and 5) identifications of lipid residues from burned rock features. The detailed results of the lipid residue, macrobotanical, and faunal analyses are presented in Appendices B, E, and F, respectively. Unfortunately, flotation of soil samples and analysis of charcoal for macrobotanical remains returned minimal results. Consequently, in this chapter we focus on bison presence/absence, faunal remains, and burned rock features. We demonstrate that within 41BX17 there are differences in subsistence between the Middle and Late Archaic analytical units. We then consider faunal material and burned rock feature data from a variety of other sites throughout Central Texas to explore temporal and spatial variability in subsistence at different scales.

\section{Reassessing the Middle Archaic Model of Bison Absence}

Based on paleoenvironmental reconstructions for Texas, it is apparent that climate conditions fluctuated between cool and moist and warm and dry environments during the past 12,000 years (Bousman 1998; Johnson and Good 1994). These fluctuations, discussed in Chapters 2 and 10, would have affected the types and locations of resources across Texas. One of the major impacts of these fluctuations, involving resources available to hunters and gatherers, is likely to have been vacillations in bison populations. We suggest that the fluctuations in bison availability within Texas, first proposed by Dillehay (1974; see also Collins 1995), provide a context for developing a general model that has implications for shifts in diet, technology, and mobility. Foraging theory suggests that alterations in the availability of high-ranked resources should have a primary impact on diet breadth. All else being equal, low-ranked resources should be added to the diet when high-ranked resources are unavailable because their addition would increase the overall return rate. Conversely, some lower ranked resources should be dropped from the diet when high-ranked resources become available as their elimination would increase the overall return rate. In Texas, bison would clearly have been a high-ranked resource, and fluctuations in that resource should have important ramifications for diet breadth, as well as for technology and mobility systems of hunters and gatherers.

Dillehay's (1974) research, identifying clear periods of bison presence and absence in the state, argued that bison were absent throughout the Middle Archaic (7000-4450 BP) and present throughout the Late Archaic (4450-1450 BP). Collins (1995) revised Dillehay's results by suggesting four presence periods, Period I (11,950-8950 BP), Period II (5950-4950 BP), Period III (3950-1150 BP), and Period IV (650-300 BP), and three absence periods, Period I (8950-5950 BP), Period II (4950-3950 BP), and Period III (1150-650 BP). The first presence period occurs during the Paleoindian period, while the second develops during the first half of the Middle Archaic period. The third presence period spans the Late Archaic period, while the fourth begins during the Late Prehistoric Toyah Phase and extends into the Historic period. Collins (1995) suggested a relatively high abundance of bison in the early portion of the Middle Archaic (ca 6000$5000 \mathrm{BP}$ ), followed by an absence period until approximately $3500 \mathrm{BP}$, and then a continued presence through the Late 


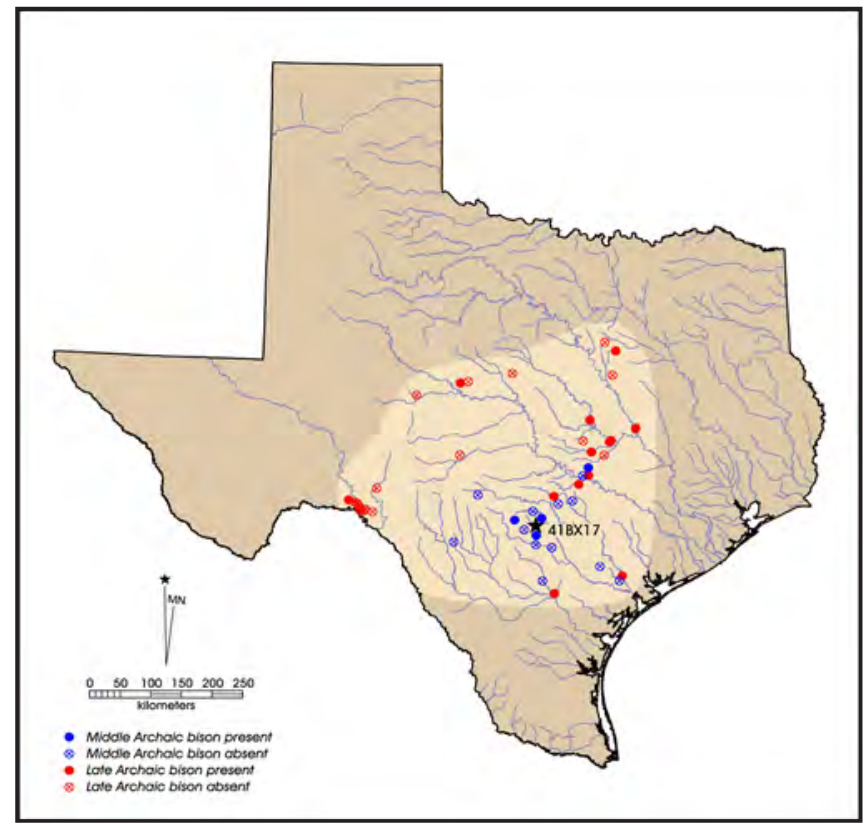

Figure 11-1. Middle $(n=22)$ and Late Archaic $(n=39)$ sites with bison presencelabsence in Central Texas.

Archaic. Data reviewed from over 180 Central and South Texas Late Archaic and Late Prehistoric components by Mauldin and Kemp (2005) demonstrate that bison were present in $33 \%$ of all Late Archaic components $(n=69)$. Of these 69 components, 18 date between 4450 and 2500 BP, a temporal range that overlaps, to some degree, the period of absence (4950 - 3950 BP) suggested by Collins (1995). Bison were present on $44 \%$ of these 18 components (Table 11-1). Mauldin and Kemp (2005) suggest that bison probably returned to Texas sometime after $4500 \mathrm{BP}$. Prior to the return of bison in the Late Archaic, white-tailed deer would have been the highest ranked resource and probably the focus of most large game hunting. We suggest that bison were abundant in the Late Archaic, though deer certainly remained an important fixture in the diet. While, depending on the frequency of bison in the environment, hunters would take deer when they were encountered (i.e., deer would still be in the optimum diet), the presence of bison should influence the use of low ranked animals and plants. The reemergence of bison, depending on its magnitude and spatial scale, should have a significant impact on the adaptations of hunters and gatherers in Texas.

Mauldin and Kemp's (2005) study considered only the Late Archaic and the Late Prehistoric periods. Consequently, we lack any recent data on bison presence/absence in the Middle Archaic within Texas. Given the importance of bison in our model, we need to establish if bison were present in the Middle Archaic in Central and South Texas. We reviewed 32 Middle Archaic components within the archeological literature within the broad research area (Table
11-2), dividing the Middle Archaic into two intervals tied to projectile point types. The initial interval, the Early Middle Archaic, is from roughly 6000 to $5000 \mathrm{BP}$, corresponding to Collins's period of bison abundance and defined primarily by the presence of Bell, Andice, and Calf Creek style projectile points. We define the second interval, the Late Middle Archaic, by the presence of Nolan, Travis, or Taylor projectile point styles. This interval spans the remaining portions of the Middle Archaic Period (ca. 5000-4000 BP). We initially reviewed sites of the appropriate age within Bexar County and then proceeded outside the county. Of the 32 reviewed components, 8 (25\%) contained bison remains, 3 of 13 (23\%) Early Middle Archaic components and 5 of 19 (26\%) Late Middle Archaic components. Figure 11-1 illustrates bison presence or absence on the 32 Middle Archaic components as well as Late Archaic components from Mauldin and Kemp (2005).

We charted the percentage of components positive for bison (Figure 11-2) by temporal periods. Our review supports Collins's (1995; 2004) suggestion that bison were present early in the Middle Archaic, however, contrary to his Late Middle Archaic data, our review determined that bison were also present in Central Texas in the Late Middle Archaic. Because many factors can affect the patterns of bison presence/absence seen in Figure 11-2 (e.g, changes in mobility systems, changes in length of site occupation, shifts in hunting strategies, field dressing practices, food preparation techniques, and disposal patterns), the percentage of positive components illustrated

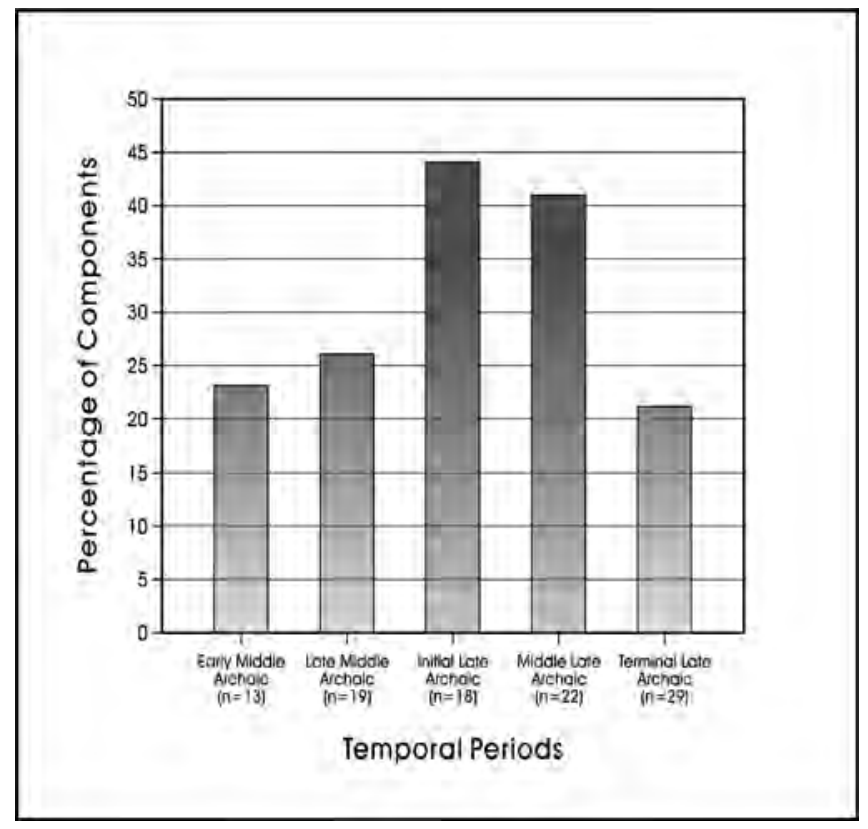

Figure 11-2. Percentage of Middle and Late Archaic components in Central Texas with bison. 
Table 11-1. Bison Presence/Absence in Central Texas Late Archaic Components

\begin{tabular}{|c|c|c|c|c|c|}
\hline Trinomial & Site Name & County & Terminal Late Archaic & Middle Late Archaic & Initial Late Archaic \\
\hline $41 \mathrm{BX} 17$ & Granberg & Bexar & $\mathrm{n} / \mathrm{a}$ & yes & $\mathrm{n} / \mathrm{a}$ \\
\hline 41BL85 & Landslide & Bell & $\mathrm{n} / \mathrm{a}$ & $\mathrm{n} / \mathrm{a}$ & yes \\
\hline 41BL104 & Evoe Terrace & Bell & yes & yes & yes \\
\hline 41BR420 & 41BR420 & Brown & no & $\mathrm{n} / \mathrm{a}$ & $\mathrm{n} / \mathrm{a}$ \\
\hline $41 \mathrm{CN} 95$ & $41 \mathrm{CN} 95$ & Coleman & no & $\mathrm{n} / \mathrm{a}$ & $\mathrm{n} / \mathrm{a}$ \\
\hline $41 \mathrm{CM} 1$ & Oblate Site & Comal & yes & yes & $\mathrm{n} / \mathrm{a}$ \\
\hline $41 \mathrm{CC} 222$ & $41 \mathrm{CC} 222$ & Concho & $\mathrm{n} / \mathrm{a}$ & $\mathrm{n} / \mathrm{a}$ & yes \\
\hline 41GD21 & 41GD21 & Goliad & $\mathrm{n} / \mathrm{a}$ & $\mathrm{n} / \mathrm{a}$ & yes \\
\hline 41HY209T & Mustang Branch & Hays & no & yes & $\mathrm{n} / \mathrm{a}$ \\
\hline 41HI055 & Sheep Shelter & Hill & no & no & $\mathrm{n} / \mathrm{a}$ \\
\hline 41HI117 & Bear Creek Shelter & Hill & $\mathrm{n} / \mathrm{a}$ & yes & yes \\
\hline 41KM69 & Flatrock Road & Kimble & no & $\mathrm{n} / \mathrm{a}$ & $\mathrm{n} / \mathrm{a}$ \\
\hline 41LK67 & 41LK67 & Live Oak & $\mathrm{n} / \mathrm{a}$ & no & no \\
\hline 41LK201 & 41LK201 & Live Oak & $\mathrm{n} / \mathrm{a}$ & $\mathrm{n} / \mathrm{a}$ & yes \\
\hline 41ML35 & Baylor Site & McLennan & no & $\mathrm{n} / \mathrm{a}$ & $\mathrm{n} / \mathrm{a}$ \\
\hline 41ML37 & Britton Site & McLennan & no & $\mathrm{n} / \mathrm{a}$ & $\mathrm{n} / \mathrm{a}$ \\
\hline $41 \mathrm{MC} 296$ & $41 \mathrm{MC} 296$ & McMullen & $\mathrm{n} / \mathrm{a}$ & yes & $\mathrm{n} / \mathrm{a}$ \\
\hline 41MM340 & 41MM340 & Milam & no & yes & yes \\
\hline 41TG91 & East Levee Site & Tom Green & $\mathrm{n} / \mathrm{a}$ & no & $\mathrm{n} / \mathrm{a}$ \\
\hline $41 \mathrm{TV} 42$ & Smith Rockshelter & Travis & yes & $\mathrm{n} / \mathrm{a}$ & $\mathrm{n} / \mathrm{a}$ \\
\hline 41VV74 & Fate Bell Shelter & Val Verde & no & $\mathrm{n} / \mathrm{a}$ & no \\
\hline 41VV82 & Coontail Spin & Val Verde & no & no & no \\
\hline $41 \mathrm{VV} 87$ & Perry Calk & Val Verde & no & $\mathrm{n} / \mathrm{a}$ & $\mathrm{n} / \mathrm{a}$ \\
\hline 41VV161 & 41VV161 & Val Verde & no & no & $\mathrm{n} / \mathrm{a}$ \\
\hline 41VV162 & $41 \mathrm{VV} 162$ & Val Verde & no & no & no \\
\hline $41 \mathrm{VV} 167$ & Eagle Cave & Val Verde & no & $\mathrm{n} / \mathrm{a}$ & no \\
\hline 41VV186 & 41VV186 & Val Verde & $\mathrm{n} / \mathrm{a}$ & $\mathrm{n} / \mathrm{a}$ & no \\
\hline 41VV187 & Parida Cave & Val Verde & no & $\mathrm{n} / \mathrm{a}$ & no \\
\hline 41VV189 & Damp Cave & Val Verde & no & $\mathrm{n} / \mathrm{a}$ & no \\
\hline 41VV213 & Baker Cave & Val Verde & no & no & no \\
\hline 41VV215 & Mosquito Cave & Val Verde & no & no & no \\
\hline $41 \mathrm{VV} 216$ & Zapilote Cave & Val Verde & no & no & $\mathrm{n} / \mathrm{a}$ \\
\hline $41 \mathrm{VV} 218$ & Bonfire Shelter & Val Verde & $\mathrm{n} / \mathrm{a}$ & yes & $\mathrm{n} / \mathrm{a}$ \\
\hline 41VV260 & Commack Site & Val Verde & no & no & $\mathrm{n} / \mathrm{a}$ \\
\hline 41WM2 & Merrell Site & Williamson & yes & $\mathrm{n} / \mathrm{a}$ & yes \\
\hline 41WM56 & Hawes Site & Williamson & no & no & $\mathrm{n} / \mathrm{a}$ \\
\hline 41WM118 & Dobias-Vitek & Williamson & yes & $\mathrm{n} / \mathrm{a}$ & $\mathrm{n} / \mathrm{a}$ \\
\hline 41WM130 & Hoxie Bridge & Williamson & yes & $\mathrm{n} / \mathrm{a}$ & $\mathrm{n} / \mathrm{a}$ \\
\hline 41WM230 & Loeve-Fox Site & Williamson & no & no & $\mathrm{n} / \mathrm{a}$ \\
\hline 41WM267 & Cervenka Site & Williamson & no & yes & $\mathrm{n} / \mathrm{a}$ \\
\hline 41WM815 & Rices Crossing & Williamson & $\mathrm{n} / \mathrm{a}$ & no & $\mathrm{n} / \mathrm{a}$ \\
\hline \multicolumn{3}{|c|}{ Total Components } & 29 & 22 & 18 \\
\hline \multicolumn{3}{|c|}{ Total Bison Present } & 6 & 9 & 8 \\
\hline \multicolumn{3}{|c|}{ Total Bison Absent } & 23 & 13 & 10 \\
\hline
\end{tabular}


Table 11-2. Bison Presence/Absence in Central Texas Middle Archaic Components

\begin{tabular}{|c|c|c|c|c|}
\hline Trinomial & Site Name & County & $\begin{array}{c}\text { Late Middle } \\
\text { Archaic }\end{array}$ & Early Middle Archaic \\
\hline 41AT123 & 41AT123 & Atascosa & no & $\mathrm{n} / \mathrm{a}$ \\
\hline 41BX1 & Olmos Dam & Bexar & yes & yes \\
\hline 41BX17 & Granberg Site & Bexar & yes & $\mathrm{n} / \mathrm{a}$ \\
\hline $41 \mathrm{BX} 47$ & 41BX47 & Bexar & no & no \\
\hline 41BX126 & Culebra Creek Site & Bexar & no & $\mathrm{n} / \mathrm{a}$ \\
\hline 41BX184 & Higgins Site & Bexar & no & no \\
\hline 41BX228 & Panther Springs & Bexar & yes & yes \\
\hline 41BX300 & 41BX300 & Bexar & no & $\mathrm{n} / \mathrm{a}$ \\
\hline 41BX377 & Cibolo Crossing Site & Bexar & $\mathrm{n} / \mathrm{a}$ & no \\
\hline 41BX831 & Richard Beene Site & Bexar & no & no \\
\hline 41BX996 & Number 6 Site & Bexar & no & $\mathrm{n} / \mathrm{a}$ \\
\hline 41CM111 & Royal Coachman Site & Comal & no & no \\
\hline 41DW270 & Smith Creek Bridge Site & DeWitt & no & no \\
\hline 41GD21 & 41GD21 & Goliad & $\mathrm{n} / \mathrm{a}$ & no \\
\hline 41HY37 & 41HY37 & Hays & no & $\mathrm{n} / \mathrm{a}$ \\
\hline 41KR537 & 41KR537 & Kerr & no & $\mathrm{n} / \mathrm{a}$ \\
\hline $41 \mathrm{LK} 31 / 32$ & $41 \mathrm{LK} 31 / 32$ & Live Oak & no & no \\
\hline 41ME29 & Jonas Terrace Site & Medina & yes & $\mathrm{n} / \mathrm{a}$ \\
\hline 41TV151 & Jetta Court Site & Travis & yes & yes \\
\hline $41 \mathrm{TV} 163$ & Millican Bench Site & Travis & no & $\mathrm{n} / \mathrm{a}$ \\
\hline 41TV1364 & Vera Daniel Site & Travis & $\mathrm{n} / \mathrm{a}$ & no \\
\hline 41UV45 & 41UV45 & Uvalde & no & $\mathrm{n} / \mathrm{a}$ \\
\hline $41 \mathrm{WN} 73$ & Shrew Site & Wilson & $\mathrm{n} / \mathrm{a}$ & no \\
\hline \multicolumn{3}{|c|}{ Total Components } & 19 & 13 \\
\hline \multicolumn{3}{|c|}{ Total Bison Present } & 5 & 3 \\
\hline \multicolumn{3}{|c|}{ Total Bison Absent } & 14 & 10 \\
\hline
\end{tabular}

in the figure are not necessarily representative of changes in bison frequencies in the natural environment through time. However, the data do demonstrate that bison were available at some density throughout the Middle Archaic and into the Late Archaic. We need to estimate what that density is in order to revise our archeological expectations.

Here, we are going to use patterns in grassland to estimate bison densities in the natural environment. As grasslands $\left(\mathrm{C}_{4}\right)$ increased in Texas from the Middle Archaic into the Late Archaic, peaking in the Initial Late Archaic, we suggest that bison densities will follow. We expect bison to steadily increase in number from the Early Middle Archaic into the Initial Late Archaic. Subsequently, as grasslands gradually decreased into the Terminal Late Archaic, we expect a corresponding decrease in bison densities. Population fluctuations of this highly ranked resource in response to shifts in grassland densities may result in short-term shifts in diet breadth at small temporal scales.

Prior to our review of Middle Archaic components, based on available data (McDonald 1981), we expected that Collins's (1995; 2004) suggestion, that bison were present early in the Middle Archaic, would be unsupported by our review. We expected an absence of bison throughout the entirety of the Middle Archaic period. Based on this expectation, we posited that during the Middle Archaic hunter-gatherer diets would be relatively broader than those of Late Archaic populations, with deer being the highest ranked post-encounter item. As bison re-enter the state sometime in the early portion of the Late Archaic, we expected a narrowing of the diet with hunters and gatherers dropping lower ranked plants and animals that 


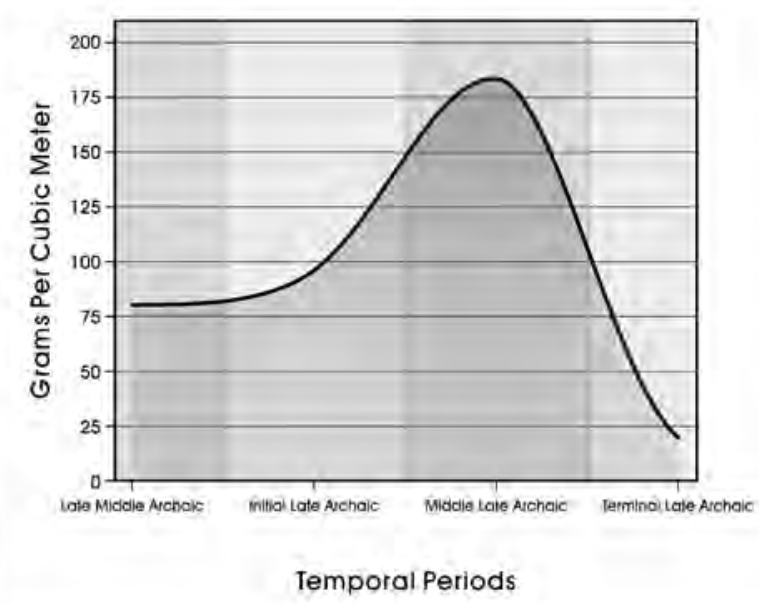

Figure 11-3. Volume of bone recovered from $41 B X 17$ by time period.

they had pursued during the Middle Archaic. Our review of Middle Archaic components did not meet our expectations. Bison are present throughout the period. If, as suggested by the climate data presented previously (see Figure 9-7), grasslands were increasing throughout the Middle Archaic, then we expect that bison were also increasing in number. If grasslands were extensive at the beginning of the Late Archaic period and declined gradually throughout the period, we also expect bison densities to have peaked in the early portion of the Late Archaic and decreased accordingly. At the same time, these climate changes may have resulted in increased habitat for deer. That is, we expect that near the end of the Late Archaic bison populations may have been smaller and more variable from year to year and from season to season, while deer populations would have been increasing. Below, we consider these suggestions in the context of faunal and floral remains.

\section{Faunal Remains}

Faunal remains recovered during the CAR's testing of 41BX17 that could be assigned to one of the four analytical units (AUs) weighed 1,834 grams. Table 11-3 shows the distribution of the vertebrate faunal remains by taxon and analytical unit. The largest sample was recovered from the Middle Late Archaic (MLA) AU (571 gm) followed by the Late Middle Archaic (LMA, $497 \mathrm{gm}$ ) and the Initial Late Archaic (ILA, $398 \mathrm{gm}$ ). The smallest sample was collected from the Terminal Late Archaic (TLA) AU (66 gm). The highest bone weight per cubic meter of sediment was found in the MLA AU $\left(185 \mathrm{gm} / \mathrm{m}^{3}\right)$ followed by the ILA $(97 \mathrm{gm} /$ $\left.\mathrm{m}^{3}\right)$ and the LMA $\left(80 \mathrm{gm} / \mathrm{m}^{3}\right)$. The smallest volume was recovered from the TLA $\left(20 \mathrm{gm} / \mathrm{m}^{3}\right)$. With the exception of the TLA AU, there appears to be a decrease in volume of bone from the youngest to the oldest AU (Figure 11-3). This pattern may be reflecting differential preservation. The faunal raw data is provided in Appendix F.

Although only $46.4 \mathrm{gm}$ of bone (MLA AU) could be unequivocally identified as bison (Bison bison), many of the mammalian bones could be categorized in terms of size into small, medium, large, and very large mammal groups. The small group (18 $\mathrm{gm}$ ) is derived from rabbit-sized animals, the medium-sized group (1 gm) consists of dogsized specimens, the large-sized group (545 gm) contains deer-sized bones, and the very large-sized group (354 gm) contains bison-sized animal bones. The breakdown of the specimens in the very large mammal category by analytical unit indicates that bison-sized remains make up $67 \mathrm{gm} / \mathrm{m}^{3}$ (36\%) of the MLA AU (identified Bison bison, Bovinae and very large mammal), $32 \mathrm{gm} / \mathrm{m}^{3}$ (33\%) of the ILA AU (very large mammal), $10 \mathrm{gm} / \mathrm{m}^{3}$ (12\%) of the LMA AU (Bovinae and very large mammal), and $7 \mathrm{gm} / \mathrm{m}^{3}$ (35\%) of the TLA AU (very large mammal). Figure 11-4 charts the percentage of bison-sized, deer-sized, and rabbit-sized animal bone by AU. Bison-sized mammals are present in all four AUs, increasing from the LMA through the Late Archaic with a very slight decrease in the TLA period.

The faunal data from 41BX17 supports our conclusions drawn from our bison presence/absence data discussed previously. Bison are present throughout the Middle and Late Archaic periods (Figure 11-4). The Middle Archaic diet varies from those of Late Archaic occupations with a higher percentage of deer-sized and rabbit-sized mammals corresponding to the

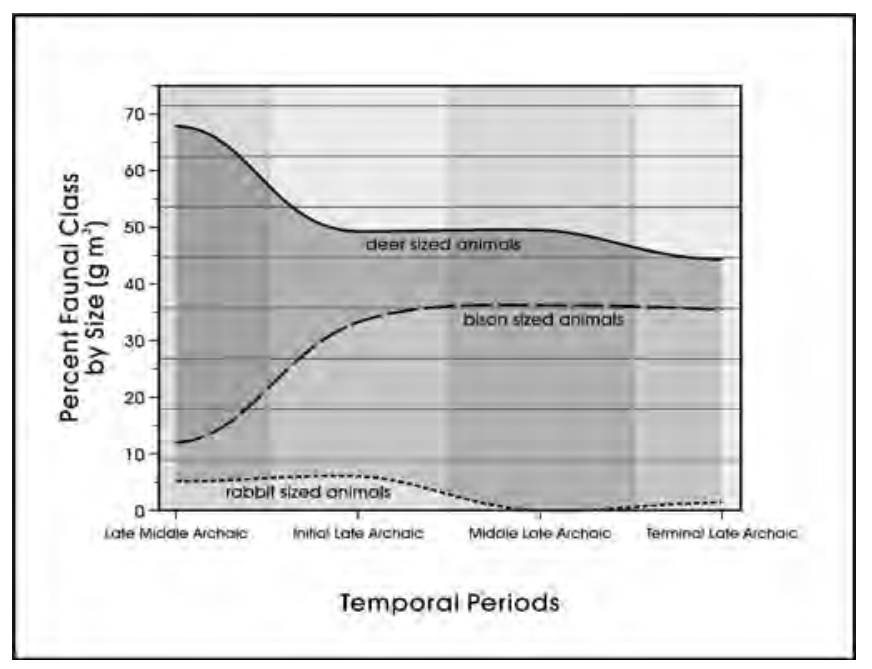

Figure 11-4. Taxa combined by size-class from 41BX17 by time period. 
lower incidence of bison. As bison presence increases to 33\% of the ILA assemblage, the presence of deer-sized mammals drops. As bison percentage increases into the MLA, deer presence remains steady, but rabbit-sized mammals decrease. Concurrent with the slight decrease in bison presence from this AU into the TLAAU, rabbit-sized mammals slightly increase while deer slightly decrease. Of interest, the percentage of deer-sized mammals in the assemblage decreases as bison presence increases, but deer never drop below $45 \%$ of the total assemblage. Although slight fluctuations in numbers of deer-sized mammals are expected with fluctuations in bison numbers, deer remain a vital part of the optimum diet and were likely hunted whenever encountered.

Two measures used to track diet breadth in faunal material are measures of taxa richness and shifts in the percentages of unclassified fragments. An increase in species richness signals an increase in diet breadth, while a decrease in number of species present in an assemblage signals a narrowing of the diet. As a group, taxa richness should be greater in the Middle Archaic when compared to the Late Archaic pattern. In addition, within both periods, taxa richness should be higher in components without bison when contrasted with components that have bison present. Finally, we expect taxa richness to slowly decrease throughout the Middle Archaic as bison densities increase resulting in the elimination of lower ranked plants and animals, whereas taxa richness should slowly increase throughout the Late Archaic, as bison decline resulting in the incorporation of lower ranked plants and animal, and an increased focus on deer. Collapsing the 41BX17 assemblage from Table 11-3 into 23 faunal classes (Table 11-4) resulted in 10 taxa for the LMA AU, 8 for the

Table 11-3. Weight and Volume of Taxa by Time Period from 41BX17

\begin{tabular}{|c|c|c|c|c|c|c|c|c|c|}
\hline \multirow[b]{2}{*}{ Taxa } & \multicolumn{2}{|c|}{$\begin{array}{c}\text { Terminal Late } \\
\text { Archaic }\end{array}$} & \multicolumn{2}{|c|}{ Middle Late Archaic } & \multicolumn{2}{|c|}{ Initial Late Archaic } & \multicolumn{2}{|c|}{ Late Middle Archaic } & \multirow{2}{*}{$\begin{array}{c}\text { Total } \\
\text { wt (gm) }\end{array}$} \\
\hline & wt (gm) & $\operatorname{vol}\left(\mathrm{gm} / \mathrm{m}^{3}\right)$ & wt (gm) & $\operatorname{vol}\left(\mathrm{gm} / \mathrm{m}^{3}\right)$ & wt (gm) & $\operatorname{vol}\left(\mathrm{gm} / \mathrm{m}^{3}\right)$ & wt (gm) & $\operatorname{vol}\left(\mathrm{gm} / \mathrm{m}^{3}\right)$ & \\
\hline Antilocapra americana & 2.4 & 0.74 & 0 & 0.00 & 0 & 0.00 & 1.3 & 0.21 & 3.7 \\
\hline Artiodactyl & 0 & 0.00 & 8 & 2.59 & 2.4 & 0.58 & 50.5 & 8.15 & 60.9 \\
\hline Aves & 0 & 0.00 & 0 & 0.00 & 0.16 & 0.04 & 0.3 & 0.05 & 0.46 \\
\hline Aves--large & 0.4 & 0.12 & 0 & 0.00 & 0 & 0.00 & 0 & 0.00 & 0.4 \\
\hline Aves--medium & 0 & 0.00 & 1.5 & 0.49 & 0.4 & 0.10 & 3.8 & 0.61 & 5.7 \\
\hline Aves--small & 0 & 0.00 & 0 & 0.00 & 0.2 & 0.05 & 0 & 0.00 & 0.2 \\
\hline Bison bison & 0 & 0.00 & 46.4 & 15.02 & 0 & 0.00 & 0 & 0.00 & 46.4 \\
\hline Bovinae & 0 & 0.00 & 10.9 & 3.53 & 0 & 0.00 & 8 & 1.29 & 18.9 \\
\hline Canis sp. & 0 & 0.00 & 0.3 & 0.10 & 0 & 0.00 & 0 & 0.00 & 0.3 \\
\hline Carnivora & 0 & 0.00 & 0 & 0.00 & 0 & 0.00 & 0.3 & 0.05 & 0.3 \\
\hline Geomys sp. & 0 & 0.00 & 0.1 & 0.03 & 0 & 0.00 & 0 & 0.00 & 0.1 \\
\hline Lepus Californicus & 0 & 0.00 & 0.3 & 0.10 & 0.3 & 0.07 & 4.9 & 0.79 & 5.5 \\
\hline Mammal & 13 & 4.02 & 74.82 & 24.21 & 51.77 & 12.57 & 62.18 & 10.03 & 201.77 \\
\hline Mammal--large & 26.2 & 8.11 & 183.6 & 59.42 & 143.44 & 34.82 & 191.44 & 30.88 & 544.68 \\
\hline Mammal--medium & 0 & 0.00 & 0.6 & 0.19 & 0 & 0.00 & 0.3 & 0.05 & 0.9 \\
\hline Mammal--small & 0.4 & 0.12 & 2.1 & 0.68 & 2.6 & 0.63 & 13.2 & 2.13 & 18.3 \\
\hline Mammal--very large & 23.2 & 7.18 & 149.46 & 48.37 & 130.02 & 31.56 & 51.29 & 8.27 & 353.97 \\
\hline Neotoma sp. & 0 & 0.00 & 0 & 0.00 & 0 & 0.00 & 0.5 & 0.08 & 0.5 \\
\hline Odocoileus virginianus & 0 & 0.00 & 90.5 & 29.29 & 46.1 & 11.19 & 101.94 & 16.44 & 238.54 \\
\hline Rodentia & 0 & 0.00 & 0.3 & 0.10 & 0.11 & 0.03 & 0.3 & 0.05 & 0.71 \\
\hline Sigmodon hispidus & 0 & 0.00 & 0 & 0.00 & 0.2 & 0.05 & 0.3 & 0.05 & 0.5 \\
\hline Sylvilagus sp. & 0 & 0.00 & 0.2 & 0.06 & 0.5 & 0.12 & 5 & 0.81 & 5.7 \\
\hline Testudines & 0.2 & 0.06 & 1.6 & 0.52 & 19.58 & 4.75 & 0.9 & 0.15 & 22.28 \\
\hline Ursus americanus & 0 & 0.00 & 0.6 & 0.19 & 0 & 0.00 & 0 & 0.00 & 0.6 \\
\hline Vertebrata & 0 & 0.00 & 0 & 0.00 & 0 & 0.00 & 0.8 & 0.13 & 0.8 \\
\hline Viperidae & 0 & 0.00 & 0 & 0.00 & 0 & 0.00 & 0.1 & 0.02 & 0.1 \\
\hline Total & 65.8 & 20.37 & 571.28 & 184.88 & 397.78 & 96.55 & 497.35 & 80.22 & 1834.010 \\
\hline
\end{tabular}


ILA, 12 for the MLA, and 5 for the TLA. The decrease in taxa from the LMA to the ILA is as expected, correlating with the increase in bison and pointing to a decreasing diet breadth over time as bison become more abundant on the landscape. However, the increase in taxa richness from the ILA to the MLA does not correspond with the slight increase in bison. We would expect the taxa richness to decrease as bison become more available to hunters resulting in a decreased diet breadth.

The second measure used to track diet breadth focuses on differences in the relative frequencies of bone fragments in the faunal assemblage. We expect that, on sites and during periods where bison are absent, the weight of fragments will account for a higher proportion of the total faunal assemblage weight. Conversely, when bison are present, the inverse should occur. Because of the intensive processing of skeletal remains for bone grease or marrow extraction, many faunal remains from archeological sites in Texas consist of fragmented, unidentified specimens. The fragmentation should be especially common during periods of dietary stress, when more intensive processing is anticipated, and less common under conditions of bison abundance. While researchers often ignore this class of remains, the weight of unidentifiable fragments relative to those that can be identified within an assemblage may provide a gross measure of processing and, indirectly, a measure of dietary stress. While complicated by the observation that larger animals are more likely to be involved with extensive processing for marrow and grease, we suggest that when bison are present (i.e., a narrow diet breadth) the overall weight of fragments to identified items will be lower than under conditions of dietary stress. Table 11-5 presents the weights of unidentified fragments by AU for the Granberg faunal assemblage. The ratio of unidentified to identified fragments for the LMA, ILA, MLA, and TLA are 1.9:1, 4.8:1, 2.6:1, and 24.3:1, respectively. These ratios, contradictory to expectations based on grassland/bison data discussed previously, suggest that dietary stress increased from the LMA to the ILA then dropped in the MLA followed by a sharp increase in the TLA. The large percentage of fragmented bone in the TLA may be the result of heavy equipment, used to remove overburden and for general highway construction, compacting the upper layers of the site.

\section{Regional Comparisons}

To define broad trends in subsistence practices and investigate the suggestions presented above, we compiled comparable data on 28 archeological components from 20 archeological sites (Table 11-6). The Early Middle Archaic (EMA) period is represented by seven components, the Late Middle Archaic (LMA) by ten components, the Initial Late Archaic (ILA) by four components, and the Middle Late Archaic (MLA) by seven components. Because the bone from the Granberg Site recovered from the Terminal Late Archaic (see Tables 11-3 and 11-5) was sparse and was highly fragmented (96\%), we decided to eliminate the component from our regional comparison. Table 11-7 presents the number of taxa and the sample size for each of the 28 components. Components with sample sizes of less than 50 specimens were not included in our faunal analysis. Six components, three EMA, two LMA, and one MLA, were eliminated from consideration. Twentytwo components from 18 sites, four from the EMA, eight from the LMA, four from the ILA, and six from the MLA, were reviewed for taxa richness. Five of the sites are from Central Texas and eleven are from the southern edge of Central Texas. The remaining two sites, one from East-Central Texas and one from West-Central Texas are peripheral to the region. The locations of the 18 sites are shown in Figure 11-5.

We compared the patterns of taxa richness at the Granberg Site, discussed above, with taxa data gathered from the 22 selected components. The taxa richness information for the 12 Middle Archaic components and 10 Late Archaic components is presented in Tables 11-8 and 11-9, respectively. The number of taxa range from a low of 1 to a high of 15 , and sample sizes vary considerably between components. Because sample size may impact taxa richness, we used regression analysis between sample size and taxa

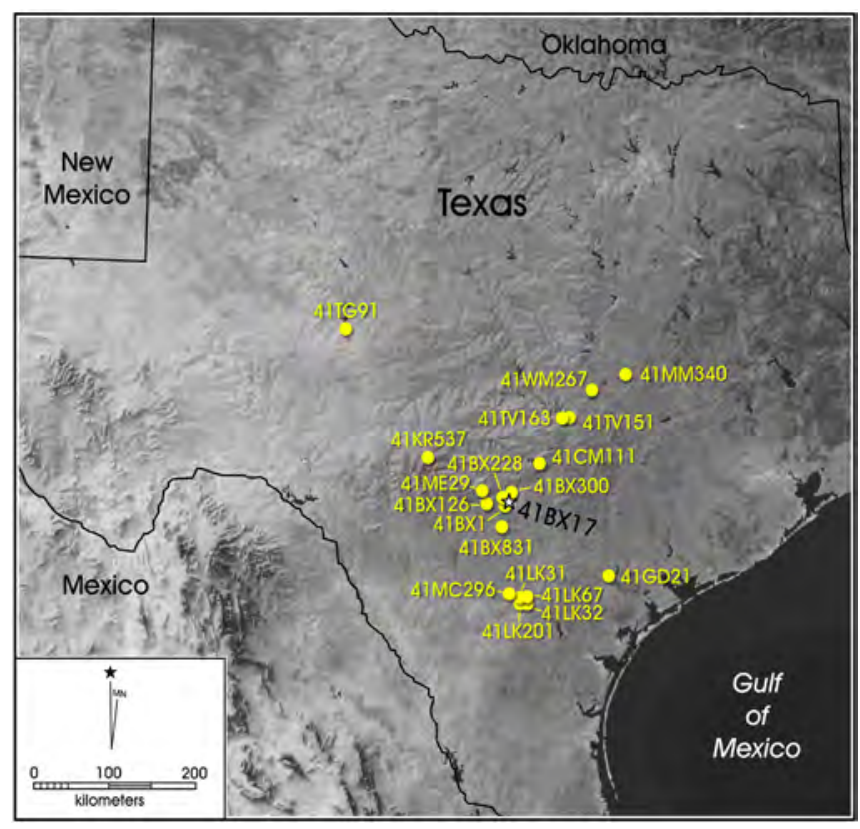

Figure 11-5. Location of archeological sites mentioned in the comparative faunal analysis discussion. 
Table 11-4. Breakdown of Faunal Assemblage by Taxa and Analytical Unit from 41BX17

\begin{tabular}{|c|c|c|c|c|c|}
\hline Taxa & Members Selected & $\begin{array}{l}\text { Late Middle } \\
\text { Archaic }\end{array}$ & $\begin{array}{c}\text { Initial Late } \\
\text { Archaic }\end{array}$ & $\begin{array}{l}\text { Middle Late } \\
\text { Archaic }\end{array}$ & $\begin{array}{c}\text { Terminal Late } \\
\text { Archaic }\end{array}$ \\
\hline Artiodactyla & $\begin{array}{c}\text { Bison, Bovidae, Bison-Sized, } \\
\text { Very Large Mammal }\end{array}$ & $\mathrm{x}$ & $\mathrm{x}$ & $\mathrm{x}$ & $\mathrm{x}$ \\
\hline Artiodactyla & Deer, Antelope, Deer-Sized & $\mathrm{x}$ & $\mathrm{x}$ & $\mathrm{x}$ & $\mathrm{x}$ \\
\hline Artiodactyla & Peccary & & & & \\
\hline Carnivora & Canis, Dog-sized & & & $\mathrm{x}$ & \\
\hline Carnivora & Felidae & & & & \\
\hline Carnivora & $\begin{array}{l}\text { Mustelidae (skunks, badgers) } \\
\text { and Procyonidae (racoons) }\end{array}$ & & & & \\
\hline Insectivora & Shrews & & & & \\
\hline Lagomorphia & Jackrabbit, Rabbit-Sized & $\mathrm{x}$ & $\mathrm{x}$ & $\mathrm{x}$ & \\
\hline Lagomorphia & Cottontail & $\mathrm{x}$ & $\mathrm{x}$ & $\mathrm{x}$ & \\
\hline Marsupialia & Oppossum & & & & \\
\hline Testudines & Turtles, Sliders, Tortoise & $\mathrm{x}$ & $\mathrm{x}$ & $\mathrm{x}$ & $\mathrm{x}$ \\
\hline Rodentia & Gophers, Medium-Sized Rodents & & & $\mathrm{x}$ & \\
\hline Rodentia & Beavers & & & & \\
\hline Rodentia & Mice,Rats, Voles, Small Rodents & $\mathrm{x}$ & $\mathrm{x}$ & $\mathrm{x}$ & \\
\hline Rodentia & Squirrel & & & & \\
\hline Aves & $\begin{array}{c}\text { Turkey, Hawks, Eagles, Large } \\
\text { Birds }\end{array}$ & & & & \\
\hline Aves & $\begin{array}{l}\text { Other Birds (Ducks, Quail, } \\
\text { Medium and Small Birds) }\end{array}$ & $\mathrm{x}$ & $\mathrm{x}$ & $\mathrm{x}$ & $\mathrm{x}$ \\
\hline Osteichtyes & Fish & & & & \\
\hline Anura & Frogs, Toads & & & & \\
\hline Reptilia & Snakes, Lizards & $\mathrm{x}$ & & & \\
\hline Various & Mussels, Oysters & $\mathrm{x}$ & & $\mathrm{x}$ & \\
\hline Various & Snails & $\mathrm{x}$ & $\mathrm{x}$ & $\mathrm{x}$ & $\mathrm{x}$ \\
\hline Various & Other & & & $\mathrm{x}$ & \\
\hline Total & & 10 & 8 & 12 & 5 \\
\hline
\end{tabular}

richness to determine the significance of impact, if any. The regression analysis resulted in a correlation coefficient of $0.163\left(\mathrm{R}^{2}=0.0266\right)$, indicating that sample size does not have a significant impact on taxa richness in this sample.

The average number of taxa in the four Early Middle Archaic components is four, ranging from two to seven classes. The nine Late Middle Archaic components average six taxa, though a wide range of one to thirteen taxa is present during this time period. An average of eight taxa types are present in the Initial Late Archaic components ranging from a low of two and a high of eleven. The seven Middle Late Archaic components average ten taxa, ranging from two to fifteen classes. Bison are represented in all four time periods, present in one of the EMA components (25\%), four of the LMA components (44\%), four of the ILA components $(80 \%)$, and five of the MLA components (71\%). This distribution corresponds nicely with the bison presence data discussed above (see Figure 11-2). Bison presence increases from the EMA to the LMA, increases steeply into the ILA, and then falls slightly in the MLA. Since bison are increasing throughout the Middle Archic, peaking in the ILA, and declining in the MLA, we could expect decreasing taxa numbers throughout the Middle Archaic into the Late Archaic followed by increasing numbers in the MLA. We would further expect variances in numbers of lower ranked resources in response to the patterns of bison on the landscape 
Table 11-5. Breakdown of Unidentified Fragments by Class and Analytical Unit from 41BX17

\begin{tabular}{|c|c|c|c|c|}
\hline Fragments & $\begin{array}{c}\text { Late Middle Archaic } \\
\text { (wt in gm) }\end{array}$ & $\begin{array}{c}\text { Initial Late } \\
\text { Archaic (wt in } \\
\mathbf{g m})\end{array}$ & $\begin{array}{c}\text { Middle Late } \\
\text { Archaic (wt in gm) }\end{array}$ & $\begin{array}{c}\text { Terminal Late } \\
\text { Archaic (wt in gm) }\end{array}$ \\
\hline Mammal--very large & 51.29 & 130.02 & 149.46 & 23.2 \\
\hline Mammal--large & 191.44 & 143.44 & 183.6 & 26.2 \\
\hline Mammal--medium & 0.3 & 0 & 0.6 & 0 \\
\hline Mammal--small & 13.2 & 2.6 & 2.1 & 0.4 \\
\hline Mammal-size indeterminate & 62.18 & 51.77 & 74.82 & 13 \\
\hline Carnivora & 0.3 & 0 & 0 & 0 \\
\hline Aves--large & 0 & 0 & 0 & 0 \\
\hline Aves--medium & 3.8 & 0.4 & 1.5 & 0 \\
\hline Aves--small & 0 & 0.2 & 0 & 0 \\
\hline Aves-size indeterminate & 0.3 & 0.16 & 0 & 0 \\
\hline Vertebrata & 0.8 & 0 & 0 & 63.2 \\
\hline Total weight (gm) & 323.61 & 328.59 & 412.08 & 0.4 \\
\hline
\end{tabular}

Table 11-6. Archeological Components Reviewed for Faunal Regional Comparison

\begin{tabular}{|c|c|c|c|c|}
\hline \multirow[b]{2}{*}{ Site } & \multicolumn{4}{|c|}{ Time Periods } \\
\hline & $\begin{array}{c}\text { Early Middle } \\
\text { Archaic }\end{array}$ & $\begin{array}{c}\text { Late Middle } \\
\text { Archaic }\end{array}$ & $\begin{array}{c}\text { Initial Late } \\
\text { Archaic }\end{array}$ & Middle Late Archaic \\
\hline 41BX1 & $\mathrm{x}$ & $\mathrm{x}$ & & \\
\hline 41BX126 & & $\mathrm{x}$ & & \\
\hline 41BX228 & $\mathrm{x}$ & $\mathrm{x}$ & & \\
\hline $41 \mathrm{BX} 300$ & & $\mathrm{x}$ & & \\
\hline $41 \mathrm{BX} 377$ & $\mathrm{x}$ & & & \\
\hline $41 \mathrm{BX} 831$ & $\mathrm{x}$ & $\mathrm{x}$ & & \\
\hline 41CM111 & $\mathrm{x}$ & & & \\
\hline 41GD21 & & & $\mathrm{x}$ & \\
\hline 41KM69 & & & & $\mathrm{x}$ \\
\hline $41 \mathrm{KR} 537$ & & $\mathrm{x}$ & & $\mathrm{x}$ \\
\hline 41LK201 & & & $\mathrm{x}$ & \\
\hline 41LK31/32 & $\mathrm{x}$ & $\mathrm{x}$ & & \\
\hline 41LK67 & & & $\mathrm{x}$ & \\
\hline $41 \mathrm{MC} 296$ & & & & $\mathrm{x}$ \\
\hline 41ME29 & & $\mathrm{x}$ & & $\mathrm{x}$ \\
\hline 41MM340 & & & $\mathrm{x}$ & $\mathrm{x}$ \\
\hline 41TG91 & & & & $\mathrm{x}$ \\
\hline $41 \mathrm{TV} 151$ & $\mathrm{x}$ & $\mathrm{x}$ & & \\
\hline $41 \mathrm{TV} 163$ & & $\mathrm{x}$ & & \\
\hline 41WM267 & & & & $\mathrm{x}$ \\
\hline Total & 7 & 10 & 4 & 7 \\
\hline
\end{tabular}


Table 11-7. Number of Genera Identified by Component within the Comparative Faunal Assemblages

\begin{tabular}{|c|c|c|c|}
\hline Component & Site & Sample Size & \# of Taxa \\
\hline Early Middle Archaic & 41BX1 & 12 & 6 \\
\hline Early Middle Archaic & 41BX228 & 27 & 4 \\
\hline Early Middle Archaic & 41BX377 & 41 & 1 \\
\hline Early Middle Archaic & $41 \mathrm{BX} 831$ & 240 & 3 \\
\hline Early Middle Archaic & 41CM111 & 2266 & 2 \\
\hline Early Middle Archaic & 41LK31/32 & 1990 & 3 \\
\hline Early Middle Archaic & $41 \mathrm{TV} 151$ & 120 & 7 \\
\hline Late Middle Archaic & $41 \mathrm{BX} 1$ & 4173 & 13 \\
\hline Late Middle Archaic & 41BX126 & 259 & 2 \\
\hline Late Middle Archaic & $41 \mathrm{BX} 228$ & 1238 & 11 \\
\hline Late Middle Archaic & 41BX300 & 305 & 1 \\
\hline Late Middle Archaic & 41BX831 & 100 & 3 \\
\hline Late Middle Archaic & 41KR537 & 16 & 1 \\
\hline Late Middle Archaic & $41 \mathrm{LK} 31 / 32$ & 271 & 4 \\
\hline Late Middle Archaic & 41ME29 & 3 & 1 \\
\hline Late Middle Archaic & $41 \mathrm{TV} 151$ & 130 & 8 \\
\hline Late Middle Archaic & $41 \mathrm{TV} 163$ & 1159 & 2 \\
\hline Initial Late Archaic & 41GD21 & 91 & 8 \\
\hline Initial Late Archaic & 41LK201 & 2532 & 11 \\
\hline Initial Late Archaic & 41LK67 & 5492 & 2 \\
\hline Initial Late Archaic & 41MM340 & 1299 & 9 \\
\hline Middle Late Archaic & 41KM69 & 3 & 2 \\
\hline Middle Late Archaic & 41KR537 & 86 & 3 \\
\hline Middle Late Archaic & 41MC296 & 1485 & 14 \\
\hline Middle Late Archaic & 41ME29 & 205 & 2 \\
\hline Middle Late Archaic & 41MM340 & 1387 & 15 \\
\hline Middle Late Archaic & 41TG91 & 634 & 11 \\
\hline Middle Late Archaic & 41WM267 & 1214 & 15 \\
\hline
\end{tabular}

(e.g. seasonal limitations, patchy forage). However the taxa richness data from the comparative components points to a narrow diet breadth in the EMA with a steady increase to a wider diet breadth in the MLA (Figure 11-6).

While the number of components in our comparative data set is small, overall these data do not support our suggestions that wider diet breadth should be reflected when bison are scarce. Only the increase in taxa between the ILA and the MLA are consistent with our expectations, and that association may be spurious. The overall pattern, where fewer taxa are present in older periods, is strongly suggestive of preservation bias. When taxa richness is used to measure diet breadth, differential preservation, due to differences in bone density, significantly impacts the representation of different species within an assemblage as well as the survivability of different elements within the skeletal remains of a single species (Lyman 1984, 1994; Mauldin et al. 2004). The bones of larger animals tend to be denser than smaller animals. Likewise, within a single skeleton, humeri mid-shaft bones are denser than ribs and vertebrae. Therefore, differential preservation tends to decrease the number of softer bones within a skeleton and/ or species with less dense bone. In addition to bone density issues, varying soil and climatic conditions, as well as the age of an assemblage, impact faunal element preservation.

Number of taxa, then, may simply be telling us about preservation in this particular sample set. While there is no effective way to overcome this bias, we can explore the faunal data further by collapsing the 22 faunal classes into 5 size categories and then calculating the percentage of each category by temporal unit. The categories consist of very large 
mammals (bison), large mammal (deer), medium to small mammals (peccary, canis, felidae, mustelidae, jackrabbit, cottontail, opossum, turtles, gophers, beavers, and birds), very small faunal (shrews, mice and rats, squirrel, fish, frogs, and reptiles), and mussel and snail. While the number of taxa increases through time, the percentage of very small faunal and mussel and snail shell decreases from the EMA to the ILA with a slight increase in the MLA (Figure 11-7). The data suggests that as bison numbers increased on the landscape the reliance on small, lower ranked resources was reduced, and when bison began to decline after the ILA, lower ranked resources increased in importance. Although these patterns are consistent with suggested shifts in diet, other causes including differential preservation, sample size effects, and differing excavation strategies should not be ruled out.

In addition to taxa richness and shifts in relative dependence on different body size groups, we used the relative frequencies of bone fragments in comparative assemblages as a measure of dietary stress. Since bone fragmentation should be more prevalent during periods of stress, when we expect more intensive processing for marrow or bone grease removal, we

Table 11-8. Comparison of Middle Archaic Faunal Assemblage Richness between Granberg and Selected Central Texas Components

\begin{tabular}{|c|c|c|c|c|c|c|c|c|c|c|c|c|c|c|}
\hline & & $\begin{array}{l}\frac{D}{7} \\
\frac{\partial}{\gamma}\end{array}$ & $\underset{\nabla}{\vec{\gamma}}$ & 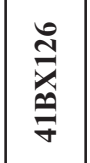 & 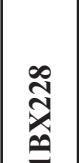 & 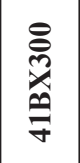 & $\bar{g}$ & & $\underset{\Xi}{\Xi}$ & & $\frac{\sqrt{2}}{\partial}$ & & $\frac{5}{5}$ & $\underset{7}{\stackrel{n}{7}}$ \\
\hline Taxa & Members Selected & LMA & LMA & LMA & LMA & LMA & EMA & LMA & EMA & EMA & LMA & EMA & LMA & LMA \\
\hline Artiodactyla & $\begin{array}{c}\text { Bison, Bovidae, Bison-Sized, Very } \\
\text { Large Mammal }\end{array}$ & $\mathrm{x}$ & $\mathrm{x}$ & & $\mathrm{x}$ & & & & & & & $\mathrm{x}$ & $\mathrm{x}$ & \\
\hline Artiodactyla & Deer, Antelope, Deer-Sized & $\mathrm{x}$ & $\mathrm{x}$ & & $\mathrm{x}$ & & & & & & $\mathrm{x}$ & $\mathrm{x}$ & $\mathrm{x}$ & \\
\hline Artiodactyla & Peccary & & & & & & & & & & & & & \\
\hline Carnivora & Canis, Dog-sized & & $\mathrm{x}$ & & $\mathrm{x}$ & & & & & & & $\mathrm{x}$ & & \\
\hline Carnivora & Felidae & & & & & & & & & & & & & \\
\hline Carnivora & $\begin{array}{l}\text { Mustelidae (skunks, badgers) and } \\
\text { Procyonidae (racoons) }\end{array}$ & & $\mathrm{x}$ & & & & & & & & & & & \\
\hline Insectivora & Shrews & & & & & & & & & & & & & \\
\hline Lagomorphia & Jackrabbit, Rabbit-Sized & $\mathrm{x}$ & $\mathrm{x}$ & $\mathrm{x}$ & $\mathrm{x}$ & & & & & & & & & \\
\hline Lagomorphia & Cottontail & $\mathrm{x}$ & $\mathrm{x}$ & & $\mathrm{x}$ & & & & & & & & $\mathrm{x}$ & \\
\hline Marsupialia & Oppossum & & $\mathrm{x}$ & & & & & & & & & & $\mathrm{x}$ & \\
\hline Testudines & Turtles, Sliders, Tortoise & $\mathrm{x}$ & $\mathrm{x}$ & & $\mathrm{x}$ & & & & & & & $\mathrm{x}$ & & \\
\hline Rodentia & Gophers, Medium-Sized Rodents & & & & & & & & & & & & $\mathrm{x}$ & \\
\hline Rodentia & Beavers & & & & & & & & & & & & & \\
\hline Rodentia & Mice,Rats, Voles, Small Rodents & $\mathrm{x}$ & $\mathrm{x}$ & & $\mathrm{x}$ & & $\mathrm{x}$ & $\mathrm{x}$ & & & & $\mathrm{x}$ & $\mathrm{x}$ & \\
\hline Rodentia & Squirrel & & & & & & & & & & & & & \\
\hline Aves & Turkey, Hawks, Eagles, Large Birds & & $\mathrm{x}$ & & $\mathrm{x}$ & & & & & & & & & \\
\hline Aves & $\begin{array}{c}\text { Other Birds (Ducks, Quail, Medium } \\
\text { and Small Birds) }\end{array}$ & $\mathrm{x}$ & $\mathrm{x}$ & & $\mathrm{x}$ & & & & & & $\mathrm{x}$ & & & \\
\hline Osteichtyes & Fish & & & & & & & & & $\mathrm{x}$ & & & & \\
\hline Anura & Frogs, Toads & & & & & & & & & & & & & \\
\hline Reptilia & Snakes, Lizards & $\mathrm{x}$ & & & & & & & & & & & & \\
\hline Various & Mussels, Oysters & $\mathrm{x}$ & $\mathrm{x}$ & & $\mathrm{x}$ & & $\mathrm{x}$ & $\mathrm{x}$ & $\mathrm{x}$ & $\mathrm{x}$ & $\mathrm{x}$ & $\mathrm{x}$ & $\mathrm{x}$ & $\mathrm{x}$ \\
\hline Various & Snails & $\mathrm{x}$ & $\mathrm{x}$ & $\mathrm{x}$ & $\mathrm{x}$ & $\mathrm{x}$ & $\mathrm{x}$ & $\mathrm{x}$ & $\mathrm{x}$ & $\mathrm{x}$ & $\mathrm{x}$ & $\mathrm{x}$ & $\mathrm{x}$ & $\mathrm{x}$ \\
\hline Total & & 10 & 13 & 2 & 11 & 1 & 3 & 3 & 2 & 3 & 4 & 7 & 8 & 2 \\
\hline
\end{tabular}


Table 11-9. Comparison of Late Archaic Faunal Assemblage Richness between Granberg and Selected Central Texas Components

\begin{tabular}{|c|c|c|c|c|c|c|c|c|c|c|c|c|c|}
\hline & & & $\begin{array}{l}n \\
\bar{x} \\
\overline{7}\end{array}$ & 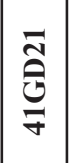 & $\begin{array}{l}\hat{n} \\
\tilde{n} \\
\approx \\
\forall\end{array}$ & $\begin{array}{l}\overline{\mathcal{O}} \\
\underline{\exists} \\
\bar{\nabla}\end{array}$ & $\begin{array}{l}\hat{\sigma} \\
\underline{y} \\
\exists\end{array}$ & 突 & $\underset{y}{\stackrel{\text { ज्ञ }}{y}}$ & & $\frac{f}{8}$ & $\begin{array}{l}\overline{8} \\
\underset{7}{\sigma}\end{array}$ & 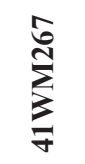 \\
\hline Taxa & Members Selected & ILA & MLA & ILA & MLA & ILA & ILA & MLA & MLA & ILA & MLA & MLA & MLA \\
\hline Artiodactyla & $\begin{array}{c}\text { Bison, Bovidae, Bison-Sized, Very Large } \\
\text { Mammal }\end{array}$ & $\mathrm{x}$ & $\mathrm{x}$ & $\mathrm{x}$ & & $\mathrm{x}$ & & $\mathrm{x}$ & $\mathrm{x}$ & $\mathrm{x}$ & $\mathrm{x}$ & & $\mathrm{x}$ \\
\hline Artiodactyla & Deer, Antelope, Deer-Sized & $\mathrm{x}$ & $\mathrm{x}$ & $\mathrm{x}$ & $\mathrm{x}$ & $\mathrm{x}$ & & $\mathrm{x}$ & $\mathrm{x}$ & $\mathrm{x}$ & $\mathrm{x}$ & $\mathrm{x}$ & $\mathrm{x}$ \\
\hline Artiodactyla & Peccary & & & & & & & $\mathrm{x}$ & & & & & \\
\hline Carnivora & Canis, Dog-sized & & $\mathrm{x}$ & & & $\mathrm{x}$ & & & & $\mathrm{x}$ & $\mathrm{x}$ & & $\mathrm{x}$ \\
\hline Carnivora & Felidae & & & & & & & & & & & & \\
\hline Carnivora & $\begin{array}{l}\text { Mustelidae (skunks, badgers) and } \\
\text { Procyonidae (racoons) }\end{array}$ & & & & & $\mathrm{x}$ & & & & $\mathrm{x}$ & $\mathrm{x}$ & & $\mathrm{x}$ \\
\hline Insectivora & Shrews & & & & & & & & & & & & \\
\hline Lagomorphia & Jackrabbit, Rabbit-Sized & $\mathrm{x}$ & $\mathrm{x}$ & & & $\mathrm{x}$ & & $\mathrm{x}$ & & $\mathrm{x}$ & $\mathrm{x}$ & $\mathrm{x}$ & $\mathrm{x}$ \\
\hline Lagomorphia & Cottontail & $\mathrm{x}$ & $\mathrm{x}$ & $\mathrm{x}$ & & $\mathrm{x}$ & & $\mathrm{x}$ & & $\mathrm{x}$ & $\mathrm{x}$ & $\mathrm{x}$ & $\mathrm{x}$ \\
\hline Marsupialia & Oppossum & & & $\mathrm{x}$ & & & & $\mathrm{x}$ & & & $\mathrm{x}$ & & \\
\hline Testudines & Turtles, Sliders, Tortoise & $\mathrm{x}$ & $\mathrm{x}$ & $\mathrm{x}$ & $\mathrm{x}$ & $\mathrm{x}$ & & $\mathrm{x}$ & & $\mathrm{x}$ & $\mathrm{x}$ & $\mathrm{x}$ & $\mathrm{x}$ \\
\hline Rodentia & Gophers, Medium-Sized Rodents & & $\mathrm{x}$ & & & & & & & & & & $\mathrm{x}$ \\
\hline Rodentia & Beavers & & & & & & & & & & $\mathrm{x}$ & & \\
\hline Rodentia & Mice,Rats, Voles, Small Rodents & $\mathrm{x}$ & $\mathrm{x}$ & $\mathrm{x}$ & & $\mathrm{x}$ & & $\mathrm{x}$ & & $\mathrm{x}$ & $\mathrm{x}$ & $\mathrm{x}$ & $\mathrm{x}$ \\
\hline Rodentia & Squirrel & & & & & & & $\mathrm{x}$ & & & & $\mathrm{x}$ & $\mathrm{x}$ \\
\hline Aves & Turkey, Hawks, Eagles, Large Birds & & & $\mathrm{x}$ & & $\mathrm{x}$ & & $\mathrm{x}$ & & & $\mathrm{x}$ & & $\mathrm{x}$ \\
\hline Aves & $\begin{array}{c}\text { Other Birds (Ducks, Quail, Medium and } \\
\text { Small Birds) }\end{array}$ & $\mathrm{x}$ & $\mathrm{x}$ & & $\mathrm{x}$ & $\mathrm{x}$ & & $\mathrm{x}$ & & & $\mathrm{x}$ & $\mathrm{x}$ & $\mathrm{x}$ \\
\hline Osteichtyes & Fish & & & $\mathrm{x}$ & & $\mathrm{x}$ & & $\mathrm{x}$ & & & $\mathrm{x}$ & $\mathrm{x}$ & $\mathrm{x}$ \\
\hline Anura & Frogs, Toads & & & & & & & $\mathrm{x}$ & & & & $\mathrm{x}$ & \\
\hline Reptilia & Snakes, Lizards & & & & & & & $\mathrm{x}$ & & & $\mathrm{x}$ & $\mathrm{x}$ & $\mathrm{x}$ \\
\hline Various & Mussels, Oysters & & $\mathrm{x}$ & & & & $\mathrm{x}$ & & & $\mathrm{x}$ & $\mathrm{x}$ & $\mathrm{x}$ & $\mathrm{x}$ \\
\hline Various & Snails & $\mathrm{x}$ & $\mathrm{x}$ & & & & $\mathrm{x}$ & & & & & & \\
\hline Various & Other & & $\mathrm{x}$ & & & & & & & & & & \\
\hline Total & & 8 & 12 & 8 & 3 & 11 & 2 & 14 & 2 & 9 & 15 & 11 & 15 \\
\hline
\end{tabular}

expect higher rates of unidentified fragments to identified fragments during periods of bison absence or scarcity. Because fragment data is rarely reported in literature, only seven components, three from the LMA, two from the ILA, and two from the MLA, are included in this analysis. Bone fragment data from all seven assemblages were collected at the Center for Archaeological Research by the faunal analyst (Table 11-10). Fragments were separated into five categories: very large mammal, large mammal, medium/small mammal, very small mammal, and mammal of indeterminate size. The total weight of the unidentified fragments for each component was divided by each component's total weight of 
Table 11-10. Comparison of Unidentified and Identified Fragment Weights (gm) from 41BX17 and Selected Central Texas Components

\begin{tabular}{|c|c|c|c|c|c|c|c|c|c|c|}
\hline \multirow{2}{*}{ Fragments } & \multicolumn{3}{|c|}{ 41BX17 } & \multirow{2}{*}{\begin{tabular}{|l|} 
41BX1 \\
LMA
\end{tabular}} & \multirow{2}{*}{$\begin{array}{c}\text { 41BX126 } \\
\text { LMA }\end{array}$} & \multirow{2}{*}{\begin{tabular}{|c|}
$41 \mathrm{BX} 228$ \\
LMA \\
\end{tabular}} & \multirow{2}{*}{\begin{tabular}{|c|} 
41LK201 \\
ILA
\end{tabular}} & \multirow{2}{*}{$\begin{array}{c}41 \mathrm{MC} 296 \\
\text { MLA }\end{array}$} & \multirow{2}{*}{$\begin{array}{c}41 \mathrm{MM} 340 \\
\text { ILA }\end{array}$} & \multirow{2}{*}{\begin{tabular}{|c|}
$41 \mathrm{MM} 340$ \\
MLA
\end{tabular}} \\
\hline & LMA & ILA & MLA & & & & & & & \\
\hline Mammal--very large & 51.29 & 130.02 & 149.46 & 83.1 & 0 & 0 & 45.16 & 269.73 & 174.93 & 324.32 \\
\hline Mammal--large & 191.44 & 143.44 & 183.6 & 305.3 & 5.7 & 352.1 & 51.38 & 296.71 & 664.18 & 752.86 \\
\hline Mammal--medium/small & 13.5 & 2.6 & 2.7 & 6.6 & 0 & 2.1 & 2.05 & 44.47 & 9.32 & 13.28 \\
\hline Mammal--very small & 0 & 0 & 0 & 0.2 & 0 & 0.3 & 0.82 & 0.75 & 0.01 & 0 \\
\hline Mammal-size indeterminate & 62.18 & 51.77 & 74.82 & 65.2 & 7.59 & 84.2 & 24.85 & 152.91 & 391.69 & 400.1 \\
\hline $\begin{array}{l}\text { Unidentified Fragments } \\
\text { (UF) }\end{array}$ & 318.41 & 327.83 & 410.58 & 460.4 & 13.29 & 438.7 & 124.26 & 764.57 & 1240.13 & 1490.56 \\
\hline Identified Fragments (IF) & 177.8 & 70.0 & 160.7 & 263.2 & 0.3 & 68.2 & 44.0 & 461.2 & 372.9 & 502.4 \\
\hline Ratio UF:IF & 1.8 & 4.7 & 2.6 & 1.7 & 47.5 & 6.4 & 2.8 & 1.7 & 3.3 & 3.0 \\
\hline
\end{tabular}

identified bone. One LMA component, 41BX126, $(\mathrm{n}=259)$ was eliminated from the comparative samples because the weight of the bone, unidentified and identified, only totaled 13.6 grams. We charted the mean ratio of the unidentified to identified bone by time period in Figure 11-8. The mean ratios for the LMA, ILA, and MLA are 3.3:1, 3.6:1, and 2.4:1, respectively. These ratios suggest that resource stress slightly increased from the LMA to the ILA then dropped in the MLA. The bone fragment data contrasts with our expectations based on bison availability estimates. We anticipated that stress would be lowest during the ILA when bison were at their peak density.

\section{Summary}

Our analysis of bison presence and absence in Central and South-Central Texas, discussed previously, established the presence of bison on archeological sites throughout the Middle and Late Archaic periods. We suggested that patterns of bison abundance should correspond to grassland densities, increasing from the Early Middle Archaic into the Initial Late Archaic, then decreasing into the Terminal Late Archaic. Based on the bison and grassland data, we expected a narrowing of the diet dreadth throughout the Middle Archaic with diet breadth widening following the peak bison densities in the Initial Late Prehistoric. The ratio of unidentified to identified bone fragments did not support our expectation but suggests that dietary stress increased from the LMA to the ILA then dropped in the MLA period. Our analysis of taxa richness at the site level, 41BX17, appeared to support the grassland data with decreasing diet breadth from the LMA to the ILA followed by an increase from the ILA to the
MLA. Patterns of taxa richness in comparative components do not support our expectations. The faunal data seem to reflect differential preservation with fewer taxa present with increasing component age. Grouping taxa by body size and focusing on shifts in the percentages of low return resources through time shows that as bison numbers increased on the landscape the reliance on small, lower ranked resources was reduced, and when bison began to decline after the ILA, lower ranked resources increased in importance. These patterns are consistent with suggested shifts in diet.

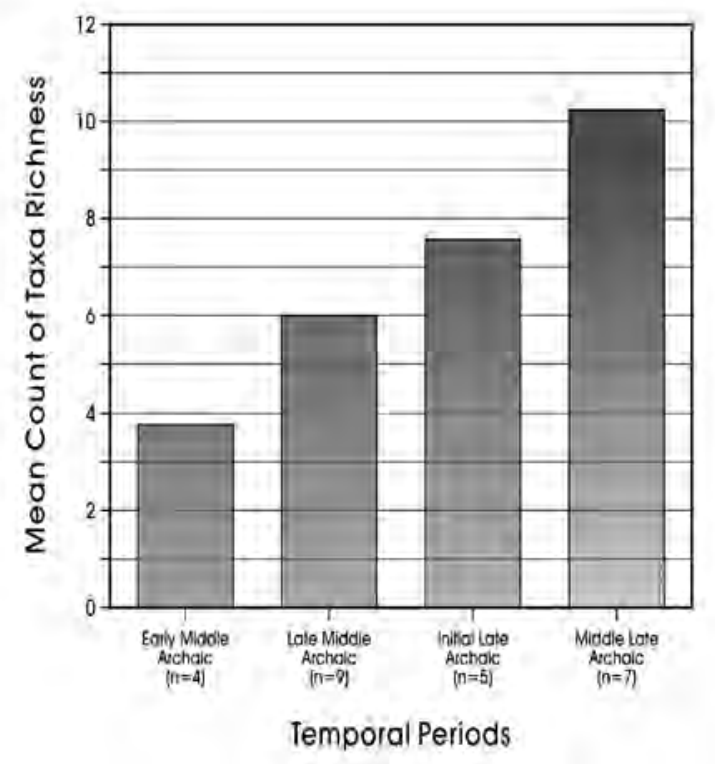

Figure 11-6. Taxa richness for comparative faunal assemblages by time period. 


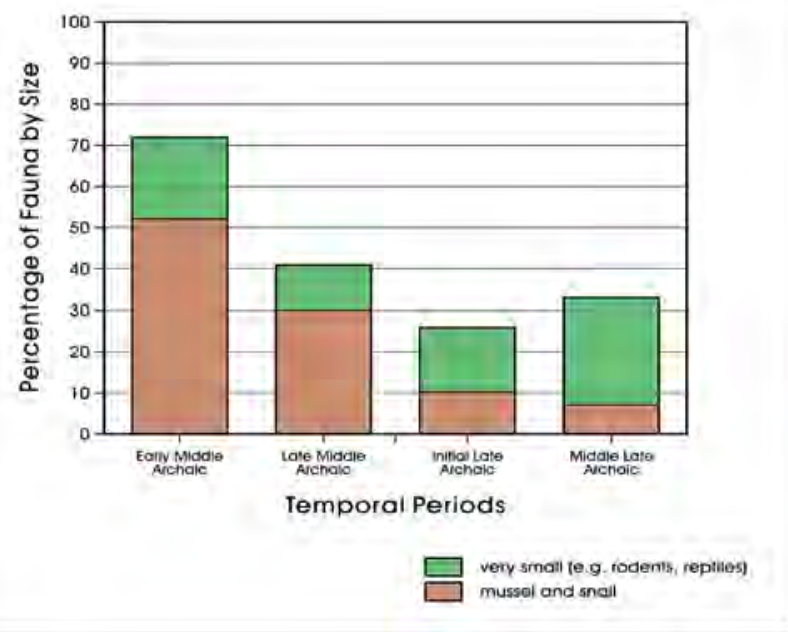

Figure 11-7. Percentage of fauna by size-class in each time period for Granberg and comparative sites.

\section{Plant Resources}

While the faunal analysis provided a measure of different animal resources collected through time, as well as data on the relative contribution of different taxa to the diet, gauging the contribution of plants to the diet is much more complicated. This complication is partly due to poor preservation of plant remains on open-air sites and to an absence of data from sites excavated prior to the mid-1970s. Therefore, direct measures, such as counts of various plant species present at a site, cannot be relied on.

Many plant resources, such as bulbs, roots, and nuts, often contain compounds that are not immediately digestible by humans. As a result, these classes of plants necessitate extended cooking times to convert the indigestible compounds to digestible resources. Figure 11-9 (bottom) shows ethnographically reported minimum cooking times for plant tissue (Wandsnider 1997). Only millet and acorns require cooking times shorter than 10 hours. Roots in general are reported to require between 15 and 20 hours of cooking, and cooking times for sotol, agave, yucca, and camas bulbs range from a minimum of 17 hours to nearly 60 hours. In contrast, cooking times for meat tissue derived from a majority of species require a maximum of five hours or less (see Figure 11-9, top). Only medium body size mammals such as deer and antelope may require $7-10$ hours of preparation and only the preparation of bison may take as much as from 4-20 hours depending on the size of the meat package being cooked. In general, however, small meat packages, such as a rack of ribs, meat fillets, and intestines, regardless of the animal, can be prepared in 1-2 hours.
Cooking facilities such as hearths without rock are adequate for preparing foods that require short cooking times and/or are cooked in containers such as pots (i.e., stews). However, when lengthier cooking times are necessary, the use of rocks to increase heat storage and lengthen heat dissipation is commonly employed (Ellis 1997; Wandsnider 1997). If we are correct in interpreting the relationship between plant and meat tissue cooking requirements and the length of cooking time required by each, we would expect that many plant resources, though not necessarily all plants, would be cooked in rock facilities especially in the absence of ceramics. Conversely, the majority of meats would be prepared in unlined hearths. Wandsnider's (1997) search of the ethnographic literature revealed a series of case studies that seem to support aspects of this general relationship. Although the sample of cases documenting facilities used to prepare animal tissue is small $(\mathrm{n}=12)$, only three $(25 \%)$ of the facilities have rock. Conversely, $76 \%$ (55 of 72) of the facilities used to cook plants contain rocks.

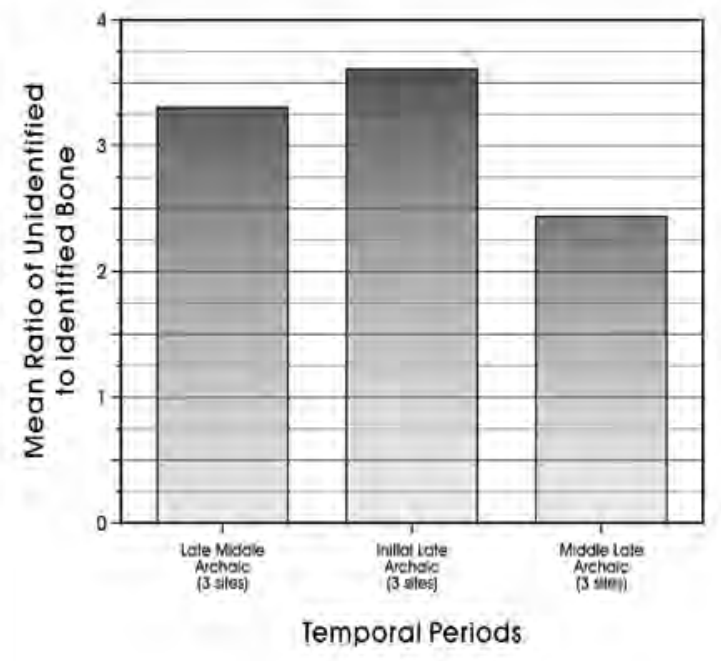

Figure 11-8. Mean ratio of unidentified bone to identified bone by time period.

Based on the ethnographic data that suggest a strong relationship between plant processing and the use of rock in thermal features, we propose that the frequency of rocklined hearths can serve as a gross proxy indicator of the intensity of plant processing, while feature type varieties, defined by feature size and rock weight, may indirectly provide a measure of the range of plants represented in the diet of hunters and gatherers. Clearly, there are a number of complications associated with this proxy that may render the measure difficult to interpret. We realize that thermal features in general, and thermal features with rock in particular, can be used for a variety of activities, some of which may have little or nothing to do with cooking. Furthermore, cooking 


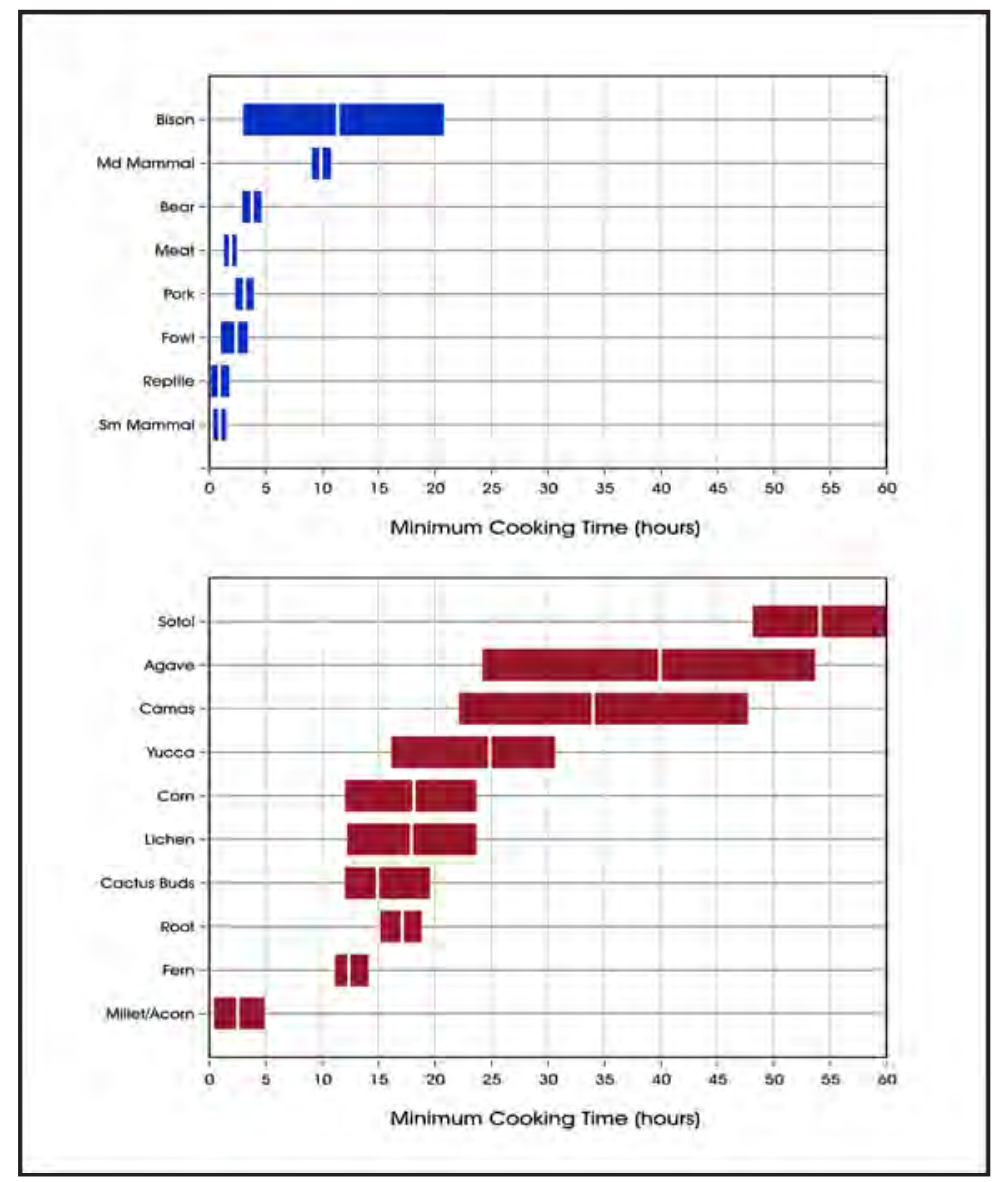

Figure 11-9. Ethnographically reported cooking time for meat (top) and plants (bottom). Bars show the interquartile range.

may frequently involve both plant and animal remains. Finally, the number and size of thermal features within a given component may be responding to a variety of other factors. These minimally may include (1) the size of the area excavated, (2) the size of the inhabiting population at a location, (3) the level of reoccupation, and (4) the way that cooking activities are organized (e.g., communal cooking versus individual household). While, as outlined subsequently, we can lessen the impact of some of these on the proposed proxy measure, we realize that the association of burned rock features with plant processing is tenuous and acknowledge that some features with burned rock, especially those with small quantities of rock, could easily represent general purpose activities where a variety of plants and animals were prepared. Nevertheless, features with significant quantities of rock are probably associated with long-term cooking, and long-term cooking is a requirement for many different types of plant resources.

In order to correct for differences in the nature of the cooking activities (communal versus individual food preparation), we monitored the size of the features identified for a given component within a site from a sample of sites in the study region. Feature size (length by width), as well as shape, was determined to arrive at an area estimate. This measure may also help ameliorate the impact of differences in the number of inhabitants, as we would expect that larger populations would generate either more hearths, or larger hearths, relative to smaller groups of hunters-gatherers. Furthermore, we can, in most cases, identify the size of the excavation area associated with a given component, and we can scale our measure relative to that area. From these data we produced a measure of the number of rock features per square meter of excavated space, as well as a measure of the relative amount of that space devoted to burned rock features. We suggest that as plant resources decrease in the diet because of increasing bison availability that both of these values should decrease.

As noted in Chapter Five, nine features were excavated during the CAR's testing of the Granberg Site, two from the LMA, five from the ILA, one from the MLA, and one from the TLA. 
Table 11-11. Size, Weight, and Shape of 41BX17 Features

\begin{tabular}{|c|c|c|c|c|c|}
\hline Fea. \# & Count & Wt. (gm) & Time Period & Shape & Type \\
\hline 100 & 417 & 44547 & TLA & Circle & Hearth \\
\hline 101 & 210 & 17819 & ILA & Irregular & Hearth \\
\hline 102 & 343 & 41648 & ILA & Irregular & Hearth \\
\hline 103 & 174 & 17961 & MLA & Circle & Hearth \\
\hline 104 & 113 & 7519 & LMA & Circle & Burned Rock Cluster \\
\hline 105 & 20 & 4776 & ILA & Circle & Hearth \\
\hline 106 & 805 & 109443 & ILA & Irregular & Burned Rock Cluster \\
\hline 107 & 22 & 7387 & LMA & Irregular & Hearth \\
\hline 108 & 113 & 14332 & ILA & Irregular & Burned Rock Cluster \\
\hline
\end{tabular}

These features were of two types: hearths and burned rock clusters. Hearth features exhibited deliberate placement of rock whereas burned rock cluster features appeared to consist of randomly placed burned rock in a concentrated area (Table 11-11). As a group these features are relatively large, averaging $123 \mathrm{~cm}$ in length by $80 \mathrm{~cm}$ in width. This average is based on measurements of the portion of the features within excavated units and do not necessarily estimate the total size of the features. By analytical unit, the ILA had the most features with 0.45 rock features $/ \mathrm{m}^{2}$, followed by the LMA with 0.33 rock features $/ \mathrm{m}^{2}$, the TLA with 0.13 rock features $/ \mathrm{m}^{2}$, and finally the MLA with 0.09 rock features $/ \mathrm{m}^{2}$. Looking at the analytical units from another angle, $51 \%$ of the ILA component was devoted to rock features, followed by $22 \%$ of the TLA, $8 \%$ of the LMA, and $7 \%$ of the MLA. As discussed in the previous section on the faunal assemblage, because bison or bison-sized mammals were present in all the components of 41BX17, overall diet breadth should be relatively narrow. Since bison populations should increase from the LMA to a peak in the ILA, followed by a gradual decrease to the TLA period, it is probable that lower ranked resources, specifically plants, would have been processed in greater numbers in the LMA and again in the TLA. With the exception of the MLA component, feature data from the site, rock features $/ \mathrm{m}^{2}$ and percent of component devoted to rock features, does not support this expectation. The ILA contains the most features per $\mathrm{m}^{2}$ and has the largest percent of excavated area devoted to rock features, while the LMA contained lower numbers of features $/ \mathrm{m}^{2}$ and a substantially lower percent of area devoted to features.

We contrasted the frequency of weights of the burned rock removed from each feature at 41BX17 to gauge their heating potential (see Black 2003). Although the association of burned rock features with plant processing is tenuous, we suggest that features with significant quantities of rock were probably associated with long-term cooking, as long-term cooking is a requirement for many different types of plant resources (Wandsnider 1997). We weighed each rock present in the Granberg Site features and constructed histograms to diagram the frequencies of rock sizes for each feature. Of the two LMA features (Figure 11-10), Feature 104 had the highest frequency of small rock (mean weight $=67 \mathrm{gm}$, Std Dev. $=93.798)$. The two features' total rock weights (see Table 11-11) were similar, although Feature 107 only contained 22 rocks in contrast to the 113 rocks in Feature
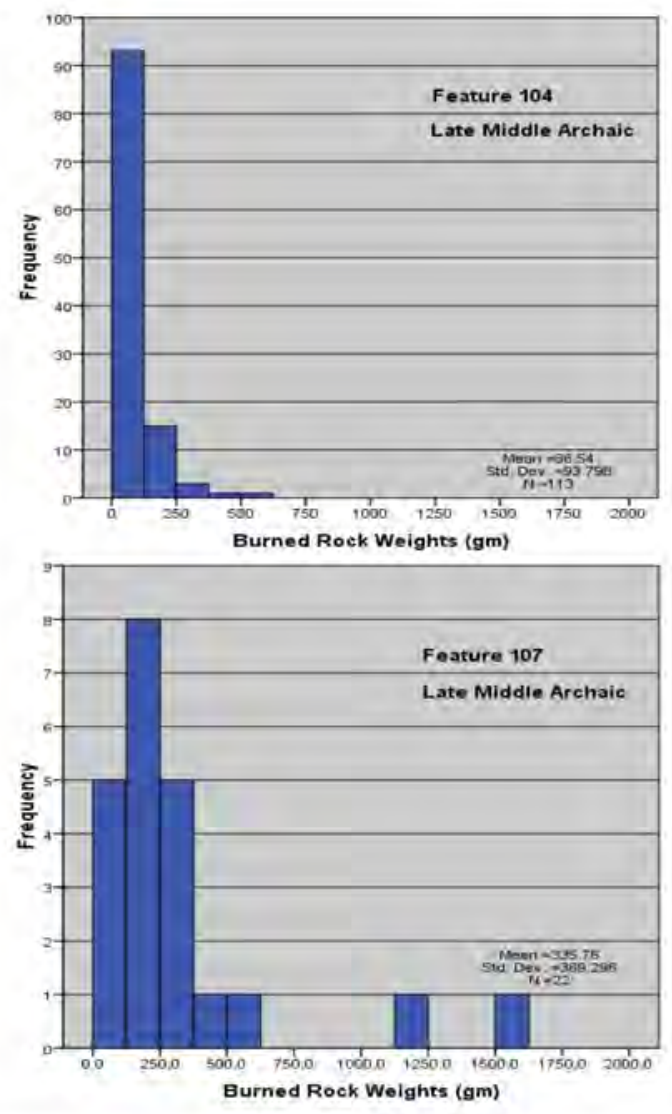

Figure 11-10. Frequency of burned rock weights in Late Middle Archaic features at $41 B X 17$. 


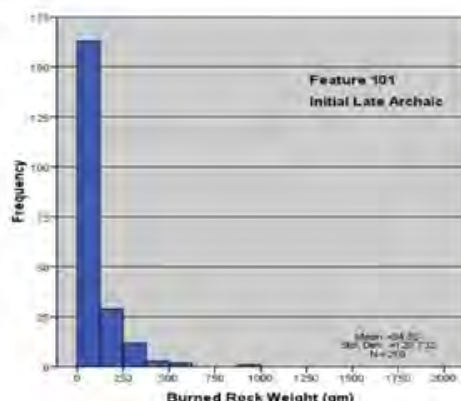

Burned Reck Weight (gm)
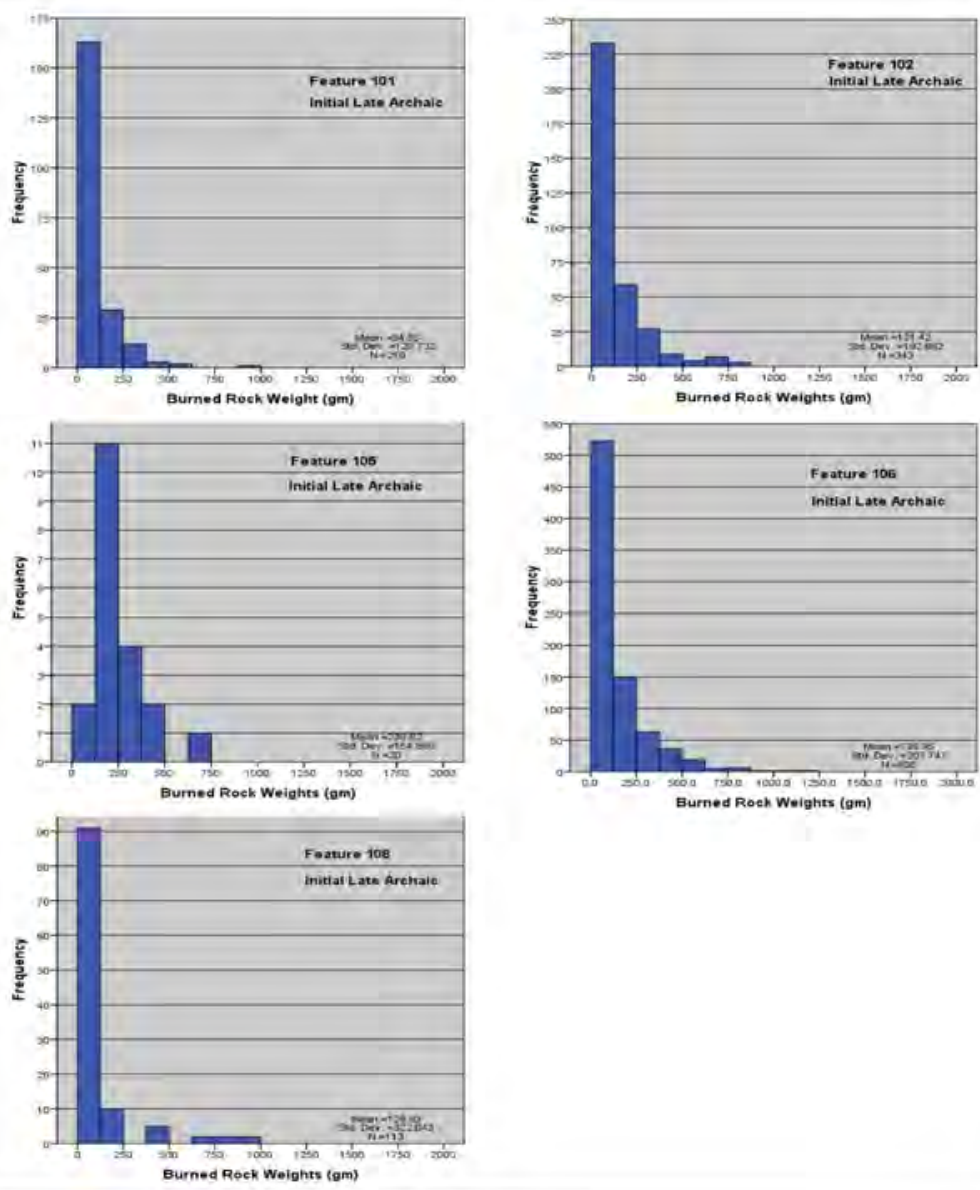

Figure 11-11. Frequency of burned rock weights in Initial Late Archaic features at $41 B \times 17$.

104. The mean rock weight for Feature 107 is $336 \mathrm{gm}$ with a standard deviation of 369.296. Higher frequencies of small rock suggests prolonged and/or repeated use of a feature with large rock breaking down over time as a result of cracking from exposure to high temperatures (see Thompson et al. 2008).

The Initial Late Archaic component contained five features with mean rock weights ranging from $85 \mathrm{gm}$ to $239 \mathrm{gm}$ (Figure 11-11). Feature 101 composed of 210 rocks weighing a total of $17,819 \mathrm{gm}$ contained the highest frequency of the small rock $($ mean $=85 \mathrm{gm})$. Features $108(\mathrm{n}=113), 102(\mathrm{n}=343)$, and $106(n=805)$ contained similar mean rock weights $(121$ $\mathrm{gm}$ to $136 \mathrm{gm}$ ) but varied in size with total rock weights of 14,332 gm, 41,648 gm, and 109,443 gm, respectively. These four ILA component features have frequencies skewed toward smaller rock weights suggesting prolonged or repeated cooking events. Feature 105 contained a larger mean rock weight $($ mean $=239 \mathrm{gm}$ ) but was substantially smaller in size, containing 20 rocks with a total weight of 4,776 gm. The smaller size and greater frequency of larger rock suggests that Feature 105 was not associated with long term cooking of plants.

The Middle Late Archaic component contained one feature, Feature 103, consisting of 174 burned rocks weighing a total of $17,961 \mathrm{gm}$ $($ mean $=103 \mathrm{gm})$. The distribution of rock is skewed towards small weights suggesting the reduction of large rock to small rock from prolonged or repeated exposure to high temperature (Figure 11-12). Feature 100, the sole Terminal Late Archaic hearth, was made up of 417 burned rocks weighing a total of 44,547 gm (mean $=107 \mathrm{gm})$. Although the distribution is skewed towards small rock, the standard deviation is high (321.883) with a fair amount of larger rock ranging from 500 gm to roughly $2000 \mathrm{gm}$ (Figure 11-13). The frequency distributions reveal that of the nine 41BX17 features, seven contained a majority of small rock suggesting prolonged and/or repeated use, possibly indicating the processing of plants requiring extended cooking. Two of the nine distributions were not skewed to small size rocks suggesting the possibility of a single event or of brief usage. Both were on the small end of the range of feature size, with one, Feature 105, consisting of only 20 rocks weighing $4,776 \mathrm{gm}$.

\section{Regional Comparisons}

To identify broad trends in subsistence practices and explore the suggestions presented above, we compiled comparable data on 34 archeological components from 23 archeological sites (Tables 11-12 to 11-15). The EMA period is represented by 7 components with 20 burned rock (BR) features, the LMA by 10 components with 12 BR features, the ILA by 4 components comprised of $16 \mathrm{BR}$ features, the MLA by 9 components with 38 BR features, and the TLA by 4 components comprised of 25 BR features. The sites are distributed across Central and South-Central Texas. Fourteen are located in South-Central Texas and six are from Central Texas. The remaining three sites are peripheral to the region, with one from East-Central Texas and two from West-Central Texas. The 23 sites are identified on Figure 11-14.

The 20 features comprising the EMA sample covered $38 \mathrm{~m}^{2}$ of a total of $238 \mathrm{~m}^{2}$ of excavated sediment while the 12 features from the LMA sample consist of $16 \mathrm{~m}^{2}$ of $171 \mathrm{~m}^{2}$ of excavation 
Table 11-12. Middle Archaic Feature Data from 41BX17 and Selected Central Texas Components

\begin{tabular}{|c|c|c|c|c|c|c|c|c|c|c|c|c|}
\hline Site & Component & $\begin{array}{c}\text { Total Burned } \\
\text { Rock Features }\end{array}$ & Feature \# & Shape & Length (m) & $\begin{array}{l}\text { Width } \\
\text { (m) }\end{array}$ & $\begin{array}{l}\text { Profile } \\
\text { Shape }\end{array}$ & $\begin{array}{l}\text { Area } \\
\left(\mathbf{m}^{2}\right)^{*}\end{array}$ & $\mid \begin{array}{c}\text { Total Rock } \\
\text { Feature } \\
\text { Area }(\mathrm{m} 2)\end{array}$ & $\begin{array}{c}\text { Total Area } \\
\text { Excavated } \\
\left(\mathbf{m}^{2}\right)\end{array}$ & $\begin{array}{c}\text { Rock } \\
\text { Features/ } \\
\mathbf{m}^{2}\end{array}$ & $\begin{array}{c}\text { Percent of } \\
\text { Component Devoted } \\
\text { to Rock Features (\%) }\end{array}$ \\
\hline \multirow{2}{*}{ 41BX17 } & \multirow{2}{*}{ LMA } & \multirow{2}{*}{2} & 104 & circular & 0.50 & 0.35 & basin & 0.142 & \multirow{2}{*}{0.474} & \multirow{2}{*}{6} & \multirow{2}{*}{0.33} & \multirow{2}{*}{7.90} \\
\hline & & & 107 & irregular & 0.70 & 0.60 & flat & 0.332 & & & & \\
\hline \multirow{4}{*}{ 41BX1 } & EMA & $\overline{0}$ & $\mathrm{n} / \mathrm{a}$ & $\mathrm{n} / \mathrm{a}$ & $\mathrm{n} / \mathrm{a}$ & $\mathrm{n} / \mathrm{a}$ & $\mathrm{n} / \mathrm{a}$ & $\mathrm{n} / \mathrm{a}$ & 0.000 & 60 & 0.00 & 0.00 \\
\hline & \multirow{3}{*}{ LMA } & \multirow{3}{*}{3} & 1 & oval & 0.35 & 0.25 & flat & 0.071 & \multirow{3}{*}{0.464} & \multirow{3}{*}{64} & \multirow{3}{*}{0.05} & \multirow{3}{*}{0.73} \\
\hline & & & 7 & irregular & 0.30 & 0.40 & no data & 0.096 & & & & \\
\hline & & & 9 & oval & 0.85 & 0.38 & flat & 0.297 & & & & \\
\hline \multirow{3}{*}{ 41BX126 } & \multirow{3}{*}{ LMA } & \multirow{3}{*}{3} & 7 & irregular & 1.30 & 1.30 & basin & 1.327 & \multirow{3}{*}{4.422} & \multirow{3}{*}{12} & \multirow{3}{*}{0.25} & \multirow{3}{*}{36.85} \\
\hline & & & 11 & circular & 1.30 & 1.30 & no data & 1.327 & & & & \\
\hline & & & 12 & irregular & 2.00 & 1.00 & no data & 1.767 & & & & \\
\hline \multirow{2}{*}{ 41BX228 } & EMA & 0 & $\mathrm{n} / \mathrm{a}$ & $\mathrm{n} / \mathrm{a}$ & $\mathrm{n} / \mathrm{a}$ & $\mathrm{n} / \mathrm{a}$ & $\mathrm{n} / \mathrm{a}$ & $\mathrm{n} / \mathrm{a}$ & 0.000 & 20 & 0.00 & 0.00 \\
\hline & LMA & 1 & $\mathrm{PO}$ & circular & 3.75 & 3.00 & basin & 8.946 & 8.946 & 25 & 0.04 & 35.78 \\
\hline $41 \mathrm{BX} 300$ & LMA & 0 & $\mathrm{n} / \mathrm{a}$ & $\mathrm{n} / \mathrm{a}$ & $\mathrm{n} / \mathrm{a}$ & $\mathrm{n} / \mathrm{a}$ & $\mathrm{n} / \mathrm{a}$ & $\mathrm{n} / \mathrm{a}$ & 0.000 & 4 & 0.00 & 0.00 \\
\hline & & & 9 & oval & 2.60 & 1.60 & no data & 3.464 & & & & \\
\hline & & & 10 & circular & 2.10 & 1.00 & flat & 1.887 & & & & \\
\hline & & & 11 & circular & 0.47 & 0.43 & basin & 0.159 & & & & \\
\hline & & & 17 & irregular & 0.50 & 0.40 & no data & 0.159 & & & & \\
\hline & & & 18 & circular & 3.80 & 2.40 & basin & 7.548 & & & & \\
\hline & & & 19 & irregular & 4.00 & 2.75 & flat & 8.946 & & & & \\
\hline 41BX377 & EMA & 13 & 24 & circular & 1.10 & 0.65 & no data & 0.601 & 25.596 & 59 & 0.22 & 43.38 \\
\hline & & & $25 \mathrm{~A}$ & rectangular & 0.80 & 0.35 & no data & 0.260 & & & & \\
\hline & & & $25 \mathrm{~B}$ & circular & 0.40 & 0.30 & no data & 0.096 & & & & \\
\hline & & & 27 & circular & 0.71 & 0.65 & flat & 0.363 & & & & \\
\hline & & & 28 & irregular & 1.00 & 1.00 & no data & 0.785 & & & & \\
\hline & & & 29 & circular & 1.40 & 1.00 & flat & 1.131 & & & & \\
\hline & & & 30 & circular & 0.80 & 0.20 & flat & 0.196 & & & & \\
\hline 41PY831 & EMA & 0 & $\mathrm{n} / \mathrm{a}$ & $\mathrm{n} / \mathrm{a}$ & n/a & $\mathrm{n} / \mathrm{a}$ & $\mathrm{n} / \mathrm{a}$ & $\mathrm{n} / \mathrm{a}$ & 0.000 & 37 & 0.00 & 0.00 \\
\hline 4IDADग1 & LMA & 1 & 26 & oval & 0.60 & 0.38 & basin & 0.189 & 0.189 & 24 & 0.04 & 0.79 \\
\hline 41CM111 & EMA & 1 & 3 & circular & 1.00 & 1.00 & no data & 0.785 & 0.785 & 34 & 0.03 & 2.31 \\
\hline 41KR537 & LMA & 0 & $\mathrm{n} / \mathrm{a}$ & $\mathrm{n} / \mathrm{a}$ & $\mathrm{n} / \mathrm{a}$ & $\mathrm{n} / \mathrm{a}$ & $\mathrm{n} / \mathrm{a}$ & $\mathrm{n} / \mathrm{a}$ & 0.000 & 2 & 0.00 & 0.00 \\
\hline & & & 1 & oval & 0.65 & 0.35 & basin & 0.196 & & & & \\
\hline & ת & 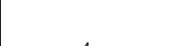 & 2 & irregular & 1.90 & 1.55 & no data & 2.337 & $0-10$ & 1 & $30-$ & $60^{2}$ \\
\hline $41 \mathrm{LK} 31 / 32$ & EMA & 4 & 3 & oval & 0.50 & 0.70 & basin & 0.283 & 8.542 & 16 & 0.25 & 53.39 \\
\hline & & & 10 & irregular & 3.00 & 2.40 & no data & 5.726 & & & & \\
\hline & LMA & 1 & 6 & circular & 1.10 & 0.87 & basin & 0.762 & 0.762 & 9 & 0.11 & 8.47 \\
\hline A1MEרO & IMA & 2 & 8 & oval & 0.35 & 0.35 & flat & 0.096 & 0234 & 6 & 032 & 556 \\
\hline 41ME29 & LMA & 2 & 9 & oval & 0.55 & 0.55 & flat & 0.238 & 0.334 & 6 & 0.33 & 5.56 \\
\hline & FMA & 2 & $2 \& 4$ & oval & 1.60 & 0.60 & flat & 0.950 & 3105 & 12 & 017 & 2012 \\
\hline 41TV151 & LIVIA & 2 & 6 & irregular & 1.80 & 1.80 & no data & 2.545 & 3.495 & 12 & 0.17 & 29.13 \\
\hline & LMA & 1 & 1 & irregular & no data & no data & flat & no data & no data & 12 & no data & no data \\
\hline $41 \mathrm{TV} 163$ & LMA & 0 & $\mathrm{n} / \mathrm{a}$ & $\mathrm{n} / \mathrm{a}$ & $\mathrm{n} / \mathrm{a}$ & $\mathrm{n} / \mathrm{a}$ & $\mathrm{n} / \mathrm{a}$ & $\mathrm{n} / \mathrm{a}$ & 0.000 & 7 & 0.00 & 0.00 \\
\hline Totals & & 34 & & & & & & & 54.008 & 409 & 0.08 & 13.21 \\
\hline
\end{tabular}

* The square meters recorded pertain to the portion of the feature excavated only and does not necessarily estimate the total size of the feature. 
Table 11-13. Initial Late Archaic Feature Data from 41BX17 and Selected Central Texas Components

\begin{tabular}{|c|c|c|c|c|c|c|c|c|c|c|c|c|}
\hline Site & Component & \begin{tabular}{|c} 
Total \\
Burned \\
Rock \\
Features
\end{tabular} & Rock Feature \# & Shape & $\begin{array}{c}\text { Length } \\
\text { (m) }\end{array}$ & $\begin{array}{c}\text { Width } \\
\text { (m) }\end{array}$ & $\begin{array}{l}\text { Profile } \\
\text { Shape }\end{array}$ & $\begin{array}{l}\text { Area } \\
\left(\mathrm{m}^{2}\right) *\end{array}$ & \begin{tabular}{|l} 
Total Rock \\
Feature \\
Area $(\mathrm{m} 2)$
\end{tabular} & $\begin{array}{l}\text { Total Area } \\
\text { Excavated } \\
\left(\mathbf{m}^{2}\right)\end{array}$ & $\begin{array}{c}\text { Rock Features/ } \\
\mathbf{m}^{2}\end{array}$ & $\begin{array}{c}\text { Percent of Component } \\
\text { Devoted to Rock } \\
\text { Features (\%) }\end{array}$ \\
\hline \multirow{5}{*}{ 41BX17 } & \multirow{5}{*}{ ILA } & \multirow{5}{*}{5} & 101 & irregular & 1.80 & 1.00 & flat & 1.539 & \multirow{5}{*}{5.636} & \multirow{5}{*}{11} & \multirow{5}{*}{0.45} & \multirow{5}{*}{51.23} \\
\hline & & & 102 & irregular & 2.00 & 1.00 & irregular & 1.767 & & & & \\
\hline & & & 105 & oval & 0.60 & 0.35 & irregular & 0.177 & & & & \\
\hline & & & 106 & irregular & 2.00 & 1.00 & flat & 1.767 & & & & \\
\hline & & & 108 & irregular & 0.47 & 0.93 & irregular & 0.385 & & & & \\
\hline 41GD21 & ILA & 1 & 1 & circular & 0.60 & 0.55 & no data & 0.260 & 0.260 & 6 & 0.17 & 4.33 \\
\hline \multirow{6}{*}{ 41LK67 } & \multirow{6}{*}{ ILA } & \multirow{6}{*}{6} & 8 & circular & 1.40 & 1.30 & no data & 1.431 & \multirow{6}{*}{3.741} & \multirow{6}{*}{68} & \multirow{6}{*}{0.09} & \multirow{6}{*}{5.50} \\
\hline & & & 24 & irregular & 1.04 & 0.47 & no data & 0.448 & & & & \\
\hline & & & 25 & irregular & 1.35 & 0.70 & no data & 0.825 & & & & \\
\hline & & & 26 & irregular & 1.07 & 0.70 & no data & 0.615 & & & & \\
\hline & & & 27 & irregular & 0.82 & 0.55 & no data & 0.369 & & & & \\
\hline & & & 28 & no data & 0.30 & 0.22 & no data & 0.053 & & & & \\
\hline \multirow{5}{*}{ 41LK201 } & \multirow{5}{*}{ ILA } & \multirow{5}{*}{5} & 4 & irregular & 0.60 & 0.30 & no data & 0.159 & \multirow{5}{*}{2.444} & \multirow{5}{*}{13} & \multirow{5}{*}{0.38} & \multirow{5}{*}{18.80} \\
\hline & & & 5 & oval & 0.85 & 0.80 & no data & 0.535 & & & & \\
\hline & & & 7 & irregular & 1.20 & 0.35 & no data & 0.472 & & & & \\
\hline & & & 8 & irregular & 1.30 & 0.80 & no data & 0.866 & & & & \\
\hline & & & 9 & oval & 0.80 & 0.65 & no data & 0.413 & & & & \\
\hline \multirow{4}{*}{ 41MM340 } & \multirow{4}{*}{ ILA } & \multirow{4}{*}{4} & 36 & irregular & 1.90 & 0.90 & no data & 1.539 & \multirow{4}{*}{3.242} & \multirow{4}{*}{56} & \multirow{4}{*}{0.07} & \multirow{4}{*}{5.79} \\
\hline & & & 44 & circular & 0.41 & 0.40 & no data & 0.129 & & & & \\
\hline & & & 47 & oval & 1.30 & 1.00 & no data & 1.039 & & & & \\
\hline & & & 49 & irregular & 1.25 & 0.40 & no data & 0.535 & & & & \\
\hline Totals & & 21 & & & & & & & 15.322 & 154 & 0.14 & 9.95 \\
\hline
\end{tabular}

* The square meters recorded pertain to the portion of the feature excavated only and does not necessarily estimate the total size of the feature.

resulting in each interval having 0.08 rock features $/ \mathrm{m}^{2}$ (Table 11-12). Sixteen percent of the EMA component is devoted to rock features, whereas only nine percent of the LMA is covered by the features. The ILA component contains 21 burned rock features covering $15 \mathrm{~m}^{2}$ of $154 \mathrm{~m}^{2}$ excavated $\left(0.14\right.$ rock features $\left./ \mathrm{m}^{2}\right)$. Ten percent of the component is comprised of rock features (Table 11-13). Thirty-nine features were uncovered on the MLA components consisting of $16 \mathrm{~m}^{2}$ of the $1,550 \mathrm{~m}^{2}$ of excavated sediment, translating to 0.03 rock features $/ \mathrm{m}^{2}$ (Table 11-14). One percent of the MLA component is devoted to burned rock features. Table 11-15 presents the burned rock feature data for the TLA component. Twenty-six features covered $17 \mathrm{~m}^{2}$ of an excavated $1,106 \mathrm{~m}^{2}$ $\left(0.02\right.$ rock features $\left./ \mathrm{m}^{2}\right)$. Two percent of the component is devoted to rock features. The percentage of each component devoted to burned rock features is illustrated on Figure 11-15.

Based on bison presence and climate data discussed in the previous sections, we expect the percentage of burned rock features to be fairly low across all the components with a decrease in percentage from the EMA to the ILA followed by a slight increase into the MLA and continuing to the TLA period. Diet breadth should have been narrow due to the presence of bison in all components, but fluctuating distributions (e.g. seasonal variance, patchy forage availability) should have resulted in the additions of low return resources (e.g. slow cooking plants) in times of scarceness or low reliability, 
Table 11-14. Middle Late Archaic Feature Data from 41BX17 and Selected Central Texas Components

\begin{tabular}{|c|c|c|c|c|c|c|c|c|c|c|c|c|}
\hline Site & Component & $\begin{array}{c}\text { Total } \\
\text { Burned } \\
\text { Rock } \\
\text { Features }\end{array}$ & $\begin{array}{c}\text { Rock Feature } \\
\#\end{array}$ & Shape & $\begin{array}{c}\text { Length } \\
\text { (m) }\end{array}$ & $\begin{array}{c}\text { Width } \\
\text { (m) }\end{array}$ & $\begin{array}{l}\text { Profile } \\
\text { Shape }\end{array}$ & $\begin{array}{l}\text { Area } \\
\left(\mathbf{m}^{2}\right)^{*}\end{array}$ & $\begin{array}{c}\text { Total Rock } \\
\text { Feature } \\
\text { Area }(\mathrm{m} 2)\end{array}$ & $\begin{array}{c}\text { Total Area } \\
\text { Excavated } \\
\left(\mathbf{m}^{2}\right)\end{array}$ & $\begin{array}{c}\text { Rock Features/ } \\
\mathbf{m}^{2}\end{array}$ & $\begin{array}{c}\text { Percent of } \\
\text { Component } \\
\text { Devoted to } \\
\text { Rock Features } \\
(\%)\end{array}$ \\
\hline 41BX17 & MLA & 1 & 103 & circular & 1.00 & 1.00 & irregular & 0.785 & 0.785 & 11 & 0.09 & 7.14 \\
\hline 41BX1032 & MLA & 1 & 4 & no data & 0.41 & 0.34 & basin & 0.110 & 0.110 & 3 & 0.33 & 3.68 \\
\hline \multirow{12}{*}{ 41KM69 } & \multirow{12}{*}{ MLA } & \multirow{12}{*}{12} & 35 & circular & 0.55 & 0.50 & basin & 0.217 & \multirow{12}{*}{2.321} & \multirow{12}{*}{745} & \multirow{12}{*}{0.02} & \multirow{12}{*}{0.31} \\
\hline & & & 36 & irregular & 0.40 & 0.60 & flat & 0.196 & & & & \\
\hline & & & 42 & no data & 0.75 & 0.50 & no data & 0.307 & & & & \\
\hline & & & 43 & no data & 0.49 & 0.35 & no data & 0.139 & & & & \\
\hline & & & 50 & oval & 0.60 & 0.42 & no data & 0.204 & & & & \\
\hline & & & 55 & no data & 0.53 & 0.24 & no data & 0.116 & & & & \\
\hline & & & 99 & circular & 0.30 & 0.30 & flat & 0.071 & & & & \\
\hline & & & 80 & oval & 0.54 & 0.32 & no data & 0.145 & & & & \\
\hline & & & 88 & oval & 0.60 & 0.35 & basin & 0.177 & & & & \\
\hline & & & 89 & oval & 0.40 & 0.50 & flat & 0.159 & & & & \\
\hline & & & 97 & oval & 0.75 & 0.50 & irregular & 0.307 & & & & \\
\hline & & & 98 & circular & 0.60 & 0.60 & basin & 0.283 & & & & \\
\hline \multirow{2}{*}{$41 \mathrm{MC} 296$} & \multirow{2}{*}{ MLA } & \multirow{2}{*}{2} & 1 & oval & 2.20 & 1.40 & no data & 2.545 & \multirow{2}{*}{2.704} & \multirow{2}{*}{23} & \multirow{2}{*}{0.09} & \multirow{2}{*}{11.76} \\
\hline & & & 3 & oval & 0.50 & 0.40 & no data & 0.159 & & & & \\
\hline \multirow{6}{*}{ 41ME29 } & \multirow{6}{*}{ MLA } & \multirow{6}{*}{6} & 1 & circular & 0.40 & 0.40 & basin & 0.126 & \multirow{6}{*}{1.986} & \multirow{6}{*}{54} & \multirow{6}{*}{0.11} & \multirow{6}{*}{3.68} \\
\hline & & & 3 & circular & 0.50 & 0.50 & no data & 0.192 & & & & \\
\hline & & & 2 & oval & 0.50 & 0.15 & no data & 0.083 & & & & \\
\hline & & & 4 & oval & 0.53 & 0.38 & no data & 0.163 & & & & \\
\hline & & & 5 & no data & 0.90 & 0.90 & no data & 0.636 & & & & \\
\hline & & & 10 & no data & 1.00 & 1.00 & basin & 0.785 & & & & \\
\hline \multirow{5}{*}{$41 \mathrm{MM} 340$} & & & 5 & circular & 0.60 & 0.52 & no data & 0.246 & & & & \\
\hline & & & 16 & irregular & 0.89 & 0.49 & no data & 0.374 & & & & \\
\hline & MLA & 5 & 23 & irregular & 1.55 & 0.90 & basin & 1.179 & 2.511 & 56 & 0.09 & 4.48 \\
\hline & & & 27 & circular & 0.50 & 0.45 & no data & 0.177 & & & & \\
\hline & & & 41 & circular & 0.85 & 0.80 & no data & 0.535 & & & & \\
\hline & & & 11 & circular & 0.31 & 0.31 & basin & 0.076 & & & & \\
\hline & & & 10 & circular & 0.40 & 0.40 & no data & 0.126 & & & & \\
\hline 41RN3 & MLA & 5 & 12 & irregular & 0.40 & 0.50 & flat & 0.159 & 0.803 & 17 & 0.29 & 4.72 \\
\hline & & & 7 & circular & 0.56 & 0.56 & flat & 0.246 & & & & \\
\hline & & & 9 & circular & 0.70 & 0.30 & basin & 0.196 & & & & \\
\hline & & & 18 & no data & 0.53 & 0.45 & no data & 0.189 & & & & \\
\hline $411 \mathrm{ISI}$ & MLA & 2 & 16 & circular & 0.60 & 0.60 & no data & 0.283 & $0.4 / 1$ & 36 & 0.06 & 1.31 \\
\hline & & & 8 & no data & 0.67 & 0.64 & no data & 0.338 & & & & \\
\hline 41UV60 & MLA & 3 & 29 & no data & 0.98 & 0.92 & no data & 0.702 & 1.935 & 580 & 0.01 & 0.33 \\
\hline & & & 35 & linear & 1.53 & 0.61 & no data & 0.895 & & & & \\
\hline 15: & N & a & 4 & irregular & 1.40 & 0.95 & no data & 1.084 & 20 & 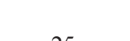 & $n^{2}$ & 10 \\
\hline $41 \mathrm{WM} 26 /$ & MLA & 2 & 11 & irregular & 1.75 & 1.05 & no data & 1.539 & 2.624 & 25 & 0.08 & 10.49 \\
\hline Totals & & 39 & & & & & & & 16.249 & 1550 & 0.03 & 1.05 \\
\hline
\end{tabular}

* The square meters recorded pertain to the portion of the feature excavated only and does not necessarily estimate the total size of the feature. 


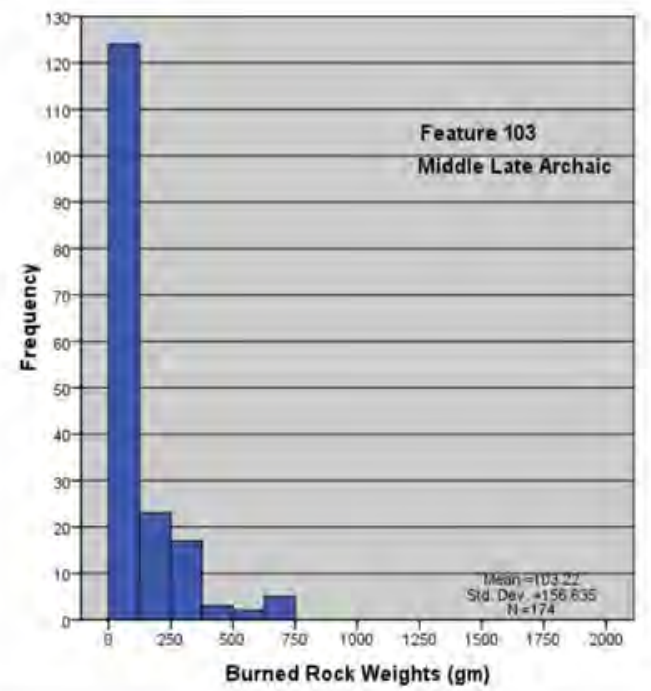

Figure 11-12. Frequency of burned rock weights in Middle Late Archaic features at 41 BX17.

notably in the Middle Archaic and in the latter intervals of the Late Archaic. The feature data (Figure 11-15) does not support our expectation. Our data points to a decrease in the percentage of the component devoted to rock features from the EMA to the LMA followed by an increase into the ILA, a time of increasing bison presence on the landscape. The percentage decreases sharply from the ILA to the MLA then increases slightly in the TLA. Because the Middle Archaic and Late Archaic periods are not equal temporally, comparing the number of features $/ \mathrm{m}^{2}$ by component is misleading. To standardize time for each component we calculated the

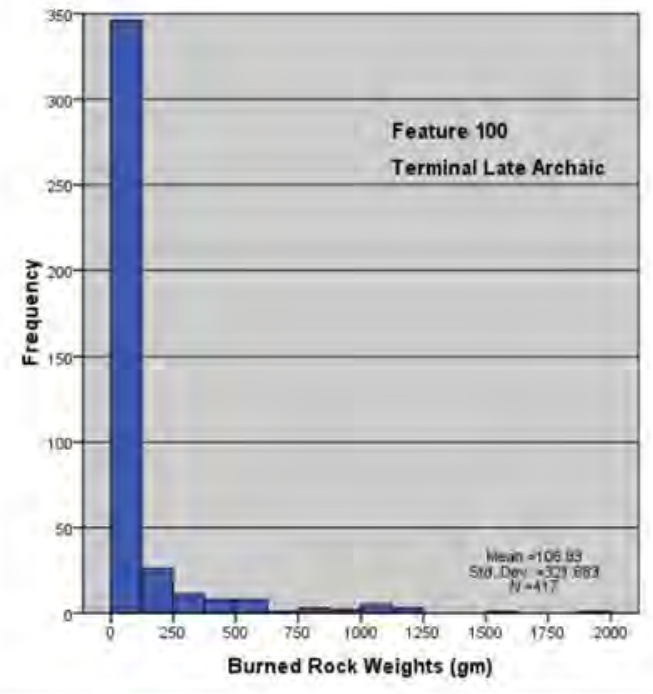

Figure 11-13. Frequency of burned rock weights in Terminal Late Archaic features at $41 B X 17$. number of features per $100 \mathrm{~m}^{2}$ per 100 years. For example, the MLA, covering 900 years, contained 39 burned rock features in $1,550 \mathrm{~m}^{2}$. Our calculation is $\left[(39 / 1550)^{*} 100\right] / 9=.28$ features $/ 100 \mathrm{~m}^{2} / 100$ years. Employing this standardization (Figure 11-16) results in a slight decrease in burned rock features from the EMA to the ILA, then a sharp decrease in the MLA followed by a steep increase into the TLA. This varies from the trend discussed earlier based on features $/ \mathrm{m}^{2}$. In most aspects this trend meets our expectations for burned rock features and plant dependence given patterns in bison availability. However, the sharp decrease in features in the MLA does not support our expectation of a gradual increase in rock features after the ILA when bison are expected to have begun a gradual decrease in population in south and South-Central Texas as a response to decreasing grasslands.

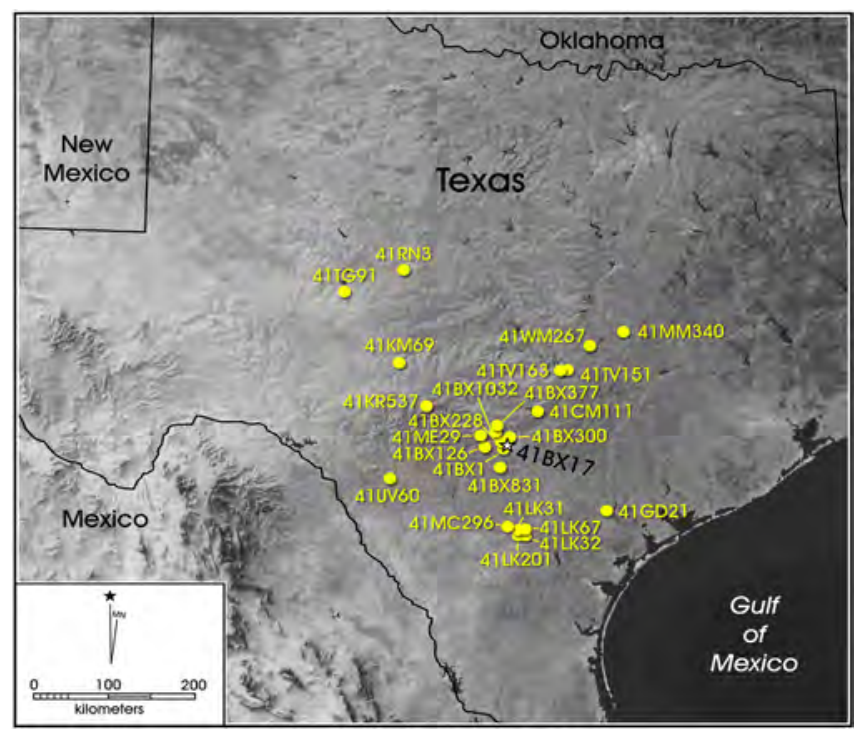

Figure 11-14. Location of archeological sites mentioned in the comparative feature analysis.

In addition to determining the percentage of features on the comparative sites, we used the density of burned rock in features, where burned rock weight was available (Table 11-16), to gauge heating potential (see Black 2003). As stated previously, we suggest that features with significant quantities of rock were probably associated with long-term cooking, as long-term cooking is a requirement for many different types of plant resources, especially those dominated by starch (Wandsnider 1997). Twelve components from seven sites, two from the EMA, five representing the LMA, one from the ILA, two from the MLA, and two representing the TLA, contained data on the burned rock weights from forty-nine features. Burned rock weights from the features range from $1,135 \mathrm{gm}$ to $280,373 \mathrm{gm}$, averaging $23,531 \mathrm{gm}$. The mean density $\left(\mathrm{gm} / \mathrm{cm}^{2}\right)$ per 100 years is illustrated for each component on Figure 11-17. We would expect density to decrease from the EMA to the ILA, then gradually increase into the TLA. Our results support our expectation of a 
decrease into the ILA but not the increase in density from the EMA to the LMA. Our results also support the increase in feature density subsequent to the ILA period.

As discussed in the previous sections on the faunal assemblage, because bison or bison-sized mammals were present in all the components of 41BX17, overall diet breadth should be relatively narrow. We suggested that patterns of bison abundance should correspond to grassland densities, increasing from the Early Middle Archaic into the Initial Late Archaic, then decreasing into the Terminal Late Archaic. Based on the bison and grassland data, we expected a relatively narrow diet breadth throughout both the Middle and Late Archaic periods, slightly wider in the Middle Archaic in comparison to the Late Archaic period, with a decrease from the LMA to the ILA followed by a gradual widening of diet throughout the Late Archaic period. We expected that lower ranked resources, specifically plants, would have been processed in greater numbers in the LMA and again in the TLA. We analyzed feature data using several methods, including features $/ \mathrm{m}^{2}$, percent of component devoted to features, feature burned rock weight, and burned rock density. With a few exceptions, the feature data does not support our expectations. Because our data indicate that bison were present throughout the Middle and Late Archaic

Table 11-15. Terminal Late Archaic Feature Data from 41BX17 and Selected Central Texas Components

\begin{tabular}{|c|c|c|c|c|c|c|c|c|c|c|c|c|}
\hline Site & Component & $\begin{array}{c}\text { Total } \\
\text { Burned } \\
\text { Rock } \\
\text { Features }\end{array}$ & $\begin{array}{c}\text { Rock } \\
\text { Feature \# }\end{array}$ & Shape & $\begin{array}{l}\text { Length } \\
\text { (m) }\end{array}$ & $\begin{array}{l}\text { Width } \\
\text { (m) }\end{array}$ & $\begin{array}{l}\text { Profile } \\
\text { Shape }\end{array}$ & $\begin{array}{l}\text { Area } \\
\left(\mathbf{m}^{2}\right)^{*}\end{array}$ & $\begin{array}{c}\text { Total Rock } \\
\text { Feature } \\
\text { Area }(\mathrm{m} 2)\end{array}$ & $\begin{array}{c}\text { Total Area } \\
\text { Excavated } \\
\left(\mathbf{m}^{2}\right)\end{array}$ & $\begin{array}{c}\text { Rock Features/ } \\
\mathbf{m}^{2}\end{array}$ & $\begin{array}{c}\text { Percent of } \\
\text { Component } \\
\text { Devoted to } \\
\text { Rock Features } \\
(\%)\end{array}$ \\
\hline 41BX17 & TLA & 1 & 100 & irregular & 2.00 & 1.00 & irregular & 1.767 & 1.767 & 8 & 0.13 & 22.09 \\
\hline \multirow{10}{*}{ 41LK67 } & \multirow{10}{*}{ TLA } & \multirow{10}{*}{10} & $1 \mathrm{~A}$ & irregular & 0.95 & 0.70 & no data & 0.535 & \multirow{10}{*}{5.632} & \multirow{10}{*}{121} & \multirow{10}{*}{0.08} & \multirow{10}{*}{4.65} \\
\hline & & & 1B & irregular & 0.75 & 0.60 & no data & 0.358 & & & & \\
\hline & & & 2 & oval & 0.90 & 0.75 & no data & 0.535 & & & & \\
\hline & & & 3 & oval & 0.70 & 0.58 & no data & 0.322 & & & & \\
\hline & & & 4 & irregular & 1.20 & 0.40 & no data & 0.503 & & & & \\
\hline & & & 6 & circular & 1.75 & 1.65 & no data & 2.270 & & & & \\
\hline & & & 7 & oval & 1.20 & 0.65 & no data & 0.672 & & & & \\
\hline & & & 19 & irregular & 0.37 & 0.28 & no data & 0.083 & & & & \\
\hline & & & 20 & no data & 0.55 & 0.35 & no data & 0.159 & & & & \\
\hline & & & 22 & no data & 0.70 & 0.30 & no data & 0.196 & & & & \\
\hline \multirow{9}{*}{ 41MM340 } & \multirow{9}{*}{ TLA } & \multirow{9}{*}{9} & 11 & oval & 1.41 & 1.10 & no data & 1.237 & \multirow{9}{*}{6.276} & \multirow{9}{*}{56} & \multirow{9}{*}{0.16} & \multirow{9}{*}{11.21} \\
\hline & & & 12 & irregular & 1.55 & 1.25 & basin & 1.539 & & & & \\
\hline & & & 13 & oval & 0.92 & 0.69 & no data & 0.509 & & & & \\
\hline & & & 14 & circular & 0.40 & 0.45 & no data & 0.142 & & & & \\
\hline & & & 15 & irregular & 0.65 & 0.30 & no data & 0.177 & & & & \\
\hline & & & 26 & irregular & 0.81 & 0.65 & no data & 0.419 & & & & \\
\hline & & & 31 & irregular & 1.10 & 0.70 & no data & 0.636 & & & & \\
\hline & & & 37 & oval & 0.65 & 0.45 & no data & 0.238 & & & & \\
\hline & & & 48 & oval & 1.45 & 1.20 & no data & 1.379 & & & & \\
\hline \multirow{6}{*}{ 41UV60 } & \multirow{6}{*}{ TLA } & \multirow{6}{*}{6} & 13 & circular & 0.40 & 0.40 & basin & 0.124 & \multirow{6}{*}{3.617} & \multirow{6}{*}{900} & \multirow{6}{*}{0.01} & \multirow{6}{*}{0.40} \\
\hline & & & 10 & circular & 0.61 & 0.49 & basin & 0.237 & & & & \\
\hline & & & 9 & no data & 0.73 & 0.43 & no data & 0.264 & & & & \\
\hline & & & 6 & irregular & 0.73 & 0.61 & no data & 0.354 & & & & \\
\hline & & & 3 & oval & 1.34 & 1.22 & basin & 1.289 & & & & \\
\hline & & & 11 & no data & 1.53 & 1.10 & flat & 1.351 & & & & \\
\hline 41WM267 & TLA & 0 & $\mathrm{n} / \mathrm{a}$ & $\mathrm{n} / \mathrm{a}$ & $\mathrm{n} / \mathrm{a}$ & $\mathrm{n} / \mathrm{a}$ & $\mathrm{n} / \mathrm{a}$ & $\mathrm{n} / \mathrm{a}$ & 0.000 & 21 & 0.00 & 0.00 \\
\hline Totals & & 26 & & & & & & & 17.292 & 1106 & 0.02 & 1.56 \\
\hline
\end{tabular}

* The square meters recorded pertain to the portion of the feature excavated only and does not necessarily estimate the total size of the feature. 


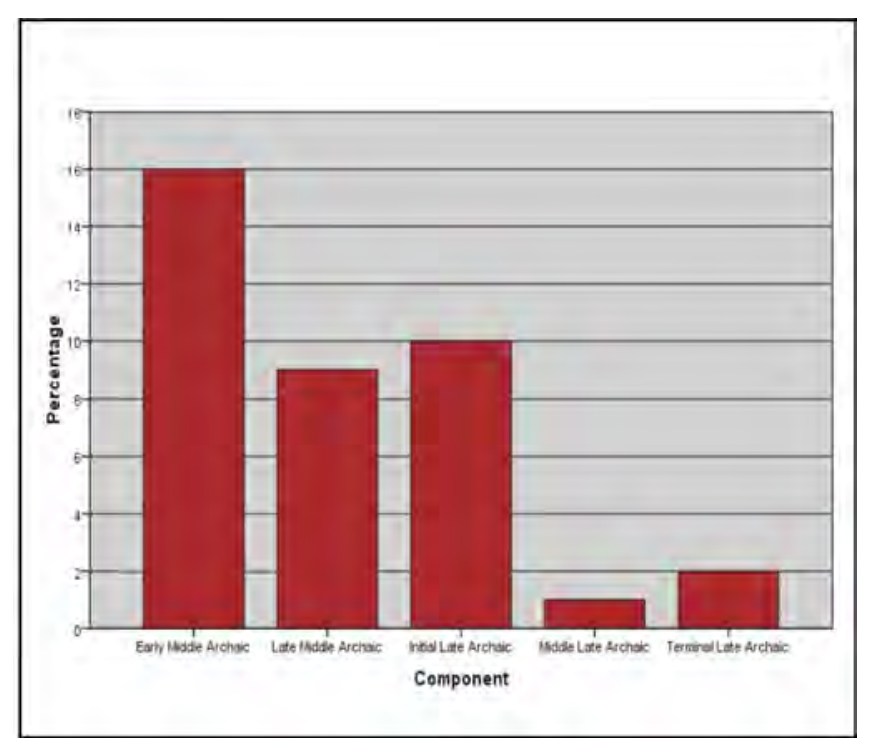

Figure 11-15. Percentage of each component devoted to burned rock features.

periods, the unexpected results from the feature data may be due to variances in bison across the landscape (e.g. seasonal distributions, patchy supportive vegetation, etc.), resulting in an abundance of the large mammals in some sites and a scarcity in others.

\section{Lipid Residue Analysis}

Two principal sources remain for our analysis of diet breadth change over the occupations of the Granberg Site: identifications of lipid residues from burned rock features and macrobotanical identifications of charred nuts and seed fragments. The analysis of lipids from archeological specimens, first used by Condamin et al. (1976), has

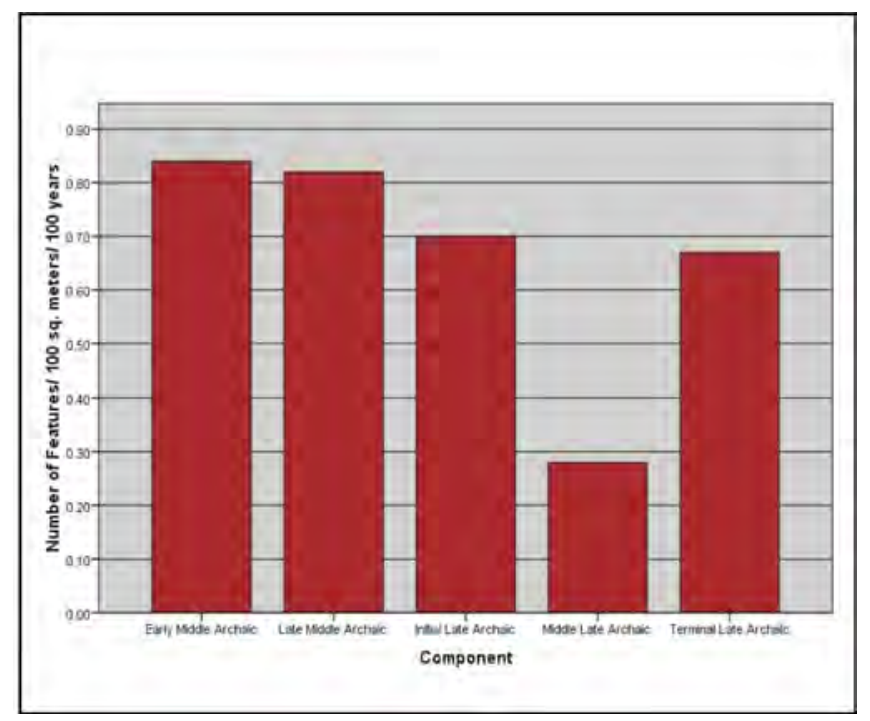

Figure 11-16. Number of burned rock features per 100 square meters per 100 years. recently been expanded through the work of Marchbanks (1989), Skibo (1992), Loy (1994), and Malainey (2000). Lipids are abundant in plants and animals, and different groups of plants and animals have fatty acids with different molecular structure. These varying molecular signatures of fatty acids can be identified in archeological situations (see also Quigg et al. 2002). Several broad groups of plant and animal signatures have been developed based on fatty acid composition, and while some overlaps exist, lipid analysis can provide an additional clue to determining the range of plants, or animals, processed in rock features at the site. We submitted 27 samples of burned rock, three from each of the nine features, to Dr. Mary Malainey in Winnepeg Manitoba for lipid residue analysis (see Appendix B).

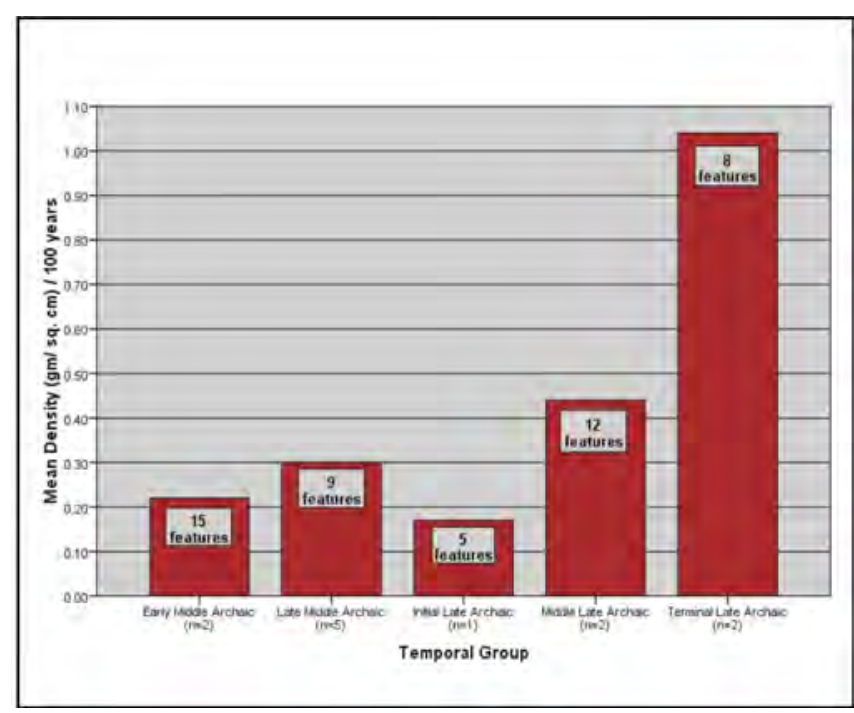

Figure 11-17. Mean density (gm/cm2) per 100 years.

Seventeen samples contained insufficient lipids to attempt identification. The ten rocks with sufficient lipid residue represent six of the nine features $(100,103,104,105,106$, and 107), two Middle Archaic, Features 104 and 107, and four Late Archaic, Features 100, 103, 105, and 106 (Table 11-17). Middle Archaic features included two rocks with plant residue only and two rocks with animal or plant residue. The lipid residue from Feature 104 is representative of a large fatty herbivore, javelina, or a combination of lean meat with fatty seeds and/or nuts. Feature 107 contained residue samples from three burned rock specimens. One was indicative of lean meat (bison or deer), javalena, or sotol seeds; another of fatty seeds and/or nuts; and the last of very fatty seeds and/or nuts. The six Late Archaic samples presenting residue included four rocks with plant or animal residue and two rocks with only plant residue. The residue from Feature 100 is indicative of a large herbivore (bison 
Table 11-16. Burned Rock Feature Data for 41BX17 and Comparative Sites

\begin{tabular}{|c|c|c|c|c|}
\hline Site & Component & Feature \# & B/R Weight (gm) & Density $\left(\mathrm{gm} / \mathrm{cm}^{2}\right)$ \\
\hline 41BX377 & EMA & 28 & 3000 & 0.38 \\
\hline 41BX377 & EMA & 29 & 4750 & 0.42 \\
\hline 41BX377 & EMA & 9 & 46000 & 1.33 \\
\hline 41BX377 & EMA & 30 & 3000 & 1.53 \\
\hline 41BX377 & EMA & 18 & 124831.7 & 1.65 \\
\hline 41BX377 & EMA & 10 & 32355.1 & 1.72 \\
\hline 41BX377 & EMA & $25 \mathrm{~A}$ & 4500 & 1.73 \\
\hline 41BX377 & EMA & 27 & 8000 & 2.20 \\
\hline 41BX377 & EMA & 19 & 280373.2 & 3.14 \\
\hline 41BX377 & EMA & $25 \mathrm{~B}$ & 4000 & 4.16 \\
\hline 41BX377 & EMA & 17 & 7000 & 4.40 \\
\hline 41BX377 & EMA & 11 & 7250 & 4.56 \\
\hline 41BX377 & EMA & 24 & 28610.8 & 4.76 \\
\hline 41LK31/32 & EMA & 10 & 12716.2 & 0.22 \\
\hline 41LK31/32 & EMA & 1 & 1254.7 & 0.64 \\
\hline 41BX17 & ILA & 101 & 17819 & 1.16 \\
\hline $41 \mathrm{BX} 17$ & ILA & 102 & 41648 & 2.36 \\
\hline 41BX17 & ILA & 105 & 4776 & 2.70 \\
\hline 41BX17 & ILA & 108 & 14332 & 3.73 \\
\hline $41 \mathrm{BX} 17$ & ILA & 106 & 109443 & 6.20 \\
\hline 41BX1 & LMA & 9 & 5000 & 1.68 \\
\hline 41BX1 & LMA & 1 & 1400 & 1.98 \\
\hline 41BX1 & LMA & 7 & 2100 & 2.18 \\
\hline 41BX126 & LMA & 12 & 74495.6 & 4.22 \\
\hline $41 \mathrm{BX} 126$ & LMA & 11 & 72433.83 & 5.46 \\
\hline 41BX17 & LMA & 107 & 7387 & 2.23 \\
\hline 41BX17 & LMA & 104 & 7519 & 5.30 \\
\hline 41BX831 & LMA & 26 & 3300 & 1.75 \\
\hline 41LK31/32 & LMA & 6 & 18012.6 & 2.37 \\
\hline 41BX17 & MLA & 103 & 17961 & 2.29 \\
\hline 41KM69 & MLA & 97 & 2339.00 & 0.79 \\
\hline 41KM69 & MLA & 88 & 2979.50 & 1.81 \\
\hline 41KM69 & MLA & 80 & 2901.70 & 2.14 \\
\hline 41KM69 & MLA & 89 & 4127.80 & 2.63 \\
\hline 41KM69 & MLA & 50 & 6548.70 & 3.31 \\
\hline 41KM69 & MLA & 43 & 4934.80 & 3.67 \\
\hline 41KM69 & MLA & 98 & 11630.20 & 4.12 \\
\hline 41KM69 & MLA & 35 & 11877.20 & 5.50 \\
\hline 41KM69 & MLA & 42 & 17600.30 & 5.98 \\
\hline 41KM69 & MLA & 99 & 4345.10 & 6.15 \\
\hline 41KM69 & MLA & 36 & 17023.20 & 9.04 \\
\hline 41BX17 & TLA & 100 & 44547 & 2.52 \\
\hline 41KM69 & TLA & 87 & 1135.2 & 1.18 \\
\hline 41KM69 & TLA & 48 & 18971 & 2.08 \\
\hline 41KM69 & TLA & 96 & 3433.1 & 2.73 \\
\hline 41KM69 & TLA & 40 & 7882.7 & 4.56 \\
\hline 41KM69 & TLA & 94 & 6164.9 & 4.99 \\
\hline 41KM69 & TLA & 95 & 11797.8 & 5.47 \\
\hline 41KM69 & TLA & 49 & 7524.7 & 5.57 \\
\hline
\end{tabular}

or deer), a javalena, or sotol seeds (tropical oil seeds). Feature 103 had lipid residues from two sample rocks, one representing plant use (fatty to very fatty seeds and nuts) and the other bison or deer, javalena or sotol seeds. Feature 105 contained residue indicative of the processing of a large fatty herbivore, javalena, or a combination of lean meat with fatty seeds and/or nuts. Feature 106 returned residues from two sample rocks, one similar to Feature 105's signature and one suggestive of plant processing with fatty to very fatty seeds and/or nuts.

Malainey's data suggests that Middle Archaic features at 41BX17 were being used to process plant as well as animal material, specifically large herbivores (bison and deer), javalena, lean meat with fatty seeds and nuts, and sotol. Because the lipid residue indicates the same mix of plant and animal residues from the Late Archaic features, it is difficult to use the data as a tool to reconstruct diet breadth during the occupations at the Granberg Site. Both periods resulted in feature rocks with plant residues, suggesting the features were employed to process low return plant material in addition to processing high return meat items throughout the site's occupation. If accurate, these lipid results suggest that high return meat items contradict, to some degree, our expectations regarding the use of burned rock features.

\section{Macrobotanical Analysis}

The final aspect of our analysis of diet breadth alteration is the macrobotanical identifications of charred nuts and seed fragments from features at the Granberg Site. We submitted nine individual flotation samples from each of the thermal features to Dr. J. Philip Dering of Shumla Archeobotanical Services in Comstock, Texas, for recovery of carbonized seeds or other plant parts that may reflect what items were cooked in the features (Appendix E). All of the samples except one, which was from Feature 108, contained charred plant material. Most of the wood charcoal identified is oak suggesting that the vegetation on the site during its occupation was dominated by oak trees or that the inhabitants were carefully selecting oak over other wood species for fuel. No geophyte/root fragments, fruit, or seeds were identified in the samples.

\section{Summary}

We began this chapter with an analysis of bison presence or absence in South and South-Central Texas during the Middle Archaic period. Based on Dillehay's (1974) and Collins's (1995) research, we expected bison to be absent throughout the entirety of the Middle Archaic period and, 
Table 11-17. Identification of Lipid Residues from 41BX17

\begin{tabular}{|c|c|c|c|c|c|c|}
\hline Feature \# & Time Period & C14 Date (BP) & Identification & C18:1 (\%) & C18:0 (\%) & C18:2(\%) \\
\hline 107 & LMA & & very fatty seeds/nuts & 57.35 & 12.36 & 7.35 \\
\hline 107 & LMA & & fatty seeds/nuts & 44.19 & 19.5 & 5.31 \\
\hline 107 & LMA & & large herbivores, javalena, or sotol & 4.32 & 52 & 0.48 \\
\hline 104 & LMA & $4290-4080$ & $\begin{array}{c}\text { large fatty herbivore, javalena, or lean meat with fatty seeds/ } \\
\text { nuts. }\end{array}$ & 31.67 & 30.51 & 3.34 \\
\hline 105 & ILA & $3980-3820$ & $\begin{array}{c}\text { large fatty herbivore, javalena, or lean meat with fatty seeds/ } \\
\text { nuts. }\end{array}$ & 24.04 & 31.03 & 3.04 \\
\hline 106 & ILA & & $\begin{array}{c}\text { large fatty herbivore, javalena, or lean meat with fatty seeds/ } \\
\text { nuts. }\end{array}$ & 20.32 & 33.76 & 1.09 \\
\hline 106 & ILA & & fatty to very fatty seeds/nuts. & 51.21 & 13.24 & 5.2 \\
\hline 103 & MLA & $2740-2380$ & large herbivores, javalena, or sotol & 6.72 & 48.81 & 0.73 \\
\hline 103 & MLA & $2740-2380$ & fatty to very fatty seeds/nuts. & 50.74 & 18.07 & 6.45 \\
\hline 100 & TLA & $2010-1860$ & large herbivores, javalena, or sotol & 6.32 & 44.41 & 0.18 \\
\hline
\end{tabular}

therefore, suggested that during the Middle Archaic huntergatherer diets would be relatively broader than those of Late Archaic populations. We suggested several patterns that may be expected, including a reduction in diet breadth when bison were abundant and a widening of diet breadth when bison were absent or available in low densities. We also proposed that increased processing of bone resulting in unidentified fragmentary specimens should be expected under conditions of bison absence. Finally, we suggested that the density and/or area devoted to rock hearths can be used as a gross measure of plant dependence and should decrease as bison availability increased and vice versa. We expected that during the Late Archaic the density and/or area devoted to rock hearths should decrease relative to sites dating to the Middle Archaic. In addition, we anticipated that bison numbers would slowly decline throughout the Late Archaic as grasslands slowly shrink, and as fluctuations in bison densities are anticipated to be slowly increasing because of these same climatic processes, we expected that the density and/or area devoted to rock hearths would gradually increase within the Late Archaic period.

Bison data gathered from multiple Middle Archaic components in South and South-Central Texas did not support our expectation gathered from the literature of an absence of bison during this period. Bison were present throughout both the Middle and the Late Archaic periods. Using data from 41BX17, our contrast between the Middle Archaic period analytical unit and the Late Archaic period analytical unit only partially supported our suggestions of decreased diet breadth when bison are a component of the diet and did not support our expectation of greater amounts of fragmentary bone when bison were scarce or unevenly distributed. Our suggestion that the density and/or area devoted to rock hearths can be used as a gross measure of plant dependence and should decrease as bison availability increased and vice versa, with the exception of the Middle Late Archaic, was not supported. The analysis of lipid residue from 41BX17 features resulted in plant and animal residues suggesting that both were processed throughout the Middle and Late Archaic periods.

We then conducted a regional comparison using faunal and burned rock data from a number of sites. We had suggested that bison availability will impact the diet breadth of huntergatherers and expected a narrowing of diet breadth when bison were present. Our taxa richness data from the comparative components do not support our suggestions that wider diet breadth should be reflected when bison are absent or scarce. However, while the number of taxa increased with increasing bison presence, contrary to expectations, the percentage of very small faunal and mussel and snail shell, items that should be eliminated from the diet when bison were present, decrease from the EMA to the ILA and then increased in the MLA. The data suggests that as grasslands, and by extension bison, increased in Central and South-Central Texas, the reliance on small, lower ranked resources was reduced. Although the taxa data does not support our expectations, it appears that lower ranked resources were greatly reduced when bison were present. We explored the relative frequencies of bone fragments in comparative assemblages as a measure of diet breadth. The resultant bone fragment data contrasted with our expectations. Finally, we compiled comparable burned rock feature data to identify broad trends in subsistence practices and explore the suggestions presented above. With a few exceptions, the feature data does not support our expectations.

With the exception of patterns in dependence on low return animals, and some specific changes in burned rock 
feature data, the archeological data do not pattern as we anticipated. There are a number of possible reasons for this lack of correpondence; the most obvious of which is that the general approach is not a useful way to look at the archeological record. Given that aspects of this position have been successfully used elsewhere (see Keene 1981; Smith and Winterhalder 1992; Yesner 1981), including data sets from Central and South Texas (Mauldin et al. 2009; Tomka et al. 2004b), we do not think that this is the case. Clearly, some of the data sets, such as the taxa data, seem to have been affected by differential preservation with the average number of taxa decreasing with increasing time depth. In addition, the lack of patterning in the fragmentation data is not surprising as large mammals are differentially involved with bone and marrow processing. The unexpected results from the faunal and feature data may be due to variances in bison across the landscape (e.g. seasonal distributions, patchy supportive vegetation, etc.) resulting in an abundance of the large mammals in some sites and a scarcity in others. If bison were not available year-round, we expect that huntergatherer diets may have narrowed during seasons of bison availability and broadened during seasons of bison absence in the region. These seasonal changes may show up as high variability between components within a temporal period, but the overall pattern may be ambiguous.

Another possibility is that the unexpected results from the feature data may be the result of site specific discrepancies, discrepancies resulting from varying levels of excavations (i.e., testing versus mitigation). The patterns may be dictated by the amount of sediment removed. Considering that testing projects often focus on areas of known features and generally are more limited in scale, it is probable that features are not always completely exposed, and in comparison to mitigation projects, a much smaller volume of the site is investigated. Therefore, our data from testing projects may overestimate one aspect versus the other (i.e., site size versus feature coverage) affecting the calculation of number of features/ $\mathrm{m}^{2}$ and percent of component devoted to rock features. In addition, because some projects removed much larger amounts of sediments than others (i.e., $900 \mathrm{~m}^{2}$ at the TLA AU for $41 \mathrm{UV} 60$ versus $56 \mathrm{~m}^{2}$ at the TLA AU at 41MM340), the pattern may be dictated by large scale excavations.

Finally, note that in developing our estimate of feature density per unit of excavated space per unit of time, we make several assumptions that may not be warranted in all cases. While this type of analysis allows us to look at temporal changes in features without radiocarbon dates, one of the major assumptions is that the features within a given excavation area are, in effect, used for the duration of that time period. For some feature types, such as burned rock middens, and for some time periods, such as the Terminal Late Archaic which we estimated at 350 years in duration, this assumption is probably not too far off (see Black and Creel 1997; Mauldin et al. 2003). However, most features used in our analysis are small, and it is unlikely that they have been extensively reused over hundreds of years. In addition, note that the longer the temporal period, the more likely it is that the assumption of continuous use is wrong. In this analysis, several of our time periods, such as those dividing the Middle Archaic or the Initial Late Archaic, are in excess of 900 years in length. It may be the case that this type of analysis is not well suited for these longer temporal periods. 


\title{
Chapter 12: Assessing Changes in Technological Organization
}

\author{
Cynthia M. Munoz and Raymond P. Mauldin
}

In this chapter we investigate selected aspects of technological organization. Technological organization concerns how people structured activities associated with the manufacture, repair, and replacement of tools, and how these activities may have been conditioned by factors, such as the availability and form of tool stone, as well as reliability and maintainability considerations of the tool itself. This chapter addresses two primary research issues proposed in the research design (Munoz et al. 2007) related to lithic technology at 41BX17. The two principal research areas consist of 1) variability in formal versus expedient tools through time and 2) evidence of gearing up in anticipation of future need verses on-demand tool replacement. Both of these topics will be discussed in detail.

In our general hunter-gatherer model presented in Chapter 9, we argued that changes in the presence/absence of largebody-sized prey within the area exploited by hunter-gatherers should have significant impact on tool design and the organization of tool manufacture and repair strategies. Given that our review of bison demonstrates that they are always present in the region, at least at the temporal scale at which we can monitor their presence and absence, we need to frame our expectations in terms of shifts in bison density. Using shifts in grasslands as a base, we suggest that as bison are increasingly common in the Middle Archaic and into the Initial Late Archaic, the use of a tool kit that was more specialized and, consequently, more expensive both to produce and maintain should decline. In contrast, we expect that as bison begin to decline in numbers and become more temporally and spatially restricted in the Middle and Terminal Late Archaic, more investment in the production of specialized tools would tend to be favored. In anticipation of future needs and failure rates, we also expect that large numbers of these specialized tools would have been produced in a gearing-up activity as bison became increasingly restricted in time and space.

\section{Assessing Tool Manufacturing Costs}

To investigate the assumed relationship between energy expended in the manufacture of a tool and variance in bison availability, we reviewed all the tools from the Middle and Late Archaic analytical units recovered from the CAR's testing of 41BX17 along with selected lithic assemblages from comparative components in Central Texas. Our goal was to categorize each specimen according to the level of energy that has been expended for its manufacture. The making of lithic tools is a reductive activity that leaves some relative evidence of the amount of effort that has been invested in the manufacture process. Specifically, we suggest that the area covered by retouch (i.e., flake removals) on a tool can serve as a proxy for the level of effort expended in its manufacture. Although the stone portion of the tool often represents only one element of a compound tool, we assume that there is a correlation between the level of effort expended in overall tool manufacture and the level of effort invested in the manufacture of the stone portion of that tool.

Given the anticipated relationship between the manufacture costs (i.e., generalized versus specialized tools) and resource procurement strategies (i.e., residential versus logistical foragers), we suggest that comparisons of assemblages in terms of stone tool manufacture costs can be a productive research avenue for differentiation of technological organization and resource procurement strategies. Specifically, we expect that when bison are increasingly common emphasis on the manufacture of specialized tools will decline. These tools will be more expensive to make, more likely to be hafted, and more likely to be curated from site to site. This use of these tools should decline through the Middle Archaic and into the Initial Late Prehistoric (ILA). It is in the ILA that bison are most common. Consequently, there should be less need to invest in complex, expensive tools. In the Middle Late Archaic (MLA) and the Terminal Late Archaic (TLA), when the grassland data suggests that bison are declining in numbers and probably are increasingly restricted in space, increasingly specialized tools, perhaps prepared in anticipation of need, will be common.

Of course, within any tool kit used by hunter-gatherers, there will be some functionally specific forms (e.g., projectile points) that may not fit these general expectations since manufacture costs tend to be conditioned by the degree of dependence of the tool user upon the specific tool (Tomka 2001). That is, within any system, some of the tools used will be costly to manufacture because of the high degree of dependence on this tool to carry out specific tasks in an effective manner. Bison procurement may be one such task where specific tools are required regardless of increases or decreases in abundance of the animal. If that is the case, then the patterns of specialized tool abundance, at least in some functional sets, will pattern exactly opposite of what we have suggested. Under this scenario, increasing bison will 
require more specialized tools within an assemblage, while decreasing bison will require relatively fewer specialized tools.

To explore these suggestions, we categorized stone tools from each assemblage into one of five categories. Our focus is on manufacturing costs. From the least energy expensive to the most energy expensive these categories are: (1) utilized flakes; (2) marginally retouched items; (3) unifacially retouched specimens; (4) bifacially retouched forms; and (5) retouched items with haft elements. This classification scheme assumes that as the amount of retouch increases the time required in the manufacture of the tool also increases. It also assumes that the construction of haft elements will increase the manufacture costs of hafted tools, both in terms of the specific requirements of the haft production and in the production of the other elements of the tool. For example, we would argue that a "crude" uniface is less expensive, in terms of time to produce, than a formal uniface with a hafting element (e.g., "Clear Fork" uniface). Not only do the latter probably require more time to produce, but the presence of the hafting element implies that the uniface, as such, is only one element of a more complex tool. While complicated by the possibility that some tools may be reworked from older tools, thereby reducing the specific event costs, and while some groups (e.g., bifacially retouched forms) may have a large number of items that are not finished, we feel that the scheme generally reflects the manufacturing costs in the majority of cases.

The quantification of manufacture costs depends on comparing the proportions of tools found within each of our five categories. Utilized flakes represent the least energy expensive tool forms (i.e., expedient manufacture tools). Because utilized flakes are often under-reported in collections, once a collection with similar recovery methods (e.g., 1/4 in. screening) was identified, we selected a random sample of about 500 flakes from that assemblage if that number was available (Table 12-1). These were scanned for macroscopic evidence of use wear. Our goal in that review was to quantify the number of flaked tools. As such, we treated each flake with use wear present as a single tool rather than treating each edge of a flake as a potential tool. We used macroscopic patterns of use wear defined by Tringham et al.

Table 12-1. Estimation of Utilized Flakes from Debitage from Comparative Components

\begin{tabular}{|c|c|c|c|c|c|c|}
\hline Component & $\begin{array}{c}\text { Temporal } \\
\text { Period }\end{array}$ & $\begin{array}{l}\text { Total } \\
\text { Debitage } \\
\text { Counts }\end{array}$ & $\begin{array}{l}\text { Debitage Sample } \\
\text { Size Reviewed } \\
\text { for UT Flakes }\end{array}$ & $\%$ Sampled & $\begin{array}{c}\text { \# of UT } \\
\text { Flakes in } \\
\text { Sample }\end{array}$ & $\begin{array}{c}\text { Estimated \# of } \\
\text { New UT Flakes in } \\
\text { Assemblage }\end{array}$ \\
\hline 41B1 & EMA & 319 & 319 & $100.0 \%$ & 1 & 1 \\
\hline 41BX228 & EMA & 9128 & 550 & $6.0 \%$ & 1 & 17 \\
\hline 41BX228 & EMA & 9128 & 550 & $6.0 \%$ & 1 & 17 \\
\hline 41CM111 & EMA & 6809 & 514 & $7.5 \%$ & 0 & 0 \\
\hline 41LK31/32 & EMA & 1004 & 507 & $50.5 \%$ & 2 & 4 \\
\hline 41BX1 & LMA & 3519 & 566 & $16.1 \%$ & 6 & 37 \\
\hline 41BX126 & LMA & 2796 & 522 & $18.7 \%$ & 1 & 5 \\
\hline $41 \mathrm{BX} 228$ & LMA & 29070 & 516 & $1.8 \%$ & 0 & 0 \\
\hline $41 \mathrm{BX} 300$ & LMA & 5507 & 502 & $9.1 \%$ & 2 & 22 \\
\hline 41LK31/32 & LMA & 57 & 57 & $100.0 \%$ & 0 & 0 \\
\hline $41 \mathrm{TV} 163$ & LMA & 1985 & 571 & $28.8 \%$ & 3 & 10 \\
\hline 41MM340 & ILA & 9636 & 469 & $4.9 \%$ & 0 & 0 \\
\hline 41LK67 & ILA & 1296 & 492 & $38.0 \%$ & 0 & 0 \\
\hline 41LK201 & ILA & 1736 & 474 & $27.3 \%$ & 1 & 4 \\
\hline 41KM69 & MLA & 5511 & 502 & $9.1 \%$ & 1 & 11 \\
\hline $41 \mathrm{MC} 296$ & MLA & 1454 & 506 & $34.8 \%$ & 1 & 3 \\
\hline 41MM340 & MLA & 20282 & 506 & $2.5 \%$ & 0 & 0 \\
\hline 41KM69 & TLA & 9981 & 433 & $4.3 \%$ & 1 & 23 \\
\hline 41MM340 & TLA & 18010 & 522 & $2.9 \%$ & 1 & 35 \\
\hline 41LK67 & TLA & 4598 & 473 & $10.3 \%$ & 0 & 0 \\
\hline Totals & & 141826 & 9551 & & 22 & 189 \\
\hline
\end{tabular}


Table 12-2. 41BX17 Tool Manufacturing Costs by Analytical Unit

\begin{tabular}{|c|c|c|c|c|c|c|c|c|c|c|}
\hline \multirow{2}{*}{$\begin{array}{c}\text { Tool Type } \\
\text { (least to most expensive) }\end{array}$} & \multicolumn{2}{|c|}{$\begin{array}{l}\text { Late Middle } \\
\text { Archaic }\end{array}$} & \multicolumn{2}{|c|}{$\begin{array}{c}\text { Initial Late } \\
\text { Archaic }\end{array}$} & \multicolumn{2}{|c|}{$\begin{array}{l}\text { Middle Late } \\
\text { Archaic }\end{array}$} & \multicolumn{2}{|c|}{$\begin{array}{l}\text { Terminal Late } \\
\text { Archaic }\end{array}$} & \multicolumn{2}{|c|}{$\begin{array}{c}\text { Combined } \\
\text { Late Archaic }\end{array}$} \\
\hline & $\mathrm{n}$ & $\%$ & $\mathrm{n}$ & $\%$ & $\mathrm{n}$ & $\%$ & $\mathrm{n}$ & $\%$ & $\mathrm{n}$ & $\%$ \\
\hline Utilized Flakes & 32 & 43 & 7 & 23 & 31 & 50 & 2 & 22 & 40 & 37 \\
\hline Marginally Retouched Items & 7 & 9 & 1 & 3 & 3 & 5 & 0 & 0 & 4 & 4 \\
\hline Unifacially Retouched Items & 2 & 3 & 3 & 10 & 2 & 3 & 0 & 0 & 5 & 5 \\
\hline Bifacially Retouched Items & 21 & 28 & 14 & 45 & 12 & 19 & 5 & 56 & 34 & 31 \\
\hline $\begin{array}{l}\text { Retouched Items with Haft } \\
\text { Elements }\end{array}$ & 12 & 16 & 6 & 19 & 14 & 23 & 2 & 22 & 25 & 23 \\
\hline Total & 74 & 100 & 31 & 100 & 62 & 100 & 9 & 100 & 108 & 100 \\
\hline
\end{tabular}

(1974) to classify tools into the task-related categories. On a given tool, when we had evidence of only a single task (e.g., cutting), regardless of how many edges have that evidence, the utilized flake was classified as "single-use." When more than one task-specific activity was reflected (e.g., scraping, cutting, perforating), the tool was classified as "multipleuse." The task-specific data will be used to quantify the relative contribution of specialized versus generalized tools to individual assemblages (see subsequent chapter on assessing changes in mobility). When selected specimens could not be classified as either single-use or multiple-use based on macroscopic use wear, they were subjected to lowpower micro-wear analysis at 50-80 times magnification to discern the utilized edge as well as the manner of use performed with the tool. Following this examination, if the specimen still could not be classified into one of the two categories, it was excluded from further consideration. We used the percentage of single-use and multiple-use flakes in the sample to estimate the total number of single and multiple tools in the overall assemblage.

Table 12-2 presents the breakdown of all the tools from the Granberg Site from the least energy expensive to the most energy expensive category by analytical unit. In the Late Middle Archaic (LMA) analytical unit (AU), utilized flakes account for 32 of the 74 tools (43\%) followed by bifacially retouched items (28\%). This distribution flips in the ILA AU with 14 of $31(45 \%)$ tools identified as bifacially retouched items and 7 (23\%) as utilized flakes. Fifty percent (31 of 62) of the tools in the MLA AU are utilized flakes, followed by 14 retouched items with haft elements (23\%). In the TLA AU the largest percentage of tools are bifacially retouched items $(56 \%)$ accounting for 5 out of 9 recovered tools.

The percentages of expensive, formal tools (unifaces, bifaces, and hafted tools) from each component are charted by percentage in Figure 12-1. Note that percentages of expedient tools (i.e., utilized flakes and marginally retouched items; see Table 12-2) would form a mirror image of the formal pattern shown in Figure 12-1. Our grassland data suggests that the presence of bison was highest in the ILA and lowest in the TLA. Consequently, we expected that formal tools should be lowest in the ILA, and highest in the TLA. The Figure 12-1 pattern, then, is only partially consistent with our expectations. While the TLA does have the highest percentage of formal tools, the 41BX17 tool kit becomes more specialized from the LMA to the ILA rather than less specialized. The TLA percentages fit our predictions in that we expected specialized tools to become more apparent in the latter years of the Late Archaic period as bison become more variable on the landscape. However, the pattern of greater generalization in the MLA and the high percentage in the ILA are not consistent with our expectations.

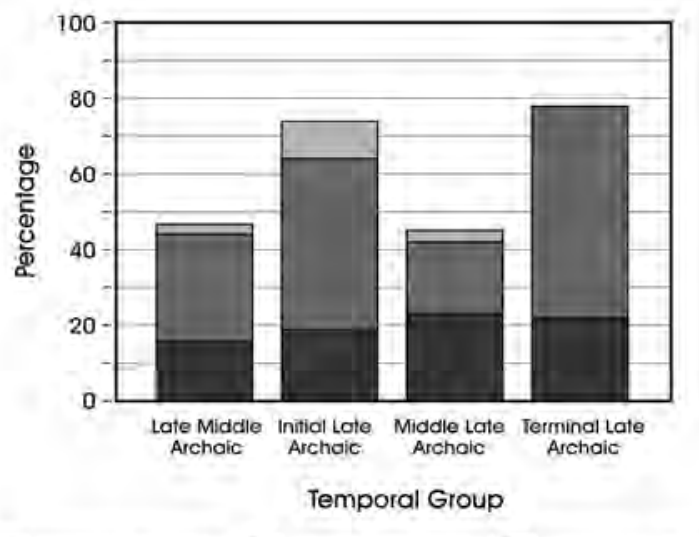

Unilocially retouched

Bifacially relouched

Retouched with nall

Figure 12-1. Percentage of formal tools from $41 B X 17$ by analytical units (see also Table 12-2). 
Table 12-3. Tool Manufacturing Costs by Temporal Period for 41BX17 and Comparative Collections

\begin{tabular}{|c|c|c|c|c|c|c|c|c|c|c|c|c|}
\hline \multirow[t]{2}{*}{ Component } & \multirow[t]{2}{*}{$\begin{array}{c}\text { Temporal } \\
\text { Period }\end{array}$} & \multicolumn{2}{|c|}{ Utilized Flakes } & \multicolumn{2}{|c|}{$\begin{array}{l}\text { Marginally } \\
\text { Retouched }\end{array}$} & \multicolumn{2}{|c|}{$\begin{array}{l}\text { Unifacially } \\
\text { Retouched }\end{array}$} & \multicolumn{2}{|c|}{$\begin{array}{l}\text { Bifacially } \\
\text { Retouched }\end{array}$} & \multicolumn{2}{|c|}{$\begin{array}{c}\text { Retouched Items } \\
\text { with Hafting } \\
\text { Elements }\end{array}$} & \multirow[t]{2}{*}{ Total Tools } \\
\hline & & $\mathbf{n}$ & $\%$ & $\mathbf{n}$ & $\%$ & $\mathbf{n}$ & $\%$ & $\mathbf{n}$ & $\%$ & $\mathbf{n}$ & $\%$ & \\
\hline 41BX17 & LMA & 32 & 43 & 7 & 9 & 2 & 3 & 21 & 28 & 12 & 16 & 74 \\
\hline 41BX17 & ILA & 7 & 23 & 1 & 3 & 3 & 10 & 14 & 45 & 6 & 19 & 31 \\
\hline 41BX17 & MLA & 31 & 50 & 3 & 5 & 2 & 3 & 12 & 19 & 14 & 23 & 62 \\
\hline 41BX17 & TLA & 2 & 22 & 0 & 0 & 0 & 0 & 5 & 56 & 2 & 22 & 9 \\
\hline 41BX1 & EMA & 8 & 62 & 3 & 23 & 0 & 0 & 2 & 15 & 0 & 0 & 13 \\
\hline 41BX1 & LMA & 62 & 61 & 8 & 8 & 3 & 3 & 12 & 12 & 17 & 17 & 102 \\
\hline 41BX126 & LMA & 39 & 58 & 5 & 7 & 4 & 6 & 7 & 10 & 12 & 18 & 67 \\
\hline $41 \mathrm{BX} 228$ & EMA & 33 & 32 & 5 & 5 & 3 & 3 & 39 & 38 & 22 & 22 & 102 \\
\hline 41BX228 & LMA & 24 & 26 & 6 & 7 & 3 & 3 & 35 & 38 & 24 & 26 & 92 \\
\hline 41BX300 & LMA & 31 & 44 & 4 & 6 & 2 & 3 & 17 & 24 & 16 & 23 & 70 \\
\hline 41CM111 & EMA & 2 & 3 & 3 & 5 & 0 & 0 & 41 & 62 & 20 & 30 & 66 \\
\hline 41LK31/32 & EMA & 5 & 62 & 1 & 13 & 0 & 0 & 2 & 25 & 0 & 0 & 8 \\
\hline 41TV163 & LMA & 20 & 18 & 15 & 13 & 1 & 1 & 30 & 27 & 45 & 40 & 111 \\
\hline 41LK201 & ILA & 5 & 25 & 4 & 20 & 2 & 10 & 6 & 30 & 3 & 15 & 20 \\
\hline 41LK67 & ILA & 10 & 43 & 6 & 26 & 1 & 4 & 5 & 22 & 1 & 4 & 23 \\
\hline 41MM340 & ILA & 16 & 18 & 23 & 26 & 1 & 1 & 26 & 29 & 23 & 26 & 89 \\
\hline 41KM69 & MLA & 12 & 22 & 7 & 13 & 0 & 0 & 24 & 44 & 11 & 20 & 54 \\
\hline 41MC296 & MLA & 8 & 38 & 5 & 24 & 1 & 5 & 6 & 29 & 1 & 5 & 21 \\
\hline 41MM340 & MLA & 94 & 43 & 29 & 13 & 8 & 4 & 52 & 24 & 34 & 16 & 217 \\
\hline 41KM69 & TLA & 24 & 24 & 5 & 5 & 11 & 11 & 36 & 35 & 26 & 25 & 102 \\
\hline 41MM340 & TLA & 65 & 42 & 24 & 16 & 1 & 1 & 35 & 23 & 29 & 19 & 154 \\
\hline 41LK67 & TLA & 23 & 27 & 33 & 39 & 7 & 8 & 18 & 21 & 3 & 4 & 84 \\
\hline Totals & & 554 & & 197 & & 55 & & 445 & & 321 & & 1572 \\
\hline
\end{tabular}

The differences between our expectations and the patterns in formal tool use at $41 \mathrm{BX} 17$ may be related to the use of specific tools to conduct specific tasks associated with bison procurement. As we noted above, bison procurement may require specific tools regardless of increases or decreases in abundance. Examination of the individual tool types (i.e., unifaces, bifaces, hafted tools) suggest that the major differences in the periods are probably due to fluctuations in the relative contribution of bifaces. It is likely that most of these bifaces were either used as tools or were discarded prior to completion. In all probability, they would have been in the hafted tool class when completed. Hafted tools are more likely to be task specific, such as might be involved with bison procurement. Given this, the overall investment in specialized tools does follow the suggested shifts in bison during the first three periods. At 41BX17, only in the TLA, when bison abundance declines but the relative percentage of formal tools increases, does the trend differ from the expected pattern. It appears likely, then, that a functional relationship between specific tools and tasks account for the Figure 12-1 patterns.

\section{Regional Comparisons}

To identify broad trends in the organization of tool manufacture and explore the suggestions presented above, we compiled comparable data on 18 archeological components from 12 archeological sites (Table 12-3). The Early Middle Archaic (EMA) period is represented by four components, the LMA by five components, and the ILA, MLA, and TLA by three components each. The sites are distributed across Central and South-Central Texas (Figure 12-2). Eight are located in South-Central Texas, three are from Central Texas, and one is from East-Central Texas.

We collapsed the comparative components on Table 12-3 into the combined values of each component (Table 124). In the EMA AU bifacially retouched items were the 
most abundant at $45 \%(n=84)$ of the total tools followed by utilized flakes $(25 \%)$. Utilized flakes made up $40 \%$ of the LMA $(n=209)$ followed by bifacially retouched items and retouched items with haft elements, each accounting for $24 \%$ of the total tools. The ILA contained $31 \%(n=51)$ bifacially retouched flakes and $24 \%(n=38)$ utilized flakes. Utilized flakes accounted for $41 \%(n=145)$ of the MLA, and bifacially retouched items followed with $27 \%(n=94)$. Finally, the TLA contained 33\% $(n=114)$ utilized flakes and $27 \%(n=94)$ bifacially retouched items.

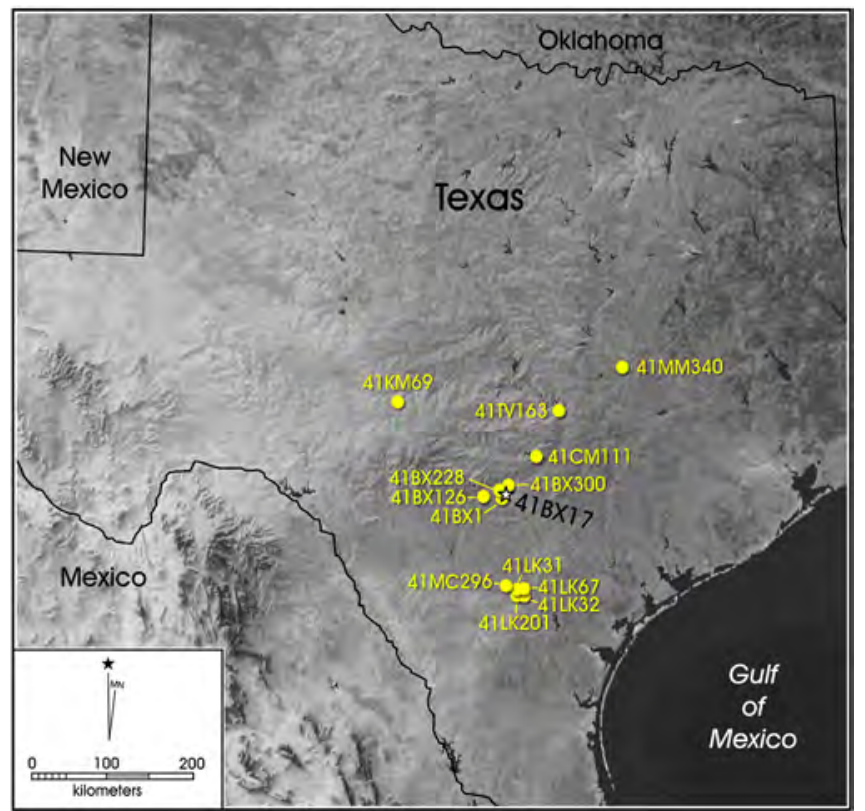

Figure 12-2. Location of archeological sites mentioned in the manufacturing cost analysis.

The percentage of formal tools from these comparative components and 41BX17 are shown in Figure 12-3 (see also Table 12-4). This figure suggests that the tool kit was generally less specialized in time. Tools become less specialized in the
LMA, remain roughly the same in the ILA, and then decline slightly in the MLA. Unlike the TLA pattern seen when 41BX17 was examined separately (Figure 12-1), there is no appreciable increase apparent in the percentage of expensive tools in this data set (Figure 12-3). The tool cost data from the comparative sites do not support our expectations of a tool kit reflecting more specialized tools as a response to decreasing bison or more generalized tools in response to bison increases.

An examination of the counter argument that formal tools, which are more likely to reflect task specific requirements, are correlated directly with increases or decreases in bison has marginal support. The Middle Archaic assemblages do not pattern with our anticipated increase in bison. However, there is a small drop from the Initial Late Archaic into the Middle Late Archaic. The pattern then levels off (Figure 123 ). It may be the case, then, that certain types of expensive tools are designed specifically for bison and are not tied to increases or decreases in these large animals, at least in the manner that we suggested. However, the percentage changes are minimal through time (see Table 12-4). If numbers of expensive tools are increasing when bison are increasing and decreasing when bison are declining, then the Figure 12-3 data suggest marginal changes in bison availability over the time frame considered here.

\section{Monitoring Gearing-Up}

Gearing-up signifies the manufacture, at one location, of large numbers of tools in response to anticipated needs and failure rates rather than ongoing needs for tool replacement. This strategy of manufacturing tools for future needs can be contrasted with a strategy where tool manufacture is responsive to on-demand replacement of failed tools. Because this strategy involves the manufacture of specimens at the location where the tool failed, on-demand replacement has

Table 12-4. Summary of Tool Manufacturing Costs by Temporal Period

\begin{tabular}{|c|c|c|c|c|c|c|c|c|c|c|c|}
\hline \multirow{2}{*}{$\begin{array}{l}\text { Tool Type (least to most } \\
\text { expensive) }\end{array}$} & \multicolumn{2}{|c|}{$\begin{array}{c}\text { Early Middle } \\
\text { Archaic }\end{array}$} & \multicolumn{2}{|c|}{$\begin{array}{c}\text { Late Middle } \\
\text { Archaic }\end{array}$} & \multicolumn{2}{|c|}{$\begin{array}{c}\text { Initial Late } \\
\text { Archaic }\end{array}$} & \multicolumn{2}{|c|}{$\begin{array}{c}\text { Middle Late } \\
\text { Archaic }\end{array}$} & \multicolumn{2}{|c|}{$\begin{array}{c}\text { Terminal Late } \\
\text { Archaic }\end{array}$} & \multirow{2}{*}{ Total } \\
\hline & $\mathbf{n}$ & $\%$ & $\mathbf{n}$ & $\%$ & $\mathbf{n}$ & $\%$ & $\mathbf{n}$ & $\%$ & $\mathbf{n}$ & $\%$ & \\
\hline Utilized Flakes & 48 & 25 & 209 & 40 & 38 & 24 & 145 & 41 & 114 & 33 & 554 \\
\hline Marginally Retouched Items & 12 & 6 & 45 & 9 & 34 & 21 & 44 & 12 & 62 & 18 & 197 \\
\hline Unifacially Retouched Items & 3 & 2 & 15 & 3 & 7 & 4 & 11 & 3 & 19 & 5 & 55 \\
\hline Bifacially Retouched Items & 84 & 45 & 122 & 24 & 51 & 31 & 94 & 27 & 94 & 27 & 445 \\
\hline $\begin{array}{l}\text { Retouched Items with Haft } \\
\text { Elements }\end{array}$ & 42 & 22 & 126 & 24 & 33 & 20 & 60 & 17 & 60 & 17 & 321 \\
\hline Total & 189 & 100 & 517 & 100 & 163 & 100 & 354 & 100 & 349 & 100 & 1572 \\
\hline
\end{tabular}


the effect of immediately reintroducing a needed implement into the systemic context, resulting in the production of one replacement tool for each use-failed tool. A successful tool manufacture process will terminate in the production of a complete functional specimen that will replace the usefailed component of a tool. There is a chance, however, that the manufacture of a replacement tool will result in a manufacture-failed specimen either due to stochastic factors, such as unidentified imbedded fracture lines within the parent material or technical/mechanical errors on the part of the craftsmen. We cannot estimate the actual failure rates of prehistoric tool manufacture activities. However, we will assume that mean manufacture failure rates were relatively constant through time for the period under consideration.

Accepting these assumptions, we suggest that comparisons of failure rates (i.e., manufacture versus use) within expensive tool classes can profitably be used to identify gearing-up strategies. When resource procurement occurs on a day-to-day basis, we expect that tool failure and tool manufacture for on-demand replacement will result in lower numbers of manufacture-failed items relative to use-failed specimens within broad functionally specific groups (e.g., use and manufacture broken points reflecting acquisition, knives reflecting processing, etc.). Conversely, if some procurement is likely to be conducted under time constraints or resources are processed for bulk transport, we anticipate that hunters will "gear-up" by placing some emphasis on tool manufacture for future use and possibly organize that procurement logistically. If that is the case, there should also be locations where these tools, manufactured earlier, are used

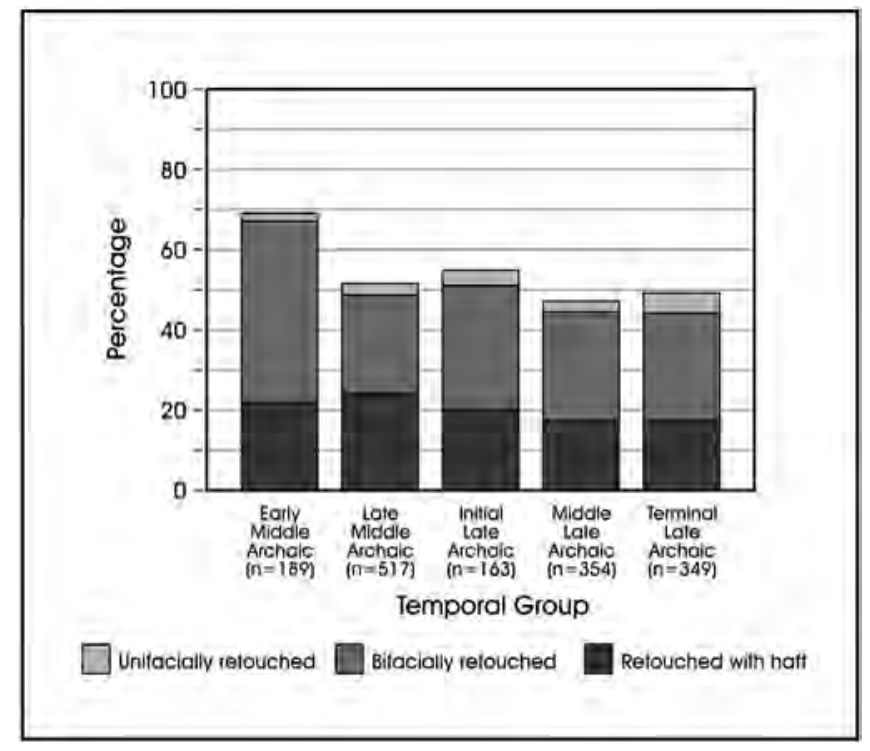

Figure 12-3. Percentages of formal tools from $41 B X 17$ and comparative components by temporal units (see also Table 12-4).

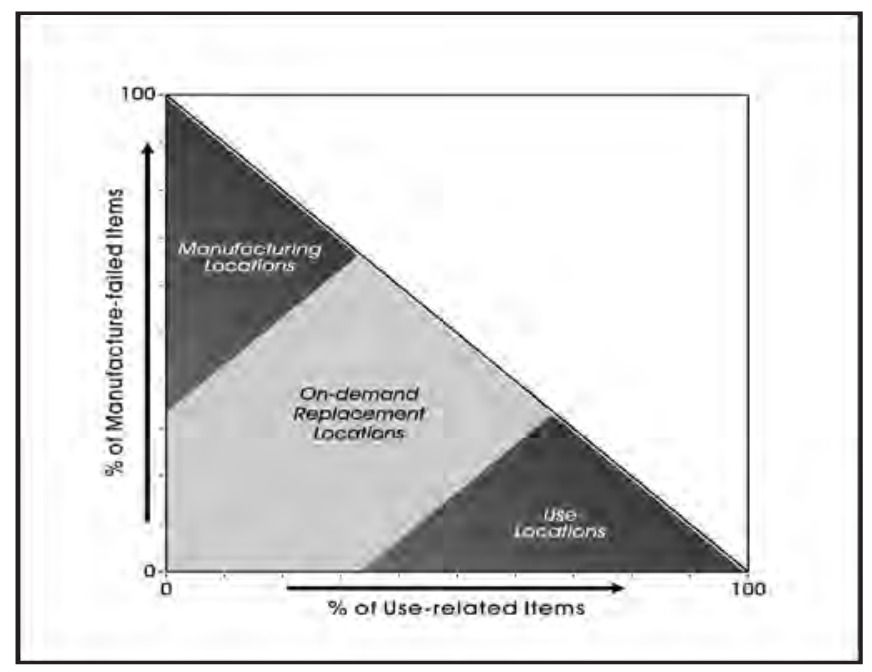

Figure 12-4. Proposed relationship between manufacturefailed and use-related items for locations in two (on-demand vs. gearing-up) stategies.

and sometimes broken. These locations should be dominated by higher frequencies of use-failed items relative to items broken during manufacture because manufacturing occurred earlier at another location. Figure 12-4 presents the proposed relationship between manufacture-failed and use-failed items for locations in on-demand and gearing-up systems. Note that the proposed break points and sections on the graph, divided by shading differences, are done for illustrative purposes only. The exact location of these cut points is not known and varies from case to case depending on a variety of systems specific variables.

In terms of bison procurement, when are time restricted activities, and by extension gearing-up strategies, likely to occur? Under conditions of improving grasslands, bison will be increasingly common in the environment, and they will be encountered more frequently. Time-stress should be lessened under these conditions. Conversely, when grasslands are shrinking, bison populations should be declining. They may be available only seasonally with increasing fluctuations. Hunters will encounter the animal less frequently. Under these conditions, time-stress should be increasing, and we anticipate a gearing-up strategy is more likely. One of the complicating elements, however, is the potential that even if there was no significant time stress, bison procurement could have been organized logistically with bison processed in bulk. Such an organization would also favor the implementation of a gearing-up strategy. As we suggested earlier, a logistical organization should always be focused on high return resources, but high return resources do not necessarily require a logistical system. While we explore this complication in the subsequent chapter, it is the case that logistical systems are increasingly likely when critical 
Table 12-5. Failure Cause for 41BX17 Tool Groups

\begin{tabular}{|c|c|c|c|c|c|c|c|c|}
\hline \multirow[b]{2}{*}{ Tool Category } & \multicolumn{4}{|c|}{ Middle Archaic } & \multicolumn{4}{|c|}{ Late Archaic ** } \\
\hline & 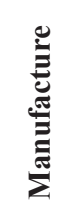 & $\ddot{\mathscr{D}}$ & 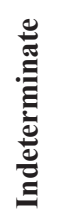 & $\frac{\frac{0}{0}}{\bar{z}}$ & 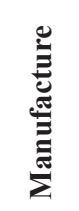 & $\stackrel{\mathscr{D}}{\mathscr{D}}$ & 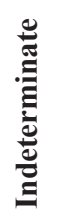 & 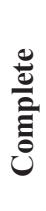 \\
\hline Non-point hafted Items (Knives, Adzes, Gouges, Unifaces) & 0 & 1 & 1 & 1 & 2 & 3 & 1 & 3 \\
\hline Points and Preforms & 0 & 6 & 0 & 3 & 2 & 5 & 2 & 6 \\
\hline Miscellaneous Bifaces & 14 & 1 & 5 & 0 & 12 & 4 & 12 & 8 \\
\hline Totals & 19 & 12 & & & 36 & 21 & & \\
\hline Manufacture and Use Failure Rates & $61 \%$ & $39 \%$ & & & $63 \%$ & $37 \%$ & & \\
\hline
\end{tabular}

**6 tools ( 2 hafted bifaces, 3 miscellaneous bifaces, and 1 hafted point/preform) could not be split into Late Archaic intervals.

resources exhibit increased spatial incongruence (see Binford 1980; 2001:269). We think this is most likely to occur when bison are declining in numbers but acknowledge that some bison procurement may have been organized logistically during all periods as bison are a high-return item. Finally, note that it is certainly possible that both a gearing-up and an on-demand replacement strategy could operate in the same system, shifting on the basis of elements such as resource type or seasonality.

To monitor the frequency of gearing-up present in the prehistoric assemblages, we differentiated use-broken from manufacture-failed specimens within the formal tool category. The identification of failure cause was based on comparative specimens and descriptions of the break morphologies of experimentally broken items (Callahan 1979; Crabtree 1972; Johnson 1979, 1981; Muto 1971; Tomka 1986). Tools were classified into one of four groups. Besides manufacture and use breaks, tools could also be complete or the breakage pattern could be indeterminate. We considered manufacture and use failure rates in projectile points and preforms, other hafted bifaces, and break data from miscellaneous bifaces. For the purposes of this discussion, items classified as miscellaneous bifaces are, with few exceptions that clearly have use breaks, considered to reflect manufacturing failures. Miscellaneous bifaces are thought to primarily reflect a stage in the production of some more formal tool, and most specimens do have breaks classified as occurring during manufacturing. Note also that in a small number of cases, a miscellaneous biface lacks any breaks and is considered "complete." These complete items, discarded prior to the production of a finished tool, along with items considered as having an "indeterminate" break pattern, are classified as manufacturing failures. Conversely, complete hafted tools are classified as use-related. Items classified as "indeterminate" breaks in other tool categories are listed, but do not play a significant role in this analysis.

While we will subsequently consider patterns in individual AUs at 41BX17, Table 12-5 contrasts the Middle Archaic and the combined Late Archaic materials for the site. In the Middle Archaic, tools reflecting acquisition (e.g., points) and processing (e.g., hafted bifaces) both have $100 \%$ use failure and complete items, though the sample sizes are small in the non-point hafted group. However, when failure rates for miscellaneous bifaces are included, $61 \%$ of the overall breakage patterns are related to manufacturing (Table 125). The combined Late Archaic period at $41 \mathrm{BX} 17$ has lower frequencies of use breaks for both points $(85 \%)$ and other hafted items (75\%) and a lower overall relative frequency of use broken and complete items (63\%) relative to the Middle Archaic, though the differences are minimal. Differences at this temporal scale, with only two components to compare, are difficult to interpret. The higher use breakage in the Middle Archaic at the individual tool type level are consistent with a gearing-up system, though the overall rates at the component level are not significantly different from the combined Late Archaic pattern at 41BX17.

\section{Regional Comparisons}

To place the Table 12-5 patterns into a larger context, we gathered comparable data from the same 18 archeological components from 12 archeological sites that we reviewed for manufacturing costs (see Figure 12-2). We eliminated 
Table 12-6. Failure Cause for Early and Late Middle Archaic Comparative Assemblages

\begin{tabular}{|c|c|c|c|c|c|}
\hline 41BX228-EMA & Points/ Preforms & Other Hafted & Misc. Bifaces & Overall Totals & $\%$ \\
\hline Manufacture & 5 & 0 & 25 & 41 & 67 \\
\hline Use & 11 & 2 & 1 & 20 & 33 \\
\hline Complete & 4 & 2 & 7 & & \\
\hline Indeterminate & 0 & 0 & 4 & & \\
\hline 41CM111-EMA & Points/ Preforms & Other Hafted & Misc. Bifaces & Overall Totals & $\overline{\%}$ \\
\hline Manufacture & 10 & 0 & 21 & 35 & 60 \\
\hline Use & 13 & 0 & 1 & 23 & 40 \\
\hline Complete & 8 & 1 & 4 & & \\
\hline Indeterminate & 3 & 0 & 0 & & \\
\hline 41BX17-LMA & Points/ Preforms & Other Hafted & Misc. Bifaces & Overall Totals & $\%$ \\
\hline Manufacture & 0 & 0 & 14 & 19 & 61 \\
\hline Use & 6 & 1 & 1 & 12 & 39 \\
\hline Complete & 3 & 1 & 0 & & \\
\hline Indeterminate & 0 & 1 & 5 & & \\
\hline 41BX1-LMA & Points/ Preforms & Other Hafted & Misc. Bifaces & Overall Totals & $\%$ \\
\hline Manufacture & 3 & 0 & 3 & 12 & 46 \\
\hline Use & 7 & 0 & 1 & 14 & 54 \\
\hline Complete & 6 & 0 & 6 & & \\
\hline Indeterminate & 3 & 0 & 0 & & \\
\hline 41BX126-LMA & Points/ Preforms & Other Hafted & Misc. Bifaces & Overall Totals & $\%$ \\
\hline Manufacture & 5 & 0 & 3 & 12 & 67 \\
\hline Use & 2 & 1 & 0 & 6 & 33 \\
\hline Complete & 3 & 0 & 4 & & \\
\hline Indeterminate & 1 & 0 & 0 & & \\
\hline 41BX228-LMA & Points/ Preforms & Other Hafted & Misc. Bifaces & Overall Totals & $\%$ \\
\hline Manufacture & 7 & 0 & 14 & 36 & 64 \\
\hline Use & 10 & 2 & 5 & 20 & 36 \\
\hline Complete & 0 & 3 & 15 & & \\
\hline Indeterminate & 2 & 1 & 0 & & \\
\hline 41BX300-LMA & Points/ Preforms & Other Hafted & Misc. Bifaces & Overall Totals & $\%$ \\
\hline Manufacture & 0 & 0 & 9 & 15 & 47 \\
\hline Use & 10 & 2 & 2 & 17 & 53 \\
\hline Complete & 3 & 0 & 5 & & \\
\hline Indeterminate & 1 & 0 & 1 & & \\
\hline 41TV163-LMA & Points/ Preforms & Other Hafted & Misc. Bifaces & Overall Totals & $\%$ \\
\hline Manufacture & 6 & 0 & 19 & 33 & 46 \\
\hline Use & 28 & 0 & 2 & 39 & 54 \\
\hline Complete & 9 & 0 & 3 & & \\
\hline Indeterminate & 3 & 0 & 5 & & \\
\hline
\end{tabular}

two EMA components from our review, 41BX1 and 41LK31/32, one Initial ILA component, 41LK67, and the TLA component from 41BX17 because of small breakage sample sizes. With the remaining 41BX17 material, the EMA period is represented by two components, the LMA by six components, the ILA by three components, the MLA by four components, and the TLA by three components. Tables
12-6 and 12-7 present the Middle Archaic and Late Archaic breakage patterns.

A review of both Tables 12-6 and 12-7 will show that there are surprisingly few "other hafted" items during any period. Eliminating indeterminate breakage types, the largest sample size for any component is 5 items, with four of the 
Table 12-7. Failure Cause for Initial, Middle, and Terminal Late Archaic Comparative Assemblages

\begin{tabular}{|c|c|c|c|c|c|}
\hline 41BX17-ILA & Points/ Preforms & Other Hafted & Misc. Bifaces & Overall Totals & $\%$ \\
\hline Manufacture & 1 & 0 & 3 & 15 & 75 \\
\hline Use & 2 & 1 & 1 & 5 & 25 \\
\hline Complete & 1 & 0 & 5 & & \\
\hline Indeterminate & 0 & 1 & 6 & & \\
\hline 41LK201-ILA & Points/ Preforms & Other Hafted & Misc. Bifaces & Overall Totals & $\%$ \\
\hline Manufacture & 0 & 0 & 0 & 4 & 50 \\
\hline Use & 0 & 0 & 2 & 4 & 50 \\
\hline Complete & 1 & 1 & 1 & & \\
\hline Indeterminate & 0 & 1 & 3 & & \\
\hline 41MM340-ILA & Points/ Preforms & Other Hafted & Misc. Bifaces & Overall Totals & $\%$ \\
\hline Manufacture & 6 & 0 & 14 & 25 & 59.5 \\
\hline Use & 8 & 0 & 7 & 17 & 40.5 \\
\hline Complete & 1 & 1 & 3 & & \\
\hline Indeterminate & 1 & 0 & 2 & & \\
\hline 41BX17-MLA & Points/ Preforms & Other Hafted & Misc. Bifaces & Overall Totals & $\%$ \\
\hline Manufacture & 1 & 1 & 6 & 13 & 52 \\
\hline Use & 2 & 2 & 2 & 12 & 48 \\
\hline Complete & 4 & 2 & 1 & & \\
\hline Indeterminate & 1 & 0 & 4 & & \\
\hline 41KM69-MLA & Points/ Preforms & Other Hafted & Misc. Bifaces & Overall Totals & $\%$ \\
\hline Manufacture & 2 & 1 & 11 & 21 & 64 \\
\hline Use & 3 & 0 & 6 & 12 & 36 \\
\hline Complete & 2 & 1 & 2 & & \\
\hline Indeterminate & 2 & 0 & 5 & & \\
\hline 41MC296-MLA & Points/ Preforms & Other Hafted & Misc. Bifaces & Overall Totals & $\%$ \\
\hline Manufacture & 0 & 0 & 2 & 3 & 43 \\
\hline Use & 1 & 0 & 3 & 4 & 57 \\
\hline Complete & 0 & 0 & 0 & & \\
\hline Indeterminate & 0 & 0 & 1 & & \\
\hline 4IMM340-MLA & Points/ Preforms & Other Hafted & Misc. Bifaces & Overall Totals & $\%$ \\
\hline Manufacture & 7 & 0 & 29 & 47 & 57 \\
\hline Use & 11 & 0 & 12 & 35 & 43 \\
\hline Complete & 12 & 0 & 3 & & \\
\hline Indeterminate & 4 & 0 & 8 & & \\
\hline 41KM69-TLA & Points/ Preforms & Other Hafted & Misc. Bifaces & Overall Totals & $\%$ \\
\hline Manufacture & 0 & 0 & 24 & 31 & 53 \\
\hline Use & 19 & 0 & 5 & 28 & 47 \\
\hline Complete & 2 & 2 & 2 & & \\
\hline Indeterminate & 3 & 0 & 5 & & \\
\hline 41LK67-TLA & Points/ Preforms & Other Hafted & Misc. Bifaces & Overall Totals & $\%$ \\
\hline Manufacture & 0 & 0 & 4 & 10 & 50 \\
\hline Use & 0 & 1 & 8 & 10 & 50 \\
\hline Complete & 1 & 0 & 2 & & \\
\hline Indeterminate & 1 & 0 & 4 & & \\
\hline 41MM340-TLA & Points/ Preforms & Other Hafted & Misc. Bifaces & Overall Totals & $\%$ \\
\hline Manufacture & 5 & 1 & 17 & 36 & 60 \\
\hline Use & 8 & 1 & 6 & 24 & 40 \\
\hline Complete & 7 & 2 & 1 & & \\
\hline Indeterminate & 5 & 0 & 12 & & \\
\hline
\end{tabular}




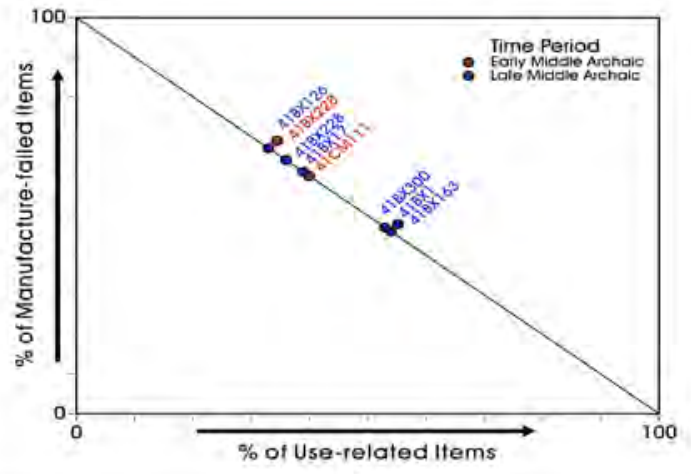

Figure 12-5. The relationship between manufacture-failed and use-related tools from each site dating to the Early Middle and Late Middle Archaic from 41 BX17 and comparative components.

18 having no items. While we will count these items in the overall patterns, the average samples size of 1.77 items per component effectively eliminates any meaningful intercomponent comparison in this category. Most tools are classified as projectile points and preforms, and it is likely that most of the miscellaneous bifaces are involved in generating replacements for that group. The overall totals on Tables 12-6 and 12-7 consist of the counts highlighted with bold print with the manufacture overall totals including points/preforms, other hafted, and miscellaneous bifaces with manufacture breaks as well as miscellaneous bifaces that were categorized as complete and indeterminate. The use overall totals include points/preforms, other hafted, and miscellaneous bifaces with use breaks as well as complete points/preforms and other hafted.

To consider the breakage patterns, we arrayed data on bivariate plots with the percentage of use-related items plotted along the $\mathrm{X}$-axis, and the percentage of manufacture-failed items plotted along the Y-axis. Systems characterized by gearingup behavior should have a high frequency of components in the upper left and lower right of the plot. Conversely, those systems characterized by on-demand replacement should have a high number of assemblages in the central portion of the plot (see Figure 12-4). The location of the dividing lines between the various sections of the graph will depend on a variety of factors (e.g., failure rates, production trajectories, activity levels). We cannot realistically estimate these factors for prehistoric material. In spite of these limitations, however, we anticipate that if our model is useful, then assemblage patterns from Middle Archaic components, when bison are increasing in numbers, and ILA components, when bison are at their peak, should tend to have assemblages in the center of the bivariate plots. Conversely, during the MLA and the TLA, assemblages should be increasingly common in the upper left and lower right portions of the plot.

Figures 12-5, 12-6, and 12-7 present the overall patterns of use and manufacture related items for the Middle Archaic, Initial Late Archaic, and the Middle and Terminal Late Archaic, respectively. The eight Middle Archaic components (Figure 12-5; Table 12-6) seem to form two clusters with a group of three components (41BX1-LMA, 41BX300-LMA, 41TV163-LMA) falling close to the 50\% manufacture-failure, $50 \%$ use-related point and the remaining five components clustering in the 60 to $70 \%$ manufacture-fail area of the graph. No components are significantly below the $50 / 50$ break point in the high use-related area of the graph. Only three sites are present in the Initial Late Archaic (Figure 12-6, see also Table 12-7), but the same two groups can be distinguished. The component at 41LK201 has a 50/50 breakdown, though the sample size is small $(\mathrm{n}=8)$. The two other ILA components (41L17 and 41MM340) both have higher manufacture-failed percentages. Again, no component is in the use-related section of the figure. Finally, there are seven components that date to the Middle and Terminal Late Archaic, a period of time when bison appear to be declining in numbers in the natural environment. Reference to Figure 12-7 (see also Table 12-7) shows that three components (41BX17-MLA, 41KM69-TLA, 41LK67-TLA) all cluster around the 50\% mark and three components (41KM69-MLA, 41MM340MLA, 41MM340-TLA) have higher manufacture-failed percentages. With $57 \%$ of the items reflecting some form of use-related dominance 41MC296-MLA has what may be a different pattern. This is the highest use-related dominance of any of the 18 components considered in these graphs. While

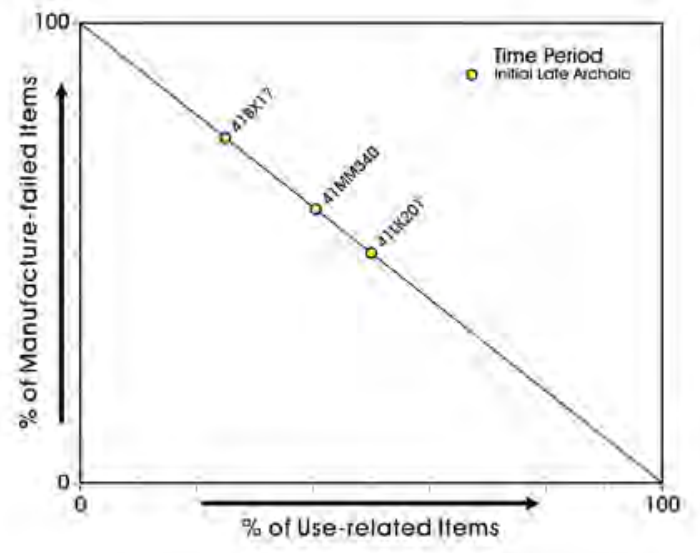

Figure 12-6. The relationship between manufacture-failed and use-related tools from each site dating to the Initial Late Archaic from $41 B X 17$ and comparative components. 


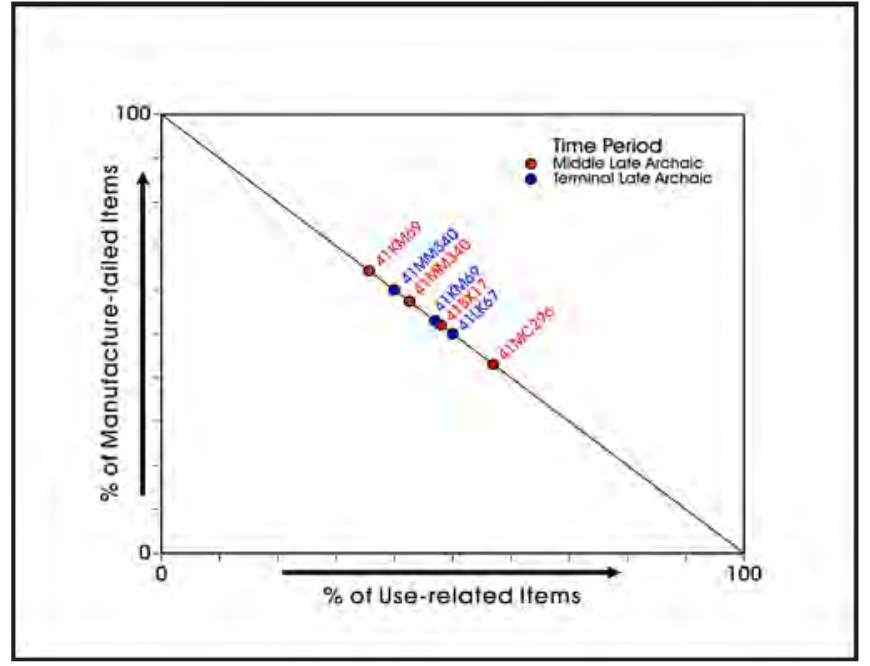

Figure 12-7. The relationship between manufacture-failed and use-related tools from each site dating to the Middle Late Archaic and the Terminal Late Archaic from $41 B X 17$ and comparative components.

this may signify a component trending towards the lower right portion of the graph, the low sample size $(n=7)$ prevents any firm conclusions regarding the validity of the pattern.

Based on the presence of bison throughout the Middle and Late Archaic periods, we anticipated a gearing-up system might be present, especially in the later portions of the Late Archaic as bison declined in availability. We anticipated that during other periods, while some evidence of gearing-up would be present, components would be dominated by ondemand replacement. The patterns in Figures 12-5 through $12-7$, where most sites cluster around the $50 \%$ point in the graphs, suggest that an on-demand replacement strategy is probably operating throughout most of the time frame considered here. While some components have patterns that are consistent with a manufacturing location during all periods, only a single component (41MC296-MLA) is dominated by use-related items. While the presence of this component is consistent with our expectations that later in time, as bison densities decline, we should see increasing evidence of a "gearing-up" system, only seven tools are in the Middle Late Archaic assemblage from 41MC296. A shift of one assignment, from use-related to manufacturing, would effectively eliminate this component as being something different. At present, then, we find little solid evidence for the presence of a "gearing-up" system.

\section{Summary}

In this chapter we investigated two aspects of technological organization. We looked at variability in formal versus expedient tools through time and searched for evidence of gearing-up in anticipation of future needs. We argued that changes in the availability of bison should impact both of these elements. We suggested that if bison are increasingly common in the Middle Archaic and into the Initial Late Archaic, the use of a tool kit that was more specialized, and consequently more expensive both to produce and maintain, should decline. In contrast, we expect that as bison begin to decline in numbers and become more temporally and spatially restricted in the Middle and Terminal Late Archaic, more investment in the production of specialized tools would tend to be favored. In anticipation of future needs and failure rates, we also expect that large numbers of these specialized tools would have been produced in a gearing-up activity as bison became increasingly restricted in time and space.

Our review of both 41BX17 data and data from other Middle and Late Archaic sites shows that, with few exceptions, the arguments for a more specialized tool kit as a response to decreasing bison or a more generalized tool kit in response to increasing bison availability were not supported. An examination of the counterargument, that formal tools, which are more likely to reflect task specific requirements, are correlated directly with increases or decreases in bison, also has marginal support. The Middle Archaic assemblages do not pattern with our anticipated increase in bison. However, there is a small drop in expensive tools from the Initial Late Archaic into the Middle Late Archaic. The pattern then levels off into the Terminal Late Archaic. It may be the case that certain types of expensive tools are designed specifically for bison although the percentage changes through time are minimal.

Similarly ambiguous results are present for our investigation of "gearing-up" behavior. Based on the presence of bison throughout the Middle and Late Archaic periods, we anticipated a gearing-up system might be present, especially in the later portions of the Late Archaic as bison declined in availability. We anticipated that during other periods, while some evidence of gearing-up would be present, components would be dominated by on-demand replacement. While we did have some support for these suggestions, the validity of the pattern seen can be questioned on the basis of sample size. 



\title{
Chapter 13: Assessing Changes in the Scale of Mobility
}

\author{
Cynthia M. Munoz and Raymond P. Mauldin
}

The previous chapter discussed aspects of technological organization associated with the manufacture, repair, and replacement of lithic tools. Chapter 13 assesses changes in the scale of mobility by investigating how these technological activities may have been conditioned by the availability and form of tool stone. Mobility systems may be organized as relatively small scale, foraging-based systems or significantly larger-scale logistical organizations. This chapter addresses two primary research issues proposed in the research design (Munoz et al. 2007) related to mobility at 41BX17. The two principal research areas consist of: 1) measures of artifact variety as a method for distinguishing locations used in a residential manner from those used for more task-specific activities; and 2) diversity in raw material types as a further indicator of scale of mobility. Both of these topics will be discussed in detail.

\section{Assessing Changes in Mobility}

The hunter-gatherer model developed in Chapter 9 suggested that the presence or absence of bison in regions exploited by hunter-gatherers should guide mobility strategies (i.e., foraging-based versus logistical forms). Based on an expected absence of the large mammal in the Middle Archaic followed by an expected re-emergence in the Late Archaic, we anticipated that the Middle Archaic material would be characterized by relatively small scale, foragingbased systems, while the Late Archaic occupations would be involved in a significantly larger-scale system, increasingly using a logistical form of organization especially near the close of the Late Archaic as fluctuations in bison become more pronounced as grasslands deteriorate. The results of our bison presence/absence study (see Chapter 11) did not support our expectations. Because bison were found to be present throughout the Middle and Late Archaic periods, we altered our expectations from a focus on bison presence/absence to a focus on shifts in bison density. Hunters and gatherers use logistical strategies to target higher-ranked resources, however while this system always focuses on higher return resources, the exploitation of higher return resources does not necessarily require a logistical system. Because procurement conflicts will be reduced when the critical resource (i.e., bison) increases in frequency on the landscape, hunters and gatherers should decrease their reliance on logistical organization. Based on the pattern of changing grassland densities, suggesting that the large mammal was increasingly common in the Middle Archaic into the Initial Late Archaic followed by a gradual decline in the Middle and Terminal Late Archaic, we suggest that logistical forms of mobility organization should decline from the Middle into the Initial Late Archaic and then gradually increase into the Terminal Late Archaic. The first principal research area to be discussed in this chapter consists of using artifact variety as a method for distinguishing locations used in a residential manner from those used for more task-specific activities. Following this discussion on artifact variety, we will address the final research area: the assessment of the diversity in raw material types as a further indicator of the scale of mobility.

\section{Artifact Variety}

Binford (1980; see also Kelly 1995) defined forager systems as having daily inputs of food to a residential camp. That food was gathered from within a short radius of the camp, and frequent residential moves occurred as resources within the foraging radius were exhausted. Foragers are characterized by no bulk storage and relatively small group size. Collectors are defined by a lower frequency of residential moves, larger group size, bulk inputs of food into the residential site generated by task groups, and bulk storage of food stuffs. Collectors minimally should generate two different site types, residential camps and special-purpose sites. Binford's (1980) description of collector and forager systems relied on ethnographic data. While translating these ethnographic descriptions into an archeological context is complicated by problems of reuse of locations for different activities, as well as the observation that the archeological record is generated at a much longer time scale, we can begin to approach the task by considering different levels of activities conducted at locations. A wider range of activities occur at most collector and forager residential sites relative to special-purpose locations (e.g., Yellen 1977). While complicated by aspects such as the use-life of tools and the length of occupation (Schiffer 1975; Shott 1989), the number of diverse activities at residential sites should be reflected by a wider variety of artifact types when compared to residential locations with special-purpose locations.

Because several researchers have shown that sample size has a significant influence on variety (see Bobrowsky and Ball 1989; Kintigh 1989), we cannot simply contrast the number of different artifact types at a series of components. Figure 13-1 presents these expected relationships. We expect 


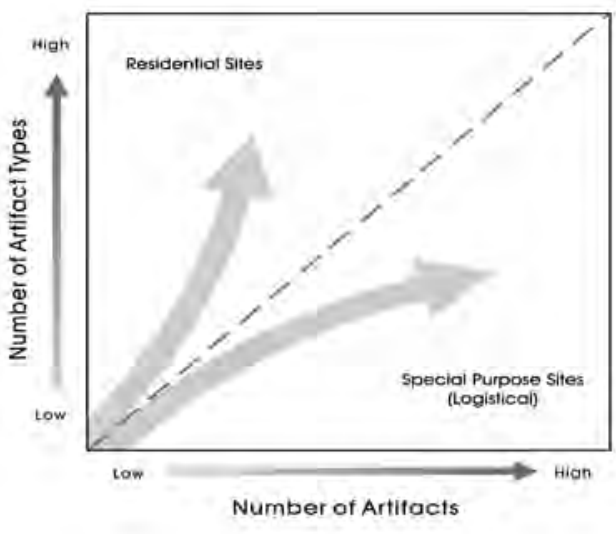

Figure 13-1. Expected relationship between the number of artifact types and sample size for residential and special purpose sites.

that the number of different artifact types will increase at a faster rate on residential sites because hunters and gatherers are likely to conduct a wider variety of activities and occupy these camps for longer periods of time. Conversely, activities at special-purpose locations are, by definition, more restricted. Occupations of most special purpose locations will differentially increase the number of artifacts relative to the addition of new artifact types. Conducting the same set of activities will increase the number of items without a concomitant increase in the artifact types. While the interpretations are complicated by the possibility that some special-purpose locations are reoccupied for a different range of activities, we suggest that the pattern shown in Figure 13-1 will be present in most cases. We expect that foraging based systems will characterize wider diet breadth and that narrower diet breadth will be increasingly organized through logistical activities.

To explore the proposed relationship between artifact variety (i.e., richness and evenness) and different levels of activity, we have identified 16 artifact categories (Table 13-1) that may be present within selected archeological components. We sorted all the tools collected from 41BX17 that could be assigned to our analytical units. The Middle Archaic and Middle Late Archaic (MLA) components had the widest range of artifact types, ten each, followed by the Initial Late Archaic (ILA) with nine and then the Terminal Late Archaic (TLA) with four. We compiled comparable data from the same 19 archeological components from 12 archeological sites that we reviewed for manufacturing costs and gearing-up strategies. (Table 13-1, see Figure 12-3) in order to identify the number of different types of tools as well as information on the sample sizes. The Early Middle Archaic (EMA) period is represented by four components, the Late Middle Archaic (LMA) by six components, and the ILA, MLA, and TLA by three components each. The sites are distributed across Central and South-Central Texas with one from East-Central Texas. The comparative sites ranged from a low of one artifact type at 41LK31/32 to a high of eleven types from 41MM340. The total number of artifacts ranged from a low of 2 at 41LK31/32 to a high of 258 at 41MM340.

We plotted the number of different types of items against the total number of items in each component (Figure 132). Note that the $X$-axis in the figure is the square root of the number of artifacts. The original plot was non-linear, and the transformation of the $\mathrm{X}$ variable reduces the nonlinear impact. We fit a least squares regression line through the data along with $95 \%$ confidence bands on that line. Overall, Pearson's correlation coefficient is 0.698 with a coefficient of variation $\left(\mathrm{R}^{2}\right)$ of 0.488 . This suggests a tenuous relationship between the sample size and artifact variety. In 15 of the 23 cases, the variation in the number of artifact types can be attributed to differences in organization rather than as a function of the number of artifacts. We suggest that residential sites will plot above the line and special purpose below. To develop truly empirical expectations, we would need more information about specific sites. Future research directions for investigating special purpose versus residential status might include exploring specific facilities located on each site type (e.g., burned rock middens), distance to water, and evidence of separation of activities.

An examination of Figure 13-2 shows that the TLA component of 41BX17, along with seven other components, fall within the $95 \%$ confidence band. These cases are primarily determined by sample size and, therefore, do not provide information on site types. Eight components (35\%), consisting of the LMA components at 41BX17, 41BX300, and 41BX228, the ILA components at 41BX17, 41LK67, and 41LK201, and the MLA components at 41BX17 and 41MC296, are above the upper confidence limit in the "residential" area of the plot. There are seven $(30 \%)$ components, five well below and two just below the lower confidence interval, in the "special purpose" area. These include the EMA components at $41 \mathrm{CM} 111$ and 41BX228, the LMA components at 41LK31/32, 41BX1, and 41TV163, the MLA component at $41 \mathrm{MM} 340$, and the TLA component at 41KM69. We expected an overrepresentation of Middle Archaic and TLA sites in the "special purpose" section of our plot, whereas ILA sites should plot on the "residential" portion of the graph. Of the eight Middle Archaic components that are outside of the confidence intervals, five are classified as "special purpose" locations. The one TLA component not in the confidence bands is also located on this portion of the graph. In the ILA, all three components outside of the confidence intervals are 
Table 13-1. Artifact Variety at 41BX17 and in Comparative Assemblages

\begin{tabular}{|c|c|c|c|c|c|c|c|c|c|c|c|c|c|c|c|c|c|c|}
\hline Component & 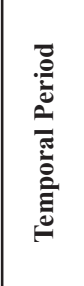 & 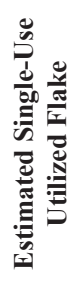 & 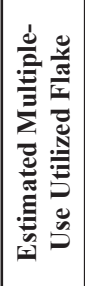 & 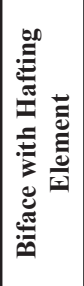 & 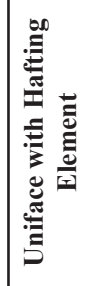 & 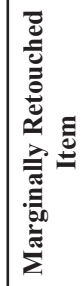 & 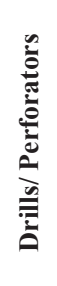 & 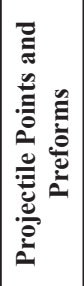 & 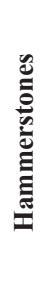 & 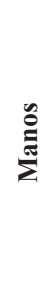 & 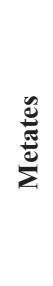 & 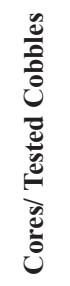 & 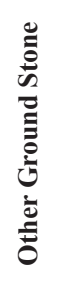 & 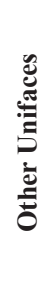 & 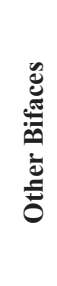 & 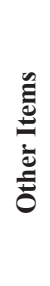 & 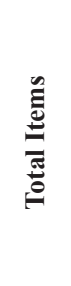 & 递 \\
\hline 41BX17 & LMA & 16 & 14 & 3 & 0 & 7 & 0 & 9 & 0 & 0 & 0 & 21 & 1 & 2 & 20 & 1 & 94 & 10 \\
\hline 41BX17 & ILA & 8 & 1 & 2 & 0 & 1 & 0 & 4 & 1 & 0 & 0 & 10 & 0 & 3 & 14 & 0 & 44 & 9 \\
\hline 41BX17 & MLA & 23 & 8 & 3 & 2 & 3 & 0 & 8 & 0 & 0 & 0 & 3 & 0 & 2 & 13 & 2 & 67 & 10 \\
\hline 41BX17 & TLA & 2 & 0 & 0 & 0 & 0 & 0 & 2 & 0 & 0 & 0 & 1 & 0 & 0 & 5 & 0 & 10 & 4 \\
\hline 41BX1 & EMA & 7 & 1 & 0 & 0 & 3 & 0 & 0 & 0 & 0 & 0 & 1 & 0 & 0 & 2 & 0 & 14 & 5 \\
\hline 41BX1 & LMA & 43 & 19 & 0 & 0 & 8 & 0 & 19 & 0 & 0 & 0 & 8 & $\overline{0}$ & 3 & 12 & 0 & 112 & 7 \\
\hline 41BX126 & LMA & 21 & 18 & 1 & 0 & 5 & 0 & 11 & 0 & 0 & 0 & 0 & 0 & 4 & 7 & 0 & 67 & 7 \\
\hline 4 41BX228 & EMA & 25 & 8 & 4 & 0 & 5 & 0 & 20 & 0 & 0 & 0 & 12 & 0 & 3 & 39 & 0 & 116 & 8 \\
\hline 41BX228 & LMA & 9 & 15 & 4 & 0 & 6 & 2 & 19 & 1 & 0 & 0 & 6 & 0 & 3 & 35 & 0 & 100 & 10 \\
\hline 41BX300 & LMA & 27 & 4 & 0 & 0 & 4 & 2 & 14 & 1 & 0 & 1 & 5 & 0 & 2 & 17 & 0 & 77 & 10 \\
\hline 41CM111 & EMA & 2 & 0 & 1 & 0 & 3 & 0 & 34 & 1 & 0 & 0 & 3 & 0 & 0 & 41 & 0 & 85 & 7 \\
\hline $41 \mathrm{LK} 31 / 32$ & EMA & 5 & 0 & 0 & 0 & 1 & 0 & 0 & 0 & 0 & 0 & 2 & 0 & 0 & 2 & 0 & 10 & 4 \\
\hline $41 \mathrm{LK} 31 / 32$ & LMA & 0 & 0 & 0 & 0 & 2 & 0 & 0 & 0 & 0 & 0 & 0 & 0 & 0 & 0 & 0 & 2 & 1 \\
\hline 41TV163 & LMA & 16 & 4 & 0 & 0 & 15 & 0 & 46 & 0 & 2 & 0 & 8 & 0 & 1 & 30 & 0 & 122 & 8 \\
\hline 41MM340 & ILA & 12 & 4 & 1 & 0 & 23 & 0 & 22 & 3 & 0 & 0 & 36 & 0 & 1 & 26 & 0 & 128 & 9 \\
\hline 41LK67 & ILA & 8 & 2 & 0 & 0 & 6 & 0 & 1 & 0 & 0 & 2 & 8 & 1 & 1 & 5 & 4 & 38 & 10 \\
\hline 41LK201 & ILA & 5 & 0 & 2 & 0 & 4 & 0 & 1 & 0 & 13 & 0 & 22 & 2 & 2 & 6 & 3 & 60 & 10 \\
\hline 41MM340 & MLA & 66 & 28 & 0 & 0 & 29 & 0 & 34 & 4 & 0 & 1 & 36 & 0 & 8 & 52 & 0 & 258 & 9 \\
\hline 41 KM69 & MLA & 6 & 6 & 2 & 0 & 7 & 0 & 9 & 0 & 0 & 0 & 3 & 0 & 0 & 24 & 0 & 57 & 7 \\
\hline $41 \mathrm{MC} 296$ & MLA & 4 & 4 & 0 & 0 & 5 & 0 & 1 & 0 & 11 & 16 & 20 & 4 & 1 & 6 & 0 & 72 & 10 \\
\hline 41LK67 & TLA & 21 & 2 & 1 & 0 & 33 & 0 & 2 & 0 & 0 & 1 & 29 & 1 & 7 & 18 & 0 & 115 & 10 \\
\hline 41KM69 & \begin{tabular}{|l|} 
TLA \\
\end{tabular} & 23 & 0 & 1 & 0 & 5 & 1 & 24 & 0 & 0 & 0 & 9 & 0 & 11 & 36 & 0 & 110 & 8 \\
\hline $41 \mathrm{MM} 340$ & TLA & 44 & 21 & 5 & 0 & 24 & 0 & 24 & 1 & 1 & 1 & 31 & 0 & 1 & 35 & 0 & 188 & 11 \\
\hline
\end{tabular}

classified as "residential sites", whereas two of the three MLA sites are "residential". This pattern suggests that a logistical form of mobility organization was used early in the Middle Archaic, used to a lesser degree in the LMA and followed by a residential pattern in the ILA. The residential pattern decreases in the MLA and TLA components. This pattern fits our expectations, suggesting that as bison densities peaked in the ILA period procurement conflicts were reduced, which decreased the need for a reliance on a logistical organization. Perhaps an uneven distribution in the early years of the Middle Archaic and the latter years of the Late Archaic resulted in a heavier reliance on logistical strategies as bison became more difficult to procure. However, it should be noted that three of the "residential" components are from a single location, 41BX17. This suggests that other elements may be involved in creating the pattern.

\section{Assessing the Scale of Mobility}

The final research topic considered in this chapter involves investigating the scale of mobility by assessing the diversity in raw material types. We have suggested that mobility levels should be responding, in part, to alterations in diet. Specifically, when diet breadth is narrow, the scale of mobility should be increased as a function of increased search time associated with high-ranked animal prey. A greater component of mobility is expected to be organized in a logistical mode. This is especially anticipated to be the case near the close of the Late Archaic when bison densities are expected to begin to fluctuate in response to fluctuations in grasslands. As the scale of mobility increases, there should be associated increases in the range of tool stone encountered 


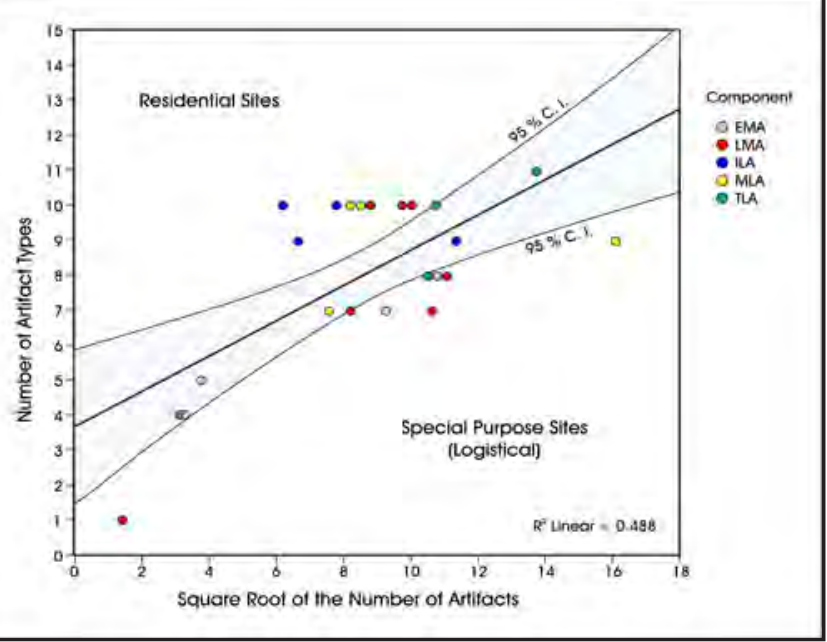

Figure 13-2. The relationship between number of artifact types and sample size for $41 B X 17$ and comparative components by time period.

and used in tool production. The greater the scale of mobility the more likely it is that some of the tool stone present on site arrived there from nonlocal resources in the form of staged, finished, or well-worn tools and represents the debris from staged manufacture, rejuvenation, and reworking of tools.

Several studies (e.g., Amick 1994) have shown that debitage and tools can be used to track mobility. While these studies are often conducted by tracing specific raw materials with known source locations, the relationship demonstrated by these earlier studies is applicable even if the specific tool stone sources are not known. Figure 13-3 presents the proposed relationship between the number of raw material types present and mobility. The upper right quadrant of the graph should be dominated by logistically organized residential components. Whether the acquisition of tool stone is embedded in other activities or is a task-specific activity, these logistical residential components should reflect the range of raw materials present in the system. Regardless of the activities, task-specific locations should have a smaller range of raw material types present. Similarly, foraging components should also encounter a smaller range of raw materials simply as a function of the more limited scale of mobility. We focused on chert color as the defining variable in this analysis and further developed the use of digital photography as a component of this assessment.

To investigate the relationships between raw material variety and different strategies of mobility, we analyzed the color of 100 percent of the debitage recovered from 41BX17. The patterns identified within the distinct components of the site were compared with patterns noted in samples of debitage from selected components of other sites. The debitage contained some items that were heat treated. Because heat treating changes the color and texture of a material, which can artificially raise the number of material types, heat treated items as well as heavily patinated specimens were removed from the data set. All of the formal tools from 41BX17 were also included in this data set. Tools, especially those that are more expensive to produce, and therefore more likely to be maintained, should remain in the overall system longer. As such, these items are likely to reflect the overall scale of mobility. The tools from 41BX17 were assessed with samples of tools from comparative sites. We gathered comparable data from 13 archeological components from 9 archeological sites including two Early Middle Archaic (41BX228 and 41CM111), five Late Middle Archaic (41BX1, 41BX126, 41BX228, 41BX300, and 41TV163), one Initial Late Archaic (41MM340), two Middle Late Archaic (41KM69 and 41MM340), and three Terminal Late Archaic components (41KM69, 41LK67, and 41MM340). Six of the components are located in South-Central Texas, four are from Central Texas, and three are from eastern edge of Central Texas.

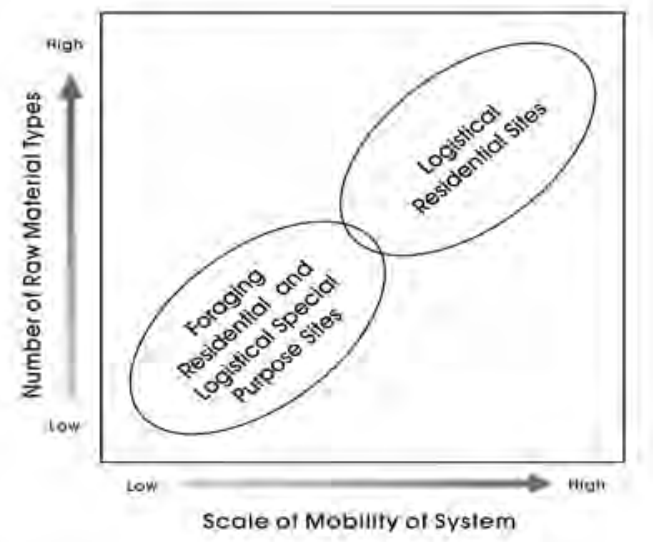

Figure 13-3. Proposed relationship between the number of raw material types present and mobility.

\section{Methodological Considerations}

Our previous investigations of raw material differences (e.g., Tomka et al. 2003; see also Larson and Kornfeld 1997) have relied on grouping chert debitage by reference to colors using standardized rock color charts and then subsequently dividing these color groups by reference to the presence or absence of inclusions. While the procedure has proven to be effective 
at characterizing large scale differences in raw materials (e.g., local versus non-local), there are several drawbacks, especially when the primary concern is with characterizing the number of material sources. The procedure is extremely time-consuming, requiring multiple passes through the data, multiple assessments of individual items, and combinations and partitions of preliminary groupings. Ultimately, the process results in the creation of groups that are frequently impossible to replicate. This is because the grouping procedure relies on qualitative impressions. At the end of the process, a number of "groups" contain only a few items of debitage with some represented by single cases. Along with a consistent definition of what constitutes a material group, the lack of a quantitative component in the analysis, results in a classification that is of limited value, especially when comparisons are made between sites.

In an effort to overcome these methodological shortcomings, the CAR developed a new procedure for assessing material groups. The procedure relies on digital photography of debitage and tools and the quantitative assessment of colors in the photographic image using the RGB scale at a multiple pixel level. The method still contains several arbitrary elements. In addition, the new procedure essentially ignores inclusions, focusing only on color variation in stone. However, the procedure, discussed below, does provide quantitative data on color and is highly replicable.

\section{Photography, Gaussian Blurs, and RGB Pixel Values}

Following the removal of all burned and heat altered items from the lithic assemblages, our initial step in the procedure focused on acquiring high-quality, digital images of debitage and tools under consistent light conditions. All photographs were taken with a Canon Rebel XT with a $60 \mathrm{~mm}$ Canon macro lens equipped with a ring flash. Flash settings were at $1 / 4$ power from a fixed, standard camera height onto a photogray background. Camera settings were maintained for all photographs. To document and assess consistency between photos, four color chips were incorporated into each photo. Once the photos were taken, one of these color chips was used to assess the consistency of each image. When the Red value on the RGB (Red, Green, Blue) scale fell outside of the range for values seen in previous work, we lightened or darkened the photograph as required to bring the image into the expected Red range. This insured that photographs were consistent through time. Provenience data (Field Sack Numbers) were also incorporated in each photo. Figure 13-4 provides an example of a photo of debitage from 41BX17, showing the background, color chips, and a handful of flakes. Photos were taken in groups of 20 to 30 items.
Following image correction, it was necessary to select an area within each tool or debitage piece that would be representative of the color of that item. Depending on the homogeneity of the flake surface, individual pixels may not provide an adequate representation of the overall flake color. While we experimented with several different methods, including multiple readings and subsequent averaging of pixel values, we eventually determined that color was best captured by the use of a Gaussian Blur filtering method in Corel PhotoPaint, Version 12.0. A Gaussian Blur is essentially a filter that reduces image details by homogenizing individual pixels. The procedure relies on a weighted average of pixel values and uses a normal distribution with more weight being given to the central pixel within a chosen radius. Once calculated, the area over which the blur is applied has pixel values that are more uniform than the original pixel ranges. For this analysis, we chose a radius of 25 pixels, meaning that approximately 1,963 pixels were involved in the blur. Figure 13-5 shows an example of the impact of the blur, which can be seen as a consistent circle of color within the outlined black circle. Gaussian Blurs were done on all individual flakes, and their locations were identified with a black circle. This provides precise identification of where the measurements were taken, allowing for replication.

Once blurs were done, pixel values were acquired from each blur through the use of a software program known as Pixeur (Version 2.9.0.9). The program records the RGB values of individual pixels which can then be exported into Excel. Figure 13-6 provides an example of the RGB values for the blurred portion of the flakes shown previously in Figure 134. Over 9,000 pieces of debitage and 100 formal tools from 41BX17, as well as over 3,500 pieces of debitage and 250 formal tools from the comparative sites, were photographed, blurred, and recorded using this system.

The RGB values essentially provide a description of colors seen by the human eye on a video screen with specific graphics configurations (see Cowlishaw 1985). The scale is based on the additions and intensities of three primary colors (Red, Green, Blue), with variations in hue ranging from 0 to 255 for each primary color. For reference, an RGB value of R0/G0/B0 would produce black, R255/G255/B255 would be white, R255/G0/B0 would be red, and R0/R255/R0 would be green. With 256 potential values on each scale, well over 16.7 million color distinctions can be made $\left(256^{3}\right)$, though it is unlikely that many of these color differences can be seen with the human eyes on a video screen.

Rock colors probably occupy only a small number of color possibilities on the RGB scale. However, the potential of over 16.7 million possible colors raises the problem of 


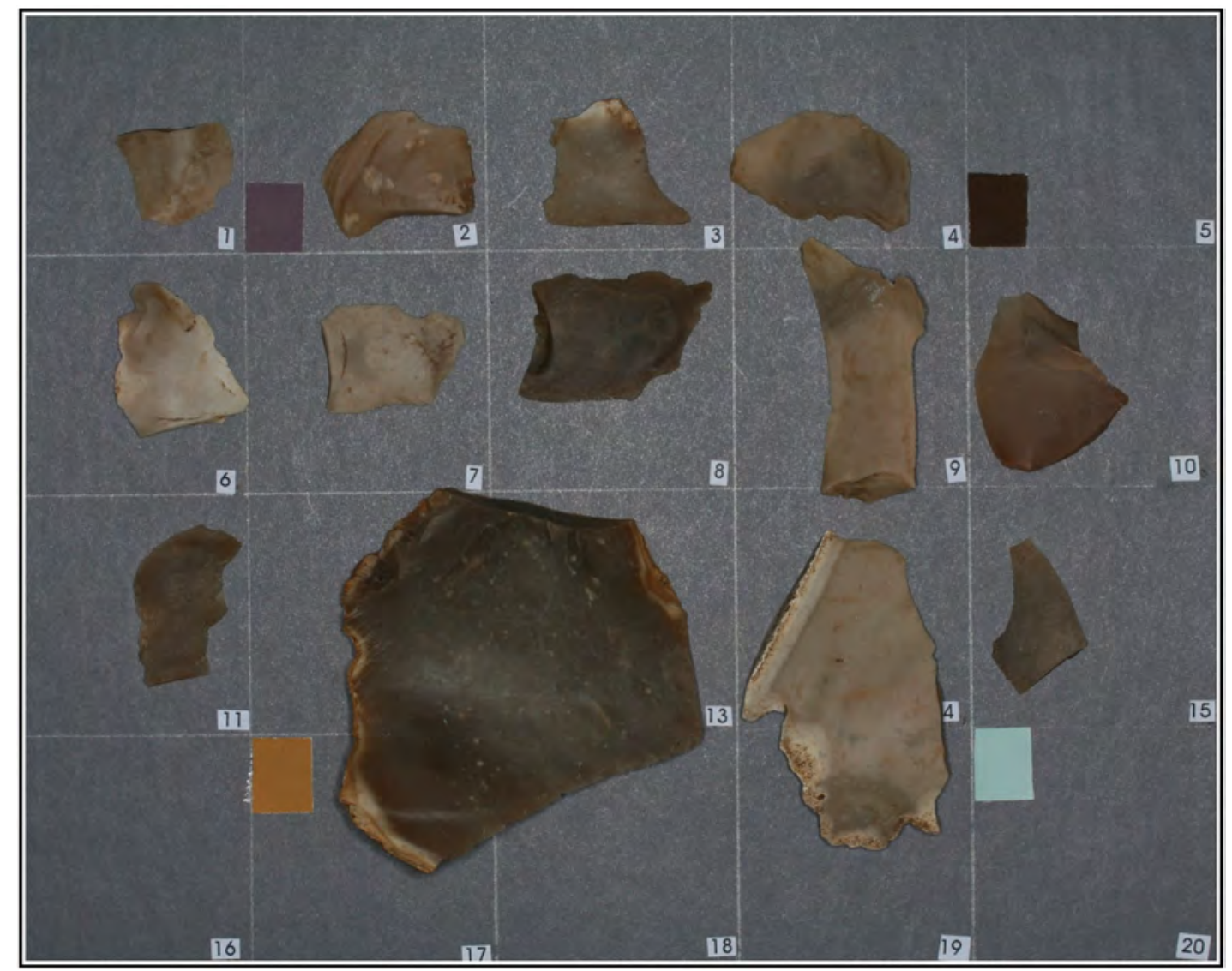

Figure 13-4. An example of debitage photos for material collected during testing at $41 B X 17$.

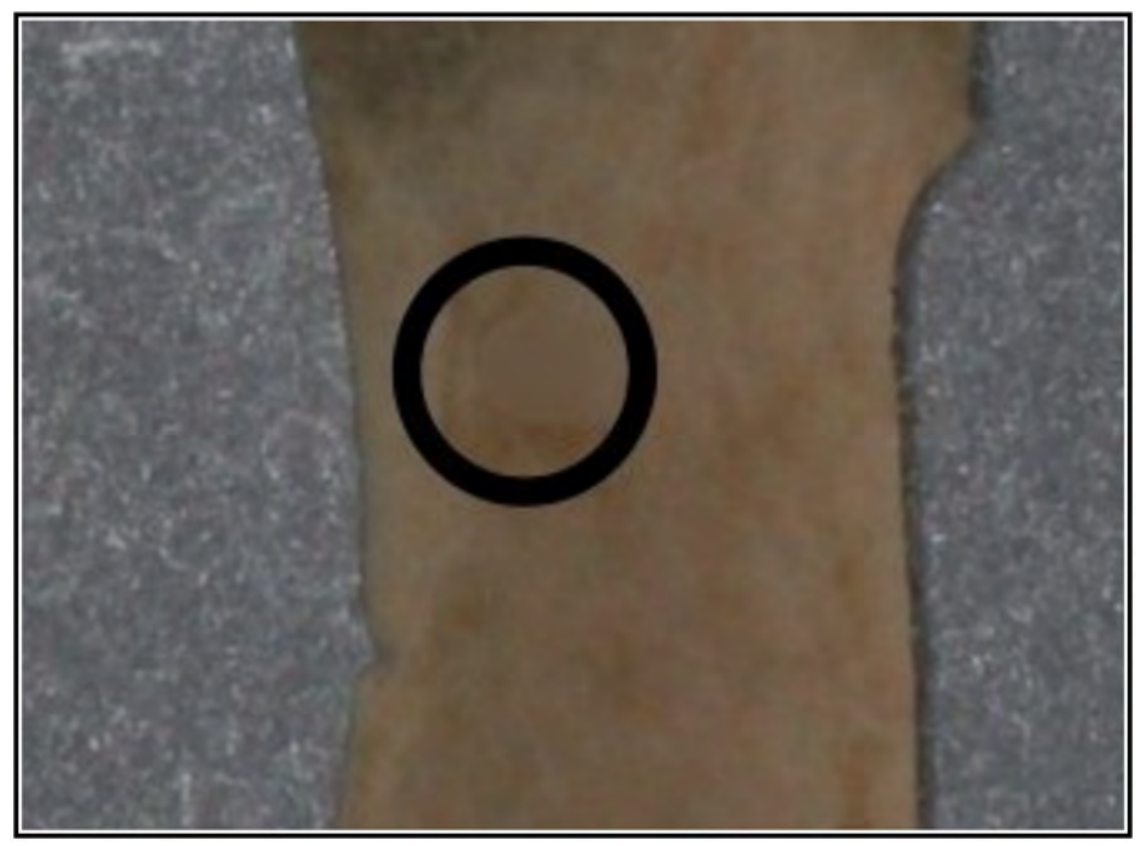

Figure 13-5. An example of the impact of a Gaussian Blur highlighted within the black circle. 
classification. Specifically, at what point is a "different" color present? For example, reference to Figure 13-5 shows that the first two flakes in the top row have relatively close RGB values, hovering around R93/G76/B58. The third flake is relatively close to the first two in the Red and Green values, but differs by a value of around 14 from the first two specimens on the Blue value. Are these two different color groups?

Ideally, of course, groups would be defined based on variation in chert colors derived from known source locations. Unfortunately, no such comparative data base exists. A different approach would be to define colors for a given assemblage empirically, possibly with some form of cluster analysis. However, the strong empirical basis of cluster analysis (see Afifi and Clark 1984) assures that different color types will be defined on an assemblage by assemblage basis. That is, cluster analysis defines groups based on what samples are present within an assemblage. As such, it is probable that, at least in some cases, the same RGB value recorded on flakes from two different assemblages would be assigned to two different color groups because the groups are created by reference to what colors are and are not present in the rest of the assemblage. As one of the goals of this analysis is to compare assemblages in terms of the number of groups represented, this type of solution is not workable. Alternatively, clustering could be done only a single time after all analysis was complete, essentially treating all debitage at once. While this would eliminate the potential for a single RGB value to be classified into two different clusters, if the sample size changes, such as through the addition of other assemblages, a new cluster solution would be necessary, and new color groups would be created. Consequently, these clustering based solutions are probably not a viable approach for the types of comparisons undertaken here.

\section{Results}

Figures 13-7, 13-8, and 13-9 provide bi-variant plots of color pairs (Green/Blue; Red/Blue; Red/Green) for Late Archaic and Middle Archaic debitage from 41BX17. Note that the vast majority of samples fall close together along similar sections of the plots for both time periods. While there is a lack of clear separation of distinct color groups in any of the plots, the overall spread of values for the Late Archaic is greater in all three ranges when compared to the Middle Archaic distributions. Figure 13-10, which shows the distribution of

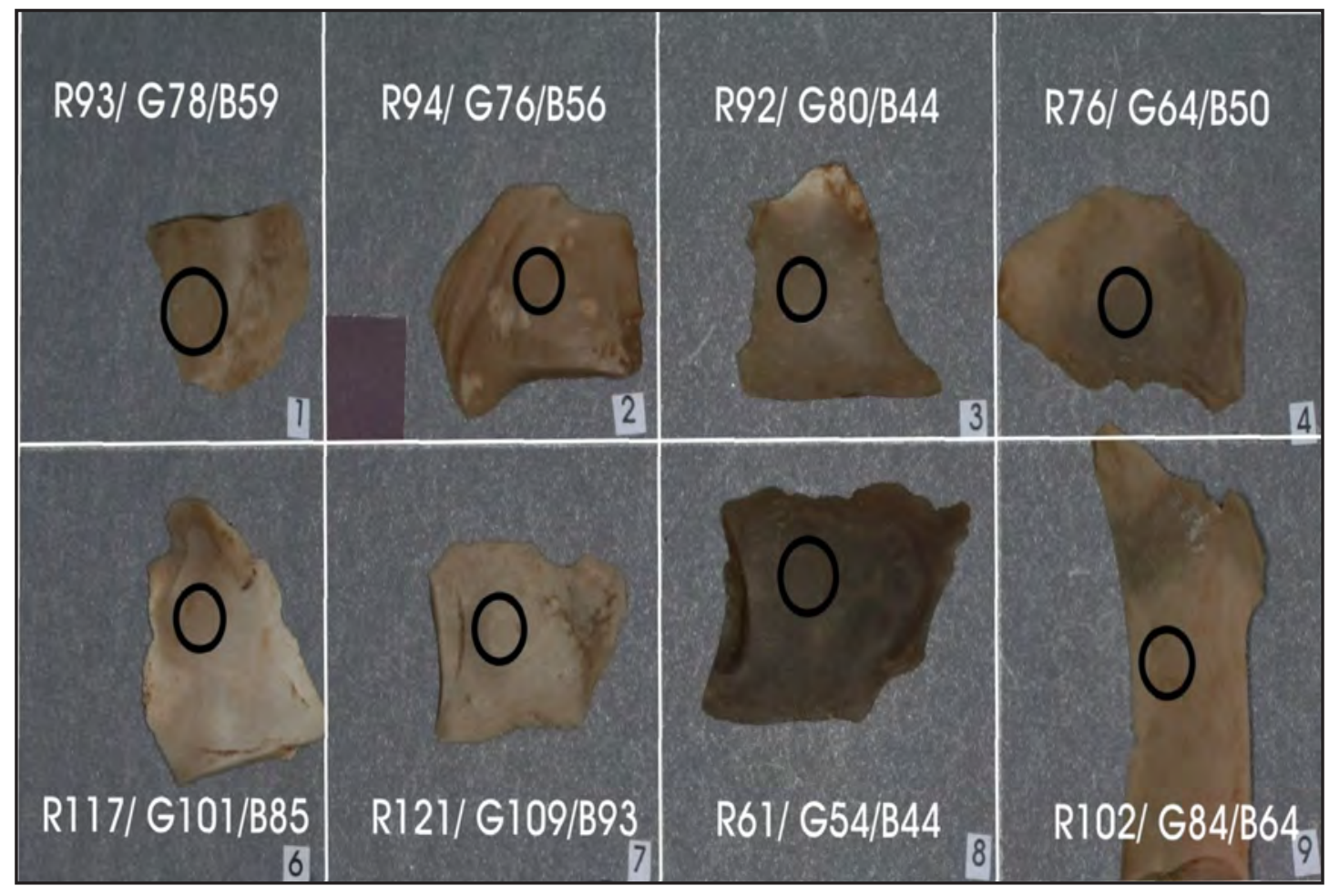

Figure 13-6. An example of RGB colors on debitage for the Gaussian Blur portion of the flake, identified within the dark circle. 

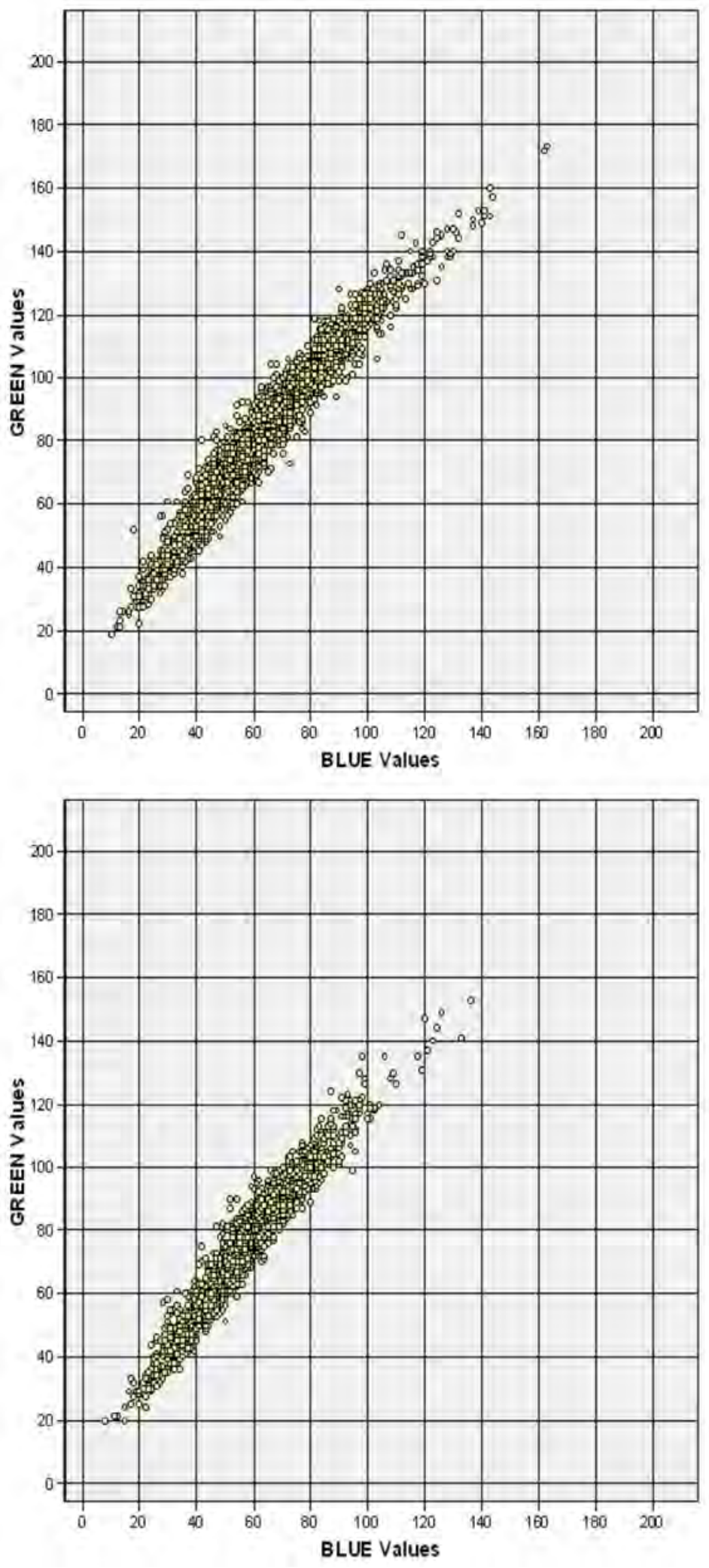

Figure 13-7. Plot of green vs. blue values for Late Archaic (top) and Middle Archaic (bottom) debitage from $41 B \times 17$. 

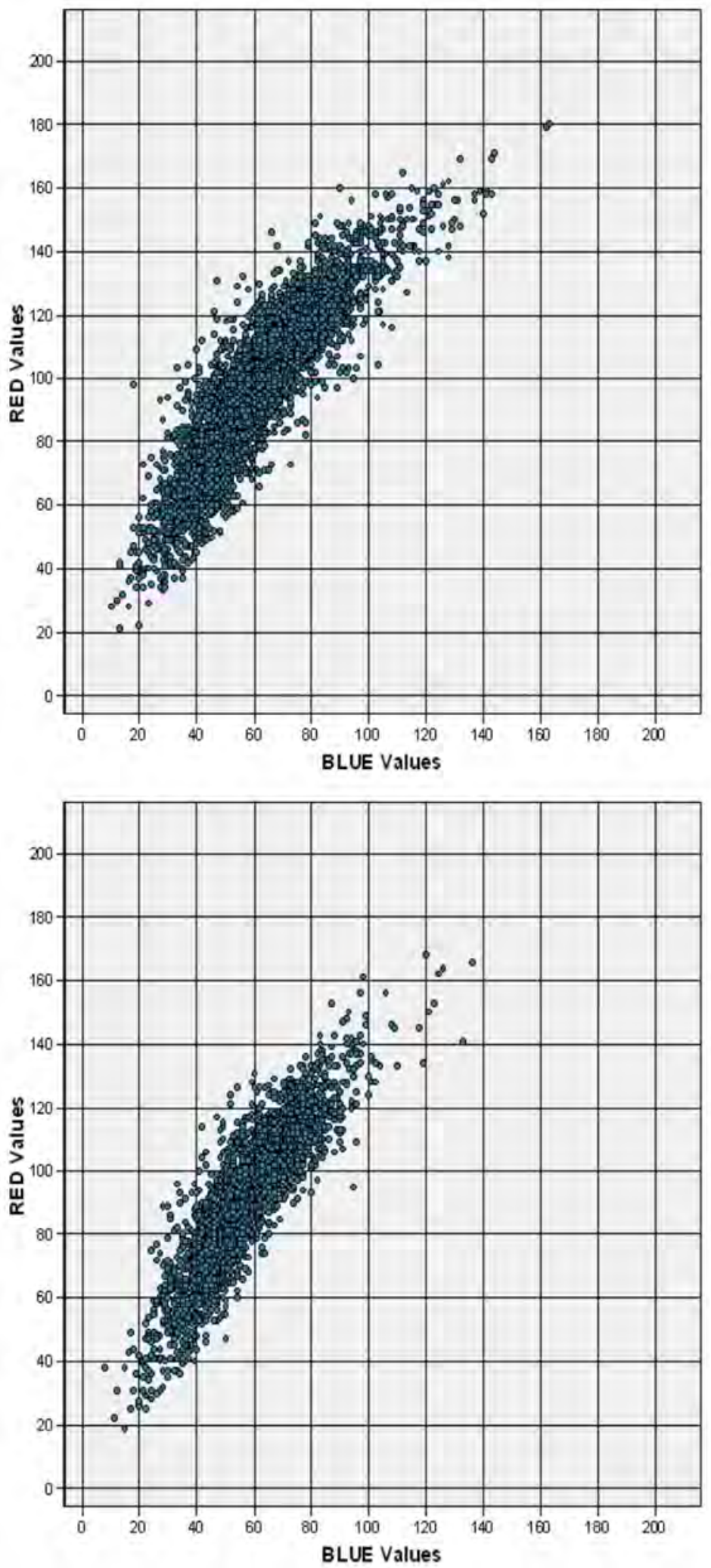

Figure 13-8. Plot of red vs. blue values for Late Archaic (top) and Middle Archaic (bottom) debitage from $41 B X 17$. 

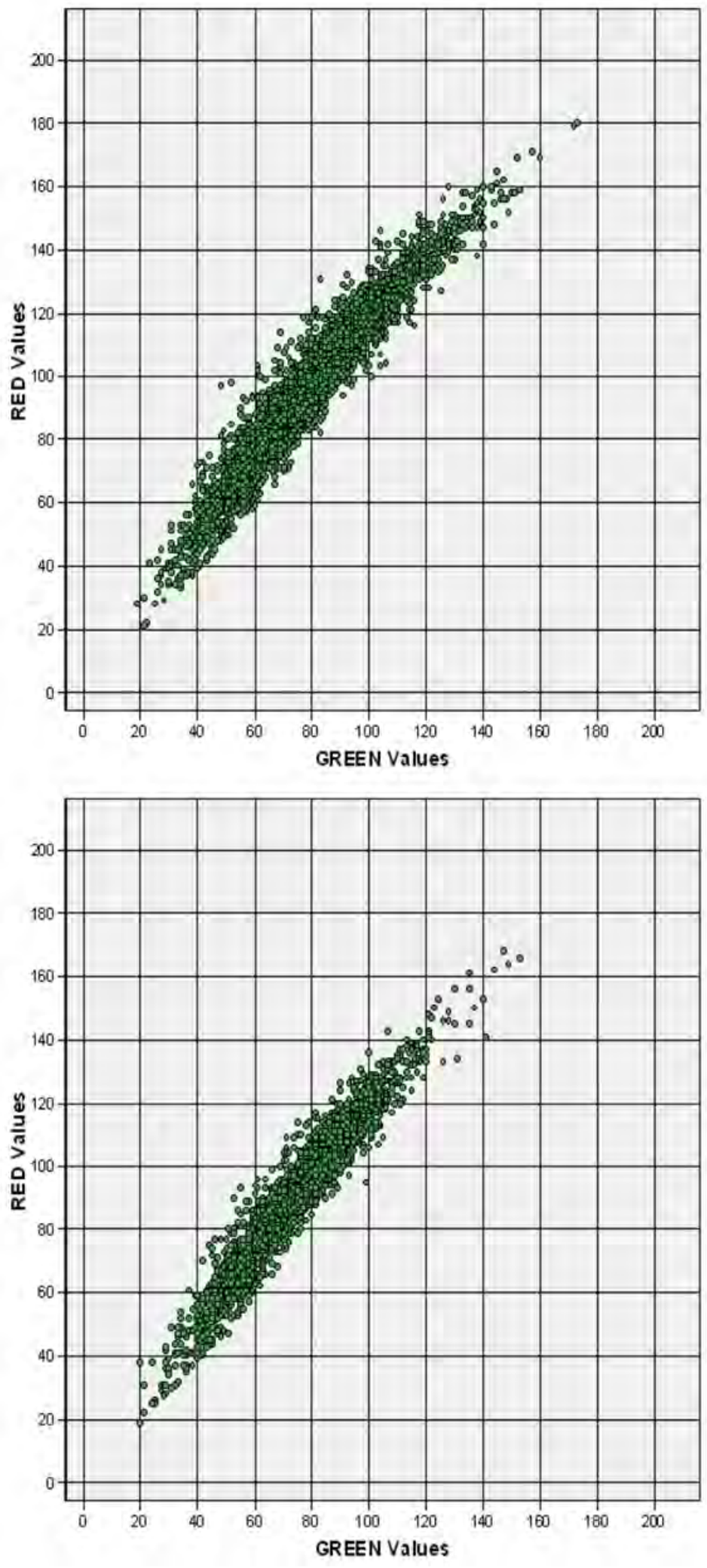

Figure 13-9. Plot of red vs. green values for Late Archaic (top) and Middle Archaic (bottom) debitage from $41 B X 17$. 
blue values in a histogram format, provides a clearer example of the higher variability in the Late Archaic color ranges relative to the Middle Archaic. The coefficient of variation (CV), which is caluculated as the standard deviation (SD) divided by the mean, for the Late Archaic is 0.303 . For the Middle Archaic debitage, the CV is 0.269 . Note also that the distributions for the individual periods differ, a fact that is reflected by the differences in the mean values (Late Archaic $=60.79, \mathrm{SD}=18.436$; Middle Archaic $=57.18, \mathrm{SD}=15.423$ ) and in the overall range of values (Late Archaic, 10 to 163; Middle Archaic, 8 to 136). The mean, SD, and CV for Late Archaic and Middle Archaic red values are 95.39, 22.959, 0.241 , and $91.27,21.379,0.234$, respectively. Green values for the mean, SD, and CV for the Late and Middle Archaic are $78.64,20.655,0.263$, and $74.87,18.244,0.244$, respectively. However, it should be noted that the sample sizes for the two periods also differ. The Late Archaic assemblage is represented by 5,413 color values, while the Middle Archaic has 3,129 values. The greater variability may, then, simply reflect the larger sample sizes. We sampled the Late Archaic assemblage using a random procedure that selected 3,129 items from the larger data set. We will use this Late Archaic sample in subsequent comparisons to lessen the impact of sample size differences. Using SPSS Version 18 we ran a resampling with replacement procedure to generate estimates of the sampling distribution of CV (Table 13-2). The means, standard deviations, and coefficients of variation of the single random sample used in our analysis fall within the ranges generated by the bootstrapping procedure.

To assess the range of material colors for the lithic material from the Granberg Site, we considered each individual color scale as an independent variable, and focused on documenting variability within that scale. Table 13-2 presents summary statistics for the sample of 3,129 items from the Late Archaic along with the 3,129 pieces of Middle Archaic debitage recovered from 41BX17. For this comparison, the $\mathrm{CV}$ is the primary measure of interest. While differences between the $\mathrm{CV}$ values are minimal along the red scale, along all three scales the $\mathrm{CV}$ for the sample of debitage dating to the Late Archaic exceeds that shown for the Middle Archaic debitage. This suggests that the debitage from the Late Archaic deposits at 41BX17 has greater variability in raw material colors than the Middle Archaic debitage from the site.

In Table 13-3, we contrast the mean and standard deviation of debitage values for the red, green, and blue scales, shown above in Table 13-2, with their corresponding tool values by time period. If tools are made from the same color range of raw material as reflected by the debitage at the site, it is probable that much of the production is local. However, if there are significant differences between debitage and tool color ranges within a period, then it is probable that tools were produced elsewhere and brought to the site from locations outside the range of the local materials. The latter would also imply a greater scale of mobility. Reference to Table 13-3 shows that there are minimal differences between the mean values on the red, green, and blue scales when Middle Archaic tools and debitage are compared. This impression is confirmed by a t-test on the mean values that shows no significant difference between tool and debitage mean color values on any of the three scales. In contrast, t-tests comparing debitage and tool color values for the Late Archaic material show statistically significant differences for all three color scale comparisons. To the degree that the varieties of color values for cherts reflect raw material sources, the Table 13-3 results, as well as those presented previously, suggest that the Late Archaic components at 41BX17 were using larger spatial scales when contrasted to the Middle Archaic components.

\section{Comparative Components}

We characterized the distribution, mean value, and standard deviations of the individual colors for the 13 comparative components. Calculation of the $\mathrm{CV}$ provides a method of assessing the variability within each primary color. Higher $\mathrm{CV}$ figures along all three scales suggest that a greater range of colors, and by extension a greater range of chert sources, is present. Tables 13-4 and 13-5 present these values for debitage and tools. For this comparison, the CV is the primary measure of interest. These values are highest, along all three color scales, in the Late Archaic components from 41KM69 and 41LK67, as well as the Late Middle Archaic component from 41BX300. This suggests that the debitage and tools from these components have greater variability in raw material colors than the remaining components. In contrast, the lowest $\mathrm{CV}$ values along all color scales are from the LMA components at 41BX228 (debitage) and 41BX1 (tools). The Initial Late Archaic component from 41MM340 also has low $\mathrm{CV}$ values in comparison to other components, suggesting lower variability in raw material colors.

In Tables 13-6 and 13-7, we contrast the mean and standard deviation of debitage values for the red, green, and blue scales, shown above in Tables 13-4 and 13-5, with their corresponding tool values for four Middle Archaic components (41BX228EMA, 41CM111-EMA, 41BX300-LMA, and 41TV163LMA) and for three Late Archaic components (41MM340MLA, 41KM69-TLA, and 41MM340-TLA). Although all of the tools and debitage from all 13 components on Tables 13-4 and 13-5 were contrasted, only components resulting in significant differences were included in the tables. If tools are made from the same color ranges of raw material as reflected by the debitage at the site, it is probable that much of the production is local. However, if there are significant 
Table 13-2. Comparison of RGB Values for Late and Middle Archaic Debitage from 41BX17

\begin{tabular}{|c|c|c|c|c|c|c|c|}
\hline \multicolumn{8}{|c|}{ Red Values } \\
\hline & & \multicolumn{3}{|c|}{ Simple Random Sample } & \multicolumn{3}{|c|}{ Bootstrap Resampling } \\
\hline Time Period & $\mathrm{n}$ & Mean & Std. Dev. & $\mathrm{CV}$ & Range of Mean & Range of Std. Dev. & Range of CV \\
\hline Late Archaic & 3129 & 95.58 & 22.873 & 0.239 & $94.74-96.35$ & $22.306-23.422$ & $0.235-0.243$ \\
\hline Middle Archaic & 3129 & 91.27 & 21.379 & 0.234 & $90.59-92.04$ & $20.885-21.905$ & $0.231-0.238$ \\
\hline \multicolumn{8}{|c|}{ Green Values } \\
\hline & & \multicolumn{3}{|c|}{ Simple Random Sample } & \multicolumn{3}{|c|}{ Bootstrap Resampling } \\
\hline & & Mean & Std. Dev. & C.V. & Range of Mean & Range of Std. Dev. & Minimum CV \\
\hline Late Archaic & 3129 & 78.72 & 20.624 & 0.262 & $77.96-79.41$ & $20.071-21.179$ & $0.258-0.267$ \\
\hline Middle Archaic & 3129 & 74.87 & 18.244 & 0.244 & $74.27-75.52$ & $17.813-18.686$ & $0.240-0.247$ \\
\hline \multicolumn{8}{|c|}{ Blue Values } \\
\hline & & \multicolumn{3}{|c|}{ Simple Random Sample } & \multicolumn{3}{|c|}{ Bootstrap Resampling } \\
\hline & & Mean & Std. Dev. & C.V. & Range of Mean & Range of Std. Dev. & Minimum CV \\
\hline Late Archaic & 3129 & 60.79 & 18.425 & 0.303 & $60.12-61.40$ & $17.865-18.974$ & $0.297-0.309$ \\
\hline Middle Archaic & 3129 & 57.18 & 15.423 & 0.269 & $56.66-57.73$ & $14.996-15.865$ & $0.265-0.275$ \\
\hline
\end{tabular}

Table 13-3. Comparison of RGB Values for Middle Archaic Debitage/Tools and Samples of Late Archaic Debitage/Tools

\begin{tabular}{|c|c|c|c|}
\hline \multicolumn{4}{|c|}{ Red Values } \\
\hline & Mean & Std. Dev. & T-Value and Significance \\
\hline Middle Archaic- Debitage $(n=3129)$ & 91.27 & 21.379 & $\mathrm{t}=.26$ \\
\hline Middle Archaic- Tools $(n=35)$ & 91.17 & 28.236 & Sig. $=.979$ \\
\hline \multicolumn{4}{|c|}{ Green Values } \\
\hline & Mean & Std. Dev. & \\
\hline Middle Archaic- Debitage $(n=3129)$ & 74.87 & 18.244 & $\mathrm{t}=.23$ \\
\hline Middle Archaic- Tools $(n=35)$ & 74.8 & 26.349 & Sig. $=.982$ \\
\hline \multicolumn{4}{|c|}{ Blue Values } \\
\hline & Mean & Std. Dev. & \\
\hline Middle Archaic- Debitage $(n=3129)$ & 57.18 & 15.423 & $\mathrm{t}=.316$ \\
\hline Middle Archaic- Tools $(n=35)$ & 56.34 & 23.112 & Sig. $=.752$ \\
\hline \multicolumn{4}{|c|}{ Red Values } \\
\hline & Mean & Std. Dev. & \\
\hline Late Archaic- Debitage $(\mathrm{n}=3129)$ & 95.58 & 22.873 & $t=4.204$ \\
\hline Late Archaic- Tools $(\mathrm{n}=35)$ & 79.2 & 27.446 & Sig. $=.000$ \\
\hline \multicolumn{4}{|c|}{ Green Values } \\
\hline & Mean & Std. Dev. & \\
\hline Late Archaic- Debitage $(n=3129)$ & 78.72 & 20.624 & $t=3.665$ \\
\hline Late Archaic- Tools $(n=35)$ & 65.86 & 22.634 & Sig. $=.000$ \\
\hline \multicolumn{4}{|c|}{ Blue Values } \\
\hline & Mean & Std. Dev. & \\
\hline Late Archaic- Debitage $(\mathrm{n}=3129)$ & 60.79 & 18.425 & $\mathrm{t}=3.326$ \\
\hline Late Archaic- Tools $(\mathrm{n}=35)$ & 50.37 & 18.286 & Sig. $=.001$ \\
\hline
\end{tabular}



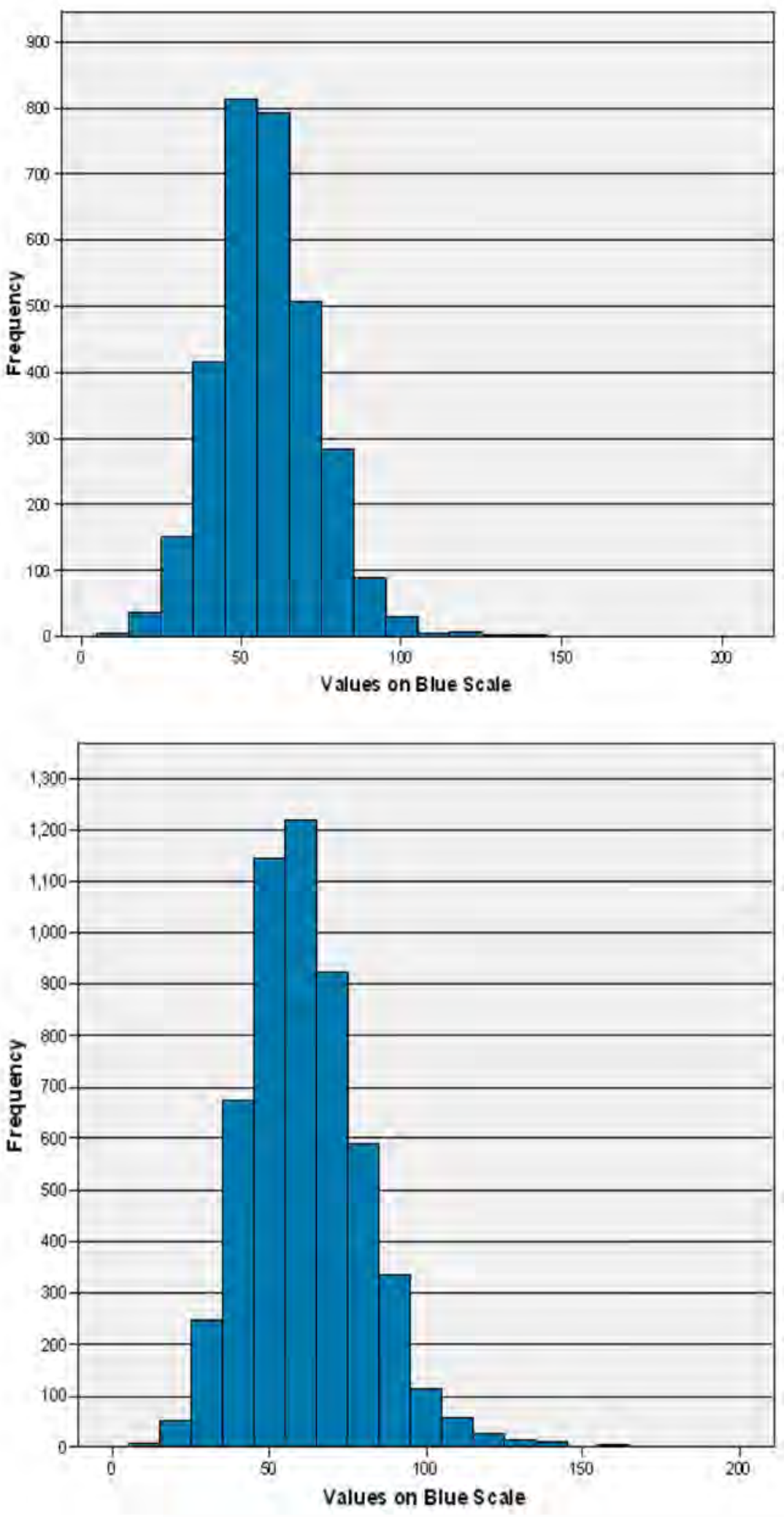

Figure 13-10. Histogram of blue values for Late Archaic (top) and Middle Archaic (bottom) debitage from $41 B \times 17$. 
Table 13-4. Means, Standard Deviations, and CV for Red, Green, and Blue Values of Debitage

\begin{tabular}{|c|c|c|c|c|c|c|c|c|c|c|c|}
\hline & & & \multicolumn{3}{|c|}{ RED } & \multicolumn{3}{|c|}{ GREEN } & \multicolumn{3}{|c|}{ BLUE } \\
\hline Site & Component & $\begin{array}{c}\text { Debitage } \\
\text { Count }\end{array}$ & Mean & $\begin{array}{c}\text { Standard } \\
\text { Deviation }\end{array}$ & $\mathrm{CV}$ & Mean & $\begin{array}{c}\text { Standard } \\
\text { Deviation }\end{array}$ & $\mathrm{CV}$ & Mean & $\begin{array}{l}\text { Standard } \\
\text { Deviation }\end{array}$ & $\mathrm{CV}$ \\
\hline BX1 & LMA & 414 & 100.3 & 20.5 & 0.204 & 82.9 & 16.8 & 0.203 & 63.4 & 13.6 & 0.214 \\
\hline BX126 & LMA & 301 & 98.8 & 22.8 & 0.231 & 82.5 & 17.7 & 0.215 & 60.8 & 14.1 & 0.232 \\
\hline BX228 & EMA & 377 & 116.3 & 23.8 & 0.205 & 92.6 & 18.4 & 0.199 & 69.0 & 15.1 & 0.218 \\
\hline BX228 & LMA & 360 & 113.0 & 20.0 & 0.177 & 91.8 & 16.3 & 0.178 & 67.8 & 13.5 & 0.199 \\
\hline BX300 & LMA & 366 & 105.6 & 28.2 & 0.267 & 90.8 & 26.3 & 0.290 & 72.4 & 24.3 & 0.335 \\
\hline CM111 & EMA & 388 & 124.4 & 23.3 & 0.187 & 113.3 & 21.9 & 0.194 & 94.4 & 20.5 & 0.217 \\
\hline TV163 & LMA & 480 & 115.3 & 26.4 & 0.229 & 107.1 & 23.6 & 0.220 & 90.7 & 21.5 & 0.237 \\
\hline 41MM340 & ILA & 469 & 108.0 & 18.7 & 0.173 & 90.1 & 16.7 & 0.185 & 67.6 & 14.9 & 0.220 \\
\hline 41KM69 & MLA & 521 & 89.3 & 21.3 & 0.238 & 75.6 & 17.5 & 0.231 & 61.7 & 15.5 & 0.251 \\
\hline 41MM340 & MLA & 496 & 104.9 & 19.7 & 0.188 & 85.8 & 18.1 & 0.211 & 64.7 & 16.2 & 0.250 \\
\hline 41KM69 & TLA & 447 & 86.3 & 23.3 & 0.270 & 73.2 & 19.1 & 0.260 & 59.6 & 16.5 & 0.276 \\
\hline 41LK67 & TLA & 467 & 100.8 & 25.8 & 0.256 & 83.4 & 23.7 & 0.284 & 63.1 & 21.3 & 0.338 \\
\hline 41MM340 & TLA & 470 & 103.4 & 21.4 & 0.207 & 84.1 & 17.9 & 0.212 & 62.2 & 14.8 & 0.237 \\
\hline Totals & $n=13$ & 5556 & & & & & & & & & \\
\hline & EMA & 765 & 120.4 & 23.9 & 0.198 & 103.1 & 22.7 & 0.221 & 81.9 & 22.1 & 0.269 \\
\hline & LMA & 1921 & 107.2 & 24.8 & 0.232 & 92.0 & 22.8 & 0.248 & 72.3 & 21.4 & 0.296 \\
\hline & ILA & 469 & 108.0 & 18.7 & 0.173 & 90.1 & 16.7 & 0.185 & 67.6 & 14.9 & 0.220 \\
\hline & MLA & 1017 & 96.9 & 21.9 & 0.226 & 80.5 & 18.5 & 0.230 & 63.2 & 15.9 & 0.251 \\
\hline & TLA & 1384 & 97.0 & 24.7 & 0.255 & 80.4 & 20.9 & 0.260 & 61.7 & 17.8 & 0.288 \\
\hline
\end{tabular}

Table 13-5. Means, Standard Deviations, and CV for Red, Green, and Blue Values of Tools

\begin{tabular}{|c|c|c|c|c|c|c|c|c|c|c|c|}
\hline \multirow[b]{2}{*}{ Site } & \multirow[b]{2}{*}{ Component } & \multirow[b]{2}{*}{$\begin{array}{c}\text { Tool } \\
\text { Count }\end{array}$} & \multicolumn{3}{|c|}{ RED } & \multicolumn{3}{|c|}{ GREEN } & \multicolumn{3}{|c|}{ BLUE } \\
\hline & & & Mean & $\begin{array}{l}\text { Standard } \\
\text { Deviation }\end{array}$ & $\mathrm{CV}$ & Mean & $\begin{array}{l}\text { Standard } \\
\text { Deviation }\end{array}$ & $\mathrm{CV}$ & Mean & $\begin{array}{l}\text { Standard } \\
\text { Deviation }\end{array}$ & $\mathrm{CV}$ \\
\hline BX1 & LMA & 27 & 97.2 & 19.6 & 0.201 & 80.5 & 14.8 & 0.184 & 57.6 & 12.4 & 0.215 \\
\hline BX126 & LMA & 17 & 95.7 & 31.1 & 0.324 & 81.8 & 26.0 & 0.318 & 61.8 & 23.0 & 0.372 \\
\hline BX228 & EMA & 51 & 106.3 & 22.6 & 0.213 & 84.9 & 19.0 & 0.224 & 60.8 & 16.0 & 0.264 \\
\hline BX228 & LMA & 47 & 107.6 & 26.1 & 0.242 & 89.2 & 22.2 & 0.249 & 66.0 & 19.0 & 0.288 \\
\hline BX300 & LMA & 21 & 89.1 & 35.3 & 0.397 & 76.2 & 29.2 & 0.384 & 56.9 & 24.8 & 0.436 \\
\hline CM111 & EMA & 38 & 113.8 & 31.6 & 0.277 & 103.9 & 30.0 & 0.289 & 85.2 & 27.6 & 0.323 \\
\hline TV163 & LMA & 63 & 111.1 & 36.1 & 0.325 & 102.5 & 29.8 & 0.290 & 82.3 & 24.6 & 0.299 \\
\hline 41MM340 & ILA & 50 & 110.3 & 26.0 & 0.235 & 91.1 & 22.5 & 0.246 & 66.4 & 19.2 & 0.289 \\
\hline 41KM69 & MLA & 34 & 84.9 & 24.1 & 0.283 & 72.9 & 18.7 & 0.257 & 59.5 & 16.7 & 0.281 \\
\hline 41MM340 & MLA & 87 & 107.1 & 24.7 & 0.231 & 90.0 & 21.7 & 0.241 & 67.4 & 18.7 & 0.278 \\
\hline 41KM69 & TLA & 62 & 98.7 & 30.9 & 0.313 & 83.3 & 26.4 & 0.316 & 67.3 & 23.7 & 0.353 \\
\hline 41LK67 & TLA & 21 & 92.7 & 34.3 & 0.370 & 81.2 & 31.5 & 0.388 & 68.0 & 28.0 & 0.411 \\
\hline 41MM340 & TLA & 64 & 109.9 & 23.3 & 0.212 & 89.7 & 21.1 & 0.236 & 67.6 & 17.5 & 0.258 \\
\hline \multirow[t]{6}{*}{ Totals } & $\mathrm{n}=13$ & 582 & & & & & & & & & \\
\hline & EMA & 89 & 109.5 & 26.9 & 0.246 & 93.0 & 26.0 & 0.279 & 71.3 & 24.8 & 0.347 \\
\hline & LMA & 175 & 103.9 & 31.6 & 0.304 & 90.4 & 27.2 & 0.301 & 69.0 & 23.7 & 0.343 \\
\hline & ILA & 50 & 110.3 & 25.9 & 0.235 & 91.1 & 22.4 & 0.246 & 66.4 & 19.2 & 0.289 \\
\hline & MLA & 121 & 100.8 & 26.4 & 0.262 & 85.2 & 22.2 & 0.260 & 65.2 & 18.5 & 0.283 \\
\hline & TLA & 147 & 102.7 & 29.0 & 0.282 & 85.8 & 25.1 & 0.293 & 67.5 & 21.8 & 0.322 \\
\hline
\end{tabular}


Table 13-6. T-Test Results for RGB Values for Middle Archaic Debitage and Tools from 41BX228, 41CM111, 41BX300, and 41TV163

\begin{tabular}{|c|c|c|c|c|c|}
\hline \multirow{12}{*}{ 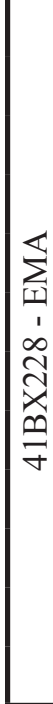 } & \multicolumn{5}{|c|}{ Red Values } \\
\hline & & $\mathrm{n}$ & Mean & Std. Dev. & T-Value and Significance \\
\hline & Debitage & 377 & 116.29 & 23.848 & $\mathrm{t}=2.822$ \\
\hline & Tools & 51 & 106.31 & 22.592 & Sig. $=.005$ \\
\hline & \multicolumn{5}{|c|}{ Green Values } \\
\hline & & $\mathrm{n}$ & Mean & Std. Dev. & T-Value and Significance \\
\hline & Debitage & 377 & 92.63 & 18.410 & $\mathrm{t}=2.789$ \\
\hline & Tools & 51 & 84.94 & 19.018 & Sig. $=.006$ \\
\hline & \multicolumn{5}{|c|}{ Blue Values } \\
\hline & & $\mathrm{n}$ & Mean & Std. Dev. & T-Value and Significance \\
\hline & Debitage & 377 & 68.99 & 15.058 & $t=3.600$ \\
\hline & Tools & 51 & 60.84 & 16.043 & Sig $=.000$ \\
\hline \multirow{12}{*}{ 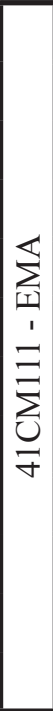 } & \multicolumn{5}{|c|}{ Red Values } \\
\hline & & $\mathrm{n}$ & Mean & Std. Dev. & T-Value and Significance \\
\hline & Debitage & 388 & 124.36 & 23.268 & $\mathrm{t}=2.579$ \\
\hline & Tools & 38 & 113.79 & 31.568 & Sig. $=.010$ \\
\hline & \multicolumn{5}{|c|}{ Green Values } \\
\hline & & $\mathrm{n}$ & Mean & Std. Dev. & T-Value and Significance \\
\hline & Debitage & 388 & 113.31 & 21.928 & $\mathrm{t}=2.434$ \\
\hline & Tools & 38 & 103.89 & 30.046 & Sig. $=.015$ \\
\hline & \multicolumn{5}{|c|}{ Blue Values } \\
\hline & & $\mathrm{n}$ & Mean & Std. Dev. & T-Value and Significance \\
\hline & Debitage & 388 & 94.43 & 20.501 & $\mathrm{t}=2.548$ \\
\hline & Tools & 38 & 85.24 & 27.568 & Sig $=.011$ \\
\hline \multirow{12}{*}{ 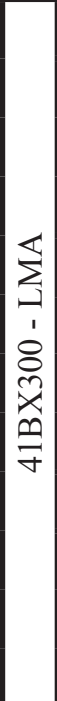 } & \multicolumn{5}{|c|}{ Red Values } \\
\hline & & $\mathrm{n}$ & Mean & Std. Dev. & T-Value and Significance \\
\hline & Debitage & 366 & 105.55 & 28.150 & $\mathrm{t}=2.574$ \\
\hline & Tools & 21 & 89.05 & 35.332 & Sig. $=.010$ \\
\hline & \multicolumn{5}{|c|}{ Green Values } \\
\hline & & $\mathrm{n}$ & Mean & Std. Dev. & T-Value and Significance \\
\hline & Debitage & 366 & 90.83 & 26.334 & $\mathrm{t}=2.463$ \\
\hline & Tools & 21 & 76.19 & 29.243 & Sig. $=.014$ \\
\hline & \multicolumn{5}{|c|}{ Blue Values } \\
\hline & & $\mathrm{n}$ & Mean & Std. Dev. & T-Value and Significance \\
\hline & Debitage & 366 & 72.36 & 24.273 & $\mathrm{t}=2.842$ \\
\hline & Tools & 21 & 56.86 & 24.794 & Sig $=.005$ \\
\hline
\end{tabular}


Table 13-6. Continued....

\begin{tabular}{|c|c|c|c|c|c|}
\hline & & & & & \\
\hline & & $\mathrm{n}$ & Mean & Std. Dev. & T-Value and Significance \\
\hline & Debitage & 480 & 115.33 & 26.419 & $\mathrm{t}=1.128$ \\
\hline & Tools & 63 & 111.14 & 36.117 & Sig. $=.260$ \\
\hline 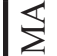 & & & & & \\
\hline- & & $\mathrm{n}$ & Mean & Std. Dev. & T-Value and Significance \\
\hline - & Debitage & 480 & 107.05 & 23.581 & $\mathrm{t}=1.390$ \\
\hline$\frac{\theta}{F}$ & Tools & 63 & 102.51 & 29.769 & Sig. $=.165$ \\
\hline & & & & & \\
\hline & & $\mathrm{n}$ & Mean & Std. Dev. & T-Value and Significance \\
\hline & Debitage & 480 & 90.7 & 21.519 & $\mathrm{t}=2.880$ \\
\hline & Tools & 63 & 82.25 & 24.589 & $\mathrm{Sig}=.004$ \\
\hline
\end{tabular}

differences between debitage and tool color ranges within a period, then it is probable that tools were produced elsewhere and brought to the site from locations outside the range of the local materials. The latter would, of course, also imply a greater scale of mobility. There are differences between the mean values on the red, green, and blue scales when tools and debitage are compared (Table 13-6). This impression is confirmed by a t-test on the mean values that shows significant differences between tool and debitage mean color values on all three scales in three of the four Middle Archaic components. The fourth component, 41TV163-LMA, only suggests statistically significant differences on the blue color scale. To the degree that the varieties of color values for cherts reflect raw material sources, the Table 13-6 results suggest that some Middle Archaic components were using larger spatial scales than others in Central Texas. Of the six Late Archaic components, three resulted in significant differences between the mean values for tools and debitage. All three color scales of lithic material from the TLA components at 41KM69 and 41MM340 are significantly different; whereas only the green scale from 41MM340 (MLA) suggests a significant difference. In Table 13-7, the results suggest that two of the six Late Archaic components were using larger spatial scales than the others. The data supports our expectations of higher mobility during periods of fluctuating grasslands, specifically in the TLA, pointing to an increase in logistical strategies to procure fluctuating critical resources. Combining the debitage and tools by time period suggests that the ILA interval has the least variability in colors (reflected in debitage and tool CV values), whereas the TLA (debitage $\mathrm{CV}$ values) and the LMA (tool CV values) have the greatest. The CV values suggest that the ILA component was using the smallest spatial scale while the TLA and LMA were using the greatest spatial scale. These results support our anticipation of less need for logistical organization (i.e., high mobility) when bison were ubiquitous on the landscape.

The t-test is only meaningful on normally distributed data. Based on histograms of the RGB values, the debitage appears to fall into a normal distribution. Because some component's tool RGB values did not appear to be normally distributed, possibly due to smaller sample sizes of tools, in Table 13-7 we contrast the mean rank of debitage RGB values with their corresponding tool values using the non-parametric MannWhitney Test. The non-parametric test results confirmed the t-test results by showing significant differences between tool and debitage mean rank of color values (Table 13-8).

Figures 13-11 through 13-13 provide bi-variant plots of color pairs (Red/Green, Red/Blue; Green/Blue) for the Late Middle Archaic occupation at 41TV163 as an example of the differences in tool and debitage distribution for a given area. Note that the vast majority of samples fall close together along similar sections of the plots. There is a lack of clear separation of distinct color groups in any of the plots, with the distribution forming a continuum. Similar patterns were noted in several other distributions examined. At the scale of these distributions there is no clear separation between color values associated with debitage and tools.

Figure 13-14 illustrates the differences for each color scale between debitage and expensive tools (hafted items, bifaces), using the $41 \mathrm{CM} 111$ database. The medians and interquartile 
Table 13-7. T-Test Results for RGB Values for Late Archaic Debitage and Tools from 41MM340 and 41KM69

\begin{tabular}{|c|c|c|c|c|c|}
\hline \multirow{12}{*}{ 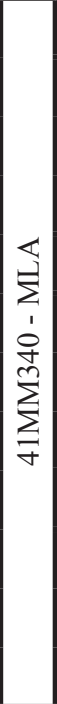 } & \multicolumn{5}{|c|}{ Red Values } \\
\hline & & $\mathrm{n}$ & Mean & Std. Dev. & T-Value and Significance \\
\hline & Debitage & 496 & 104.9 & 19.700 & $\mathrm{t}=-0.908$ \\
\hline & Tools & 87 & 107.1 & 24.700 & Sig. $=.364$ \\
\hline & \multicolumn{5}{|c|}{ Green Values } \\
\hline & & $\mathrm{n}$ & Mean & Std. Dev. & T-Value and Significance \\
\hline & Debitage & 496 & 85.8 & 18.100 & $t=-1.967$ \\
\hline & Tools & 87 & 90 & 21.700 & Sig. $=.050$ \\
\hline & \multicolumn{5}{|c|}{ Blue Values } \\
\hline & & $\mathrm{n}$ & Mean & Std. Dev. & T-Value and Significance \\
\hline & Debitage & 496 & 64.7 & 16.200 & $\mathrm{t}=-1.416$ \\
\hline & Tools & 87 & 67.4 & 18.700 & $\mathrm{Sig}=.157$ \\
\hline \multirow{12}{*}{ 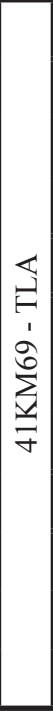 } & \multicolumn{5}{|c|}{ Red Values } \\
\hline & & $\mathrm{n}$ & Mean & Std. Dev. & T-Value and Significance \\
\hline & Debitage & 447 & 86.3 & 23.300 & $t=-3.773$ \\
\hline & Tools & 62 & 98.7 & 30.890 & Sig. $=.000$ \\
\hline & \multicolumn{5}{|c|}{ Green Values } \\
\hline & & $\mathrm{n}$ & Mean & Std. Dev. & T-Value and Significance \\
\hline & Debitage & 447 & 73.2 & 19.100 & $t=-3.700$ \\
\hline & Tools & 62 & 83.3 & 26.360 & Sig. $=.000$ \\
\hline & \multicolumn{5}{|c|}{ Blue Values } \\
\hline & & $\mathrm{n}$ & Mean & Std. Dev. & T-Value and Significance \\
\hline & Debitage & 447 & 59.6 & 16.500 & $\mathrm{t}=-3.230$ \\
\hline & Tools & 62 & 67.3 & 23.730 & $\mathrm{Sig}=.001$ \\
\hline \multirow{12}{*}{ 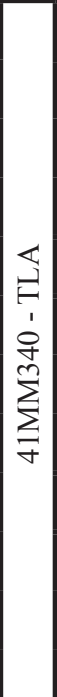 } & \multicolumn{5}{|c|}{ Red Values } \\
\hline & & $\mathrm{n}$ & Mean & Std. Dev. & T-Value and Significance \\
\hline & Debitage & 470 & 103.4 & 21.400 & $\mathrm{t}=-2.271$ \\
\hline & Tools & 64 & 109.9 & 23.340 & Sig. $=.024$ \\
\hline & \multicolumn{5}{|c|}{ Green Values } \\
\hline & & $\mathrm{n}$ & Mean & Std. Dev. & T-Value and Significance \\
\hline & Debitage & 470 & 84.1 & 17.900 & $\mathrm{t}=-2.290$ \\
\hline & Tools & 64 & 89.7 & 21.140 & Sig. $=.022$ \\
\hline & \multicolumn{5}{|c|}{ Blue Values } \\
\hline & & $\mathrm{n}$ & Mean & Std. Dev. & T-Value and Significance \\
\hline & Debitage & 470 & 62.2 & 14.800 & $t=-2.685$ \\
\hline & Tools & 64 & 67.6 & 17.460 & $\mathrm{Sig}=.007$ \\
\hline
\end{tabular}



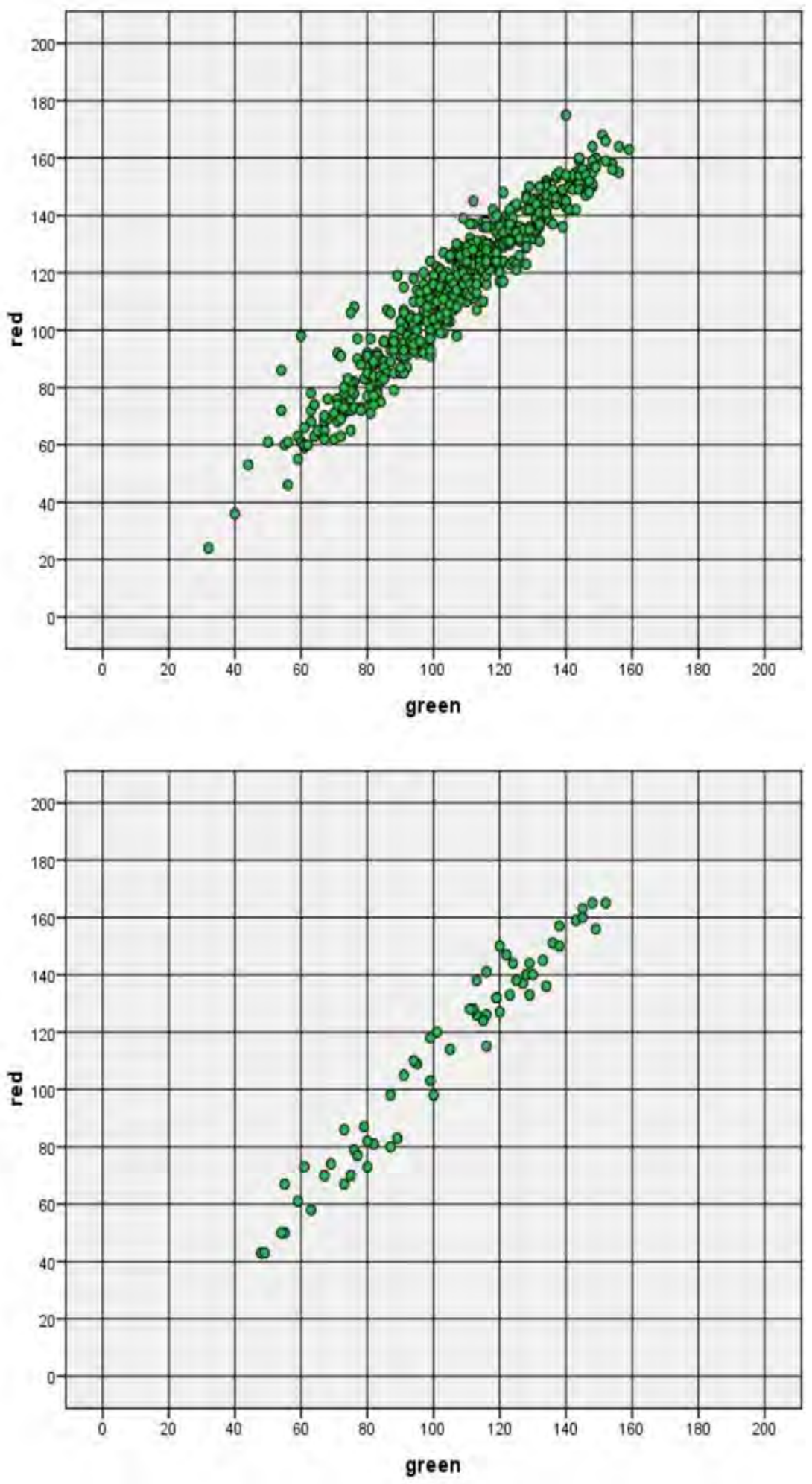

Figure 13-11. Plot of red and green values for debitage (top) and "expensive" tools (bottom) from $41 T V 163$. 


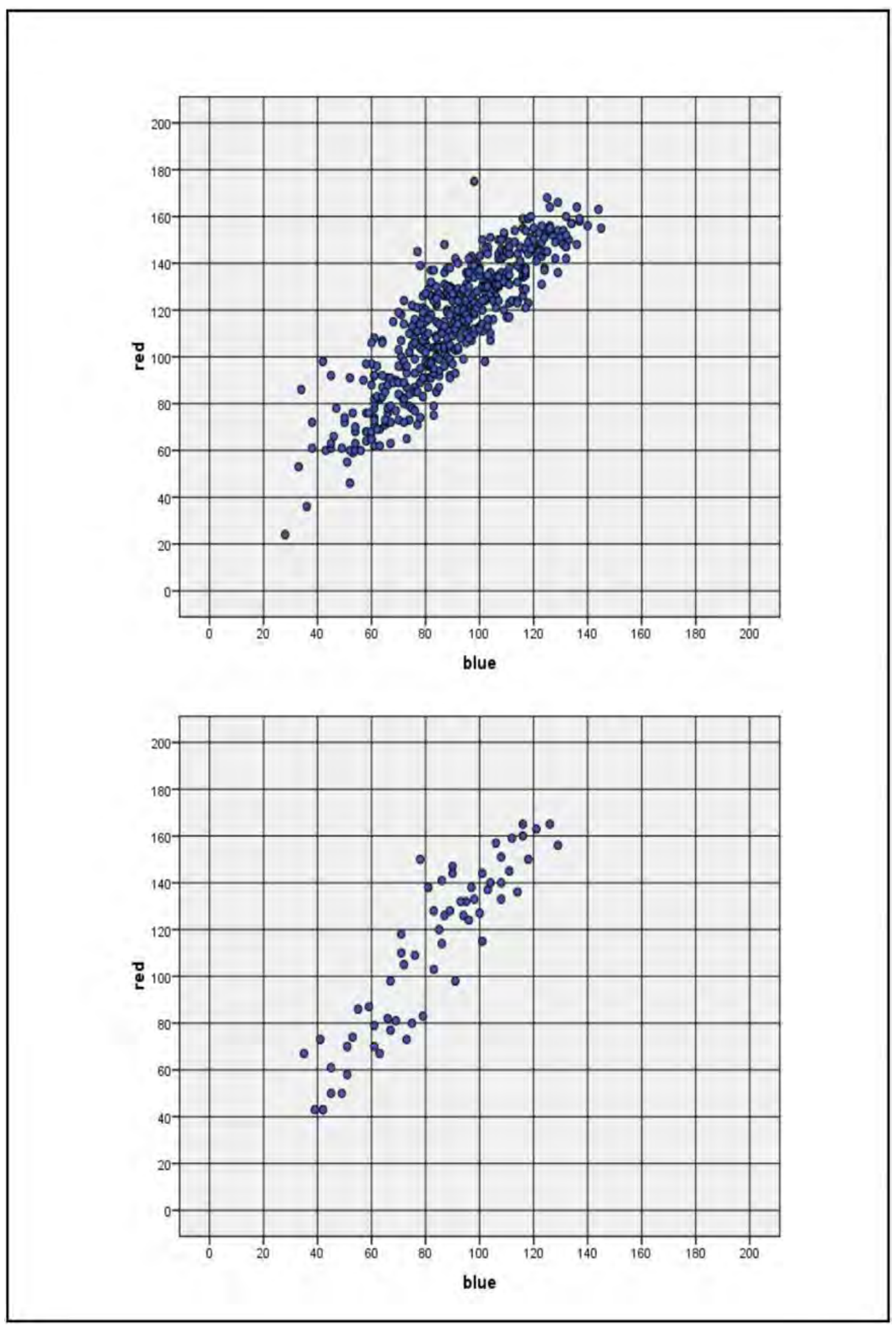

Figure 13-12. Plot of red and blue values for debitage (top) and "expensive" tools (bottom) from $41 T V 163$. 


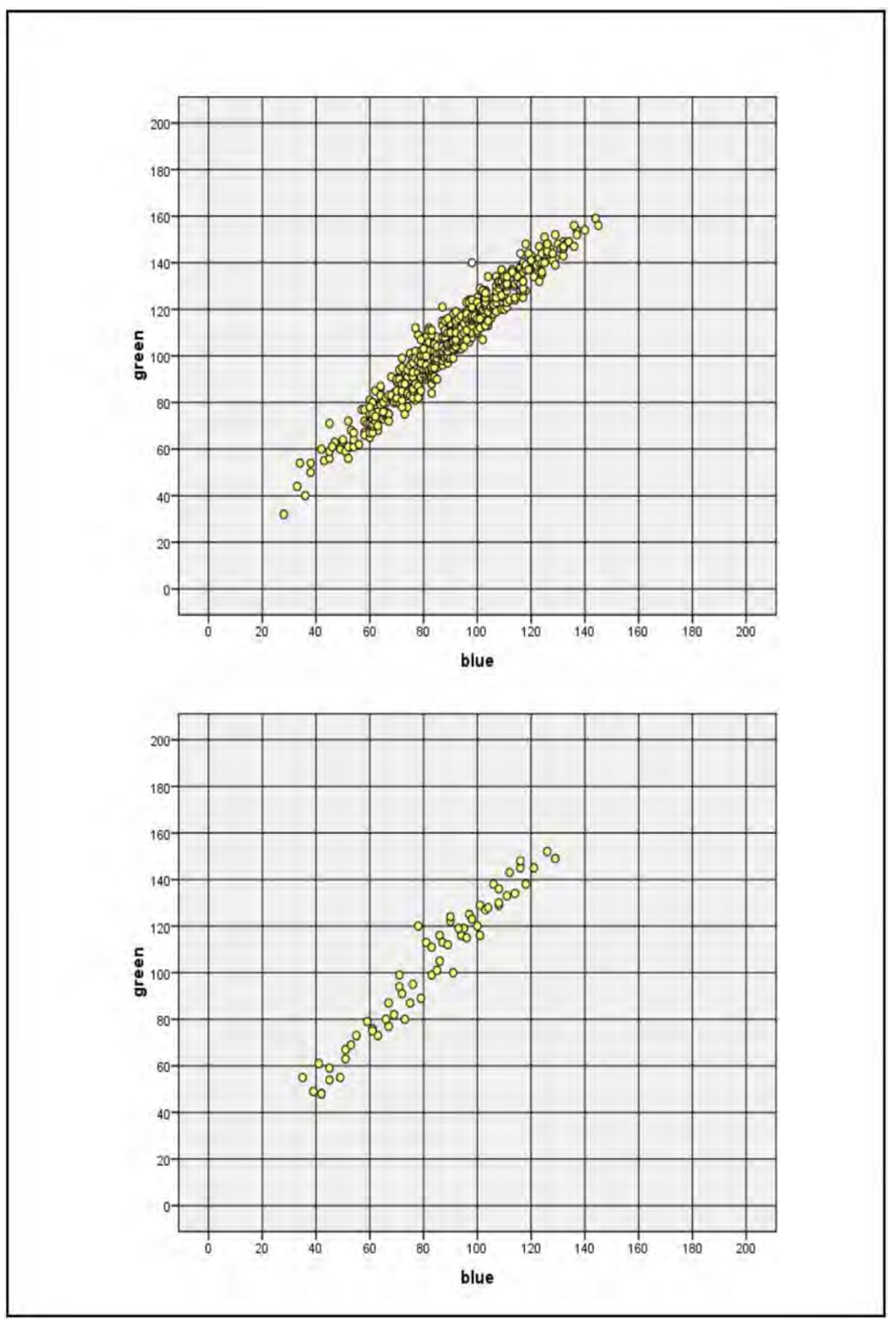

Figure 13-13. Plot of green and blue values for debitage (top) and "expensive" tools (bottom) from $41 T V 163$. 
Table 13-8. Mann-Whitney Test Results for RGB Values for Debitage and Tools at 41BX228, 41CM111, 41BX300, and 41TV163

\begin{tabular}{|c|c|c|c|c|c|}
\hline \multirow{12}{*}{ 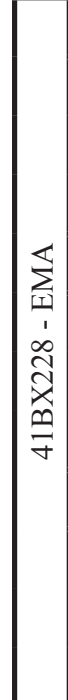 } & \multicolumn{5}{|c|}{ Red Values } \\
\hline & & $\mathrm{n}$ & Mean Rank & Sum of Ranks & Z-Value and Significance \\
\hline & Debitage & 377 & 221.04 & 83333.50 & $Z=-2.976$ \\
\hline & Tools & 51 & 166.13 & 8472.50 & Sig. $=.003$ \\
\hline & \multicolumn{5}{|c|}{ Green Values } \\
\hline & & $\mathrm{n}$ & Mean Rank & Sum of Ranks & Z-Value and Significance \\
\hline & Debitage & 377 & 221.14 & 83368.50 & $Z=-3.018$ \\
\hline & Tools & 51 & 165.44 & 8437.50 & Sig. $=.003$ \\
\hline & \multicolumn{5}{|c|}{ Blue Values } \\
\hline & & $\mathrm{n}$ & Mean Rank & Sum of Ranks & Z-Value and Significance \\
\hline & Debitage & 377 & 222.78 & 83988.00 & $Z=-3.766$ \\
\hline & Tools & 51 & 153.29 & 7818.00 & $\mathrm{Sig}=.000$ \\
\hline \multirow{12}{*}{ 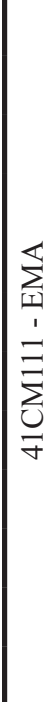 } & \multicolumn{5}{|c|}{ Red Values } \\
\hline & & $\mathrm{n}$ & Mean Rank & Sum of Ranks & Z-Value and Significance \\
\hline & Debitage & 388 & 218.27 & 84689.50 & $Z=-2.556$ \\
\hline & Tools & 38 & 164.78 & 6261.50 & Sig. $=.011$ \\
\hline & \multicolumn{5}{|c|}{ Green Values } \\
\hline & & $\mathrm{n}$ & Mean Rank & Sum of Ranks & Z-Value and Significance \\
\hline & Debitage & 388 & 218.49 & 84774.50 & $Z=-2.674$ \\
\hline & Tools & 38 & 162.54 & 6176.50 & Sig. $=.007$ \\
\hline & \multicolumn{5}{|c|}{ Blue Values } \\
\hline & & $\mathrm{n}$ & Mean Rank & Sum of Ranks & Z-Value and Significance \\
\hline & Debitage & 388 & 218.77 & 84883.50 & $Z=-2.824$ \\
\hline & Tools & 38 & 159.67 & 6067.50 & $\mathrm{Sig}=.005$ \\
\hline \multirow{12}{*}{ 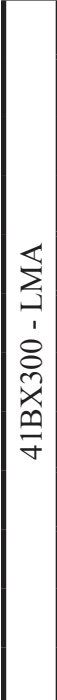 } & \multicolumn{5}{|c|}{ Red Values } \\
\hline & & $\mathrm{n}$ & Mean Rank & Sum of Ranks & Z-Value and Significance \\
\hline & Debitage & 366 & 197.4 & 72247.00 & $Z=-2.494$ \\
\hline & Tools & 21 & 134.81 & 2831.00 & Sig. $=.013$ \\
\hline & \multicolumn{5}{|c|}{ Green Values } \\
\hline & & $\mathrm{n}$ & Mean Rank & Sum of Ranks & Z-Value and Significance \\
\hline & Debitage & 366 & 197.57 & 72309.50 & $Z=-2.619$ \\
\hline & Tools & 21 & 131.83 & 2768.50 & Sig. $=.009$ \\
\hline & \multicolumn{5}{|c|}{ Blue Values } \\
\hline & & $\mathrm{n}$ & Mean Rank & Sum of Ranks & Z-Value and Significance \\
\hline & Debitage & 366 & 198.15 & 72521.50 & $Z=-3.044$ \\
\hline & Tools & 21 & 121.74 & 2556.50 & $\mathrm{Sig}=.002$ \\
\hline
\end{tabular}


Table 13-8. Continued....

\begin{tabular}{|c|c|c|c|c|c|}
\hline & \multicolumn{5}{|c|}{ Red Values } \\
\hline & & $\mathrm{n}$ & Mean Rank & Sum of Ranks & Z-Value and Significance \\
\hline & Debitage & 480 & 272.81 & 130948.50 & $Z=-.332$ \\
\hline & Tools & 63 & 265.83 & 16747.50 & Sig. $=.740$ \\
\hline \multirow{8}{*}{ 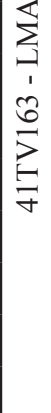 } & \multicolumn{5}{|c|}{ Green Values } \\
\hline & & $\mathrm{n}$ & Mean Rank & Sum of Ranks & Z-Value and Significance \\
\hline & Debitage & 480 & 274.04 & 131537.00 & $Z=-.835$ \\
\hline & Tools & 63 & 256.49 & 16159.00 & Sig. $=.404$ \\
\hline & \multicolumn{5}{|c|}{ Blue Values } \\
\hline & & $\mathrm{n}$ & Mean Rank & Sum of Ranks & Z-Value and Significance \\
\hline & Debitage & 480 & 277.8 & 133342.00 & $Z=-2.376$ \\
\hline & Tools & 63 & 227.84 & 14354.00 & Sig $=.017$ \\
\hline
\end{tabular}

ranges point to significant differences between the values of debitage and expensive tools. These differences suggest that expensive tools and debitage may originate from sources that have different color ranges.

\section{Chert Availability}

Dramatic differences exist within the study area, especially in chert availability, which complicate this color comparison. Raw material is plentiful at various locations on the Edwards Plateau and has a much more limited distribution in South and East Texas. Sites on the Edwards Plateau have greater access to a wider variety of cherts regardless of any differences in mobility. To control for these differences, we assessed the availability of chert relative to any given site through a review of the geological atlas sheets developed by the Bureau of Economic Geology. We located each site in our sample on these sheets. We determined the area (in square meters) that contains chert-bearing deposits, including river gravels, within a $30 \mathrm{~km}$ radius of the site. While the square meters of chert-bearing deposits do not necessarily correlate with the availability of chert, this procedure should allow us to group components into at least two broad classes, those with high raw material access and those with low access. The rationale for documenting this component is that some sites are located on the Edward's Plateau (41CM111), an area of high chert availability, while others (41MM340) are located off the

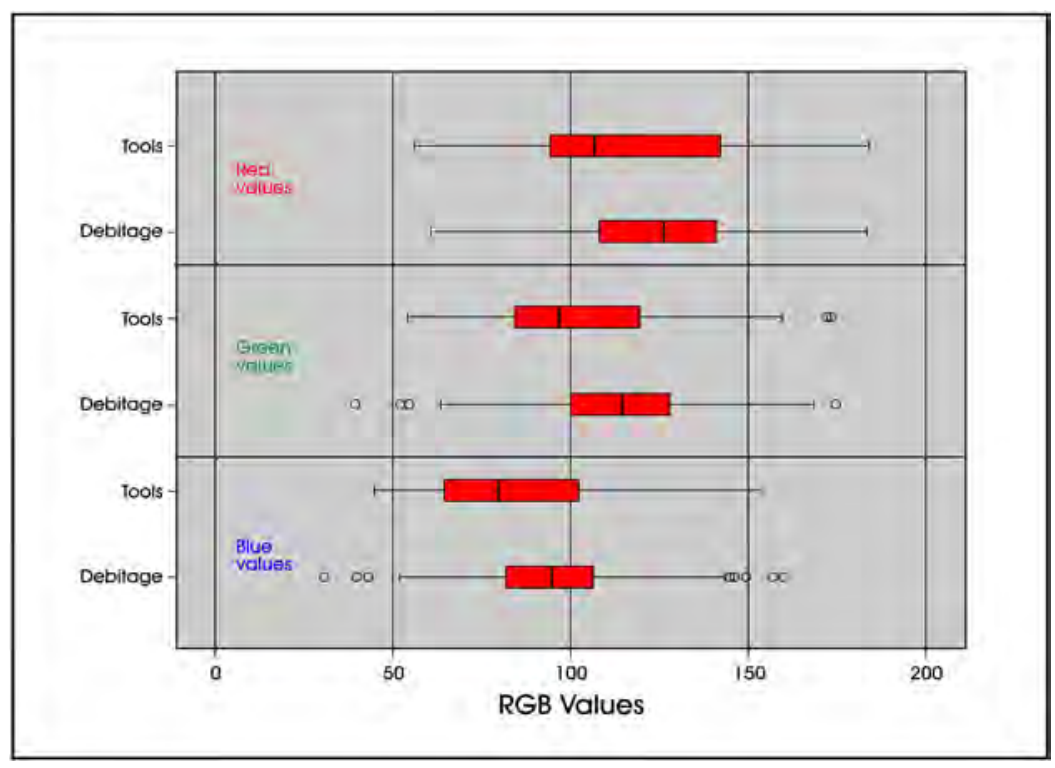

Figure 13-14. Boxplots for red, green, and blue values at 41CM111. 
plateau. We suggest that both the amount of chert bearing deposits, as well as the number of different types of deposits, should impact the range of chert colors.

\section{Methodological Considerations}

We plotted 12 comparative sites along with 41BX17 in ArcGIS 9.2 using UTM coordinates given in the Texas Historical Commission Archeological Site Atlas. Three of the twelve were not used in our debitage and tool color analysis (see Tables 13-4 and 13-5) because of very low counts of recovered tools. A $30 \mathrm{~km}$ radius spatial extent, approximately $2,832 \mathrm{~km}^{2}$, was centered on each site by clipping geologic digital data (2007) developed by the USGS for the Texas Water Development Board. These data are based on the Bureau of Economic Geology's (BEG) Geologic Atlas of Texas (1961-1987). "Local" chert sources were defined as being within $30 \mathrm{~km}$ radius of each site. The CAR used both the digital data, as well as the descriptions in the BEG Atlas to identify chert bearing deposits for each polygon. Identified chert sources were not distinguished as to whether they were a primary or secondary source. Also note that the polygons labelled "water" are modern reservoirs and thus exclude any potential chert resources. The Choke Canyon site, LK31/32, contains this water polygon although the polygon accounted for less than $4 \%$ of the approximately $2832 \mathrm{~km}^{2}$ area. Using the spatial statistics tool found in the ArcToolbox, we calculated the area for each individual polygon represented by chert bearing deposits.

\section{Results}

Table 13-9 provides a summary of the chert availability for the 13 sites. The first column lists the eight sites. The second column identifies the number of distinct rock units that contained chert within the $30 \mathrm{~km}$ radius. Column 3 provides the area, in $\mathrm{km}^{2}$ of chert, followed by the percentage of availability (Column 4) and ranking of availability (Column 5). This table suggests that chert availability is highest at site $41 \mathrm{KM} 69$, with almost $80 \%$ of the area surrounding the site containing chert bearing deposits, and lowest at 41MM296, where only $15 \%$ of the surrounding area contains chert. The lowest mean color values (see Table 13-4) on all three scales were evident in the 41KM69 material, whereas the highest values were found in the 41CM111 material. Both components are in Central Texas located on the Edwards Plateau.

\section{Summary}

The final research area in this chapter focused on gathering data relevant to assessing shifts in mobility levels by focusing on color shifts in raw material from debitage and tools on 16 Middle and Late Archaic components in Central Texas. We acquired data on raw material colors from tools and debitage through the use of digital photography and computeraided color characterization. Roughly 6,900 individual pieces of debitage and tools from comparative collections

Table 13-9. Chert Bearing Deposits within a 30 km Radius

\begin{tabular}{|c|c|c|c|c|}
\hline Site & $\begin{array}{c}\text { Number of Rock Units } \\
\text { with Chert Present }\end{array}$ & $\begin{array}{c}\text { Area of Chert Bearing } \\
\text { Deposits }\left(\mathbf{k m}^{2}\right)\end{array}$ & $\begin{array}{c}\text { Percentage of Chert } \\
\text { Bearing Deposits within } \\
\text { Area }\end{array}$ & $\begin{array}{c}\text { Ranking of Chert } \\
\text { Availability }\end{array}$ \\
\hline 41KM69 & 5 & 2280 & $79.8 \%$ & 1 \\
\hline 41LK31/32 & 6 & 1401 & $51.5 \%$ & 2 \\
\hline 41BX126 & 5 & 1040 & $37.1 \%$ & 3 \\
\hline 41BX1 & 4 & 1014 & $36.2 \%$ & 4 \\
\hline 41BX228 & 4 & 1003 & $35.5 \%$ & 5 \\
\hline 41CM111 & 7 & 977 & $35.0 \%$ & 6 \\
\hline 41BX300 & 4 & 987 & $34.9 \%$ & 7 \\
\hline 41BX17/271 & 4 & 970 & $34.6 \%$ & 9 \\
\hline 41TV163 & 5 & 786 & $28.4 \%$ & 10 \\
\hline 41MM340 & 2 & 776 & $27.4 \%$ & 11 \\
\hline 41LK67 & 3 & 747 & $26.3 \%$ & 12 \\
\hline 41LK201 & 2 & 682 & $24.0 \%$ & 13 \\
\hline 41MM296 & 3 & 423 & $14.9 \%$ & \\
\hline
\end{tabular}


and over 9,000 pieces of debitage and 100 formal tools from 41BX17 were photographed and characterized. The resulting pattern was one of a continuum of color values rather than distinct types. Comparing the range of RGBs by period, it is apparent that there is greater variability in color in the Middle Archaic and the Terminal Late Archaic compared to the Initial Late Archaic. There are significant differences between RGB values of debitage and tools in the Middle Archaic and Terminal Late Archaic material suggesting that tools were made off site. In contrast, Initial Late Archaic debitage and tool RGB values are not statistically different suggesting that tools were generally produced on site, indicative of a smaller scale mobility strategy. A consideration of chert availability within a 30 kilometer radius of these sites suggests that chert was more readily available for some sites than others, ranging from a low of $15 \%$ of an area to a high of $80 \%$. Components from sites in proximity tend to have similar color ranges. For a given area, it appears that comparisons of debitage and tool RGB values can potentially provide information on temporal shifts.

\section{Summary and Conclusions}

This chapter focused on two principal research issues: 1) the differentiation of residential locations from special purpose locations; and 2) the scale of mobility as indicated by diversity in raw material types. Our goal was to address these issues by examining the lithic material, debitage and tools, from both the Granberg Site and comparative sites from throughout South-Central and Central Texas.

Because our review of bison presence and absence in Central and South-Central Texas (see Chapter 11) demonstrates that the mammal was continually present in the area throughout the Middle and Late Archaic periods, we based our expectations on anticipated shifts in bison density. We suggest that bison densities will mirror shifts in grassland densities, becoming increasing common in the Middle Archaic into the Initial Late Archaic, then gradually decreasing through the Middle Late Archaic into the Terminal Late Archaic. The fluctuating densities of the large mammal should guide mobility strategies (i.e., logistical forms versus foragingbased). Because scheduling conflicts will be reduced when bison increase in frequency on the landscape, hunters and gatherers should decrease their reliance on logistical organization. Based on this pattern we expected a decline in logistical forms of mobility organization from the Middle into the Initial Late Archaic, followed by a gradual increase into the Terminal Late Archaic. Using a bivariate graph, we plotted the number of artifacts to number of artifact types. The bivariate plot suggests that patterns of logistical mobility, used in all the EMA components, declined through the LMA, changing to a residential pattern in the ILA. Subsequently, in the MLA and TLA, the mobility pattern returns to a more logistically based strategy. The results of our analysis fit our expectations, suggesting that as bison densities peaked in the Initial Late Archaic period procurement conflicts were reduced, decreasing the need for a reliance on a logistical organization. The data suggests that an uneven distribution of bison in the early years of the Middle Archaic and the latter years of the Late Archaic resulted in a heavier reliance on logistical strategies as bison became more difficult to locate.

The final research topic considered in this chapter involved investigating the scale of mobility by assessing the diversity in raw material types. We expected a greater component of mobility to be organized in a logistical mode during the Middle and Late Archaic as a response to the continued presence of bison. This was especially anticipated to be the case near the close of the Late Archaic, when bison densities are expected to begin to fluctuate in response to a fluctuation in grasslands. As the scale of the mobility increases, there should be associated increases in the range of tool stone encountered and used in tool production. We acquired data on raw material colors in tools and debitage through the use of digital photography and computer-aided color characterization. The resulting pattern was one of a continuum of color values rather than distinct types. A comparison of the range of RGBs by period indicating greater color variability in the Middle Archaic and the Terminal Late Archaic compared to the Initial Late Archaic, and significant differences between RGB values of debitage and tools in the Middle Archaic and Terminal Late Archaic material compared to no significant differences in the Initial Late Archaic suggests a smaller scale of mobility at the beginning of the Late Archaic period. The results of the color analysis and the analysis of artifact variety generally correspond, pointing to a decrease in mobility and a more residential based mobility strategy when bison populations are anticipated to be higher in response to increasing grassland production in the Initial Late Archaic. Although we determined that chert was more readily available for some sites than others (26\% to $80 \%$ coverage), all the sites used for the RGB analysis had access to chert within a 30 kilometer radius. For a given area, it appears that comparisons of debitage and tool RGB values can potentially provide information on temporal shifts. 


\title{
Chapter 14: Summary and Conclusions
}

\author{
Cynthia M. Munoz and Raymond P. Mauldin
}

\section{Summary}

The Center for Archaeological Research (CAR) at The University of Texas at San Antonio under contract with the Texas Department of Transportation (TxDOT; Work Authorization No. 57510SA005) conducted archeological significance testing from January to March 2006 at the Granberg Site, 41BX17, located in Bexar County, Texas. Based on the testing, and in consultation with TxDOT Environmental Division staff, a series of research questions were developed that could be pursued with site data. Following agreement on the general research directions and specific analyses, the CAR was instructed to produce a final report.

This document constitutes the final report on the work at 41BX17. The Granberg Site has a long history of archeological work dating back to the early 1960s. This report includes a summary of the early investigations as well as a description of the site, excavation procedures, and an analysis of cultural materials collected from selected components from the 2006 testing.

Archeological significance testing was conducted in advance of improvements made by TxDOT to N.E. Loop 410 in the vicinity of 41BX17. The archeological work was necessary to address the requirements of Section 106 of the National Historic Preservation Antiquities Code of 1966, as amended, the implementing regulations of 36 CFR Part 800 , and the Texas Antiquities Code. The construction impacts land owned by the State of Texas and is partially funded by the Federal Highways Administration (FHWA).

The initial three chapters of this document provided background on the project, including an overview of the physical and cultural setting of the site. Chapter 4 summarized the field work completed in the 1960s and 1970s and outlined the field and laboratory methods used during the 2006 testing. Chapter 5 provided a summary of materials recovered, including descriptions of artifacts and features. A detailed review of the geological setting of 41BX17 was provided in Chapter 6. Chapter 7 identified analytical units based on the distribution and clustering of diagnostic projectile points and supported by radiocarbon dates. These analytical units covered two temporal periods spanning the Late Middle Archaic through the Terminal Late Archaic. These analytical units were subsequently used to address a series of research questions. Chapter 8 addressed the theoretical perspective used as the basis of our research design, while Chapter 9 used this perspective to develop a model of hunter-gatherer adaptations and archeological expectations. Chapters 10-13 addressed three diachronic research topics: changes in the paleoclimate, changes in subsistence practices, and changes in chipped stone technology.

In Chapter 10, we addressed the paleoenvironmental conditions during the Middle and Late Archaic occupations at 41BX17 at the site level. We used various data sets from the site to determine if climate change is consistent with the proposed increase in grasslands into the Late Archaic suggested by pollen and carbon isotope data (see Bousman 1998; Cooke 2005; Nickels and Mauldin 2001; Nordth et al. 2002). The results of gastropod, diatom, and phytolyth analyses on data collected from 41BX17 suggest that at the commencement of the occupation of the site the climate was relatively dry with moderately open woodland canopy. The area became cooler, wetter, and more forested, followed once again by a more xeric period, and finally another mesic interval. At the transition from the Middle to the Late Archaic period, the data suggest a more homogenous climate with both woodland and open habitat indicators. Subsequently, as the Late Archaic progresses the environment becomes increasingly mesic. The site level findings correlate relatively well with the larger overall pattern apparent from pollen and soil carbonate sequences.

Chapter 11 used bison presence/absence data from a literature review of South-Central and Central Texas archeological components, faunal and floral data from the Middle and Late Archaic analytical units at 41BX17, and flotation analysis and lipid residue analysis from 41BX17 features to investigate changes in subsistence. Operating from the perspective of optimal foraging theory, we outlined a series of expectations regarding the potential impact of changes in the availability and density of higher-ranked bison on the diet. We based these expectations (Munoz et al. 2007) on the prediction of an absence of bison throughout the entirety of the Middle Archaic period and, therefore, suggested that during the Middle Archaic hunter-gatherer diets would be relatively broader than those of Late Archaic populations. Bison data gathered from our literature review and from the 
analysis of faunal material from selected assemblages did not support our expectation. Contrary to traditional perspective, bison were present throughout both the Middle and Late Archaic periods.

We altered our overall expectation from a bison presence/ absence framework to one in which the focus was on changing bison densities. We used regional changes in $\mathrm{C}_{4}$ grasses, described by several different data sets, as a proxy for bison availability. As bison were always present, we expected a relatively narrow diet breadth throughout the occupations at 41BX17. We anticipated variances during the latter years of the Late Archaic, based on reduction of $\mathrm{C}_{4}$ grasses, and possible variances in the Middle Archaic, based on the expectation that bison were gradually emerging in Central Texas as a response to increasing $\mathrm{C}_{4}$ grasses. These expectations were partially supported by the 41BX17 data. Our analysis of taxa richness partially supported our suggestions of decreased diet breadth as we found evidence for both increases and decreases in the number of genera throughout the site occupations. Our analysis of the ratio of unidentified fragmentary bone to identified bone did not support our suggestions. Our suggestion that the density and/or area devoted to rock hearths can be used as a gross measure of plant dependence was not supported. The results of lipid residue analysis pointed to both plant and animal residues in Middle and Late Archaic features suggesting that both were processed throughout the occupations at Granberg. Macrobotanical findings were minimal.

We then conducted a regional comparison using faunal material and burned rock feature data from a number of sites. Again, as with the site level data, some aspects of our expectations were supported and others were not. The data suggests that as grasslands, and by extension bison, increased in Central and South-Central Texas the reliance on small, lower ranked resources was reduced. Although the taxa data from comparative sites does not support our expectations, it appears that lower ranked resources were greatly reduced when bison were present. With the exception of patterns in dependence on low return animals, and some specific changes in burned rock feature data, the archeological data do not pattern as we anticipated. Overall, our assessment of faunal and floral materials from 41BX17 suggests that variation rather than homogeneity in subsistence characterized any given period.

We suggested a number of possible reasons for this lack of correspondence, including that our general approach is not a useful way to look at the archeological record; that some data (i.e., recovered taxa) may have been affected by differential preservation; that different processing techniques were used for different mammal species; that bison may not have been evenly distributed across Central Texas, temporally or spatially; that site specific discrepancies resulting from varying excavation techniques and effort may have over- or underestimated various elements of our data; and that several of our assumptions (i.e., regarding feature density) may not have be warranted in all cases.

In Chapter 12, we examined two aspects of chipped stone technology. Using data from the Middle and Late Archaic analytical units of 41BX17 and from comparative assemblages from South-Central and South Texas, we looked at variability in formal versus expedient tools through time and searched for evidence of gearing-up in anticipation of future needs. We suggested that changes in the availability of bison should impact both of these elements. Our review shows that, with a few exceptions, the arguments for a more specialized tool kit as a response to decreasing bison or a more generalized tool kit in response to increasing bison availability were not supported. The counterargument that formal tools, which are more likely to reflect task-specific requirements, are correlated directly with increases or decreases in bison was marginally supported. The Middle Archaic assemblages do not pattern with our anticipated increase in bison. However, there is a small drop in expensive tools from the Initial Late Archaic into the Middle Late Archaic. The pattern then levels off into the Terminal Late Archaic. Although the percentage changes through time are minimal, it may be the case that certain types of expensive tools are designed specifically for bison.

The results from our investigation of "gearing-up" behavior were also unclear. Based on the presence of bison throughout the Middle and Late Archaic periods, we suggested that a gearing-up system should be present, especially in the later portions of the Late Archaic as bison declined in availability. We anticipated that during other periods, while some evidence of gearing-up would be present, components would be dominated by on-demand replacement. While these suggestions were somewhat supported by our analysis, the validity of the resultant pattern is questionable on the basis of sample size.

Scales of mobility were discussed in Chapter 13. Because our review of bison presence and absence in Central and South-Central Texas (see Chapter 11) demonstrated that the mammal was continually present in the area throughout the Middle and Late Archaic periods, we based our expectations 
on anticipated shifts in bison density. We reasoned that bison densities should fluctuate with grassland densities, becoming increasingly frequent in the Middle Archaic into the Initial Late Archaic and then gradually decreasing through the Middle Late Archaic into the Terminal Late Archaic. We suggested that sporadic densities of the large mammal should direct mobility strategies (i.e., logistical forms versus foraging-based) and that procurement conflicts will be reduced when bison increase in frequency on the landscape, permitting hunters and gatherers to decrease their reliance on logistical organization. Therefore, we anticipated a decline in logistical forms of mobility organization from the Middle into the Initial Late Archaic followed by a gradual increase into the Terminal Late Archaic. The results of our analysis fit our expectations. As bison densities peaked in the Initial Late Archaic period procurement conflicts should have been reduced, decreasing the need for reliance on a logistical organization. The data suggest that an uneven distribution of bison in the early years of the Middle Archaic and the latter years of the Late Archaic, anticipated from variances in $\mathrm{C}_{4}$ grass distribution, resulted in a heavier reliance on logistical strategies as bison became more difficult to locate.

We concluded Chapter 13 with an investigation into the scale of mobility via an assessment of diversity in raw material types. Based on the patterns discussed above, we expected a greater component of mobility to be organized in a logistical mode, evident in a more diverse raw material assemblage, during the Middle Archaic and the latter years of the Late Archaic. As the scale of the mobility increases, there should be associated increases in the range of tool stone encountered and used in tool production. Digital photography and computer-aided color characterization resulted in RGB patterns pointing to a continuum of color values rather than distinct types. The range of RGBs by period indicates greater color variability in the Middle Archaic and the Terminal Late Archaic compared to the Initial Late Archaic. Significant differences between RGB values of debitage and tools in the Middle Archaic and Terminal Late Archaic material compared to no significant differences in the Initial Late Archaic suggests a smaller scale of mobility at the beginning of the Late Archaic period.

Both the results of the color analysis and the analysis of artifact variety suggest a decrease in mobility and a more residentially based mobility strategy when bison populations are anticipated to be higher in response to increasing grassland production in the Initial Late Archaic. We determined that chert was more readily available for some sites than others ( $26 \%$ to $80 \%$ coverage) but that all the sites used for the RGB analysis had access to chert within a $30 \mathrm{~km}$ radius.

\section{Conclusions}

The research design (Munoz et al. 2007) guiding the four analytical chapters was based on a model derived from foraging theory intended to provide a coherent set of concepts and an explicit analytical framework for investigating aspects of hunter-gatherer adaptations (see Chapter 9). However, variability in the quality and quantity of resources operating at a number of temporal and spatial scales render anticipation of detailed responses of hunters and gatherers to that variability difficult. Different responses are possible given alternative conditions. For example, based on our analysis of bison presence/absence, we have concluded that bison were present in Central and South-Central Texas throughout the occupations of the Granberg Site. The density of animals remains unknown, but it was likely to have fluctuated seasonally and in response to fluctuating forage production. What would hunters and gatherers do under such a scenario? Hunter-gatherers could potentially have a number of different responses. Using the cost/benefit framework provided by foraging theory, our model suggested several general relationships that should be applicable to investigating aspects of diet, technology, and mobility in hunters and gatherers. We have suggested that during this period a number of adaptive changes were initiated as a response to changes in the availability of bison. Each of the analytical chapters attempted to develop one or more of the general relationships using data from the Granberg Site and from comparative components. Results of these analyses varied, not always supporting our expectations but suggesting a general pattern of greater mobility (i.e., logistical organization) in the Middle Archaic and latter part of the Late Archaic along with some evidence of gearing-up strategies. Although our data did not support a narrow diet breadth throughout the occupations, it is apparent that low return resources decreased in number through time as bison populations increased, a pattern consistent with our overall expectations.

As this report progressed it became apparent that even when the patterns outlined above were supported, they were not particularly strong. The work at the Granberg Site illustrates a need for the development of better archeological breakdowns in time and in space. In this report, we attempted to assess the utility of our model by reference to a behavioral pattern (e.g., gearing-up, increases in taxa) over substantial time periods (e.g., 1,000 plus years) across enormously large areas. It is unlikely that a single behavior will be consistent over a large time frame, and a behavior will likely increase or decrease in response to specific circumstances that vary in space. Our analyses point to the need for tighter spatial and temporal windows along with better ways to monitor those variables that are important to the model. Because aspects of foraging 
theory were originally developed to answer questions requiring timely answers (e.g. "should I pursue that resource, or should I keep looking...."), we need to develop ways to look at slices of time, on the scale of a couple of hundred years, not a couple of thousand years (e.g. the Initial Late Archaic). Perhaps acquiring more C-14 dates and/or putting more emphasis on small scale shifts in artifacts (see Tomka et al. 2003) could be beneficial for reducing the temporal and spatial scales.

Future research should involve refining the current paleoclimate data by acquiring more accurately dated samples. The current pollen and stable isotope data sets contain major gaps (i.e. gaps of several hundred years) between many data points (see Bousman 1998; Cooke 2005; Nickels and Mauldin 2001; Nordt et al. 2002). Better dated paleoclimate data would tighten up the temporal control. We should also develop improved methods for estimating bison density in the natural environment. In this report, we treated the entire region (i.e. Central and South-Central Texas) as if it were the same. Beneficial future research would involve obtaining smaller scale spatial data. Smaller scale data and more accurately dated paleoclimate data would enable our analyses to focus on a particular portion of the landscape at a tighter temporal scale (e.g. "during this period in this portion of Central Texas grasslands are increasing while at the same time in the other location in Central Texas grasslands are stable"). Two possible avenues for acquiring smaller temporal and spatial scale data that we are pursuing outside of this current work involve analyzing changes in snail populations (i.e., stable isotope analysis of shell carbonate) and shifts in stable isotope signatures in bone collagen of small herbivores
(Kemp et al. 2008; Munoz et al. 2008, 2009). It may be the case that changes in bison densities through time were not that major; perhaps, as grasslands expanded in the Middle Archaic into the Initial Late Prehistoric, bison increased only slightly and decreased only slightly in the Middle and Late Archaic. It is possible that shifts in the grassland data were not that dramatic resulting in small shifts in archaeological materials. Even so, the development of better estimates of climate change at smaller scales may help clarify when and where bison were available to hunters and gatherers.

Other avenues of future research concerns further clarification of the residential versus logistical distinction proposed in Chapter 13. Specifically, we should explore other attributes, such as distance to water, numbers of features, or site size that should correlate with these organizational stances. In addition, it may be useful to initiate INAA analysis of selected archeological samples, representing specific color ranges, when analyzing raw materials to strengthen the link between color ranges and chert sources. In the future, to develop greater sophistication in faunal analyses it would be beneficial to attempt to assess taphonomic processes that may impact changes in taxa diversity through time. By focusing on what individual elements are present and what the soil/burial conditions are, an understanding of what to expect as far as taphonomy could be developed for Central and South-Central Texas. Finally, note that we currently lack answers to many basic technological questions (e.g., production costs and use life for baskets/stone boiling relative to ceramics production and direct fire cooking) that could be productively pursued through both experimental archaeology and a focused review of ethnographic literatures. 


\section{References Cited:}

Abbott, J.T.

1994 Geomorphic Context of the Barton Site (41HY202) and the Mustang Branch Site (41HY209). In Archaic and Late Prehistoric Human Ecology in the Middle Onion Creek Valley, Hays County, Texas, by R.A. Ricklis and M.B. Collins, pp. 353-379. Studies in Archeology 19. Texas Archeological Research Laboratory, The University of Texas at Austin.

Afifi, A.A., and V. Clark

1984 Computer-Aided Multivariate Analysis. Wadsworth, Inc. Belmont, California.

Amaral, W.W., and D.C. Witter

1973 Some Ecological Interpretations of a Prehistoric Land Snail Fauna, 41WM118. In Salvage Archeology in the Laneport Reservoir District Central Texas, by F.W. Eddy, pp. 413-432. Texas Archeological Survey, The University of Texas at Austin.

Amick, D.S.

1994 Folsom Diet Breadth and Land Use in the American Southwest. Unpublished Ph.D. dissertation, Department of Anthropology, University of New Mexico, Albuquerque.

Anderson, A.E., D.E. Medin, and D.C. Bowden

1972 Indices of Carcass Fat in a Colorado Mule Deer Population. Journal of Wildlife Management 36(2):579-594.

Armstrong, W.E., and E.L. Young

2001 White-tailed Deer Management in the Texas Hill County. Texas Parks and Wildlife, Austin.

Assad, C.

1979 Archaeological Testing in the Devine Road Area North of Olmos Dam, San Antonio, Texas. Archaeological Survey Report, No. 53. Center for Archaeological Research, The University of Texas at San Antonio.

Bamforth, D.B.

1988 Ecology and Human Organization on the Great Plains. Plenum Press, New York.

Bamforth, D.B., and P. Bleed

1997 Technology, Flake Stone Technology, and Risk. In Rediscovering Darwin: Evolutionary Theory in Archaeological Explanation, edited by C.M. Barton and G.A. Clark, pp. 109-140. Archaeological Papers of the American Anthropological Association, No. 7. Arlington, Virginia.

Barnes, V.E.

1983 Geological Atlas of Texas. San Antonio Sheet. Robert Hamilton Cuyler Memorial Edition, Bureau of Economic Geology, The University of Texas at Austin.

Binford, L.R.

1977 Forty-seven Trips: A Case Study in the Character of Archaeological Formation Process. In Stone Tools as Cultural Markers, edited by R.V.S. Wright. pp. 24-36. Australian Institute of Aboriginal Studies. Canberra, Australia.

1978 Nunamiut Ethnoarchaeology. Academic Press, New York.

1979 Organization and Formation Processes: Looking at Curated Techniques. Journal of Anthropological Research 35(3):255-273. 
1980 Willow Smoke and Dog's Tails: Hunter-Gatherer Settlement Systems and Archaeological Site Formation. American Antiquity 45:4-20.

1992 Seeing the Present and Interpreting the Past — and Keeping Things Straight. In Space, Time, and Archaeological Landscapes, edited by J. Rossignol and L. Wandsnider, pp. 43-59. Plenum Press, New York.

2001 Constructing Frames of Reference: An Analytical Method for Archaeological Theory Building Using HunterGatherer and Environmental Data Sets. University of California Press, Berkeley.

Black, S.L.

1986 The Clemente and Herminia Hinojosa Site, 41JW8: A Toyah Horizon Campsite in Southern Texas. Special Report No. 18. Center for Archaeological Research, The University of Texas at San Antonio.

1989a Central Texas Plateau Prairie. In From the Gulf Coast to the Rio Grande: Human Adaptation in Central, South and Lower Pecos Texas, by T.R. Hester, S.L. Black, D.G. Steele, B.W. Olive, A.A. Fox, K.J. Reinhard, and L.C. Bement, pp. 17-38. Research Series, No. 33. Arkansas Archeological Survey, Fayetteville.

1989b Environmental Setting. In From the Gulf Coast to the Rio Grande: Human Adaptation in the Central, South, and Lower Pecos Texas, by T.R. Hester, S.L. Black, D.G. Steele, B.W. Olive, A.A. Fox, K.J. Reinhard, and L.C. Bement, pp. 5-17. Research Series, No. 33. Arkansas Archeological Survey, Fayetteville.

2003 Research Module 2: Studying the Hearths of the Greater Edwards Plateau. In Pavo Real (41BX52): A Paleoindian and Archaic Camp and Workshop on the Balcones Escarpment, South-Central Texas, by M.B. Collins, D.B. Hudler, and S.L. Black. pp. 375-405. Studies in Archeology, No. 41. The Texas Archeological Research Laboratory. Archeological Studies Program, Report 50. Environmental Affairs Division. Texas Department of Transportation, Austin.

Black, S.L., and D.G. Creel

1997 The Central Texas Burned Rock Midden Reconsidered. In Hot Rock Cooking on the Greater Edwards Plateau: Four Burned Rock Midden Sites in West Central Texas, edited by S.L. Black, L.W. Ellis, D.G. Creel, and G.T. Goode, pp. 446-515. Studies in Archeology 22. Texas Archeological Research Laboratory, The University of Texas at Austin.

Black, S.L., L.W. Ellis, D.G. Creel, and G.T. Goode

1997 Hot Rock Cooking on the Greater Edwards Plateau: Four Burned Rock Midden Sites in West Central Texas. 2 vols. Studies in Archeology 22. Texas Archeological Research Laboratory, The University of Texas at Austin. Archeology Studies Program, Report 2 Texas Department of Transportation Environmental Affairs Department.

Black, S.L., K. Jolly, C.D. Frederick, J.R. Lucas, J.W. Karbula, P.R. Takac, and D.R. Potter

1998 Archeology along the Wurzbach Parkway. Module 3. Investigations and Experimentation at the Higgins Site (41BX184). Volume 1 and 2. Studies in Archeology 27. Texas Archeological Research Laboratory, The University of Texas at Austin.

Black, S.L., J.W. Karbula, C.D. Frederick, and C.G. Mear

1998 Archeology along the Wurzbach Parkway. Module 5. Testing and Geoarcheological Evaluation at the Number-6 Site (41BX996) and Other Sites. Studies in Archeology 29. Texas Archeological Research Laboratory, The University of Texas at Austin.

Black, S.L. and A.J. McGraw

1985 The Panther Springs Creek Site: Cultural Change and Continuity in the Upper Salado Creek Drainage, SouthCentral Texas. Archaeological Survey Report, No. 100. Center for Archaeological Research, The University of Texas at San Antonio.

Blair, W.F.

1950 The Biotic Provinces of Texas. The Texas Journal of Science 2(1):93-117. 
Bleed, P.

1986 The Optimal Design of Hunting Weapons: Maintainability or Reliability. American Antiquity 51:737-747.

Bobrowsky, P.T., and B.F. Ball

1989 The Theory and Mechanics of Ecological Diversity in Archeology. In Quantifying Diversity in Archaeology, edited by R.D. Leonard and G. T. Jones, pp. 4-12. Cambridge University Press, New York.

Bousman, C.B.

1998 Paleoenvironmental Change in Central Texas: The Palynological Evidence. Plains Anthropologist 43(164):201-219.

Bocek, B.

1986 Rodent Ecology and Burrowing Behavior: Predicted Effects on Archaeological Site Formation. American Antiquity 51(3):589-603.

Brown, D.A.

1993 Early Nineteenth-Century Grasslands of the Midcontinent Plains. Annals of the Association of American Geographers 83:589-612.

Brown, K.M., D.R. Potter, G.D. Hall, and S.L. Black

1982 Excavations at 41LK67 A Prehistoric Site in the Choke Canyon Reservoir, South Texas. Choke Canyon Series, Vol. 7. Center for Archaeological Research, The University of Texas at San Antonio.

Brown, T.E., N.B. Waechter, and V.E. Barnes

1983 Geologic Atlas of Texas, San Antonio Sheet. The University of Texas at Austin, Bureau of Economic Geology (1:250,000-scale). Austin.

Brune, G.

1981 Springs of Texas. Vol. 1. Branch-Smith, Inc., Fort Worth, Texas.

Buckner, H.D., and W.J. Shelby

1991 Water Resources Data, Texas, Water Year 1991. Vol. 3. Colorado River basin, Lavaca River basin, Guadalupe River basin, Nueces River basin, Rio Grande River basin, and Intervening coastal basins. Geological Survey Water Data Report TX-91-3. United States Department of the Interior, Washington, D.C.

Buikstra, J.E., and D.H. Ubelaker

1994 Standards for Data Collection from Human Skeletal Remains. Research Series, No. 44. Arkansas Archeological Survey, Fayetteville.

Callahan, E.

1979 The Basics of Biface Knapping in the Eastern Fluted Point Tradition: A Manual for Flintknappers and Lithic Analysts. Archaeology of Eastern North America 7:1-180.

Campbell, T.N., and T.J. Campbell

1981 Historic Indians of the Choke Canyon Reservoir Surrounding Area, Southern Texas. Choke Canyon Series, No. 1. Center for Archaeological Research, The University of Texas at San Antonio.

Camper, H.A.

1991 Pollen analysis of Patschke Bog. Unpublished M.S. thesis, Department of Botany, Texas A\&M University, Bryant. Data archived at the World Data Center-A for paleoclimatology data. NOAA/NGDC Paleoclimatology Program, Boulder.

Cane, S.

1987 Australian Aboriginal Subsistence in the Western Desert. Human Ecology 15:391-434. 
Caran, S.C., and Baker, V.E.

1986 Flooding along the Balcones Escarpment, Central Texas. In The Balcones Escarpment: Geology, Hydrology, Ecology, and Social Development in Central Texas, edited by P.L. Abbott and C.M. Woodruff, Jr., pp. 1-14. Geological Society of America. Comet Reproduction Service, Santa Fe Springs, California.

Charnov, E.L.

1976 Optimal Foraging, the Marginal Value Theorem. Theoretical Population Biology 9(2):129-136.

Charnov, E.L., G.H. Orians, and K. Hyatt

1976 The Ecological Implications of Resource Depression. American Naturalist 110:247-259.

Cheatum, E.P., and R.W. Fullington

1971 The Aquatic and Land Mollusca of Texas. Part One: The Recent and Pleistocene Members of the Gastropod Family Polygyridae in Texas. Bulletin 1. Dallas Museum of Natural History, Dallas.

1973 The Aquatic and Land Mollusca of Texas. Part Two: The Recent and Pleistocene Members of the Pupillidae and Urocoptidae (Gastropoda) in Texas. Bulletin 1. Dallas Museum of Natural History, Dallas.

Chisholm, B., J. Driver, S. Duben, and H.P. Schwarz

1986 Assessment of Prehistoric Bison Foraging and Movement Patterns Via Stable-carbon Isotopic Analysis. Plains Anthropologist 31:193-205.

Cliff, M.B., and N.A. Nash

2001 Results of National Register Investigations Conducted on Site 41KR537, Kerr County, Texas. Archeological Studies Program Report, No. 33. PBS\&J, Austin.

Collins, M.B.

1995 Forty Years of Archeology in Central Texas. Bulletin of the Texas Archaeological Society 66:361-400.

1998 Wilson-Leonard: An 11,000-year Archeological Record of Hunter-Gatherers in Central Texas. Studies in Archeology 31. Texas Archeological Research Laboratory, The University of Texas at Austin.

1999 Gault Site. In The Handbook of Texas, edited by R.R. Barkley, pp. 117- 118. Texas State Historical Association, Austin.

2004 Archeology in Central Texas. In The Prehistory of Texas, edited by T.K. Perttula, pp. 205-265. Texas A\&M University Press, College Station.

Collins, M.B., B. Ellis, and C. Dodt-Ellis

1990 Excavations at the Camp Pearl Wheat Site (41KR243): An Early Archaic Campsite on Town Creek Kerr County, Texas. Studies in Archeology 6. Texas Archeological Research Laboratory, The University of Texas at Austin.

Collins, M.B., D. Hudler, and S.L. Black

2003 Pavo Real (41BX52): A Paleoindian and Archaic Camp and Workshop on the Balcones Escarpment, South-Central Texas. Studies in Archeology 41. Texas Archeological Research Laboratory, The University of Texas at Austin.

Condamin, J., F. Formenti, M.O. Metais, M. Michel, and P. Blond

1976 Application of Gas Chromatography to the Tracing of Oil in Ancient Amphorae. Archaeometry 18(2):195-201.

Cooke, M.J.

2005 Soil Formation and Erosion in Central Texas: Insights from Relict Soils and Cave Deposits. Unpublished Ph.D. Dissertation. The University of Texas at Austin. 
Coppedge, B.R., D.M. Leslie, Jr., and J.H. Shaw

1998 Botanical Composition of Bison Diets on Tallgrass Prairie in Oklahoma. Journal of Range Management 51(4):379382.

Córdova, K.J., B.K. Moses, and R.P. Mauldin

2005 Records and Collections Assessment of Previous Investigations at Sites 41BX17 and 41BX271 (Granberg I and II) within the ROW of Loop 410 East at Salado Creek, San Antonio, Bexar County, Texas. Report on file, Center for Archaeological Research, The University of Texas at San Antonio.

Coupland, R.T.

1979 The Nature of Grassland. In Grassland Ecosystems of the World: Analysis of Grasslands and their Uses, edited by R.T. Coupland, pp. 23-30. International Biological Programme No. 18. Cambridge University Press, Cambridge.

Cowlishaw, M.F.

1985 Fundamental Requirements for Picture Presentation. Proceedings of the Society for Information Display 26(2): 101-107.

Crabtree, D.E.

1972 An Introduction to Flintworking. Occasional Papers of the Idaho State Museum, No. 28. Idaho State University, Pocatello.

Creel, D.G.

1990 Excavations at 41TG91, Tom Green County, 1978. Publications in Archeology, No. 38. Texas State Department of Highways and Public Transportation, Austin.

1986 Study of Prehistoric Burned Rock Middens in West Central Texas. Unpublished Ph.D. dissertation. Department of Anthropology, The University of Arizona, Tucson.

Cummings, L.S.

1994 Pollen, Phytolith, Macrofloral, and Charcoal Analyses at the Mustang Branch Site (41HY209) and the Barton Site (41HY202). In Archaic and Late Prehistoric Human Ecology in the Middle Onion Creek Valley, Hays County, Texas, by R.A. Ricklis and M.B. Collins, pp. 387-402. Studies in Archeology 19. Texas Archeological Research Laboratory, The University of Texas at Austin.

Dalquist, W.W., and V.B. Scheffer

1942 Origin of Mima Mounds of Western Washington. Journal of Geology 50:68-84.

Davis, W.B., R.R. Ramsey, and J.M. Arendale, Jr.

1938 Distribution of Pocket Gophers (Geomys breviceps) in Relation to Soils. Journal of Mammalogy 19:412-418.

Davis, W.B., and D.J. Schmidly

1994 The Mammals of Texas. Texas Parks and Wildlife, Austin.

Dering, J.P.

1994 Appendix D: Plant Remains from 41GM224, Grimes County, Texas. In Excavations at Site 41GM224 in the Gibbons Creek Lignite Mine Permit 38A Area, Grimes County, Texas, by R. Rogers, Espey, Huston and Associates, Inc., Austin.

2002 Rainfall Reconstruction Using Mesquite Wood Charcoal from Archeological Sites in South Texas. In Archeological Data Recovery Excavations along Becerra Creek (41WB556), Webb County, Texas, by R.B. Mahoney, R.P. Mauldin, and S.A. Tomka, pp. 206-216. Archaeological Survey Report, No. 321. Center for Archaeological Research, The University of Texas at San Antonio, Archeological Studies Program, Report No. 30. Environmental Affairs Division, Texas Department of Transportation, Austin. 
Diamond, D.D., D.H. Riskind, and S.L. Orzell

1987 A Framework for Plant Community Classification and Conservation in Texas. The Texas Journal for Science 39(3):203-221.

Dillehay, T.

1974 Late Quaternary Bison Population Changes on the Southern Plains. Plains Anthropologist 19(64):180-196.

Doughty, R.W.

1983 Wildlife and Man in Texas. Texas A\&M University Press, College Station.

Dunnell, R.C.

1992 The Notion of Site. In Space, Time, and Archaeological Landscapes, edited by J. Rossigno and L. Wandsnider, pp. 21-41. Plenum Press, New York.

Ebert, J.I.

1992 Distributional Archaeology. University of New Mexico Press, Albuquerque.

Ellis, L.W.

1997 Hot Rock Technology. In Hot Rock Cooking on the Greater Edwards Plateau: Four Burned Rock Midden Sites in West Central Texas, by S.L. Black, L.W. Ellis, D.G. Creel, and G.T. Goode, pp 43-81. Studies in Archeology 22. Texas Archeological Research Laboratory, The University of Texas at Austin. Archeological Studies Program, Report No. 2. Environmental Affairs Division, Texas Department of Transportation, Austin.

Epp, H.T.

1988 Way of the Migrant Herds: Dual Dispersion Strategy among Bison. Plains Anthropologist 33:309-320.

Epstein, H.E., W.K. Lauenroth, I.C. Burke, and D.P. Coffin

1997 Productivity Patterns of $\mathrm{C}_{3}$ and $\mathrm{C}_{4}$ Functional Types in the U.S. Great Plains. Ecology 78(3):722-731.

Erlandson, J.M.

1984 A Case Study in Faunalturbation: Delineating the Effects of the Burrowing Pocket Gopher on the Distribution of Archaeological Materials. American Antiquity 49(4):785-790.

Evans, D.E.

1992 Movement and Activity Patterns of White-Tailed Deer in East Texas. UMI Dissertation Services, Stephen F. Austin State University, Nacogdoches, Texas.

Favata, M.A., and J.B. Fernandez

1993 The Account: Núñez Cabeza de Vaca's Relación. Arte Público Press, Houston.

Fenneman, N.M.

1946 Physical divisions of the United States: Washington, D.C., United States Department of the Interior, Geological Survey (map, 1:7,000,000-scale).

Figueroa, A.L.

2008 An Intensive Pedestrian Archaeological Survey of the Salado Creek Greenway, Wetmore Avenue to Eisenhauer Road, San Antonio, Bexar County, Texas. Phase II: N. E. Loop 410 to Wetmore. Archaeological Report, No. 395. Center for Archaeological Research, The University of Texas at San Antonio.

2009 National Register of Historic Places Eligibility Testing of 41BX1764 (The Dos Mujeres Site), Bexar County, Texas. Archaeological Report, No. 398. Center for Archaeological Research, The University of Texas at San Antonio. 
Figueroa, A.L., and C.D. Frederick

2008 Archeological Testing of the Pavo Real Site (41BX52), San Antonio, Bexar County, Texas. Archaeological Report, No. 382. Center for Archaeological Research, The University of Texas at San Antonio.

Figueroa, A.L., and K.M. Ulrich

2006 Archaeological Survey of the North Salado Greenway Belt, San Antonio, Bexar County, Texas. Archaeological Report, No. 367. Center for Archaeological Research, The University of Texas at San Antonio.

Foster, W.C.

1998 The La Salle Expedition to Texas: The Journal of Henri Joutel 1664-1687. Texas State Historical Association, Austin.

Fox, A.A.

1979 Archaeological and Historical Investigations at 41BX180, Walker Ranch, San Antonio, Texas: Phase I.

Archaeological Survey Report, No. 83. Center for Archaeological Research, The University of Texas at San Antonio.

Fox, D.E., G.L. Evans, H. Murrary, and H.G. Uecker

1979 Archaeological Investigations of Two Prehistoric Sites on the Coleto Creek Drainage, Goliad County, Texas. Archaeological Survey Report, No. 69. Center for Archaeological Research, The University of Texas at San Antonio.

Fullington, R., and K. Fullington

1982 Invertebrate Faunal Analysis. In Archaeological Investigations at the San Gabriel Reservoir District, Central Texas, Vol. 2, pp. 15-33-15-56. Institute of Applied Sciences, North Texas State University, Denton.

Fullington, R.W., and W.L. Pratt, Jr.

1974 The Aquatic and Land Mollusca of Texas. Part Three: The Helicinidae, Carychiidae, Achatinidae, Bradybaenidae, Bulimulidae, Cionellidae, Haplotrematidae, Helicidae, Oreohelicidae, Spiraxidae, Streptaxidae, Strobilopsidae, Thysanophoridae, Valloniidae (Gastropoda) in Texas. Bulletin 1. Dallas Museum of Natural History, Dallas.

Gadus, E.F., R.C. Fields, and K.W. Kibler.

2006 Data Recovery Excavations at the J.B. White Site (41MM341), Milam County, Texas. Archeological Studies Program, Report No. 87. Environmental Affairs Division, Texas Department of Transportation, Austin.

Galin, D.

1979 Gastropod Analysis 41 BX271 (Granberg II Site) Summer 1979. Manuscript on file, Center for Archaeological Research, The University of Texas at San Antonio.

Geological Survey

1973 Longhorn, Texas. United States Department of the Interior (topographic map, 1:24,000-scale). Washington, D.C.

1980 San Antonio, Texas. United States Department of the Interior (topographic map, 1:250,000-scale). Washington, D.C.

Gerstle, A., T.C. Kelly, and C. Assad

1978 The Fort Sam Houston Project: An Archaeological and Historical Assessment. Archaeological Survey Report, No. 40. Center for Archaeological Research, The University of Texas at San Antonio.

Givens, R.D.

1968 A Preliminary Report on Excavations at Hitzfelder Cave. Bulletin of the Texas Archeological Society 38:47-50. 
Godwin, M.F.

2000 Archeological Investigations of the Spring Lake Water Line for City of San Marcos, Hays County, Texas. Archeological Investigations Report, No. 3. Antiquities Planning \& Consulting, Kyle.

Golley, F.B., L. Ryszkowski, and J.T. Sokur

1975 The Role of Small Mammals in Temperate Forests, Grasslands and Cultivated Fields. In Small Mammals: Their Productivity and Population Dynamics, edited by F.B. Golley, K. Petrusewicz, and L. Ryszkowski, pp. 223-242. Cambridge University Press, Cambridge.

Goode, G.T.

1991 Late Prehistoric Burned Rock Middens in Central Texas. In The Burned Rock Middens of Texas: An Archaeological Symposium, edited by T.R. Hester, pp. 71-93. Studies in Archeology 13. Texas Archeological Research Laboratory, The University of Texas at Austin.

Goode, G.T., L. Johnson, and R.W. Neck

2002 The Anthon Site: A Prehistoric Encampment in Southern Uvalde County, Texas. Archeological Studies Program Report, No. 38. Environmental Affairs Division, Texas Department of Transportation, Austin.

Gordon, B.H.C.

1979 Of Men and Herds in Canadian Plains Prehistory. Canadian Museum of Civilization Mercury Series, Archaeological Survey of Canada Paper 84. Ottawa.

Griffin, F.E.

n.d. Preliminary Report on Lithic of Granberg II, Bexar County. Manuscript on file, Center for Archaeological Research, The University of Texas at San Antonio.

Griffiths, J.F., and J. Bryan

1987 The Climates of Texas Counties. University of Texas at Austin, Natural Fibers Information Center, Austin, Texas.

Grinnell, J.

1923 The Burrowing Rodents of California as Agents in Soil Formation. Journal of Mammalogy 4:137-149.

Hall, G.D.

1981 Allens Creek: A Study in the Cultural Prehistoric of the Brazos River Valley, Texas. Research Report 61. Texas Archeological Survey, The University of Texas at Austin.

Hall, G.D., T.R. Hester, and S.L. Black

1986 The Prehistoric Sites at Choke Canyon Reservoir, Southern Texas: Results of the Phase II Archaeological Investigations. Choke Canyon Series, No. 10. Center for Archaeological Research, The University of Texas at San Antonio.

Hansen, R.M., and M.J. Morris

1968 Movement of Rocks by Northern Pocket Gophers. Journal of Mammalogy 43:391-399.

Hart, R.H., O.M. Abdalla, D.H. Clark, M.B. Marshall, M.H. Hamid, J.A. Hagar, and J.W. Waggoner, Jr.

1983 Quality of Forage and Cattle Diets on the Wyoming High Plains, Journal of Range Management 36:46-51.

Henderson J., and G.T. Goode

1991 Pavo Real: An Early Paleoindian Site in South-Central Texas. Current Research in the Pleistocene 8:26-28. 
Hester, T.R.

1977 Excavations at St. Mary's Hall (41BX229): A Buried Plainview Campsite in South Central Texas. Typescript of paper presented at the 1977 Texas Archaeological Society Annual Meeting in Arlington, Texas. Center for Archaeological Research, The University of Texas at San Antonio.

1980 11,000 Years of South Texas Prehistory. In Digging into South Texas Prehistory, pp. 131-164. Corona Publishing, San Antonio.

1984 Report of Materials Found at Site in 11/84 and 12/84. Letter Report on file, Center for Archaeological Research, The University of Texas at San Antonio.

1995 The Prehistory of South Texas. Bulletin of the Texas Archaeological Society 66:427-459.

2009 Handbook of Texas Online. Electronic document, http://www.tshaonline.org/handbook/online/articles/SS/bbs1.html, accessed February 13, 2009.

Hester, T.R., S.L. Black, D.G. Steele, B.W. Olive, A.A. Fox, K.J. Reinhard, and L.C. Bement

1989 From the Gulf to the Rio Grande: Human Adaptation in Central, South, and Lower Pecos Texas. Study Unit 3 of the Southwestern Division Archeological Overview. Center for Archaeological Research, The University of Texas at San Antonio.

Hester, T.R., and H. Kohnitz

1975 Chronology and Placement of "Guadalupe" Tools. La Tierra 2(2):22-25.

Highley, C.L.

1986 Archaeological Investigations at 41LK201, Choke Canyon Reservoir, Southern Texas. Choke Canyon Series, No. 11. Center for Archaeological Research, The University of Texas at San Antonio.

Hill, K., and K. Hawkes

1983 Neotropical Hunting among the Ache of Eastern Paraguay. In Adaptive Responses of Native Amazonians, edited by R.B. Hames and W.T. Vickers, pp. 139-188. Academic Press, New York.

Hill, R.T., and T.W. Vaughn

1988 Geology of the Edwards Plateau and Rio Grande Plain adjacent to Austin and San Antonio, Texas, with reference to the Occurrence of Underground Waters. United States Department of the Interior, Geological Survey Annual Report 18, Part 2, pp. 193-321. Washington, D.C.

Houk, B.A., and J.C. Lohse

1993 Archaeological Investigations at the Mingo Site, Bandera County, Texas. Bulletin of the Texas Archeological Society 61:193-247.

Hudler, D., K. Prilliman, and T. Gustavson

2002 The Smith Creek Bridge Site (41DW270): A Terrace Site in De Witt County, Texas. Studies in Archeology 35. Texas Archeological Research Laboratory, University of Texas at Austin. Archeology Studies Program, Report No. 17. Environmental Affairs Division, Texas Department of Transportation, Austin.

Hudson, W.R., W.M. Lynn, and D.S. Scurlock

1974 Walker Ranch: An Archaeological Reconnaissance and Excavation in North Bexar County, Texas. Office of the State Archeologist, Report 26. Texas Historical Commission, Austin. 
Huebner, J.A.

1991 Late Prehistoric Bison Populations in Central and Southern Texas. Plains Anthropologist 36: 343-358.

Hurt, R.D.

1980 Archeological Investigations of Portions of the Middle Concho Valley. Unpublished Master's thesis, Texas Tech University, Lubbock.

Ingles, L.G.

1952 Ecology of the Mountain Pocket Gopher, Thomomys monticola. Ecology 33:87-95.

Inglis, J.M., R.E. Hood, B.A. Brown, and C.A. DeYoung

1979 Home Range of White-Tailed Deer in Texas Coastal Prairie Brushland. Journal of Mammalogy 60:377-389.

Jochim, M.

1975 Hunter-gatherer subsistence and settlement: A predictive model. Academic Press, New York.

Johnson, J.K.

1979 Archaic Biface Manufacture: Production Failures, a Chronicle of the Misbegotten. Lithic Technology 8(2):25-35.

1981 Further Additional Biface Production Failures. Lithic Technology 10(20):26-28.

Johnson, L., Jr.

1962 The Archeology of the Devil's Mouth Site, Amistad Reservoir. Manuscript on file, Center for Archaeological Research, The University of Texas at San Antonio.

1995 Past Cultures and Climates at Jonas Terrace, 41ME29, Medina County, Texas. Office of the State Archeologist, Report 40. Texas Department of Transportation and Texas Historical Commission, Austin.

Johnson, L., and G. Goode

1994 A New Try at Dating and Characterizing Holocene Climates, as well as Archaeological Periods, on the Eastern Edwards Plateau. Bulletin of the Texas Archaeological Society 65:1-15.

Jones, C.J., J.W. Kunert, and P.M. Foster

1979 Analysis of Debitage Material Recovered from 1979 Summer Field School Excavation of 41 BX271 (Granberg II). Manuscript on file, Center for Archaeological Research, The University of Texas at San Antonio.

Jones, K.T., and D.B. Madsen

1989 Calculating the Cost of Resource Transportation: A Great Basin Example. Current Anthropology 30:529-534.

Kaplan, K.H., and K. Hill

1992 The Evolutionary Ecology of Food Acquisition. In Evolutionary Ecology and Human Behavior, edited by E.A. Smith and B. Winterhalder, pp. 167-201. Aldine de Gruyter, New York.

Katz, P.R.

1987 Archaeological Mitigation at 41BX300, Salado Creek Watershed, South-Central Texas. Archaeological Survey Report, No. 130. Center for Archaeological Research, The University of Texas at San Antonio.

Keene, A.S.

1981 Optimal Foraging in a Nonmarginal Environment: A Model of Prehistoric Subsistence Strategies in Michigan. In Hunter-Gatherer Foraging Strategies: Ethnographic and Archeological Analyses, edited by B. Winterhalder and E.A. Smith, pp. 171-193. The University of Chicago Press, Chicago. 
Kelly, R.L.

1995 The Foraging Spectrum. Smithsonian Institution Press, Washington, D.C.

Kelly, T.C.

1975 Flake Analysis 41BX271. Manuscript on file, Center for Archaeological Research, The University of Texas at San Antonio.

Kemp, L., and B.K. Moses

2008 An Archaeological Survey of the South Salado Creek Greenway, San Antonio, Bexar County, Texas: Rigsby Avenue to Southside Lion's Park East. Archaeological Report, No. 381. Center for Archaeological Research, The University of Texas at San Antonio.

Kemp, L., C. Munoz, R.P. Mauldin, D. Paul, and G. Skrzypek

2008 Appropriate Scales and Bunny Tales: Using Small Herbivores from Archaeological Sites in Ecological Reconstruction. Paper presented at the 2008 Meetings of the Texas Academy of Sciences, Corpus Christi.

Kibler, K.W., and K.M. Gardner

1997 Archeological Survey and National Register Testing at 41BX377, Camp Bullis Military Reservation, Bexar and Comal Counties, Texas. Reports of Investigations, No. 101. Prewitt and Associates, Inc. Austin.

Kibler, K.W., and A.M. Scott

2000 Archaic Hunters and Gatherers of the Balcones Canyonlands: Data Recovery at the Cibolo Crossing Site (41BX377), Camp Bullis Military Reservation, Bexar County, Texas. Reports of Investigations, No. 126. Prewitt and Associates, Inc., Austin.

Kintigh, K.W.

1989 Sample Size, Significance, and Measures of Diversity. In Quantifying Diversity in Archaeology, edited by R.D. Leonard and G.T. Jones, pp. 25-36. Cambridge University Press, New York.

Kroll, J.C.

1991 Producing and Harvesting Quality White-tailed Deer. Center for Applied Studies in Forestry, Stephen F. Austin State University, Nacogdoches.

Labadie, J.H., M.B. Collins, R.A. Searles, and D.G. Steele

1988 Archaeological Excavations at the Shrew Site, 41WN73, Wilson County, Southern Texas. Contract Reports in Archaeology, No. 2. Texas State Department of Highways and Public Transportation, Austin.

Larson, M.L., and M. Kornfeld

1997 Chipped Stone Nodules: Theory, Method, and Examples. Lithic Technology 22(1):4-18.

Linsdale, J.M.

1946 The California Ground Squirrel. University of California Press, Berkeley.

Long, C.

2009 Handbook of Texas Online. Electronic document, http://www.tshaonline.org/handbook/online/articles/BB/hcb7.html, accessed February 2009.

Loy, T.

1994 Residue Analysis of Artifacts and Burned Rock from the Mustang Branch and Barton Sites (41HY209 and 41HY202). In Archaic and Late Prehistoric Human Ecology in the Middle Onion Creek Valley, Hays County, Texas, Vol. 2: Topical Studies, by R.A. Ricklis and M.B. Collins, pp. 607-627. Studies in Archeology 19. Texas Archeological Research Laboratory, University of Texas at Austin. 
Luke, C.J.

1980 Continuing Archaeology on State Highway 16: The Shep Site (41KR109) and the Wounded Eye Site (41KR107). Publications in Archaeology Report No. 16. Texas State Department of Highways and Public Transportation.

Lukowski, P.D.

1987 Archaeological Investigations Along the Leona River Watershed, Uvalde County, Texas. Archaeological Survey Report, No. 132. Center for Archaeological Research, The University of Texas at San Antonio.

1988 Archaeological Investigations at 41BX1, Bexar County, Texas. Archaeological Survey Report, No. 135. Center for Archaeological Research, The University of Texas at San Antonio.

Lyman, R.L.

1984 Bone Density and Differential Survivorship of Fossil Classes. Journal of Anthropological Archaeology 3:259-299.

1994 Vertebrate Taphonomy. Cambridge University Press, Cambridge.

MacArther, R.H., and E.R. Pianka

1966 On Optimal Use of a Patchy Environment. American Naturalist 100:603-609.

Mahoney, R.B., H.J. Shafer, S.A. Tomka, L.C. Nordt, and R.P. Mauldin

2003 Royal Coachman (41CM111): An Early Middle Archaic Site along Cordova Creek in Comal County, Texas. Archaeological Survey Report, No. 332. Center for Archaeological Research, The University of Texas at San Antonio. Archeological Studies Program, Report No. 49. Environmental Affairs Division. Texas Department of Transportation.

Mahoney, R.B., and S.A. Tomka

2001 National Register Eligibility Testing of 41 MM340 and 41MM341, along Little River, Milam County, Texas. Archaeological Survey Report, No. 303. Center for Archaeological Research, The University of Texas at San Antonio. Archeological Studies Program, Report No. 30. Environmental Affairs Division, Texas Department of Transportation, Austin.

Mahoney, R.B., S.A. Tomka, R.P. Mauldin, H.J. Shafer, L.C. Nordt, R.D. Greaves, and R.R. Galdeano

2003 Data Recovery Excavations at 41MM340: A Late Archaic Site along Little River in Milam County, Texas. Archaeological Survey Report, No. 340. Center for Archaeological Research, The University of Texas at San Antonio. Archeological Studies Program, Report No. 54. Environmental Affairs Division, Texas Department of Transportation, Austin.

Malainey, M.E.

2000 Analysis of Fatty Acid Compositions of Burned Rock Residues from site 41ZP364, Zapata County, Texas. In Data Recovery at 41ZP364: An Upland Campsite at Falcon Reservoir, Zapata County, Texas, by J.M. Quigg and C. Cordova, pp. 331-345. Technical Report, No. 22317. TRC Mariah Associates Inc., Austin.

Marchbanks, M.L.

1989 Lipid Analysis in Archaeology: An Initial Study of Ceramics and Subsistence at the George C. Davis Site. Unpublished Master's thesis, The University of Texas at Austin.

Markey, B.

1979 Granberg II: 41BX271. Manuscript on file, Center for Archaeological Research, The University of Texas at San Antonio.

Marks, S.A.

1976 Large Mammals and a Brave People, Subsistence Hunters in Zambia. University of Washington Press, Seattle. 
Martinez, V., S. Dial, P. Buttles, and M.B. Collins

1994 An Assessment of Documents and Collections from the Pavo Real Site (41BX52), Bexar County, Texas. Manuscript on file, Texas Archeological Research Laboratory, The University of Texas at Austin.

Mauldin, R.P., and L. Kemp

2005 An Initial Summary of Bison Presence/Absence Associated with Data Recovery at 41ZV202. Report on file, Center for Archaeological Research, The University of Texas at San Antonio.

Mauldin, R.P., D.L. Nickels, and C.J. Broehm

2003 Archaeological Testing to Determine the National Register Eligibility Status of 18 Prehistoric Sites on Camp Bowie, Brown County, Texas. Archaeological Survey Report, No. 334. 2 vols. Center for Archaeological Research, The University of Texas at San Antonio.

Mauldin, R.P., J. Thompson, C.M. Munoz, and L. Kemp

2009 Hunter-Gatherer Research Intensification and Changing Patterns of Fire-Cracked Rock Features in Central and South Texas. Poster Presented at 2009 Meetings of the Society of American Archaeologists, Atlanta, Georgia.

Mauldin, R.P., S.A. Tomka, and H.J. Shafer

2004 Millican Bench (41TV163): A Multicomponent Site in Travis County, Texas. Archaeological Survey Report, No. 351. Center for Archaeological Research, The University of Texas at San Antonio.

Mauldin, R.P., S.A. Tomka, and J. Thompson

2006 Research Design for Analysis of Testing and Data Recovery Materials from 41KM69, Kimble County, Texas. Report on file, Center for Archaeological Research, The University of Texas at San Antonio.

McDonald, J.N.

1981 North American Bison, Their Classification and Evolution. University of California Press, Berkeley.

McGraw, A.J., and F. Valdez

1977 A Preliminary Assessment of Archaeological Resources at Tobins Oakwell Farm, San Antonio, Texas. Archaeological Survey Report, No 43. Center for Archaeological Research, The University of Texas at San Antonio.

Meissner, B.A.

2000 Monitoring of Excavations for Construction of an Outdoor Classroom Facility at Walker Ranch Park (41BX1271), San Antonio, Texas. Letter Report, No. 127. Center for Archaeological Research, The University of Texas at San Antonio.

2006 Archaeological Testing for the Walker Ranch Park Bridge Project (41BX1271), San Antonio, Bexar County, Texas. Archaeological Report, No. 365. Center for Archaeological Research, The University of Texas at San Antonio.

Metcalfe, D., and K.R. Barlow

1992 A Model for Exploring the Optimal Tradeoff Between Field Processing and Transport. American Anthropologist 94:340-356.

Miller, R.S.

1964 Ecology and Distribution of Pocket Gophers (Geomyidae) in Colorado. Ecology 45:256-272.

Morgan, R.G.

1980 Bison Movement Patterns on the Canadian Plains: An Ecological Analysis. Plains Anthropologist 25(88):143-160. 
Munoz, C.M.

2008 An Intensive Pedestrian Archaeological Survey or the Salado Creek Greenway, Wetmore Avenue to Eisenhauer Road, San Antonio, Bexar County, Texas Phase I: N.E. Loop 410 to Eisenhauer Road. Technical Report, No. 8. Center for Archaeological Research, The University of Texas at San Antonio.

Munoz, C.M., L. Kemp, R.P. Mauldin, and R. Hard

2008 Is There Gold in Them Thar Hares? Using Small Herbivores from Archaeological Sites in Paleo-ecological Reconstruction. Poster Presented at the 79th Texas Archeological Society Annual Meeting, Lubbock.

Munoz, C.M., J.L. Thompson, and R.P. Mauldin

2007 Research Design for the Analysis of Archeological Materials Recovered from Significance Testing of the Granberg Site (41BX17), Bexar County, Texas. Report on file, Center for Archaeological Research, The University of Texas at San Antonio.

Munoz, C.M., L. Wack, K. Daiber, O. Short, and P. Villanueva

2009 Paleoecological Reconstruction Using Small Herbivore from Archaeological Sites. Paper Presented at the 2009 Meetings of the Texas Academy of Sciences, Junction.

Murray, D.F.

1967 Gravel Mounds at Rocky Flats, Colorado. Mountain Geologist 4:99-107.

Muto, G.R.

1971 A Technological Analysis of the Early Stages in the Manufacture of Lithic Artifacts. Unpublished Master's thesis. Idaho State University, Pocatello.

Nickels, D.L.

2000 The Beisenbach Site (41WN88): A Case Study in Diet Breadth. Unpublished Master's thesis. College of Liberal and Fine Arts. The University of Texas at San Antonio.

Nickels, D.L., C.B. Bousman, J.D. Leach, and D.A. Cargill

2001 Test Excavations at the Culebra Creek Site, 41BX126, Bexar County, Texas. Archaeological Survey Report, No. 265. Center for Archaeological Research, The University of Texas at San Antonio. Archeology Studies Program, Report 3. Environmental Affairs Division, Texas Department of Transportation, Austin.

Nickels, D.L., and R.P. Mauldin

2001 The Project Environment. In An Archaeological Survey of Twin Buttes Reservoir, Tom Green County, Texas, Vol. 1, by R.P. Mauldin and D.L. Nickels. Archaeological Survey Report, No. 300. Center for Archaeological Research, The University of Texas at San Antonio.

Nordt, L.C., T.W. Boutton, J.S. Jacob, and R. Mandel

$2002 \mathrm{C}_{4}$ Plant Productivity and Climate- $\mathrm{CO}_{2}$ Variations in South-Central Texas during the Late Quaternary. Quaternary Research 58(2):182-188.

Paruelo, J.M., and W.K. Lauenroth

1996 Relative Abundance of Plant Functional Types in Grasslands and Shrublands of North America. Ecological Applications 6(4):1212-1224.

Peden, D.G.

1976 Botanical Composition of Bison Diets on Shortgrass Plains. American Midland Naturalist 96(1):225-229.

Peden, D.G., G.M. Van Dyne, R.W. Rice, and R.M. Hansen

1974 The Trophic Ecology of Bison bison L. on Shortgrass Plains. The Journal of Applied Ecology 11(2):489-497. 
Peter, D.E., D. Prikryl, O. McCormick, and M.A. Demuynck

1982 Site Excavation Reports: Primary Contract. In Archaeological Investigations at the San Gabriel Reservoir Districts, Central Texas, edited by T.R. Hays, vol. 1, pp. 8-1-8-297. Institute of Applied Sciences, North Texas State University, Denton.

Potter, D.R.

1980 An Archaeological Assessment of 4BX197 and Vicinity, Walker Ranch National Register Historic District, San Antonio, Texas. Archaeological Survey Report, No. 91. Center for Archaeological Research, The University of Texas at San Antonio.

Potter, D.R., and S.L. Black

1995 Archeology along the Wurzbach Parkway, Module 2: Initial Testing and Evaluation of Five Prehistoric Sites in the Upper Salado Watershed, Bexar County, Texas. Studies in Archeology 18. Texas Archeological Research Laboratory, The University of Texas at Austin.

Potter, D.R., S.L. Black, and K. Jolly

1995 Archaeology Along the Wurzbach Parkway, Module 1: Introduction, Conceptual Framework and Contexts of Archaeological Investigations in Bexar County, South-Central Texas. Studies in Archeology. No. 17. Texas Archeological Research Laboratory, The University of Texas at Austin.

Prewitt, E.R.

1974 Archeological Investigations at the Loeve-Fox Site. Research Report 49. Texas Archeological Survey, The University of Texas at Austin.

1981 Culture Chronology in Central Texas. Bulletin of the Texas Archeological Society 52:65-89.

1982 Archeological Investigations at the Loeve-Fox, Loeve, and Tombstone Bluff Sites in the Granger Lake District of Central Texas. Denton Institute of Applied Sciences, The University of North Texas.

1985 From Circleville to Toyah: Comments on Central Texas Chronology. Bulletin of the Texas Archeological Society 54:201-238.

Quigg, J.M.

1997 The Sanders Site (41HF128) A Single Event Late Archaic Camp/Bison Processing Site Hansford County, Texas. Technical Report, No. 19751. TRC Mariah Associates Inc., Austin.

Quigg, J.M., S. Pritchard, and G. Smith

2002 The Boiler Site (41WB557): Utilization of an Upland Setting Over the Last 4200 Years, Webb County, Texas. Technical Report No. 27277. TRC Mariah Associates. Archeological Studies Program, Report, No. 45. Environmental Affairs Division, Texas Department of Transportation, Austin.

Ramsey, C.B.

2003 Oxcal Program Version 3.0. Radiocarbon Accelerator Unit, University of Oxford, Oxford.

Rauzi, F., and A.K. Dobrenz

1970 Seasonal Variation of Chlorophyll in Western Wheatgrass and Blue Grama. Journal of Range Management 23:372-373.

Ricklis, R.A., M.D. Blum, and M.B. Collins

1991 Archeological Testing at the Vara Daniel Site (41TV1364) Zilker Park, Austin, Texas. Studies in Archeology, No. 12. Texas Archeological Research Laboratory, The University of Texas at Austin. 
Robinson, D.G., S.C. Caran, D. Drake, L.S. Cummings, and J. Turpin

1995 Upland Sites in the Middle Nueces Zone: Testing in the San Miguel Mine, Atascosa County, Texas. Archeological Report, No. 1. Borderlands Archeological Research Unit, The University of Texas at Austin.

Robinson, R.L.

1982 Biosilica Analysis of Three Prehistoric Archaeological Sites in the Choke Canyon Reservoir, Live Oak County, Texas: Preliminary Summary of Climatic Implications. In Archaeological Investigations at Choke Canyon Reservoir, South Texas: The Phase I Findings, by G.D. Hall, S.L. Black, and C. Graves. Choke Canyon Series, Vol. 5. Center for Archaeological Research, The University of Texas at San Antonio.

1985 Preliminary Biosilica Analysis of the Panther Springs Creek Site, 41BX228, Bexar County, Texas, Appendix I in The Panther Springs Creek Site: Cultural Change and Continuity within the Upper Salado Creek Watershed, SouthCentral Texas, edited by S.L. Black and A.J. McGraw. Center for Archaeological Research, The University of Texas at San Antonio. Archaeological Survey Report, No. 100.

Roe, F.G.

1951 The North American Buffalo: A Critical Study of the Species in Its Wild State. University of Toronto Press, Toronto.

Sala, O.E., and W.K. Lauenroth

1982 Small Rainfall Events: an Ecological Role in Semiarid Regions. Oecologia 53:301-314.

Scheffer, T.H.

1931 Habits and Economic Status of the Pocket Gophers. USDA Technical Bulletin 224.

Schiffer, M.B.

1975 The Effects of Occupation Span on Site Content. In The Cache River Project, edited by M. Schiffer and J. House, pp. 265-269. Arkansas Archaeological Survey, Fayetteville.

Schuetz, M.K.

1966 The Granberg Site: An Archaic Indian Habitation in Bexar County, Texas. Witte Museum Studies, No. 1. San Antonio, Texas.

Scott, R.F., and D.E. Fox

1982 Excavations at Sites 41LK31/32 and 41LK202 in the Choke Canyon Reservoir, South Texas. Choke Canyon Series, No. 8. Center for Archaeological Research, The University of Texas at San Antonio.

Scurlock, D., and W.R. Hudson, Jr.

1973 An Archeological Investigation of Walker Ranch. Texas Historical Commission, Office of the State Archeologist, Special Report, No. 9.

Shott, M.J.

1989 Diversity, Organization, and Behavior in the Material Record: Ethnographic and Archaeological Examples. Current Anthropology 30:283-315.

Simms, S.

1987 Behavioral Ecology and Hunter-Gatherer Foraging: An Example from the Great Basin. British Archaeological Reports, International Series 381. Oxford.

Skibo, J.M.

1992 Pottery Function: A Use-Alteration Perspective. Plenum Press, New York. 
Slade, R.M., and J. Patton

2006a Major and Catastrophic Storms and Floods in Texas. USGS Open File Report 03-193. Electronic document, http://pubs.usgs.gov/of/2003/ofr03-193/cd_files/USGS_Storms/index.htm, accessed August 2006.

2006b Peak Streamflow for Salado Creek at Loop 410. USGS Open File Report 03-193. Electronic document, http://pubs.usgs.gov/of/2003/0fr03193/cd_files/USGS_Storms/USGS_maps_pages/peakdata/08178700.htm, accessed August 2006.

Smith, E.A., and B. Winterhalder

1992 Evolutionary Ecology and Human Behavior. Aldine De Gruyter, New York.

Soil Survey Staff

1997 Official Series Descriptions-Lewisville Series: Washington, D.C., United States Department of Agriculture, Natural Resources Conservation Service. Electronic document, http://soils.usda.gov/technical/classification/osd/index. html, accessed August 2006.

Southern Region Headquarters National Oceanic and Atmospheric Administration

2009 San Antonio Climate Records. Electronic document, http://www.srh.noaa.gov/ewx/html/cli/sat.satmonpcpn.htm, accessed February 2009.

Southern Regional Climate Center

2009 Climate Atlas. Electronic document, http://www.srcc.lsu.edu/southernClimate/atlas/climograph?id=41795, accessed February 2009.

Speth, J.D.

1983 Bison Kills and Bone Counts Decision Making by Ancient Hunters. Prehistoric Archeology and Ecology Series. University of Chicago Press, Chicago.

Speth, J.D., and K.A. Spielmann

1983 Energy Source, Protein Metabolism and Hunter-gatherer Subsistence Strategies. Journal of Anthropological Archaeology 2:1-31.

Stephens, D.W., and J.R. Krebs

1986 Foraging Theory. Princeton University Press, Princeton, New Jersey.

Steuter, A.A., and H.A. Wright.

1980 White-Tailed Deer Densities and Brush Cover on the Rio Grande Plain. Journal of Range Management 33(5):328-331.

Story, D. A.

1985 Adaptive Strategies of Archaic Cultures of the West Gulf Coastal Plain. In Prehistoric Food Production in North America, edited by R.I. Ford, pp. 19-56. Anthropological Papers No. 75. Museum of Anthropology, University of Michigan, Ann Arbor.

Taylor, R.

1996 The New Handbook of Texas in Six Volumes. The Texas State Historical Association, Austin.

Taylor, A.J., and C.L. Highley

1995 Archaeological Investigations at the Loma Sandia Site (41LK28): A Prehistoric Campsite in Live Oak County, Texas. 2 vols. Studies in Archeology, No. 20. Texas Archeological Research Laboratory, The University of Texas at Austin. 
Taylor, F.B., R.B. Hailey, and D.L. Richmond

1962 Soil Survey of Bexar County, Texas. United States Department of Agriculture, Soil Conservation Service. Washington, D.C.

1991 Soil Survey of Bexar County, Texas. United States Department of Agriculture, Soil Conservation Service. Washington, D.C.

Teeri, J.A., and L.G. Stowe

1976 Climatic Patterns and the Distribution of $\mathrm{C}_{4}$ Grasses in North America. Oecologia 23:1-12.

Tennis, C.L., R.J. Hard, C.B. Bousman, L.C. Nordt, and W. Gose

1996 Archaic Land Use of Upper Leon Creek Terraces: Archaeological Testing in Northern Bexar County, Texas. Archaeological Survey Report, No. 234. Center for Archaeological Research, The University of Texas at San Antonio.

Texas Handbook Online (THO)

Electronic document, http://www.tsha.utexas.edu/handbook/online/articles/SS/bbs1.html, accessed May 2007.

Texas Historical Commission (THC)

2008 Texas Archeological Site Atlas. Electronic document, http://www.nueces.thc.state.tx.us/, accessed March 2008.

2009 Texas Archeological Site Atlas. Electronic document, http://www.nueces.thc.state.tx.us/, accessed February 2009.

Texas Parks and Wildlife Department (TPWD)

1984 TPWD GIS Data. On file, Center for Archaeological Research, The University of Texas at San Antonio.

2007 Electronic document, http://www.tpwd.state.tx.us/huntwild/huntwild/hunt/planning/rut_whitetailed_deer/, The Rut in White-tailed Deer, accessed February, 2007.

2009 The Vegetation Types of Texas. Electronic document, http://www.tpwd.state.tx.us/publications/pwdpubs/pwd_bn_w7000_120/, accessed February 2009.

Thomas, D.H.

1983 The Archaeology of Monitor Valley: 2. Gatecliff Shelter. Anthropological Papers Vol. 59, Pt. 1. American Museum of Natural History, New York.

1989 Diversity in Hunter-Gatherer Cultural Geography. In Quantifying Diversity in Archaeology, edited by R. D. Leonard and G. T. Jones, pp. 85-91. Cambridge University Press, Cambridge.

Thomas, D.H., and R.L. Kelly.

2006 Archaeology. 4th ed. Thomson Wadsworth, California.

Thompson, J.L.

2006a Data Recovery at KM69, Flatrock Road Site in Junction, Kimble County, Texas. Manuscript on file, Center for Archaeological Research, The University of Texas at San Antonio.

2006b National Register of Historic Places/State Archeological Landmark Eligibility Testing of the Granberg Site (41BX17). Manuscript on file, Center for Archaeological Research, The University of Texas at San Antonio.

Thompson, J.L., R.P. Mauldin, and C.M. Munoz

2008 Assessing Hearth Reuse Frequency through Patterning in Burned Rock Size. Presentation for the $79^{\text {th }}$ Annual Texas Archaeological Society Meetings, Lubbock, Texas 
Thoms, A.

2008 Learning from Cabeza de Vaca. Electronic document, http://www.texasbeyondhistory.net/cabeza-cooking/index.html, accessed April 10, 2008.

Thoms, A.V., and R.D. Mandel

2007 Archaeological and Paleoecological Investigations at the Richard Beene Site, South-Central Texas. Reports of Investigations 8. Center for Ecological Archaeology, Texas A\&M University.

Tilman, D.

1982 Resource Competition and Community Structure. Princeton University Press, Princeton.

1988 Plant Strategies and the Dynamics of Structure of Plant Communities. Princeton University Press, Princeton.

1994 Competition and Biodiversity in Spatially Structured Habitats. Ecology 75(1):2-16.

Tomka, S.A.

1986 Biface Manufacture Failures. Manuscript on file, Texas Archeological Research Laboratory, The University of Texas at Austin.

1998 An Archaeological Survey of Walker Ranch Park, Bexar County, Texas. Archaeological Survey Report, No. 282. Center for Archaeological Research, The University of Texas at San Antonio.

2001 The Effect of Processing Requirements on Reduction Strategies and Tool Form: A New Perspective. In Lithic Debitage Context, Form and Meaning, edited by W. Andrefsky, Jr., pp. 207-223. The University of Utah Press, Salt Lake City.

Tomka, S.A., and R.P. Mauldin

2003 Paleoenvironmental Reconstruction. In Data Recovery Excavations at 41 MM340 A Late Archaic Site along Little River in Milam County, Texas, by R.B. Mahoney and S.A. Tomka, pp. 95-108. Archaeological Survey Report, No. 340. Environmental Affairs Division, Texas Department of Transportation, Austin.

Tomka, S.A., R.P. Mauldin, and R.D. Greaves

2004a Research Design for Analysis of Testing and Data Recovery Materials from 41ZV202, Zavala County, Texas. Report on file, Center for Archaeological Research, The University of Texas at San Antonio.

2004b Late Prehistoric and Late Archaic Subsistence Practices A Comparative Analysis. In Millican Bench (41TV163) A Multicomponent Site in Travis County, Texas, by R.P. Mauldin, S.A. Tomka, and H.J. Shafer, pp. 69-79. Archaeological Survey Report, No. 351. Center for Archaeological Research, The University of Texas at San Antonio. Archeological Studies Program, Report No. 66. Environmental Affairs Division, Texas Department of Transportation, Austin.

Tomka, S.A., H.J. Shafer, and R.P. Mauldin

2003 Lithic Technology at 41MM340. In Data Recovery Excavations at 41 MM340 A Late Archaic Site along Little River in Milam County, Texas, by R.B. Mahoney and S.A. Tomka, pp. 133-154. Archaeological Survey Report, No. 340. Environmental Affairs Division, Texas Department of Transportation, Austin.

Toomey, R.S.

1993 Late Pleistocene and Holocene Faunal Environmental Changes at Hall's Cave, Kerr County, Texas. Ph.D. dissertation, The University of Texas at Austin. University Microfilms, Ann Arbor.

Toomey, R.S., M.D. Blum, and S. Valastro, Jr.

1993 Late Quaternary Climates and Environments of the Edwards Plateau, Texas. Global and Planetary Change 7:299-320. 
Torrence, R.

1989 Retooling: Towards a Behavioral Theory of Stone Tools. In Time, Energy, and Stone Tools, edited by R. Torrence, pp. 57-66. Cambridge University Press, Cambridge.

Treece, A.C., C. Lintz, W.N. Trierweiler, J.M. Quigg, and K.A. Miller

1993 Cultural Resource Investigations in the O.H. Ivie Reservoir, Concho, Coleman, and Runnels Counties, Texas: Volume IV: Data Recovery from Ceramic Sites. Technical Report No. 346-IV. Mariah Associates, Austin.

Tringham, R., G. Cooper, G. Odell, R. Voytek, and A. Whitman

1974 Experimentation in the Formation of Edge Damage: A New Approach to Lithic Analysis. Journal of Field Archaeology 1:171-196.

Turgeon, D.D., J.F. Quinn, Jr., A.E. Bogan, E.V. Coan, F.G. Hochberg, W.G. Lyons, P.M. Mikkelsen, R.J. Neves, C.F.E. Roper, G. Rosenberg, B. Roth, A. Scheltema, F.G. Thompson, M. Vecchione, and J.D. Williams

1998 Common and Scientific Names of Aquatic Invertebrates from the United States and Canada: Mollusks. 2nd ed. American Fisheries Society Special Publication 26. Bethesda, Maryland.

Turner, S.E. and T.R. Hester

1993 A Field Guide to Stone Artifacts of Texas Indians. 2nd ed. Gulf Publishing, Houston.

1999 A Field Guide to Stone Artifacts of Texas Indians. 3rd ed. Gulf Publishing, Houston.

Vines, R.A.

1960 Trees, Shrubs, and Woody Vines of the Southwest. University of Texas Press, Austin.

Watt, F.H.

1978 Radiocarbon Chronology of Sites in the Central Brazos Valley. Bulletin of the Texas Archeological Society 49:111-138.

Wade, M.

1998 The Native Americans of the Texas Edwards Plateau and Related Area, 1582-1799. Unpublished Ph.D. dissertation, The University of Texas at Austin.

Wandsnider, L.

1997 The Roasted and the Boiled: Food Consumption and Heat Treatment with Special Emphasis on Pit-Hearth Cooking. Journal of Anthropological Archaeology 16:1-48.

Waters, M.R.

1992 Principles of Geoarchaeology. The University of Arizona Press, Tucson.

Webb, S.L

2005 Home Range, Mortality, and Water Use of Mature Male White-Tailed Deer in South Texas. UMI Dissertation Services, Texas A\&M University-Kingsville.

Weir, F.A.

1976 The Central Texas Archaic. Unpublished Ph.D. dissertation. Anthropology Department, Washington State University.

Wesolowsky, A.B., T.R. Hester, and D.R. Brown

1976 Archeological Investigations at the Jetta Court Site (41TV151) Travis County, Texas. Bulletin of the Texas Archeological Society 47:25-87. 
Weston, J.D., and R. Greaves

2003 Archaeological Survey and Geoarchaeological Investigations at 41BX1271, Walker Ranch Park, Bexar County, Texas. Archaeological Survey Report, No. 337. Center for Archaeological Research, The University of Texas at San Antonio.

Weston, J.D., B.K. Moses, R.D. Greaves, B.A. Meissner, and R.B. Mahoney

2004 Archaeological Survey of the Proposed Salado Creek Hike and Bike Trail, City of San Antonio, Bexar County, Texas. Archaeological Survey Report, No. 338. Center for Archaeological Research, The University of Texas at San Antonio.

White, J.R.

1980 A Closer Look at Clusters. American Antiquity 45(1):66-74.

Wilder, M.C., J.K. McWilliams, K.W. Kibler, and M.D. Freeman

2003 Cultural Resources Survey of 4423 Acres and National Register Testing at Five Prehistoric Site, Camp Bullis Military Reservation, Bexar and Comal Counties, Texas. Reports of Investigation No. 135. Submitted to the U.S. Army Corps of Engineers by Prewitt and Associates, Inc., Austin.

Wilkins, K.T.

1989 Burrowing Vertebrates and Their Role in Archaeological Site Decay. In Interdisciplinary Workshop on the PhysicalChemical-Biological Processes Affecting Archeological Sites, edited by C.C. Mathewson, pp. 195-217. Contract Report EL-89-1. U.S. Army Corps of Engineers, Waterways Experiment Station, Vicksburg, Miss.

Windberg, L.A.

1997 Annual Fruit Production of Pricklypear (Opuntia engelmanni) and Mesquite (Prosopis glandulosa) in Southern Texas. Texas Journal of Science 49(1):65-72.

Winsborough, B.

2001 Diatom Paleoenvironmental Analysis of Sediments. In National Register Eligibility Testing of 41 MM340 and 41MM341, along Little River, Milam County, Texas, by R.B. Mahoney and S.A. Tomka, pp. 114-117. Archaeological Survey Report, No. 303. Center for Archaeological Research, The University of Texas at San Antonio. Environmental Affairs Division, Archeological Studies Program, Report No. 30. Texas Department of Transportation, Austin.

Winterhalder, B.

1981 Optimal Foraging Strategies and Hunter-Gatherer Research in Anthropology: Theory and Models. In HunterGatherer Foraging Strategies: Ethnographic and Archaeological Analyses, edited by B. Winterhalder and E.A. Smith, pp. 13-35. The University of Chicago Press, Chicago.

Yellen, J.

1977 Archaeological Approaches to the Present. Academic Press, New York.

Yesner, D.R.

1981 Archeological Applications of Optimal Foraging Theory: Harvest Strategies of Aleut Hunter-Gatherers. In HunterGatherer Foraging Strategies: Ethnographic and Archeological Analyses, edited by B. Winterhalder and E.A. Smith, pp. 148-170. The University of Chicago Press, Chicago. 

Appendix A:

Land Snails of the Granberg Site (41BX17), Bexar

County, Texas: The Paleoenvironmental History

Manuel R. Palacios-Fest 



\title{
Appendix A
}

\section{Land Snails of the Granberg Site (41BX17), Bexar County, Texas: The Paleoenvironmental History}

\author{
Manuel R. Palacios-Fest \\ Terra Nostra Earth Sciences Research, \\ P.O. Box 37195 Tuscon, AZ 85740-7195 \\ TNESR Report No. 0708
}

\begin{abstract}
Land snails constitute a valuable source of paleoenvironmental information from archeological sites. The use of these organisms from archeological sites is, frequently, focused on their value as anthropogenic subsistence. Granberg Site $41 \mathrm{BX} 17$ offers the unique opportunity to expand our knowledge on land snails as paleoenvironmental indicators in an archeological context. The site, located in northeastern San Antonio, Texas contains a rich and diverse gastropod fauna consisting of nine species and more than 1000 individuals. Often times, species replacement is accompanied by a significant overriding of one species over the rest. This paper documents the environmental history of this archeological site and offers an explanation about the possible origin of the malacofauna (natural or aboriginal subsistence).
\end{abstract}

\section{Introduction}

Land snails, a common feature of archeological sites, have been used as indicators of the environmental conditions that prevailed in the region at the time of accumulation of the shells. These organisms, however, can also reflect human subsistence habits. Recognizing one signature from the other is of paramount relevance for identifying the effects of human adaptation on native species or otherwise the magnitude of change imposed by the environment. Faunal density and diversity are two of the most important parameters in recognizing the human from the natural signatures (Malof 2007). Malof summarizes the current literature on snails in archeological sites in Texas. Among the many authors cited by Malof, two are discussed in this study because of their particular relevance to paleoenvironmental reconstructions in archeological contexts: Allen and Cheatum (1960) and Goodfriend (1992). By no means, this selective selection represents all the points of view on the issue, but they are appropriate for the purpose of this study described later in this section.

Allen and Cheatum (1960) and Goodfriend (1992) conducted some of the most relevant research studies on the implications of the ecological characteristics of fresh-water and land snails for reconstructing past environments related to human activity. Allen and Cheatum (1960), for example, highlighted the value of ethnoconchology focusing on the identification of mollusk remains from the natural environment or shell artifacts as aids in interpreting the environment in which they existed. In their study, these authors concentrate on the ecological implications of mollusks as indicators of climate change, as there is difference in the ecological requirements of each individual species. They propose that natural associations, consisting of an array of adult and juvenile forms, are distinguished from the selectively humanly gathered populations of mostly adults. This approach must be a starting point for the paleoenvironmental reconstruction of Granberg Site (41BX17) at Bexar County, Texas.

Goodfriend (1992) used land snails for reconstructing Quaternary paleoenvironments by means of several methods. First, he dated the events using radiocarbon dating, amino-acid racemization and epimerization, and suggested the use of the $\mathrm{Th} / \mathrm{U}$ series. Once the age of the stratigraphic units have been established he proposed to examine the faunal composition of the assemblages for identifying paleoenvironmental characteristics such as biome, temperature, and moisture conditions. Stable isotope analysis and amino-acid epimerization are two powerful tools for reconstructing paleotemperatures.

The reconstruction of climate change is often extrapolated from patterns of occurrence and abundance of certain snail species. As many other biologic groups, snails are sensitive to and selective of the environment where they settle and grow. In this 
sense, gastropods may indicate the particular characteristics of the habitat. For example, some species prefer moist deeply wooded forests suggesting a mesic environment (e.g., Strobilops texasiana, Helicodiscus parallelus, Hawaiia minuscule, and Gastrocopta contracta); other species favor open grassy areas to sparsely wooded areas (e.g., Rabdotus dealbatus dealbatus, Polygyra mooreana, Helicina orbiculata tropica, Gastrocopta pellucida hordeacella, and Zonitoides arboreus). Some other prefer moss-rich to moist forest soils to shallow riffle streams (e.g., Carychium mexicanum and Lampsilis teres). Sometimes, however, the paleoenvironmental signature may be biased by human selection. Species like Rabdotus dealbatus dealbatus or Helicina orbiculata tropica may have been consumed by indigenous people. Recognition of natural from anthropogenic assemblages is crucial for an accurate paleoenvironmental reconstruction.

The Granberg Site 41BX17, a multi-component site in northeastern San Antonio, Bexar County, Texas, offers a unique opportunity to analyze the land snail composition using routine paleontological and paleoecological procedures for reconstructing the environments that prevailed in the region at the time of prehistoric occupation. Previous archeological investigations at Granberg Site 41BX17 are summarized in Córdova et al. (2005). The Granberg Site has a history of unexpected discoveries during construction projets that have prompted archeological investigation. For example, in 1962 the City of San Antonio did a salvage effort to mitigate the impacts of road construction after discovery of human remains (Munoz et al. 2007). A similar situation occurred in 1973 during construction of the city's utility facilities. It was not until 1979 that planned excavations took place in Granberg Site but in 1980 another unexpected discovery was made during new road construction. The Center for Archaeological Research (CAR) of the University of Texas at San Antonio initiated in 2006 the latest professional excavations of the site. For details on previous studies the reader is recommended to consult Munoz et al. (2007).

Based upon previous research, the present study is focused on the paleoenvironmental reconstruction of the Granberg Site using the criteria of Allen and Cheatum (1960) and Goodfriend (1992). It is the purpose of this study to address the project's two main questions: (1) What were the paleoenvironmental conditions during the Middle and Late Archaic occupations of 41BX17? (2) Is there evidence of climate change that is consistent, or inconsistent, with the proposed increase in grassland suggested by pollen and carbon isotopes? This work will focus on identifying and quantifying the land snail populations for recognizing changes in the environment using the faunal diversity and population structure to distinguish natural from anthropogenic assemblages.

\section{Area of Study}

The Granberg Site 41BX17 is located along the east bank of Salado Creek. The eastbound lanes of Loop 410 and its access roads intersect the site (Figure 1 of Munoz et al. 2007). The site is a portion of a much larger prehistoric site that includes a separately recorded site located immediately south (41BX271). Since the early 1960s the site has undergone testing studies, including those of Harvey Kohnitz (Córdova et al. 2005; Schuetz 1966; Hester and Kohnitz in 1973-1974; Hester in 1980, 1984, and 1995). More recently, Córdova et al. (2005), Thompson (2006b), and Munoz et al. (2007) studied the site finding that it probably extends for an unknown distance southward and beyond the fence line into property recently purchased by the City of San Antonio. Prehistoric occupation started about 4000 BC and extended to about AD 1200, as shown by projectile types uncovered from these earlier excavations (Córdova et al. 2005; Schuetz 1966; Thompson 2006b).

Munoz et al. (2007) initiated a new phase of testing analysis to determine the extent and nature of archeological deposits that may be impacted by the construction of the road improvements of Loop 410. Preliminary testing demonstrated the presence of Middle to Late Archaic deposits in the right-of-way (ROW). In addition to archeological artifacts and features, Munoz et al.'s study recovered ethnobotanical and faunal remains, of which mollusks are the matter of this report.

\section{Materials and Methods}

Twenty bags containing mollusk shells from the same number of $1 / 4$ inch screen samples collected from Test Units (TU) 3,5 , and 6 were sent to Terra Nostra Earth Sciences Research in Tucson, Arizona for identification, quantification, and paleoecological analysis. In general, two sets of bags per sample were shipped for analysis, large and small screen fractions; each containing often times different snail species. The specimens were, when possible, identified to the species level. Diversity, total and relative abundance, and population maturity (a ratio of adult/juvenile shells) were recorded for reconstructing the paleoenvironmental 
history of the site. However, because at least one species (Rabdotus dealbatus dealbatus Say, 1821) was probably used as a food source, an effort for identifying natural from anthropogenic conditions will be assessed in the Interpretation section of this report. The snail population per sample was calculated by dividing the number of specimens by the sample volume (in liters, L). This number produced an estimate of the number of organisms per liter of soil that will be used in the Interpretation section for the paleoenvironmental reconstruction of the site.

Taphonomic parameters, like fragmentation, abrasion, and encrustation, as well as the maturity ratios per species were recorded for inferring the living and burial conditions of the shells. For example, high degree of fragmentation and/or abrasion is interpreted as an indicator of transport (Adams et al. 2002), whereas increasing mineral overgrowth on the shells indicates excess salt concentration in the soils favoring the adherence of "exotic" minerals to the shells after burial (Adams et al. 2002). The maturity ration was used for identifying a biocenosis (life assemblage) from a tanathocenosis (dead assemblage). That is, faunal assemblages consisting of a suite of adults and juvenile shells more frequently represent a local, living population (Whatley 1983). By contrast, a tanathocenosis is generally skewed by one of the size groups, either heavily or exclusively dominated by adults or juveniles. This type of assemblages usually suggests the population was not local but either transported (if naturally) or selectively gathered (if by human activity).

Based upon the criteria defined in this section land snails were identified and analyzed for reconstructing the environmental history of Granberg Site 41BX17.

\section{Results}

\section{Species Identification}

In all 5,236 snail were assigned to seven land species and two aquatic or riparian species from Granberg Site. The terrestrial species were: Rabdotus dealbatus dealbatus (Say, 1821), Helicina orbiculata tropica (Say), Polygyra mooreana (Binney), Helicodiscus parallelus (Say), Pupoides albilabris (Adams 1841), Haplotrema concavum (Say 1821), Gastrocopta cristata (Pilsbry and Vanatta, 1900). The aquatic or riparian species were: Succinea luteola Gould, 1848, and Planorbella trivolvis intertexta (Sowerby, 1878). Table A-1 shows the ecological requirements of the species recovered from the site. The table shows the species identification, family to which it belongs, and the general and specific environmental conditions the species prefers.

Table A-2 shows the total and relative abundance of the species identified, as well as the population maturity of each species. The latter is keen for recognizing natural from anthropogenic environments. The land snail population ranged from extremely rare to extremely abundant ${ }^{1^{*}}$. TU-5/6 consisted of 17 samples, two of which (6 and 20) were collected from TU-6 in a stratigraphic sequence matching that of TU-5, therefore, the data were merged for the site's paleoenvironmental reconstruction. The stratigraphic sequence at TU-5/6 yields radiocarbon dates between the Middle Archaic (4830-4520 BP) and Late Archaic (4290-4080 BP to 2010-1860 BP; Figure A-1).

All nine-land snail species were identified at TU-5/6, including the aquatic and/or riparian species S. luteola and P. trivolvis intertexta. H. orbiculata tropica $(>29<65 \%)$ was the most common and abundant species in two anthropogenic horizons (features 100 and 101), followed by $R$. dealbatus dealbatus $(>10<30 \%)$ and P. mooreana $(>3<60 \%)$. However, abundance declined significantly in natural horizons. G. cristata, H. parallelus, and P. albilabris $(>0.5<20 \%)$ occurred throughout the stratigraphic column in low concentrations. The aquatic or riparian species occurred once each at different intervals. $S$. luteola was identified in TU-6, sample $20(160 \mathrm{~cm} \mathrm{bd})$; whereas $P$. trivolvis intertexta was found in TU-5, sample 8 (45 cm bd) associated with an anthropogenic horizon (feature 101).

TU-3 consisted of three samples containing all seven terrestrial species at least in one interval. Late Archaic period radiocarbon dates (3980-3820 BP to 2740-2450 BP) were obtained for this sequence. Mollusks, however, were recovered from only three intervals between 40 and $70 \mathrm{~cm}$ below datum (bd). The dominant species in this unit was H. orbiculata tropica $(>54 \%)$, followed by $H$. concavum $(>16<28 \%)$, and $R$. dealbatus dealbatus $(>9<25 \%)$. P. mooreana, although present in all samples, occurred in low proportions $(<4 \%)$. Other species (G. cristata, H. parallelus, and P. albilabris) randomly occurred in TU-3 (Figure A-2).

$1 \quad$ *Abundance explanation: extremely abundant $(>501)$, very abundant $(>101<500)$, abundant $(>51<100)$, common $(>21<50)$, rare $(>11<20)$, very rare $(>6<10)$, and extremely rare $(<5)$. 
Table A-1. Ecological Requirements of Mollusc Species Identified from 41BX17, Bexar County, Texas

\begin{tabular}{|c|c|c|c|}
\hline Species & Family & Environment & Habitat \\
\hline Rabdotus dealbatus dealbatus (Say 1821) & Bulimulidae & Terrestrial & Semi-arid open country ("prairie snail") ${ }^{1}$ \\
\hline Helicina orbiculata tropica (Say) & Helicinidae & Terrestrial & $\begin{array}{l}\text { Upland woodlands, with deep layers of leaf litter } \\
\text { and fallen timber on the ground, and calcareous } \\
\text { soils }{ }^{2}\end{array}$ \\
\hline Polygyra mooreana (Binney) & Polygyridae & Terrestrial & Woodland and prairie ${ }^{3}$ \\
\hline Helicodiscus parallelus (Say) & Helicodiscidae & Terrestrial & $\begin{array}{l}\text { Swamp forests or fens, surface maybe rich in } \\
\text { bryophytes, moss, and herbs }{ }^{4}\end{array}$ \\
\hline Pupoides albilabris (Adams 1841) & Pupillidae & Terrestrial & Bare ground ${ }^{3}$ \\
\hline Haplotrema concavum (Say 1821) & Haplotrematidae & Terrestrial & Temperate forest ${ }^{5}$ \\
\hline Gastrocopta cristata (Pilsbry and Vanatta 1900) & Pupillidae & Terrestrial & $\begin{array}{l}\text { Moist soils under logs or stones on wooded slopes } \\
\text { and poorly drained floodplains and among grass on } \\
\text { open slopes }\end{array}$ \\
\hline Succinea luteola (Gould, 1848) & Succineidae & Riparian & $\begin{array}{l}\text { Moist soils near ponds, swamps, and streams, often } \\
\text { among trees or shrubs }\end{array}$ \\
\hline Planorbella trivolis intertexta (Sowerby 1878) & Planorbidae & $\begin{array}{l}\text { Aquatic or } \\
\text { moist soil }\end{array}$ & $\begin{array}{c}\text { Shallow stagnant water, swampy shores, in } \\
\text { marshes, or in stagnant pools, with mud or fine } \\
\text { sandy-silt bottoms }{ }^{6}\end{array}$ \\
\hline
\end{tabular}

\footnotetext{
${ }^{1}$ Allen and Cheatum (1960)

${ }^{2}$ Waggoner et al. (2006)

${ }^{3}$ Malof (2007)

${ }^{4}$ Nekola (2002)

${ }^{5}$ Hotopp (2006)

${ }^{6}$ Zimmerman (1960)
}

Low fragmentation $(<10 \%)$, low abrasion $(<5 \%)$, discolored shells, and a suite of adults and juveniles characterized the fauna. In features 100 and $101 \mathrm{H}$. orbiculata tropica, however, consisted of an adult-only population. $R$. dealbatus dealbatus, a common food resource for prehistoric and historic Native-Americans, consisted of a $30 \%$ adults in the same intervals. No evidence of encrustation was recorded on the shells.

\section{Interpretation}

Munoz et al. (2007) documented the current vegetation records in the vicinity of the Granberg Site. Four locations around the site show evidence of increasing grassland towards the Middle Archaic. For example, the Medina River in southern Bexar County (Nordt et al. 2002), shows a gradual increase in grassland $\left(\mathrm{C}_{4}\right)$ vegetation at the late Middle Archaic that remained high throughout the Late Archaic. At Hall's Cave in Kerr County (Cooke 2005), about $100 \mathrm{~km}$ northwest of the site, $\mathrm{C}_{4}$ vegetation began its expansion about $6000 \mathrm{BP}$ (early Middle Archaic) with little fluctuations throughout the rest of the period and into the Late Archaic. At Boriak and Patschke bogs in Lee County, about $180 \mathrm{~km}$ to the northeast (Bousman 1998; Camper 1991; Nickels and Mauldin 2001) fluctuating conditions mark the same time interval, however, grassland vegetation seems to dominate between $5500 \mathrm{BP}$ and $2500 \mathrm{BP}$. These data suggest an increase in grassland towards the Middle Archaic that in turn would have favored bison availability. Land snails will be used to test this hypothesis and to propose the likelihood of this alternative or a new one to explain the environmental history of Granberg Site. 


\begin{tabular}{|c|c|c|c|c|c|c|c|c|c|c|c|c|c|c|c|c|c|c|c|c|c|c|c|}
\hline \multirow{3}{*}{ 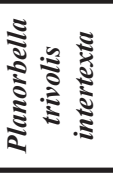 } & 8 & & & & & & & & 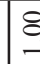 & & & & & & & & & & & & & & \\
\hline & $\partial^{\circ}$ & & & & & & & & â & & & & & & & & & & & & & & \\
\hline & \# & & & & & & & & - & & & & & & & & & & & & & & \\
\hline \multirow{3}{*}{ 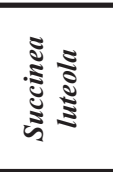 } & 8 & & & & & & & & & & & & & & & & & & & $\underset{-}{8}$ & & & \\
\hline & $\partial^{\circ}$ & & & & & & & & & & & & & & & & & & & $\stackrel{n}{2}$ & & & \\
\hline & \# & & & & & & & & & & & & & & & & & & & - & & & \\
\hline \multirow{3}{*}{ 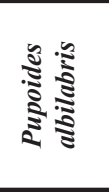 } & 8 & & î & & & 吕 & & 8 & ¿́ & $\S$ & & $\begin{array}{l}0 \\
? \\
0 \\
\end{array}$ & & & & & & & & & & & \\
\hline & $\partial^{\circ}$ & $\begin{array}{c}\tilde{6} \\
-\end{array}$ & $\tilde{n}$ & 0 & & $\begin{array}{l}\text { g) } \\
\text { in }\end{array}$ & & శ̊ & 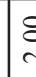 & 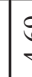 & & $\vec{U}$ & & & & & & & & & & & \\
\hline & $\#$ & $\circ$ & F & & & in & & $m$ & $\alpha$ & 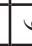 & & $\infty$ & & & & & & & & & & & \\
\hline \multirow{3}{*}{ 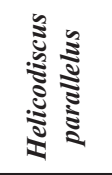 } & 8 & & : & & & $\underset{-}{\stackrel{8}{\circ}}$ & $\stackrel{8}{\stackrel{-}{-}}$ & & & 7 & & $=$ & & & & & & & & & & & \\
\hline & $\partial^{\circ}$ & & के & & & $\begin{array}{l}\stackrel{\text { N }}{\mathrm{d}} \\
\end{array}$ & $\tilde{\overbrace{}}$ & & & 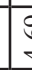 & & . & & & & & & & & & & & \\
\hline & \# & & $m$ & & & $\mathrm{~N}$ & - & & 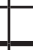 & - & & 0 & & & & & & & & & & & \\
\hline \multirow{3}{*}{ 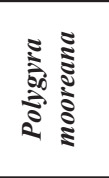 } & 8 & $\begin{array}{l}8 \\
\\
\end{array}$ & $\stackrel{8}{-8}$ & $\stackrel{8}{-}$ & & & 8 & $\begin{array}{l}\infty \\
\infty \\
0\end{array}$ & 8 & & & & & & & & & & & & & & \\
\hline & $\partial^{\circ}$ & \begin{tabular}{|l|} 
\\
0 \\
$\dot{m}$
\end{tabular} & $\hat{\rho}$ & ? & & & તి & $\frac{7}{n}$ & $\stackrel{g}{r}$ & $y$ & & & & & & & & & & & & & \\
\hline & \# & 2 & in & $m$ & & & \pm & $\because$ & 5 & & & & & & & & & & & & & & \\
\hline \multirow{3}{*}{ 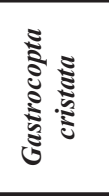 } & 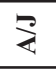 & & & ? & $\begin{array}{l}0 \\
0 \\
0 \\
0\end{array}$ & & & & & & & & $\stackrel{8}{0}$ & $\stackrel{8}{8}$ & $\begin{array}{l}8 \\
0\end{array}$ & ¿̊. & $\frac{\theta}{0}$ & & $\begin{array}{l}\text { İ } \\
\text { o }\end{array}$ & fo & 3 & & \\
\hline & $\partial^{\circ}$ & & & $\stackrel{+}{\vec{i}}$ & $\begin{array}{l}\stackrel{0}{1} \\
\stackrel{0}{\varrho}\end{array}$ & & & & & & & & $\begin{array}{c}\infty \\
\stackrel{n}{N}\end{array}$ & $\begin{array}{l}\infty \\
\stackrel{\infty}{N} \\
\end{array}$ & $\stackrel{7}{F}$ & 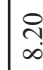 & is & & $\begin{array}{l}\tilde{W} \\
\infty\end{array}$ & $\stackrel{\infty}{\stackrel{\infty}{=}}$ & $\underset{\infty}{\infty}$ & & \\
\hline & \# & & & 으 & + & & & & & & & & - & - & - & in & r & & $\pi$ & 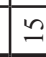 & 6 & & \\
\hline \multirow{3}{*}{ 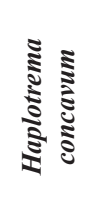 } & $\stackrel{8}{8}$ & 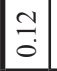 & & $\stackrel{8}{\circ}$ & $\stackrel{0}{\circ}$ & $\stackrel{0}{0}$ & ¿্. & & a & & & $\frac{0}{0}$ & $\stackrel{\dddot{0}}{0}$ & $\begin{array}{l}\text { ి } \\
\text { ஸे }\end{array}$ & 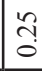 & $\because$ & $\frac{7}{0}$ & & $\frac{1}{0}$ & $\underset{0}{\stackrel{5}{0}}$ & $\hat{z}$ & & \\
\hline & $\partial^{\circ}$ & 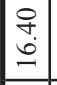 & 8 & $\begin{array}{l}\hat{i} \\
\infty \\
\text { i }\end{array}$ & $\frac{\infty}{\dot{\infty}}$ & $\begin{array}{l}7 \\
8 \\
8\end{array}$ & 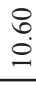 & & : & & & हn & $\begin{array}{l}\stackrel{0}{\infty} \\
\infty \\
\infty \\
\end{array}$ & $\begin{array}{l}\text { से } \\
\text { ू̆ }\end{array}$ & $\begin{array}{l}\infty \\
\infty \\
\infty\end{array}$ & $\begin{array}{l}2 \\
n \\
\infty \\
\infty \\
\end{array}$ & $\begin{array}{l}8 \\
3 \\
6\end{array}$ & & $\begin{array}{l}\stackrel{1}{1} \\
2 \\
\infty \\
\end{array}$ & $\begin{array}{l}\vec{J} \\
\text { तi }\end{array}$ & $\begin{array}{l}n \\
5 \\
5 \\
y\end{array}$ & & \\
\hline & \# & $\overrightarrow{0}$ & & $\bar{\Xi}$ & 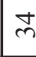 & $\approx n$ & f & & = & $\$$ & & $\mathrm{~N}$ & $\bar{n}$ & q & ते & $\approx$ & $\infty$ & & J & $\infty$ & n & & \\
\hline \multirow{3}{*}{ 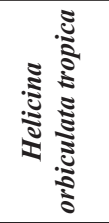 } & 8 & $\hat{3}$ & $\stackrel{R}{0}$ & $\stackrel{\overrightarrow{0}}{\circ}$ & $\stackrel{8}{-}$ & $\stackrel{\circ}{\circ}$ & $\stackrel{8}{-}$ & \& & $£$ & S & & $\stackrel{8}{8}$ & & & & & 8 & & $\begin{array}{l}5 \\
0 \\
0\end{array}$ & $\hat{0}$ & 8 & & $\stackrel{8}{-}$ \\
\hline & $\partial^{\circ}$ & \begin{tabular}{|l|}
$\tilde{N}$ \\
$\dot{H}$ \\
\end{tabular} & $\begin{array}{l}f \\
\dot{0} \\
\infty\end{array}$ & $\begin{array}{l}7 \\
8\end{array}$ & $\begin{array}{l}0 \\
i \\
i \\
\end{array}$ & \begin{tabular}{|l}
6 \\
2 \\
2
\end{tabular} & $\stackrel{7}{i}$ & $\begin{array}{l}0 \\
\infty \\
\infty\end{array}$ & है & $\vdots$ & & 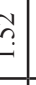 & & & & & సे & & $\exists$ & 尺े & $\stackrel{8}{\circ}$ & & $\begin{array}{l}\hat{6} \\
\dot{0} \\
\end{array}$ \\
\hline & $\#$ & 离 & $\frac{7}{6}$ & $\tilde{\varkappa}$ & - & $\hat{\sim}$ & $\stackrel{\circ}{m}$ & $\approx$ & है & . & & - & & & & & $\stackrel{\infty}{\sim}$ & & $m$ & $a$ & $m$ & & $\sim$ \\
\hline \multirow{3}{*}{ 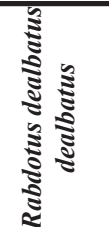 } & 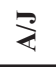 & 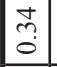 & $\vec{m}$ & $\tilde{3}$ & & $\begin{array}{l}n \\
n \\
0\end{array}$ & कै & శี & $\frac{9}{c}$ & ] & & $\begin{array}{l} \pm \\
0 \\
0\end{array}$ & & & ले & & f & $\hat{\overbrace{}}$ & लु & $\stackrel{\infty}{\stackrel{\infty}{0}}$ & 7 & & $\begin{array}{l}8 \\
: \\
0\end{array}$ \\
\hline & $\partial^{\circ}$ & $\mid \begin{array}{l}\infty \\
0 \\
\dot{\sim} \\
\end{array}$ & $\begin{array}{l}\infty \\
\infty \\
\dot{I} \\
\end{array}$ & $\begin{array}{c}\infty \\
\stackrel{2}{2} \\
a\end{array}$ & & 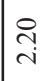 & $\stackrel{\infty}{\stackrel{\infty}{O}}$ & 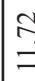 & $\begin{array}{l}\text { ô } \\
\text { ñ }\end{array}$ & $\oint$ & & 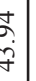 & సิ & $\begin{array}{l}\infty \\
\stackrel{i}{i}\end{array}$ & $\begin{array}{c}\stackrel{i}{n} \\
\end{array}$ & bُ & $\mid \begin{array}{l}\infty \\
0 \\
0\end{array}$ & $\begin{array}{l}\stackrel{8}{0} \\
\stackrel{0}{0}\end{array}$ & $\exists$ & $\mid \begin{array}{l}\infty \\
\infty \\
\infty\end{array}$ & $\hat{z}$ & & $\underset{\infty}{\stackrel{\leftrightarrow}{\infty}}$ \\
\hline & \# & $\hat{n}$ & $\cong$ & $F$ & & N & F & 吉 & Э & & & 2 & $\nabla$ & - & $m$ & न & 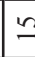 & i & $m$ & $\approx$ & $\sigma$ & & 의 \\
\hline \multicolumn{2}{|c|}{$\frac{\vec{l}}{\frac{\omega}{\underline{m}}}$} & $\mid \begin{array}{c}\not{\alpha} \\
\dot{f}\end{array}$ & రై & मे & $\stackrel{\infty}{\sim}$ & i & $\stackrel{\text { वे }}{2}$ & $=$ & is & & & 寸 & $\tilde{\lambda}$ & 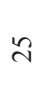 & तి & $\underbrace{\infty}_{ల}$ & $\infty$ & $\stackrel{\circ}{\circ}$ & \& & $n$ & $m$ & & $\stackrel{\pi}{\exists}$ \\
\hline \multicolumn{2}{|c|}{ 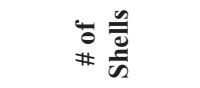 } & 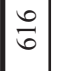 & 8 & $\stackrel{\infty}{\mathscr{\gamma}}$ & ले & $\bar{\sigma}$ & $\underset{F}{F}$ & 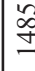 & 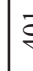 & & & 8 & $\mathcal{F}$ & $\mathcal{F}$ & $\stackrel{\sim}{d}$ & 5 & $\stackrel{\infty}{\cong}$ & in & 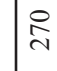 & $\tilde{\cong}$ & $m$ & & $\simeq$ \\
\hline \multicolumn{2}{|c|}{ อ } & 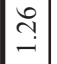 & $\cong$ & $\stackrel{n}{-6}$ & $\stackrel{+}{ \pm}$ & $\stackrel{9}{\rightarrow}$ & $\stackrel{n}{-}$ & בี & a & & & $?$ & $\stackrel{\infty}{-}$ & 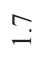 & 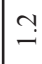 & $=$ & 7 & $\stackrel{-}{-}$ & $m$ & $\stackrel{+}{\mathrm{i}}$ & - & & $\stackrel{\Xi}{\Xi}$ \\
\hline \multicolumn{2}{|c|}{ } & 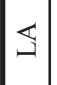 & $\leftrightarrows$ & 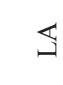 & 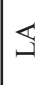 & $\leftrightarrows$ & 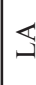 & 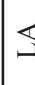 & $\leq$ & & & $\mathbb{\Sigma}$ & $\mathbb{\Sigma}$ & $\overleftrightarrow{\Sigma}$ & 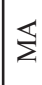 & 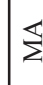 & $\Sigma$ & 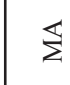 & 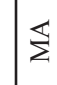 & 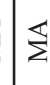 & $\$$ & & 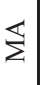 \\
\hline \multicolumn{2}{|c|}{$\overline{3}$} & in & 6 & $r$ & - & N & $m$ & t & 4 & & & - & $\infty$ & $a$ & 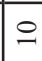 & $=$ & $\simeq$ & $\stackrel{m}{\sim}$ & \pm & 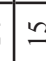 & co & & $\simeq$ \\
\hline \multicolumn{2}{|c|}{$?$} & $m$ & $m$ & $m$ & in & in & 6 & in & 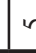 & & & in & $n$ & in & in & in & in & in & in & n & n & & 6 \\
\hline
\end{tabular}




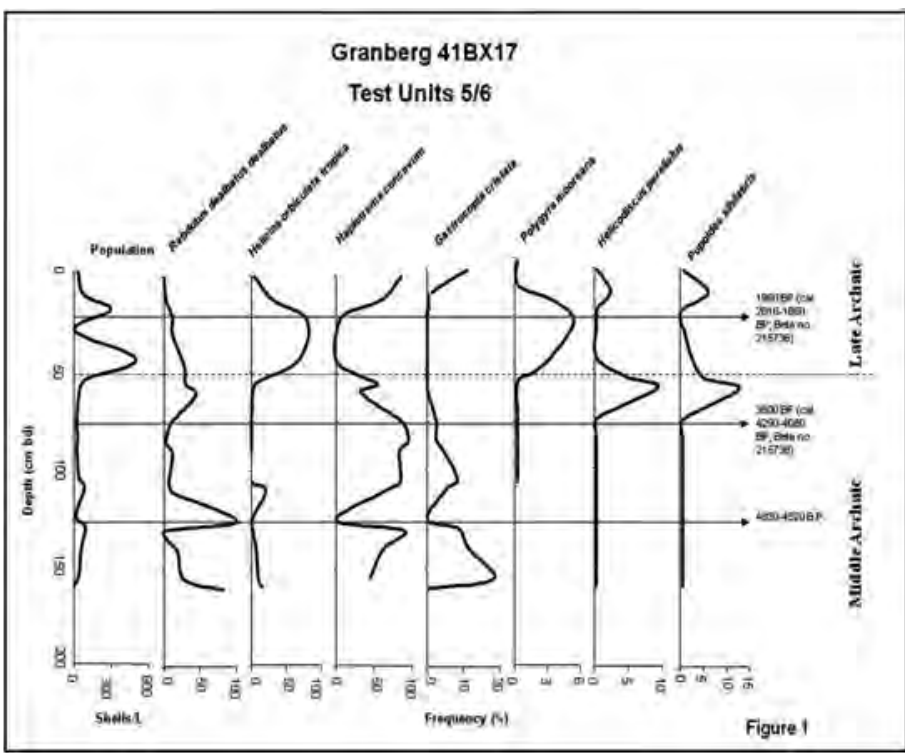

Figure A-1. Paleoenvironmental reconstruction of Test Units 5 and 6, Block 1 at Granberg Site 41BX17, Bexar County, Texas.
The paleoenvironmental reconstruction of Granberg Site 41BX17 is based on the total and relative abundance, and the maturity ratios of the nine snail species present in the area. In addition, the taphonomic parameters described earlier constitute a key element for identifying the nature of the shell deposits and quality of preservation. Combined, the faunal composition and taphonomy permitted the reconstruction of the environment. For practical purposes the reconstruction is made chronostratigraphically from the older to the more recent strata using Munoz et al. (2007) format and criteria.

Recreation of paleoenvironments can be approached by two methods. One is through survey level data using local and regional collections, and the other is through experimental studies (Goodfriend 1992:666). Survey data is probably the most common method of analysis in use because it allows determining such variables as biome abundance or frequency, elevation, rainfall amounts and frequency, temperature, and moisture (Goodfriend 1992: Tables 1 and 2). For example, $R$. dealbatus dealbatus and $H$. orbiculata tropica may respond differently to soil moisture, temperature, and light as shown in Table A-1. As discussed by Henry (1995), species of Rabdotus and Helicina vary inversely, with woodland adapted Helicina replacing Rabdotus over time. This general pattern is observed in Granberg Site 41BX17.

P. mooreana is a highly adaptive species capable of living in open or forested areas, but H. parallelus prefers near-water environments like swamps or fens, as $S$. luteola and . trivolvis intertexta do. G. cristata prefers moist soils under logs or rocks on poorly drained floodplains, an environment similar to that preferred by $H$. parallelus. P. albilabris prefers an environment like that for $R$. dealbatus dealbatus; whereas $H$. concavum is better adapted to a temperate forest. Any combination of these species throughout the stratigraphic record of Granberg Site indicates the environmental conditions at any given time. No evidence of burning on shells argues for a natural deposition rather than an anthropogenic accumulation. Therefore, a reliable paleoenvironmental reconstruction is feasible using land snails.

During the Middle Archaic at TU-5/6 (pre-occupation, and Features 102 and 104), during the pre-occupation period between 4830-4520 BP and 3800 BP (cal 4290-4080 BP; Beta no. 215738), the total land snail population ranged from less than 16 to 90 specimens/L of soil sample (see Figure A-2 for a graphic history of environmental change at TU-5/6). Diversity was relatively low, with no more than four species present at a time in the record. At the base of the record $R$. dealbatus dealbatus and $H$. orbiculata tropica are the only species representing a rare population dominated by the first of the two species. Prior to 4830$4520 \mathrm{BP}$, the poor record indicates a changing environment somewhat similar to the trends shown by the Medina River, and the Boriak and Patschke bogs $\mathrm{C}_{3} / \mathrm{C}_{4}$ plants but not to Hall's Cave between 5000 and 4500 BP (Munoz et al. 2007: Figure 27). At this time Granberg Site is subject to a gradual change to open country (prairie) more xeric conditions.

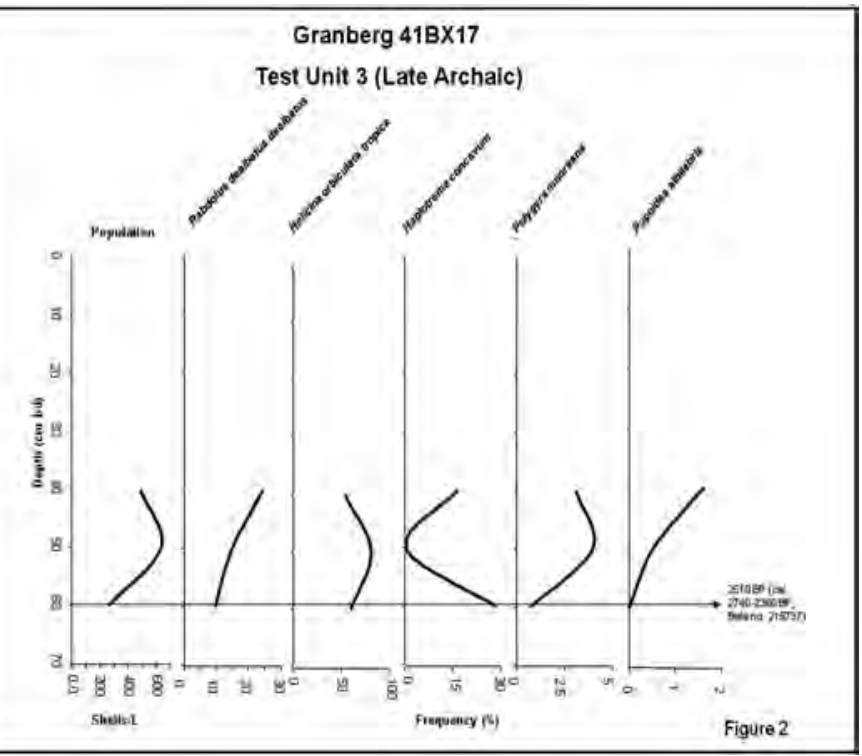

Between the beginning of the record and $4830 \mathrm{BP}$, a variable Figure A-2. Paleoenvironmental reconstruction of Test Unit 3 ,
environment is marked by the rapid decline of $R$. dealbatus Block 1 at Granberg Site 41BX17, Bexar County, Texas.

Between the beginning of the record and $4830 \mathrm{BP}$, a variable Figure A-2. Paleoenvironmental reconstruction of Test Un
environment is marked by the rapid decline of $R$. dealbatus Block 1 at Granberg Site 41BX17, Bexar County, Texas. 
dealbatus, slow increase of $H$. orbiculata tropica, the first occurrence of G. cristata, the sharp increase of $H$. concavum, and the only occurrence of $S$. luteola (a riparian species). The latter four species prefer more mesic conditions than $R$. dealbatus dealbatus. Only Boriak Bog and possibly Hall's Cave seem to correlate with the pattern shown by the land snails of Granberg Site (Munoz et al. 2007: Figure 27). The Medina River and Patschke Bog $\mathrm{C}_{3} / \mathrm{C}_{4}$ plant patterns still indicate an increasing grassland environment. The Rabdotus population, suddenly increased at the end of the interval as all other species disappeared supporting the hypothesis of a $\mathrm{C}_{4}$ dominated environment. H. concavum, a fearsome predator, may be associated with the increasing abundance of food resources. At this interval the inverse correlation between Rabdotus and Helicina is obvious. Increasing xeric conditions forced the mesic snails to decline.

For the interval comprised between $4830 \mathrm{BP}$ and $3800 \mathrm{BP}$, the overall land snail population remained low (20-81 specimens/L), Rabdotus reached its maximum abundance during the Middle Archaic but declined rapidly as $H$. concavum became more abundant. Regardless of the lack of evidence of depredation over Rabdotus shells (no holes visible), there is a good possibility that Haplotrema preyed on $R$. dealbatus dealbatus. It is assumed that the faunal change is a response to ecological replacement as resources availability increased for $H$. concavum. In addition, G. cristata slightly increased during this interval as $H$. orbiculata tropica disappeared from the stratigraphic column. Since these two species live in moist environments, it is unclear why H. orbiculata tropica disappeared. The extremely rare abundance of G. cristata during the late Middle Archaic; however, may imply that fully mesic conditions were not reached but semi-arid conditions prevailed and favored the occurrence of $R$. dealbatus dealbatus. If this interpretation is correct, then occurrence of $H$. concavum may be explained in response to an abundance of food resources supplied by $R$. dealbatus dealbatus.

At the end of the Middle Archaic (first occupation period recorded at Features 102 and 104) two species appeared in the record, H. parallelus and $P$. albilabris. The two species are very rare and occurred at the last interval of the Middle Archaic period in the stratigraphic sequence. The land snail population remained low (around 44-91 specimens/L). Helicodiscus and Pupoides indicate contrasting conditions that, however, may not oppose to each other. The former prefers swamp forests or fens, with abundant moss and bryophytes, whereas the latter wanders in bare ground that must be moist in order for the species to breath and hatch its eggs (Turgeon et al. 1998). During this interval H. concavum reached its highest abundance (64-95\%) in Granberg Site adding more pressure on other snail populations like Rabdotus that fluctuated from 6 to $44 \%$. The co-occurrence of $H$. parallelus, $P$. albilabris, and $R$. dealbatus dealbatus at the end of the Middle Archaic indicates decreasing moisture affecting H. concavum (it declined to 33\%). It is at this time that Medina River, and Boriak and Patschke bogs show a sharp increase in $\mathrm{C}_{4}$ plants whereas Hall's Cave shows the opposite trend (Munoz et al. 2007: Figure 27). Land snails indicate that the transition from the Middle Archaic to Late Archaic is increasingly arid at Granberg Site.

At Granberg Site (Features 100 and 101) the Late Archaic period is represented by soils dated between 3800 BP (cal 42904080 BP; Beta no. 215738) and 1990 BP (cal 2010-1860 BP; Beta no. 215736). At the beginning of the Late Archaic, the site experienced a more diverse gastropod fauna. The population reached its maximum $(289-1000+$ specimens/L). Seven of the nine species were recorded including $R$. dealbatus dealbatus, $H$. orbiculata tropica, H. concavum, G. cristata, H. parallelus, $P$. albilabris, and the only occurrence of $P$. trivolvis intertexta. Assuming an aggradation rate of $2.5 \mathrm{~mm} / \mathrm{yr}$ for this interval, the first 400-500 years were subject to increasing xeric conditions. H. concavum continued to decline despite the modest increase of $R$. dealbatus dealbatus and P. albilabris. H. orbiculata, G. cristata, and H. parallelus, with the extremely rare occurrence of $P$. trivolvis intertexta indicate an episode of increasing effective precipitation and the possible formation of a swamp in the vicinity. The poor record of $P$. trivolvis intertexta argues for the natural occurrence of the species, but is not enough to justify further interpretation. The other moist-prone species provide a better indication of the environmental conditions prevailing at Granberg Site at this time.

That conditions were becoming xeric is indicated by the gradual increase of Rabdotus, consistent with the trend shown by the Medina River, and the Boriak and Patschke records (Munoz et al. 2007: Figure 27). However, conditions may have been variable as the moist-prone species occurred. It is likely that a seasonal pattern may be indicated by this assemblage. For example, Rabdotus may appear in the area early in the spring before the Monsoon season, thrive through this period and hibernate at the end of the fall, whereas the other species may be limited to the wet Monsoon (late June-late September). Based on this assumption, $R$. dealbatus dealbatus abundance may be explained, as it is greater than that of any other species.

By contrast with this early stage of the Late Archaic, the following interval-again assuming an agraddation rate of 2.5 $\mathrm{mm} / \mathrm{yr}$ - witnessed a significant increase increase of $\mathrm{H}$. orbiculata tropica, the appearance and population growth of P. mooreana, and the decline of all other species. Between around 3400 BP and 2900 BP, Granberg Site was subject to 
increasing effective precipitation causing Rabdotus to retreat to drier areas and favoring Helicina to colonize the environment. Medina River does not show change in the $\mathrm{C}_{3} / \mathrm{C}_{4}$ trend during this interval. Hall's Cave, and Boriak and Patschke bogs, however, indicate a gradual or even sharp decline (like Patschke Bog) in $\mathrm{C}_{4}$ plants, consistent with this interpretation.

Mesic conditions in Granberg Site prevailed between around 2900 BP and 1990 BP as H. orbiculata tropica reached its maximum abundance (64-84\%). The high abundance of the species in an archeological feature argues for human gathering and consumption, however, careful optical analysis of the shells showed no evidence of plucking or burning indicative of anthropogenic activity. It is inferred, instead, that Features 100 and 101 provided shelter to the species at a time of increasing effective moisture. Medina River does not show a significant change in $\mathrm{C}_{3} / \mathrm{C}_{4}$ plants but Hall's Cave and the bogs (Boriak and Patschke) indicate alternating episodes of $\mathrm{C}_{3}$ and $\mathrm{C}_{4}$ plants during this period. Medina River, the closest to Granberg Site, argues for semi-arid conditions in the area; hence it would favor an interpretation of anthropogenic accumulation of $H$. orbiculata tropica. This alternative, however, has been discarded based on the arguments aforementioned.

The post-occupation interval (post 1990 BP) is in sharp contrast with the Late Archaic occupation periods but similar to the pre-occupation episodes of the Middle Archaic. Species diversity remained high (six species present) but abundance declined (28-70 specimens/L). Rabdotus disappeared, Helicina showed a sharp decline, whereas Haplotrema increased, Gastrocopta occurred once, and Helicodiscus and Pupoides vanished from the record. H. concavum inhabits forested areas throughout the eastern United States (Hotopp 2006). Its occurrence and dominance in this site indicates increasing mesic conditions, as well as predatory activity. The Medina River site does not show changes on the $\mathrm{C}_{3} / \mathrm{C}_{4}$ plant trends until $1200 \mathrm{BP}$; however, Hall's Cave indicates a decline in $\mathrm{C}_{4}$ plants and Patschke Bog shows rapid fluctuations in plant composition (Munoz et al. 2007: Figure 27). Effective moisture increased in Granberg Site after human occupation.

At TU-3, a short but informative record was obtained for Granberg Site $41 \mathrm{bX} 17$. The time interval indicated by a radiocarbon date of 2510 BP (cal 2740-2380 BP; Beta no. 215737) does not exceed 3981 BP according to a radiocarbon sample submitted from Feature 105 at $71 \mathrm{cmbd}$ (Munoz et al. 2007:25). That is, it correlates in time with the early Late Archaic interval from TU-5/6 (Features 100 and 101). Land snail diversity is high (seven species) and population is very to extremely abundant (259636 specimens/L). H. orbiculata tropica (54-81\%) and R. dealbatus dealbatus (9-25\%) dominated the record. H. concavum occurred at the base and top of the stratigraphic column. P. mooreana and P. albilabris were extremely to very rare (less than $3 \%$ ). Two species, however, occurred once in the record: G. cristata and H. parallelus (less than $2 \%$ when present). By contrast with TU-5/6, the TU-3 record is not associated with an archeological feature (Table 2). The paleoecological trend shown by this faunal assemblage indicates that the Granberg Site land snail population reflects the natural accumulation of organisms in the area as the result of favorable ecological conditions. This interpretation supports that for early Late Archaic period at TU-5/6.

In general, the land snail population increased during this interval following the same pattern described for TU-5/6 at the early Late Archaic. Rabdotus increased slightly at TU-3 but remained stable at TU-5/6. Helicina, Haplotrema, and Polygyra followed the same trends in both test units. Pupoides, however, mirrored the trend in TU-3. If the assumption that TU-3 represents the natural setting, then it is reasonable to argue that the land snail record is consistent with the paleoenvironmental history of other locations surrounding Granberg Site. Mesic conditions prevailed in the area permitting H. orbiculata tropica to dominate the faunal assemblage. Abundance of Helicina in TU-3 argues in favor of the previous interpretation for TU-5/6 that a natural population established in the area and that humans did not feed on this abundant snail.

\section{Discussion}

\section{Environmental Change Verses Anthropogenic Use of Snails}

Land snails are a common associate in archeological sites either as the result of a plethora of resources derived from anthropogenic activity that attract them into the site, or because humans gathered and fed on them. The density of gastropods in archeological sites demands attention for understanding the role these organisms played in an archeological context. The primary goal of this study was to identify the origin of the fauna and to determine if the patterns of land snail occurrence and abundance in the site was in response to environmental change or human impact. Based on several lines of evidence to be discussed in this section, this study proposes that land snails at Granberg Site 41BX17 indicate changes in the environment rather than by the indigenous people. 
Recognition of climate change from human impact requires answering questions regarding dating methods, climate and environmental reconstruction, and aboriginal subsistence (Malof 2007). Gastropods are relatively short-lived. Radiocarbon dating using snails allows to date prehistoric events with great accuracy. In addition, snails are sensitive to the environment and niche specific. In the archeological and paleoenvironmental literature they, often, have been used for reconstructing the paleoclimate (Allen and Cheatum 1960; Goodfriend 1992; Snodgrass 1998; Zimmerman 1960). Some species in an archeological context, however, may be so ubiquitous and abundant that often times are interpreted as the result of anthropogenic gathering and consumption (Malof 2007). The research design and field methods offer the best procedure for distinguishing the paleoclimate from the anthropogenic signatures. For the present study, to the best of my knowledge, I focused on the quantification of the total and species-specific snail populations as the primary parameter to determine if any given species was a portion of the subsistence base or scavengers feeding-off of human detritus. Snail populations were significantly high at the occupation horizons making the origin of some species suspicious of subsistence gathering.

The second approach to discriminate between the paleoenvironmental and human signatures, consisted on the detailed inspection of the shells in search of burning or plucking marks indicative of consumption. The final strategy for recognizing natural from gathered populations consisted on the identification of any changes in species ratios. These three methods proved to be very useful for the reconstruction of the land snail history at Granberg Site. However, the study was limited to the large species and specimens available for analysis. Brown (1999:213) indicates that microscopic snails are more vulnerable to selective pressure, and so more reliable indicators of surrounding environmental variables.

Based on the research design and approach taken for land snail analysis, a plausible paleoenvironmental reconstruction is proposed in this study. Snail data correlates well with the plant and pollen records discussed by Munoz et al. (2007:54-56). Shifts in $\mathrm{C}_{3}$ and $\mathrm{C}_{4}$ plants recorded from Medina River area (Nordt et al. 2002), the Hall's Cave (Cooke 2005), and the Boriak (Bousman 1998) and Patschke (Camper 1991; Nickels and Mauldin 2001) bogs show trends that, for most of the snail records, agree with the interpretation presented in this study.

\section{Conclusions}

- Through the analysis of gastropods it was possible to infer past climate conditions at Granberg Site 41BX17.

- Land snail diversity and abundance provided basal information for recognizing climate change from human impact at the site.

- Lack of anthropogenic signatures on the shells argues for a natural faunal assemblage at Granberg Site, both from the occupation and non-occupation features.

- Rabdotus dealbatus dealbatus was often times replaced by Helicina orbiculata tropica, a species that overrode $R$. dealbatus dealbatus in abundance, especially in features 100-104.

- Land snail data correlate well with $\mathrm{C}_{3}$ and $\mathrm{C}_{4}$ plant and pollen records from localities in the vicinity of Granberg Site. 


\section{References Cited:}

Adams, K.R., S.J. Smith, and M.R. Palacios-Fest

2002 Pollen and Micro-invertebrates from Modern Earthen Canals and Other Fluvial Environments along the Middle Gila River, Central Arizona: Implications for archaeological interpretation. Manuscript on file, GRIC, Sacaton.

Allen, D.C., and E.P. Cheatum

1960 Ecological Implications of Fresh-Water and Land Gastropods in Texas Archeological Studies. Bulletin of the Texas Archeological Society 31:291-316.

Bousman, C.B.

1998 Paleoenvironmental Change in Central Texas: The Palynological Evidence. Plains Anthropologist 43(164):201-219.

Brown, K.M.

1999 Snails from the Quarter-Inch and Eighth-Inch Screens. In The Smith Creek Bridge Site (41DW270) A Terrace Site in DeWitt County, Texas, by D. Hudler, K. Prilliman, and T. Gustavson, pp. 213-275. Texas Archeological Research Laboratory, Studies in Archeology 35. Archeology Studies Program, Report 17. Environmental Affairs Division, Texas Department of Transportation, Austin.

Camper, H.A.

1991 Pollen Analysis of Patschke Bog. Unpublished M.S. thesis, Department of Botany, Texas A\&M University, Bryant. Data Archive at the World Data Center-A for paleoclimatology data. NOAA/NGDC Paleoclimatology Program, Boulder.

Cooke, M.J.

2005 Soil Formation and Erosion in Central Texas: Insights from Relict Soil and Cave Deposits. Unpublished Ph.D. Dissertation. University of Texas at Austin.

Córdova, K.J., B.K. Moses, and R.P. Mauldin

2005 Records and Collections Assessment of Previous Investigations at Sites 41BX17 and 41BX271

(Granberg I and II) with the ROW of Loop 410 East at Salado Creek, San Antonio, Bexar County, Texas. Report on file at the Center for Archaeological Research, The University of Texas at San Antonio.

Goodfriend, G.A.

1992 The Use of Land Snail Shells in Paleoenvironmental Reconstruction. Quaternary Science Reviews 11:665-685.

Henry, D.O.

1995 Cultural and Paleoenvironmental Successions Revealed by the Hog Creek Archeological Investigations, Central Texas, in Advances in Texas Archeology: Contributions from Cultural Resource Management, Volume 1, edited by J.E. Bruseth, and T. K. Perttula. Cultural Resource Management Report No. 5, Texas Historical Commission Department of Antiquities Protection.

Hester, T.R.

1980 11,00 Years of South Texas Prehistory. In Digging into the South Texas Prehistory, pp. 131-164. Corona Publishing, San Antonio.

1984 Report of Materials Found at Site in 11/84 and 12/84. Letter Report on file, Center for Archaeological Research, The University of Texas at San Antonio.

1995 The Prehistory of South Texas. Bulletin of the Texas Archeological Society 66:427-459. 
Hotopp, K.

2006 Land Snails of Pennsylvania, Species Profile: Haplotrema concavum (Say, 1821). Available at http://www.carnegiemnh.org/mollusks/palandsnails/accounts/ha_conc.htm, accessed on September 5, 2007.

Malof, A.F.

2007 Texas Snails in Archaeological Context. Available at http://www.dirtbrothers.org/editorial/malof.htm, accessed on September 5, 2007.

Munoz, C., J.L. Thompson, and R.P. Mauldin

2007 Research Design for the Analysis of Archeological Materials Recovered from Significance Testing of the Granberg Site (41BX17), Bexar County, Texas. Center for Archaeological Research, Department of Anthropology, The University of Texas at San Antonio, CSJ No. 0521-04-187, 95 pp.

Nekola, J.C.

2002 Distribution and Ecology of Terrestrial Gastropods in Northwestern Minnesota. Final Report: 2001-2002 Natural Heritage and Nongame Research Program, Division of Fish and Wildlife, Minnesota Department of Natural Resources, St. Paul.

Nickels, D.L., and R.P. Mauldin

2001 The Project Environment. In Archaeological Survey of Twin Buttes Reservoir, Tom Green County, Texas, Volume 1, by R. P. Mauldin and D. L. Nickels. Archaeological Survey Report, No. 300. Center for Archaeological Research, The University of Texas at San Antonio.

Nordt, L.C., T.W. Boutton, J.S. Jaco, and R. Mandel

$2002 \mathrm{C}_{4}$ Plant Productivity and Climate CO2 Variations in South-Central Texas during the Late Quaternary. Quaternary Research 58(2):182-188.

Schuetz, M.K.

1966 The Granberg Site: An Archaic Indian Habitation in Bexar County, Texas. Witte Museum Studies No. 1, San Antonio, Texas.

Snodgrass, K.M.

1998 Ancient Climate as Inferred by Land Snails at the Brokenleg Bend Locality, Oklahoma. Available at http://murpylibrary.uwlax.edu/digital/jur/1998/snodgrass.pdf, accessed on September 5, 2007.

Thompson, J.L.

2006 National Register of Historic Places/State Archeological Landmark Eligibility Testing of the Granberg Site (41BX17). Manuscript on file. The Center for Archaeological Research, The University of Texas at San Antonio.

Turgeon, D.D., J.F. Quinn, Jr., A.E. Bogan, E.V. Coan, F. G. Hochberg, W.G. Lyons, P.M. Mikkelsen, R.J. Neves, C.F.E. Roper, G. Rosenberg, B. Roth, A. Scheltema, F.G. Thompson, M. Vecchione, and J.D. Williams

1998 Common and scientific names of aquatic invertebrates from the United States and Canada: Mollusks. 2nd ed. American Fisheries Society Special Publication 26, Bethesda, Maryland: 526 pp.

Waggoner, J., S.A. Clark, K.E. Perez, and C. Lydeard

2006 A Survey of Terrestrial Gastropods of the Sipsey Wilderness (Bankhead National Forest), Alabama. Southeastern Naturalist 5(1):57-68.

Whatley, R.

1983 Some Simple Procedures for Enhancing the Use of Ostracoda in Paleoenvironmental Analysis. NPD Bulletin. (2): 129-146.

Zimmerman, J.A.

1960 Pleistocene Molluscan Faunas of the Newell Lake Deposit, Logan County, Ohio. The Ohio Journal of Science 60(1):13-39. 

Appendix B:

Analysis of the Fatty Acid Compositions of Burned Rock Residues from the Granberg Site, 41BX17

Mary E. Malainey 



\title{
Appendix B
}

\section{Analysis of the Fatty Acid Compositions of Burned Rock Residues from the Granberg Site, 41BX17}

\author{
Mary E. Malainey \\ 11 Mager Drive West, Winnipeg, MB, Canada R2M OR9
}

\section{Introduction}

A total of 27 burned rocks were submitted for analysis and subsamples were taken from these large rocks. Exterior surfaces were ground off to remove any contaminants and samples were crushed. Absorbed lipid residues were extracted with organic solvents. Fatty acid components of the lipid extracts were analyzed using gas chromatography. Residues were identified using criteria developed from the decomposition patterns of experimental residues. The first section of this report outlines the development of the identification criteria. Following this, analytical procedures and results are presented.

\section{Fatty Acids and Development of the Identification Criteria}

\section{Introduction and Previous Research}

Fatty acids are the major constituents of fats and oils (lipids) and occur in nature as triglycerides, consisting of three fatty acids attached to a glycerol molecule by ester-linkages. The shorthand convention for designating fatty acids, Cx:y $\mathrm{z}$, contains three components. The "Cx" refers to a fatty acid with a carbon chain length of $\mathrm{x}$ number of atoms. The " $\mathrm{y}$ " represents the number of double bonds or points of unsaturation, and the " $\triangleright \mathrm{z}$ " indicates the location of the most distal double bond on the carbon

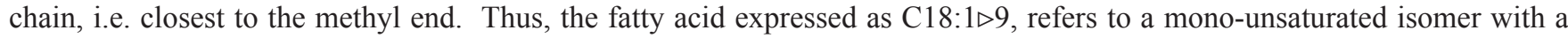
chain length of 18 carbon atoms with a single double bond located nine carbons from the methyl end of the chain. Similarly, the shorthand designation, C16:0, refers to a saturated fatty acid with a chain length of 16 carbons.

Their insolubility in water and relative abundance compared to other classes of lipids, such as sterols and waxes, make fatty acids suitable for residue analysis. Since employed by Condamin et al. (1976), gas chromatography has been used extensively to analyze the fatty acid component of absorbed archeological residues. The composition of uncooked plants and animals provides important baseline information, but it is not possible to directly compare modern uncooked plants and animals with highly degraded archeological residues. Unsaturated fatty acids, which are found widely in fish and plants, decompose more readily than saturated fatty acids, sterols or waxes. In the course of decomposition, simple addition reactions might occur at points of unsaturation (Solomons 1980) or peroxidation might lead to the formation of a variety of volatile and non-volatile products which continue to degrade (Frankel 1991). Peroxidation occurs most readily in fatty acids with more than one point of unsaturation.

Attempts have been made to identify archeological residues using criteria that discriminate uncooked foods (Marchbanks 1989; Skibo 1992; Loy 1994). Marchbanks' (1989) percent of saturated fatty acids (\%S) criteria has been applied to residues from a variety of materials including pottery, stone tools and burned rocks (Marchbanks 1989; Marchbanks and Quigg 1990; Collins et al. 1990). Skibo (1992:89) could not apply the $\% \mathrm{~S}$ technique and instead used two ratios of fatty acids, C18:0/C16:0 and C18:1/ C16:0. He (1992) reported that it was possible to link the uncooked foods with residues extracted from modern cooking pots actively used to prepare one type of food; however, the ratios could not identify food mixtures. The utility of these ratios did not extend to residues extracted from archeological potsherds because the ratios of the major fatty acids in the residue changed with decomposition (Skibo 1992:97). Loy (1994) proposed the use of a Saturation Index (SI), determined by the ratio: SI $=1-[(\mathrm{C} 18: 1+\mathrm{C} 18: 2) / \mathrm{C} 12: 0+\mathrm{C} 14: 0+\mathrm{C} 16: 0+\mathrm{C} 18: 0)]$. He (1994) admitted, however, that poorly understood decompositional changes to the original suite of fatty acids make it difficult to develop criteria for distinguishing animal and plant fatty acid profiles in archeological residues. 
Table B-1. Summary of Average Fatty Acids Compositions of Modern Food Groups

Generated by Hierarchical Cluster Analysis

\begin{tabular}{|c|c|c|c|c|c|c|c|c|c|c|c|c|c|c|c|}
\hline \multirow{2}{*}{$\frac{\text { Cluster }}{\text { Subcluster }}$} & \multicolumn{4}{|c|}{ A } & \multicolumn{6}{|c|}{ B } & \multicolumn{5}{|c|}{$\mathrm{C}$} \\
\hline & I & II & III & IV & $\mathbf{V}$ & VI & VII & VIII & IX & $\mathbf{X}$ & XI & XII & XIII & XIV & $\mathbf{X V}$ \\
\hline \multirow[t]{3}{*}{ Type } & Mammal & $\begin{array}{c}\text { Large } \\
\text { Herbivore }\end{array}$ & \multirow[t]{3}{*}{ Fish } & \multirow[t]{3}{*}{ Fish } & \multirow{3}{*}{$\begin{array}{c}\text { Berries } \\
\text { and } \\
\text { Nuts }\end{array}$} & \multirow[t]{3}{*}{ Mixed } & \multirow{3}{*}{$\begin{array}{c}\text { Seeds } \\
\text { and } \\
\text { Berries }\end{array}$} & \multirow[t]{3}{*}{ Roots } & \multirow[t]{3}{*}{ Seeds } & \multirow[t]{3}{*}{ Mixed } & \multirow[t]{3}{*}{ Greens } & \multirow[t]{3}{*}{ Berries } & \multirow[t]{3}{*}{ Roots } & \multirow[t]{3}{*}{ Greens } & \multirow[t]{3}{*}{ Roots } \\
\hline & Fat and & Meat & & & & & & & & & & & & & \\
\hline & Marrow & & & & & & & & & & & & & & \\
\hline C16:0 & 19.9 & 19.39 & 16.07 & 14.1 & 3.75 & 12.06 & 7.48 & 19.98 & 7.52 & 10.33 & 18.71 & 3.47 & 22.68 & 24.19 & 18.71 \\
\hline C18:0 & 7.06 & 20.35 & 3.87 & 2.78 & 1.47 & 2.36 & 2.58 & 2.59 & 3.55 & 2.43 & 2.48 & 1.34 & 3.15 & 3.66 & 5.94 \\
\hline C18:1 & 56.77 & 35.79 & 18.28 & 31.96 & 51.14 & 35.29 & 29.12 & 6.55 & 10.02 & 15.62 & 5.03 & 14.95 & 12.12 & 4.05 & 3.34 \\
\hline C18:2 & 7.01 & 8.93 & 2.91 & 4.04 & 41.44 & 35.83 & 54.69 & 48.74 & 64.14 & 39.24 & 18.82 & 29.08 & 26.24 & 16.15 & 15.61 \\
\hline C18:3 & 0.68 & 2.61 & 4.39 & 3.83 & 1.05 & 3.66 & 1.51 & 7.24 & 5.49 & 19.77 & 35.08 & 39.75 & 9.64 & 17.88 & 3.42 \\
\hline VLCS & 0.16 & 0.32 & 0.23 & 0.15 & 0.76 & 4.46 & 2.98 & 8.5 & 5.19 & 3.73 & 6.77 & 9.1 & 15.32 & 18.68 & 43.36 \\
\hline VLCU & 0.77 & 4.29 & 39.92 & 24.11 & 0.25 & 2.7 & 1 & 2.23 & 0.99 & 2.65 & 1.13 & 0.95 & 2.06 & 0.72 & 1.1 \\
\hline
\end{tabular}

VLCS - Very Long Chain (C20, C22 and C24) Saturated Fatty Acids

VLCU - Very Long Chain (C20, C22 and C24) Unsaturated Fatty Acids

The major drawback of the distinguishing ratios proposed by Marchbanks (1989), Skibo (1992) and Loy (1994) is they have never been empirically tested. The proposed ratios are based on criteria that discriminate food classes on the basis of their original fatty acid composition. The resistance of these criteria to the effects of decompositional changes has not been demonstrated. Rather, Skibo (1992) found his fatty acid ratio criteria could not be used to identify highly decomposed archeological samples.

In order to identify a fatty acid ratio unaffected by degradation processes, Patrick et al. (1985) simulated the long-term decomposition of one sample and monitored the resulting changes. An experimental cooking residue of seal was prepared and degraded in order to identify a stable fatty acid ratio. Patrick et al. (1985) found that the ratio of two C18:1 isomers, oleic and vaccenic, did not change with decomposition; this fatty acid ratio was then used to identify an archeological vessel residue as seal. While the fatty acid composition of uncooked foods must be known, Patrick et al. (1985) showed that the effects of cooking and decomposition over long periods of time on the fatty acids must also be understood.

\section{Development of the Identification Criteria}

As the first stage in developing the identification criteria used herein, the fatty acid compositions of more than 130 uncooked Native food plants and animals from Western Canada were determined using gas chromatography (Malainey 1997; Malainey et al. 1999a). When the fatty acid compositions of modern food plants and animals were subject to cluster and principal component analyses, the resultant groupings generally corresponded to divisions that exist in nature (Table B-1). Clear differences in the fatty acid composition of large mammal fat, large herbivore meat, fish, plant roots, greens and berries/seeds/nuts were detected, but the fatty acid composition of meat from medium-sized mammals resembles berries/seeds/nuts.

Samples in cluster A, the large mammal and fish cluster had elevated levels of C16:0 and C18:1 (Table B-1). Divisions within this cluster stemmed from the very high level of C18:1 isomers in fat, high levels of C18:0 in bison and deer meat and high levels of very long chain unsaturated fatty acids (VLCU) in fish. Differences in the fatty acid composition of plant roots, greens and berries/seeds/nuts reflect the amounts of $\mathrm{C} 18: 2$ and $\mathrm{C} 18: 3 \triangleright 3$ present. The berry, seed, nut and small mammal meat samples appearing in cluster B have very high levels of C18:2, ranging from 35\% to 64\% (Table B-1). Samples in subclusters V, VI and VII have levels of C18:1 isomers from $29 \%$ to $51 \%$, as well. Plant roots, plant greens and some berries appear in cluster C. All cluster $\mathrm{C}$ samples have moderately high levels of C18:2; except for the berries in subcluster XII, levels of C16:0 are also

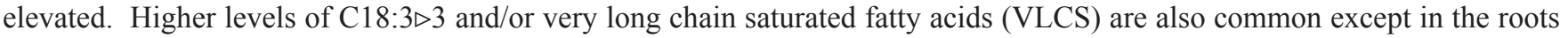
which form subcluster XV. 
Table B-2. Criteria for the Identification of Archeological Residues Based on the Decomposition Patterns of Experimental Cooking Residues Prepared in Pottery Vessels

\begin{tabular}{|c|c|c|c|}
\hline Identification & Medium Chain & C18:0 & C18:1 isomers \\
\hline Large herbivore & $£ 15 \%$ & ${ }^{3} 27.5 \%$ & $15 \%$ \\
\hline $\begin{array}{c}\text { Large herbivore with plant OR } \\
\text { Bone marrow }\end{array}$ & low & ${ }^{3} 25 \%$ & L \\
\hline Plant with large herbivore & ${ }^{3} 15 \%$ & ${ }^{3} 25 \%$ & no data \\
\hline Beaver & low & $£ 25 \%$ & ${ }^{3} 25 \%$ \\
\hline Fish or Corn & low & $£ 25 \%$ & $15 \% £ X 27.5 \%$ \\
\hline Fish or Corn with Plant & ${ }^{3} 15 \%$ & $15 \% £ X £ 27.5 \%$ \\
\hline Plant (except corn) & ${ }^{3} 10 \%$ & $£ 27.5 \%$ & $£ 15 \%$ \\
\hline
\end{tabular}

Secondly, the effects of cooking and degradation over time on fatty acid compositions were examined. Originally, 19 modern residues of plants and animals from the plains, parkland and forests of Western Canada were prepared by cooking samples of meats, fish and plants, alone or combined, in replica vessels over an open fire (Malainey 1997; Malainey et al. 1999b). After four days at room temperature, the vessels were broken and a set of sherds analyzed to determine changes after a short term of decomposition. A second set of sherds remained at room temperature for 80 days, then placed in an oven at $75 \rightarrow \mathrm{C}$ for a period of 30 days in order to simulate the processes of long term decomposition. The relative percentages were calculated on the basis of the ten fatty acids (C12:0, C14:0, C15:0, C16:0, C16:1, C17:0, C18:0, C18:1w9, C18:1w11, C18:2) that regularly appeared in Precontact Period vessel residues from Western Canada. Observed changes in fatty acid composition of the experimental cooking residues enabled the development of a method for identifying the archeological residues (Table B-2).

It was determined that levels of medium chain fatty acids (C12:0, $\mathrm{C} 14: 0$ and $\mathrm{C} 15: 0), \mathrm{C} 18: 0$ and $\mathrm{C} 18: 1$ isomers in the sample could be used to distinguish degraded experimental cooking residues (Malainey 1997; Malainey et al. 1999b). These fatty acids are suitable for the identification criteria because saturated fatty acids are stable and the mono-unsaturated fatty acid degrades very slowly, as compared to polyunsaturated fatty acids (deMan 1992). Higher levels of medium chain fatty acids, combined with low levels of C18:0 and C18:1 isomers, were detected in the decomposed experimental residues of plants, such as roots, greens and most berries. High levels of C18:0 indicated the presence of large herbivores. Moderate levels of C18:1 isomers, with low levels of C18:0, indicated the presence of either fish or foods similar in composition to corn. High levels of C18:1 isomers with low levels of C18:0, were found in residues of beaver or foods of similar fatty acid composition. The criteria for identifying six types of residues were established experimentally; the seventh type, plant with large herbivore, was inferred (Table B-2). These criteria were applied to residues extracted from more than 200 pottery cooking vessels from 18 Western Canadian sites (Malainey 1997; Malainey et al. 1999c; 2001b). The identifications were found to be consistent with the evidence from faunal and tool assemblages for each site.

Work has continued to understand the decomposition patterns of various foods and food combinations (Malainey et al. 2000a, 2000b, 2000c, 2001a; Quigg et al. 2001). The collection of modern foods has expanded to include plants from the Southern Plains. The fatty acid compositions of mesquite beans (Prosopis glandulosa), Texas ebony seeds (Pithecellobium ebano Berlandier), tasajillo berry (Opuntia leptocaulis), prickly pear fruit and pads (Opuntia engelmannii), Spanish dagger pods (Yucca treculeana), cooked sotol (Dasylirion wheeler), agave (Agave lechuguilla), cholla (Opuntia imbricata), piñon (Pinus edulis) and Texas mountain laurel (or mescal) seed (Sophora secundiflora) have been determined. Experimental residues of many of these plants, alone or in combination with deer meat, have been prepared by boiling foods in clay cylinders or using sandstone for either stone boiling (Quigg et al. 2000) or as a griddle. In order to accelerate the processes of oxidative degradation that naturally occur at a slow rate with the passage of time, the rock or clay tile containing the experimental residue was placed in an oven at $75 \rightarrow$ C. After either 30 or 68 days, residues were extracted and analyzed using gas chromatography. The results of these decomposition studies enabled refinement of the identification criteria. 


\section{Methodology}

Descriptions of the samples are presented in Table B-3. Exterior surfaces were removed by grinding off exterior surfaces with a Dremel ${ }^{\circledR}$ tool fitted with a silicon carbide bit. Immediately thereafter, the sample was crushed with a hammer mortar and pestle and the powder transferred to an Erlenmeyer flask. Lipids were extracted using a variation of the method developed by Folch et al. (1957). The powdered sample was mixed with a 2:1 mixture, by volume, of chloroform and methanol ( 2 X $25 \mathrm{~mL}$ ) using ultrasonication ( 2 X $10 \mathrm{~min}$ ). Solids were removed by filtering the solvent mixture into a separatory funnel. The lipid/solvent filtrate was washed with $13 \mathrm{~mL}$ of ultrapure water. Once separation into two phases was complete, the lower chloroform-lipid phase was transferred to a round-bottomed flask and the chloroform removed by rotary evaporation. Any remaining water was removed by evaporation with benzene $(1.5 \mathrm{~mL}) ; 1.5 \mathrm{~mL}$ of chloroform-methanol $(2: 1, \mathrm{v} / \mathrm{v})$ was used to transfer the dry total lipid extract to a screw-top glass vial with a Teflon ${ }^{\circledR}-l i n e d ~ c a p$. The sample was flushed with nitrogen and stored in a $-20 \rightarrow$ C freezer.

A $400 \triangleleft \mathrm{L}$ sample of the total lipid extract solution was placed in a screw-top test tube and dried in a heating block under nitrogen. Fatty acid methyl esters (FAMES) were prepared by treating the dry lipid with $5 \mathrm{~mL}$ of $0.5 \mathrm{~N}$ anhydrous hydrochloric acid in methanol $\left(68^{\circ} \mathrm{C} ; 60 \mathrm{~min}\right)$. Fatty acids that occur in the sample as di- or triglycerides are detached from the glycerol molecule and converted to methyl esters. After cooling to room temperature, $3.4 \mathrm{~mL}$ of ultrapure water was added. FAMES were recovered with petroleum ether $(2.5 \mathrm{~mL})$ and transferred to a vial. The solvent was removed by heat under a gentle stream of nitrogen; the FAMES were dissolved in $75 \mu \mathrm{L}$ of iso-octane then transferred to a GC vial with a conical glass insert.

Table B-3. List of Burned Rock Samples Analyzed from Site 41BX17

\begin{tabular}{|c|c|c|c|c|c|c|c|}
\hline Lab No. & CAR Sample & Feature Number & Test Unit & Level & Top Elev. (bd) & Bottom Elev. (bd) & Sample Mass (g) \\
\hline 7UT 16 & 1 & 100 & 6 & 4 & 33 & 33 & 27.922 \\
\hline 7UT 17 & 2 & 100 & 6 & 4 & 35 & 35 & 28.37 \\
\hline 7UT 18 & 3 & 100 & 6 & 4 & 31 & 31 & 26.893 \\
\hline 7UT 19 & 4 & 101 & 5 & 5 & 40 & 50 & 28.213 \\
\hline 7UT 20 & 5 & 101 & 5 & 5 & 40 & 50 & 32.417 \\
\hline 7UT 21 & 6 & 101 & 5 & 5 & 40 & 50 & 33.927 \\
\hline 7UT 22 & 7 & 102 & 5 & 6 & 50 & 50 & 26.9 \\
\hline 7UT 23 & 8 & 102 & 5 & 6 & 52 & 52 & 31.017 \\
\hline 7UT 24 & 9 & 102 & 5 & 6 & 49 & 49 & 27.018 \\
\hline 7UT 25 & 10 & 103 & 4 & 5 & 44 & 44 & 25.913 \\
\hline 7UT 26 & 11 & 103 & 4 & 5 & 43 & 43 & 25.906 \\
\hline 7UT 27 & 12 & 103 & 4 & 5 & 45 & 45 & 31.488 \\
\hline 7UT 28 & 13 & 104 & 5 & 7 & 60 & 70 & 29.655 \\
\hline 7UT 29 & 14 & 104 & 5 & 7 & 60 & 70 & 29.964 \\
\hline 7UT 30 & 15 & 104 & 5 & 7 & 60 & 70 & 29.526 \\
\hline 7UT 31 & 16 & 105 & 3 & 8 & 73 & 81 & 29.917 \\
\hline 7UT 32 & 17 & 105 & 3 & 8 & 76 & 80 & 28.55 \\
\hline 7UT 33 & 18 & 105 & 3 & 8 & 73 & 78 & 25.045 \\
\hline 7UT 34 & 19 & 106 & 7 & 3 & 22 & 27 & 33.101 \\
\hline 7UT 35 & 20 & 106 & 7 & 3 & 24 & 25 & 26.778 \\
\hline 7UT 36 & 21 & 106 & 8 & 3 & 28 & 28 & 28.001 \\
\hline 7UT 37 & 22 & 107 & 4 & 10 & 93 & 93 & 31.415 \\
\hline 7UT 38 & 23 & 107 & 4 & 10 & 95 & 95 & 30.555 \\
\hline 7UT 39 & 24 & 107 & 4 & 10 & 90 & 100 & 28.858 \\
\hline 7UT 40 & 25 & 108 & 10 & 8 & 70 & 70 & 31.412 \\
\hline 7UT 41 & 26 & 108 & 10 & 8 & 70 & 70 & 31.738 \\
\hline 7UT 42 & 27 & 108 & 10 & 8 & 72 & 72 & 28.968 \\
\hline
\end{tabular}


Solvents and chemicals were checked for purity by running a sample blank. The entire lipid extraction and methyl esterification process was performed and FAMES were dissolved in $75 \searrow \mathrm{L}$ of $i s o$-octane. Traces of contamination were subtracted from sample chromatograms. The relative percentage composition was calculated by dividing the integrated peak area of each fatty acid by the total area of fatty acids present in the sample.

The step in the extraction procedure where the chloroform, methanol and lipid mixture is washed with water is standard procedure for the extraction of lipids from modern samples. Following Evershed et al. (1990), who reported that this step was unnecessary for the analysis of archeological residues, previously the solvent-lipid mixture was not washed. This step was adopted to remove impurities so that clearer chromatograms could be obtained in the region where very long chain fatty acids (C20:0, C20:1, C22:0 and C24:0) occur. It was anticipated that the detection and accurate assessment of these fatty acids could be instrumental in separating residues of animal origin from those of plant (Malainey et al. 2000a, 2000b, 2000c, 2001a).

In order to identify the residue, the relative percentage composition was determined first with respect to all fatty acids present in the sample (including very long chain fatty acids) (see Table B-4) and secondly with respect to the ten fatty acids utilized in the development of the identification criteria (C12:0, C14:0, C15:0, C16:0, C16:1, C17:0, C18:0, C18:1w9, C18:1w11 and C18:2) (not shown). The second step is necessary for the application of the identification criteria presented in Table B-2.

It must be understood that the identifications given do not necessarily mean that those particular foods were actually prepared because different foods of similar fatty acid composition and lipid content would produce similar residues. It is possible only to say that the material of origin for the residue was similar in composition to the food(s) indicated.

\section{Gas Chromatography Analysis Parameters}

The GC analysis was performed on a Varian 3800 gas chromatograph fitted with a flame ionization detector connected to a personal computer. Samples were separated using a DB-23 fused silica capillary column (30 m X $0.25 \mathrm{~mm}$ I.D.; J\&W Scientific; Folsom, CA). An autosampler injected a $3 \succ \mathrm{L}$ sample using a split/splitless injection system. Hydrogen was used as the carrier gas with a column flow of $1.0 \mathrm{~mL} / \mathrm{min}$. Column temperature was held at $80^{\circ} \mathrm{C}$ for 1 minute then increased to $140^{\circ} \mathrm{C}$ at a rate of $20^{\circ} \mathrm{C}$ per minute. It was then programmed from 140 to $230^{\circ} \mathrm{C}$ at $4^{\circ} \mathrm{C}$ per minute. The upper temperature was held for 17 minutes. Chromatogram peaks were integrated using Varian MS Workstation ${ }^{\circledR}$ software and identified through comparisons with external qualitative standards (NuCheck Prep; Elysian, MN).

\section{Results of Archeological Data Analysis}

The fatty acid compositions of residues extracted of 10 samples are presented in Table B-4. The term, Area, represents the area under the chromatographic peak of a given fatty acid, as calculated by the Varian MS Workstation ${ }^{\circledR}$ software minus the solvent blank. The term, Rel\%, represents the relative percentage of the fatty acid with respect to the total fatty acids in the sample. Hydroxide or peroxide degradation products interfered with the integration of the C22:0 and C22:1 peaks; these fatty acids were excluded from the analysis. Insufficient lipids were present in 17 residues, 7UT 17-25, 7UT 28, 7UT 30-31, 7UT 33, 7UT 36 and 7UT 40-42, to attempt their identification. Lipid recoveries from samples 7UT 16, 7UT 27, 7UT 29 and 7UT 37 were relatively low.

The level of C18:1 isomers in one residue, 7UT 39, is 57.35\%, which is very high. Similar levels are observed in the decomposed residues of very high fat content seeds or nuts, such as piñon. Rendered fats of certain mammals (other than large herbivores) exhibit similarly very high levels of C18:1 isomers, but only when fresh. Residue 7UT 39 also has an elevated level of C18:2 and a low level of $\mathrm{C} 18: 0$, suggesting it is from plant material. 
Table B-4. Fatty Acid Composition and Identification of Residues from Site 41BX17

\begin{tabular}{|c|c|c|c|c|c|c|c|c|c|c|}
\hline \multirow{2}{*}{ Fatty acid } & \multicolumn{2}{|r|}{ 7UT 16} & \multicolumn{2}{|c|}{ 7UT 26} & \multicolumn{2}{|c|}{ 7UT 27} & \multicolumn{2}{|c|}{ 7UT 29} & \multicolumn{2}{|c|}{ 7UT 32} \\
\hline & Area & Rel\% & Area & Rel\% & Area & Rel\% & Area & Rel\% & Area & Rel\% \\
\hline C12:0 & 770 & 0.23 & 1522 & 0.08 & 172 & 0.04 & 0 & 0 & 1631 & 0.33 \\
\hline C14:0 & 8079 & 2.42 & 13114 & 0.66 & 7491 & 1.93 & 5878 & 1.35 & 10379 & 2.11 \\
\hline C14:1 & 2501 & 0.75 & 0 & 0 & 0 & 0 & 0 & 0 & 2627 & 0.53 \\
\hline C15:0 & 10040 & 3.01 & 4572 & 0.23 & 3378 & 0.87 & 14690 & 3.37 & 6144 & 1.25 \\
\hline C16:0 & 117548 & 35.25 & 464493 & 23.21 & 149135 & 38.35 & 116516 & 26.7 & 154545 & 31.4 \\
\hline C16:1 & 6076 & 1.82 & 0 & 0 & 0 & 0 & 0 & 0 & 13988 & 2.84 \\
\hline C17:0 & 0 & 0 & 4213 & 0.21 & 1940 & 0.5 & 1946 & 0.45 & 2070 & 0.42 \\
\hline C18:0 & 148095 & 44.41 & 361523 & 18.07 & 189799 & 48.81 & 133169 & 30.51 & 152728 & 31.03 \\
\hline C18:1s & 21064 & 6.32 & 1015434 & 50.74 & 26119 & 6.72 & 138215 & 31.67 & 118302 & 24.04 \\
\hline C18:2 & 587 & 0.18 & 129175 & 6.45 & 2851 & 0.73 & 14594 & 3.34 & 14956 & 3.04 \\
\hline C18:3w3 & 3233 & 0.97 & 0 & 0 & 0 & 0 & 0 & 0 & 0 & 0 \\
\hline C20:0 & 4256 & 1.28 & 3685 & 0.18 & 4890 & 1.26 & 5998 & 1.37 & 2098 & 0.43 \\
\hline C20:1 & 6842 & 2.05 & 3470 & 0.17 & 3076 & 0.79 & 5412 & 1.24 & 6449 & 1.31 \\
\hline C24:0 & 4388 & 1.32 & 0 & 0 & 0 & 0 & 0 & 0 & 6222 & 1.26 \\
\hline Total & 333479 & 100 & 2001201 & 100 & 388851 & 100 & 436418 & 100 & 492139 & 100 \\
\hline Identification & & Large herbivore & $\begin{array}{l}\text { Borderlin } \\
\text { Very high }\end{array}$ & $\begin{array}{l}\text { High and } \\
\text { it content }\end{array}$ & Large 1 & bivore & $\begin{array}{r}\text { Large h } \\
\text { fat (fatt } \\
\text { lean mea }\end{array}$ & $\begin{array}{l}\text { ivore } \& \\
\text { meat or } \\
\text { nd plant }\end{array}$ & $\begin{array}{r}\text { Large he } \\
\text { fat (fatty } \\
\text { lean meat } \\
0\end{array}$ & $\begin{array}{l}\text { ivore } \& \\
\text { neat or } \\
\text { nd plant }\end{array}$ \\
\hline \multirow{2}{*}{ Fatty acid } & \multicolumn{2}{|r|}{ 7UT 34} & \multicolumn{2}{|c|}{ 7UT 35} & \multicolumn{2}{|c|}{ 7UT 37} & \multicolumn{2}{|c|}{ 7UT 38} & \multicolumn{2}{|c|}{ 7UT 39} \\
\hline & Area & Rel\% & Area & Rel\% & Area & Rel\% & Area & Rel\% & Area & Rel\% \\
\hline C12:0 & 388 & 0.07 & 2135 & 0.33 & 0 & 0 & 0 & 0 & 0 & 0 \\
\hline C14:0 & 17649 & 3.17 & 10454 & 1.63 & 5984 & 1.67 & 7009 & 1.12 & 7265 & 0.59 \\
\hline C14:1 & 2722 & 0.49 & 0 & 0 & 0 & 0 & 0 & 0 & 0 & 0 \\
\hline C15:0 & 10569 & 1.9 & 29297 & 4.57 & 1064 & 0.3 & 2414 & 0.38 & 3213 & 0.26 \\
\hline C16:0 & 182846 & 32.81 & 108018 & 16.84 & 135570 & 37.8 & 145322 & 23.17 & 243453 & 19.64 \\
\hline C16:1 & 4647 & 0.83 & 1366 & 0.21 & 3333 & 0.93 & 12763 & 2.04 & 3234 & 0.26 \\
\hline C17:0 & 5557 & 1 & 4556 & 0.71 & 1687 & 0.47 & 1800 & 0.29 & 4061 & 0.33 \\
\hline C18:0 & 188123 & 33.76 & 84965 & 13.24 & 186492 & 52 & 122263 & 19.5 & 153244 & 12.36 \\
\hline C18:1s & 113219 & 20.32 & 328522 & 51.21 & 15491 & 4.32 & 277111 & 44.19 & 710763 & 57.35 \\
\hline C18:2 & 6052 & 1.09 & 33393 & 5.2 & 1729 & 0.48 & 33282 & 5.31 & 91066 & 7.35 \\
\hline C18:3w3 & 0 & 0 & 12626 & 1.97 & 0 & 0 & 0 & 0 & 0 & 0 \\
\hline C20:0 & 9981 & 1.79 & 3125 & 0.49 & 7263 & 2.03 & 6774 & 1.08 & 7711 & 0.62 \\
\hline C20:1 & 15520 & 2.78 & 14509 & 2.26 & 0 & 0 & 6688 & 1.07 & 5224 & 0.42 \\
\hline C24:0 & 0 & 0 & 8600 & 1.34 & 0 & 0 & 11674 & 1.86 & 10125 & 0.82 \\
\hline Total & 557273 & 100 & 641566 & 100 & 358613 & 100 & 627100 & 100 & 1239359 & 100 \\
\hline Identification & \multicolumn{2}{|c|}{$\begin{array}{l}\text { Large herbivore \& fat (fatty meat or lean } \\
\text { meat and plant oil) }\end{array}$} & \multicolumn{2}{|c|}{$\begin{array}{l}\text { Borderline High and } \\
\text { Very high fat content }\end{array}$} & \multicolumn{2}{|c|}{ Large Herbivore } & \multicolumn{2}{|c|}{ High fat content } & \multicolumn{2}{|c|}{ Very high fat content } \\
\hline
\end{tabular}


The level of C18:1 isomers in two other residues, 7UT 26 and 7UT 35, is slightly lower, between 50.74\% and 51.21\%. The fat content of these residues falls on the border between very high and high. High fat content residues can result from the processing of locally available high fat content seeds and nuts or rendered animal fat (other than large herbivore). While it is possible they represent the decomposed residues of either plant or animal material, both residues have somewhat elevated C18:2 levels and relatively low levels of C18:0, suggesting they are of plant origin.

Residue 7UT 38 is characterized by C18:1 isomer levels of about 44\%, somewhat elevated levels of C18:2 and a relatively low level of C18:0. Locally available high fat content seeds and nuts are likely the best candidate for this decomposed residue.

The remaining six residues have elevated levels of $\mathrm{C} 18: 0$, which is often associated with the preparation of large herbivore products. Large herbivore residues result from the preparation of bison, deer, moose, fat elk meat or other bovines or cervids; but javelina meat and tropical oil seeds also produce residues high in C18:0 and must be considered as potential sources where available. Levels of C18:0 are high, between $44 \%$ and 52\% in three residues, 7UT 16, 7UT 27 and 7UT 37, and levels of C18:1 isomers are low, between about $4 \%$ and $7 \%$. The combination of high levels of C18:0 and low levels of C18:1 isomers is found in the decomposed cooking residues of lean meat; however, sotol seeds, which is a type of tropical oilseed, produce similar residues. While levels of C18:0 exceed 30\% in three other residues, 7UT 29, 7UT 32 and 7UT 34, levels of C18:1 isomers are also quite high, ranging from $20 \%$ to $32 \%$. Decomposed residues with similar fatty acid compositions result from the preparation of fatty large herbivore (or javelina) meat alone. Alternatively, combinations of lean meat (or sotol seeds) and plant seeds or nuts with moderate-high to very high fat content would also produce residues with similar fatty acid compositions. It may also be useful to obtain radiocarbon dates on the organic component of these rocks to strengthen the assertion that the burned rock residues are cultural, not natural. 


\section{References Cited:}

Collins M. B., B. Ellis, and C. Dodt-Ellis

1990 Excavations at the Camp Pearl Wheat Site (41KR243): An Early Archaic Campsite on Town Creek, Kerr County, Texas. Studies in Archaeology 6. Texas Archaeological Research Laboratory, The University of Texas at Austin.

Condamin, J., F. Formenti, M.O. Metais, M. Michel, and P. Blond

1976 The Application of Gas Chromatography to the Tracing of Oil in Ancient Amphorae. Archaeometry 18(2):195-201.

deMan, J.M

1992 Chemical and Physical Properties of Fatty Acids. In Fatty Acids in Foods and their Health Implications, edited by C. K. Chow, pp. 17-39. Marcel Dekker, New York.

Evershed, R.P., C. Heron, and L.J. Goad

1990 Analysis of Organic Residues of Archaeological Origin by High Temperature Gas Chromatography and Gas Chromatography-Mass Spectroscopy. Analyst 115:1339-1342.

Folch, J., M. Lees, and G.H. Sloane-Stanley

1957 A Simple Method for the Isolation and Purification of Lipid Extracts from Brain Tissue. Journal of Biological Chemistry 191:833.

Frankel, E.N.

1991 Recent Advances in Lipid Oxidation. Journal of the Science of Food and Agriculture 54:465-511.

Loy, T.

1994 Residue Analysis of Artifacts and Burned Rock from the Mustang Branch and Barton Sites (41HY209 and 41HY202). In: Archaic and Late Prehistoric Human Ecology in the Middle Onion Creek Valley, Hays County, Texas. Volume 2: Topical Studies, by R. A. Ricklis and M. B. Collins, pp. 607- 627. Studies in Archeology 19, Texas Archaeological Research Laboratory, The University of Texas at Austin.

Malainey, M.E.

1997 The Reconstruction and Testing of Subsistence and Settlement Strategies for the Plains, Parkland and Southern Boreal Forest. Unpublished Ph.D. thesis, University of Manitoba.

Malainey, M.E., K.L. Malisza, R. Przybylski, and G. Monks

2001a The Key to Identifying Archaeological Fatty Acid Residues. Paper presented at the $34^{\text {th }}$ Annual Meeting of the Canadian Archaeological Association, Banff, Alberta, May 2001.

Malainey, M.E., R. Przybylski, and B.L. Sherriff

1999a The Fatty Acid Composition of Native Food Plants and Animals of Western Canada. Journal of Archaeological Science 26:83-94.

1999b The Effects of Thermal and Oxidative Decomposition on the Fatty Acid Composition of Food Plants and Animals of Western Canada: Implications for the Identification of archaeological vessel residues. Journal of Archaeological Science 26:95-103.

1999c Identifying the Former Contents of Late Precontact Period Pottery Vessels from Western Canada Using Gas Chromatography. Journal of Archaeological Science 26(4): 425-438.

2001b One Person's Food: How and Why Fish Avoidance May Affect the Settlement and Subsistence Patterns of HunterGatherers. American Antiquity 66(1): 141-161. 
Malainey, M.E., R. Przybylski, and G. Monks

2000a The Identification of Archaeological Residues Using Gas Chromatography and Applications to Archaeological Problems in Canada, United States and Africa. Paper presented at The $11^{\text {th }}$ Annual Workshops in Archaeometry, State University of New York at Buffalo, February 2000.

2000b Refining and Testing the Criteria for Identifying Archaeological Lipid Residues Using Gas Chromatography. Paper presented at the 33rd Annual Meeting of the Canadian Archaeological Association, Ottawa, May 2000.

2000c Developing a General Method for Identifying Archaeological Lipid Residues on the Basis of Fatty Acid Composition. Paper presented at the Joint Midwest Archaeological \& Plains Anthropological Conference, Minneapolis, Minnesota, November 2000.

Marchbanks, M.L.

1989 Lipid Analysis in Archaeology: An Initial Study of Ceramics and Subsistence at the George C. Davis Site. Unpublished M.A. thesis, The University of Texas at Austin.

Marchbanks, M.L., and J.M. Quigg

1990 Appendix G: Organic Residue and Phytolith Analysis. In Phase II Investigations at Prehistoric and Rock Art Sites, Justiceburg Reservoir, Garza and Kent Counties, Texas, Volume II, by D. K. Boyd, J. T. Abbott, W. A.Bryan, C. M. Garvey, S. A. Tomka and R. C. Fields. pp. 496-519. Reports of Investigations No. 71. Prewitt and Associates, Inc, Austin.

Patrick, M., A.J. de Konig, and A.B. Smith

1985 Gas Liquid Chromatographic Analysis of Fatty Acids in Food Residues from Ceramics Found in the Southwestern Cape, South Africa. Archaeometry 27(2): 231-236.

Quigg, J.M., C. Lintz, S. Smith, and S. Wilcox

2000 The Lino Site: A Stratified Late Archaic Campsite in a Terrace of the San Idelfonzo Creek, Webb County, Southern Texas. Technical Report No. 23765, TRC Mariah Associates Inc., Austin. Archaeological Studies Program Report 20. Environmental Affairs Division, Texas Department of Transportation, Austin.

Quigg, J.M., M.E. Malainey, R. Przybylski, and G. Monks

2001 No Bones about It: Using Lipid Analysis of Burned Rock and Groundstone Residues to Examine Late Archaic Subsistence ractices in South Texas. Plains Anthropologist 46(177): 283-303.

Skibo, J.M.

1992 Pottery Function: A Use-Alteration Perspective. Plenum Press, New York.

Solomons, T.W.G.

1980 Organic Chemistry. John Wiley \& Sons, Toronto. 



\section{Appendix C:}

Diatom Paleoenvironmental Analysis of Middle and

Late Archaic Material from the Granberg Archeological

Site (41BX17), Bexar County, Texas

Barbara M. Winsborough 



\title{
Appendix C
}

\section{Diatom Paleoenvironmental Analysis of Middle and Late Archaic Material from the Granberg Archeological Site (41BX17), Bexar County, Texas}

\author{
Barbara M. Winsborough \\ Winsborough Consulting \\ Glen Ribbit, 23606 Round Mountain Circle, Leander, Texas 78641
}

\section{Introduction}

Diatoms are unicellular, pigmented, photosynthetic algae distinguished by the possession of a silica cell wall. Diatoms can be found living in a wide variety of natural and man-made terrestrial and aquatic habitats, including seeps, wet walls, dry and damp soil, springs, streams, creeks, sloughs, lakes, rivers, canals, ponds, marshes, lagoons, estuaries, bays, and oceans. Most are cosmopolitan - found in many parts of the world under similar environmental conditions, and many species have predictable environmental requirements and pollution tolerances. Therefore water quality directly effects diatom species composition. Diatoms can be readily identified to species, and a large and growing body of information exists on the range of ecological tolerance of many common taxa. Large diatom data sets from various parts of the world have shown that living diatom communities provide reliable analogs for estimates of past salinity, depth, trophic (nutrient) level, $\mathrm{pH}$, habitat, and (indirectly) climate. Since diatoms are sensitive to so many physical and chemical parameters, and are often found in large numbers in sedimentary deposits, they are well-suited for use in paleoenvironmental reconstruction.

Diatom life forms include free-floating planktonic (lives suspended in the water column) and tychoplanktonic (opportunistically planktonic during turbid periods) taxa; and benthic species, associated with sediment, microbial mats and vegetation at or near the floor of a stream or lake. Motile benthic forms glide through mud (epipelic), and others are firmly attached to macrophytes or larger algae (epiphytic), rock (epilithic) and sand (epipsammic). Related to the benthic diatoms, in terms of overlapping habitats, are the aerophilic (commonly found living exposed to air) or sediment diatoms that are adapted to damp or dry habitats.

This report presents the results of a diatom paleoenvironmental analysis of 18 soil samples from Middle and Late Archaic intervals of the Granberg Site, 41BX17, a multi-component site in northeastern San Antonio in Bexar County, Texas. The site, occupied from about 4000 BC to AD 1200, is located along the east bank of Salado Creek. Salado Creek is a spring-fed freshwater stream about 44 miles long in the San Antonio River Basin. It arises just north of San Antonio, flows around the city, and joins the San Antonio River just south of town.

\section{Methods}

Samples were cleaned of organic material and soluble minerals in preparation for microscopic analysis by boiling first in hydrogen peroxide and then in hydrochloric acid. The oxidized, decalcified material was rinsed repeatedly until a pH of about 6-7 was reached. A few drops of the cleaned material was air-dried onto $22 \times 22 \mathrm{~mm}$ cover glasses and mounted onto glass slides using NAPHRAX ${ }^{\odot}$ a synthetic resin with a high index of refraction, developed to aid in resolving the details of diatom cell wall morphology. Each slide was scanned at 600x magnification, until 500 diatoms were recorded, or the entire slide was scanned and all diatoms and diatom fragments were recorded.

\section{Results}

A complete list of the samples analyzed in included on Table C-1. The names and amounts of each of the diatom species found during this study are listed on Table C-2. Six of the 18 samples, numbers 7, 9, 11, 14, 15, and 16 were barren of diatoms. The 
other samples contained variable numbers and kinds of diatoms. A total of 594 diatoms belonging to 26 soil and freshwater species, and 7 brackish or marine species were recorded from the 12 diatomaceous samples. Three basic kinds of diatoms were found in the samples: aquatic freshwater species, aerophilous soil, moss and mud species, and marine species. The aquatic and mud diatoms are often found together in habitats that are seasonally dry or in riparian areas where the habitats of aquatic diatoms and mud species meet. The marine species do not co-occur with the freshwater and aerophilous diatoms found in the samples.

Table C-1. List of Samples Analyzed from the Granberg Site, 41BX17

\begin{tabular}{|c|c|c|c|c|c|c|c|c|c|}
\hline Sample \# & FS\# & Ext \# & Feature & Test Unit & Northing & Easting & Level & Top el. (bd) & Bottom el. (bd) \\
\hline 1 & 62 & 4 & 0 & 3 & 567 & 1006 & 5 & 40 & 50 \\
\hline 2 & 73 & 1 & 0 & 3 & 567 & 1006 & 6 & 50 & 60 \\
\hline 3 & 85 & 1 & 0 & 3 & 571 & 1006 & 7 & 60 & 70 \\
\hline 4 & 40 & 1 & 0 & 5 & 571 & 1004 & 1 & 0 & 10 \\
\hline 5 & 45 & 1 & 0 & 5 & 571 & 1004 & 2 & 12 & 20 \\
\hline 6 & 56 & 3 & 101 & 5 & 571 & 1004 & 5 & 45 & 50 \\
\hline 7 & 59 & 2 & 102 & 5 & 571 & 1004 & 6 & 56 & 60 \\
\hline 8 & 75 & 1 & 104 & 5 & 571 & 1004 & 7 & 60 & 70 \\
\hline 9 & 80 & 1 & 0 & 5 & 571 & 1004 & 8 & 75 & 80 \\
\hline 10 & 81 & 2 & 0 & 5 & 571 & 1004 & 9 & 85 & 90 \\
\hline 11 & 84 & 1 & 0 & 5 & 571 & 1004 & 10 & 90 & 100 \\
\hline 12 & 88 & 1 & 0 & 5 & 571 & 1004 & 11 & 105 & 110 \\
\hline 13 & 94 & 1 & 0 & 5 & 571 & 1004 & 12 & 110 & 115 \\
\hline 14 & 99 & 1 & 0 & 5 & 571 & 1004 & 13 & 125 & 130 \\
\hline 15 & 102 & 1 & 0 & 5 & 571 & 1004 & 14 & 130 & 135 \\
\hline 16 & 106 & 1 & 0 & 5 & 571 & 1004 & 15 & 140 & 145 \\
\hline 17 & 110 & 1 & 0 & 5 & 571 & 1004 & 16 & 155 & 160 \\
\hline 18 & 47 & 3 & 100 & 6 & 571 & 1005 & 3 & 20 & 30 \\
\hline
\end{tabular}

\section{Discussion}

Paleoenvironmental analysis is based on recorded occurrences of the diatoms in question, coupled with the experience of the taxonomist in analyzing diatom samples from the same area. These data provide the basis for establishing modern analogs for the interpretation of paleoenvironmental conditions. Published information about the individual diatoms found during this investigation is summarized on Table C-3. The references from which the information was obtained are included in the References section of the report.

The most abundant group of diatoms found at this site is aquatic, benthic species (a few of the benthic species are also opportunistically planktonic). The benthic diatoms include epiphytic, epilithic, epipsammic, and epipelic species. These species are typically found in shallow streams, and around the edge of ponds attached to vegetation, sand, pebbles or rocks. Another distinct group of diatoms well-represented in this assemblage includes the aerophilic species, found typically in the soil and mud of marginal, occasionally or temporarily wet habitats. These taxa live along the banks of streams and the upper margins of ponds and lakes and are often found together with the aquatic species in very shallow habitats with fluctuating water levels.

Some of the samples contained very few diatoms (Table C-2) but the diatoms that were found are similar in environmental requirements and limitations, and are found typically in shallow carbonate-rich streams. Some general observations can be made about the paleoenvironment of the assemblage as a whole. The benthic (aquatic) and aerophilic groups of diatoms in these samples are all typical of what might be found in a Central Texas, limestone spring-fed stream. All have $\mathrm{pH}$ preferences 
Table C-2. List of Diatoms Found in Sediment Samples from 41BX17

\begin{tabular}{|c|c|c|c|c|c|c|c|c|c|c|c|c|c|}
\hline Type & Diatom name & 1 & 2 & 3 & 4 & 5 & 6 & 8 & 10 & 12 & 13 & 17 & 18 \\
\hline \multirow[t]{26}{*}{ Freshwater } & $\begin{array}{c}\text { Achnanthidium biasolettianum (Grunow) } \\
\text { Lange-Bertalot }\end{array}$ & & 1 & 4 & & & & & & & 2 & 2 & \\
\hline & $\begin{array}{c}\text { Achnanthidium minutissimum (Kützing) } \\
\text { Czarnecki }\end{array}$ & & 292 & & & & & & & & & & \\
\hline & Amphora pediculus (Kützing) Grunow & & 2 & & & & & & & & & & \\
\hline & Brachysira vitrea (Grunow) Ross & & 1 & & & & & & & & & & \\
\hline & Cocconeis pediculus Ehrenberg & & 22 & & & & & & & & & & \\
\hline & Cocconeis placentula Ehrenberg & & & 2 & & & & & & & & & \\
\hline & Cymbella delicatula Kützing & & 51 & & 2 & & & & & & & & \\
\hline & Cymbella excisa Kützing & & 15 & & & & & & & & & & \\
\hline & Denticula kuetzingii Grunow & & & & 2 & & & & & & & & \\
\hline & Encyonema evergladianum Krammer & & 1 & & & & & & & & & & \\
\hline & $\begin{array}{l}\text { Encyonema silesiacum (Bleisch in } \\
\text { Rabenhorst) D.G. Mann }\end{array}$ & & 20 & & & & & & & & & & \\
\hline & $\begin{array}{c}\text { Encyonopsis microcephala (Grunow) } \\
\text { Krammer }\end{array}$ & & 68 & & & & & & & & & & \\
\hline & Eucocconeis flexella (Kützing) Brun & & 1 & & & & & & & & & & \\
\hline & $\begin{array}{c}\text { Eunotia pectinalis (O.F. Müller) } \\
\text { Rabenhorst }\end{array}$ & & & & 2 & & & & & & & & \\
\hline & Fragilaria capucina Desmazières & & & & 2 & & & & & & & & \\
\hline & Fragilaria nanana Lange-Bertalot & & 4 & & & & & & & & & & \\
\hline & $\begin{array}{l}\text { Gomphonema angustatum (Kützing) } \\
\text { Rabenhorst }\end{array}$ & 1 & & & 2 & & 2 & & & & & & \\
\hline & Hantzschia abundans Lange-Bertalot & 3 & & & 14 & 8 & 2 & 1 & & & 2 & & 3 \\
\hline & $\begin{array}{c}\text { Luticola goeppertiana (Bleisch) D.G. } \\
\text { Mann }\end{array}$ & & 2 & & 1 & 1 & & & & & & & \\
\hline & Navicula cryptotenella Lange-Bertalot & & 5 & & & & & & & & & & \\
\hline & Navicula stroemii Hustedt & & 2 & & & & & & & & & & \\
\hline & Nitzschia amphibia Grunow & 4 & 3 & & & & & & 3 & & & & \\
\hline & Nitzschia amphibioides Hustedt & & 1 & & & & & & & & & & \\
\hline & $\begin{array}{c}\text { Staurosirella (Fragilaria) pinnata } \\
\text { Ehrenberg }\end{array}$ & & 4 & & & & & & & & & & \\
\hline & Surirella angusta Kützing & & & & & & & 2 & & & & & \\
\hline & Synedra ulna (Nitzsch) Ehrenberg & 5 & 5 & 1 & 2 & & & & & & & & \\
\hline Total & & 13 & 500 & 7 & 27 & 9 & 4 & 3 & 3 & $\mathbf{0}$ & 4 & 2 & 3 \\
\hline \multirow[t]{7}{*}{ Marine } & Chaetoceros sp. (fragments \& spores) & & & & & & & & & 3 & & & \\
\hline & Cocconeis sp. (frags.) & & & & & & & & & 2 & & & \\
\hline & Rouxia fusiformis Tsumura (frags.) & & & & & & & & & 3 & & & \\
\hline & Synedra fasciculata Kützing (frags.) & & & & & & & & & 3 & & & \\
\hline & $\begin{array}{c}\text { Thalassionema nitzschioides (Grunow) } \\
\text { Grunow (frags.) }\end{array}$ & & & & & & & & & 6 & & & \\
\hline & \begin{tabular}{|c|}
$\begin{array}{c}\text { Thalassiosira oestrupii (Ostenfeld) Hasle } \\
\text { (whole) }\end{array}$ \\
\end{tabular} & & & & & & & & & 1 & & & \\
\hline & Thalassiosira sp. (frag.) & & & & & & & & & 1 & & & \\
\hline Total & & & & & & & & & & 19 & & & \\
\hline
\end{tabular}


Table C-3. Ecological Characteristics of Diatoms in Samples from 41BX17

\begin{tabular}{|c|c|}
\hline Diatom name & Ecology \\
\hline $\begin{array}{l}\text { Achnanthidium biasolettianum (Grunow) } \\
\text { Lange-Bertalot }\end{array}$ & aquatic, benthic, in oligotrophic to mesotrophic carbonate-rich water with moderate to high conductivity \\
\hline $\begin{array}{c}\text { Achnanthidium minutissimum (Kützing) } \\
\text { Czarnecki }\end{array}$ & $\begin{array}{l}\text { aquatic, benthic, epiphytic and epilithic in brackish-fresh to fresh water, prefers flowing or at least well- } \\
\text { aerated fresh water, often a primary colonizer of disturbed habitats, oligohalobous-indifferent, tolerates } \\
\text { organic pollution, prefers carbonate-rich water (alkaliphilous), circumneutral pH. }\end{array}$ \\
\hline Amphora pediculus (Kützing) Grunow & $\begin{array}{l}\text { aquatic, benthic in shallow lakes, rivers, springs, and ponds, epiphytic and epipelic, oligohalobous- } \\
\text { indifferent, alkaliphilous, mesotrophic but can tolerate highly polluted environments, prefers carbonate-rich } \\
\text { water, circumneutral } \mathrm{pH}\end{array}$ \\
\hline Brachysira vitrea (Grunow) Ross & aquatic, benthic, oligotrophic, carbonate-rich water \\
\hline Cocconeis pediculus Ehrenberg & $\begin{array}{l}\text { aquatic, benthic, epiphytic, epipelic, oligohalobous-indifferent, medium to high conductivity \& brackish } \\
\text { water, alkaliphilous, current indifferent, eurysaprobic }\end{array}$ \\
\hline Cocconeis placentula Ehrenberg & $\begin{array}{l}\text { aquatic, benthic in fresh to brackish water, epiphytic, epilithic, epipsammic, often a primary colonizer of } \\
\text { disturbed habitats, oligohalobous-indifferent, alkaliphilous, tolerates polluted water, inhibited by high light } \\
\text { intensities, circumneutral to slightly alkaline water, current indifferent }\end{array}$ \\
\hline Cymbella delicatula Kützing & aquatic, benthic, epiphytic, oligotrophic carbonate-rich water \\
\hline Cymbella excisa Kützing & aquatic, benthic, epilithic \& epiphytic in flowing and stagnant water \\
\hline Denticula kuetzingii Grunow & $\begin{array}{c}\text { aquatic, benthic, moderate to high conductivity, tolerate broad salinity concentrations and seasonally drying } \\
\text { conditions, flowing and standing water }\end{array}$ \\
\hline Encyonema evergladianum Krammer & $\begin{array}{c}\text { aquatic, benthic, epiphytic, circumneutral } \mathrm{pH} \text {, alkaliphilous to slightly brackish water, usually in flowing } \\
\text { water }\end{array}$ \\
\hline $\begin{array}{c}\text { Encyonema silesiacum (Bleisch in Rabenhorst) } \\
\text { D.G. Mann }\end{array}$ & $\begin{array}{c}\text { aquatic, benthic in fresh to brackish water, oligohalobous-indifferent, } \mathrm{pH} \text { indifferent, common in standing } \\
\text { and flowing water }\end{array}$ \\
\hline $\begin{array}{c}\text { Encyonopsis microcephala (Grunow) } \\
\text { Krammer }\end{array}$ & $\begin{array}{l}\text { aquatic, benthic, epiphytic, oligotrophic carbonate-rich water, moderate conductivity, oligohalobous- } \\
\text { indifferent, alkaliphilous, in well-aerated lakes and rivers, eurysaprobic }\end{array}$ \\
\hline Eucocconeis flexella (Kützing) Brun & aquatic, benthic, in lakes, ponds, and bogs, pH indifferent \\
\hline Eunotia pectinalis (O.F. Müller) Rabenhorst & aquatic, benthic, moderate conductivity, oligotrophic to eutrophic \\
\hline Fragilaria capucina Desmazières & $\begin{array}{c}\text { aquatic, benthic, orefers slightly alkaline water, indifferent to small amounts of sodium chloride, } \\
\text { eurysaprobic }\end{array}$ \\
\hline Fragilaria nanana Lange-Bertalot & aquatic, benthic, in flowing water \\
\hline $\begin{array}{l}\text { Gomphonema angustatum (Kützing) } \\
\text { Rabenhorst }\end{array}$ & $\begin{array}{l}\text { aquatic, benthic, epiphtic in fresh and brackish water, alkaliphilous, } \mathrm{pH} \text { neutral-slightly alkaline, oligotrophic } \\
\text { to eutrophic, eurosaprobic }\end{array}$ \\
\hline Hantzschia abundans Lange-Bertalot & $\begin{array}{l}\text { aerophilic, soil, sand and mud, fresh-brackish water, in exposed zones along pond and stream margins, } \\
\text { oligohalobous-indifferent, in damp leaf litter, becomes frequent after rewetting, tolerates droughts }\end{array}$ \\
\hline Luticola goeppertiana (Bleisch) D.G. Mann & $\begin{array}{c}\text { aerophilic, on moss, soil and mud, also aquatic, benthic, epiphytic, in moderately high conductivity water, } \\
\text { tolerates high levels of pollution }\end{array}$ \\
\hline Navicula cryptotenella Lange-Bertalot & $\begin{array}{l}\text { aquatic, epiphytic, benthic, tolerates a wide range from oligotrophic to eutrophic waters, tolerates brackish } \\
\text { water but prefers fresh water, oligohalobous-indifferent, mesosaprobic, indifferent to organic pollution }\end{array}$ \\
\hline Navicula stroemii Hustedt & aquatic, benthic, alkaliphilic, high conductivity, on waterfalls, springs, streams \\
\hline Nitzschia amphibia Grunow & $\begin{array}{l}\text { aquatic, benthic, epiphytic, epipelic, epilithic, in lakes, ponds, and streams, oligohalobous-indifferent, } \\
\text { alkaliphilous to alkalibiontic, pH over } 8 \text {, tolerant of a wide range from oligotrophic to eutrophic water, } \\
\text { tolerates fluctuations in osmotic pressure, can live in a thin film of water }\end{array}$ \\
\hline Nitzschia amphibioides Hustedt & $\begin{array}{l}\text { aquatic, benthic, streams and ponds, warm water, moderate to high conductivity, tolerate broad salinity } \\
\text { concentrations and seasonally drying conditions, flowing and standing water }\end{array}$ \\
\hline Staurosirella (Fragilaria) pinnata Ehrenberg & $\begin{array}{c}\text { aquatic, benthic and opportunistically planktonic, epipelic, tolerates a wide range from oligotrophic to } \\
\text { eutrophic waters, in fresh and brackish water, lakes and rivers, can survive variations in osmotic pressure } \\
\text { (drying), circumneutral to slightly alkaline } \mathrm{pH} \text {, oligohalobous, alkaliphilous, eutrophic, tolerates a broad } \\
\text { salinity range, eurysaprobic }\end{array}$ \\
\hline
\end{tabular}


Table C-3. Continued...

\begin{tabular}{|c|c|}
\hline Diatom name & Ecology \\
\hline Surirella angusta Kützing & aquatic, benthic, in warm, high conductivity water \\
\hline Synedra ulna (Nitzsch) Ehrenberg & $\begin{array}{l}\text { aquatic, planktonic and benthic in fresh-slightly brackish water, epiphytic, moderate conductivity, eutrophic } \\
\text { water, alkaliphilous, oligohalobous-indifferent, eutrophic, } \mathrm{pH} \text { indidfferent }\end{array}$ \\
\hline Chaetoceros sp. (fragments \& spores) & marine, planktonic \\
\hline Cocconeis sp. (frags.) & marine, benthic \\
\hline Rouxia fusiformis Tsumura (frags.) & marine, benthic \\
\hline Synedra fasciculata Kützing (frags.) & $\begin{array}{l}\text { brackish and marine, benthic and planktonic, halophilic, littoral zone, epiphytic, eurysaprobic, indicates } \\
\text { shallow, standing or stagnant water conditions, abundant in hypersaline water }\end{array}$ \\
\hline $\begin{array}{l}\text { Thalassionema nitzschioides (Grunow) } \\
\text { Grunow (frags.) }\end{array}$ & coastal marine, planktonic, polyhalobous, neritic, pelagic, common in coastal environments \\
\hline $\begin{array}{l}\text { Thalassiosira oestrupii (Ostenfeld) Hasle } \\
\text { (whole) }\end{array}$ & marine, planktonic \\
\hline Thalassiosira sp. (frag.) & marine, planktonic \\
\hline
\end{tabular}

that range from circumneutral (about 7) to definitely alkaline, living in a $\mathrm{pH}$ of at least 8 . The water was moderately to very rich in calcium carbonate as many of the diatoms are alkaliphils. The water was shallow enough or swift enough to exclude phytoplankton, probably vegetated, and clear enough to permit light to reach the bottom. The nutrient preferences of the diatoms suggest a range in trophic conditions (phosphate and nitrate concentrations) from moderate to eutrophic, but most, if not all are characteristically able to tolerate wide variations in organic pollution as well as at least moderate fluctuations in $\mathrm{pH}$ and salinity. The diatoms are indifferent to current velocity and many prefer flowing water (Table C-2). The water in which these diatoms grew could have been seasonal, at least in flow volume.

Diatoms were much more concentrated in sample 2 than in any other sample. Achnanthidium minutissimum (Kützing) Grunow, dominated the sample. It is an early colonizer (particularly on vegetation, rocks and pebbles) of freshly wetted, circumneutral to slightly alkaline, well-aerated habitats, in as shallow as a thin film of water. It is usually found in bright sun and is replaced by other taxa in mature aquatic settings. The rest of the diatoms are also benthic or aerophilic (Hantzschia abundans and Luticola goeppertiana). The diatoms probably lived in the same area where they were found. Achnanthidium minutissimum is a very small, delicate diatom that would show evidence of substantial transport. The gross surface area/volume ratio was found to be a useful index of a particular diatom species' propensity to dissolve. The good preservation and the number of benthic diatoms in the sample, in spite of the fact that the diatoms were heavily diluted with sediment, suggest that the material containing the benthic, aquatic and aerophilic diatoms may represent a habitat such as a disturbed or mucky stream or pond margin, where diatoms are mixed into the sediment by foot traffic. Anthropogenic transport of diatoms incidentally included when retrieving water or rocks for domestic purposes is also a consideration, depending on context.

Sample 12 contained a very different diatom assemblage. These are estuarine-marine diatoms found typically in the shallow areas of the coast. They were found embedded in an organic film, probably mucilage associated with a microbial mat. There are several ways that the marine fragments could wind up associated with an archaeological site. One mechanism is as inclusions in salt used to preserve meat. Diatoms accumulate in salt ponds during solar evaporation of water, both from seawater and from saline springs and ponds. They become trapped as impurities in the salt when it is collected. Another mechanism for transport of marine diatoms to the site is by means of seasonal vertebrate migrations. Diatomaceous mats contain abundant mucilage that can dry in the fur of large wading mammals and remain attached until washed off later, making bison (and migrating waterfowl) potential vectors. Discriminating between these various possibilities will require further analysis. A similar group of marine diatoms, also apparently embedded in mucilage, has now been found in 5 archaic sites in Texas. There are no precedents for the interpretation of these findings other than to speculate on the possibility that salt may have been an important commodity that was collected and traded or used further inland where it was needed as a preservative. 


\section{References Cited:}

Admiraal, W.

1984 The Ecology of Estuarine Sediment-inhabiting Diatoms. In Round, F., and D.J. Chapman eds., Progress in Phycological Research 3, Biopress Ltd., Bristol: 269-322.

Campeau, S., R. Pienitz, A. Héquette

1999 Diatoms from the Beaufort Sea Coast, Southern Arctic Ocean (Canada), Modern Analogues for Reconstructing Late Quaternary Environments and Relative Sea Levels. Bibliotheca Diatomologica 42:1-244.

Cumming, B.F., and J.P. Smol

1993 Development of Diatom-based Salinity Models for Paleoclimatic Research from Lakes in British Columbia (Canada). Hydrobiologia 269/270: 179-196.

Czarnecki, D.B.

1979 Epipelic and Epilithic Diatom Assemblages in Montezuma Well National Momument, Arizona. Journal of Phycology 15:346-352.

Ehrlich, A.

1995 Atlas of the Inland-water Diatom Flora of Israel. The Geological Survey of Israel, The Israel Academy of Sciences and Humanities, Jerusalem.

Evans, J.H.

1958 The Survival of Freshwater Algae during Dry Periods. Journal of Ecology 46:149-168.

1960 Further Investigations of the Algae of Pond Margins. Hydrobiologia 15:384-394.

Fritz, S.C., and R. W. Battarbee

1988 Sedimentary Diatom Assemblages in Freshwater and Saline Lakes of the Northern Great Plains, North America: Preliminary Results. In Proceedings of the $9^{\text {th }}$ International Diatom Symposium, edited by F.E. Round,pp. 265-271. Biopress Ltd., Bristol.

Garcia-Baptista, M.

1993 Psammic Algae from Praia Azul, Brazil. Bibliotheca Phycologica Band 94:1-167. J. Cramer, Berlin.

Gasse, F.

1986 East African Diatoms, Taxonomy, Ecological Distribution. Bibliotheca Diatomologica 11:1-201. J, Cramer, Berlin.

Gasse, F., and F. Tekaia

1983 Transfer Functions for Estimating Paleoecological Conditions (pH) from East African Diatoms. Hydrobiologia 103:85-90.

Haworth, E.Y.

1977 The sediments of Lake George (Uganda) V. the Diatom Assemblages in Relation to the Ecological History. Arch. Hydrobiol 80(2): 200-215.

Hodgson, D, W. Vyverman, and P. Tyler

1997 Diatoms of Meromictic Lakes Adjacent to the Gordon River, and of the Gordon River Estuary in South-west Tasmania. Bibliotheca Diatomologica Band 35:1-173. J. Cramer, Berlin. 
Krammer, K., and H. Lange-Bertalot

1991 Susswassweflora von Mitteleuropa Bd 2, Bacillariophyceae, Teil 4, Achnanthaceae. In H. Ettl, H. Gerloff, H Heynig, D. Mollenhauer (Hrg.), Gustav Fischer Stuttgart, New York.

Lange-Bertalot, H., and S.I. Genkal

1999 Diatoms from Siberia, 1. Islands in the Arctic Ocean (Yugorsky-Shar Strait). Iconographia Diatomologica 6:1-271.

Larson, D.D.

1974 Paleoecological Investigations of Diatoms in a Core from Kerguelen Islands, Southeast Indian Ocean. Institute of Polar Studies Report 50, The Ohio State University Research Foundation, pp. 1-61. Columbus, Ohio.

Maulood, B.K., and G.C. Hinton

1979 Tychoplanktonic Diatoms from a Stenothermal Spring in Iraqi Kurdistan. British Phycology Journal 14:175-183.

Metcalf, S.E., A. Bimpson, A.J. Courtice, S.L. O'Hara, and D.M. Taylor

1997 Climate Change at the Monsoon/Westerly Boundary in Northern Mexico. Journal of Paleolimnology 17:155-171.

Roberts, D., and A. McMinn

1999 Diatoms of the Saline Lakes of the Vestfold Hills, Antarctica. Biblioteca Diatomologica 44:1-81.

Round, F.E., R.M. Crawford \& D.G. Mann

1990 The Diatoms, Biology and Morphology of the Genera. Cambridge University Press, Cambridge.

Vos, P.C., and H. de Wolf

1993 Diatoms as a Tool for Reconstructing Sedimentary Environments in Coastal Wetlands; Methodological Aspects. Hydrobiologica 269/270: 285-296.

Watanabe, T., K. Asai, and A. Houki

1988 Numerical Water Quality Monitoring of Organic Pollution Using Diatom Assemblages. In Proceedings of the Ninth International Diatom Symposium, edited by F. Round, pp. 123-141. Biopress Ltd., Bristol and Koelts Scientific Books, Koenigstein..

Watanabe, T., and K. Asai

2004 Dominant Taxa in Epilithic Diatom Assemblages and Their Ecological Properties. In Seventeenth International Diatom Symposium, 2002, edited by M. Poulin, pp. 423-432. Biopress Limited, Bristol: 423-432.

Zalat, A.

2003 Paleoecological and Environmental History of Lake Mariut, Egypt, by Means of Diatoms. Diatom Research 18(1):161-184. 



\section{Appendix D: \\ Phytolith Analysis of Feature and Stratigraphic Samples from the Granberg Site, 41BX17, Bexar County, Texas \\ Chad Yost and Linda Scott Cummings}





\title{
Appendix D
}

\section{Phytolith Analysis of Feature and Stratigraphic Samples from the Granberg Site, 41BX17, Bexar County, Texas}

\author{
Chad Yost and Linda Scott Cummings \\ Paleo Research Institute, Inc. \\ Golden, Colorado
}

\section{Introduction}

Feature and stratigraphic samples from the Granberg Site, 41BX17, located in northeastern San Antonio, Bexar County, Texas, were submitted for plant opal phytolith analysis. This is a multi-component site with occupations that encompass a period from about 4000 BC to AD 1200. The site is located along the Salado Creek on a small knoll with scattered trees, shrubs and grasses (Munoz 2007). Currently, three major vegetation associations converge within the boundaries of Bexar County: 1) Edwards Plateau (mid-height grasses, oak and juniper), 2) Blackland Prairies (little bluestem and other tall grasses), and 3) South Texas Plains (tall grasslands and savannas; Lewis 1962). Phytolith analysis should provide general environmental and climatic information and help determine paleoenvironmental change since the earliest occupations of the site.

\section{Methods}

Extraction of phytoliths from these sediments was based on heavy liquid floatation. Sodium hypochlorite (bleach) was first used to destroy the organic fraction from $15 \mathrm{ml}$ of sediment. Once this reaction was complete, the samples were rinsed to remove the bleach. If the samples contained calcium carbonates, they were reacted with hydrochloric acid, then the samples were rinsed until neutral. A small quantity of sodium hexametaphosphate was added to each sample once it reached neutrality, then the samples were allowed to settle according to Stoke's Law in settling columns. This process was repeated with EDTA. These steps remove clay prior to heavy liquid separation. Next the samples were freeze dried. The dried silts and sands were then mixed with sodium polytungstate (density 2.3) and centrifuged to separate the phytoliths, which will float, from the other silica, which will not. Phytoliths, in the broader sense, might include opal phytoliths and calcium oxalate crystals. Calcium oxalate crystals are formed by Opuntia (prickly pear cactus),Yucca (yucca), and other plants, and they are separated, rather than destroyed, using this extraction technique if these forms have survived in the sediments. Any remaining clay was floated with the phytoliths and was further removed by mixing with sodium hexametaphosphate and distilled water. The samples were then rinsed with distilled water, then alcohols to remove the water. After several alcohol rinses, the samples were mounted in immersion oil for counting with a light microscope at a magnification of 500x. Phytolith diagrams are produced using Tilia, which was developed by Dr. Eric Grimm of the Illinois State Museum for diagraming pollen.

\section{Phytolith Review}

Phytoliths are silica bodies produced by plants when soluble silica in the ground water is absorbed by the roots and carried up to the plant via the vascular system. Evaporation and metabolism of this water result in precipitation of the silica in and around the cellular walls. Opal phytoliths, which are distinct and decay-resistant plant remains, are deposited in the soil as the plant or plant parts die and break down. They are, however, subject to mechanical breakage and erosion and deterioration in high $\mathrm{pH}$ soils. Phytoliths are usually introduced directly into the soils in which the plants decay. Transportation of phytoliths occurs primarily by animal consumption, gathering of plants by humans, or by erosion or transportation of the soil by wind, water, or ice.

The three major types of grass short-cell phytoliths include festucoid, chloridoid, and panicoid. Smooth elongate phytoliths are of no aid in interpreting either paleoenvironmental conditions or the subsistence record because they are produced by all 
grasses. Phytoliths tabulated to represent "total phytoliths" include the grass short-cells, buliform, trichome, elongate, and dicot forms. Frequencies for all other bodies recovered are calculated by dividing the number of each type recovered by the "total phytoliths".

The festucoid class of phytoliths is ascribed primarily to the Subfamily Pooideae and occur most abundantly in cool, moist climates. However, Brown (1984) notes that festucoid phytoliths are produced in small quantity by nearly all grasses. Therefore, while they are typical phytoliths produced by the Subfamily Pooideae, they are not exclusive to this subfamily. Chloridoid phytoliths are found primarily in the Subfamily Chloridoideae, a warm season grass that grows in arid to semi-arid areas and require less available soil moisture. Chloridoid grasses are the most abundant in the American Southwest (Gould 1983). Bilobates and polylobates are produced mainly by panicoid grasses, although a few of the festucoid grasses also produce these forms. Panicoid phytoliths occur in warm-season or tall grasses that frequently thrive in humid conditions. Twiss (1987:181) also notes that some members of the Subfamily Chloridoideae produce both bilobate (Panicoid) and Festucoid phytoliths. "According to (Gould 1983:110) more than $97 \%$ of the native US grass species $(1,026$ or 1,053) are divided equally among three subfamilies Pooideae, Chloridoideae, and Panicoideae" (Twiss 1987:181).

Buliform phytoliths are produced by grasses in response to wet conditions and are to be expected in wet habitats of floodplains and other places. Trichomes represent silicified hairs, which may occur on the stems, leaves, and the glumes or bran surrounding grass seeds.

Conifers produce opal silica phytoliths in their inner bark and needles. Polyhedral phytoliths are noted to be observed in leaves (Bozarth 1993), while the authors have observed the blocky forms in bark reference samples.

Woody plants often accumulate amorphous aggregates of silica embedded with debris. Here, the term "wood phytolith" is used to represent these forms. They cannot be identified to genus or even family; they simply represent woody tissue of trees or shrubs.

Lobate phytoliths are most characteristic of the grass subfamily Panicoideae (e.g., warm and moist season tall grass prairie species, sugarcane), but are also sometimes found in the Chloridoideae (e.g., warm and dry season short grass prairie species, cord grass), Erhartoideae (e.g., white rice, North American wild rice) and Bambusoideae (bamboos). Lobate phytoliths are typically comprised of two lobes joined by a shank, and have been described as resembling a dumbbell. The lobate phytolith classification used here is based on: (1) the length of the lobate shank and (2) the shape of the outer margin of the two lobes. This lobate classification follows that used by $\mathrm{Lu}$ and Liu (2003) and their analysis of 250 modern grass species. Their work demonstrated a link between lobate phytolith morphology, grass taxonomy and environmental conditions. Detailed bilobate phytolith classification can potentially detect the presence of economically and culturally significant grass species. In addition, detailed bilobate classification might be more sensitive to subtle precipitation change than that detectable by festucoid, chloridoid and panicoid relative abundance.

A few diatoms and sponge spicules also were noted. Pennate diatoms are cosmopolitan, occurring in many sediments, and they indicate at least some soil moisture. Sponge spicules represent fresh water sponges. Diatoms are single-celled algae with a siliceous cell wall. They grow in a wide range of aerophilous habitats, including on wet plants and rocks, in damp soils, marshes, wetlands, mudflats, and all types of standing and flowing aquatic habitats. Their silica cells often are preserved in sedimentary deposits. Because individual taxa have specific requirements and preferences with respect to water chemistry, hydrologic conditions, and substrate characteristics, the presence (and subsequent identification to the species level) of diatoms in paleoenvironmental context can provide information about the nature of the local environment. These data, coupled with input about local geology, hydrology, soil characteristics, pollen and phytoliths, provide evidence of the paleoenvironmental setting. In the context of phytolith samples, diatoms are noted but not identified beyond the split of "pennate" and "centric" forms. Centric diatoms often indicate wet conditions, while at least some of the pennate diatoms are cosmopolitan, occurring nearly everywhere. Both diatoms and sponge spicules can be transported with sediment. As an illustration, recovery of sponge spicules in upland soils is noted to accompany loess deposits derived from floodplains in Illinois (Jones 1963). 
Table D-1. Provenience Data for Samples from Site 41BX17

\begin{tabular}{|c|c|c|c|c|c|c|c|}
\hline Sample No. & FS No. & $\begin{array}{c}\text { Feature } \\
\text { No. }\end{array}$ & Test Unit & Level & Location & Radiocarbon Dates & Analysis \\
\hline 1 & 62 & 0 & 3 & 5 & N567, E1006 & & Phytolith \\
\hline 2 & 73 & 0 & 3 & 6 & N567, E1006 & & Phytolith \\
\hline 3 & 85 & 0 & 3 & 7 & N567, E1006 & & Phytolith \\
\hline 4 & 40 & 0 & 5 & 1 & N571, E1004 & & Phytolith \\
\hline 5 & 45 & 0 & 5 & 2 & N571, E1004 & & Phytolith \\
\hline 18 & 47 & 100 & 6 & 3 & N571, E1005 & 2010-1860 cal BP & Phytolith \\
\hline 6 & 56 & 101 & 5 & 5 & N571, E1004 & & Phytolith \\
\hline 7 & 59 & 102 & 5 & 6 & N571, E1004 & & Phytolith \\
\hline 8 & 75 & 104 & 5 & 7 & N571, E1004 & $4290-4080$ cal BP & Phytolith \\
\hline 9 & 80 & 0 & 5 & 8 & N571, E1004 & & Phytolith \\
\hline 10 & 81 & 0 & 5 & 9 & N571, E1004 & & Phytolith \\
\hline 11 & 84 & 0 & 5 & 10 & N571, E1004 & & Phytolith \\
\hline 12 & 88 & 0 & 5 & 11 & N571, E1004 & & Phytolith \\
\hline 13 & 94 & 0 & 5 & 12 & N571, E1004 & & Phytolith \\
\hline 14 & 99 & 0 & 5 & 13 & N571, E1004 & & Phytolith \\
\hline 15 & 102 & 0 & 5 & 14 & N571, E1004 & & Phytolith \\
\hline 16 & 106 & 0 & 5 & 15 & N571, E1004 & $4830-4520$ cal BP & Phytolith \\
\hline 17 & 110 & 0 & 5 & 16 & N571, E1004 & & \\
\hline
\end{tabular}

\section{Discussion}

The Granberg Site (41BX17) is a multi-component site with occupations that encompass a period from about $4000 \mathrm{BC}$ to AD 1200. The site is located along the Salado Creek on a small knoll with scattered trees, shrubs and grasses. Phytolith analysis was conducted on samples from Test Units 3, 5 and 6, all within Block I (Table D-1). Test Units 5 and 6 are about 3 meters north of Test Unit 3. One meter of overburden was removed from each unit prior to excavation.

Three stratigraphic samples, representing levels 5, 6, and 7, were examined from Test Unit 3 (N567, E1006). No features are represented by these samples; however, level 8 does contain a hearth feature with a radiocarbon age range of 3980-3820 cal years BP. One interesting aspect of these three samples is the large quantity of microscopic charcoal (Figure D-1) remaining in the samples. Also, these samples contain some of the highest percentages of festucoid-type phytoliths associated with coolseason grasses (Figure D-2).

Fourteen stratigraphic/feature samples from Test Unit 5 (N571, E1004) and one sample from Test Unit 6 (N571, E1005) were examined for phytoliths. Units 5 and 6 are adjacent to each other, and all levels, except level 4, were part of the samples submitted for analysis. Several features are associated with these samples. Feature 100, a large burned rock cluster/ hearth feature (2010-1860 cal BP) is represented by sample number 18. Feature 101, a burned rock cluster/hearth feature is represented by sample number 6 . Feature 102, a hearth feature, is represented by sample number 7 . Feature 104, burned rock scatter (4298-4080 cal BP), is represented by sample number 8. A dense gravel stratum, which encompasses much of levels 7, 8 and 9, might have been deposited relatively quickly, and might have been the result of a flooding event. Samples 8, 9 and 10 are phytolith samples analyzed from within this dense gravel stratum. For interpretive purposes, sample 18 (Test Unit 6, level 3) was placed within the samples from Test Unit 5 to better represent its stratigraphic provenience. Although samples 4 through 18 represent a stratigraphic record suitable for recording environmental change, the thermal features in levels 3 , 5, 6 and 7 might have influenced phytolith deposition, both as the result of fuels and foods burned, and in the microhabitats that they create after abandonment. 


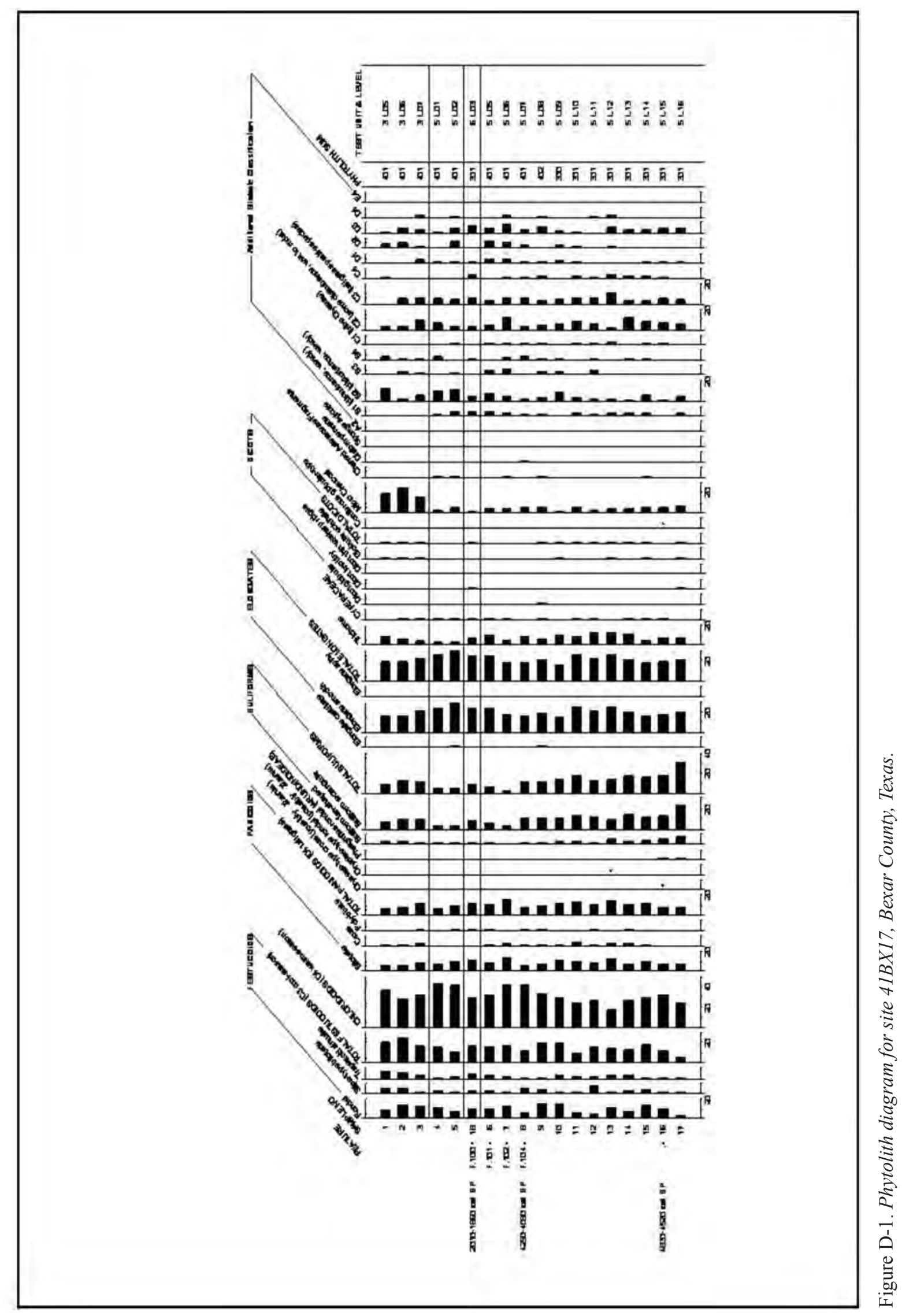


Phytoliths representative of warm season, arid to semi-arid $\mathrm{C}_{4}$ chloridoid grasses are dominant throughout all of the samples examined, with values that fluctuate between 40 and $65 \%$ of the total phytolith assemblage (Figure D-2). Dominant chloridoid grass species for the North American Great Plains include grama grass (Bouteloua sp.), buffalo grass (Buchloe dactyloides), and plains muhly (Muhlenbergia sp.). Modern West Texas grasslands are dominated by grama grass and buffalo grass.

Phytoliths representative of cool season $\mathrm{C}_{3}$ festucoid grasses are the second most abundant phytolith type for all samples examined, with values ranging from $15 \%$ to as high as $45 \%$ of the total grass short cell phytolith assemblage (Figure D-2). Dominant festucoid grass species for the North American Great Plains include Kentucky bluegrass (Poa sp.), fescue (Festuca sp.), junegrass (Koeleria sp.), western wheatgrass (Agropyron sp.), wild rye (Elymus sp.), and foxtail barley (Hordeum sp.). Festucoids have no large scale dominance in Texas; however, festucoids can be dominant on a smaller-scale, especially within more suitable microhabitats. Festucoids can also be temporally dominant during cool and moist periods; however, the phytolith record would most likely still be dominated by warm-season chloridoidtype phytoliths.

Phytoliths representative of tall grass, warm-season $\mathrm{C}_{4}$ panicoids, which typically thrive in humid conditions, are slightly less abundant than the $\mathrm{C}_{3}$ festucoids. Their values fluctuate around $20 \%$ throughout all of the samples examined (Figure 2). Panicoid grasses such as big bluestem (Andropogon gerardii), Indian grass (Sorghastrum sp.), and switch grass (Panicum sp.) were common and co-dominant in portions of eastern Texas grasslands at the time of European settlement. Specifically, grasslands dominated by the panicoid big bluestem (Andropogon) and the chloridoid gramma grass (Bouteloua) stretched from eastern Texas to western Minnesota. Bexar County, Texas, lies within the historic range of this big bluestem/gramma grass dominated grassland.

In their study of modern phytolith assemblages from the North American Great Plains, Fredlund and Tieszen (1994) analyzed 50 grassland soil samples, including 5 from modern Texas grasslands. Overall, the phytolith assemblage throughout the

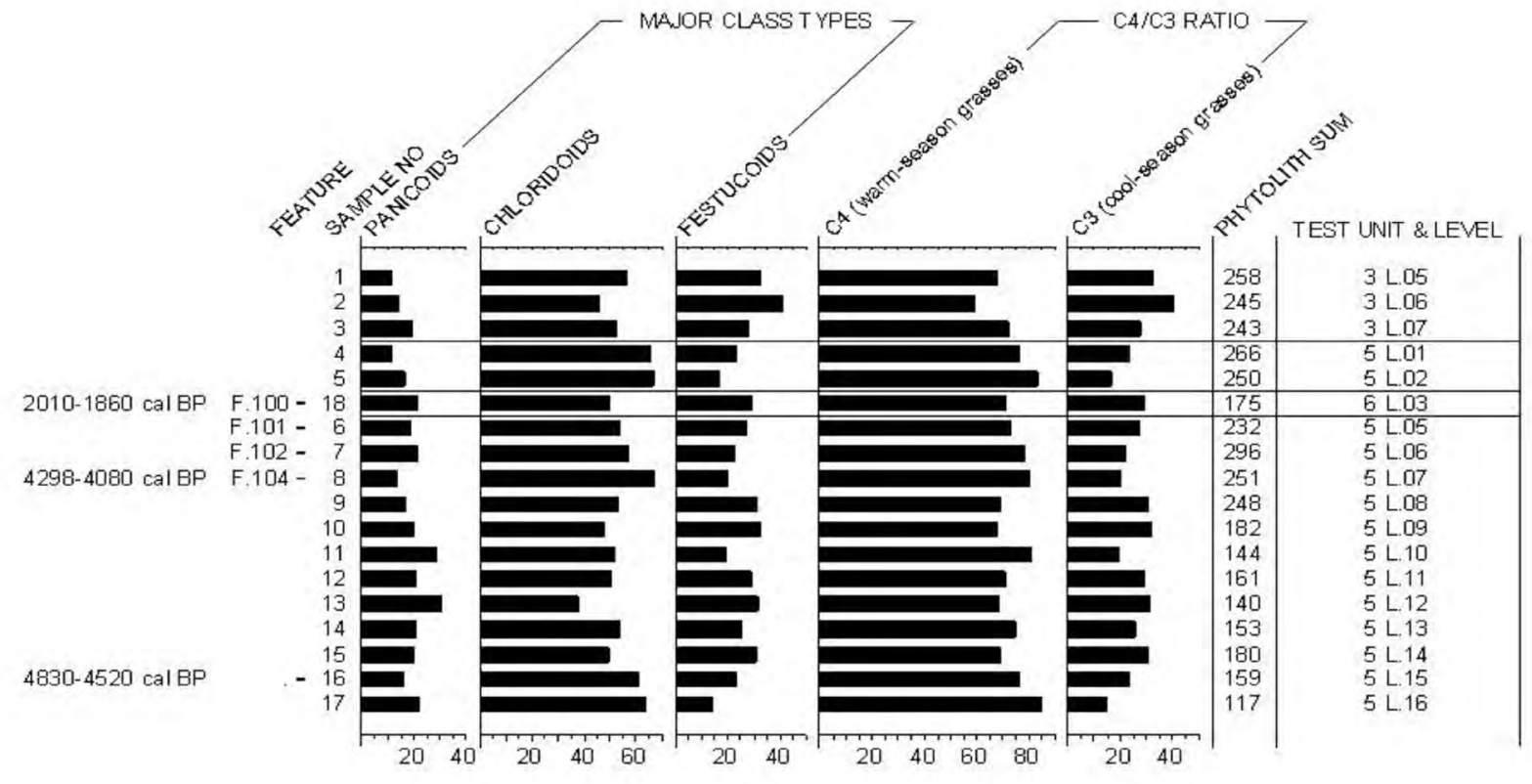

Figure D-2. Major phytolith class and C4/C3 ratio diagram for site 41BX17. 
stratigraphic record is fairly stable and most closely matched with modern phytolith assemblages of a bluestem/grama grass dominated grassland. Typically, native grama grass/buffalo grass dominated grasslands, of western Texas, western Oklahoma, and eastern Colorado have chloridoid phytolith percentages between 65 and $70 \%$. For the samples examined here, at only a few times do the chloridoid percentages exceed $60 \%$. They are typically between 50 and $55 \%$, and are as low as $40 \%$ in the sample 13 from Test Unit 5, Level 12. This suggests that moisture and temperatures were moderate and favorable for both tall grass panicoids and grama grasses. Further, with $\mathrm{C}_{3}$ festucoid values of $20 \%$ or more throughout much of the record, this suggests that cool-season grasses were a significant part of the regional grass assemblage. Also, the bilobate phytolith record, with the prominence of the bilobate-type associated with tall grass prairie species, further supports tall grass presence (Figure D-1, bilobate classification).

Although the phytolith record is overall fairly stable, subtle variations within the record are evident, as well as an overall trend from wetter to dryer conditions at the site. Most indicative of a wetter past is the presence of rondel phytoliths diagnostic of the wetland obligate common reed (Phragmites) in Test Unit 5, levels 15 and 16 (Figure D-1). Also, buliform phytoliths are produced by grasses in response to wet conditions and are to be expected in wet habitats of floodplains and other similar places. The buliform record has its highest relative abundance in samples 16 and 17, and gradually decreases there after. Interestingly, a single cross-type phytolith, possibly associated with wild rice (Zizania sp.) was observed in sample 16 (TU5, Level 15), and a rondel-type phytolith commonly associated with wild rice inflorescence was observed in sample 13 (TU5, Level 13; Yost 2007). Cross-type phytoliths from wild rice culm and sheath material typically have an indent or cleft on one or more of the four lobes. The cross-type phytolith observed in sample 16 had a cleft on one of its lobes. Although additional reference work needs to be completed, especially with the tribe Oryzeae, this characteristic may be diagnostic of wild rice (Davidson 2003; Yost 2007). The single Zizaniatype rondel phytolith observed in sample 13 is an indented type that is prolific in lemma and palea material (husk) that surrounds the seed. Although possible indented rondel confusers have been observed from Poa grass reference material (fesucoid), the type observed here is most characteristic of wild rice (Yost 2007). At the time of earliest occupation of the Granberg Site, the floodplain and associated wetland species might have been much closer to the site. Currently, an endangered species of wild rice (Zizania texana) is endemic to a $1.5 \mathrm{~km}$ stretch of the San Marcos river, in San Marcos, Texas, which is approximately $80 \mathrm{~km}$ (50 miles) northeast of San Antonio. Virtually nothing is known about the past distribution of Texas wild rice; however, it is believed that Zizania texana represents a relic population that was once more extensive during the early and mid-Holocene (Horne 1997). The southern United States might have been a refugia for the species during the last glacial maximum. Interestingly, although separated by over $1000 \mathrm{~km}$, Texas wild rice is more closely related to northern wild rice (Zizania palustris) than southern wild rice (Zizania aquatica), which can be found presently in Louisiana (Horne 1997).

It has been reported that a dense gravel stratum, which encompasses much of levels 7, 8 and 9 in Test Units 5 and 6, might have been deposited relatively quickly, and may have been the result of a flooding event (Munoz 2007). Samples 8, 9 and 10 are phytolith samples analyzed from within this dense gravel stratum. The phytolith record from samples 8,9 and 10 does not deviate significantly from levels adjacent to this zone. This is not unexpected if the rapid deposition is the result of flash flood waters with a fairly localized sediment load. As long as the sediments are local, it is expected that the phytolith assemblage would be approximately the same as that near the site. A few siliceous algae frustules (diatoms) and sponge spicules were observed in samples 7, 8 and 9 and are likely the result of high river water deposition at the site (Figure D-1). The phytolith record and soil grain size suggests that the alluvial gravel zone was the result of a flash flood event, as opposed to an increase in precipitation and sedimentation over a longer period of time.

\section{Summary and Conclusions}

Feature and stratigraphic samples from Test Unit 3 and the adjacent Test Units of 5 and 6 were analyzed for archaeobotanical remains in the form of plant opal phytoliths from the Granberg Site, 41BX17, Bexar County, Texas. It was the intent of this analysis to better understand the environment and environmental change since the earliest occupations of the site at approximately $4000 \mathrm{BC}$, to around AD 1200. Bexar County is located in an area where three distinct vegetation types converge: 1) Edwards Plateau (mid-height grasses, oak and juniper), 2) Blackland Prairies (little bluestem and other tall grasses), and 3) South Texas Plains (tall grasslands and savannas). Despite the likely presence of a diversity of plant taxa within the greater Bexar County region, overall, the phytolith record is fairly stable throughout the time period sampled. The phytolith assemblage indicates the predominance of a bluestem/grama grass (Andropogon/Bouteloua) grassland, as well as a fairly stable cool season

$\left(\mathrm{C}_{3}\right.$ festucoid) grass presence, from the earliest time period sampled (approximately $4800 \mathrm{cal} \mathrm{BP}$ ) to around $1200 \mathrm{cal}$ BP. Within this time period, there was likely subtle to moderate shifts in the exact composition of regional grass species, with the 
ratio of $\mathrm{C}_{4}$ to $\mathrm{C}_{3}$ grasses changing in response to the amount and seasonality of precipitation (Figure 2). Overall, temperature and precipitation was likely moderate, but variable, especially from around $4000 \mathrm{cal} \mathrm{BP}$, when bilobate phytoliths, associated with weedy, disturbance grasses, increase (Figure 1, B1 and B2 bilobate types). However, it is possible that the increase in weedy, disturbance grasses is due to anthropogenic activities at the site. The earliest levels sampled (TU5, Levels 15 and 16) indicate that wetland species might have been closer to the site due to higher water levels and an expanded riparian zone. The observation of possible wild rice phytoliths from levels 12 and 15 raises the intriguing possibility of wild rice utilization by the site occupants. This is especially plausible given the fact that Texas wild rice (Zizania texana) presently occurs along the San Marcos river, a mere $80 \mathrm{~km}$ northeast of the Granberg Site. Further analysis of phytolith samples from a stratigraphic location closer to Salado Creek is recommended to pursue more positive identification of local growth of wild rice.

The larger quantity microscopic charcoal noted in TU 3 samples might reflect the thermal feature (F. 103) located in close proximity to the levels sampled. Alternatively, it is possible that recovery of the larger quantity of microscopic charcoal is an artifact of lab process of the samples, with more effective removal of microscopic charcoal from the TU 5 and 6 samples.

One potentially confusing aspect of the environmental interpretation is the use of feature and non-feature samples to build a stratigraphic record of environmental change. Non-feature samples from Test Unit 3, Levels 5, 6 and 7, deviate, as expected, from feature samples Test Unit 5, Levels 5, 6 and 7. It is unclear what effect the features had on microhabitat after abandonment. Basin-shaped features often hold water while they fill, providing additional moisture to grasses growing in the depression. Placement of a stratigraphic column for the purpose of environmental change analysis might have been more effective if placed closer to Salado Creek. Knolls, hill tops and ridge tops might not be as sensitive to change and periodic disturbance as areas positioned closer to a fluctuating water table. However, given the likely constraints of the project area, the samples analyzed here are sufficient and give an accurate record of the overall environment during occupation of the Granberg Site. 


\section{References Cited:}

Bozarth, S.

1993 Biosilicate Assemblages of Boreal Forests and Aspen Parklands. In MASCA Research Papers in Science and Archaeology, edited by D. M. Pearsall and D. R. Piperno, pp. 95-105. vol. 10. The University of Pennsylvania Museum of Archaeology and Anthropology, University of Pennsylvania, Philadelphia.

Brown, D.A.

1984 Prospects and Limits of Phytolith Key for Grasses in the Central United States. Journal of Archeological Science 11:345-368.

Friedlund, G.G. and L.T. Tieszen

1994 Modern Phytolith Assemblages from the North American Great Plains. Journal of Biogeography 21:321-335.

Gould, F. N. and R. B. Shaw

1983 Grass Systematics. Texas A\&M University Press, College Station.

Jones, R. L. and A. H. Beavers

1963 Sponge Spicules in Illinois Soils. Soil Science Proceedings 27(4):438-440.

Lu, H. and K.-B. Liu

2003 Morphological Variations of Lobate Phytoliths from Grasses in China and the South-Eastern United States. Diversity and Distributions 9:73-87.

Lu, H. and K.-b. Liu

2003 Phytoliths of Common Grasses in the Coastal Environments of Southeastern USA. Estuarine and Coastal Marine Science 58:587-600.

Munoz, C.M., J.L. Thompson, and R.P. Mauldin

2007 Research Design for the Analysis of Archeological Materials Recovered from Significance Testing of the Granberg Site (41BX17), Bexar County, Texas. Report on file at the Center for Archaeological Research, The University of Texas at San Antonio, Texas.

Twiss, P. C.

1987 Grass-Opal Phytoliths as Climatic Indicators of the Great Plains Pleistocene. In Quaternary Environments of Kansas, edited by W. C. Johnson, pp. 179-188. 5th ed. Kansas Geological Survey Guidebook Series.

Yost, C.

2007 Diagnostic Phytolith Evidence for the Presence and Abundance of Wild Rice (Zizania sp) from Central Minnesota Lake Sediments. Student Paper. St. Cloud State University. 


\section{Appendix E: \\ Botanical Analysis of Flotation Samples from 41BX17 \\ J. Philip Dering}





\title{
Appendix E
}

\section{Botanical Analysis of Flotation Samples from 41BX17}

\author{
J. Philip Dering \\ Shumla Archeobotanical Services \\ P.O. Box 944,187 Alpine St., Comstock, TX 78837
}

This report presents the analysis of nine flotation samples from 41BX17. The samples were submitted by the Center for Archaeological Research (CAR), The University of Texas at San Antonio. The objectives of this analysis are to identify the plant resources utilized at the site, identify an adequate sample of mesquite wood for xylem analysis, and to carry out xylem analysis if mesquite wood is present in the sample. The purpose of the study is to provide more base-line data from xylem analysis for the Holocene in southern Texas. The hope is that xylem analysis will eventually provide another proxy data source for determining Holocene environmental history in the region.

\section{Method}

\section{Flotation}

Flotation is the process by which organic remains, primarily charred plant fragments, are recovered from archeological sediments using water as the separating agent. The samples from $41 \mathrm{MV} 164$ were processed using a simple screen and swirl technique by pouring the sample into a 5-gallon water-filled bucket. The sample is stirred gently with a narrow metal rod and rocked back and forth. The heavy material, consisting of large clasts, some bone, and occasionally heartwood charcoal or nut charcoal, falls to the bottom of the bucket, and the lighter material, including most of the plant material, both carbonized and uncarbonized, floats to the surface. The floating material is directed onto a $0.375-\mathrm{mm}$ screen, a mesh small enough to catch the smallest seeds. This floating material is called the light fraction. The material that sinks to the bottom, termed the heavy fraction, is passed through a 1-mm stainless steel screen. Both fractions are tagged and slowly dried before they are examined in the laboratory. Flotation recovery was tested in two samples using 50 poppy seeds, and $96 \%$ of the poppy seeds were recovered.

\section{Laboratory Procedures}

The analysis follows standard archeobotanical laboratory procedures. The light fraction of each flotation sample is passed through a nested set of screens of 4-mm, 2-mm, 1- $\mathrm{mm}$, and $0.450-\mathrm{mm}$ mesh and examined for charred material that is separated for identification. Carbonized wood from the $4 \mathrm{~mm}$ and $2 \mathrm{~mm}$ screens (smaller pieces are seldom identifiable) is separated in a 25-piece grab sample and identified. Care is taken to select representative materials from both levels (cf. Diehl 2003:213; Huckell 2002:645; Miksicek 1994:243). If the sample contains more than 25 fragments, all the material is scanned and separated into taxonomic categories, and the volume and weight of each taxon or wood type is recorded.

Charred material caught on all of the sieve levels, including the bottom pan, is scanned for floral parts, fruits, seeds, and other potentially edible plant parts such as agave or maize fragments, and these plant parts are counted and examined for identification. Screen- or point-collected macrobotanical samples (radiocarbon samples, etc.) are also sorted, identified, and weighed to the nearest $0.1 \mathrm{~g}$.

\section{Disturbance Indicators}

Sample content may be affected by various physical and biological disturbance factors, including insect or small mammal activity, and plant root growth. In an effort to assess this impact, the amount of roots, insect parts, termite pellets, gastropods, rodent fecal pellets, and other biological material is estimated. These amounts are reported on a scale of 1-25 (+), 25-50 (++), and over $50(+++)$. 


\section{Identification}

Due to the rapid decomposition of plant material in soils, only carbonized seeds and wood fragments are considered to be a part of the archeological sample. Identification of carbonized wood is accomplished by using the snap technique, examining the transverse, radial, and tangential surfaces at 8 to 45 power with a binocular dissecting microscope, and comparing the material to reference specimens in the Shumla Archeobotanical Services herbarium. The anatomy of some woods is so similar that identification to species or even genus is not possible. For this reason I combine some taxa into wood types. All identifications in the "type" category represent identifications to the taxon level indicated by the name of the type. For example, willow (Salix sp.) and cottonwood (Populus sp.), both members of the Salicaceae or willow family, have been placed in an artificial category, Salicaceae (cottonwood-willow). The wood of mesquite and acacia, all members of the legume family (Fabaceae), are also difficult to distinguish. Mesquite usually can be separated from other woody members of that family, but in cases where this is a problem, the material is assigned to the Fabaceae or woody legume type.

\section{Wood (Xylem) Analysis}

Tree trunks and limbs function to 1) support the tree, 2) conduct water and minerals from the roots to the leaves, and 3) to conduct food produced by photosynthesis from the leaves to the back into the stems, trunk and roots. Most of a tree is composed of xylem tissue, otherwise known as wood. Xylem is composed of several types of tissues and cells, including vessel elements and rays that conduct water, and several types of fibers that act as structural support for the tree. In seed-bearing plants, vessel elements act as the primary conduits for water that is transported from the roots to the leaves.

The shape and arrangement of these cells in wood (xylem) is unique to the genus or species of most trees, allowing for trees to be identified from its wood. When wood is charred it usually retains its anatomical integrity, allowing charcoal to be identified by its characteristic arrangement of cell types. In other words, wood anatomy is specific to the genus or species of the tree, and it is preserved in the charring process.

As a reaction to local environmental conditions, wood anatomy can also vary within the basic recognizable pattern of a species. Recent studies in South Africa have demonstrated that the anatomical characteristics of wood of the same tree species will vary across a moisture gradient. Within the same tree species, vessel elements, the primary water conductors in the wood of a tree, may vary in size and density according to local rainfall regimes while retaining its recognizable anatomical characteristics (February 1992).

Studies in South Africa have demonstrated that some tree species demonstrate predictable changes in vessel diameter and density according to changes in rainfall regime, and preliminary studies in Texas have shown the potential for these studies. Using two commonly occurring species, Protea roupelliae and Protea caffra, that are distributed across a wide range of annual precipitation, February (1994:103) has demonstrated that vessel diameter increases and vessel density decreases as rainfall increases across a geographic gradient. In other words, plants growing in wetter environments have larger and fewer vessels than the same species growing in dryer environments.

\section{Results}

The results of the analysis are presented in Table E-1. Disturbance indicators were abundant, in most of the samples. Both roots and gastropods were common in Feature 100, roots were moderately abundant in most of the other features. The sample from Feature 108 was the only sample that did not contain charred plant material. No seeds, fruit, or geophyte/root fragments occurred in the samples.

The total weight of wood charcoal identified in the samples is 9.2-g. Most of the wood is oak. Three very small mesquite charcoal fragments occurred in Feature 100, and three other fragments were attributable to the woody legume type. These six fragments weighed less than 0.1 -g. and do not provide an adequate sample for xylem analysis. Oak was identified in samples from Features 100, 101, 104, and 105. The largest quantity of wood charcoal came from Feature 104, all identified as oak. 
Table E-1. Flotation Analysis

\begin{tabular}{|c|c|c|c|c|c|c|c|c|c|c|c|c|c|}
\hline 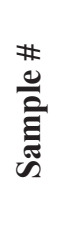 & 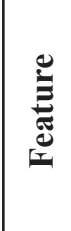 & $\infty$ & $\underset{r}{\#}$ & 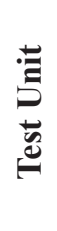 & d & $\frac{\mathscr{E}}{\dot{\Xi}}$ & 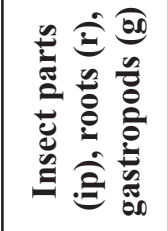 & 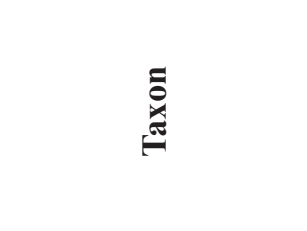 & 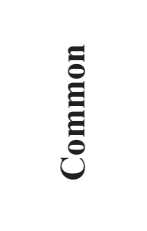 & 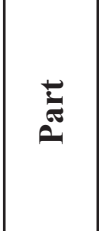 & $\ddot{\Xi}$ & 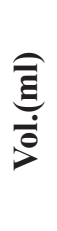 & $\underbrace{00}_{\overrightarrow{3}}$ \\
\hline 1 & 100 & 47 & 1 & 6 & 3 & 1.6 & $\mathrm{r}+++, \mathrm{g}+++$ & Prosopis glandulosa & Mesquite & Wood & 3 & -- & $<.1$ \\
\hline 1 & 100 & 47 & 1 & 6 & 3 & 1.6 & $\mathrm{r}+++, \mathrm{g}+++$ & Fabaceae & $\begin{array}{l}\text { Woody } \\
\text { legume }\end{array}$ & Wood & 3 & -- & $<.1$ \\
\hline 1 & 100 & 47 & 1 & 6 & 3 & 1.6 & $\mathrm{r}+++, \mathrm{g}+++$ & Indeterminate & NA & Wood & 10 & -- & 0.3 \\
\hline 1 & 100 & 47 & 1 & 6 & 3 & 1.6 & $\mathrm{r}+++, \mathrm{g}+++$ & Quercus sp. & Oak & Wood & 6 & -- & 0.1 \\
\hline 2 & 101 & 56 & 3 & 5 & 5 & 0.8 & $\mathrm{r}++$ & Quercus sp. & Oak & Wood & 11 & -- & 0.6 \\
\hline 3 & 102 & 59 & 2 & 5 & 6 & 1.4 & $\mathrm{r}++, \mathrm{g}+$ & Quercus sp. & Oak & Wood & 5 & & 0.2 \\
\hline 4 & 103 & 60 & 3 & 4 & 5 & 1.5 & $\mathrm{r}+++, \mathrm{g}+$ & Indeterminate & NA & Wood & 14 & -- & $<.1$ \\
\hline 5 & 104 & 75 & 1 & 5 & 7 & 1.5 & $\mathrm{r}+++$ & Quercus sp. & Oak & Wood & $25+$ & 47 & 7.9 \\
\hline 6 & 105 & 93 & 1 & 3 & 8 & 0.7 & $\mathrm{r}++$ & Quercus sp. & Oak & Wood & 14 & -- & 0.1 \\
\hline 7 & 106 & 118 & 1 & 7 & 4 & 0.9 & $\mathrm{r}+++, \mathrm{g}+$ & Indeterminate & $\mathrm{NA}$ & Wood & 1 & & $<.1$ \\
\hline 8 & 107 & 108 & 1 & 4 & 10 & 1 & $\mathrm{r}+++, \mathrm{g}+$ & Indeterminate & NA & Wood & 6 & -- & $<.1$ \\
\hline 9 & 108 & 178 & 8 & 10 & 8 & 1.7 & $\begin{array}{c}\text { ip }++, \mathrm{r}+ \\
\mathrm{g}+\end{array}$ & $\begin{array}{l}\text { No charred plant } \\
\text { remains }\end{array}$ & -- & -- & -- & -- & -- \\
\hline
\end{tabular}

\section{Conclusion}

Although a small amount of mesquite was present in a single sample, the fragments were not large enough to conduct xylem analysis. None of the flotation samples contained edible plant parts. Instead, oak wood charcoal dominated the assemblage. Interestingly, the analysis demonstrates that the vegetation round the site during its occupation likely consisted primarily of oak. Bexar County still contains a western extension of post oaks, and many of the creek and river terraces house a mixed hardwood overstory of oak, pecan, hickory and elm. Either the inhabitants of 41BX17 were carefully selecting oak over mesquite, or the wood vegetation around the immediate area of the site was dominated by oak trees. 


\section{References Cited:}

Diehl, M.

2003 Prehistoric Subsistence Strategies and the Macrobotanical Assemblage. In Hohokam Farming on the Salt River Floodplain, edited by T. Kathleen Henderson, pp. 211-230. Anthropological Papers No. 42, Center for Desert Archaeology. Tucson, Arizona. Anthropological Papers No. 9. Pueblo Grande Museum. Phoenix.

February, E.C.

1992 Archaeological Charcoals as Indicators of Vegetation Change and Human Fuel Choice in the Late Holocene at Elands Bay, Western Cape Province, South Africa. Journal of Archaeological Science 19:347-354.

1994 Rainfall Reconstruction Using Wood Charcoal from Two Archaeological Sites in South Africa. Quaternary Research 42:100-107.

Huckell, L.

2002 Paleoethnobotany. In Tonto Creek Archaeological Project Artifact and Environmental Analyses. Volume 2: Stone Tool and Subsistence Studies, ed. Jeffery J. Clark, pp. 643-709. Anthropological Papers No. 23. Center for Desert Archaeology. Tucson.

Miksicek, C.

1994 Deceptive Barrenness: Archaeobotanical Material From the Schuk Toak Project Area. In Archaeological Studies of the Avra Valley, Arizona: Excavations in the Schuk Toak District. Vol 2. Scientific Studies and Interpretations, ed. by Allen Dart, pp. 243-266. Anthropological Papers No. 16. Center for Desert Archaeology. Tucson. 
Appendix F:

Faunal Remains

Barbara Meissner 

Table F-1. Faunal Bone Recovered from the Middle and Late Archaic Components of 41BX17

\begin{tabular}{|c|c|c|c|c|c|c|}
\hline LA/MA & Unit & Level & Feature & Taxa & Description & Weight (g) \\
\hline LA & Test Unit 03 & 0 & 0 & Mammal & Size indeterminate & 0.4 \\
\hline LA & Test Unit 03 & 1 & 0 & Mammal & Size indeterminate & 0.2 \\
\hline LA & Test Unit 03 & 1 & 0 & Mammal--V. lg. & Cattle, bison, horse-sized & 1 \\
\hline LA & Test Unit 03 & 2 & 0 & Antilocapra americana & Pronghorn & 2.4 \\
\hline LA & Test Unit 03 & 2 & 0 & Mammal & Size indeterminate & 0.7 \\
\hline LA & Test Unit 03 & 2 & 0 & Mammal--lg. & Deer, sheep-sized & 0.9 \\
\hline LA & Test Unit 03 & 3 & 0 & Aves--large & Chicken-sized & 0.4 \\
\hline LA & Test Unit 03 & 3 & 0 & Mammal & Size indeterminate & 2.1 \\
\hline LA & Test Unit 03 & 3 & 0 & Mammal--lg. & Deer, sheep-sized & 3.3 \\
\hline LA & Test Unit 03 & 4 & 0 & Mammal & Size indeterminate & 3 \\
\hline LA & Test Unit 03 & 4 & 0 & Mammal--lg. & Deer, sheep-sized & 2 \\
\hline LA & Test Unit 03 & 5 & 0 & Mammal & Size indeterminate & 4.9 \\
\hline LA & Test Unit 03 & 5 & 0 & Mammal & & 0.2 \\
\hline LA & Test Unit 03 & 5 & 0 & Mammal & & 1.12 \\
\hline LA & Test Unit 03 & 5 & 0 & Mammal--lg. & Deer, sheep-sized & 11.3 \\
\hline LA & Test Unit 03 & 5 & 0 & Mammal--lg. & & 1.3 \\
\hline LA & Test Unit 03 & 5 & 0 & Mammal--sm. & Rabbit-sized & 0.4 \\
\hline LA & Test Unit 03 & 5 & 0 & Mammal--V. lg. & Cattle, bison, horse-sized & 15.9 \\
\hline LA & Test Unit 03 & 5 & 0 & Mammal--V. lg. & & 13.6 \\
\hline LA & Test Unit 03 & 5 & 0 & Mammal--V. lg. & & 16.26 \\
\hline LA & Test Unit 03 & 5 & 0 & Odocoileus virginianus & White-tailed deer & 11.2 \\
\hline LA & Test Unit 03 & 6 & 0 & Mammal & Size indeterminate & 1.9 \\
\hline LA & Test Unit 03 & 6 & 0 & Mammal--lg. & Deer, sheep-sized & 6.7 \\
\hline LA & Test Unit 03 & 6 & 0 & Mammal--sm. & Rabbit-sized & 0.2 \\
\hline LA & Test Unit 03 & 6 & 0 & Mammal--V. lg. & Cattle, bison, horse-sized & 6.7 \\
\hline LA & Test Unit 03 & 7 & 0 & Mammal & & 1.1 \\
\hline LA & Test Unit 03 & 7 & 0 & Mammal--lg. & & 7.9 \\
\hline LA & Test Unit 03 & 7 & 0 & Odocoileus virginianus & White-tailed deer & 3.3 \\
\hline MA & Test Unit 03 & 8 & 105 & Artiodactyl & Deer, sheep, goats & 10.2 \\
\hline MA & Test Unit 03 & 8 & 0 & Mammal & & 4.82 \\
\hline MA & Test Unit 03 & 8 & 0 & Mammal & Size indeterminate & 8.4 \\
\hline MA & Test Unit 03 & 8 & 105 & Mammal & Size indeterminate & 1.2 \\
\hline MA & Test Unit 03 & 8 & 0 & Mammal--lg. & & 13.54 \\
\hline MA & Test Unit 03 & 8 & 105 & Mammal--lg. & Deer, sheep-sized & 2.6 \\
\hline MA & Test Unit 03 & 8 & 0 & Odocoileus virginianus & White-tailed deer & 5.64 \\
\hline MA & Test Unit 03 & 9 & 0 & Artiodactyl & Deer, sheep, goats & 1.6 \\
\hline MA & Test Unit 03 & 9 & 0 & Mammal & Size indeterminate & 0.2 \\
\hline
\end{tabular}


Table F-1. Continued...

\begin{tabular}{|c|c|c|c|c|c|c|}
\hline LA/MA & Unit & Level & Feature & Taxa & Description & Weight (g) \\
\hline MA & Test Unit 03 & 9 & 0 & Mammal & Size indeterminate & 3.7 \\
\hline MA & Test Unit 03 & 9 & 0 & Mammal & & 0.26 \\
\hline MA & Test Unit 03 & 9 & 0 & Mammal--lg. & Deer, sheep-sized & 18.7 \\
\hline MA & Test Unit 03 & 9 & 0 & Mammal--V. lg. & & 13.39 \\
\hline MA & Test Unit 03 & 9 & 0 & Odocoileus virginianus & White-tailed deer & 4.9 \\
\hline MA & Test Unit 03 & 9 & 0 & Viperidae & Poisonous snakes & 0.1 \\
\hline MA & Test Unit 03 & 10 & 0 & Artiodactyl & & 2.1 \\
\hline MA & Test Unit 03 & 10 & 0 & Lepus californicus & Blacktailed jackrabbit & 2.5 \\
\hline MA & Test Unit 03 & 10 & 0 & Mammal & & 3.2 \\
\hline MA & Test Unit 03 & 10 & 0 & Mammal--lg. & & 4.4 \\
\hline MA & Test Unit 03 & 10 & 0 & Mammal--sm. & & 4.6 \\
\hline MA & Test Unit 03 & 10 & 0 & Mammal--V. lg. & & 6.7 \\
\hline MA & Test Unit 03 & 10 & 0 & Sylvilagus sp. & & 0.7 \\
\hline MA & Test Unit 03 & 10 & 0 & Testudines & & 0.9 \\
\hline MA & Test Unit 03 & 10 & 0 & Vertebrata & & 0.8 \\
\hline MA & Test Unit 03 & 11 & 0 & Mammal & Size indeterminate & 0.9 \\
\hline MA & Test Unit 03 & 11 & 0 & Mammal--V. lg. & Cattle, bison, horse-sized & 2 \\
\hline MA & Test Unit 03 & 12 & 0 & Mammal & & 0.5 \\
\hline MA & Test Unit 03 & 12 & 0 & Odocoileus virginianus & White-tailed deer & 17.5 \\
\hline MA & Test Unit 03 & 12 & 0 & Sylvilagus sp. & & 0.2 \\
\hline MA & Test Unit 03 & 13 & 0 & Carnivora & Carnivores & 0.3 \\
\hline MA & Test Unit 03 & 13 & 0 & Mammal & Size indeterminate & 1.5 \\
\hline MA & Test Unit 03 & 13 & 0 & Sylvilagus sp. & Cottontail rabbit & 1.2 \\
\hline MA & Test Unit 03 & 14 & 0 & Mammal & Size indeterminate & 0.2 \\
\hline MA & Test Unit 03 & 14 & 0 & Mammal--sm. & Rabbit-sized & 0.3 \\
\hline MA & Test Unit 03 & 17 & 0 & Antilocapra americana & Pronghorn & 1.3 \\
\hline MA & Test Unit 03 & 17 & 0 & Mammal & & 0.6 \\
\hline MA & Test Unit 03 & 17 & 0 & Mammal--lg. & & 3.2 \\
\hline LA & Test Unit 04 & 2 & 0 & Mammal & Size indeterminate & 1.2 \\
\hline LA & Test Unit 04 & 2 & 0 & Mammal--lg. & Deer, sheep-sized & 1.3 \\
\hline LA & Test Unit 04 & 3 & 0 & Mammal & Size indeterminate & 1.3 \\
\hline LA & Test Unit 04 & 3 & 0 & Mammal--lg. & Deer, sheep-sized & 1.7 \\
\hline LA & Test Unit 04 & 3 & 0 & Mammal--V. lg. & Cattle, bison, horse-sized & 0.9 \\
\hline LA & Test Unit 04 & 4 & 0 & Mammal & Size indeterminate & 1.9 \\
\hline LA & Test Unit 04 & 4 & 0 & Mammal--lg. & Deer, sheep-sized & 2.6 \\
\hline LA & Test Unit 04 & 5 & 103 & Artiodactyl & Deer, sheep, goats & 0.2 \\
\hline LA & Test Unit 04 & 5 & 103 & Geomys sp. & Pocket gopher & 0.1 \\
\hline
\end{tabular}


Table F-1. Continued...

\begin{tabular}{|c|c|c|c|c|c|c|}
\hline LA/MA & Unit & Level & Feature & Taxa & Description & Weight (g) \\
\hline LA & Test Unit 04 & 5 & 103 & Mammal & Size indeterminate & 8.1 \\
\hline LA & Test Unit 04 & 5 & 103 & Mammal--lg. & Deer, sheep-sized & 24.7 \\
\hline LA & Test Unit 04 & 5 & 103 & Mammal--lg. & Deer, sheep-sized & 1.4 \\
\hline LA & Test Unit 04 & 5 & 103 & Mammal--med. & Dog-sized & 0.6 \\
\hline LA & Test Unit 04 & 5 & 103 & Mammal--V. lg. & Cattle, bison, horse-sized & 36.3 \\
\hline LA & Test Unit 04 & 5 & 103 & Testudines & Turtles & 0.3 \\
\hline LA & Test Unit 04 & 6 & 103 & Artiodactyl & Deer, sheep, goats & 2.2 \\
\hline LA & Test Unit 04 & 6 & 0 & Aves & & 0.16 \\
\hline LA & Test Unit 04 & 6 & 103 & Mammal & Size indeterminate & 0.1 \\
\hline LA & Test Unit 04 & 6 & 0 & Mammal & & 13.27 \\
\hline LA & Test Unit 04 & 6 & 0 & Mammal--lg. & & 13.24 \\
\hline LA & Test Unit 04 & 6 & 103 & Mammal--V. lg. & Cattle, bison, horse-sized & 54.1 \\
\hline LA & Test Unit 04 & 6 & 0 & Mammal--V. lg. & & 7.52 \\
\hline LA & Test Unit 04 & 6 & 0 & Odocoileus virginianus & White-tailed deer & 2.9 \\
\hline LA & Test Unit 04 & 6 & 0 & Rodentia & & 0.11 \\
\hline LA & Test Unit 04 & 6 & 0 & Testudines & & 0.48 \\
\hline LA & Test Unit 04 & 7 & 0 & Mammal & Size indeterminate & 2 \\
\hline LA & Test Unit 04 & 7 & 0 & Mammal--lg. & Deer, sheep-sized & 1.5 \\
\hline LA & Test Unit 04 & 7 & 0 & Mammal--V. lg. & Cattle, bison, horse-sized & 6.1 \\
\hline LA & Test Unit 04 & 7 & 0 & Odocoileus virginianus & White-tailed deer & 1.8 \\
\hline MA & Test Unit 04 & 8 & 0 & Mammal & Size indeterminate & 3.3 \\
\hline MA & Test Unit 04 & 8 & 0 & Mammal--lg. & Deer, sheep-sized & 3 \\
\hline MA & Test Unit 04 & 8 & 0 & Mammal--sm. & Rabbit-sized & 0.5 \\
\hline MA & Test Unit 04 & 8 & 0 & Odocoileus virginianus & White-tailed deer & 0.8 \\
\hline MA & Test Unit 04 & 9 & 0 & Mammal & Size indeterminate & 1 \\
\hline MA & Test Unit 04 & 9 & 0 & Mammal--lg. & Deer, sheep-sized & 3.1 \\
\hline MA & Test Unit 04 & 9 & 0 & Mammal--sm. & Rabbit-sized & 0.4 \\
\hline MA & Test Unit 04 & 10 & 0 & Mammal & Size indeterminate & 3.2 \\
\hline MA & Test Unit 04 & 10 & 0 & Mammal--lg. & Deer, sheep-sized & 35.3 \\
\hline MA & Test Unit 04 & 10 & 0 & Mammal--sm. & Rabbit-sized & 0.6 \\
\hline MA & Test Unit 04 & 10 & 0 & Sylvilagus sp. & Cottontail rabbit & 0.7 \\
\hline MA & Test Unit 04 & 11 & 0 & Lepus californicus & Blacktailed jackrabbit & 1.1 \\
\hline MA & Test Unit 04 & 11 & 0 & Mammal & Size indeterminate & 0.9 \\
\hline MA & Test Unit 04 & 11 & 0 & Mammal--lg. & Deer, sheep-sized & 0.8 \\
\hline MA & Test Unit 04 & 11 & 0 & Mammal--sm. & Rabbit-sized & 1.1 \\
\hline MA & Test Unit 04 & 11 & 0 & Sylvilagus sp. & Cottontail rabbit & 0.4 \\
\hline MA & Test Unit 04 & 12 & 0 & Mammal & Size indeterminate & 1 \\
\hline
\end{tabular}


Table F-1. Continued...

\begin{tabular}{|c|c|c|c|c|c|c|}
\hline LA/MA & Unit & Levle & Feature & Taxa & Description & Weight (g) \\
\hline MA & Test Unit 04 & 12 & 0 & Mammal--lg. & Deer, sheep-sized & 7 \\
\hline MA & Test Unit 04 & 12 & 0 & Odocoileus virginianus & White-tailed deer & 8.8 \\
\hline MA & Test Unit 04 & 13 & 0 & Mammal--sm. & Rabbit-sized & 0.3 \\
\hline MA & Test Unit 04 & 14 & 0 & Mammal & Size indeterminate & 0.1 \\
\hline MA & Test Unit 04 & 14 & 0 & Mammal--lg. & Deer, sheep-sized & 4.9 \\
\hline MA & Test Unit 04 & 14 & 0 & Odocoileus virginianus & White-tailed deer & 5.3 \\
\hline MA & Test Unit 04 & 14 & 0 & Rodentia & Rodents & 0.1 \\
\hline MA & Test Unit 04 & 17 & 0 & Mammal--V. lg. & Cattle, bison, horse-sized & 27.6 \\
\hline MA & Test Unit 04 & 18 & 0 & Mammal--lg. & Deer, sheep-sized & 1.2 \\
\hline LA & Test Unit 05 & 1 & 0 & Mammal--lg. & Deer, sheep-sized & 1.2 \\
\hline LA & Test Unit 05 & 2 & 0 & Mammal & Size indeterminate & 1.1 \\
\hline LA & Test Unit 05 & 2 & 0 & Mammal--lg. & Deer, sheep-sized & 2.2 \\
\hline LA & Test Unit 05 & 3 & 0 & Mammal & Size indeterminate & 1.2 \\
\hline LA & Test Unit 05 & 3 & 0 & Mammal--lg. & Deer, sheep-sized & 5.2 \\
\hline LA & Test Unit 05 & 3 & 0 & Mammal--V. lg. & Cattle, bison, horse-sized & 5.6 \\
\hline LA & Test Unit 05 & 3 & 0 & Mammal--V. lg. & Cattle, bison, horse-sized & 14.3 \\
\hline LA & Test Unit 05 & 4 & 100 & Artiodactyl & Deer, sheep, goats & 5.2 \\
\hline LA & Test Unit 05 & 4 & 100 & Bison bison & American bison & 7.8 \\
\hline LA & Test Unit 05 & 4 & 100 & Bison bison & American bison & 38.6 \\
\hline LA & Test Unit 05 & 4 & 100 & Mammal & Size indeterminate & 22.5 \\
\hline LA & Test Unit 05 & 4 & 100 & Mammal--lg. & Deer, sheep-sized & 41.4 \\
\hline LA & Test Unit 05 & 4 & 100 & Mammal--sm. & Rabbit-sized & 0.4 \\
\hline LA & Test Unit 05 & 4 & 100 & Mammal--V. lg. & Cattle, bison, horse-sized & 46.3 \\
\hline LA & Test Unit 05 & 4 & 100 & Odocoileus virginianus & White-tailed deer & 5.7 \\
\hline LA & Test Unit 05 & 4 & 100 & Rodentia & Rodents & 0.3 \\
\hline LA & Test Unit 05 & 4 & 100 & Testudines & Turtles & 1.2 \\
\hline LA & Test Unit 05 & 5 & 101 & Mammal & Size indeterminate & 2.9 \\
\hline LA & Test Unit 05 & 5 & 101 & Mammal & Size indeterminate & 0.2 \\
\hline LA & Test Unit 05 & 5 & 101 & Mammal--lg. & Deer, sheep-sized & 19.3 \\
\hline LA & Test Unit 05 & 5 & 101 & Mammal--lg. & Deer, sheep-sized & 18.5 \\
\hline MA & Test Unit 05 & 8 & 0 & Mammal--lg. & Deer, sheep-sized & 10.2 \\
\hline MA & Test Unit 05 & 9 & 0 & Mammal--lg. & Deer, sheep-sized & 0.4 \\
\hline MA & Test Unit 05 & 9 & 0 & Mammal--V. lg. & Cattle, bison, horse-sized & 1.6 \\
\hline MA & Test Unit 05 & 10 & 0 & Mammal & Size indeterminate & 1 \\
\hline MA & Test Unit 05 & 11 & 0 & Mammal & Size indeterminate & 0.7 \\
\hline MA & Test Unit 05 & 11 & 0 & Mammal--sm. & Rabbit-sized & 0.2 \\
\hline MA & Test Unit 05 & 12 & 0 & Artiodactyl & Deer, sheep, goats & 16.1 \\
\hline
\end{tabular}


Table F-1. Continued...

\begin{tabular}{|c|c|c|c|c|c|c|}
\hline LA/MA & Unit & Level & Feature & Taxa & Description & Weight (g) \\
\hline MA & Test Unit 05 & 12 & 0 & Aves--medium & Pidgeon-sized & 3.7 \\
\hline MA & Test Unit 05 & 12 & 0 & Lepus californicus & Blacktailed jackrabbit & 0.3 \\
\hline MA & Test Unit 05 & 12 & 0 & Mammal & Size indeterminate & 3.9 \\
\hline MA & Test Unit 05 & 12 & 0 & Mammal--lg. & Deer, sheep-sized & 6.4 \\
\hline MA & Test Unit 05 & 12 & 0 & Mammal--sm. & Rabbit-sized & 1.1 \\
\hline MA & Test Unit 05 & 12 & 0 & Rodentia & Rodents & 0.2 \\
\hline MA & Test Unit 05 & 12 & 0 & Sigmodon hispidus & Cotton rat & 0.3 \\
\hline MA & Test Unit 05 & 12 & 0 & Sylvilagus sp. & Cottontail rabbit & 0.9 \\
\hline MA & Test Unit 05 & 13 & 0 & Mammal & Size indeterminate & 2 \\
\hline MA & Test Unit 05 & 13 & 0 & Mammal--lg. & Deer, sheep-sized & 1.5 \\
\hline MA & Test Unit 05 & 13 & 0 & Mammal--sm. & Rabbit-sized & 1.9 \\
\hline MA & Test Unit 05 & 13 & 0 & Neotoma sp. & Woodrats & 0.5 \\
\hline MA & Test Unit 05 & 13 & 0 & Sylvilagus sp. & Cottontail rabbit & 0.3 \\
\hline MA & Test Unit 05 & 14 & 0 & Artiodactyl & Deer, sheep, goats & 20.5 \\
\hline MA & Test Unit 05 & 14 & 0 & Mammal & Size indeterminate & 0.6 \\
\hline MA & Test Unit 05 & 14 & 0 & Mammal--lg. & Deer, sheep-sized & 1.6 \\
\hline LA & Test Unit 06 & 0 & 0 & Mammal & Size indeterminate & 1.8 \\
\hline LA & Test Unit 06 & 0 & 0 & Mammal--lg. & Deer, sheep-sized & 31.1 \\
\hline LA & Test Unit 06 & 0 & 0 & Odocoileus virginianus & White-tailed deer & 4.9 \\
\hline LA & Test Unit 06 & 2 & 0 & Mammal & Size indeterminate & 0.3 \\
\hline LA & Test Unit 06 & 2 & 0 & Mammal--lg. & Deer, sheep-sized & 1.3 \\
\hline LA & Test Unit 06 & 3 & 100 & Mammal--lg. & Deer, sheep-sized & 4.5 \\
\hline LA & Test Unit 06 & 3 & 100 & Mammal--sm. & Rabbit-sized & 0.4 \\
\hline LA & Test Unit 06 & 3 & 100 & Mammal--V. lg. & Cattle, bison, horse-sized & 1.4 \\
\hline LA & Test Unit 06 & 3 & 100 & Testudines & Turtles & 0.2 \\
\hline LA & Test Unit 06 & 4 & 100 & Artiodactyl & Deer, sheep, goats & 0.9 \\
\hline LA & Test Unit 06 & 4 & 100 & Aves--medium & Pidgeon-sized & 0.6 \\
\hline LA & Test Unit 06 & 4 & 100 & Bovinae & Cattle or bison & 10.9 \\
\hline LA & Test Unit 06 & 4 & 100 & Lepus californicus & Blacktailed jackrabbit & 0.3 \\
\hline LA & Test Unit 06 & 4 & 100 & Mammal & Size indeterminate & 19 \\
\hline LA & Test Unit 06 & 4 & 100 & Mammal & Size indeterminate & 0.4 \\
\hline LA & Test Unit 06 & 4 & 100 & Mammal--lg. & Deer, sheep-sized & 30.8 \\
\hline LA & Test Unit 06 & 4 & 100 & Mammal--lg. & Deer, sheep-sized & 5.2 \\
\hline LA & Test Unit 06 & 4 & 100 & Mammal--sm. & Rabbit-sized & 0.5 \\
\hline LA & Test Unit 06 & 4 & 100 & Mammal--V. lg. & Cattle, bison, horse-sized & 18 \\
\hline LA & Test Unit 06 & 4 & 100 & Odocoileus virginianus & White-tailed deer & 3.1 \\
\hline LA & Test Unit 06 & 4 & 100 & Odocoileus virginianus & White-tailed deer & 24.7 \\
\hline
\end{tabular}


Table F-1. Continued...

\begin{tabular}{|c|c|c|c|c|c|c|}
\hline LA/MA & Unit & Level & Feature & Taxa & Description & Weight (g) \\
\hline LA & Test Unit 06 & 4 & 100 & Odocoileus virginianus & White-tailed deer & 45.8 \\
\hline LA & Test Unit 06 & 4 & 100 & Sylvilagus sp. & Cottontail rabbit & 0.2 \\
\hline LA & Test Unit 06 & 4 & 100 & Testudines & Turtles & 0.1 \\
\hline LA & Test Unit 06 & 4 & 100 & Ursus americanus & Black bear & 0.6 \\
\hline LA & Test Unit 06 & 5 & 101 & Aves--medium & Pidgeon-sized & 0.3 \\
\hline LA & Test Unit 06 & 5 & 101 & Aves--small & Mockingbird-sized & 0.2 \\
\hline LA & Test Unit 06 & 5 & 101 & Mammal & Size indeterminate & 15.6 \\
\hline LA & Test Unit 06 & 5 & 101 & Mammal--lg. & Deer, sheep-sized & 36 \\
\hline LA & Test Unit 06 & 5 & 101 & Mammal--sm. & Rabbit-sized & 1.3 \\
\hline LA & Test Unit 06 & 5 & 101 & Odocoileus virginianus & White-tailed deer & 19.8 \\
\hline LA & Test Unit 06 & 5 & 101 & Sylvilagus sp. & Cottontail rabbit & 0.4 \\
\hline LA & Test Unit 06 & 5 & 101 & Testudines & Turtles & 0.3 \\
\hline LA & Test Unit 06 & 6 & 102 & Lepus californicus & Blacktailed jackrabbit & 0.3 \\
\hline LA & Test Unit 06 & 6 & 102 & Mammal & Size indeterminate & 4.7 \\
\hline LA & Test Unit 06 & 6 & 102 & Mammal--lg. & Deer, sheep-sized & 24 \\
\hline LA & Test Unit 06 & 6 & 102 & Mammal--sm. & Rabbit-sized & 1.1 \\
\hline LA & Test Unit 06 & 6 & 102 & Odocoileus virginianus & White-tailed deer & 18.3 \\
\hline LA & Test Unit 06 & 6 & 102 & Sylvilagus sp. & Cottontail rabbit & 0.1 \\
\hline LA & Test Unit 06 & 6 & 102 & Testudines & Turtles & 18.8 \\
\hline LA & Test Unit 06 & 7 & 0 & Mammal & Size indeterminate & 11.5 \\
\hline LA & Test Unit 06 & 7 & 0 & Mammal--lg. & Deer, sheep-sized & 33.7 \\
\hline LA & Test Unit 06 & 7 & 0 & Odocoileus virginianus & White-tailed deer & 37.5 \\
\hline MA & Test Unit 06 & 8 & 0 & Mammal & Size indeterminate & 2.6 \\
\hline MA & Test Unit 06 & 8 & 0 & Mammal--lg. & Deer, sheep-sized & 4.9 \\
\hline MA & Test Unit 06 & 9 & 0 & Aves & Size indeterminate & 0.2 \\
\hline MA & Test Unit 06 & 9 & 0 & Mammal--sm. & Rabbit-sized & 0.4 \\
\hline MA & Test Unit 06 & 10 & 0 & Mammal--lg. & Deer, sheep-sized & 2.6 \\
\hline MA & Test Unit 06 & 12 & 0 & Aves & Size indeterminate & 0.1 \\
\hline MA & Test Unit 06 & 12 & 0 & Lepus californicus & Blacktailed jackrabbit & 1 \\
\hline MA & Test Unit 06 & 12 & 0 & Mammal & Size indeterminate & 0.9 \\
\hline MA & Test Unit 06 & 12 & 0 & Mammal--lg. & Deer, sheep-sized & 5.7 \\
\hline MA & Test Unit 06 & 12 & 0 & Mammal--sm. & Rabbit-sized & 1.5 \\
\hline MA & Test Unit 06 & 12 & 0 & Odocoileus virginianus & White-tailed deer & 3.2 \\
\hline MA & Test Unit 06 & 13 & 0 & Mammal & Size indeterminate & 3.1 \\
\hline MA & Test Unit 06 & 13 & 0 & Mammal--lg. & Deer, sheep-sized & 9 \\
\hline MA & Test Unit 06 & 13 & 0 & Mammal--sm. & Rabbit-sized & 0.1 \\
\hline MA & Test Unit 06 & 13 & 0 & Sylvilagus sp. & Cottontail rabbit & 0.4 \\
\hline
\end{tabular}


Table F-1. Continued...

\begin{tabular}{|c|c|c|c|c|c|c|}
\hline LA/MA & Unit & Level & Feature & Taxa & Description & Weight (g) \\
\hline MA & Test Unit 06 & 14 & 0 & Mammal--lg. & Deer, sheep-sized & 4 \\
\hline MA & Test Unit 06 & 14 & 0 & Odocoileus virginianus & White-tailed deer & 2.8 \\
\hline MA & Test Unit 06 & 16 & 0 & Mammal--lg. & Deer, sheep-sized & 5.5 \\
\hline MA & Test Unit 06 & 17 & 0 & Mammal--lg. & Deer, sheep-sized & 0.8 \\
\hline LA & Test Unit 07 & 1 & 0 & Artiodactyl & Deer, sheep, goats & 1.3 \\
\hline LA & Test Unit 07 & 1 & 0 & Aves--medium & Pidgeon-sized & 0.9 \\
\hline LA & Test Unit 07 & 1 & 0 & Mammal & Size indeterminate & 2.1 \\
\hline LA & Test Unit 07 & 1 & 0 & Mammal--lg. & Deer, sheep-sized & 16.2 \\
\hline LA & Test Unit 07 & 2 & 0 & Artiodactyl & Deer, sheep, goats & 0.2 \\
\hline LA & Test Unit 07 & 2 & 0 & Mammal & Size indeterminate & 2.6 \\
\hline LA & Test Unit 07 & 2 & 0 & Mammal--lg. & Deer, sheep-sized & 0.7 \\
\hline LA & Test Unit 07 & 2 & 0 & Mammal--sm. & Rabbit-sized & 0.8 \\
\hline LA & Test Unit 07 & 3 & 106 & Mammal & Size indeterminate & 0.6 \\
\hline LA & Test Unit 07 & 4 & 106 & Mammal & Size indeterminate & 0.4 \\
\hline LA & Test Unit 08 & 1 & 0 & Mammal & Size indeterminate & 3.3 \\
\hline LA & Test Unit 08 & 1 & 0 & Mammal & Size indeterminate & 0.4 \\
\hline LA & Test Unit 08 & 1 & 0 & Mammal--lg. & Deer, sheep-sized & 4.9 \\
\hline LA & Test Unit 08 & 1 & 0 & Mammal--lg. & Deer, sheep-sized & 14.1 \\
\hline LA & Test Unit 08 & 2 & 0 & Artiodactyl & Deer, sheep, goats & 0.2 \\
\hline LA & Test Unit 08 & 2 & 0 & Canis sp. & Dogs, coyotes, wolves & 0.3 \\
\hline LA & Test Unit 08 & 2 & 0 & Mammal & Size indeterminate & 8.1 \\
\hline LA & Test Unit 08 & 2 & 0 & Mammal--lg. & Deer, sheep-sized & 16.3 \\
\hline LA & Test Unit 08 & 2 & 0 & Mammal--V. lg. & Cattle, bison, horse-sized & 3.1 \\
\hline LA & Test Unit 08 & 3 & 106 & Mammal & Size indeterminate & 1.2 \\
\hline LA & Test Unit 08 & 3 & 106 & Mammal--lg. & Deer, sheep-sized & 3.5 \\
\hline LA & Test Unit 08 & 4 & 106 & Artiodactyl & Deer, sheep, goats & 0.2 \\
\hline LA & Test Unit 08 & 4 & 106 & Aves--medium & Pidgeon-sized & 0.1 \\
\hline LA & Test Unit 08 & 4 & 106 & Mammal & Size indeterminate & 6.5 \\
\hline LA & Test Unit 08 & 4 & 106 & Mammal--lg. & Deer, sheep-sized & 12.8 \\
\hline LA & Test Unit 08 & 4 & 106 & Sigmodon hispidus & Cotton rat & 0.2 \\
\hline LA & Test Unit 09 & 3 & 0 & Mammal--lg. & Deer, sheep-sized & 2.2 \\
\hline LA & Test Unit 09 & 4 & 0 & Mammal--lg. & Deer, sheep-sized & 0.5 \\
\hline LA & Test Unit 09 & 5 & 0 & Mammal & Size indeterminate & 0.3 \\
\hline LA & Test Unit 09 & 6 & 0 & Mammal & Size indeterminate & 0.4 \\
\hline LA & Test Unit 09 & 6 & 0 & Mammal--lg. & Deer, sheep-sized & 2.3 \\
\hline LA & Test Unit 09 & 7 & 0 & Artiodactyl & Deer, sheep, goats & 4.6 \\
\hline LA & Test Unit 09 & 7 & 0 & Aves & Size indeterminate & 0.1 \\
\hline
\end{tabular}


Table F-1. Continued...

\begin{tabular}{|c|c|c|c|c|c|c|}
\hline $\mathbf{L A} / \mathbf{M A}$ & Unit & Level & Feature & Taxa & Description & Weight (g) \\
\hline LA & Test Unit 09 & 7 & 0 & Aves--large & Chicken-sized & 1.2 \\
\hline LA & Test Unit 09 & 7 & 0 & Mammal & Size indeterminate & 2.6 \\
\hline LA & Test Unit 09 & 7 & 0 & Mammal--lg. & Deer, sheep-sized & 18.8 \\
\hline LA & Test Unit 09 & 7 & 0 & Odocoileus virginianus & White-tailed deer & 22.2 \\
\hline LA & Test Unit 09 & 8 & 0 & Artiodactyl & Deer, sheep, goats & 4.4 \\
\hline LA & Test Unit 09 & 8 & 0 & Mammal--lg. & Deer, sheep-sized & 9 \\
\hline LA & Test Unit 09 & 8 & 0 & Mammal--V. lg. & Cattle, bison, horse-sized & 15.4 \\
\hline LA & Test Unit 09 & 9 & 0 & Aves--large & Chicken-sized & 0.8 \\
\hline LA & Test Unit 09 & 9 & 0 & Galliformes & Pheasants, turkeys, chickens, quail & 3.4 \\
\hline LA & Test Unit 09 & 9 & 0 & Mammal & Size indeterminate & 3.1 \\
\hline LA & Test Unit 09 & 9 & 0 & Mammal--lg. & Deer, sheep-sized & 7.6 \\
\hline LA & Test Unit 09 & 10 & 0 & Artiodactyl & Deer, sheep, goats & 1.2 \\
\hline LA & Test Unit 09 & 10 & 0 & Mammal--lg. & Deer, sheep-sized & 4.3 \\
\hline LA & Test Unit 09 & 11 & 0 & Mammal--lg. & Deer, sheep-sized & 1.3 \\
\hline LA & Test Unit 09 & 12 & 0 & Mammal--lg. & Deer, sheep-sized & 0.6 \\
\hline MA & Test Unit 09 & 15 & 0 & Mammal--lg. & Deer, sheep-sized & 4 \\
\hline MA & Test Unit 09 & 16 & 0 & Mammal--lg. & Deer, sheep-sized & 1.9 \\
\hline MA & Test Unit 09 & 16 & 0 & Odocoileus virginianus & White-tailed deer & 15.5 \\
\hline MA & Test Unit 09 & 17 & 0 & Bovinae & Cattle or bison & 8 \\
\hline MA & Test Unit 09 & 17 & 0 & Mammal & Size indeterminate & 0.3 \\
\hline LA & Test Unit 10 & 3 & 0 & Mammal--lg. & Deer, sheep-sized & 0.3 \\
\hline LA & Test Unit 10 & 4 & 0 & Mammal & Size indeterminate & 0.6 \\
\hline LA & Test Unit 10 & 4 & 0 & Mammal--lg. & Deer, sheep-sized & 0.6 \\
\hline LA & Test Unit 10 & 5 & 0 & Mammal--lg. & Deer, sheep-sized & 1.3 \\
\hline LA & Test Unit 10 & 6 & 0 & Mammal & Size indeterminate & 1.5 \\
\hline LA & Test Unit 10 & 6 & 0 & Mammal--lg. & Deer, sheep-sized & 5.2 \\
\hline LA & Test Unit 10 & 6 & 0 & Mammal--sm. & Rabbit-sized & 0.2 \\
\hline LA & Test Unit 10 & 7 & 0 & Mammal & Size indeterminate & 10.2 \\
\hline LA & Test Unit 10 & 7 & 0 & Mammal--lg. & Deer, sheep-sized & 28.6 \\
\hline LA & Test Unit 10 & 7 & 0 & Mammal--med. & Dog-sized & 0.7 \\
\hline LA & Test Unit 10 & 7 & 0 & Mammal--V. lg. & Cattle, bison, horse-sized & 5.7 \\
\hline LA & Test Unit 10 & 7 & 0 & Odocoileus virginianus & White-tailed deer & 17 \\
\hline LA & Test Unit 10 & 7 & 0 & Sylvilagus sp. & Cottontail rabbit & 0.1 \\
\hline LA & Test Unit 10 & 8 & 108 & Artiodactyl & Deer, sheep, goats & 1.7 \\
\hline LA & Test Unit 10 & 8 & 108 & Aves--medium & Pidgeon-sized & 0.1 \\
\hline LA & Test Unit 10 & 8 & 108 & Mammal & Size indeterminate & 8.1 \\
\hline LA & Test Unit 10 & 8 & 108 & Mammal--lg. & Deer, sheep-sized & 14.5 \\
\hline
\end{tabular}


Table F-1. Continued...

\begin{tabular}{|c|c|c|c|c|c|c|}
\hline LA/MA & Unit & Level & Feature & Taxa & Description & Weight (g) \\
\hline LA & Test Unit 10 & 8 & 108 & Mammal--med. & Dog-sized & 0.5 \\
\hline LA & Test Unit 10 & 8 & 108 & Mammal--sm. & Rabbit-sized & 0.3 \\
\hline LA & Test Unit 10 & 8 & 108 & Mammal--V. lg. & Cattle, bison, horse-sized & 21 \\
\hline LA & Test Unit 10 & 9 & 0 & Mammal & Size indeterminate & 3.2 \\
\hline LA & Test Unit 10 & 9 & 0 & Mammal--V. lg. & Cattle, bison, horse-sized & 15.5 \\
\hline LA & Test Unit 10 & 10 & 0 & Mammal--V. lg. & Cattle, bison, horse-sized & 2.8 \\
\hline LA & Test Unit 10 & 11 & 0 & Mammal & Size indeterminate & 0.3 \\
\hline LA & Test Unit 10 & 11 & 0 & Mammal--lg. & Deer, sheep-sized & 3 \\
\hline LA & Test Unit 10 & 11 & 0 & Mammal--V. lg. & Cattle, bison, horse-sized & 2.2 \\
\hline MA & Test Unit 10 & 16 & 0 & Aves--medium & Pidgeon-sized & 0.1 \\
\hline MA & Test Unit 10 & 16 & 0 & Mammal--med. & Dog-sized & 0.3 \\
\hline MA & Test Unit 10 & 17 & 0 & Mammal & Size indeterminate & 0.6 \\
\hline MA & Test Unit 10 & 17 & 0 & Mammal--lg. & Deer, sheep-sized & 1.5 \\
\hline MA & Test Unit 10 & 17 & 0 & Mammal--sm. & Rabbit-sized & 0.2 \\
\hline MA & Test Unit 10 & 17 & 0 & Sylvilagus sp. & Cottontail rabbit & 0.2 \\
\hline LA & Test Unit 11 & 4 & 0 & Mammal--lg. & Deer, sheep-sized & 4 \\
\hline LA & Test Unit 12 & 4 & 0 & Mammal & Size indeterminate & 0.5 \\
\hline LA & Test Unit 12 & 4 & 0 & Mammal & Size indeterminate & 0.8 \\
\hline LA & Test Unit 12 & 4 & 0 & Mammal--lg. & Deer, sheep-sized & 7.7 \\
\hline LA & Test Unit 12 & 5 & 0 & Mammal & Size indeterminate & 0.8 \\
\hline LA & Test Unit 12 & 5 & 0 & Mammal--lg. & Deer, sheep-sized & 3.6 \\
\hline LA & Test Unit 12 & 6 & 0 & Mammal--V. lg. & Cattle, bison, horse-sized & 11.4 \\
\hline LA & Test Unit 12 & 6 & 0 & Mammal--V. lg. & Cattle, bison, horse-sized & 42.8 \\
\hline LA & Test Unit 12 & 7 & 0 & Mammal--V. lg. & Cattle, bison, horse-sized & 1.4 \\
\hline LA & Test Unit 12 & 9 & 0 & Mammal & Size indeterminate & 0.5 \\
\hline LA & Test Unit 12 & 10 & 0 & Mammal & Size indeterminate & 0.8 \\
\hline LA & Test Unit 13 & 3 & 0 & Mammal--lg. & Deer, sheep-sized & 1 \\
\hline LA & Test Unit 13 & 6 & 0 & Mammal & Size indeterminate & 0.2 \\
\hline LA & Test Unit 14 & 4 & 0 & Mammal & Size indeterminate & 0.1 \\
\hline LA & Test Unit 14 & 4 & 0 & Mammal--lg. & Deer, sheep-sized & 0.6 \\
\hline
\end{tabular}



Appendix G:

Radiocarbon Results

Darden Hood

Beta Analytic

Miami, Florida 



\begin{tabular}{|c|c|c|c|}
\hline Sample Data & $\begin{array}{l}\text { Measured } \\
\text { Radiocarbon Age }\end{array}$ & $\begin{array}{c}13 \mathrm{C} / 12 \mathrm{C} \\
\text { Ratio }\end{array}$ & $\begin{array}{c}\text { Conventional } \\
\text { Radiocarbon Age( })\end{array}$ \\
\hline $\begin{array}{l}\text { Beta-215735 } \\
\text { SAMPLE : } 41 \text { BXI7BHT9 } \\
\text { ANALYSIS : AMS-Advance deliver } \\
\text { MATERIAL/PRETREATMENT : } \\
\text { 2. SIGMA CALIBRATION : }\end{array}$ & $\begin{array}{l}3890+/-50 \mathrm{BP} \\
2480 \text { to } 2210(\mathrm{Cal} \mathrm{BP} 4\end{array}$ & $-25.30 / 00$ & $3890+/-50 \mathrm{BP}$ \\
\hline $\begin{array}{l}\text { Beta-215736 } \\
\text { SAMPLE: } 41 B X 17 \mathrm{~F} 100 \\
\text { ANALYSIS : } \text { MMS-Advance delivery } \\
\text { MATERIAL/PRETREATMENT: } \\
\text { 2 SIGMA CALIBRATION : }\end{array}$ & $\begin{array}{l}1990+/-40 \mathrm{BP} \\
60 \text { to } \mathrm{Cal} \mathrm{AD} 90(\mathrm{Cal})\end{array}$ & $\begin{array}{l}-24.9 \mathrm{o} / 00 \\
1860)\end{array}$ & $1990+/-40 \mathrm{BP}$ \\
\hline $\begin{array}{l}\text { Beta - } 215737 \\
\text { SAMPLE : } 41 \text { BX17F } 103 \\
\text { ANALYSIS : AMS-Adyance deliver } \\
\text { MATERIAL/PRETREATMENT : } \\
\text { 2. SIGMA CALIBRATION : }\end{array}$ & $\begin{array}{l}2510+7-40 \text { BP } \\
\text { material), acid/alkali/a } \\
790 \text { to } 500 \text { (Cal BP } 274\end{array}$ & $\begin{array}{l}-25.0 \mathrm{o} / 00 \\
\mathrm{ANDCalBC}\end{array}$ & $2510+1-40 \mathrm{BP}$ \\
\hline $\begin{array}{l}\text { Beta }-215738 \\
\text { SAMPLE: } 41 \text { BX17F } 104 \\
\text { ANALYSIS : AMS-Advance delivery } \\
\text { MATERIAL/PRETREATMENT : } \\
\text { 2SIGMA CALIBRATION : }\end{array}$ & $\begin{array}{l}3800+/-40 \mathrm{BP} \\
\text { material): acid/alkali/a } \\
2340 \text { to } 2130(\mathrm{Cal} \mathrm{BP}\end{array}$ & $-25.20 / 00$ & $3800+1-40 \mathrm{BP}$ \\
\hline $\begin{array}{l}\text { Beta-215739 } \\
\text { SAMPLE : } 41 \text { BXI7F } 105 \\
\text { ANALYSIS : AMS-Adyance deliven } \\
\text { MATERIAL/PRETREATMENT : } \\
\text { 2.SIGMA CALIBRATION : }\end{array}$ & $\begin{array}{l}3620+7-40 \mathrm{BP} \\
\text { material): acid/alkali/a } \\
2030 \text { to } 1870 \text { (Cal BP }\end{array}$ & $-26.9 \mathrm{o} / 00$ & $3590+1-40 \mathrm{BP}$ \\
\hline
\end{tabular}




\begin{tabular}{|c|c|c|c|}
\hline Sample Data & $\begin{array}{c}\text { Measured } \\
\text { Radiocarbon Age }\end{array}$ & $\begin{array}{c}13 \mathrm{C} / 12 \mathrm{C} \\
\text { Ratio }\end{array}$ & $\begin{array}{c}\text { Conventional } \\
\text { Radiocarbon Age( })\end{array}$ \\
\hline $\begin{array}{l}\text { Beta - } 215740 \\
\text { SAMPLE : } 41 \text { BXI7TU5L13 } \\
\text { ANALYSIS : AMS-Advance deliven } \\
\text { MATERIAL/PRETREATMENT : } \\
\text { 2. SIGMA CAL.IBRATION : }\end{array}$ & $\begin{array}{l}4150+\gamma-40 \mathrm{BP} \\
2880 \text { to } 2580(\mathrm{Cal} \mathrm{BP}\end{array}$ & $-26.3 \% / 00$ & $4130+/-40 \mathrm{BP}$ \\
\hline
\end{tabular}




\section{CALIBRATION OF RADIOCARBON AGE TO CALENDAR YEARS}

(Variables: $\mathrm{C} 13 / \mathrm{C} 12=-25,3: 1 \mathrm{ab}, \mathrm{mult}=1$ )

Laboratory number: Beta-215735

Conventio nal radiocarbon age: $3890 \pm 50$ BP

2 Sigma calibrated result: Cal BC 2480 to 2210 (C al BP 4430 to 4160 ) (95\% probability)

In te re ept data

Intercepts of radiocarbon age

with calibration curve: Cal BC 2400 (Cal BP 4350) and

Cal BC 2380 (Ca1BP 4330) and

Cal BC 2360 (CalBP 4300)

1 Sigma oalibrated result: Cal BC 2460 to 2290 (Cal BP 4410 to 4240) $(68 \%$ probability)

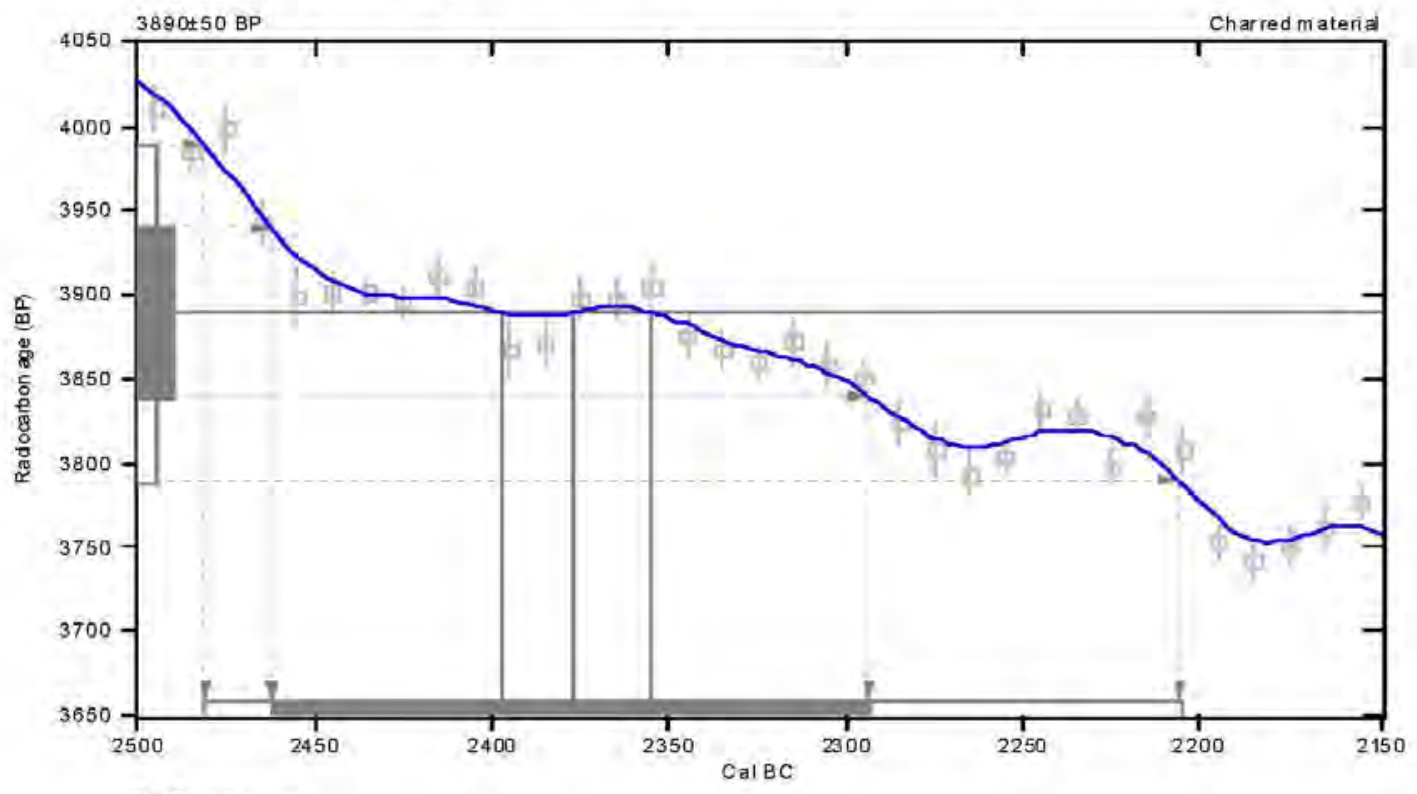

References:

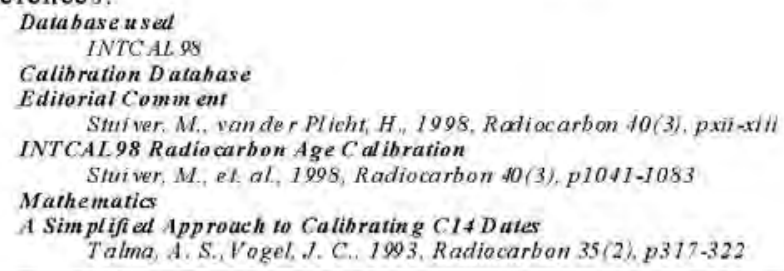

Beta Analytic Radiocarbon Dating Laboratory

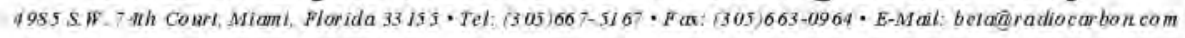




\section{CALIBRATION OF RADIOCARBON AGE TO CALENDAR YEARS}

(Variables: $\mathrm{C} 13 / \mathrm{C} 12=-24.9: 1 \mathrm{ab}, \mathrm{mult}=1$ )

La boratory number: Beta-215736

Conventio nal radiocarbon age:

$1990 \pm 40 \mathrm{BP}$

2 Sigma calibrated result:

Cal BC 60 to Cal AD 90 (Cal BP 2010 to 1860 ) (95\% probability)

In tercept data

Intercept of radiocarbon age with calibration curve: Cal AD 20 (Ca1 BP 1930)

1 Sigma calibrated result: Cal BC 40 to Cal AD 60 (Cal BP 1990 to 1890) $(68 \%$ probability)

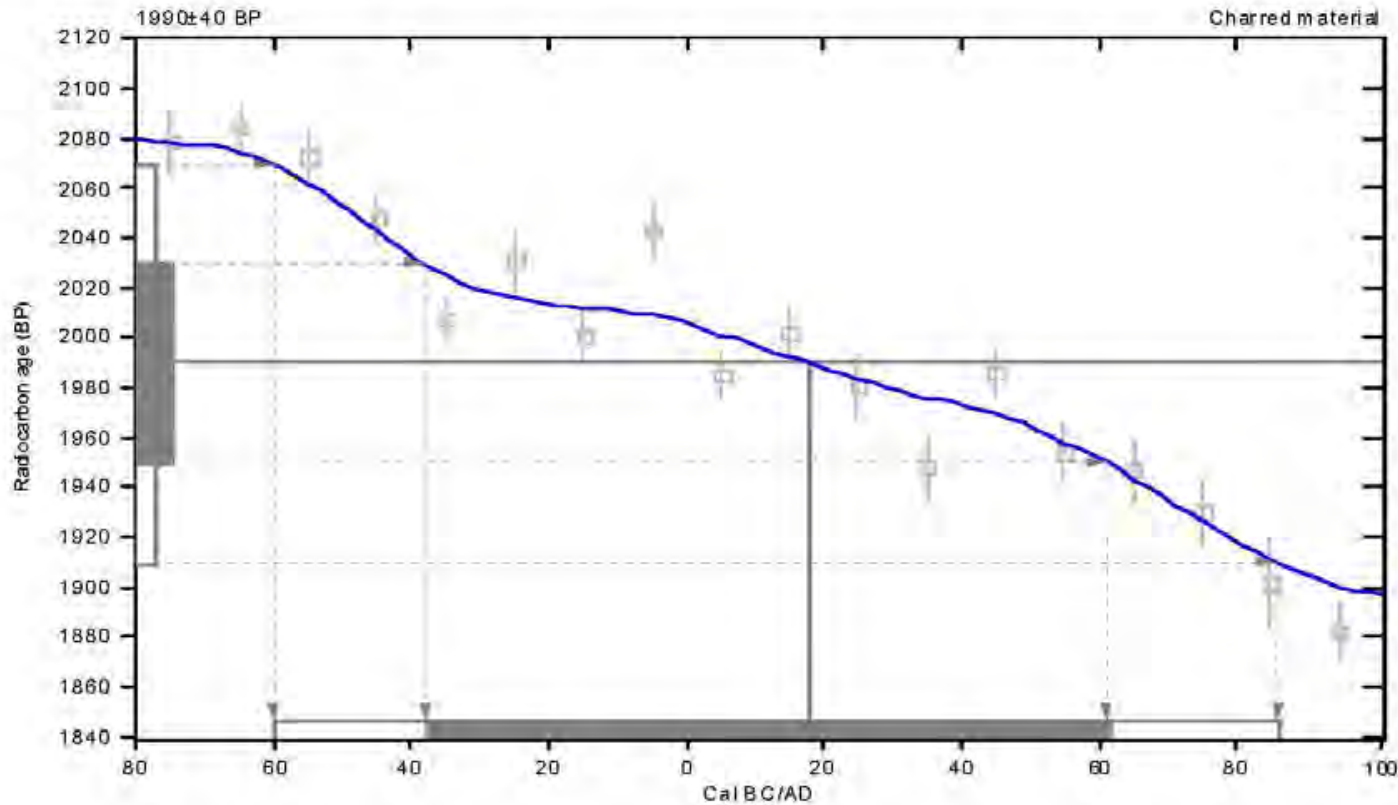

References:

Daiabase used

INTCAL gs

Calibration Datahase

Editorial Comm ens

Stuiver. M., vander Plicht, $H, 1998$, Radiocarbon 10(3), pxï-xith

INTCAL 98 Radiocarbon Age C alibration

Stuiver, M., et. al, 1998, Radiocarbon 40(3), p1041-1083

Mathematics

A Simplified Approach to Calihrating C1 $1+$ Dates

Talma, A. S., Vogel, A. C. 1993, Radiacarbon 35/2), p377-322

\section{Beta Analytic Radiocarbon Dating Laboratory}

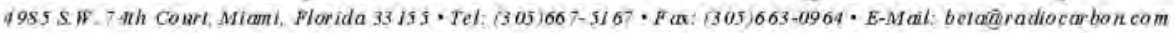




\section{CALIBRATION OF RADIOCARBON AGE TO CALENDAR YEARS}

(Variables: $\mathrm{C} 13 / \mathrm{C} 12=-25 ; \mathrm{ab}, \mathrm{mult}=1$ )

Laboratory number: Beta-215737

Conventional radiocarbon age: $2510 \pm 40 \mathrm{BP}$

2 Sigma calibrated results: Cal BC 790 to 500 (Cal BP 2740 to 2450) and (95\% probability) Cal BC 460 to 430 (Cal BP 2410 to 2380)

In tercept data

Intercept of radiocarbon age

with calibration curve: Cal BC 770 (Ca1 BP 2720)

1 Sigma calibrated results: Cal BC 780 to 750 (Cal BP 2730 to 2700) and

(68\% probability) Cal BC 700 to 540 (Cal BP 2650 to 2490 )

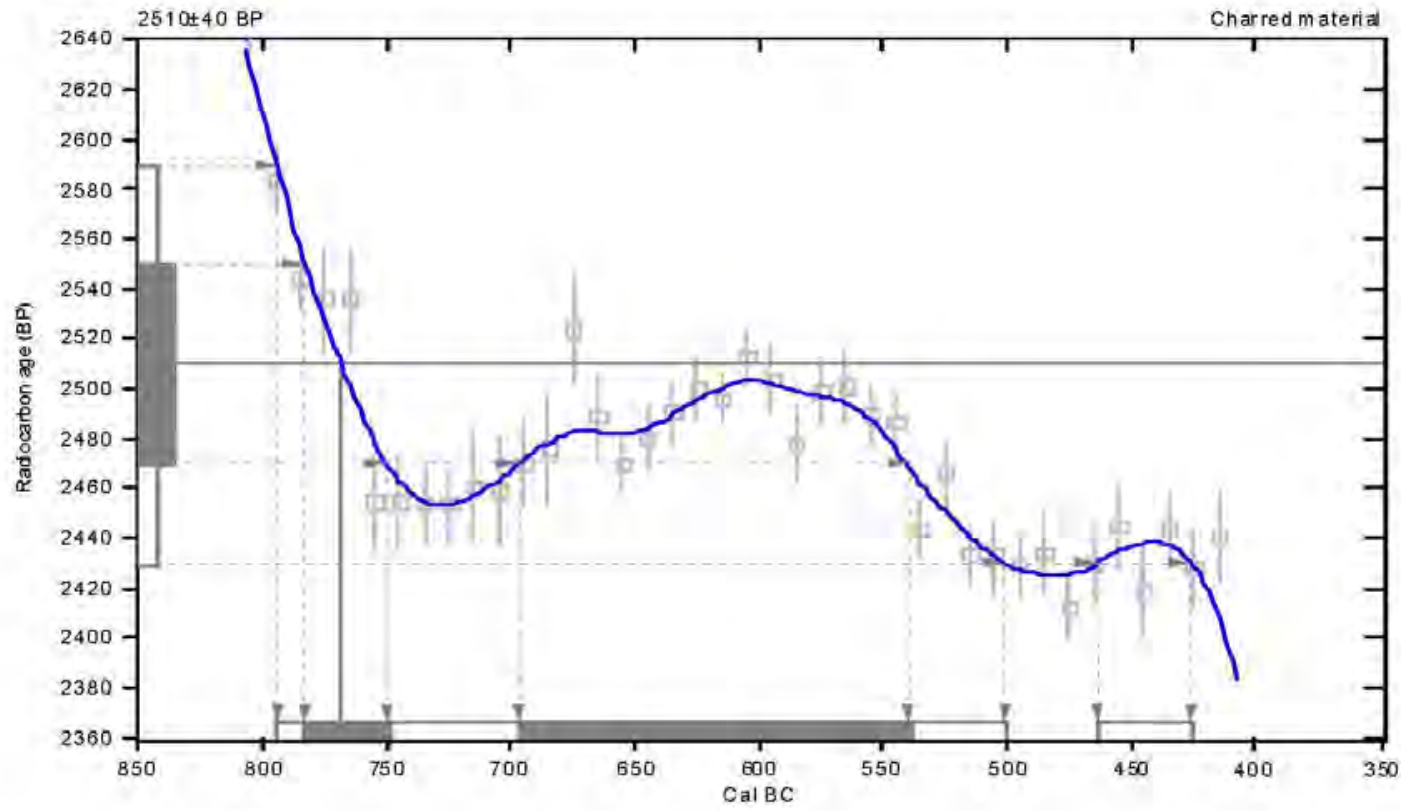

References:

Database used

INTCAL Q9

Calibration Datahase

Editorial Comm ent

Stuiver, M., vander Plicht, $H, 1998$, Radiocarbon 10(3), pxï- $x i t i$

INTCAL 98 Radio carbon Age C al ibration

Stuiver, M., et. al, 1998, Radiocarbon $40(3)$, p1041-1083

Mathematics

A Simplified Approach to Calihrating C1+Dates

Talma, A. S., Voget, J. C.. 1993, Radiocarban 35/2), p377-322

\section{Beta Analytic Radiocarbon Dating Laboratory}

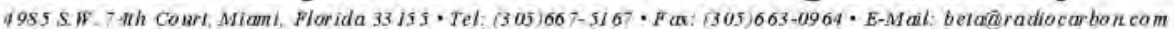




\section{CALIBRATION OF RADIOCARBON AGE TO CALENDAR YEARS}

(Variables: $\mathrm{C} 13 / \mathrm{C} 12=-25,2 ; \mathrm{lab}, \mathrm{mult}=1$ )

La boratory number: Beta-215738

Conventional radiocarbon age: $3800 \pm 40 \mathrm{BP}$

2 Sigma calibrated result: Cal BC 2340 to 2130 (Cal BP 4290 to 4080) ( $95 \%$ probability)

In te reept data

Intercept of radiocarbon age with calibration curve: Cal BC 2210 (Cal BP 4160)

1 Sigma calibrated results: Cal BC 2290 to 2190 (Cal BP 4240 to 4140 ) and ( $68 \%$ probability) Cal BC 2170 to 2150 (Cal BP 4120 to 4100 )

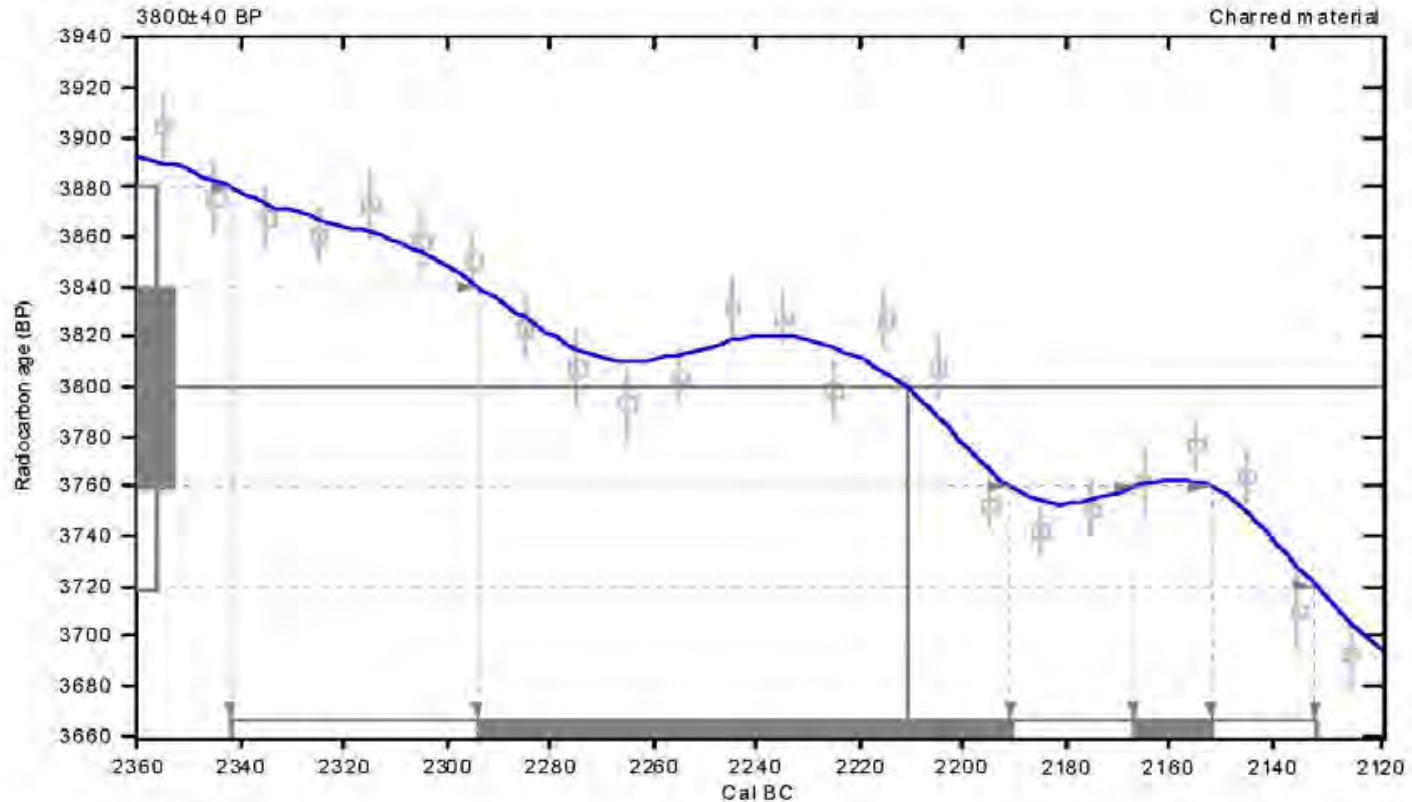

References:

Database used INTCAL QS

Calibration Datahase Editorial Comm ent

Stuiver, $M$., vander Plicht, $H, 1998$, Radiocarbon 10(3), pxï-xiti

INTCAL 98 Radio carbon Age C al ibration

Stui ver, M., et. al, 1998 , Radiocarbon 40(3), p1041-1083

Mathematics

A Simplified Approach to Calihrating C14Dates

Talma, A.S., Vogel, .7. C. 199.3, Radiocarbon 35/2), p317-322

\section{Beta Analytic Radiocarbon Dating Laboratory}

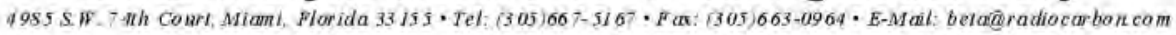




\section{CALIBRATION OF RADIOCARBON AGE TO CALENDAR YEARS}

(Variables: $\mathrm{C} 13 / \mathrm{C} 12=-26.9: 1 \mathrm{ab}, \mathrm{mult}=1$ )

La boratory number: Beta-215739

Conventional radiocarbon age: $3590 \pm 40 \mathrm{BP}$

2 Sigma calibrated result: Cal BC 2030 to 1870 (C al BP 3980 to 3820 ) (95\% probability)

In te reept data

Intercept of radiocarbon age with calibration curve: Cal BC 1940 (Ca1 BP 3880)

1 Sigma calibrated result: Cal BC 1970 to 1890 (Cal BP 3920 to 3840 ) ( $68 \%$ probability)

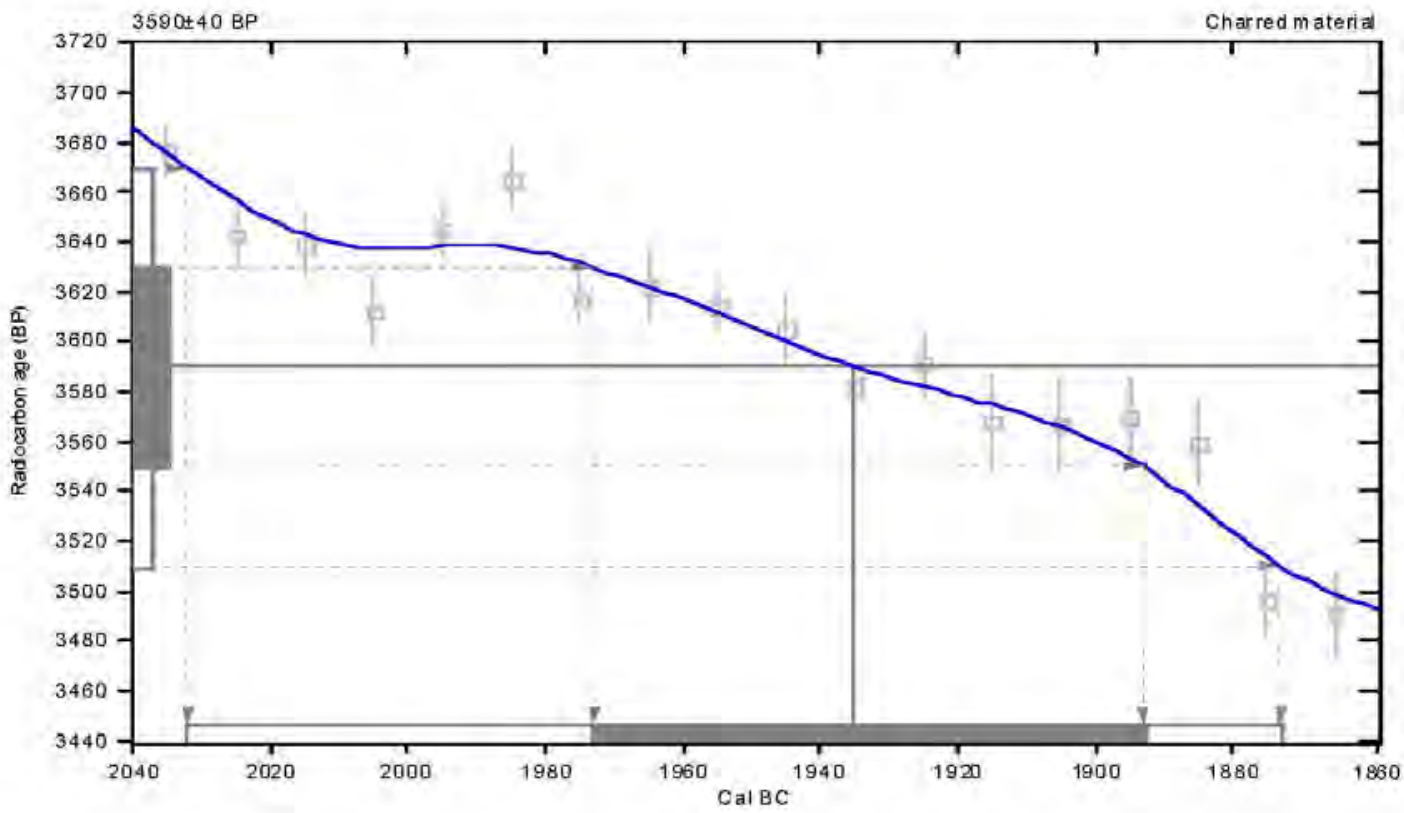

References:

Database used

INTCAL QS

Calibration Datahase

Editorial Comm ent

Sturver. M., vander Plicht, $H_{,}, 1998$, Radiocarbon 10(3), pxï-xith

INTCAL 98 Radio carbon Age C al ibration

Stuiver, M. et. al, 1998, Radiocarbon $40(3)$, p1041-1053

Mathematics

A Simplified Approach to Calibrating C1 D Dates

Talma, A.S., Vagel, 7. C.. 1993, Radiacarbon $35 / 2\rangle$, p317-322

Beta Analytic Radiocarbon Dating Laboratory

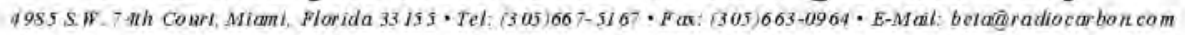




\section{CALIBRATION OF RADIOCARBON AGE TO CALENDAR YEARS}

(Variables: $\mathrm{C} 13 / \mathrm{C} 12=-26,3: 1 \mathrm{ab}, \mathrm{mult}=1$ )

La boratory number: Beta-215740

Conventional radiocarbon age: $4130 \pm 40 \mathrm{BP}$

2 Sigma calibrated result: Cal BC 2880 to 2580 (C al BP 4830 to 4520 )

(95\% probability)

In tercept data

Intercepts of radiocarbon age

with calibration curve: $\mathrm{Cal} \mathrm{BC} 2850$ (Cal BP 4800 ) and

Cal BC 2820 (Cal BP 4770) and

Cal BC 2670 (CalBP 4620)

1 Sigm a calibrated results: Cal BC 2860 to 2800 (Cal BP 4810 to 4750 ) and

(68\% probability) Cal BC 2760 to 2600 (Cal BP 4710 to 4560 )

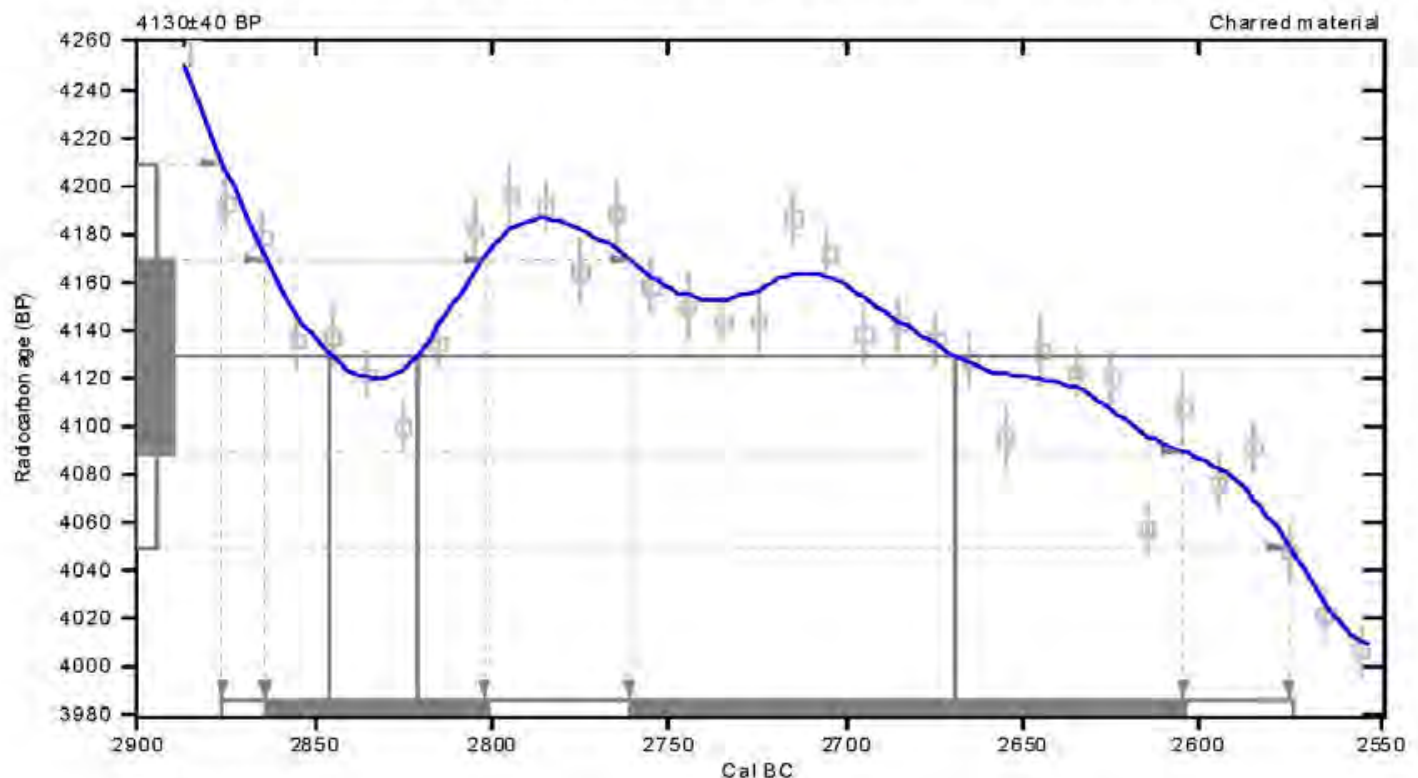

References:

Daiabase used

$$
\text { INTCAL Q8 }
$$

Calibration Datahase

Editorial Comm ent

Stufver, $M$., vander Plicht, $H, 1998$, Radiocarbon $10(3), p x i \bar{u}-x i t h$

INTCAL 98 Radio carbon Age C al ibration

Stuiver, M., et. al, 1998, Radiocarbon \$0(3), p1041-1083

Mathematics

A Simplified Approach to Calihrating C1+Dates

Talma, A.S., Voget, J. C., 1993 , Radiocarbon 35/2), p377-322

\section{Beta Analytic Radiocarbon Dating Laboratory}

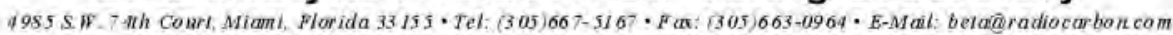


Appendix H:

Bioarcheological Analysis of a Commingled Prehistoric Burial from the Granberg Site (41BX17/271), Bexar County, Texas

Cynthia M. Munoz 



\title{
Appendix H
}

\section{Bioarcheological Analysis of a Commingled Prehistoric Burial from the Granberg Site (41BX17/271), Bexar County, Texas}

\author{
Cynthia M. Munoz \\ Center for Archaeological Research \\ The University of Texas at San Antonio
}

\section{Introduction}

In the spring of 2007, Mark Kohnitz donated human skeletal remains from the Granberg Site, 41BX17/271, to the Center for Archaeological Research (CAR) at the University of Texas at San Antonio (UTSA). These remains were recovered in 1962 by Harvey Kohnitz, an avocational archeologist, and were subsequently stored at the Kohnitz home until the 2007 donation. The Center for Archaeological Research (CAR) performed an osteological analysis on the remains. The analysis was conducted in February 2008 by Cynthia M. Munoz at the CAR laboratory for the Texas Department of Transportation, Environmental Affairs Division (TxDOT), under Work Authorization No. 57513 SA005 Supplemental Work Authorization No. 4. This work is in partial fulfillment of Texas Antiquities Permit No. 4010, with Dr. Steve A. Tomka serving as Principal Investigator.

The human remains recovered by H. Kohnitz in 1962 are believed to be the first archeologically excavated at 41BX17/271. Kohnitz and associates discovered the remains upon inspection of the walls of a City Water Board utility trench excavated for a water main across what eventually became a new segment of N. E. Loop 410. Subsequent to Kohnitz's recovery, the Witte Museum, under the direction of Mardith Schuetz, recovered an additional eight individuals (minimum number) from the site (Schuetz 1966). In 1984 one burial and another possible burial were reported by workmen during ditching activities performed by the South Texas Construction Co. in the access road right-of-way (ROW) adjacent to 41BX271. According to a letter written by Dr. Thomas Hester in 1984, the ditching activities were performed without consulting with the Highway Department as stated in the Texas Antiquities Code. These remains appear to have been disposed of and no action was taken to prevent or document the situation.

The purpose of this report is to provide a comprehensive analysis of the human skeletal remains recovered by H. Kohnitz in 1962. As part of this analysis the literature on the recovered human skeletal remains from Schuetz's investigation (1966) and literature from other excavated burials in Bexar County will be examined for comparative data.

\section{The Granberg Site Burial Features}

In 1962, Harvey Kohnitz discovered human remains while monitoring the excavation of a City of San Antonio water main trench. Kohnitz identified three burials within this trench and expanded the excavation to explore the extent of the cultural deposits. At this time, the Texas Highway Department recognized the importance of this extensive stratified site and allowed the Witte Museum, under the direction of Mardith Schuetz, to excavate. Schuetz's (1966) report discusses the results of this excavation.

The archeological excavation that occurred at the Granberg Site in 1962 was a salvage effort, designed to mitigate the impacts of road construction after discovery of prehistoric human remains. Mardith Schuetz's 1966 report documented human burials in four features from the 1962 Granberg excavations: Features 1, 2A, 2B, and 5.

Although Features 2A, 2B, and 5 appeared to contain four interments at the time of excavation, upon further examination by Dr. Tom McKern, a physical anthropologist, it was determined that the features actually contained a minimum of eight individuals (see Appendix J). Feature 1 was excavated immediately prior to Schuetz's work by Harvey Kohnitz. The Feature 1 remains recovered by Kohnitz are believed to be the first archeologically excavated at 41BX17/271. Schuetz (1966) reported 
that the feature contained three individuals. The material recovered and the related data were never turned over to the Witte Museum and, hence, were considered "lost" until the spring of 2007 at which time it was donated to the CAR. This section presents information, detailed to the extent possible, pertaining to the background of the recovery of Feature 1. The section also discusses the other three burial features.

\section{Feature 1}

The CAR accepted a donation of human remains from Mark Kohnitz in the spring of 2007. The remains consisted of burials from the Granberg Site that Harvey Kohnitz, Mark's father, excavated from a City of San Antonio water main trench in 1962. The remains were delivered to the CAR in several large boxes that had been stored in the Kohnitz garage, apparently since the 1960s. The donation included photographs of the Witte Museum excavations, photographs and sketches of artifacts, sketch maps, and brief notes. No artifacts were included with the remains. Upon inspection of the donated documentation it was determined that these remains were the "lost" Feature 1 burials. The following paragraph summarizes Kohnitz's notes included with the donated remains.

At the time of the 1962 Granberg excavations, Harvey Kohnitz was a United States Air Force Sergeant stationed in San Antonio at Lackland Air Force Base. He spent his free time as an avocational archeologist. According to Granberg hand-written notes, Sgt. Kohnitz hunted the Salado location for years, picking up surface relics. In September 1962, Kohnitz discovered a trench excavated by the City Water Board near the anticipated location of a new segment of N.E. Loop 410. Notes state that the trench was dug for the new subdivision of Fairfield. Sgt. Kohnitz stopped at the trench on the way home from work and discovered relics in the backdirt and walls. He subsequently called friends, "fellow cavers", listed as Dr. Hausmann, Dr. Everett Rhoades, Grey, Doyle, John Allyson, and Montgomery, to help collect artifacts.

On Sunday, October 21, 1962, Kohnitz, his "whole family", and friends spent the day "scratching" the sides of the trench. At sundown, after everyone left except family, the first skull was unearthed. After taking his children and mother home, Kohnitz called Mardith Schuetz of the Witte Museum for assistance. Because help was not available that evening, Kohnitz and his wife removed the burial and artifacts by themselves "by lantern light and in a hurry." Unfortunately, no photos, sketches or

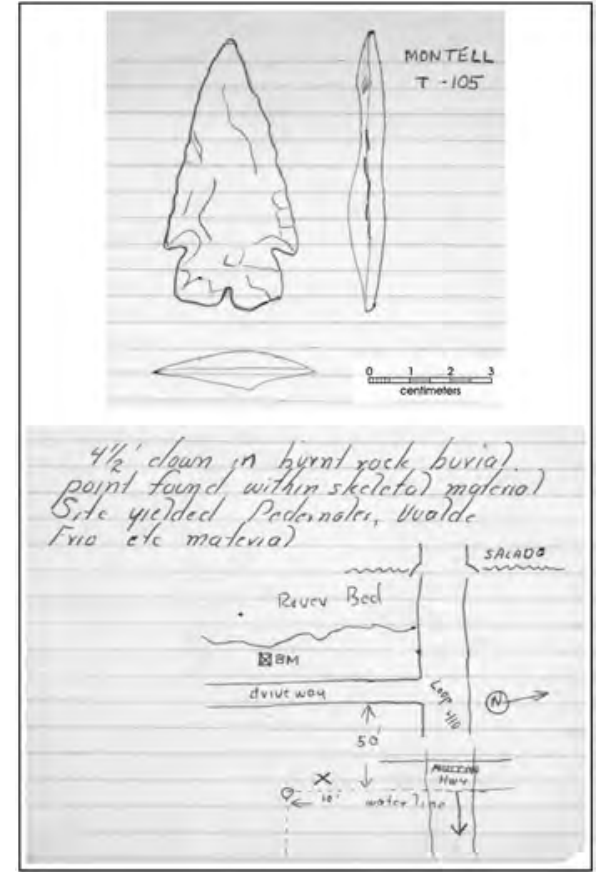

Figure H-1. Sketch by Harvey Kohnitz of Montell point and Feature 1 burial location.

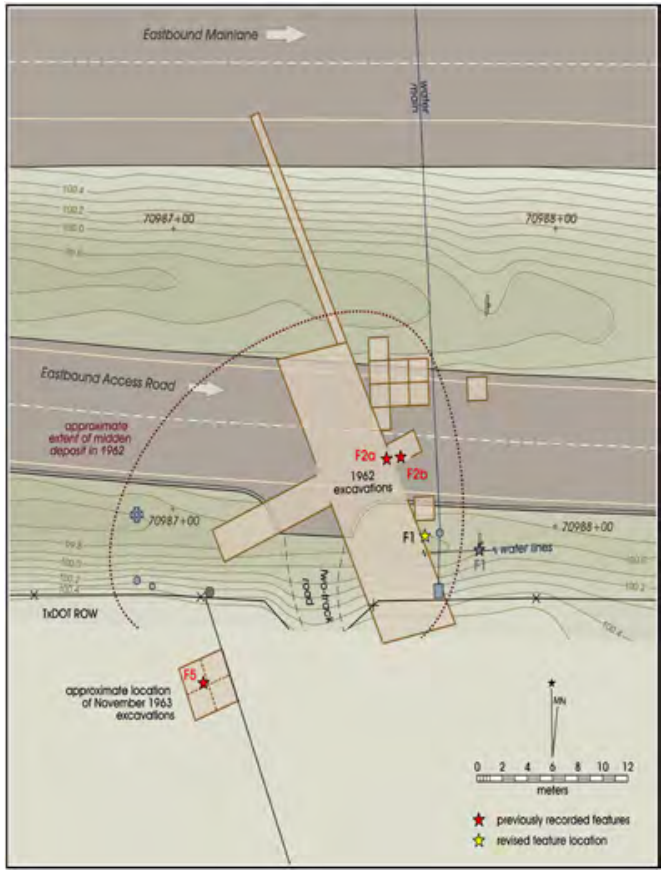

Figure H-2. Estimate of the location of Feature 1 and revised location per Kohnitz sketch map. 

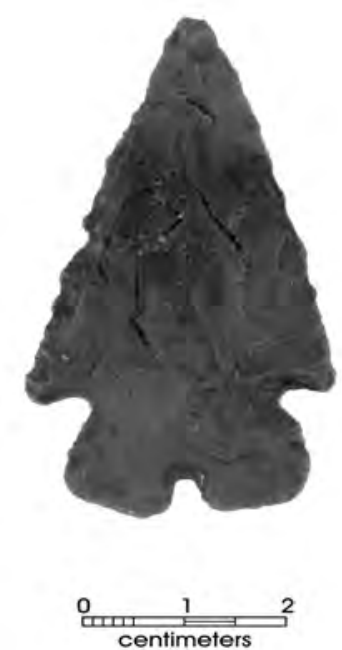

Figure H-3. Montell point associated with Feature 1 burial. other documentation indicating placement of the remains exists. It does not appear that the burials were pedestaled or removed according to archeologically sound techniques of the time, likely due to the rush and conditions of excavation.

A sketch of a Montell point was included with the donation. The point is labeled "water ditch Kohnitz site" and is described as " $4 \frac{1}{2}$ ", down in burnt rock burial, point found within skeletal material." The sketch includes a map of the waterline with an X on the burial site (Figure H-1). To date, this map is the first documentation the CAR has come across of the location of Feature 1. The map corresponds fairly closely to the Córdova et al. (2005) estimate of the location of Feature 1 (Figure H-2). Note the revised location of Feature 1 as per the Kohnitz sketch. A photograph of a point that appears to correspond to the sketch was also included with the donation (Figure H-3). A profile sketch of the water main trench detailing the burial, the location of the Montell point, the location of knives (no photos or sketches located), a "shell concho", and the location of two Castroville points was also included (Figure H-4). A photograph of a clamshell gorget in Shuetz's 1966 report attributed to Kohnitz's Feature 1 appears to be the "shell concho" (Figure H-5). The association of these

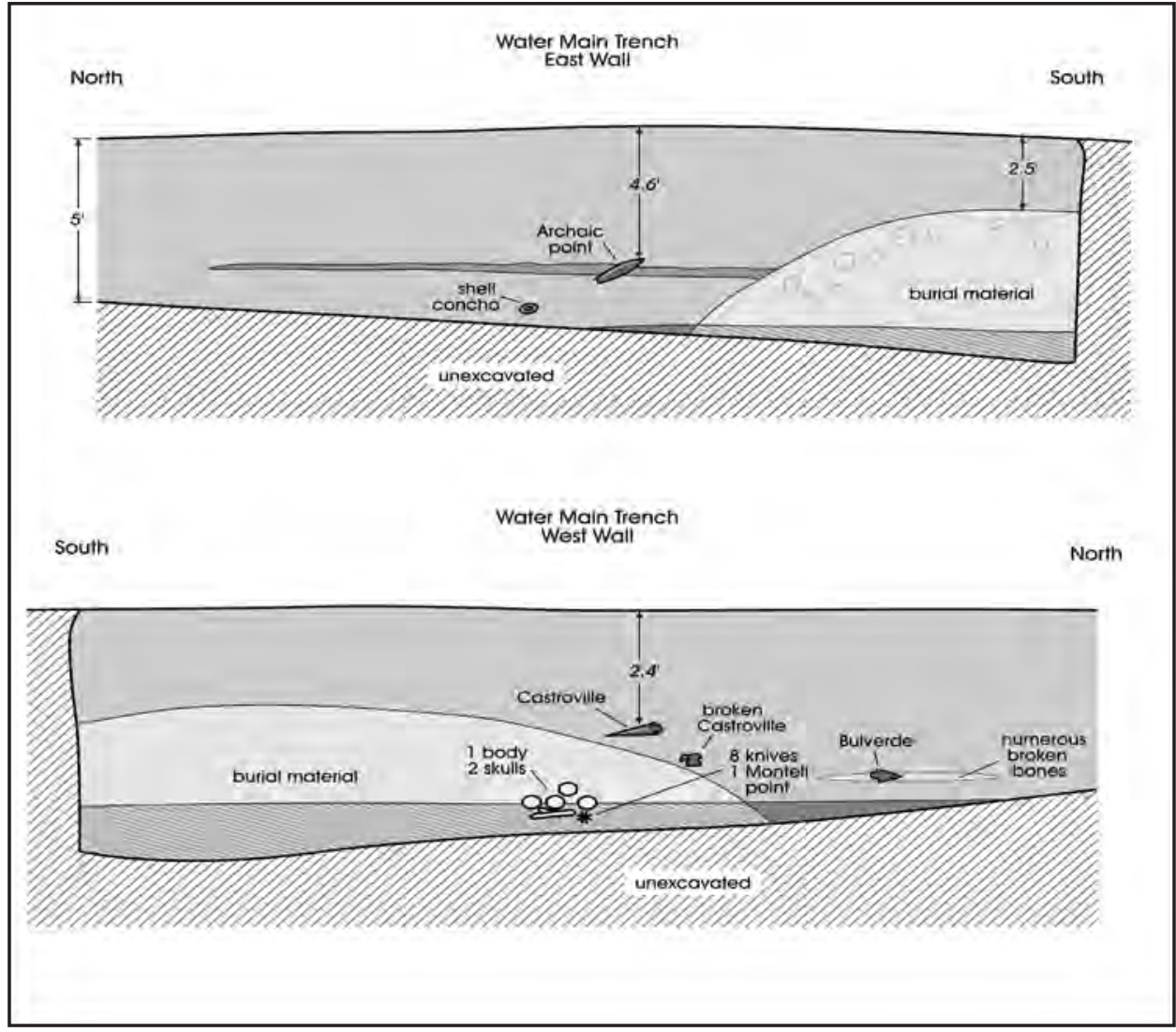

Figure H-4. Adapted from a sketch by Harvey Kohnitz of the City water main trench detailing burial and associated artifacts. 
Table H-1. Artifacts Donated to the CAR in 2010 Associated with Feature 1 Burial

\begin{tabular}{|c|c|c|c|}
\hline Description & n & Comments & Report Figure \\
\hline shell concho & 1 & Sketched in on Kohnitz map east of the burial (see Figure H-4). & Figure H-5 \\
\hline gorget & 1 & & Figure H-6 \\
\hline worked bone & 1 & Described by H. Kohnitz as a broken inscribed knife handle. & Figure H-8 \\
\hline worked bone & 1 & Described as a bone rasp by H. Kohnitz. & Figure H-8 \\
\hline mussel shell & 4 & & Figure H-7 \\
\hline tar ball & 1 & Described by H. Kohnitz as a pitch ball for cementing blades to knife handle. & Figure H-8 \\
\hline Montell point & 1 & Sketched in on Kohnitz map as part of burial (see Figure H-4). & Figure H-3 \\
\hline biface (late stage) & 7 & Sketched in on Kohnitz map as a pile of knives next to the burial (see Figure H-4). & Figures H-9, H-10 \\
\hline
\end{tabular}

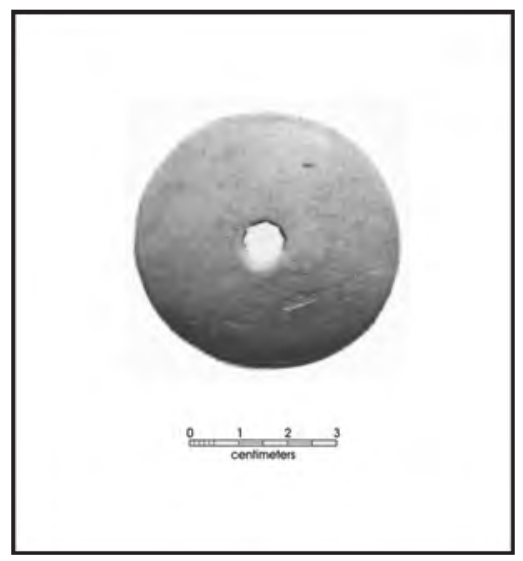

Figure H-5. Clam shell gorget from Feature 1.

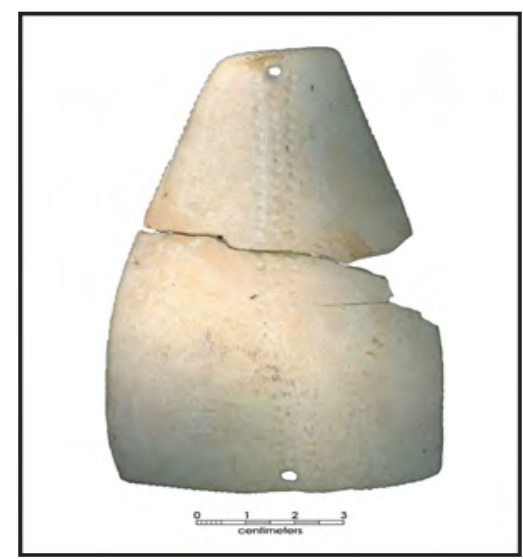

Figure H-6. Gorget associated with Feature 1 burial.

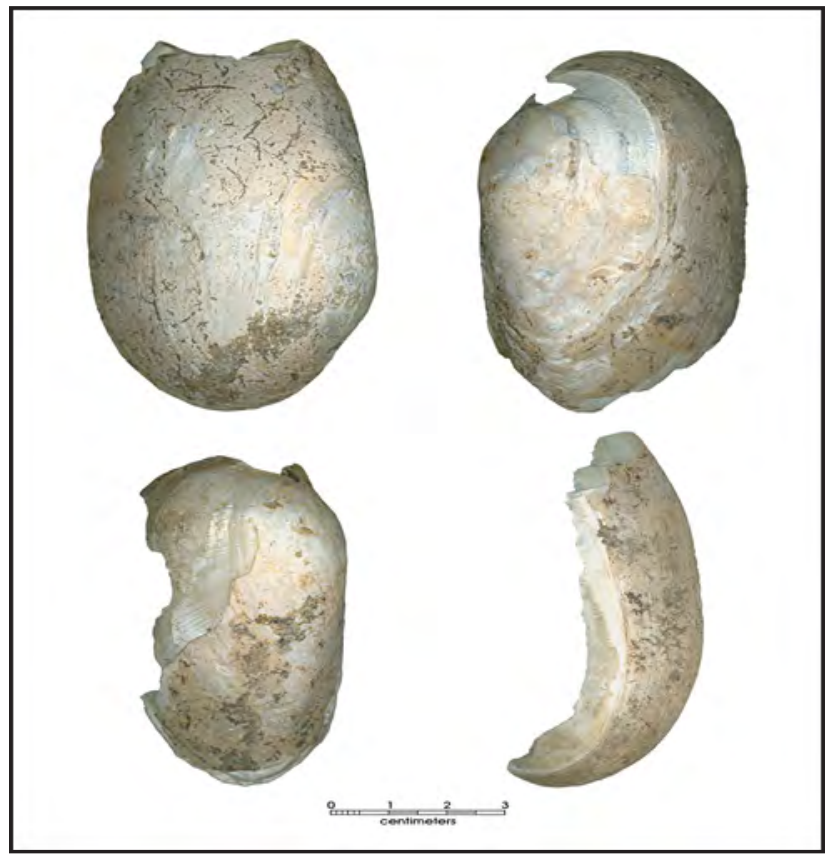

Figure H-7. Mussel shell associated with Feature 1 burial. 


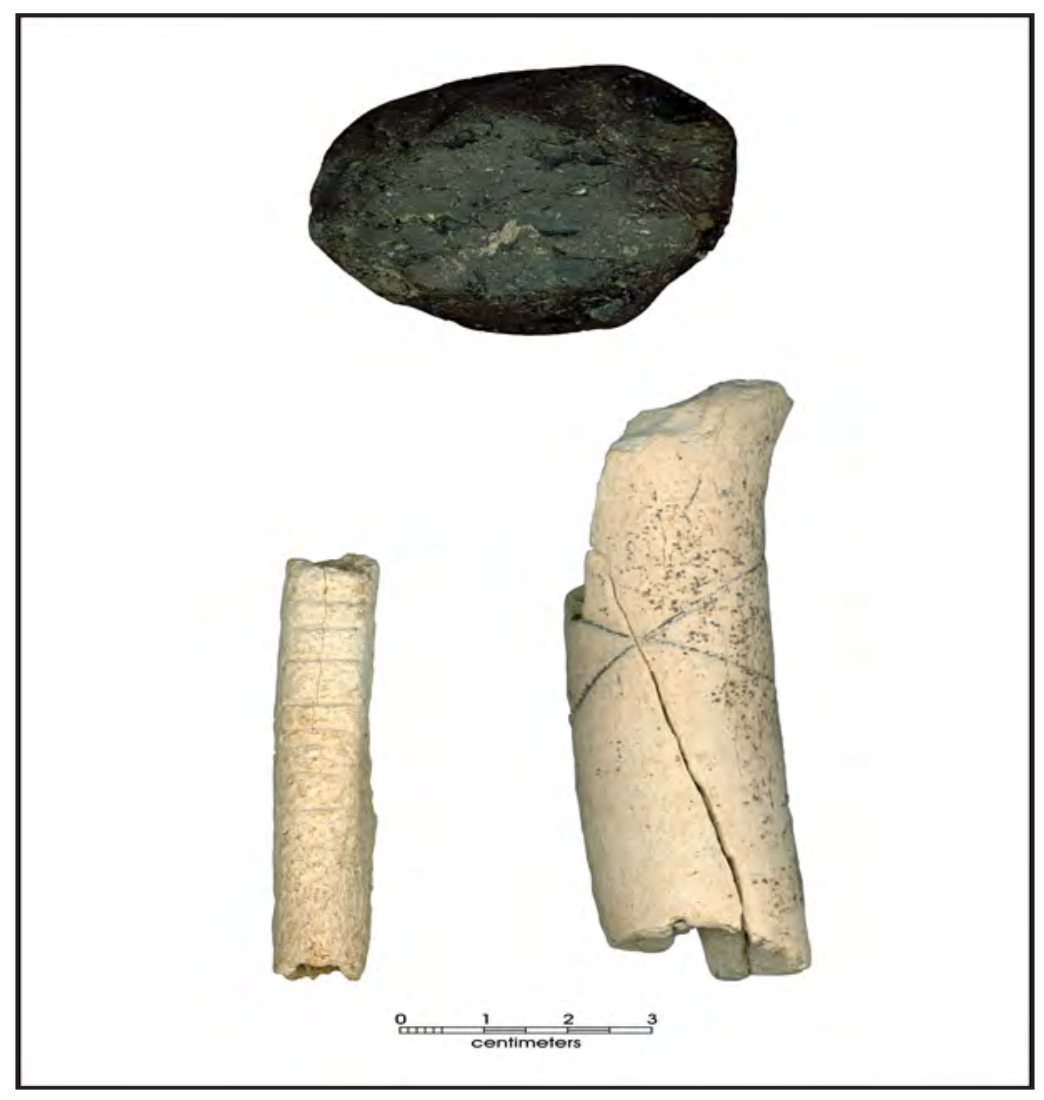

Figure H-8. Tar ball and worked bone associated with Feature 1 burial.

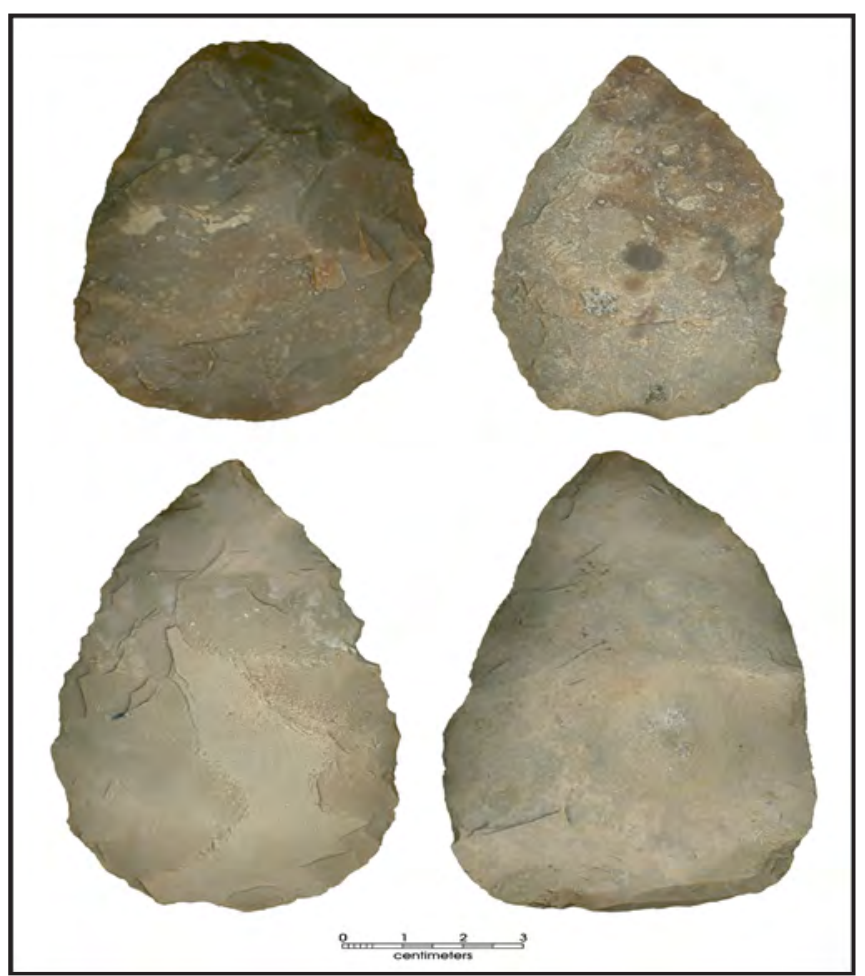

Figure H-9. Bifaces associated with Feature 1 burial.

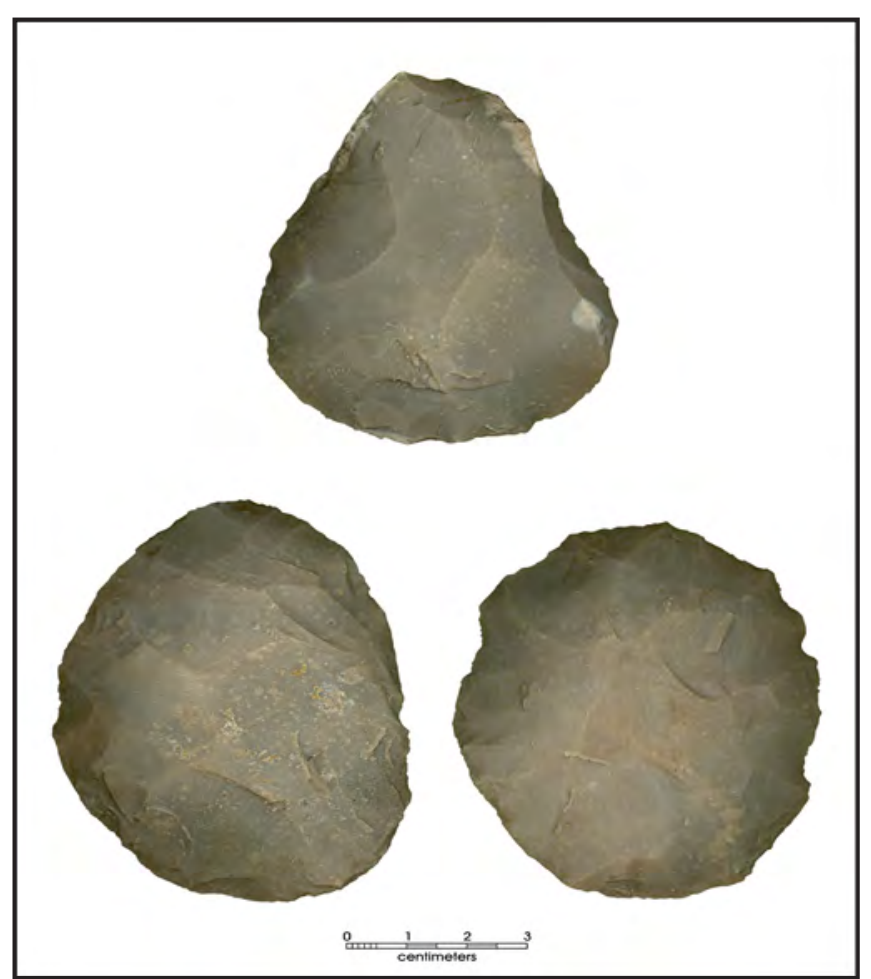

Figure H-10. Bifaces associated with Feature 1 burial. 


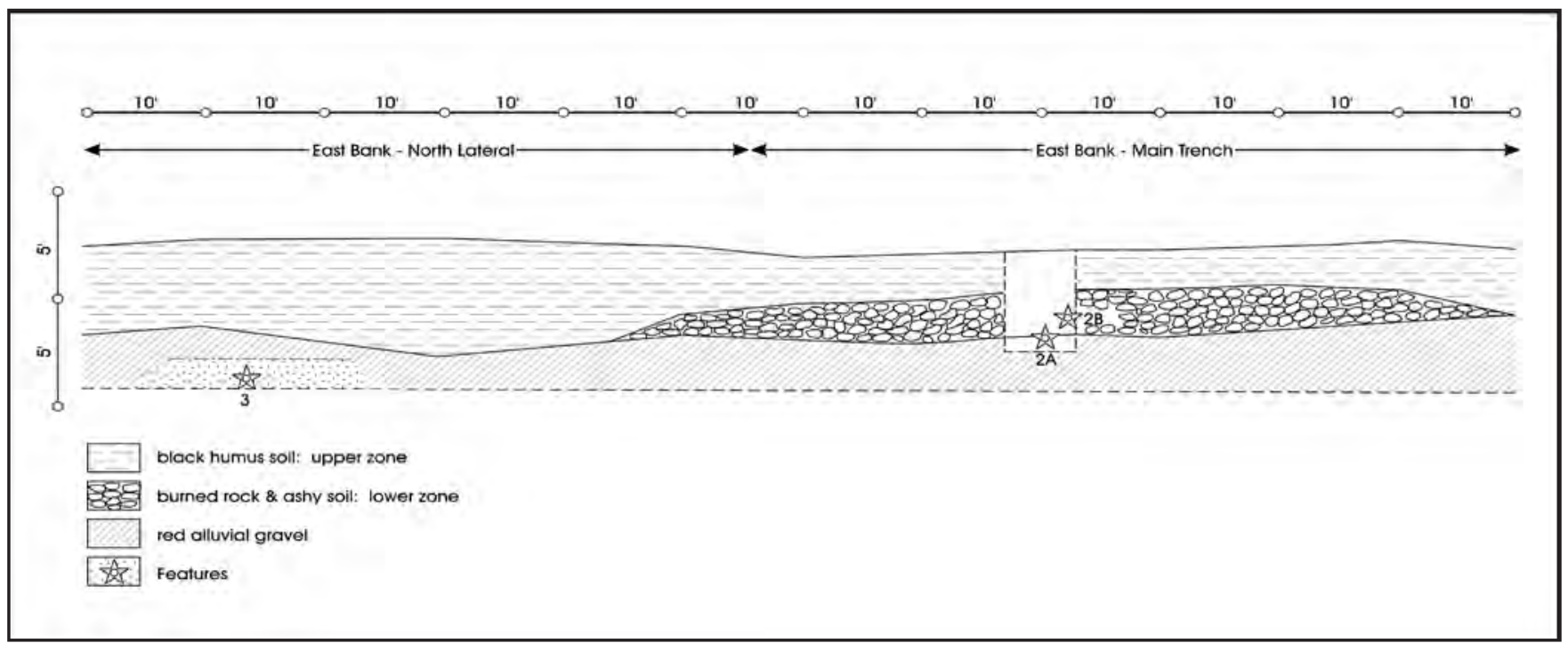

Figure H-11. Profile for trench as illustrated by Schuetz.

points with the Feature 1 remains suggests the burials date to the Late Archaic. Subsequent to excavating the trench burials, Kohnitz persuaded the highway contractor, Mr. Dean Word of Word Construction Company, to open a trench to attempt to reveal the site. The trench exposed a stratified site. At this point, October 28, 1962, the Witte Museum under the direction of Mardith Scheutz began professional excavations of the Granberg Site.

In early 2010 Mark Kohnitz donated additional artifacts, associated with his father's 1962 excavations of the water trench, to the CAR. The donation included 160 points, 69 tools, and 11 bone and shell artifacts (see Appendix K, Figures K-16-K-33 for photos of selected artifacts). Table $\mathrm{H}-1$ presents a list of the artifacts directly associated with the Feature 1 burial. See Figures H-6, H-7, H-8, H-9, and $\mathrm{H}-10$ for illustrations of the burial artifacts.

\section{Feature 2A}

Feature 2A, located in the east wall of the main trench (see Figure H-2), was originally determined by Schuetz to consist of two burials. Upon subsequent offsite inspection by Tom McKern (physical anthropologist), the count was revised to a minimum number of five individuals (see Appendix J). The following description uses Schuetz's numbering of two burials in Feature 2A. The burials are within the burned rock midden (Schuetz 1966). Figure H-11 is a profile sketch of the east wall of the north lateral, illustrating the location Figure H-12. Stone gorget from Burials 1 and 2 from Feature 2. 
of Feature 2A and Feature 2B (see next section). The first burial was encountered to the west of the second burial and Feature 2B. Burial 1 was interred in a fully flexed position on the right side facing west. The arms were displaced, postmortemly, possibly by machinery or bioturbation (root action).

Burial 2, located to the southeast of Burial 1, was oriented on a north-south axis on its left side. The bones of both Burials 1 and 2 were badly disturbed by root action and the pressure of overlying rock. In situ, it was apparent that the spinal column of Burial 2 contained several fused vertebrae. The vertebrae disintegrated upon removal and, thus, are not included in McKern's skeletal analysis (discussed in subsequent osteometric analysis). Because the double burial was exposed by machinery upon digging the trench, the upper half of Burial 2 and the cranium of Burial 1 were extensively damaged. A stone gorget was found with the displaced bones (Figure H-12). No other grave goods were present in Feature 2A (Schuetz 1966).

\section{Feature 2B}

Feature 2B lay immediately east of Feature 2A at a slightly higher elevation (see Figures H-2 and H-11). Schuetz determined that the feature was composed of one burial. As in Feature 2A, Schuetz's count of one does not agree with McKern's subsequent assessment of a minimum of two individuals. This burial was facing east on its right side. The burial was disturbed by the pressure of overlying soil and rock. No grave goods were recovered (Schuetz 1966).

\section{Feature 5}

Approximately one year after the completion of Schuetz's excavation of the Granberg Site, on November 10, 1963, another human burial was discovered. This burial, Feature 5, was located during a search for artifacts by Mr. Lewis Wilson. Wilson contacted Harvey Kohnitz, and the two subsequently excavated the remains. It was located roughly 15-23 m to the southwest of the burned rock midden (see Figure H-2). The Kohnitz donation to the CAR included brief notes and sketches of this feature. Figure H-13 is a sketch map showing the approximate location of the burial in relation to Loop 410. Figure H-14 is a rough

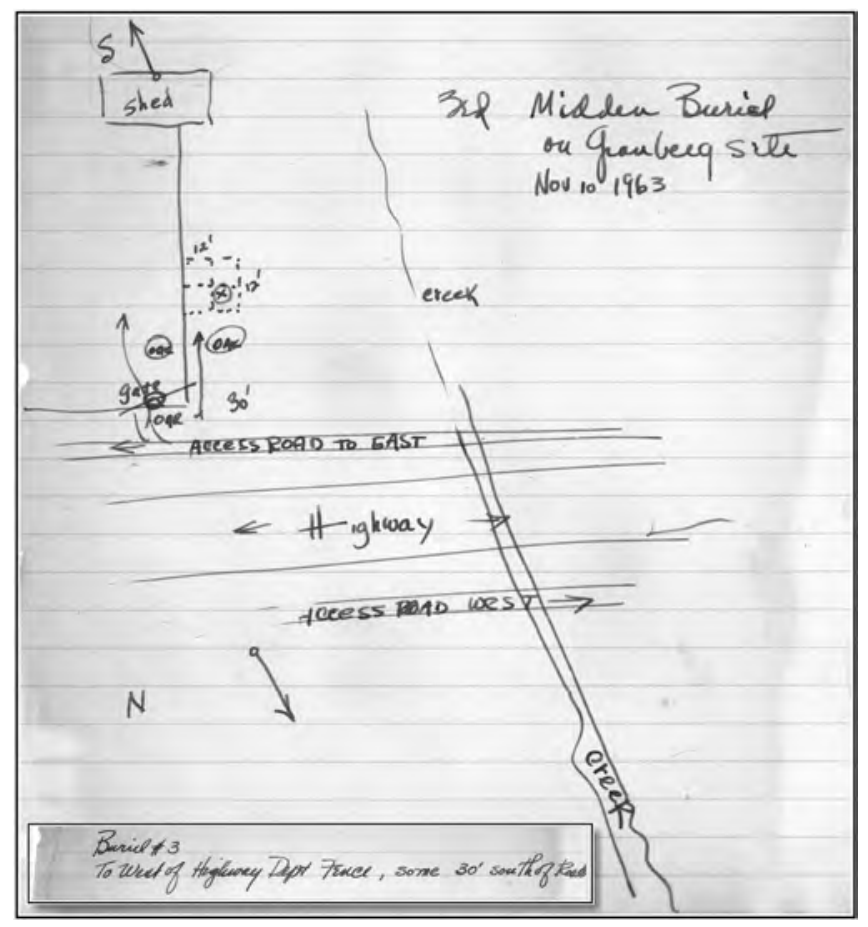

Figure H-13. Sketch map by H. Kohnitz showing the location of Feature 5 in relationship to Loop 410, 1963. 


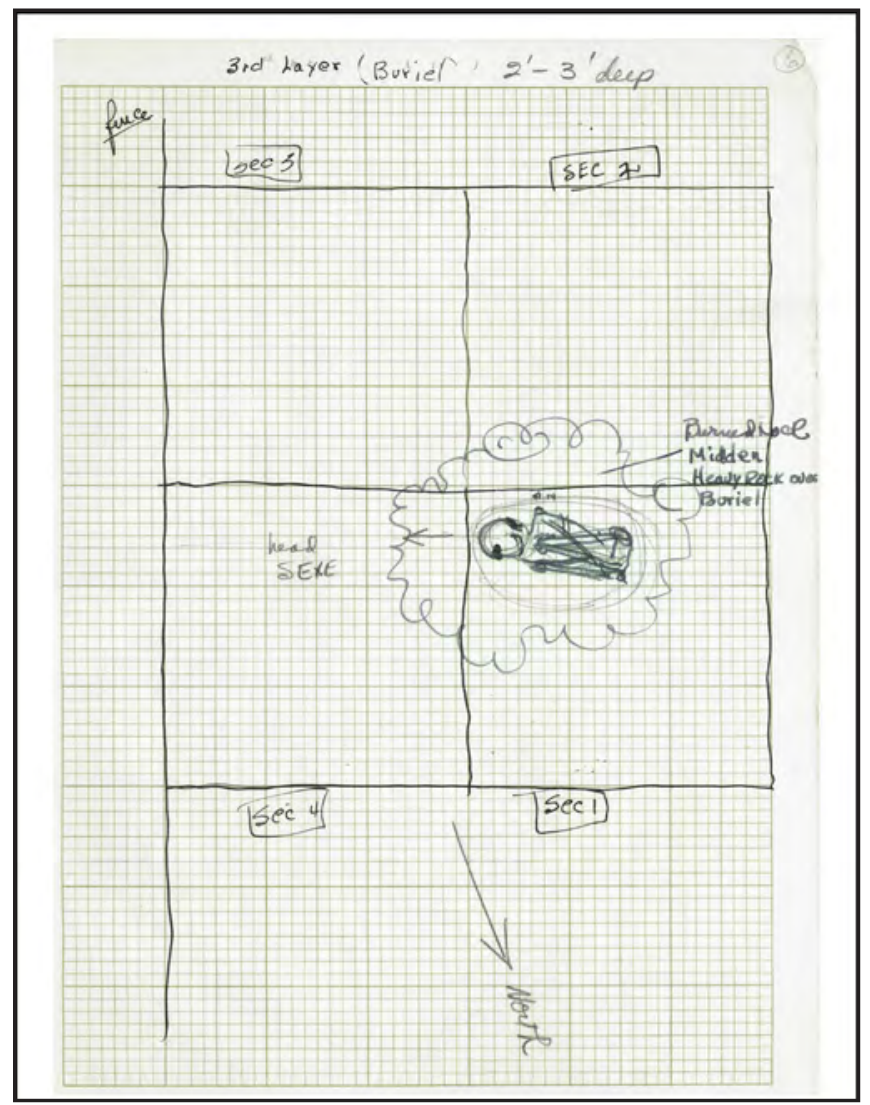

Figure H-14. Sketch of Feature 5 plan map by H. Kohnitz.

plan view of Level 3 (0.6-0.9 m below surface) showing the location and position of the burial. The burial was in a fully flexed position, oriented on an east-west axis with the head facing east. It was found in midden material beneath disturbed sediments. The bone was disturbed by heavy root action. No grave goods were recovered. The remains were curated by the Witte Museum and are included in Schuetz's 1966 report.

\section{Osteometric Analysis of Feature 1 Remains}

This section presents the osteometric analysis of the human remains donated to the CAR by Mark Kohnitz. The analysis is of commingled remains recovered from a single burial site designated Feature 1 by Mardith Schuetz of the Witte Museum in 1962. Although the remains were recovered from a multiple burial site and a 1966 report (McKern) describing other burials from the Granberg Site is available, a comparative study on population specifics is hindered by the lack of standard excavation and analytical techniques employed at the time of recovery (1962) and by the dearth of available information pertaining to Feature 1.

The intent of any osteometric analysis is to further knowledge regarding behaviors of a population. Bioarcheology is the interpretation of the lifeways of the individual and, by extension, of the community through the evidence gleaned from analysis of skeletal elements. The study of human remains contributes to the reconstruction of past lifeways, an understanding of biological and cultural history, and the relationship between a population's culture and its biology (Powell 1994). Bioarcheology is the study of the environmental effects (cultural, physical, and social) reflected in the skeletal assemblage (Steele and Olive 1989). Two examples of effective bioarcheological syntheses are found in Huebner and Comuzzie's (1992) excavations of the Blue Bayou site (41VT94) in Victoria County, Texas, and in the Jantz et al. (2002) analysis of the human remains recovered at Mission Nuestra Señora del Refugio (41RF1). The Blue Bayou analysis explores the biological affinity of this population through comparison with other skeletal collections. The Refugio synthesis used a thorough analysis of recovered human remains to address issues including pathology, dietary variation, demography, ethnicity, and mobility. 
The Blue Bayou and Refugio examples come from multiple interment mortuary sites and utilized numerous skeletal specimens. The commingled remains analyzed in this study are part of a multiple interment archeological site (a previous analysis of remains held at the Witte Museum of San Antonio reports a minimum number of individuals of eight), but due to the lack of detailed notes, photos, in situ sketches, artifacts, and provenience data accompanying the remains, conclusions as to the lifeways of the ancient population living at the Granberg Site is necessarily tenuous. As the current commingled remains are the only ones from 41BX17/271 to be analyzed following current Standards (Buikstra and Ubelaker 1994), little can be said about the population of the Granberg Site as a whole. A literature search of other burials excavated in Bexar County was undertaken for comparative purposes with the hope of revealing regional patterns. This data is presented in the following chapter. This section presents the analytical techniques applied to the commingled remains followed by a description of results and an osteological summary.

\section{Methods}

The analytical methods utilized in the current study are those recommended by Buikstra and Ubelaker (1994) for commingled remains. Destructive analysis was not performed in accordance with the work authorization mandated by TxDOT. While these remains were recovered from a multiple burial site, detailed comparable data on the other recovered burials does not exist, only brief summaries of each burial (McKern 1966). These summaries are discussed below, and McKern's report is included in this report as Appendix J.

In general, the skeletal remains analyzed in the current study are in good condition and, while many elements are fragmented, limited chemical weathering or other biological activity has not affected the fragments significantly enough to hinder their reconstruction. Reconstruction of elements was undertaken only to the degree necessary to aid in determination of the minimum number of individuals (MNI). Metric analysis was only performed on elements with the appropriate measurement landmarks intact. Reconstructed elements were not measured due to inherent postmortem alteration such as distortion and warping.

Standard osteometric analysis was utilized for the interpretation of the skeletal remains from Feature 1. Standard analysis was conducted in adherence to the criteria set forth in Standards (Buikstra and Ubelaker 1994). Available elements are present to discern the MNI and to discern sex, ancestry, and probable age. Because the remains were commingled and no documentation showing in situ arrangement was discovered, elements could not be sorted into individual interments with any degree of certainty. Therefore, it was decided not to compile and evaluate forensic data with the Forensic Database (ForDisc v. 3.0) maintained by the University of Tennessee at Knoxville (Ousley and Jantz 1996).

ForDisc consists of a databank, the Forensic Database (FDB), to which an unknown skeletal specimen can be compared. ForDisc allows an investigator to calculate discriminate functions using data from the FDB. These functions allow the user to classify an unknown into a specific ethnic group, male or female. It also has the ability to estimate stature. Due to population differences and secular changes, data from the FDB is only appropriate for the analysis of individuals born in the $20^{\text {th }}$ century. In addition to the FDB, ForDisc contains the Howells populations. This data (cranial only) may be more appropriate for older specimens. Analyzing remains from the $19^{\text {th }}$ century is aided by the addition of $19^{\text {th }}$ century American Whites and Blacks, but comparing earlier American groups, such as $17^{\text {th }}$ century to $20^{\text {th }}$ century Americans, should probably be avoided. ForDisc's primary use is in forensic identification, and therefore, it was not used with the Granberg Site Feature 1 burials. Insufficient intact cranial bone was available for metric analysis for comparison to the Howells population. ForDisc is not intended for commingled remains.

Only precision implements were employed during the attainment of metric traits of the skeletal remains. A standard wooden osteometric board was used for long bone measurements. Other skeletal measurements were obtained by Mitutoyo ${ }^{\circledR}$ Digimatic Calipers and Spreading Calipers. These data are presented in Appendix B. Following analysis, the individual elements were repackaged with identification tags noting the site, feature, and specific element identification. The skeletal elements were then stored in archival boxes. Upon completion of this portion of the project, the remains will be curated at the CAR and all required documents, including an inventory, will be submitted to the National Parks Service Native American Graves Protection and Repatriation Act (NAGPRA) Program to fulfill all obligations pertaining to the NAGPRA laws. 


\section{Results}

The skeletal remains recovered from Feature 1 of the Granberg Site in 1962 represent a minimum of 3 human individuals. This determination is based on counts of left femora and right tibiae. The human remains were donated to the CAR in three large boxes with all elements and skull fragments in mixed context. To further complicate sorting, bones from West Texas burials were also in the boxes. Because of the differing stages of preservation and the presence of a fine layer of powdery gray dirt on the West Texas bones, the Granberg bones were separated from the boxes with a high degree of certainty. An attempt was made to sort the Granberg elements into individuals, but due to a large degree of uncertainty, it was decided to treat the remains as a commingled burial.

\section{Sex Determination}

Based on the criteria set forth in the Standards (Buikstra and Ubelaker 1994), it can be established with certainty that the commingled remains include one female and one male. Adult male and female skeletons vary in both size and general shape. Therefore, accurate estimates of sex should be based on multiple factors including measurements of dimorphic dimensions, such as the maximum diameter of the femur head, and observations of morphological features known to differ between males and females. Ox Coxae morphology presents the most reliable indicator of sex in the human skeleton. Of the commingled remains, only one fragment of the ox coxae contained elements usable for sex determination, a right greater sciatic notch and right preauricular sulcus. Following Buikstra and Ubelaker (1994), assessment of these two indicators both resulted in a rating of ambiguous sex. No attributes of the subpubic region were recovered from Feature 1. The commingled remains include two fairly complete but fragmented calvaria. Based on cranial morphology, specifically on the supra-orbital margin, nuchal crest, mastoid processes, and mental eminence, one of the calvarium resulted in an overall rating of probable female and the other a probable male. Measurements of the one intact left femoral head and the one intact right femoral head $(47.5 \mathrm{~mm}$ and $49 \mathrm{~mm}$, respectively) fall in the maximum range for males ( $>47.5 \mathrm{~mm}$; Bass 1995). Measurements of the two intact humeral epicondyles (55.9 $\mathrm{mm}$ and $64.3 \mathrm{~mm}$ ) point to one female and one male, respectively (Bass 1995).

\section{Age Determination}

Frequently in commingled contexts it is only possible to distinguish immature from mature materials. Specific age range determination is rarely possible due to the difficulties encountered in isolating individual remains. Using the criteria set forth in Standards (Buikstra and Ubelaker 1994), age is based on pelvic morphological changes, degree of cranial suture closure, dentition, and morphology of the long bones and joint surfaces.

Reliable age-related changes occur in the pubic symphysis and the auricular surface of the ilium. The pelvic auricular surfaces recovered in Feature 1 are fragmentary and, as such, do not include enough of the auricular surface to make an age determination with any degree of certainty. No pubic symphyses are present. Therefore, pelvic morphological changes were not useful for age determination. Another indicator of age-related change is the degree of suture closure on the cranium. The stage of closure for available external cranial vault sutures from Feature 1 indicates one young adult is included in the commingled remains. This conclusion is based on open sutures with no evidence of minimal closure.

Eruption and wear of the teeth are commonly used in aging the human skeleton. Because of predictable formation and eruption times for teeth and because the dentition are the most regularly recovered elements in archeological contexts, dental development is the most widely used method for aging subadult remains. In addition to eruption, rates and patterns of attrition are a function of age. When the rate of wear within a population is fairly consistent, the rate can be used to assign dental ages to adult specimens (White 2000). Two mandibles were recovered from Feature 1. Eruption is complete in both mandibles indicating neither are from subadults. The dentition for both exhibit extreme wear often indicative of older adults. However, excessive wear is common among Archaic period burials recovered in Central and Coastal Texas and is not limited to older adults (Munoz 2004). Because only two mandibles were recovered, conclusions on the correlation of wear to age for this population cannot be confidently assessed. 
Postcranial epiphysis fusion is predictable in that an epiphysis fuses at a known age but may vary by individual, population, and sex (White 2000). Because there is substantial interindividual variation in the chronology of epiphyseal closure, data with fusion ranges are available on various compilational charts for specific elements by sex (Krogman and Iscan 1986; McKern and Stewart 1957; Redfield 1970; Suchey et al. 1984; Ubelaker 1989a, 1989b). Based on the long bone articular surfaces present from Feature 1, all epiphyses are completely fused except for one tibia with a billowed distal diaphysis, indicating that the three minimum individuals include one subadult under 18 years of age. However, it should be noted that many long bone articular surfaces and diaphysis ends from Feature 1 are missing.

The presence of osteoarthritis in the spine, hip, and knee is inherent as aging progresses. Nearly all individuals older than 60 years show osteoarthritic features, particularly in the lower thoracic and lumbar spine (White 2000). Although not reliable as a lone indicator, indications of osteoarthritis are useful as one element of a multifactorial age estimate. No recovered long bone joint surfaces from Feature 1 exhibit evidence of lipping, pitting, or eburnation. One lumbar vertebra and one thoracic vertebra show signs of slight lipping.

Multiple age indicators evident on the remains from Feature 1, including cranial sutures, eruption and wear of dentition, epiphysis fusion, and presence of osteoarthritic changes, suggest the three minimum individuals include a juvenile under the age of 18 years, indicated from the billowed tibia, and two adults, one possibly mature, indicated from vertebral lipping.

\section{Estimation of Ancestral Affinity}

Geographic ancestral affiliation of a skeleton or individual skeletal elements is at best tenuous, as there exists "no human skeletal markers that correspond perfectly to geographic origin" (White 2000:375). However the estimation of ancestry is necessary to the extent possible to address legal concerns, especially the NAGPRA laws. Traditional, primary indicators of general ancestral affiliation are the morphological traits of the dentition. For example, populations of Mongoloids (including Native Americans) display high rates of shovel-shaped incisors, whereas Caucasoid populations tend to have a high incidence of Carabelli's cusps. Because the dentition recovered from Feature 1 presented an extreme level of wear, neither of these indicators was observable. White (2000) presents other traits attributable specifically to Mongoloids, Caucasoids, and Negroids. Traits indicating Native American ancestry, present on the elements recovered from Feature 1, include complex cranial sutures, wide vertical ascending rami, and the presence of wormian bones. In addition to these traits, the feature's association with a Montell point, and Castroville points, dating from 1600 to $2500 \mathrm{BP}$, and the extreme dental attrition on the two recovered mandibles suggest Native American affiliation.

\section{Taphonomy}

Natural, post-depositional factors have contributed to the current physical state of the skeletal remains. All of Figure H-15. Right ulna. Inset shows healed fracture on the distal the commingled bones from Feature 1 were examined diaphysis. 
for evidence of carnivore and rodent activity. One bone, a right fibula, exhibits gnaw marks on the proximal diaphysis. The marks are in the form of parallel and oppositional striae, as expected from rodent activity. No other bones presented evidence of carnivore or rodent disturbance. Because no photos or drawings of the burial pit were found, it cannot be determined if rodent burrows displaced or otherwise disturbed the burials. In addition to rodent activity, chemical weathering has affected bone preservation in the recovered remains. Weathering is consistent on all recovered elements ranging from Stage 2 (portions of bone cracking with mild flaking) to Stage 3 (portions of bone with patches of rough compact bone missing the external concentric layers) on the Behrensmeyer scale (Behrensmeyer 1978; Buikstra and Ubelaker 1994). Although the bones were slightly degraded, overall the bones were in good condition.

\section{Pathology}

The commingled bones were examined for any evident pathology. Osteoarthritis, a typical degenerative bone disorder occurring in load bearing joints, was noted on one lumbar and one thoracic vertebra. Although very minor, slight lipping was visible along the vertebral centrums. Because no eburnation was evident, the osteoarthritis was early stage indicating that full range of motion was still possible at the time of death. It is not possible to determine if these vertebrae belonged to one or two individuals.

The distal diaphysis of one right ulna shows evidence of a healed fracture (Figure H-15). A large callus made up of integrated lamellar bone indicates that this episode of trauma did not occur recently or near the individual's time of death. Because classic defense wounds include isolated ulna shaft fracture resulting from the raising of the arm to protect against blunt injury, this injury may attest to episodes of violence in this population (Wyatt 2005). Perttula (2001) posits that hostility and violence between and within Native American groups was a significant aspect of the Late Archaic and Late Prehistoric periods in South and Central Texas. Archeological evidence, including parry fractures (Perttula 2001), points to scattered episodes of hostility at varying times and places. Overall a low frequency of death due to violence in South and Central Texas suggests that group conflicts existed as small-scale hostilities, perhaps as a result of competition for limited resources, and likely "did not play a very large role in disturbing the quality of life" (Dockall 1997:264).

\section{Mortuary}

No photographs, drawings, or detailed notes accompanied the donation of Feature 1 human remains to the CAR. Brief notes do indicate that a Montell point was recovered alongside the burial ( $1.4 \mathrm{~m}$ below ground surface) and two Castroville points were excavated from the sediments above the burial $(0.7 \mathrm{~m}$ below ground surface). Montell and Castroville points date to the Middle Late Archaic, approximately 1600-2500 BP (Collins 1995). Due to the circumstances of the recovery of the commingled remains, it is not possible to determine the disposition of the burial. It is unknown if the remains were in secondary context or in primary context or if they were located in one or more defined burial pits.

\section{Osteological Summary}

$\begin{array}{ll}\text { MNI: } & 3 \\ \text { Age at Death: } & 1 \text { subadult under 18 years, } 2 \text { adults (1 possibly mature) } \\ \text { Sex: } & 1 \text { Male, 1 Female, unknown } \\ \text { Ethnicity: } & \text { Native American } \\ \text { Manner of Death: } & \text { Indeterminate } \\ \text { Temporal Affiliation: } & \text { Late Archaic }\end{array}$

\section{McKern's (1966) Analysis of Granberg Human Remains}

Subsequent to the removal of remains by Harvey Kohnitz from Feature 1, Mardith Schuetz of the Witte Museum removed a double burial (Feature 2A) and a single burial (Feature 2B). Approximately one year after the completion of Schuetz's excavation, Harvey Kohnitz and Lewis Wilson excavated an additional burial (Feature 5), roughly15-23 m southwest of Features 2A and 2B (Schuetz 1966). See previous section for details of the excavations of these burials. Tom McKern, a 
physical anthropologist at the University of Texas at Austin, assessed the human remains removed from the Granberg Site in these features. He concluded that the excavated remains consisted of a minimum of eight individuals. McKern's analysis of these remains is summarized below. His report, in its entirety, is presented in Appendix J.

\section{Feature 2A}

Feature 2A consisted of a minimum number of five individuals. The first individual, an adult male with no signs of osteopathology, was represented by four incomplete long bones. Commingled remains made up of highly fragmented cranial and postcranial elements were determined to belong to three adult males. These three individuals all exhibited excessive dental wear, some dental caries, and osteoarthritic lipping on the lumbar vertebrae. McKern mentions that all the intact distal humerus fragments had septal aperatures of complete perforation. One additional adult male with no evident pathology was indicated by further fragments (Schuetz 1966).

\section{Feature 2B}

Feature 2B contained the remains of two individuals, one adult male and one young female. The male remains include both cranial and postcranial fragments. The cranial fragments were reconstructed and measurements were taken. McKern concluded that the male had a dolichocranic skull with a cranial index of $72.03 \mathrm{~mm}$. The left mandible indicated both premortem and postmortem tooth loss with complete resorption of the molar area. No pathology was evident on either individual (Schuetz 1966).

\section{Feature 5}

One individual, an older adult male, based on endocranial and ectocranial suture closure, was uncovered from Feature 5. This skeleton consisted of cranial and postcranial fragments. Dental wear was excessive and no pathology was noted (Schuetz 1966).

\section{Comparative Analysis}

Cemeteries are settings of multiple interments that were purposefully buried in the same location for a considerable period of time (Perttula 2001). Large cemeteries have been suggested as indicators of population aggregation and territoriality. Hall $(1995 ; 1998)$ suggests that floodplain aquatic and marine resources, in addition to prickly pear and native pecans of the coastal plain, provided the means for population growth and territorial settlement. Some cemeteries lie outside these limits. Hall posits that these areas once supported productive forests, which, in historic times, were destroyed to facilitate agriculture and to provide firewood and lumber. In time, enough deaths and burials would occur to develop sizable cemeteries. In order to mark their ties to a particular region, perhaps rights of access to a resource area, a Native group would return to the same location for a span of time to bury their dead (Perttula 1997). The number of cemeteries in Central and South Texas increased noticeably after $2850 \mathrm{BP}$, suggesting a continuing increase in population from the Middle to the late Archaic.

Cemeteries often occur in open settings, in open terrain, and are found in association with habitation areas as well as spatially separated from habitation cultural deposits. Unlike the large cemeteries of the south coastal plain, including Loma Sandia (200 plus interments), Morhiss (250 interments), and Ernest Witte (242 interments), Central Texas cemeteries tend to be smaller with Edwards escarpment/Blackland Prairie cemeteries containing at most 30 to 40 individuals (Dockall 1997; Hall 1981; Taylor and Highley 1995). Bexar County open cemetery sites are likely to be located on relatively deep terrace deposits above perennial floodplains.

Rockshelters and sinkholes, found in karst settings, are also common locations for interments. Karst regions, formed by the dissolution of soluble rocks, including limestone and dolomite, typically are landscapes made up of caves and sinkholes containing large aquifers, such as the Edwards Aquifer. These caves and sinkholes are often sites of prehistoric cemeteries although they are not often associated with occupations (Potter et al. 2005). In contrast to terrace locations, these cemetery sites tend to be inaccessible and confined (Hester et al 1998), and they are often vertical shafts where burials were dropped through an opening into the shaft (Turpin and Bement 1988). 


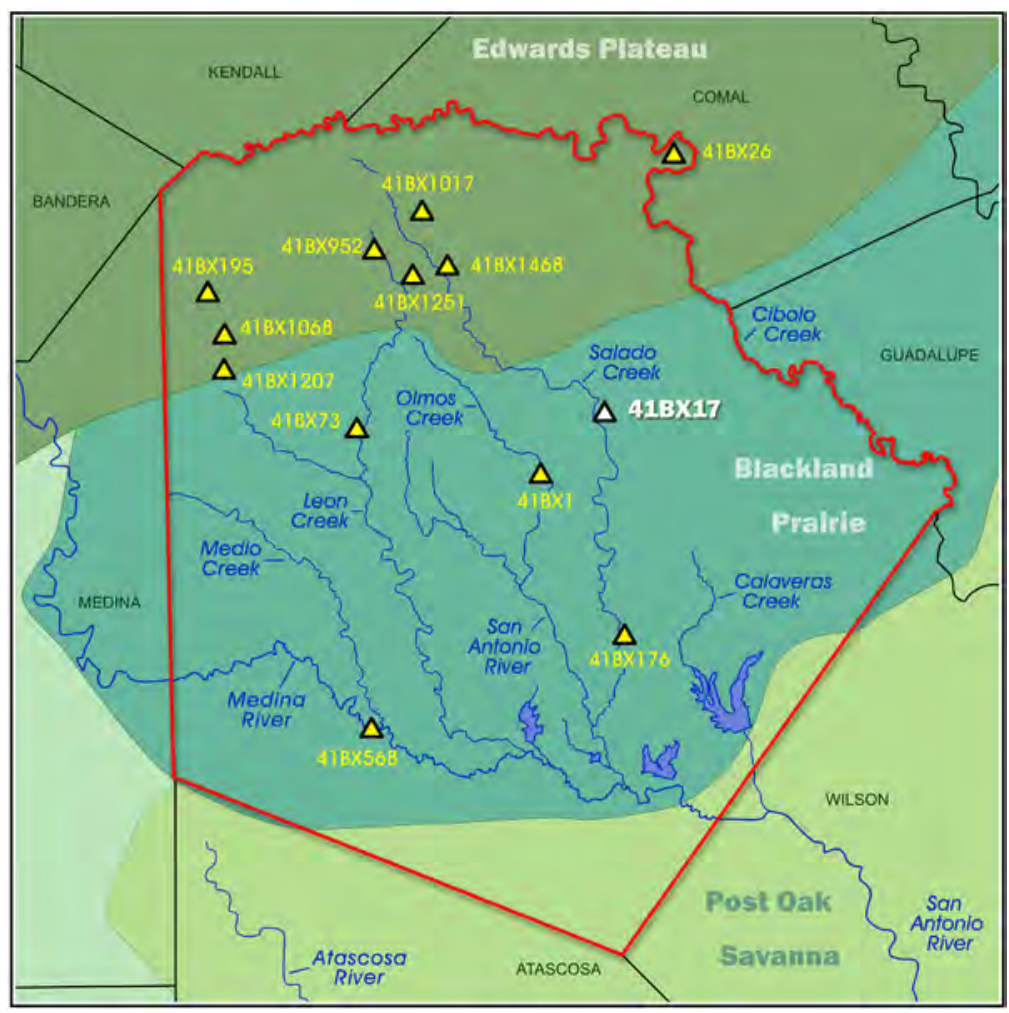

Figure H-16. Mortuary sites in Bexar County discussed in this report.

Sinkhole burials do not usually occur in association with archeological deposits, whereas, cave and rockshelter interments are often found in conjunction with cultural debris indicating site occupation and use (Perttula 2001). Large numbers of burials have been found in karst settings, such as Bering Sinkhole in Kerr County (Bement 1991; 1994), Seminole Sink in Val Verde County (Turpin1988; Turpin and Bement 1988), and Hitzfelter Cave in Bexar County (Givens 1968; Scruggs et al. 1978). The Bering Sinkhole in Kerr County contained a minimum of 62 individuals either laid out or dumped in the sinkhole over a span of at least 5000 years (Bement 1991; 1994). Bement also documents cremations and bundle burials. Unlike other documented sinkhole cemetery sites on the southern Edwards Plateau, the Bering Sinkhole was characterized by significant amounts of grave goods associated with Late Archaic burials, including antler offerings, dart points, incised bone pins, a biface cache, bone bead concentrations, mussel shell, and Olivella shell beads. After 2000 BP associated mortuary items decreased (Bement 1994).

Isolated single burials occur throughout Central and South Texas, notably in karst settings on the southern edge of the Edward's Plateau in Bexar County. The term cemetery, for this report, includes burial sites where at least two individuals were interred in proximity, indicating repeated use of an area for burials of Native American groups.

Perttula (2001:52) refers to the area "along and south of the Edwards Plateau, on the Blackland Prairie" including "sinkhole and rockshelter burials in the Edwards Plateau itself" as a region of distinguishable mortuary tradition primarily for Late Archaic and Late Prehistoric burials. This area, his Central Texas sub-region, includes Bexar County. Perttula (2001) asserts that a group of shared mortuary traits are common to this sub-region, including rock slab grave coverings or markers, flexed interments, a scarcity of mortuary artifacts, bioarcheological evidence of generally healthy populations, and bioarcheological indications of violence. He suggests that during the Late Archaic burial sites near the Edwards Plateau escarpment in the Blackland Prairie of Central Texas, including Bexar County, contain evidence of violence. Dockall notes that Late Archaic and Late Prehistoric sites with evidence of violence appear to cluster along river valleys, suggesting violence "triggered by territorial disputes over food resources" (Dockall 1997:16). The remainder of this chapter presents a brief review of cemetery and individual burials documented in Bexar County (Figure H-16). These occur on riverine terrace settings on the Blackland Prairie and in sinkholes and/or caves along or near the Edwards escarpment. 


\section{Prehistoric Burial Sites in Bexar County}

At present, there are 13 prehistoric archeological sites with burials known in Bexar County. These cemeteries and burial sites include an estimated 86-95 plus individuals, an average of 6.6-7.3 burials per site, with a wide range from one individual at over half the burial sites to as many as 40 at the Hitzfelder Cave (41BX26; Givens 1968). A background literature review of archeological sites was conducted to gather data on burials of prehistoric human remains in Bexar County. Burial data gathered from these sites along with data from the Granberg Site, including the commingled remains analyzed in this report and the data gathered from Schuetz (1966) and McKern (1966), are discussed in the following sections.

\section{Cemeteries}

In addition to the Granberg Site, four sites were found to contain multiple burials. A brief description of the four cemetery sites follow.

\section{Olmos Dam (41BX1)}

The Olmos Dam site is situated alongside Olmos Creek, an entrenched stream within relatively deep terrace deposits (Barnes 1974), near its convergence with the San Antonio River in Bexar County. Olmos Creek originates on the edge of the Edwards Plateau in northern Bexar County roughly $20 \mathrm{~km}$ upstream from its confluence with the San Antonio River. The watershed covers 34 square miles and lies between the Leon Creek and Salado Creek drainages. From December 1979 through May 1980, the CAR conducted archeological excavations for the San Antonio River Authority just north of the Olmos Dam.

Thirteen burial features containing a minimum of thirteen individuals were recovered. All were in flexed positions with headward orientations to the east, northeast, and southeast. All burials are believed to have originally been simple, single, primary inhumations of articulated individuals (Sprague 1968). Age at time of death ranged from infant to mature adult with four individuals estimated to be infants, one a child, three young adults, and five mature adults. Of the adults, four appear to be male, two female, and seven are indeterminate (Shoup 1988). The only pathologies noted on the remains were carious legions and periostitis. Two individuals each had evidence of one carious legion on one third molar and one individual exhibited signs of a periostitic condition on the anterior surfaces of the diaphyses of both tibiae and femora (Shoup 1988). Periostitis is a bone infection that can be brought about or aggravated by lifestyle stressors, such as poor nutrition or poor hygiene (Shoup 1988). A dart point was discovered inside the skull of Burial 5A. The point was located inside the right parietal during laboratory analysis. A possible entry point was radiographed but no distinct radiating fracture lines were present. It is not possible to make a determination with certainty of whether the dart point was placed into the skull for a ceremonial purpose or if the dart point was the cause of the individual's death (Shoup 1988).

Three radiocarbon assays date the burials from $1680 \mathrm{BC}$ to $1460 \mathrm{BC}, 400 \mathrm{BC}$ to $130 \mathrm{BC}$, and from $100 \mathrm{BC}$ to $\mathrm{AD} 260$. These assays limit the probable dates of the burials to between $3520+/-110 \mathrm{BP}$ and $1870+/-180 \mathrm{BP}$, indicating a Late Archaic age. Mortuary items found with the burials include: marine conch whorl pendants, conch columella dangles, a grinding slab, large chert nodules, small subrectangular mussel shell pendants, red ocher, a bone awl, bone beads, bifaces, and large deer antler racks. One interment was covered with 21 sets of racks (Lukowski 1988).

\section{The Reilly Site (41BX176)}

The Reilly Site is located on the southeast side of San Antonio, immediately adjacent to the east side of Salado Creek on the floodplain. The site was recorded by Anne Fox of the CAR in 1972. It appears that the site was damaged by looters with the top sediments mechanically stripped leaving the site open for collection. Human bone fragments were scattered about in association with Scallorn points, diagnostic of the early Late Prehistoric (Collins 1995), debitage, mussel shell, and a shell pendant with a punctuate design. The human remains consisted of three individuals (minimum number) with both child and adult elements. The current location of the human remains is unknown. The site was not protected after Fox recorded it, as per the landowner's wishes. No site report, skeletal analysis, or notes could be located (THC 2008). 


\section{Hitzfelder Cave (41BX26)}

The Hitzfelder Cave Site is a solution shaft cave located on a hill overlooking Cibolo Creek on the Balcones Escarpment in far northeast Bexar County. The site has a history of looting by the landowner but was professionally excavated in 1967 by Trinity University of San Antonio under the direction of R. Dale Givens. The cave shaft contained alternating sequences of dirt (approximately $0.6 \mathrm{~m}$ thick) and rock (15-20 cm thick) for ten levels terminating with a large soapstone boulder. Human skeletal remains were revealed roughly $9 \mathrm{~m}$ into the shaft, behind the soapstone boulder (Scruggs et al 1978). Thirty to forty individuals were recorded as part of this investigation.

The majority of the bones were disarticulated, fragmentary and in poor condition. Roughly half of the skulls recovered appear to belong to infants or juveniles (Givens 1968). Dentition shows extreme wear and no caries. Cultural material was associated with the burials, including Pedernales, Frio, and Marshall-like points, a Clear Fork gouge, a stone pendant, bone awls, and bone beads (Collins 1970; Givens 1968; Turpin and Bement 1988). Diagnostic artifacts date the cemetery to the Late Archaic (Collins 1995). One carbon sample, collected from cave fill, returned a radiocarbon date of AD $950+/-190$. It is highly probable that the carbon was washed in and does not reflect the date of the interments (Givens 1968). Joel Gunn analyzed the long bones, (femur, humerus, radius, and ulna) from the cave to attempt to sex and age the remains. He suggests that the adult population was equally divided between the sexes and that a large segment of the population was less than 22 years of age at death (Scruggs et al. 1978).

\section{The Coleman Site (41BX568)}

The Coleman Site is a prehistoric cemetery, containing multiple interments, located on private land at the confluence of Medio Creek and the Medina River in southeast Bexar County. The site was professionally excavated in 1995 by members of the Southern Texas Archaeological Association (STAA) with the assistance of the Texas Historical Commission (THC). The site is located on a private park that has greatly modified the original landform. On the western edge of Medio Valley where it meets the Medina River, quarry excavation, for the improvement of the campground facilities as well as the production of sand and gravel fill, exposed the burials (Potter et al. 2005). The Coleman Site is located on a terrace deposit roughly eight meters above the Medina River. Floodplain deposits of the Medina River and Medio Creek are exhibited topographically under the Coleman Site deposit (Potter et al. 2005).

The site contained two hearth features slightly above the burials dated to AD 1248-1396 and AD 1227-1407 (Potter et al. 2005). One lone diagnostic was recovered in association with the burials, a Scallorn or Edwards point. The $\mathrm{C}^{14}$ assays and the point suggest a Late Prehistoric period date for the Coleman cemetery.

Bioarcheological analysis suggests that the site contained a minimum of 21 individuals. The burials were all flexed on the left or right sides. The remains include two neonates, eight juveniles, three young adults, one middle adult, three old adults, and four indeterminate age adults. All of the skeletons with recovered teeth exhibited severe dental wear. One case of enamel hypoplasia and two instances of caries were documented. Pathologies included periostial infections in four individuals, osteoarthritis evident in six skeletons, a healed fractured scapula, a possible midshaft fracture of a tibia, and a parry fracture of a distal right ulna (Potter et al. 2005).

\section{Individual Burials}

Eight burial sites documented in Bexar County contained single interments. A brief description of each site follows.

\section{Camp Bullis Karst Survey (41BX1017, 41BX1251, and 41BX1468)}

A survey of karst features was completed at Camp Bullis, located in northern Bexar and southern Comal counties (Veni et al. 1998a; 1998b; 2000). Three karst sites on Camp Bullis in Bexar County contain documented burials: 41BX1017 (Tin Pot), 
41BX1251 (Ponytail Pit), and 41BX1468 (THC 2008). 41BX1017 contained a single burial with the possibility of two or more interments. The burial is dated as unknown prehistoric and appeared to have no associated artifacts. 41BX1251 contained disarticulated bone including a cranium, long bones, and a mandible fragment. The excavation stopped upon discovery of the human remains, and the cave was sealed. No diagnostic artifacts were associated with the remains, however, a biface, multiple cores, a scraper, debitage, and an observation of worn dentition suggest a prehistoric date. Site 41BX1468 is a cave containing historic trash mixed with human bone. Upon discovery of the remains, the cave was sealed until such time as further investigation is deemed warranted. It is not known to what time period the remains date (THC 2008).

\section{Government Canyon Cave Inventory (41BX1068 and 41BX1207)}

A survey of cave sites in the Government Canyon State Natural Area (GCSNA) was conducted by Texas Parks and Wildlife (TPW) between 1994 and 1996 (TPW 1995, 1996, 1997). The GCSNA is located in northwestern Bexar County, northwest of San Antonio near the town of Helotes, in South Texas. The central and northern potions of GCSNA consist of rugged, hilly limestone cut by ephemeral drainages. This has resulted in the erosion of deep canyons, creating a karst landscape. Caves, sinkholes, and solution fissures are typical features within GCSNA (Greaves et al. 2002). Human burials were documented in two caves from the TPW cave inventory. Site 41BX1068 contained several human bones in a vertical shaft within the Lubbock Area Grotto cave. Documented bones include a calvarium with maxilla, two incisors, and one molar. The teeth are noted as extremely worn. Although minimal information on the remains is available, this burial was recorded as an ossuary. The remains were reinterred in the cave (TPW 1995, 1997). Site 41BX1207 is a sinkhole containing a single human burial that was apparently uncovered prior to the TPW cave inventory. The burial was removed and is currently curated at the archeological laboratory of TPW in Austin (Greaves et al. 2002; TPW 1996).

\section{The Crystal Rivers Site (41BX195)}

One human skeleton was excavated at the Crystal Rivers Site in northwestern Bexar County. The site, located near San Geronimo Creek on the south side of the State Highway 16 right-of-way, was an extensive occupation site with a prominent, large burned rock midden (THC 2008). Site 41BX195 was professionally excavated in 1976 by the State Department of Highways and Public Transportation. Numerous diagnostic artifacts were recovered during excavations indicating occupations in the Early, Middle, and Late Archaic, and Late Prehistoric. The site was well-known to local collectors for years prior to the Highway Department excavations. Mr. George S. Meyer recovered human remains from a burial pit located southeast of the 1976 excavations on the southeastern edge of the burned rock midden. Mr. Meyer's notes suggest that the burial was in a shallow pit overlain with irregularly shaped limestone slabs. The skeleton was interred in a tightly flexed position on its right side facing north. The top of the skull was oriented to the east. No artifacts were associated with the remains (Keller 1976).

Results of a Highway Department analysis of the remains indicate, based on pelvic observations, that the skeleton was a 20 to 25 year old female. Stature, reconstructed based on measurements of the humerus following Trotter and Gleser's (1958) formula for Mongoloids, was calculated as 155.12-157.53 +/- $4.16 \mathrm{~cm}(5.0-5.3 \mathrm{ft}$.). The dentition was recorded as highly worn with shovel-shaped incisors (Keller 1976) suggesting Native American ancestry. Because no artifacts were associated with the remains, it cannot be determined when the remains were interred.

\section{Leon Creek Site \#2 (41BX73)}

Site 41BX73 was located in northeast San Antonio adjacent to Bandera Road in the vicinity of Leon Creek. The only information available pertaining to this burial site is a record from 1971 on the Texas Site Atlas (THC 2008). The atlas documents an "Old Indian Burial" that was located roughly 30 years ago (ca. 1941) during the excavation of a pit. The remains consisted of damaged bone (possibly due to pick excavation) and a shell necklace. Per the Texas Site Atlas, the burial was interred in a sitting position and had "young" teeth. No report was written, and the whereabouts of the remains are unknown (THC 2008). 


\section{$41 B \times 952$}

Site 41BX952 is located in northwestern San Antonio, on the east side of interstate I-10 near Leon Creek, in Bexar County (THC 2008). In August 1991 human remains were discovered at the bottom of looting pot holes on the site. The CAR was notified and in conjunction with members of the Southern Texas Archaeological Society (STAA) received permission from the property owners to excavate and remove the burial. The remains were articulated in a sitting position under a layer of culturally placed stone. The bone was noted to be in good to excellent condition and was determined, during a laboratory analysis, to be a male, 35 to 40 years of age. No evidence of pathology was noted. No burial goods were excavated with the remains, however, one Edwards point was removed from among the thoracic vertebrae (Meissner 1991). The presence of an Edwards point suggests possible violence/warfare as the determining factor for the demise of this individual. Because the point was not embedded in the remains, this is speculation. The point indicates a Late Prehistoric date for the interment.

\section{Discussion}

The burials documented in Bexar County, found both in karst environments and along perennial streams on terrace deposits, occur in cemetery settings and as isolated interments (Table H-2). Isolated burials include: 41BX1017, 41BX1251, 41BX1468, 41BX1068, 41BX1207, 41BX195, 41BX73, and 41BX952.

Five of the eight single burials were located in cave settings on Camp Bullis and on Government Canyon State Natural Area. Four are prehistoric; one is unknown. No diagnostics were associated with any of the burials. All five caves were sealed after the burials were revealed with no further investigation, therefore, it is possible that these sites contain multiple individuals similar to other ossuary caves such as Bering Sinkhole (Bement 1994) and Hitzfelder Cave (Givens 1968). No analysis data is available on these five individuals except for a mention of worn to extremely worn dentition on two interments. One of the sites contained nondiagnostic artifacts, however it is unclear if they were associated with the remains. Another two of the eight isolated interments, 41BX195 and 41BX73, both located on terrace deposits, cannot be assigned to a time period due to an absence of associated diagnostics. Both were determined to be prehistoric, of unknown time period, based on severely worn dentition with shovel shaped incisors and an associated shell necklace, respectively. The individual at 41BX195 was determined to be a young adult female. The final single interment, 41BX952, dates to the Late Prehistoric, based on an Edwards point found in the matrix surrounding the vertebrae. This individual was a mature adult male with no documented indications of pathology.

Table H-2. Settings and Time Periods of Bexar County Prehistoric Burials

\begin{tabular}{|c|c|c|c|c|}
\hline Trinomial & Name & Setting & Time Period & MNI \\
\hline 41BX17 & Granberg & terrace & Late Archaic & 11 \\
\hline 41BX1 & Olmos Dam & floodplain & Late Archaic & 13 \\
\hline 41BX26 & Hitzfelder Cave & karst & Late Archaic & $30-40$ \\
\hline 41BX568 & Coleman Site & terrace & Late Prehistoric & 21 \\
\hline 41BX952 & Friederick & terrace & Late Prehistoric & 1 \\
\hline 41BX176 & Reilly Site & terrace & Late Prehistoric & 3 \\
\hline 41BX195 & Crystal Rivers & terrace & Unknown Prehistoric & 1 \\
\hline 41BX73 & Leon Creek\#2 & terrace & Unknown Prehistoric & 1 \\
\hline 41BX1068 & Government Canyon & karst & Unknown Prehistoric & 1 \\
\hline 41BX1207 & Government Canyon & karst & Unknown Prehistoric & 1 \\
\hline 41BX1017 & Tin Pot & karst & Unknown Prehistoric & 1 \\
\hline 41BX1251 & Ponytail Pit & karst & Unknown Prehistoric & 1 \\
\hline 41BX1468 & Camp Bullis & karst & Unknown & 1 \\
\hline
\end{tabular}


Prehistoric cemeteries excavated in Bexar County include: the Granberg Site, Olmos Dam, the Reilly Site, Hitzfelder Cave, and the Coleman Site. The Reilly Site and the Coleman Site, both located on terrace deposits, are dated to the Late Prehistoric, based on diagnostics and radiocarbon assays in conjunction with a single diagnostic, respectively. All that is known about the Reilly Site is that it contained a minimum of three individuals with associated grave goods (THC 2008). Bioarcheological data is available from the Coleman Site. The site is made up of an equal distribution of juveniles to adults (11 adults, 10 adults). All remains with recovered teeth showed evidence of severe wear on both permanent and deciduous teeth, and two individuals had carious lesions. It should be noted that severe dental attrition obscures evidence of caries, thus the population may have had a higher rate of tooth decay than is evident. There was an instance of enamel hypoplasia and evidence of four occurrences of Harris lines on a juvenile tibia. Hypoplasias and Harris lines, both skeletal indicators of metabolic stress, point to episodes of childhood stress, possibly related to malnourishment or illness, severe enough to have arrested growth. In addition, the Coleman remains were affected by osteoarthritis and periostitis (bone infection possibly caused from injury or malnourishment). The remains point to evidence of possible interpersonal violence. One male adult had a healed fracture of the scapula, and one adult female presented a healed fracture of the distal right ulna (Potter et al. 2005). An injury to the forearm of this type is often suggestive of a defensive wound, a parry fracture, obtained when raising the arms to protect the face from an anticipated blow. Although the Coleman cemetery was established much later than the Granberg cemetery, it is interesting that both contain an individual with a possible parry fracture to the ulna.

Olmos Dam, the Granberg Site (both on terrace deposits), and Hitzfelder Cave (karst setting) all contained burials dating to the Late Archaic based on radiocarbon assays and diagnostic artifacts. All three sites contained associated grave goods and, of interest, Olmos Dam contained a burial covered with antler racks similar to a Late Archaic burial at Bering Sink Hole (Bement 1994). No skeletal pathologies were documented for the Hitzfelder Cave remains, however, it is unclear if an analysis was completed other than Gunn's sex and age study (Scruggs et al. 1978). The dentition for both the Granberg Site and Olmos Dam exhibited extreme attrition. Olmos Dam presented signs of periostitis in the lower limb bones, whereas, Granberg contained evidence of osteoarthritis of the vertebrae. Both sites contain skeletal indicators of possible episodes of violence. A point was found inside a skull cavity excavated from Olmos Dam. The point was located inside the right parietal during laboratory analysis. A possible entry point was radiographed, but no distinct radiating fracture lines were present. The edges of the opening are beveled ecto- to endocranially as would be expected from a projectile wound, however, because other missing parts of the crania also exhibit similar beveling, it is not possible to make a determination with certainty of whether the dart point was placed into the skull for a ceremonial purpose or if the dart point was the cause of the individual's death (Shoup 1988). A healed fracture of the distal ulna, indicating a possible parry fracture, was discovered during the analysis of the Kohnitz donated Granberg Feature 1 remains. As discussed previously, this type of fracture is indicative of a defensive wound, possibly obtained upon lifting the arms to ward off an anticipated blow to the face.

\section{Summary}

A review of burial sites in Bexar County suggests that two types of cemeteries/individual interments sites existed during the Late Archaic and Late Prehistoric periods on the Blackland Prairie and southern Edwards Escarpment in Central Texas. One of these is located on the Edwards Plateau in karst settings. These burial sites are generally not found in association with occupation sites but appear to function specifically as sites of final disposition of the deceased. Hitzfelder Cave in Bexar County and Bering Sinkhole in Kerr County appear to have functioned purely as ossuary sites. A second type of cemetery occurs near perennial streams on flood plains and terraces deposits. These burials are often associated with habitation sites as evidenced by hearth features, burned rock middens, and a variety of cultural artifacts. In Bexar County, the Granberg Site, the Coleman Site, Olmos Dam, the Reilly Site, Crystal Rivers, and 41BX952, all contained evidence of prehistoric occupation.

The mortuary traits Perttula (2001) attributes to his Central Texas sub-region are apparent in varying degrees in Bexar County prehistoric burials. One of the attributes is the presence of rock slabs overlying interments as a form of burial treatment. Three interment sites documented culturally placed limestone slabs over individual burials: the Coleman Cemetery, 41BX952, and the Crystal Rivers Site. Hitzfelder Cave did not have rock placed above any specific interment but did have a soapstone boulder blocking the cave immediately between the ossuary and the cave shaft opening. The opening was also blocked by alternating layers of rock and dirt. The function of slab mortuary treatment is not known. Potter et al. (2005) suggest that the rocks may have functioned as grave markers to deter later interments from intruding on existing graves or, perhaps, as protection from scavengers. He also posits that the slabs could have had cultural meaning, perhaps serving as a metaphor for a cave or sinkhole context. 
Table H-3. In-Situ Placement of Bexar County Prehistoric Burials

\begin{tabular}{|c|c|c|c|}
\hline Trinomial & Name & Position & Orientation \\
\hline 41BX17 & Granberg & 2 flexed; 2 right, 1 left side & 2 eastward; 1 westward \\
\hline $41 \mathrm{BX} 1$ & Olmos Dam & $\begin{array}{c}12 \text { flexed; } 1 \text { semi-flexed; } 4 \text { right, } 6 \text { left, } 3 \\
\text { unknown side }\end{array}$ & eastward \\
\hline 41BX26 & Hitzfelder Cave & unknown & unknown \\
\hline 41BX568 & Coleman Site & 11 flexed; 6 right, 6 left, 9 unknown side & eastward \\
\hline 41BX952 & Friederick & 1 flexed & unknown \\
\hline $41 \mathrm{BX} 176$ & Reilly Site & unknown & unknown \\
\hline 41BX195 & Crystal Rivers & 1 flexed; 1 right side & $\begin{array}{c}\text { face to north; skull to } \\
\text { east }\end{array}$ \\
\hline 41BX73 & Leon Creek\#2 & 1 flexed & unknown \\
\hline $41 \mathrm{BX} 1068$ & $\begin{array}{l}\text { Government } \\
\text { Canyon }\end{array}$ & unknown & unknown \\
\hline $41 \mathrm{BX} 1207$ & $\begin{array}{l}\text { Government } \\
\text { Canyon }\end{array}$ & unknown & unknown \\
\hline 41BX1017 & Tin Pot & unknown & unknown \\
\hline 41BX1251 & Ponytail Pit & unknown & unknown \\
\hline $41 \mathrm{BX} 1468$ & Camp Bullis & unknown & unknown \\
\hline
\end{tabular}

Another mortuary tradition Perttula links to the sub-region are flexed interments (Table H-3). All of the burial sites in Bexar County with documented information on interment position included flexed burials in various orientations. Perttula also asserts that the area tends to display a scarcity of mortuary artifacts. The Coleman site fits this pattern with only one artifact recovered from the entire cemetery. The Granberg Site also contained few associated artifacts, specifically a stone gorget, a Montell point, and possibly associated lithic knives. It must be noted that due to the nature of the Granberg excavation in the early 1960s, specifically the "public dig", it is possible that grave goods were removed and not documented as associated. Other burial sites revealed a relatively rich artifact assemblage. Olmos Dam, the Reilly Site, and Hitzfelder Cave included utilitarian items such as stone, bone, and shell tools, as well as ornamental items, including pendants, dangles, and beads. The Olmos Dam burials were associated with ocher, presumed to be included in interments for ritual functions (Perttula 2001). The Bering Sinkhole, in Kerr County, also contained an elaborate mortuary assemblage. Of interest, at the Bering Sinkhole, grave good frequency dropped at the end of the Archaic into the Late Prehistoric (Bement 1991). Olmos Dam, Hitzfelder Cave, and the Granberg Site all date to the Late Archaic, whereas, the Coleman Site was Late Prehistoric, suggesting a contrast between the Archaic and the Late Prehistoric and possibly a change in the grave good tradition over time.

A fourth attribute Perttula (2001) associates with the sub-region is bioarcheological evidence of generally healthy populations. The general health of the prehistoric individuals recovered in Bexar County is difficult to access due to the small sample sizes currently available. Some of the burial site interments have been subjected to more detailed biological study than others, and some have apparently seen little or no assessment. Some of the interments were not excavated under controlled conditions. It should be noted that the individuals recovered from Bexar County burial sites do not comprise a population but represent a collection or a sample of a larger population. Overall, the individuals associated with the Late Archaic appear to have lived fairly healthy lives (Table H-4). There is some evidence of bone infection, periostitis, and osteoarthritis, but it is fairly minimal, nothing severe enough to have significantly affected general health and well being. All the Late Archaic burials with recovered teeth showed evidence of severe attrition, but this condition is common among Central and South Texas prehistoric remains resulting from a tough, gritty, and fibrous diet (Munoz 2004). In contrast, the Late Prehistoric Coleman Site appears to represent a sample of a population that lived a life of continuous nutritional and physical hardship, evident from many instance of recorded skeletal pathologies (Potter et al. 2005). 
Table H-4. Evidence of Pathology and Violence in Bexar County Prehistoric Burials

\begin{tabular}{|c|c|c|c|}
\hline Trinomial & Name & Pathologies & Violence \\
\hline $41 \mathrm{BX} 17$ & Granberg & $\begin{array}{l}\text { dentition extreme attrition; evidence of osteoarthritis; healed ulna } \\
\text { fracture (parry); fused vertebrae in Fea 2A-noted in situ only. }\end{array}$ & parry fracture \\
\hline 41BX1 & Olmos Dam & $\begin{array}{l}2 \text { individuals each with } 1 \text { caries in M3; } 5 \mathrm{~A} \text { had periostitis of femur } \\
\text { and tibiae. }\end{array}$ & point found in skull \\
\hline 41BX26 & Hitzfelder Cave & dentition extreme attrition & none noted \\
\hline $41 \mathrm{BX} 568$ & Coleman Site & $\begin{array}{c}\text { dentition extreme attrition; } 2 \text { individuals with caries; } 1 \text { enamel } \\
\text { hypoplasia; } 1 \text { with } 4 \text { instances of harris lines; } 4 \text { with periostitis in } \\
\text { various long bones; } 2 \text { individual with healed fractures - } 1 \text { distial ulna } \\
\text { and possible fibula and } 1 \text { with fractured scapula; } 6 \text { individuals with } \\
\text { osteoarthritis. }\end{array}$ & parry fracture \\
\hline $41 \mathrm{BX} 952$ & Friederick & none & $\begin{array}{l}\text { point found in vertebral } \\
\text { matrix }\end{array}$ \\
\hline 41BX176 & Reilly Site & unknown & none noted \\
\hline 41BX195 & Crystal Rivers & dentition extreme attrition; shovel shaped incisors & unknown \\
\hline $41 \mathrm{BX} 73$ & Leon Creek\#2 & unknown & unknown \\
\hline 41BX1068 & Government Canyon & dentition extreme attrition & unknown \\
\hline 41BX1207 & Government Canyon & unknown & unknown \\
\hline 41BX1017 & Tin Pot & unknown & unknown \\
\hline 41BX1251 & Ponytail Pit & dentition extreme attrition & unknown \\
\hline $41 \mathrm{BX} 1468$ & Camp Bullis & unknown & unknown \\
\hline
\end{tabular}

The final attribute Perttula (2001) posits for this sub-region is bioarcheological indications of violence (Table H-4). Four sites in Bexar County, Olmos Dam, Granberg (both Late Archaic), the Coleman Site, and 41BX952 (both Late Prehistoric) exhibit evidence of violence. Both the Granberg Site and the Coleman Site present direct bioarcheological indications, specifically trauma to the distal ulna, the forearm, in the form of healed fractures. These fractures are classic defense wounds, known as parry fractures, usually resulting from the blocking of a blow intended for the face. The Coleman site also contains an individual with a healed fracture to the scapula, possibly from a blow to the back (Potter et al. 2005). Both Olmos Dam and 41BX952 contain points in association with an individual, one in the cavity of the skull and one in the burial matrix of the vertebrae, respectively. It appears possible that these two individuals met a violent end, however, this is speculative since neither point is embedded in bone.

An examination of data presented in Perttula (2001) from other sites in the sub-region reveals eight additional Archaic and Late Prehistoric sites with bioarcheological evidence of violence. In addition to the Granberg Site and Olmos Dam, three individuals from three other Archaic period sites, 41WM7, 41TV128, and 41KR241, are associated with projectile points: one individual with Darl and Ensor points in skull and ribs (41WM7), one associated with a dart point (41TV128), and one individual associated with a Travis point (41KR241). The Late Prehistoric period in the sub-region documents six individuals at 41WM230 with associated Scallorn arrow points, one individual with a Scallorn at 41MM19, and three other sites with point associations indicating violence. Perttula (2001) does not document the occurrence of defensive bone fractures, possibly due to a lack of consistent bioarcheological analysis. Perttula states that evidence of violence decreases from the Late Archaic into the Late Prehistoric suggesting a gradual and comparatively successful adjustment relative to subsistence competition between groups across Central and South Texas (Perttula 2001). The comparison of burial sites in Bexar County suggests that episodic violence/warfare may have continued from the Late Archaic into the Late Prehistoric.

The review of prehistoric burial sites in Bexar County suggests that the data gathered from the bioarcheological analyses of the Granberg Site human remains (McKern 1966; Munoz this document) are generally consistent with expectations from Perttula's (2001) description of the mortuary traditions in his Central Texas sub-region. Perttula's assertion that a scarcity of grave goods is typical in the sub-region contrasts with the Late Archaic cemeteries in the county. However, only one cultural artifact was 
recovered from the Late Prehistoric Coleman Site, indicating a change in mortuary tradition over time. This decrease in grave goods as well as the apparent poor health of the interred individuals at the Coleman Site in comparison to the generally healthy individuals at other Bexar County sites suggests a change through time in mortuary practices possibly one result of an increase in overall lifestyle stress.

\section{Summary}

This bioarcheological study focuses on the human skeletal remains donated by Mark Kohnitz to the Center for Archaeological Research in the spring of 2007. Harvey Kohnitz, Mark's father, recovered the commingled remains from the Granberg Site, 41BX17/271, in 1962. These remains are believed to be the first archeologically excavated at 41BX17/271. The remains were stored at the Kohnitz home until the 2007 donation. Analysis of this skeletal sample has complied to the standards as set forth by Buikstra and Ubelaker (1994).

The analysis of the remains produced an abundance of information regarding a MNI of three individuals, including one female and one male. Multiple age indicators evident on the remains suggest the three minimum individuals include a juvenile under the age of 18 and two adults, one possibly mature. Skeletal attributes, as well as an association with a diagnostic artifact of the Late Archaic period, clearly identify the remains as Native American. Lack of major degenerative and pathological disorders suggests good overall health throughout the life spans of these individuals. Minor osteoarthritis of the spinal column, a healed forearm fracture, and severe dental attrition were the only visible indicators resultant of lifestyle stress on the skeletal remains.

The context of the burial cannot be established. The remains were removed quickly by lantern light. They were not removed as per archeological standards in place during the 1960s. No photographs, drawings, or detailed notes describing the burial context accompanied the donation. Brief notes do indicate that the remains were associated with a Montell point but make no mention of the individual's positioning or orientation. Feature 1 was never mapped in with reference to later excavations, but the general area of removal can be assumed from notes referring to a City water main utility trench.

Postmortem events are apparent in the skeletal sample. Rodent activity is evident on one of the commingled fibulas. Chemical weathering is consistent on all recovered elements ranging from bones with mild cracking and flaking to bones missing portions of external compact layers. Although some degradation was present, overall the bones were in good condition.

As part of this analysis, literature from the recovered Granberg human skeletal remains from Schuetz's investigation (1966) and literature from other excavated burials in Bexar County was examined for comparative data. Perttula (2001) separated South and Central Texas into sub-regions made up of areas with similar mortuary traditions. Bexar County falls into Perttula's (2001) Central Texas sub-region. The data gathered as part of this review suggest that Bexar County burial sites, including the Granberg interments, are generally consistent with the trends noted by Perttula for this region. The one noted exception is the contrast between the variety of grave goods documented in Bexar County Late Archaic sites and Perttula's assertion of a scarcity of grave goods in the subregion during the Late Archaic and Late Prehistoric. Only one cultural artifact was recovered from the Late Prehistoric Coleman Site indicating that perhaps grave good inclusions in interments decreased temporally. As expected from Perttula's mortuary trends, health was generally good for Bexar County prehistoric inhabitants with the exception of individuals buried at the Coleman Site. The conditions at this site, decrease in grave goods, and poor general health suggest the possibility of an increase in stress, perhaps due to competition for limited resources and associated territoriality from the Late Archaic into the Late Prehistoric in Bexar County.

This study provides a comprehensive analysis of the commingled human remains from the Granberg Site. A minimum of 11 individuals were removed from the site from Kohnitz's first excavation in 1962 to the last removal in November 1963. An additional human interment, possibly more than one, was reported by Thomas Hester in 1980 when a construction company began excavations within the ROW without notifying the highway department. No emergency archeological excavation was reported for this incident, and because the whereabouts of these remains are unknown, they are not addressed to any extent in this report. 


\section{References Cited:}

Barnes, V.E.

1974 Geological Atlas of Texas. San Antonio Sheet. Robert Hamilton Cuyler Memorial Edition, Bureau of Economic Geology, The University of Texas at Austin.

Bass, W.M.

1995 Human Osteology: A Laboratory and Field Manual. Special Publication No. 2. Missouri Archaeological Society, Columbia.

Behrensmeyer, A.K.

1978 Taphonomic and Ecologic Information from Bone Weathering. Paleobiology 4:150-162.

Bement, L.C.

1991 The Thunder Valley Burial Cache: Group Investment in a Central Texas Sinkhole Cemetery. Plains Anthropologist 36(135):97-109.

1994 Hunter-Gatherer Mortuary Practices During the Central Texas Archaic. The University of Texas Press, Austin.

Buikstra, J.E., and D.H. Ubelaker.

1994 Standards for Data Collection from Human Skeletal Remains. Research Series, No. 44. Arkansas Archeological Survey, Fayetteville.

Collins, M.B.

1970 On the Peopling of Hitzfelder Cave. Bulletin of the Texas Archaeological Society 39:1-8.

1995 Forty Years of Archeology in Central Texas. Bulletin of the Texas Archaeological Society 66:361-400.

Córdova, K.J., B.K. Moses, and R.P. Mauldin

2005 Records and Collections Assessment of Previous Investigations at Sites 41BX17 and 41BX271 (Granberg I and II) within the ROW of Loop 410 East at Salado Creek, San Antonio, Bexar County, Texas. Report on file, Center for Archaeological Research, The University of Texas at San Antonio.

Dockell, H.D.

1997 Archaic Hunter-Gatherer Adaptation on the Inland Portion of the West Gulf Coastal Plain: The Bioarchaeological Evidence. Unpublished Ph.D. dissertation, Department of Anthropology, Texas A\&M University, College Station.

Givens, R.D.

1968 A Preliminary Report on Excavations at Hitzfelder Cave. Bulletin of the Texas Archeological Society 38:47-50.

Greaves, R.D., R.P. Mauldin, and S.A. Tomka

2002 An Archaeological Survey of Trail Locations in a Portion of Government Canyon State Natural Area, Bexar County, Texas. Volume 1. Project Summary, Survey Results, and Recommendations. Center for Archaeological Research. The University of Texas at San Antonio. Texas Parks and Wildlife Department, Austin.

Hall, G.D.

1981 Allens Creek: A Study in the Cultural Prehistoric of the Brazos River Valley, Texas. Research Report 61. Texas Archeological Survey, The University of Texas at Austin.

1995 Prehistoric Cemeteries on the Texas Central Coastal Plain: Interpretations and Hypotheses. In Archaeological Investigations at the Loma Sandia Site (41LK28): A Prehistoric Cemetery and Campsite in Live Oak

County, Texas, edited by A.J. Taylor and C.L. Highley, pp.633-647. Studies in Archeology 20. Texas Archeological Research Laboratory, The University of Texas at Austin. 
1998 Prehistoric Human Food Resource Patches on the Texas Coastal Plain. Bulletin of the Texas Archeological Society 69:1-10.

Hester, T.R., A. Sullivan, L. Froelich, and R.S. Crawford, Jr.

1998 Notes on South Texas Archaeology 1998-2: Artifacts and Burials from a Vertical Shaft Cave, Site 41UV356, Uvalde County, Texas. La Tierra 25(2):1-5.

Huebner, J.A., and A.G. Comuzzie

1992 The Archeology and Bioarcheology of Blue Bayou: A Late Archaic and Late Prehistoric Mortuary Locality in Victoria County, Texas. Studies in Archeology 9. Texas Archeological Research Laboratory, The University of Texas at Austin.

Jantz, L.M., R.L. Jantz, N.P. Herrmann, C.S. Sparks, K.E. Weisensee, and D.V. Kopp

2002 Archaeological Investigations at the Last Spanish Colonial Mission Established on the Texas Frontier: Nuestra Senora del Refugio (41RF1), Refugio County, Texas. Volume II: Osteological Analyses. Archaeological Survey Report No. 315. Center for Archaeological Research, The University of Texas at San Antonio; Archeological Studies Program Report No. 39. Environmental Affairs Division, Texas Department of Transportation, Austin.

Keller, J.E.

1976 Archaeology on State Highway 16: The Crystal Rivers Site. Report No. 6. State Department of Highways and Public Transportation, Austin, Texas.

Krogman, W.M., and M.Y. Iscan

1986 The Human Skeleton in Forensic Medicine. 2nd ed. Charles C. Thomas, Springfield, Illinois.

Lukowski, P.D.

1988 Archaeological Investigations at 41BX1, Bexar County, Texas. Archaeological Survey Report, No. 135. Center for Archaeological Research, The University of Texas at San Antonio.

McKern, T.

1966 The Granberg Burials in The Granberg Site: An Archaic Indian Habitation in Bexar County, Texas, edited by M.K. Schuetz. Witte Museum Studies No. 1. San Antonio, Texas.

McKern, T., and T.D. Stewart

1957 Skeletal Age Changes in Young American Males, Analyzed from the Standpoint of Identification. Technical Report EP-45. Headquarters, Quartermaster Research and Development Command, Natick, Massachusetts.

Meissner, B.A.

1991 Notes on Excavation of 41BX952. Unpublished Notes on file, Center for Archaeological Research. The University of Texas at San Antonio.

Munoz, C.M.

2004 Native American Adaptation on the Texas Coastal Plain: A Study of the Dentition from Thirteen Prehistoric and Historic Cemetery Sites. Unpublished Master's thesis. Department of Anthropology. The University of Texas at San Antonio.

Ousley, S.D. and R.L. Jantz

1996 ForDisc 3.0: Personal Computer Forensic Discriminant Functions. The University of Tennessee, Knoxville.

Perttula, T.K.

1997 Hunter-Gatherer Mortuary Practices. In Archaeology of the Rio Grande and Central Coastal Plains, Texas: A Planning Document, edited by S.A. Tomka, T.K. Perttula, and R.J. Hard, pp. 7-1-7-51 and E-1-E-21.

Archaeological Survey Report, No. 266. Center for Archaeological Research, The University of Texas at San Antonio. 
2001 Hunter-Gatherer Mortuary Practices in the Rio Grande Plains and Central Coastal Plains Archeological Regions of Texas. La Tierra 28(3\&4):2-83.

Potter, D.R., R.B. Pickering, and C.E. Mear

2005 Salvage Excavation at the Coleman Cemetery Site, 41BX568. La Tierra 32(1):1-64.

Powell, J.F.

1994 Bioarchaeological Analyses of Human Skeletal Remains from the Mitchell Ridge Site. In Aboriginal Life and Culture on the Upper Texas Coast: Archaeology at the Mitchell Ridge Site, 41GV66, Galveston Island, edited by R.A. Ricklis, pp. 287-405. Coastal Archaeological Research, Inc., Corpus Christi, Texas.

Redfield, A.

1970 A New Aid to Aging Immature Skeletons: Development of the Occipital Bone. American Journal of Physical Anthropology 33:217-220.

Schuetz, M.K.

1966 The Granberg Site: An Archaic Indian Habitation in Bexar County, Texas. Witte Museum Studies No. 1. San Antonio, Texas.

Scruggs, L., J. Gunn, and N. Hitzfelder

1978 The Hitzfelder Bone Collection. La Tierra 5(2):20-30.

Shoup, R.F.

1988 Skeletal and Dental Materials. In Archaeological Investigations at 41BX1, Bexar County, Texas, edited by P.D. Lukowski, pp. 101-114. Center for Archaeological Research, The University of Texas at San Antonio.

Sprague, R.

1968 A Suggested Terminology and Classification for Burial Description. American Antiquity 33(4):479-485.

Steele, D.G. and B.W. Olive

1989 Bioarcheology of the Region 3 Study Area. In From the Gulf Coast to the Rio Grande: Human Adaptation in the Central, South, and Lower Pecos Texas, by T.R. Hester, S.L. Black, D.G. Steele, B.W. Olive, A.A. Fox, K.J. Reinhard, and L.C. Bement, pp. 93-114. Research Series, No. 33. Arkansas Archeological Survey, Fayetteville.

Suchey, J.M., P.A. Owings, D.V. Wiseley, and T.T. Noguchi

1984 Skeletal Aging of Unidentified Persons. In Human Identification: Case Studies in Forensic Anthropology, edited by T.A. Rathbun and J.E. Buikstra, pp. 278-297. Charles C. Thomas, Springfield, Illinois.

Taylor, A.J., and C.L. Highley

1995 Archaeological Investigations at the Loma Sandia Site (41LK28): A Prehistoric Campsite in Live Oak County, Texas. 2 volumes. Studies in Archeology No. 20. Texas Archeological Research Laboratory, The University of Texas at Austin.

Texas Historical Commission (THC)

2008 Texas Archeological Site Atlas, http://www.nueces.thc.state.tx.us/, accessed March 2008.

Texas Parks and Wildlife Department (TPW)

1995 Government Canyon State Natural Area. In Texas Parks and Wildlife Department Annual Report for 1994, pp. 163-167. Cultural Resources Program, Texas Parks and Wildlife Department, Austin.

1996 Government Canyon State Natural Area. In Texas Parks and Wildlife Department Annual Report for 1995, pp. 209-215. Cultural Resources Program, Texas Parks and Wildlife Department, Austin. 
1997 Government Canyon State Natural Area. In Texas Parks and Wildlife Department Annual Report for 1996, pp. 146-149. Cultural Resources Program, Texas Parks and Wildlife Department, Austin.

Trotter, M., and G.C. Gleser

1958 A Re-Evaluation of Estimation of Stature Based on Measurements of Stature During Life and of Long Bones After Death. American Journal of Physical Anthropology, 16(1):79-123.

Turpin, S.A. (compiler)

1988 Seminole Sink: Excavation of a Vertical Shaft Tomb, Val Verde County, Texas. Memoir 22. Plains Anthropologist 33(122), Part 2.

Turpin, S.A., and L.C. Bement

1988 The Site and its Setting. In Seminole Sink: Excavation of a Vertical Shaft Tomb, Val Verde County, Texas, compiled by S. A. Turpin, pp.1-18. Memoir 2. Plains Anthropologist 33(122, part 2).

Ubelaker, D.H.

1989a Human Skeletal Remains. 2nd ed. Taraxacum Press, Washington, D. C.

1989b The Estimation of Age at Death from Immature Human Bone. In Age Markers in the Human Skeleton, edited by M. Y. Iscan, pp. 55-70. Charles C. Thomas, Springfield, Illinois.

Veni, G., W.R. Elliot, A.M. Scott, R.S. Toomey, and J.R. Reddell

1998a Hydrogeologic, Biological, and Archeological Surveys of Lower Glen Rose Caves, and Continued Biological Monitoring of Four Edwards Limestone Caves, Camp Bullis, Texas. Prewitt and Associates, Austin. George Veni and Associates, San Antonio.

1998b Hydrogeologic, Biological, and Archeological Investigations of Caves and Karst Features, and Continued Biological Monitoring of Four Edwards Limestone Caves, Camp Bullis, Texas. Prewitt and Associates, Austin. George Veni and Associates, San Antonio.

Veni, G., A.M. Scott, R.S. Toomey, J.R. Reddell and J.C. Cokendolpher.

2000 Hydrogeologic, Biological, and Archeological Karst Investigations, Northern Camp Bullis, Texas. Prewitt and Associates, Austin. George Veni and Associates, San Antonio.

White, T.D.

2000 Human Osteology. Academic Press.

Wyatt, J.P.

2005 Oxford Handbook of Accident and Emergency Medicine. Oxford University Press. 
Appendix I:

\section{Standards Data Sheets}

Cynthia M. Munoz 



\title{
Appendix I
}

\section{Standards Data Sheets}

\author{
Cynthia M. Munoz \\ Center for Archaeological Research \\ The University of Texas at San Antonio
}

\section{Human Skeletal Remains - Feature 1 \\ Granberg - 41BX17/271 \\ Harvey Kohnitz Donation - 1962 Excavations \\ Date of Analysis: February 28, 2008}

In October 1962, human remains were excavated by avocational archaeologist Sgt. Harvey Kohnitz, his family, and associates from the walls of a San Antonio City Water Board utility trench located along what eventually became N.E. Loop 410 on what was then the northeastern edge of San Antonio, Bexar County, Texas. Immediately after the recovery of the remains, the Witte Museum, under the direction of Mardith Schuetz, began mitigation of the area and subsequently labeled the Kohnitz burials Feature 1. The area was designated the Granberg Site (41BX17/271). The remains recovered were never turned over to the museum and were considered "lost" until the spring of 2007 when Mark Kohnitz, Harvey's son, donated the remains to the Center for Archaeological Research at the University of Texas at San Antonio (CAR-UTSA). Upon acquisition, the remains were sorted, cataloged, bagged and prepared for curation at CAR-UTSA.

The human remains were assessed by Cynthia Munoz, CAR Staff Archaeologist /Osteologist, in February 2008. The remains were presented to the CAR in three large boxes with all elements and skull fragments in mixed context. To further complicate sorting, bones from West Texas burials were also in the boxes. Because of differing stages of preservation and the presence of a fine layer of powdery gray dirt on the West Texas bones, the Granberg bones were separated from the boxes with a high degree of certainty. An attempt was made to sort the Granberg elements into individuals but due to the large degree of uncertainty, it was decided to treat the remains as a commingled burial. After sorting the remains by elements and side, the minimum number of individuals (MNI) was determined to be three. The MNI includes one male and one female, based on femoral head measurements, humeral epicondylar breadth measurements, and skull attributes. The remains all appear to be adult, with the exception of one tibia with a billowed distal diaphysis $(<18$ years). The cranial sutures in one calvarium are well defined pointing to a young adult, whereas another calvarium has partial suture closure. No photographs, drawings, or detailed notes accompanied the donation and, thus, it is not known if the burials were in one or more defined burial pits. Brief notes do indicate

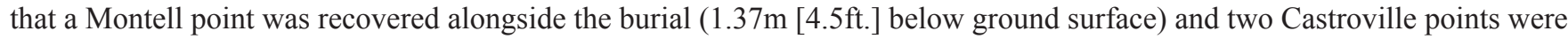
excavated from the sediments above the burial $(0.73 \mathrm{~m}$ [2.4ft.] below ground surface). Montell and Castroville points date to the Middle Late Archaic, approximately 1600-2500 BP. Taphonomic forces have slightly degraded the bone structure. Overall, the bones are in good condition.

\section{Skeletal Assessment}

\section{MNI}

MNI is three based on counts of left femora and right tibiae.

\section{Sex}

Using the criteria set forth in the Standards, cranial and pelvic dimorphic features, measurement of the femoral head diameters, and measurement of humeri epicondylar breadths indicate the three minimum individuals include one female and one male. 


\section{Age}

Using the criteria set forth in the Standards, age is based on pelvic morphological changes, degree of cranial suture closure, dentition, and morphology of the long bones and joint surfaces. The pelvic auricular surfaces recovered in Feature 1 are fragmentary and do not include enough of the auricular surface to make an age determination with any degree of certainty. The pubic symphyses are missing. The stage of closure for available external cranial vault sutures indicate one young adult based on open sutures with no evidence of minimal closure. The dentition for both recovered mandibles exhibit extreme wear often indicative of older adults. However, excessive wear is common among archaic burials recovered in central and coastal Texas and is not limited to older adults. Based on the long bone articular surfaces present, all epiphyses are completely fused except for one tibia with a billowed distal diaphysis. However, it should be noted that many long bone articular surfaces and diaphysis ends are missing. No recovered long bone joint surfaces exhibit evidence of lipping, pitting, or eburnation. One lumbar vertebra and one thoracic vertebra show signs of slight lipping. These multiple age indicators suggest the three minimum individuals include a juvenile (billowed tibia) under 18 years, and two adults, one possibly mature (vertebral lipping).

\section{Stature}

Because Feature 1 is a commingled burial it is not possible to isolate the recovered elements and determine stature of any one individual. Only two complete long bones were recovered, both radii. Based purely on conjecture, if one assumes that the larger of the two is male, using regression equations (Trotter 1970) for various ancestral affinities: Mongoloid males $=169.8 \mathrm{~cm}$ $(5.8 \mathrm{ft}$.); Mexican males $=168.8 \mathrm{~cm}(5.5 \mathrm{ft}$ ); Black males $=166.4 \mathrm{~cm}(5.5 \mathrm{ft}$ ); and White males $=172.8 \mathrm{~cm}(5.7 \mathrm{ft}$.$) . Averaging$ these stature estimates gives a male height, based on the length of the radius, of $169.45 \mathrm{~cm}(5.56 \mathrm{ft}$.).

\section{Ancestral Affinity}

The burial association with a Montell point and Castroville points (1600-2500 BP), complex cranial sutures, wide vertical ascending ramus, the presence of wormian bones, and extreme dental attrition suggest Native American affiliation.

\section{Pathology}

One lumbar vertebra and one thoracic vertebra show evidence of slight lipping indicating mild osteoarthritis. One right ulna presents evidence of a healed fracture at its distal end.

\section{Summary}

This assessment has determined that Feature 1 represents a minimum of three individuals including one male and one female. One individual is a juvenile under the age of 18 , and two are adults, one possibly a mature adult. The individuals are Native Americans, including a male possibly $167.6 \mathrm{~cm}$ (5.5ft.) tall, an individual(s) with mild osteoarthritis, and an individual with a healed fractured distal right ulna. 


\section{INVENTORY RECORDING FORM FOR COMMINGLED REMAINS AND ISOLATED BONES}

Site Name/Number:

Feature/Burial Number:

Burial/Skeleton Number:
Granberg/ 41BX17/271

Feature $1 /$ Kohnitz- city water trench

Feature 1
Observer: Cynthia Munoz

Date: 13-Feb-08

Present Location of Collection: UTSA-CAR

Report all cranial bones separately. Group Cervical Vertebrae 3-6; Thoracic Vertebrae 1-9; Ribs 3-10; Carpals; Metacarpals; Tarsals (other than Talus and Calcaneus); Metatarsals; Hand and Foot Phalanges. Vertebrae other than those grouped above should be reported individually. Identify bones by name, indicate $\mathbf{L}$ (left); R (right); $\mathbf{B}$ (Both); M (Midline); ? (Unsidable). Code articular regions, long bone diaphyses, and vertebrae by segments: PE (proximal epiphysis), P1/3 (proximal third of diaphysis), M1/3 (middle third of diaphysis), D1/3 (distal third of diaphysis), DE (distal epiphysis); B (vertebral body or centrum), NA (neural arch). Otherwise leave this category blank. Code Completeness according to the following: $1=>75 \%$ present; $2=25 \%-75 \%$ present; $3=<25 \%$ present. MNI reflects the minimum number of individuals recorded on this line. Count/Wt refers to the number/weight of fragmented materials. Age and Sex determinations should be entered as counts (see text for codes).

\begin{tabular}{|c|c|c|c|c|c|c|c|c|}
\hline Bone & Side & Segment & Completeness & MNI & $\mathrm{Ct} / \mathrm{Wt}$ & Age & & Sex \\
\hline Calcaneus & $\mathrm{L}$ & & 1 & 1 & & $\mathrm{Ad}$ & 0 & \\
\hline Clavicle & $\mathrm{L}$ & & 1 & 1 & & $\mathrm{Ad}$ & 0 & \\
\hline Clavicle & $R$ & & 1 & 1 & & $\mathrm{Ad}$ & 0 & \\
\hline Femur & $\mathrm{L}$ & $\mathrm{P} 1 / 3, \mathrm{M} 1 / 3, \mathrm{D} 1 / 3$ & $1,1,1$ & \multirow{4}{*}{3} & & $\mathrm{Ad}$ & 0 & \multirow{4}{*}{$\begin{array}{l}1 \mathrm{M}- \\
\text { femor } \\
\text { head }> \\
47.5 \mathrm{~mm}\end{array}$} \\
\hline Femur & $\mathrm{L}$ & $\begin{array}{c}\mathrm{PE}, \mathrm{P} 1 / 3, \mathrm{M} 1 / 3, \\
\mathrm{D} 1 / 3, \mathrm{DE}\end{array}$ & $2,1,1,1,2$ & & & $\mathrm{Ad}$ & 0 & \\
\hline Femur & $\mathrm{L}$ & $\mathrm{P} 1 / 3$ & 1 & & & $\mathrm{Ad}$ & 0 & \\
\hline Femur & $\mathrm{L}$ & PE & 2 & & & $\mathrm{Ad}$ & 5 & \\
\hline Femur & $\mathrm{R}$ & $\begin{array}{c}\mathrm{PE}, \mathrm{P} 1 / 3, \mathrm{M} 1 / 3, \\
\mathrm{D} 1 / 3\end{array}$ & $2,1,1,2$ & \multirow{3}{*}{2} & & $\mathrm{Ad}$ & 0 & \multirow{3}{*}{$\begin{array}{l}1 \mathrm{M}- \\
\text { femor } \\
\text { head = } \\
49 \mathrm{~mm}\end{array}$} \\
\hline Femur & $\mathrm{R}$ & $\mathrm{PE}$ & 2 & & & $\mathrm{Ad}$ & 5 & \\
\hline Femur & $\mathrm{R}$ & $\mathrm{M} 1 / 3, \mathrm{D} 1 / 3$ & 1,1 & & & $\mathrm{Ad}$ & 0 & \\
\hline Fibula & $\mathrm{L}$ & $\mathrm{P} 1 / 3, \mathrm{M} 1 / 3$ & 1,1 & \multirow{2}{*}{2} & & $\mathrm{Ad}$ & 0 & \\
\hline Fibula & $\mathrm{L}$ & $\mathrm{P} 1 / 3, \mathrm{M} 1 / 3$ & 2,1 & & & $\mathrm{Ad}$ & 0 & \\
\hline Fibula & $\mathrm{R}$ & $\begin{array}{c}\mathrm{P} 1 / 3, \mathrm{M} 1 / 3, \mathrm{D} 1 / 3 \\
\mathrm{DE}\end{array}$ & $1,1,1,1$ & \multirow{3}{*}{2} & & $\mathrm{Ad}$ & 0 & \\
\hline Fibula & $\mathrm{R}$ & $\mathrm{P} 1 / 3$ & 2 & & & $\mathrm{Ad}$ & 0 & \\
\hline Fibula & $\mathrm{R}$ & $\mathrm{D} 1 / 3$ & 2 & & & Ad & 0 & \\
\hline & & & & & & & & \\
\hline
\end{tabular}

The Center for Archaeological Research

The University of Texas at San Antonio 
Feature/Burial \#: Feature 1/ Kohnitz

Observer/Date Cynthia Munoz/ 2/13/08

\begin{tabular}{|c|c|c|c|c|c|c|c|c|}
\hline Bone & Side & Segment & Completeness & MNI & Ct/Wt & Age & & Sex \\
\hline Humerus & L & $\mathrm{D} 1 / 3, \mathrm{DE}$ & 1,1 & \multirow{2}{*}{2} & & $\mathrm{Ad}$ & 1 & \multirow{4}{*}{$\begin{array}{l}1 \mathrm{M}, 1 \mathrm{~F}- \\
\text { epicondy } \\
\text { lar } \\
\text { breadth }\end{array}$} \\
\hline Humerus & L & $\mathrm{P} 1 / 3, \mathrm{M} 1 / 3$ & 1,2 & & & $\mathrm{Ad}$ & 0 & \\
\hline Humerus & $R$ & $\mathrm{P} 1 / 3, \mathrm{M} 1 / 3, \mathrm{D} 1 / 3$ & $1,1,1$ & \multirow[b]{2}{*}{2} & & $\mathrm{Ad}$ & 0 & \\
\hline Humerus & $\mathrm{R}$ & $\begin{array}{c}\mathrm{PE}, \mathrm{P} 1 / 3, \mathrm{M} 1 / 3, \\
\mathrm{D} 1 / 3, \mathrm{DE}\end{array}$ & $1,1,1,1,1$ & & & $\mathrm{Ad}$ & 5 & \\
\hline Metatarsal & $\mathrm{R}$ & & $2 / 1$ & 1 & & $\mathrm{Ad}$ & 0 & \\
\hline Metatarsal & $L$ & & $5 / 3$ & 2 & & $\mathrm{Ad}$ & 0 & \\
\hline Ox Coxae & $?$ & Fragment & 3 & & 1 & $\mathrm{Ad}$ & 0 & \\
\hline Ox Coxae & $\mathrm{L}$ & $\begin{array}{c}\text { Ilium and Auricular } \\
\text { Surface }\end{array}$ & 1 & \multirow{3}{*}{1} & & $\mathrm{Ad}$ & 0 & \\
\hline Ox Coxae & $\mathrm{L}$ & Acetabulum & 2 & & & $\mathrm{Ad}$ & 0 & \\
\hline Ox Coxae & $\mathrm{L}$ & Acetabulum & 2 & & & $\mathrm{Ad}$ & 0 & \\
\hline Ox Coxae & $R$ & llium & 3 & \multirow{5}{*}{2} & & $\mathrm{Ad}$ & 0 & \\
\hline Ox Coxae & $R$ & $\begin{array}{l}\text { Ischium and } \\
\text { Acetabulum }\end{array}$ & 2 & & & $\mathrm{Ad}$ & 0 & \\
\hline Ox Coxae & $\mathrm{R}$ & $\begin{array}{l}\text { llium, Auricular } \\
\text { Surface, and } \\
\text { Acetabulum }\end{array}$ & 2 & & & $\mathrm{Ad}$ & 3 & \\
\hline Ox Coxae & $\mathrm{R}$ & \begin{tabular}{|c|} 
Illium and Auricular \\
Surface
\end{tabular} & 3 & & & $\mathrm{Ad}$ & 0 & \\
\hline Ox Coxae & $\mathrm{R}$ & Ilium & 3 & & & $\mathrm{Ad}$ & 0 & \\
\hline Patella & $\mathrm{R}$ & & 1 & 1 & & $\mathrm{Ad}$ & 0 & \\
\hline Patella & $\mathrm{L}$ & & 3 & 1 & & $\mathrm{Ad}$ & 0 & \\
\hline Phalanges & B & & $5 / 4$ & 1 & & $\mathrm{Ad}$ & 0 & \\
\hline Radius & $\mathrm{L}$ & $\begin{array}{c}\mathrm{PE}, \mathrm{P} 1 / 3, \mathrm{M} 1 / 3, \\
\mathrm{D} 1 / 3, \mathrm{DE}\end{array}$ & $1,1,1,1,1$ & 1 & & $\mathrm{Ad}$ & 0 & \\
\hline Radius & $R$ & $\begin{array}{c}\mathrm{PE}, \mathrm{P} 1 / 3, \mathrm{M} 1 / 3 \\
\mathrm{D} 1 / 3, \mathrm{DE}\end{array}$ & $1,1,1,1,1$ & \multirow[t]{2}{*}{2} & & $\mathrm{Ad}$ & 0 & \\
\hline Radius & $\mathrm{R}$ & $\mathrm{PE}, \mathrm{P} 1 / 3, \mathrm{M} 1 / 3$ & $1,1,2$ & & & $\mathrm{Ad}$ & 0 & \\
\hline Ribs & $?$ & & $18 / 0$ & 1 & & $\mathrm{Ad}$ & 0 & \\
\hline Ribs & $R$ & & $9 / 0$ & 1 & & $\mathrm{Ad}$ & 0 & \\
\hline Ribs & $\mathrm{L}$ & & $4 / 0$ & 1 & & $\mathrm{Ad}$ & 0 & \\
\hline Ribs - 1st & $\mathrm{L}$ & & 1 & 1 & & $\mathrm{Ad}$ & 0 & \\
\hline Ribs - 2nd & L & & 2 & 1 & & $\mathrm{Ad}$ & 0 & \\
\hline Sacrum & B & & 2 & 1 & & $\mathrm{Ad}$ & 0 & \\
\hline
\end{tabular}

The Center for Archaeological Research

The University of Texas at San Antonio 
Feature/Burial \#: Feature 1/ Kohnitz

Observer/Date Cynthia Munoz/2/13/08

\begin{tabular}{|c|c|c|c|c|c|c|c|c|}
\hline Bone & Side & Segment & Completeness & MNI & $\mathrm{Ct} / \mathrm{Wt}$ & Age & & Sex \\
\hline Scapula & $\mathrm{L}$ & Acromion Process & 3 & 1 & & $\mathrm{Ad}$ & 0 & \\
\hline Scapula & $\mathrm{R}$ & Glenoid Fossa & 1 & \multirow{4}{*}{2} & & $\mathrm{Ad}$ & 0 & \\
\hline Scapula & $\mathrm{R}$ & Glenoid Fossa & 2 & & & $\mathrm{Ad}$ & 0 & \\
\hline Scapula & $\mathrm{R}$ & Acromion Process & 3 & & & $\mathrm{Ad}$ & 0 & \\
\hline Scapula & $\mathrm{R}$ & Acromion Process & 3 & & & Ad & 0 & \\
\hline Scapula & $?$ & & 3 & & & $\mathrm{Ad}$ & 0 & \\
\hline Talus & $\mathrm{L}$ & & 1 & 1 & & $\mathrm{Ad}$ & 0 & \\
\hline Talus & $\mathrm{R}$ & & 1 & 1 & & $\mathrm{Ad}$ & 0 & \\
\hline Tarsals & $\mathrm{L}$ & & $1 / 1$ & 1 & & $\mathrm{Ad}$ & 0 & \\
\hline Tibia & L & $\mathrm{P} 1 / 3, \mathrm{M} 1 / 3, \mathrm{D} 1 / 3$ & $1,1,1$ & \multirow{2}{*}{2} & & $\mathrm{Ad}$ & 0 & \\
\hline Tibia & L & $\mathrm{P} 1 / 3, \mathrm{M} 1 / 3$ & 1,1 & & & $\mathrm{Ad}$ & 0 & \\
\hline Tibia & $\mathrm{R}$ & $\mathrm{P} 1 / 3, \mathrm{M} 1 / 3, \mathrm{D} 1 / 3$ & $1,1,1$ & \multirow{3}{*}{3} & & $\mathrm{Ad}$ & 0 & \\
\hline Tibia & $\mathrm{R}$ & $M 1 / 3, D 1 / 3$ & 1,1 & & & $\mathrm{Ad}$ & 0 & \\
\hline Tibia & $\mathrm{R}$ & $\mathrm{P} 1 / 3, \mathrm{M} 1 / 3, \mathrm{D} 1 / 3$ & $1,1,1$ & & & $\mathrm{~J}$ & 0 & \\
\hline Ulna & $\mathrm{L}$ & $\begin{array}{c}\mathrm{PE}, \mathrm{P} 1 / 3, \mathrm{M} 1 / 3, \\
\mathrm{D} 1 / 3\end{array}$ & $2,1,1,1$ & 1 & & $\mathrm{Ad}$ & 0 & \\
\hline Ulna & $\mathrm{R}$ & $\begin{array}{c}\mathrm{PE}, \mathrm{P} 1 / 3, \mathrm{M} 1 / 3, \\
\mathrm{D} 1 / 3\end{array}$ & $2,1,1,2$ & \multirow[t]{2}{*}{2} & & $\mathrm{Ad}$ & 0 & \\
\hline Ulna & $\mathrm{R}$ & $P E, P 1 / 3, M 1 / 3$ & $2,1,1$ & & & $\mathrm{Ad}$ & 0 & \\
\hline Unidentified & $?$ & & & & $129.8 \mathrm{~g}$ & & 0 & \\
\hline Vertebra - C1 & $\mathrm{L}$ & NA & 2 & \multirow{2}{*}{2} & & $\mathrm{Ad}$ & 0 & \\
\hline Vertebra - C1 & $\mathrm{R}$ & NA & 1 & & & $\mathrm{Ad}$ & 0 & \\
\hline Vertebrae & $?$ & $\mathrm{~B}$ & 3 & & 2 & & 0 & \\
\hline Vertebra - L1/L2 & $B$ & $\mathrm{NA}, \mathrm{B}$ & $2 / 1$ & \multirow{4}{*}{1} & & $\mathrm{Ad}$ & 0 & \\
\hline Vertebra - L3 & $\mathrm{B}$ & $\mathrm{NA}, \mathrm{B}$ & $2 / 1$ & & & $\mathrm{Ad}$ & 0 & \\
\hline Vertebrae - T1-T9 & $B$ & NA & $11 /$ & & & & 0 & \\
\hline Vertebrae - T1-T9 & $B$ & $\mathrm{~B}$ & 71 & & & & 0 & \\
\hline & & & & & & & & \\
\hline & & & & & & & & \\
\hline & & & & & & & & \\
\hline & & & & & & & & \\
\hline
\end{tabular}

The Center for Archaeological Research

The University of Texas at San Antonio 
Feature/Burial \#: Feature 1/ Kohnitz

Observer/Date Cynthia Munoz/ 2/13/08

\begin{tabular}{|c|c|c|c|c|c|c|c|c|}
\hline Bone & Side & Segment & Completeness & & $\mathrm{Ct} / \mathrm{Wt}$ & Age & \multicolumn{2}{|r|}{ Sex } \\
\hline Frontal & $\mathrm{B}$ & & 1 & \multirow{4}{*}{ MNI } & & YA & 2 & \multirow{11}{*}{$\begin{array}{c}1.75 \text { avg } \\
-1 \mathrm{~F} ?\end{array}$} \\
\hline Parietal & L & & 1 & & & YA & 0 & \\
\hline Parietal & $\mathrm{R}$ & & 1 & & & YA & 0 & \\
\hline Occipital & $\mathrm{R}$ & & 1 & & & YA & 2 & \\
\hline Occipital & $\mathrm{L}$ & & 1 & & & YA & 2 & \\
\hline Temporal & $\mathrm{R}$ & & 1 & \multirow{26}{*}{2} & & YA & 1 & \\
\hline Temporal & $\mathrm{L}$ & & 1 & & & YA & 1 & \\
\hline TMJ & $\mathrm{R}$ & & 1 & & & YA & 0 & \\
\hline TMJ & $\mathrm{L}$ & & 1 & & & YA & 0 & \\
\hline Mandible & $\mathrm{L}$ & & 1 & & & YA & 2 & \\
\hline Mandible & $\mathrm{R}$ & & 1 & & & YA & 2 & \\
\hline Mandibular Molars & $\mathrm{L}$ & & & & 2 & $\mathrm{Ad}$ & 0 & \\
\hline Mandibular Premolars & $\mathrm{L}$ & & & & 1 & $\mathrm{Ad}$ & 0 & \\
\hline Mandibular Premolars & $\mathrm{R}$ & & & & 1 & $\mathrm{Ad}$ & 0 & \\
\hline Mandibular Canines & $\mathrm{L}$ & & & & 1 & $\mathrm{Ad}$ & 0 & \\
\hline Mandibular Molars & $\mathrm{R}$ & & & & 1 & $\mathrm{Ad}$ & 0 & \\
\hline Frontal & $\mathrm{B}$ & & 1 & & & $\mathrm{Ad}$ & 4 & \multirow{11}{*}{$\begin{array}{c}3.5 \text { avg } \\
1 \mathrm{M} ?\end{array}$} \\
\hline Parietal & $\mathrm{R}$ & & 1 & & & $\mathrm{Ad}$ & 0 & \\
\hline Parietal & $\mathrm{L}$ & & 1 & & & $\mathrm{Ad}$ & 0 & \\
\hline Occipital & $\mathrm{ML}$ & & 2 & & & $\mathrm{Ad}$ & 3 & \\
\hline Temporal & L & & 1 & & & $\mathrm{Ad}$ & 3 & \\
\hline Temporal & $\mathrm{R}$ & & 1 & & & $\mathrm{Ad}$ & 3 & \\
\hline TMJ & $\mathrm{L}$ & & 1 & & & $\mathrm{Ad}$ & 0 & \\
\hline TMJ & $\mathrm{R}$ & & 1 & & & Ad & 0 & \\
\hline Maxilla & $\mathrm{L}$ & & 2 & & & $\mathrm{Ad}$ & 0 & \\
\hline Mandible & $\mathrm{L}$ & & 1 & & & $\mathrm{Ad}$ & 4 & \\
\hline Mandible & $\mathrm{R}$ & & 1 & & & $\mathrm{Ad}$ & 4 & \\
\hline Mandibular Molars & $\mathrm{L}$ & & & & 3 & $\mathrm{Ad}$ & 0 & \\
\hline Mandibular Molars & $\mathrm{R}$ & & & & 2 & $\mathrm{Ad}$ & 0 & \\
\hline Mandibular Premolars & $\mathrm{L}$ & & & & 2 & $\mathrm{Ad}$ & 0 & \\
\hline Mandibular Premolars & $\mathrm{R}$ & & & & 2 & $\mathrm{Ad}$ & 0 & \\
\hline Skull & $?$ & Fragments & & & $118 \mathrm{~g}$ & & 0 & \\
\hline Mandibular Canine & $\mathrm{L}$ & & & & 1 & $\mathrm{Ad}$ & 0 & \\
\hline Mandibular Incisors & B & & & & 4 & $\mathrm{Ad}$ & 0 & \\
\hline & & & & & & & & \\
\hline
\end{tabular}

The Center for Archaeological Research

The University of Texas at San Antonio 


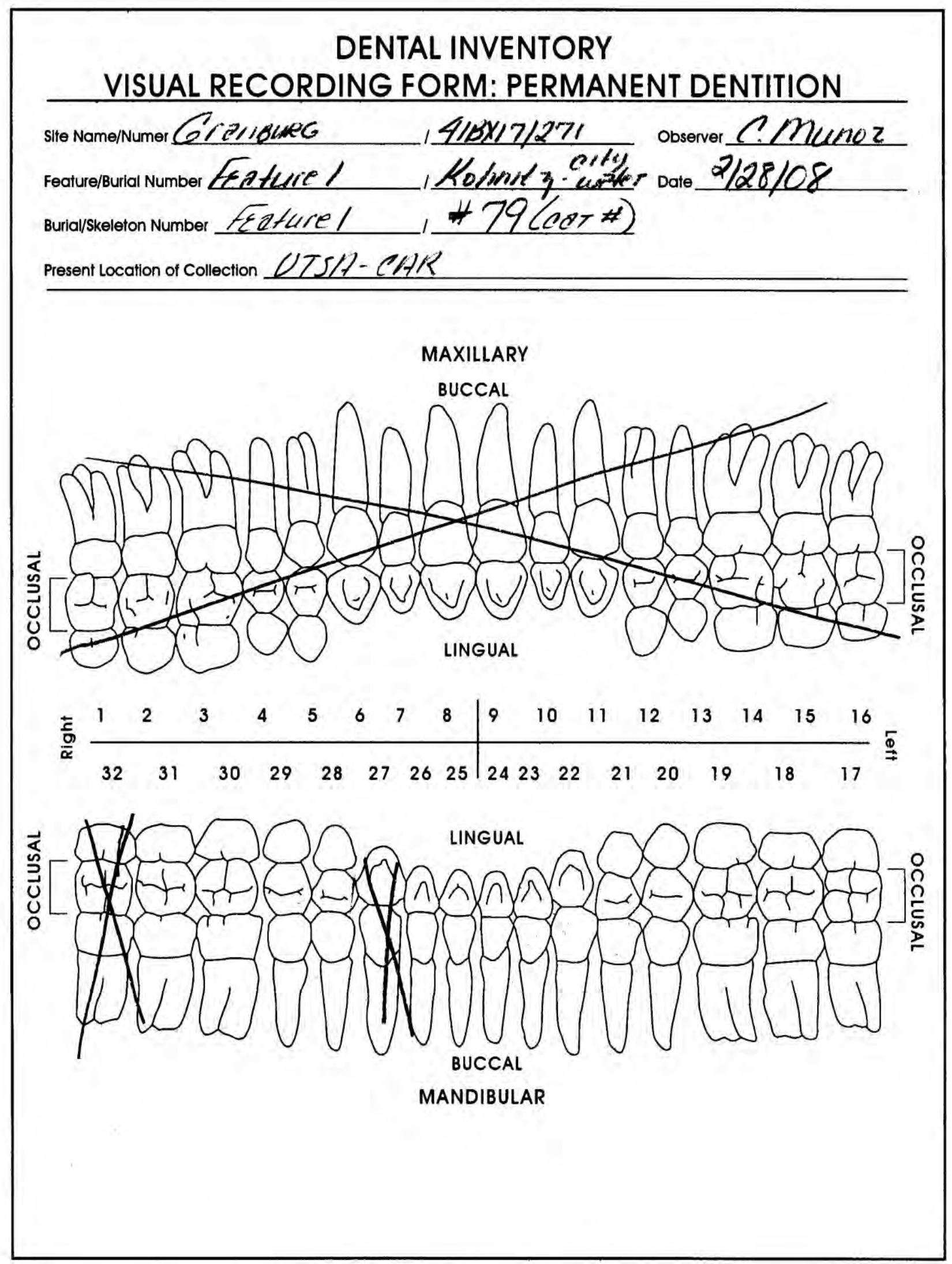




\section{DENTAL INVENTORY RECORDING FORM DEVELOPMENT, WEAR, AND PATHOLOGY: PERMANENT TEETH}

Site Name/Number

Feature/Burial Number

Burial/Skeleton Number

Present Location of Collection
Granberg/41BX17/271

Feature 1/Kohnitz- city water trench Date February 27, 2008

Feature $1 /$ cat \#79

Tooth presence and development: code 1-8. For teeth entered as 'I" (present, but not in occlusion), record stage of crown/root formation under "Development." Occlusal surface wear: use left teeth, following Smith (1984) for anterior teeth (code 1-8) and Scott (1979) for molars (code O-10). If marked asymmetry is present, record both sides. Record each molar quadrant separate in the spaces provided $(+)$ and the total for all four quadrants under 'Total." Caries: code each carious lesion separately (1 -7); Abscesses: code location (1 -2). Calculus: code $0-3,9$. Note surface affected (buccal/labial or lingual).

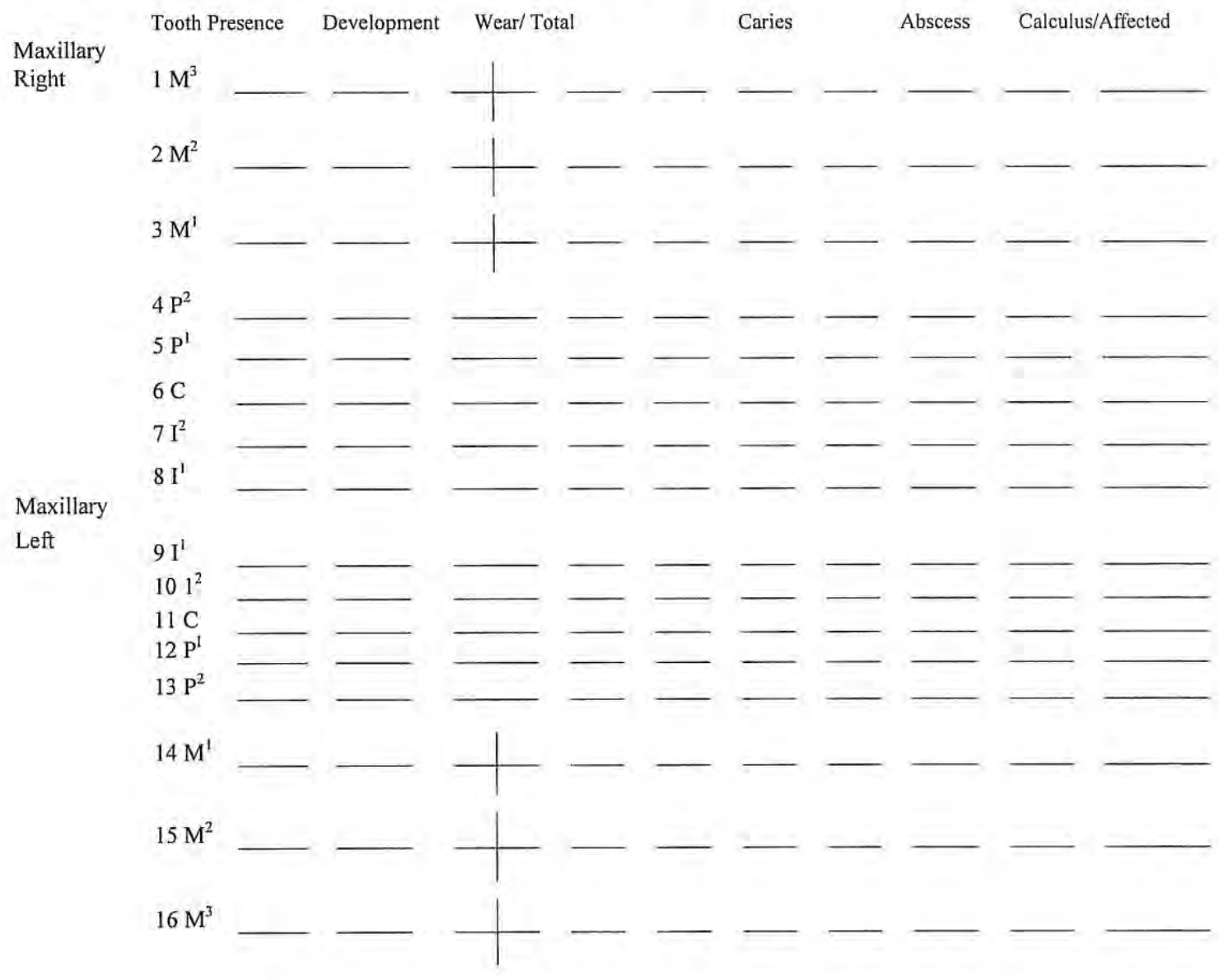


Series/Burial/Skeleton Observer/Date
Feature 1/ Kohnitz/cat \#79 Munoz/2-28-08

\begin{tabular}{|c|c|c|c|c|c|c|c|c|c|c|c|c|}
\hline \multirow{3}{*}{$\begin{array}{l}\text { Mandibular } \\
\text { Left }\end{array}$} & \multicolumn{2}{|c|}{ Tooth Presence } & \multirow[t]{2}{*}{ Development } & \multicolumn{3}{|c|}{ Wear/ Total } & \multicolumn{3}{|c|}{ Caries } & \multirow{2}{*}{$\begin{array}{c}\text { Abscess } \\
0\end{array}$} & \multicolumn{2}{|c|}{ Calculus/Affected } \\
\hline & $17 \mathrm{M}_{3}$ & 2 & & 9 & 8 & 35 & 0 & 0 & 0 & & 2 & $\mathrm{~B}$ and $\mathrm{L}$ \\
\hline & & & & 9 & 9 & & & & & & & \\
\hline \multirow[b]{9}{*}{ Mandibular } & $18 \mathrm{M}_{2}$ & 2 & & 9 & 9 & 36 & 0 & 0 & 0 & 0 & 2 & $\mathrm{~B}$ and $\mathrm{L}$ \\
\hline & $19 \mathrm{M}_{\mathrm{i}}$ & 2 & & 9 & 10 & 37 & 0 & 0 & 0 & 0 & 2 & $\mathrm{~B}$ and $\mathrm{L}$ \\
\hline & & & & 91 & 9 & & & & & & & \\
\hline & $20 \mathrm{P}_{2}$ & 2 & & 6 & & 6 & 0 & 0 & 0 & 0 & 2 & $B$ and $L$ \\
\hline & $21 \mathrm{P}_{1}$ & 2 & & 6 & & 6 & 0 & 0 & 0 & 0 & 2 & $\mathrm{~B}$ and $\mathrm{L}$ \\
\hline & $22 \mathrm{C}$ & 2 & & 6 & & 6 & 0 & 0 & 0 & 0 & 2 & $\mathrm{~B}$ and $\mathrm{L}$ \\
\hline & $23 \mathrm{I}_{2}$ & 1 & & 7 & & 7 & 0 & 0 & 0 & 0 & 1 & Interpro \\
\hline & $24 \mathrm{I}_{\mathrm{I}}$ & 1 & & 7 & & 7 & 0 & 0 & 0 & 0 & 1 & Interpro \\
\hline & & & & & & & & & & & & \\
\hline \multirow[t]{9}{*}{ Right } & $25 \mathrm{I}_{1}$ & 1 & & 7 & & 7 & 0 & 0 & 0 & 0 & 1 & Interpro \\
\hline & $261_{2}$ & 1 & & 7 & & 7 & 0 & 0 & 0 & 0 & 1 & Interpro \\
\hline & $27 \mathrm{C}$ & 5 & & & & & & & & & & \\
\hline & $28 \mathrm{P}_{1}$ & 2 & & 6 & & 6 & 0 & 0 & 0 & 0 & 2 & $\mathrm{~B}$ and $\mathrm{L}$ \\
\hline & $29 \mathrm{P}_{2}$ & 2 & & 6 & & 6 & 0 & 0 & 0 & 0 & 2 & $\mathrm{~B}$ and $\mathrm{L}$ \\
\hline & $30 \mathrm{M}_{1}$ & 2 & & 9 & 9 & 36 & 0 & 0 & 0 & 0 & 2 & $\mathrm{~B}$ and $\mathrm{L}$ \\
\hline & $31 \mathrm{M}_{2}$ & 2 & & 9 & 9 & 36 & 0 & 0 & 0 & 0 & 2 & $\mathrm{~B}$ and $\mathrm{L}$ \\
\hline & & & & & 9 & & & & & & & \\
\hline & $32 \mathrm{M}_{3}$ & 5 & & & & 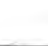 & & & & & & \\
\hline
\end{tabular}

Estimated dental age (juveniles only)

Supernumerary Teeth: Position between teeth
$\frac{1}{1}$

\begin{tabular}{cc}
$\begin{array}{c}\text { Location } \\
(1-4)\end{array}$ & $\begin{array}{c}\text { Position } \\
\text { between teeth }\end{array}$ \\
\hline & $\frac{1}{1}$ \\
\hline
\end{tabular}

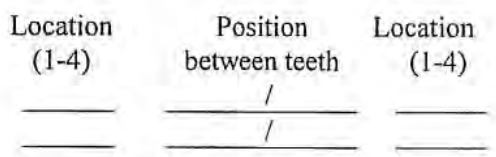

Comments:

Teeth exhibit extensive wear. Periodontal disease is indicated from lipping and pitting of alveolar surface. No caries lesions are present. Dentition has moderate calculus accumulation. Neither measurements not morphology were recorded due to extreme wear. Canines and incisors were examined for presence of enamel hypoplasias. Although no evidence of enamel defect was noted, the tooth wear was excessive with large areas of enamel worn away. 


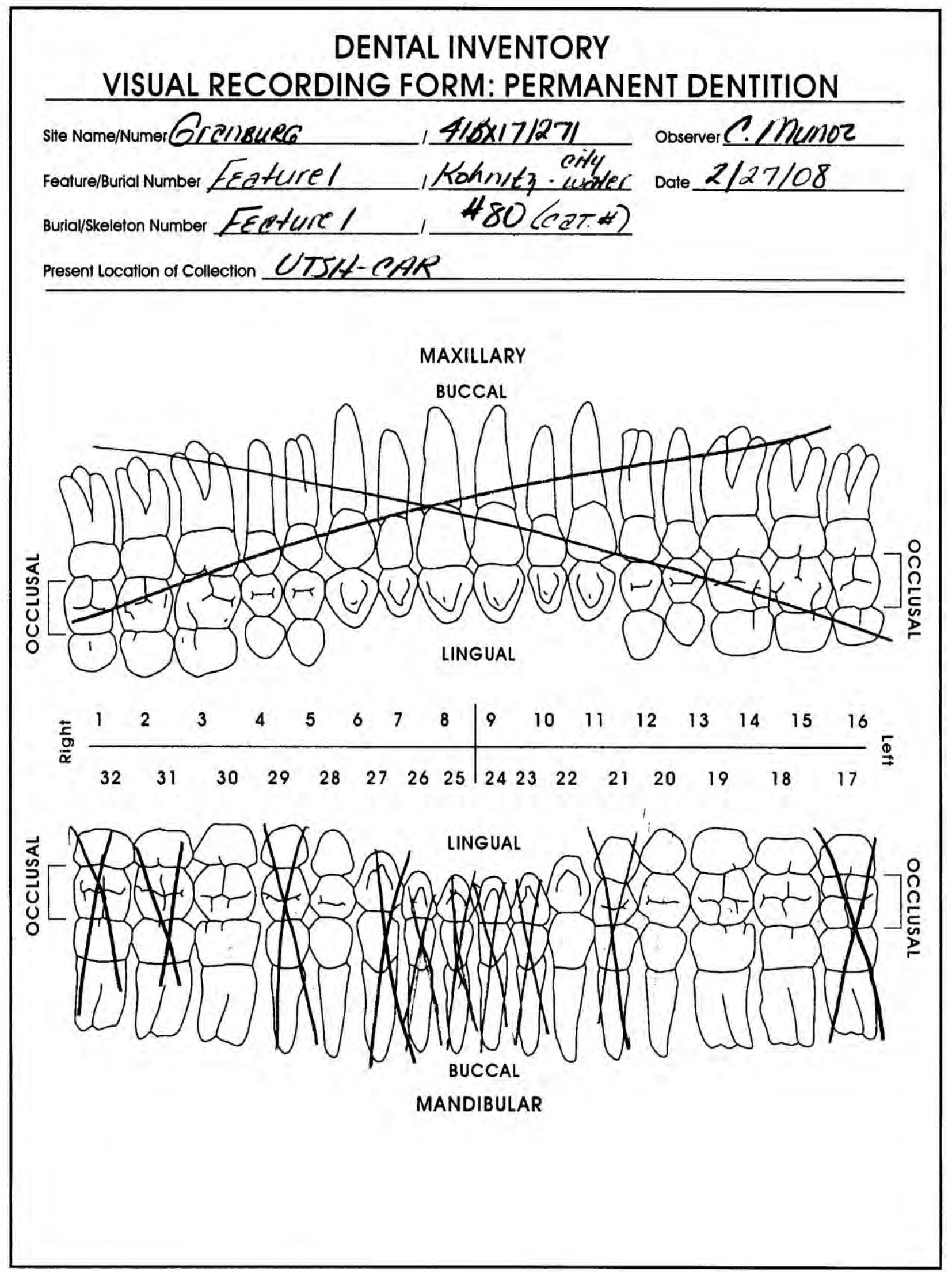




\section{DENTAL INVENTORY RECORDING FORM DEVELOPMENT, WEAR, AND PATHOLOGY: PERMANENT TEETH}

\begin{tabular}{|c|c|c|c|}
\hline Site Name/Number & Granberg/41BX17/271 & Observer & Cynthia Munoz \\
\hline Feature/Burial Number & Feature $1 /$ Kohnitz- city water trench & Date & February 27,2008 \\
\hline Burial/Skeleton Number & Feature $1 /$ cat $\# 80$ & & \\
\hline Present Location of Collection & UTSA-CAR & & \\
\hline
\end{tabular}

Tooth presence and development: code 1-8. For teeth entered as 'l" (present, but not in occlusion), record stage of crown/root formation under "Development." Occlusal surface wear: use left teeth, following Smith (1984) for anterior teeth (code 1-8) and Scott (1979) for molars (code O-10). If marked asymmetry is present, record both sides. Record each molar quadrant separate in the spaces provided $(+)$ and the total for all four quadrants under 'Total." Caries: code each carious lesion separately (1 -7); Abscesses: code location (1 -2). Calculus: code $0-3,9$. Note surface affected (buccal/labial or lingual).

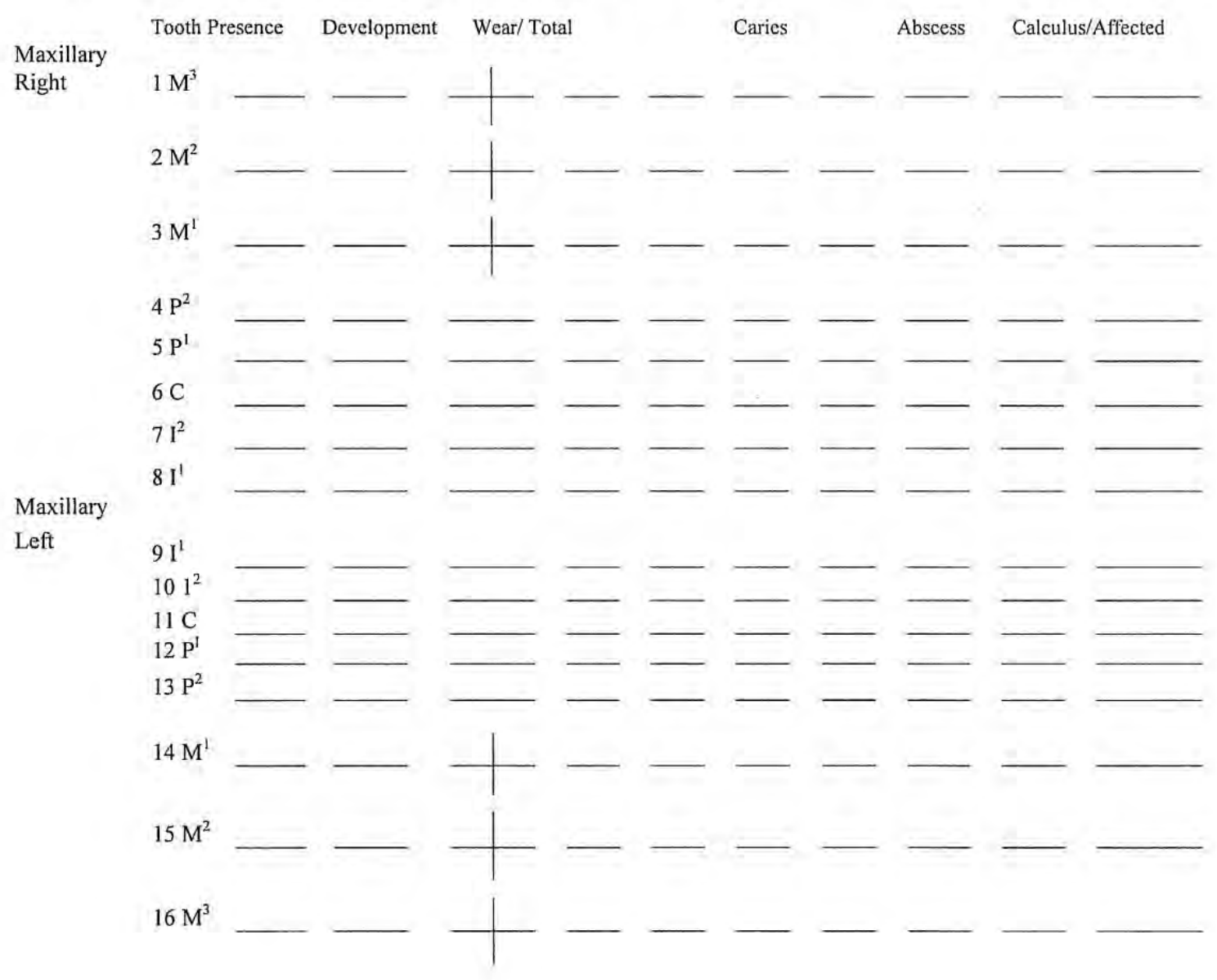




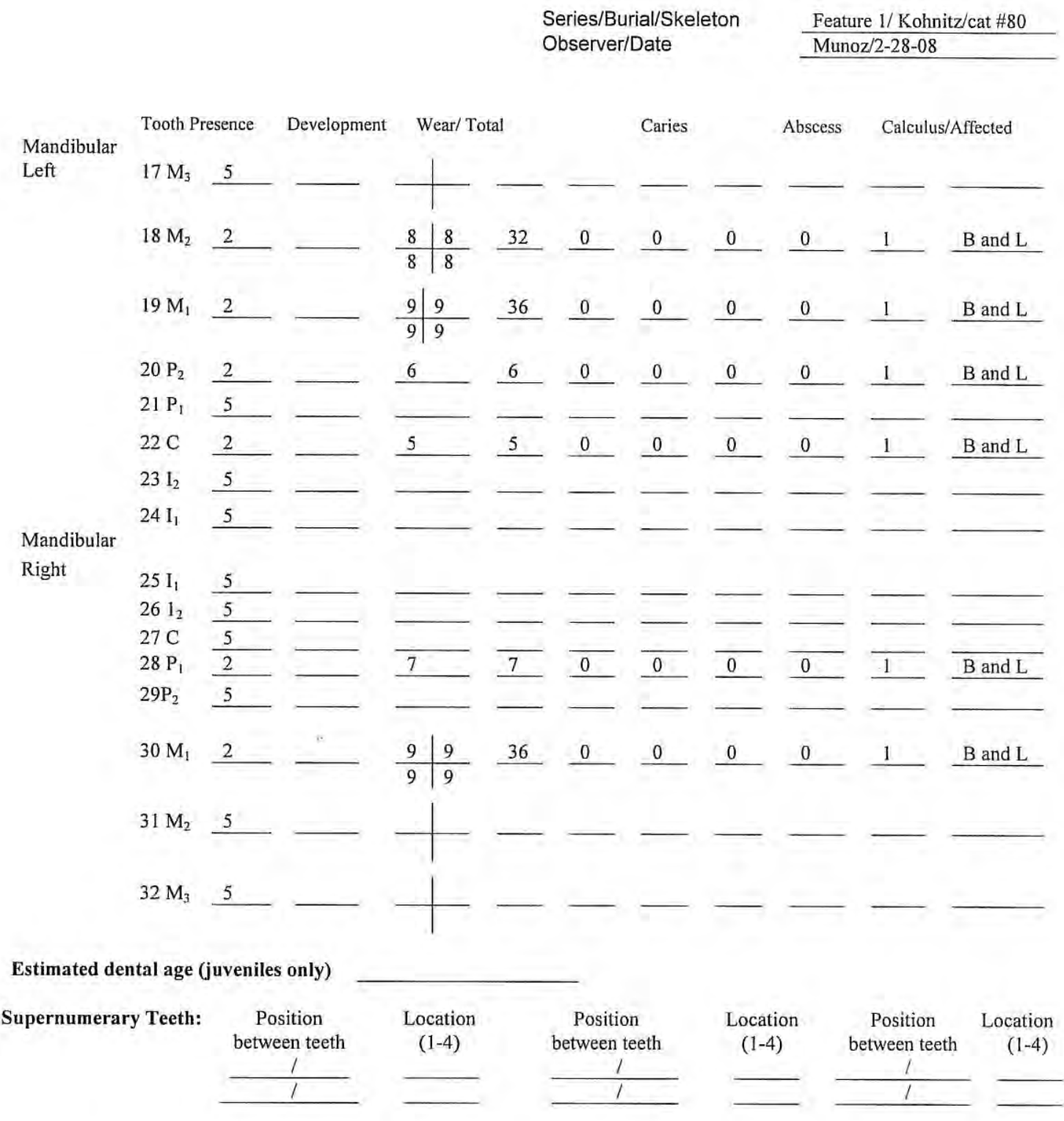

Comments:

Teeth exhibit extreme wear. Periodontal disease is indicated from lipping and pitting of alveolar surface. No caries lesions are present. Dentition has light calculus accumulation. Neither measurements not morphology were recorded due to extreme wear. 


\section{CRANIAL AND POSTCRANIAL MEASUREMENT RECORDING FORM: ADULT REMAINS}

\begin{tabular}{|c|c|c|c|}
\hline Site Name/Number: & Granberg/ 41BX17/271 & Observer: & Cynthia Munoz \\
\hline Feature/Burial Number: & Feature $1 /$ Kohnitz- city water trench & Date: & $13-$ Feb-08 \\
\hline Burial/Skeleton Number: & Feature 1 & & \\
\hline Present Location of Collection: & UTSA-CAR & & \\
\hline
\end{tabular}

Record all measurements to the nearest millimeter; in the case of bilateral measurements, take measurement on the left side. If right side is substituted, place an " $R$ " next to the measurement. If bones are fragmented, measurements should not be taken, but dimensions should be estimated for minor erosion or reconstruction; identify these with an asterisk "*".

\section{Cranial Measurements}

1. Maximum Cranial Length:

2. Maximum Cranial Breadth:

3. Bizygomatic Diameter:

4. Basion-Bregma Height:

5. Cranial Base Length:

6. Basion-Prosthion Length:

7. Maxillo-Alveolar Breadth:

8. Maxillo-Alveolar Length

9. Biauricular Breadth:

10. Upper Facial Height:

11. Minimum Frontal Breadth:

12. Upper Facial Breadth:

13 Nasal Height:

14. Nasal Breadth:

15. Orbital Breadth;

16. Orbital Height:

17. Biorbital Breadth:
$162(80)$

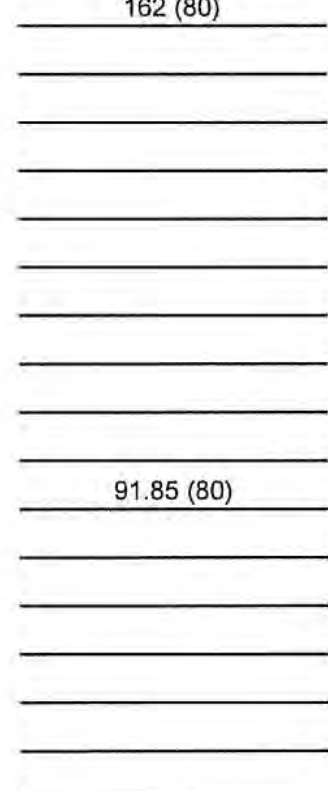

18. Interorbital Breadth:

19. Frontal Chord:

20. Parietal Chord:

21. Occipital Chord:

22. Foramen Magnum Length:

23. Foramen Magnum Breadth:

24. Mastoid Length:

25. Chin Height:

26. Height of the Mandibular Body:

27. Breadth of the Mandibular Body:

28. Bigonial Width:

29. Bicondylar Breadth:

30. Minimum Ramus Breadth:

31. Maximum Ramus Breadth:

32. Maximum Ramus Height:

33. Mandibular Length:

34. Mandibular Angle:
$107.95(80)$

36.21 (79); $26.49(80)$

$35.22(79) ; 33.03(80)$

$10.85(79) ; 9.12(80)$

$97.25(80)$

$127.49(79) ; 111.03(80)$

$36.34(79) ; 28.47(80)$

$48.31(79)$

$67.92(79) ; 61.84(80)$

$95.4(79) ; 85.8(80)$

$114(79) ; 126(80)$ 
Record all measurements to the nearest millimeter; in the case of bilateral measurements, take measurement on the left side. If right side is substituted, place an "R" next to the measurement. If bones are fragmented, measurements should not be taken, but dimensions should be estimated for minor erosion or reconstruction; identify these with an asterisk "*".

\section{Postcranial Measurements}

35. Clavicle: Maximum Length 36. Clavicle: Ant.-Post. Diameter at Midshaft:

37. Clavicle: Sup.-Inf. Diameter at Midshaft:

38. Scapula: Height:

39. Scapula: Breadth:

40. Humerus: Maximum Length:

41. Humerus: Epicondylar Breadth: 42. Humerus: Vertical Diameter of Head:

43. Humerus: Maximum Diameter at Midshaft:

44. Humerus: Minimum Diameter at Midshaft:

45. Radius: Maximum Length: 46. Radius: Anterior-Posterior Diameter at Midshaft:

47. Radius: Medial-Lateral Diameter at Midshaft:

48. Uina: Maximum Length: 49. Ulna: Anterior-Posterior Diameter:

50. Ulna: Medial-Lateral Diameter: $15.85(1) ; 17.45(3)$

51. Ulna: Physiological Length:

52. Ulna: Minimum Circumference:

53. Sacrum: Anterior Length: 54. Sacrum: Anterior Superior Breadth:

55. Sacrum: Max. Transverse Diameter of Base:

56. Ox Coxae: Height:

$239(4) ; 248(5)$

$10.56(4) ; 11.63(5)$

$14.27(4) ; 14.98(5)$

$52.16(39)$

$\begin{array}{r}145(29) \\ \hline 10.32(29) \\ \hline 7.38(29) \\ \hline \\ \hline\end{array}$

57. Os Coxae: Illiac Breadth:

58. Os Coxae: Pubis Length:

59. Os Coxae: Ischium Length:

60. Femur: Maximum Length:

61. Femur: Bicondylar Length:

62. Femur: Epicondylar Breadth:

63. Femur: Maximum Diameter of the Femur Head:

64. Femur: Ant.-Post. Subtrochanteric $31.83(15) ; 24.81$ Diameter:

65. Femur: Medial-Lateral Subtrochanteric Diameter:

66. Femur: Anterior-Posterior Midshaft Diameter

67. Femur: Medial-Lateral Midshaft Diameter:

68. Femur: Midshaft Circumference:

69. Tibia: Length:

70. Tibia: Maximum Proximal

Epiphyseal Breadth:

71. Tibia: Maximum Distal Epiphyseal Breadth:

72. Tibia: Max. Diameter at the Nutrient Foramen:

73. Tibia: Med.-Lat. Diameter at the Nutrient Foramen:

74. Tibia: Circumference at the Nutrient Foramen:

(12); $26.44(11)$

$31.08(15) ; 27.89$

(12); $30.49(11)$

$32.77(15) ; 27.11$

(12); $29.25(11)$

$27.02(15) ; 23.92$

(12); 27.04 (11)

$94(15) ; 82(12) ; 89$

(11)

$28.18(23) ; 37.82$

$(24) ; 37.48(25)$

$19.18(23) ; 26.33$

(24); $26.94(25)$

$180(23) ; 210(24) ;$ $189.5(25)$

75. Fibula: Maximum Length: 76. Fibula: Maximum Diameter at Midshaft:

77. Calcaneus: Maximum Length:

$70.36(52)$

$39.26(52)$ 


\section{PRIMARY NONMETRIC TRAITS RECORDING FORM}

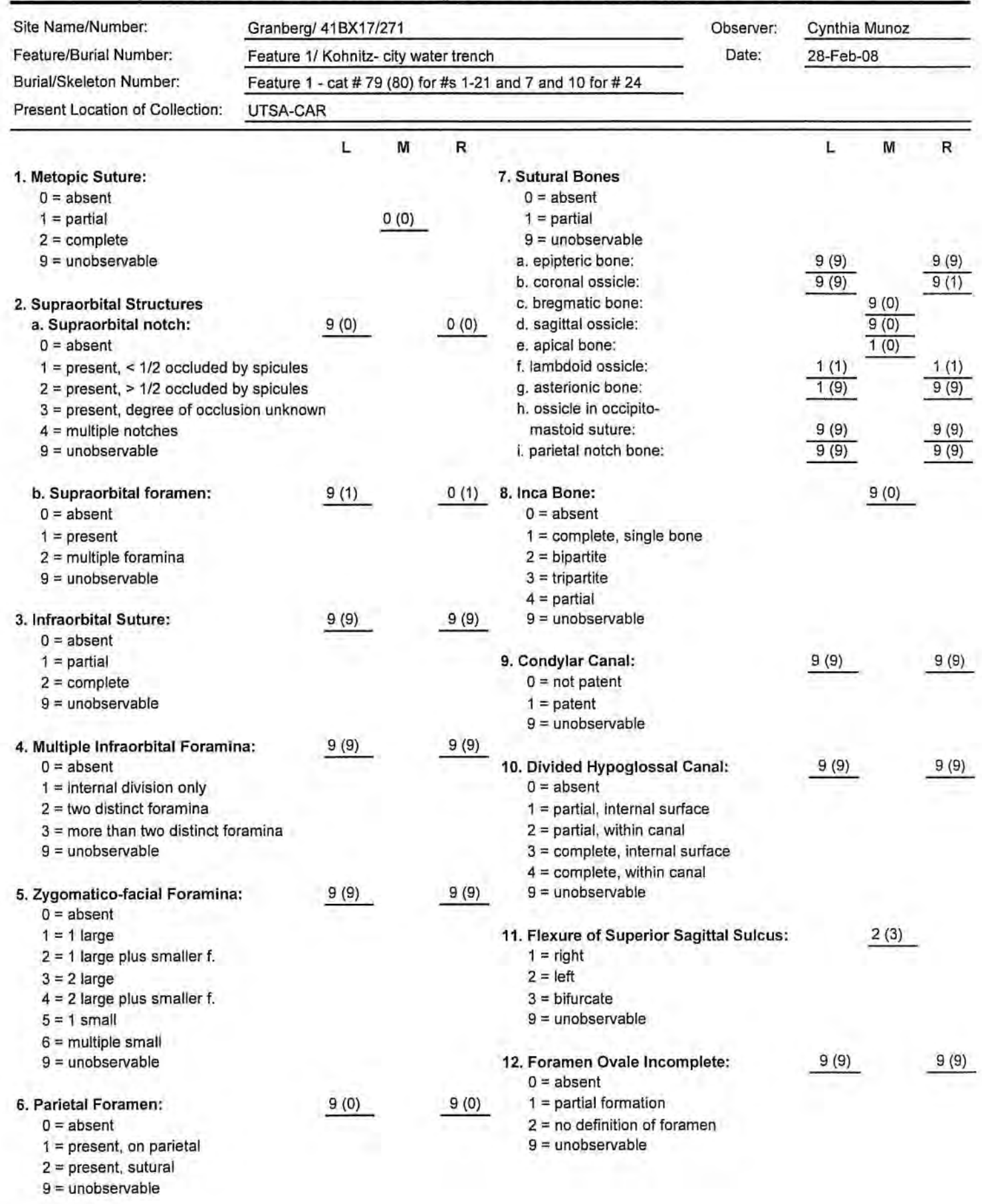

The Center for Archaeological Research The University of Texas at San Antonio 


\begin{tabular}{|c|c|c|c|c|c|c|c|c|}
\hline & & & & Series/Burial/Skeleton & Feature $1-c$ & $79(80)$ & & \\
\hline & & & & Observer/Date & C. Munoz/ $\mathrm{Fe}$ & 8,2008 & & \\
\hline & L & M & R & & & L & M & R \\
\hline $\begin{array}{l}\text { 13. Foramen Spinosum Incomplete: } \\
\begin{aligned} 0 & =\text { absent } \\
1 & =\text { partial formation } \\
2 & =\text { no definition of foramen } \\
9 & =\text { unobservable }\end{aligned}\end{array}$ & $9(9)$ & & $9(9)$ & $\begin{array}{l}\text { 20. Mandibular Torus: } \\
\begin{aligned} 0 & =\text { absent } \\
1 & =\text { trace } \text { (can palpa } \\
2 & =\text { moderate: eleva } \\
3 & =\text { marked: elevatio } \\
9 & =\text { unobservable }\end{aligned}\end{array}$ & $\begin{array}{l}\text { but not see) } \\
\text { n between } 2 \text { - } \\
\text { greater than } 5\end{array}$ & $0(0)$ & & $9(0)$ \\
\hline $\begin{array}{l}\text { 14. Pterygo-spinous Bridge: } \\
0=\text { absent }\end{array}$ & $9(9)$ & & $9(9)$ & 21. Mylohyoid Bridge & & $9(0)$ & & $0(0)$ \\
\hline $1=$ trace $($ spicule only) & & & & a. Location: & & & & \\
\hline $2=$ partial bridge & & & & $0=a b s e n t$ & & & & \\
\hline $3=$ complete bridge & & & & $1=$ near mandibular & ramen & & & \\
\hline $9=$ unobservable & & & & $\begin{array}{l}2=\text { center of groove } \\
3=\text { both bridges des }\end{array}$ & ibed in 1) and & with hiatus & & \\
\hline $\begin{array}{l}\text { 15. Pterygo-alar Bridge: } \\
0=\text { absent }\end{array}$ & $9(9)$ & & $9(9)$ & $\begin{array}{l}4=\text { both bridges des } \\
9=\text { unobservable }\end{array}$ & ibed in 1) and & to hiatus & & \\
\hline $1=$ trace $($ spicule only) & & & & b. Degree: & & $9(0)$ & & $0(0)$ \\
\hline $2=$ partial bridge & & & & $0=a b s e n t$ & & & & \\
\hline $3=$ complete bridge & & & & $1=$ partial & & & & \\
\hline $9=$ unobservable & & & & $2=$ complete & & & & \\
\hline & & & & $9=$ unobservable & & & & \\
\hline 16. Tympanic Dihiscence: & $9(9)$ & & $9(9)$ & & & & & \\
\hline $0=a b s e n t$ & & & & 22. Atlas Bridging & & & & \\
\hline $1=$ foramen only & & & & a. Lateral Bridging: & & & & \\
\hline 2 = full defect present & & & & $0=a b s e n t$ & & & & \\
\hline $9=$ unobservable & & & & $1=$ partial & & & & \\
\hline & & & & $2=$ complete & & & & \\
\hline 17. Auditory Exostosis: & $1(2)$ & & $2(2)$ & $9=$ unobservable & & & & \\
\hline $0=a b s e n t$ & & & & b. Posterior Bridgin & & & & \\
\hline $1=<1 / 3$ canal occluded & & & & $0=a b s e n t$ & & & & \\
\hline $2=1 / 3-2 / 3$ canal occluded & & & & $1=$ partial & & & & \\
\hline $3=>2 / 3$ canal occluded & & & & $2=$ complete & & & & \\
\hline $9=$ unobservable & & & & $9=$ unobservable & & & & \\
\hline 18. Mastoid Foramen & $9(9)$ & & $9(9)$ & 23. Accessory Transve & Foramina: & & & \\
\hline a. Location: & & & & (in 7th Cervical Verte & & & & \\
\hline $0=a b s e n t$ & & & & $0=a b s e n t$ & & & & \\
\hline $1=$ temporal & & & & $1=$ partial & & & & \\
\hline $2=$ sutural & & & & $2=$ complete & & & & \\
\hline $3=$ occipital & & & & $9=$ unobservable & & & & \\
\hline $4=$ both sutural and temporal & & & & & & & & \\
\hline $\begin{array}{l}5=\text { both occipital and temporal } \\
9=\text { unobservable }\end{array}$ & & & & $\begin{array}{l}\text { 24. Septal Aperture: } \\
0=\text { absent }\end{array}$ & & $2(7)$ & & $2(10)$ \\
\hline b. Number: & $9(9)$ & & $9(9)$ & $1=$ small foramen & hole) only & & & \\
\hline $0=a b s e n t$ & & & & $2=$ true perforation & & & & \\
\hline $1=1$ & & & & $9=$ unobservable & & & & \\
\hline $2=2$ & & & & & & & & \\
\hline $3=$ more than 2 & & & & & & & & \\
\hline $9=$ unobservable & & & & & & & & \\
\hline $\begin{array}{l}\text { 19. Mental Foramen: } \\
0=\text { absent }\end{array}$ & $1(1)$ & & $1(1)$ & & & & & \\
\hline & & & & & & & & \\
\hline $\begin{array}{l}1=1 \\
2=2\end{array}$ & & & & & & & & \\
\hline $3=$ more than 2 & & & & & & & & \\
\hline $9=$ unobservable & & & & & & & & \\
\hline
\end{tabular}




\section{TAPHONOMY RECORDING FORM II: WEATHERING, DISCOLORATION, POLISH, CUTMARKS, GNAWING, and, OTHER CULTURAL MODIFICATIONS}

\begin{tabular}{llll}
\hline Site Name/Number & Granberg/41BX17/271 & Observer & C. Munoz \\
\cline { 2 - 2 } Feature/Burial Number & Feature 1/Kohnitz-city water trench & Date & February 21, 2008 \\
Burial/Skeleton Number & Feature 1 & \\
\cline { 2 - 2 } Present Location of Collection & UTSA-CAR & \\
\cline { 2 - 3 }
\end{tabular}

This form is to be used in recording the following modifications: discoloration due to contact with metals, polish, cutmarks, other forms of cultural modifications, and rodent/carnivore gnawing. The following should be recorded. In every example, the nature of the modification should also be described in the space allocated.

Weathering: 1) Bone identification, 2) photographs of representative samples, 3) degree of weathering (use Behrensmeyer system provided in Table 1 for coding degree of weathering).

Discoloration: 1) Bone identification, 2) location (append drawing and photograph), 3) color of discolored bone and "normal" adjacent bone (use appropriate Munsell Chart(s)).

Polish: 1) Bone identification, 2) location (append drawing and photograph).

Cutmarks: 1) Bone identification, 2) location (append drawing and photograph), 3) number of cuts, 4) average cut length, 5) range of cut lengths, 6) sketch and cast (optional but recommended) of representative cut(s).

Evidence of Rodent and Carnivore Gnawing: 1) Bone identification, 2) location (append drawing and photograph), 3) number of paired grooves or incisions. Evidence of rodent and carnivore gnawing should be recorded separately.

Other Forms of Cultural Modification Including the Creation of Artifacts: 1) Bone identification, 2) shape (append drawing and photograph).

\begin{tabular}{|c|c|c|c|}
\hline Type of Bone Alteration & $\begin{array}{l}\text { Location of } \\
\text { Modification }\end{array}$ & $\begin{array}{l}\text { \# of Photographs/ } \\
\text { \# of Drawings }\end{array}$ & $\begin{array}{l}\text { Additional Descriptive } \\
\text { Information }\end{array}$ \\
\hline Weathering - Stage 3 & Fibula - L - P1/3, M1/3 & Photo \#1 & $\sim 50 \%$ of fragment \\
\hline Weathering - Stage 3 & Fibula - L - P1/3, M1/3 & Photo \#1 & $\sim 50 \%$ of fragment \\
\hline Weathering - Stage 3 & $\begin{array}{l}\text { Fibula - R - P1/3, M1/3, } \\
\text { D1/3, DE }\end{array}$ & Photo \#1 & $\sim 50 \%$ of fragment \\
\hline Gnawing & $\begin{array}{l}\text { Fibula - R - P1/3, M1/3, } \\
\text { D1/3, DE }\end{array}$ & Photo \#2 & $\sim 25$ paired grooves \\
\hline Weathering - Stage 3 & Fibula - R - P1/3 & Photo \#1 & $\sim 50 \%$ of fragment \\
\hline Weathering - Stage 3 & Fibula - R-DI/3 & Photo \#1 & $\sim 50 \%$ of fragment \\
\hline Weathering - Stage 2 & Patella-R & Photo \#1 & $<25 \%$ of complete bone \\
\hline Weathering - Stage 2 & Patella - L & Photo \#1 & $<25 \%$ of fragment \\
\hline Weathering - Stage 3 & $\begin{array}{l}\text { Tibia - L - P1/3, M1/3, } \\
\text { D1/3 }\end{array}$ & Photo \#3 & $\sim 50 \%$ of fragment \\
\hline Weathering - Stage 3 & Tibia - L - P1/3, M1/3 & Photo \#3 & $\sim 50 \%$ of fragment \\
\hline Weathering - Stage 3 & $\begin{array}{l}\text { Tibia-R-P1/3, M1/3, } \\
\text { D1/3 }\end{array}$ & Photo \#3 & $\sim 50 \%$ of fragment \\
\hline Weathering - Stage 3 & Tibia-R-M1/3, D1/3 & Photo \#3 & $-50 \%$ of fragment \\
\hline Weathering - Stage 2 & $\begin{array}{l}\text { Tibia - R-P1/3, M1/3, } \\
\text { D1/3 }\end{array}$ & Photo \#4 & $\sim 25 \%$ of fragment \\
\hline Weathering - Stage 1 & Calcaneus - L & Photo \#5 & $100 \%$ \\
\hline Weathering - Stage 1 & Talus - $\mathrm{L}$ & Photo \#5 & $\sim 25 \%$ of fragment \\
\hline
\end{tabular}




\begin{tabular}{|c|c|c|c|}
\hline Weathering - Stage 2 & Metatarsals - L $(n=5)$ & Photo \#5 & $\sim 25 \%$ of fragment \\
\hline Weathering - Stage 2 & $\begin{array}{l}\text { Phalanges - Unsided } \\
(n=5)\end{array}$ & Photo \#5 & $\sim 25 \%$ of fragment \\
\hline Weathering - Stage 2 & Tarsal & Photo \#5 & $\sim 50 \%$ of fragment \\
\hline Weathering - Stage 1 & Talus - $\mathrm{R}$ & Photo \#5 & $\sim 25 \%$ of fragment \\
\hline Weathering - Stage 2 and 3 & Metatarsals $-R(n=2)$ & Photo \#5 & $\sim 25 \%-50 \%$ of fragment \\
\hline Weathering - Stage 2 and 3 & Ox Coxae $-\mathrm{L}$ & Photo \#6 & $\sim 25 \%-50 \%$ of fragment \\
\hline Weathering - Stage 2 and 3 & Ox Coxae - R & Photo \#6 & $\sim 25 \%-50 \%$ of fragment \\
\hline Weathering - Stage 3 & Frontal & Photo \#7 & $\sim 75 \%$ of fragment \\
\hline Weathering - Stage 3 & Parietal $-\mathrm{L}$ and $\mathrm{R}$ & Photo \#7 & $\sim 75 \%$ of fragment \\
\hline Weathering - Stage 3 & Occipital & Photo \#7 & $\sim 75 \%$ of fragment \\
\hline Weathering - Stage 2 & Temporal $-\mathrm{L}$ and $\mathrm{R}$ & Photo \#7 & $\sim 50 \%$ of fragment \\
\hline Weathering - Stage 1 & Maxilla & Photo \#7 & $-25 \%$ of fragment \\
\hline Weathering - Stage 3 & Mandible $-\mathrm{L}$ and $\mathrm{R}$ & Photo \#7 & $\sim 50 \%$ of fragment \\
\hline Weathering - Stage 2 & Frontal & Photo \#8 & $\sim 75 \%$ of fragment \\
\hline Weathering-Stage 2 & Parietal - L and $\mathrm{R}$ & Photo \#8 & $\sim 75 \%$ of fragment \\
\hline Weathering - Stage 2 & Occipital & Photo \#8 & $\sim 75 \%$ of fragment \\
\hline Weathering - Stage 3 & Temporal $-\mathrm{L}$ and $\mathrm{R}$ & Photo \#8 & $\sim 75 \%$ of fragment \\
\hline Weathering - Stage 3 & Mandible & Photo \#8 & $\sim 75 \%$ of fragment \\
\hline Weathering - Stage 3 & Clavicle - L & Photo \#9 & $\sim 50 \%$ of fragment \\
\hline Weathering - Stage 3 & Clavicle - $\mathrm{R}$ & Photo \#9 & $\sim 75 \%$ of fragment \\
\hline Weathering - Stage 2 & Sacrum & Photo \#9 & $\sim 25 \%$ of fragment \\
\hline Weathering - Stage 2 & Ribs & Photo \#10 & $-25-50 \%$ of fragments \\
\hline Weathering - Stage $1 / 2$ & Cervicle Vertebrae & Photo \#11 & $\sim 25 \%$ of fragments \\
\hline Weathering - Stage 2 & Lumbar Vertebrae & Photo \#11 & $\sim 50 \%$ of fragments (slight lipping) \\
\hline Weathering - Stage $2 / 3$ & Thoracic Vertebrae & Photo \#11 & $\begin{array}{l}\sim 50 \% \text { of fragments (slight lipping } \\
\text { on } 1 \text { specimen) }\end{array}$ \\
\hline Weathering - Stage $2 / 3$ & Femur-R & Photo \#12 & $\sim 50-75 \%$ of fragments \\
\hline Weathering - Stage $2 / 3$ & Femur - L & Photo \#13 & $\sim 50 \%$ of fragments \\
\hline Weathering - Stage $2 / 3$ & Scapula $\mathrm{L}$ and $\mathrm{R}$ & Photo \#14 & $\sim 25-50 \%$ of fragments \\
\hline Weathering - Stage 3 & Ulna $-\mathrm{L}$ and $\mathrm{R}$ & Photo \#15 & $\begin{array}{l}\sim 50 \% \text { of fragment (healed fracture } \\
\text { at distal end of } \# 2 \text { ) }\end{array}$ \\
\hline Weathering - Stage 3 & Radius $-\mathrm{L}$ and $\mathrm{R}$ & Photo \#16 & $\sim 50 \%$ of fragment \\
\hline Weathering - Stage 3 & Humerus $-\mathrm{L}$ and $\mathrm{R}$ & Photo \#17 & $\sim 50-75 \%$ of fragment \\
\hline & & & \\
\hline & & & \\
\hline & & & \\
\hline & & & \\
\hline & & & \\
\hline & & & \\
\hline & & & \\
\hline & & & \\
\hline & & & \\
\hline & & & \\
\hline & & & \\
\hline
\end{tabular}


Appendix J:

Granberg Burials

(reproduced from Appendix 2 in Schuetz 1966)

Tom McKern 

Appendix No. 2

\section{THE GRANBERG BURIALS}

The study of the human bones was made by Dr. Tom McKern, Physical Anthropologist at the University of Texas. A few clarifying remarks preceed Dr. Mckern's report.

Some of the bone from burials 1 and 2 from Feature $2 A$ were mixed because they had been brought up by the bulldozer in straightening the east wall of the main trench and the bone was recovered by screening. Apparently there were additional burials in the trench which were disturbed by the bulldozer before the museum was notified of the site. This would account for the greater number of individuals than we knew of. The burial of Feature $2 \mathrm{~B}$ was undercut and brought to the laboratory intact because of its poor condition. The appearance of cranial bone from a second individual with $2 \mathrm{~B}$ I think must be explained in terms of the displacement of an earlier burial at the time individual $2 \mathrm{~B}$ was interred.

Most of the vertebrae of burial 2, Feature $2 \mathrm{~A}$ disintegrated before it could be removed, so that Dr. Mckern did not have the chance to see the fused vertebtae. Therefore he notes only the arthritic lipping of lumbar vertebrae. Dr. Mark Huff, Chief Resident in Orthopedics at Baylor University Hospital Center in Dallas, inspected the photographs of burial 2 and offered the following observations and opinion:

"From the review of the photographs of burial II in Feature II, I feel there is evidence of mild arthritic changes as suggested by the lipping of the vertebra. In addition there is a short fused 
segment in the lower back. This fused segment probably involves only two or three vertebra and is most likely secondary to an old compression fracture. I am of the opinion that this individual did not have a crippling arthritis, and postulate that there was actually minimal deformity and discomfort. These changes are not the result of tuberculosis or Rheumatoid Spondylitis, but rather that of Degenerative Arthritis secondary to trauma."

Dr. Mokern's report follows:

"Human skeletal material excavated from the Granberg Site consists of the fragmentay remains of eight individuals. Due to its fragmented status, reconstruction was minimal and mensuration was not undertaken. However, general observations were recorded on the individuals represented in each feature. The results are as follows:

Feature 2A, No. 1. Four incomplete long bones represent the human remains from this burial. It is possible that these extremity fragments belong to an individual from one of the other burials but identifying details were not present. All that can be said for these remains is that they belonged to a well-muscled adult male. There are no signs of osteo-pathology.

"Feature $2 A$, Nos. 1 and 2 . The conmingled cranial and postcranial remains of three individuals, all highly fragmented, make up the total number of individuals from this burial. Partial reconstruction was accomplished but segregation was not possible. All three individuals were adult males. Dental wear was excessive but not abnormal for prehistoric populations from Texas. Some dental caries were observed and there was some evidence of arthritic lipping along the anterior borders of the lumbar vertebrae of one of the three 
individuals. It is interesting to note that all of the intact distal humerus fragments demonstrated complete septal perforation. The meaning of this feature has never been clear but a number of authorities have suggested genetic implications.

Feature $2 \pi$, No. 2. Here are represented the scanty, fragmentary remains of one individual, identified as an adult male. No osteopathology was noted.

"Feature $2 B$, No. 3. There are two individuals represented in this burial; the cranial and postcranial remains of an adult male, and the postcranial fragments of a young female. Nothing more can be said about the female but nost of the calvaria of the male was reconstructed. Length and breadth measurements indicate a dolichocranic skull with a cranial index of $72.03 \mathrm{~mm}$. A portion of the left horizontal ramus demonstrated both ante- and post-mortem loss of teeth. The molar area exhibited complete resorption. No osteopathology was observed.

"Feature 5. Skeletal naterial from this burial is represented by the fragmentary cranial and postcranial remains of one individual. The skeleton is that of a male, probably in his middle fifties (based on endocranial and ectocranial suture closure). Muscle markings are moderate and body build was probably slight. Dental wear is excessive as usual. No important pathology was observed.

Summary

"The skeletal remains excavated from the Granberg Site consisted of at least eight individuals; seven adult males and one young female. Due to the high degree of fragmentation, mensuration was not 
84

feasible and information was based on detailed observations. The general morphology of this group is reminiscent of late Archaic

Indian populations of Central Texas. No outstanding osteo-pathology was observed. Mild arthritic lipping in some of the articular areas represents mormal maturative processes." 


\section{Appendix K:}

Selected Artifacts from the CAR-UTSA's 1973-74 Excavation Collection, the Witte Museum's 1962 Excavation Collection, and the October 1962 Excavation of the Water Trench Immediately Prior to the Witte Excavations 



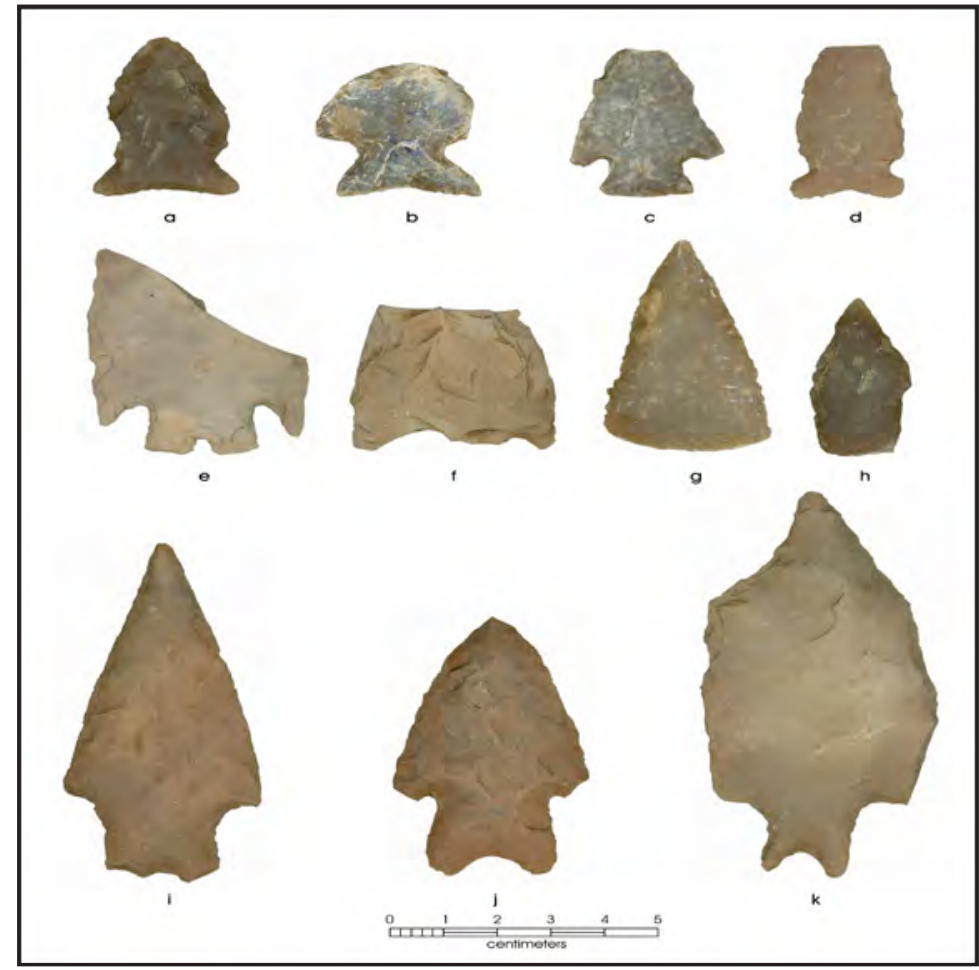

Figure K-1. Projectile points from the 1974 work at $41 B X 271$ including Terminal Late Archaic forms (a-d), Montell (e), Abasalo (g), Bulverde (h), and Late Archaic Perdenales (i-k).

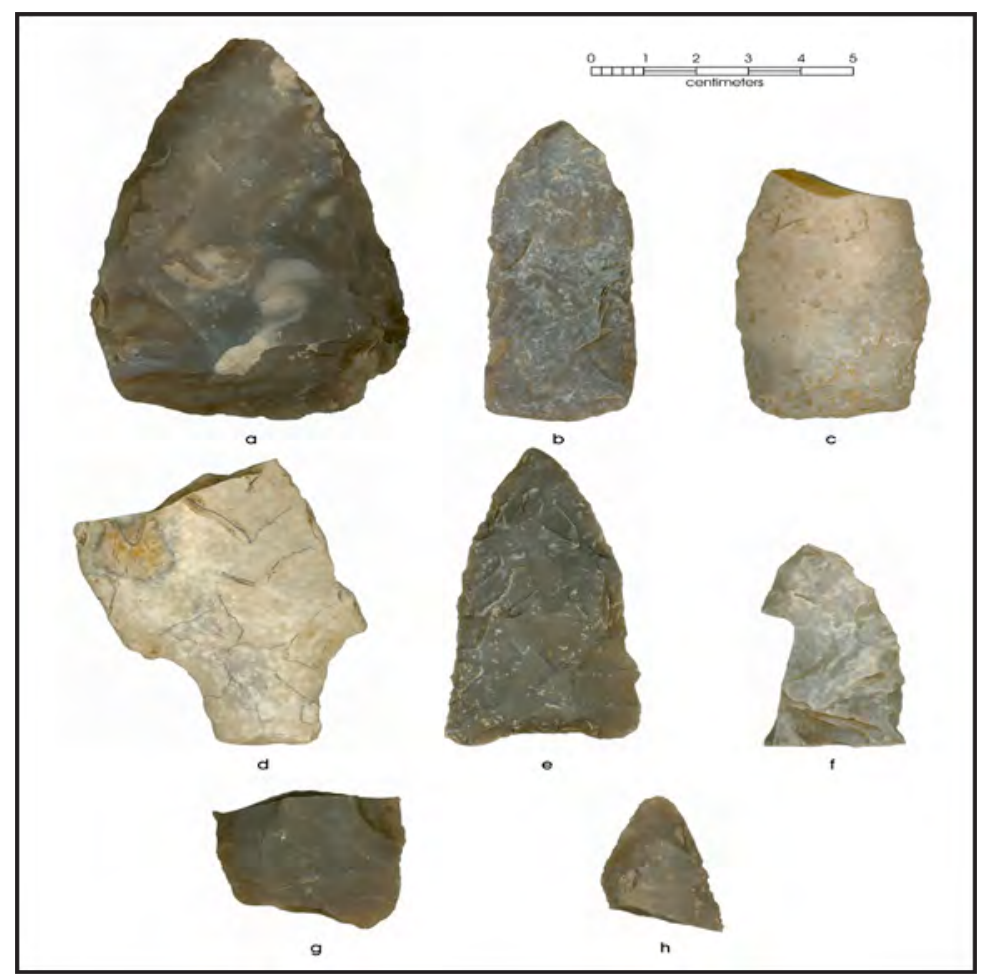

Figure K-2. Bifaces from the 1974 work at $41 B X 271$. 


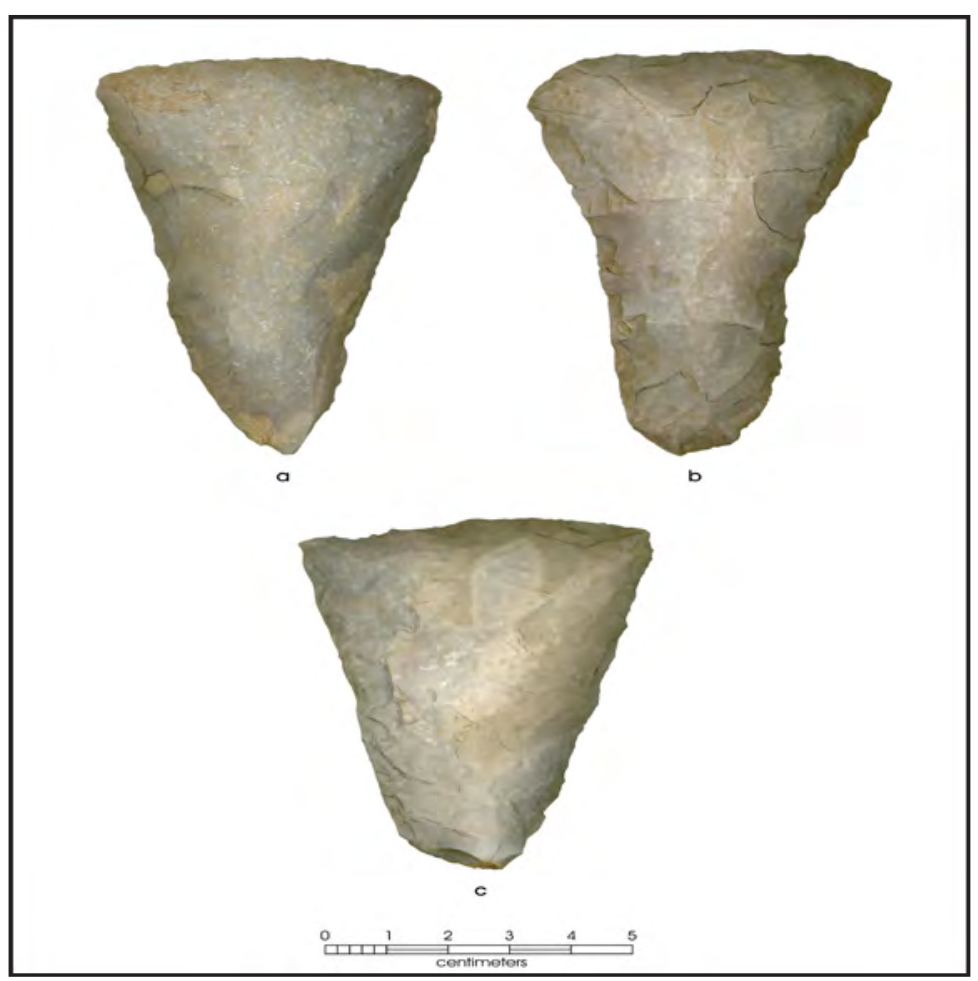

Figure K-3. "Clear Fork" tools from the 1974 work at 41 BX271.

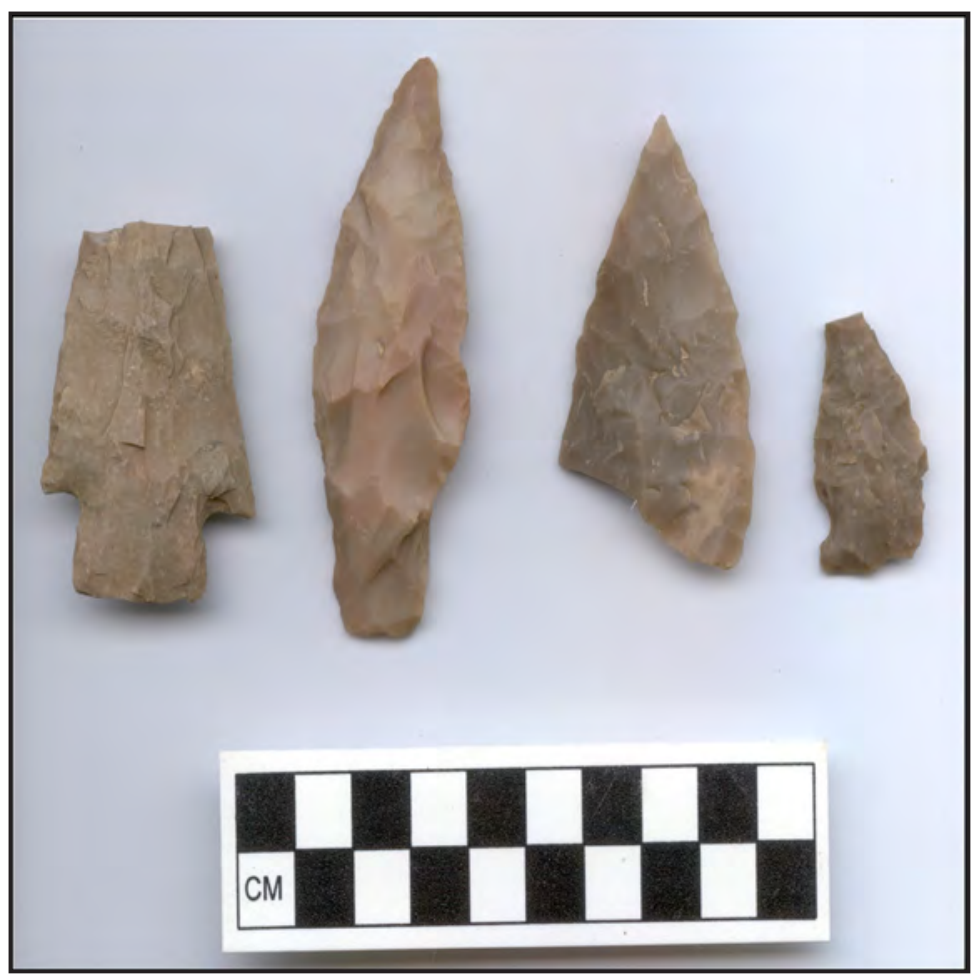

Figure K-4. Selected artifacts from the Granberg I, 1962 excavations. 


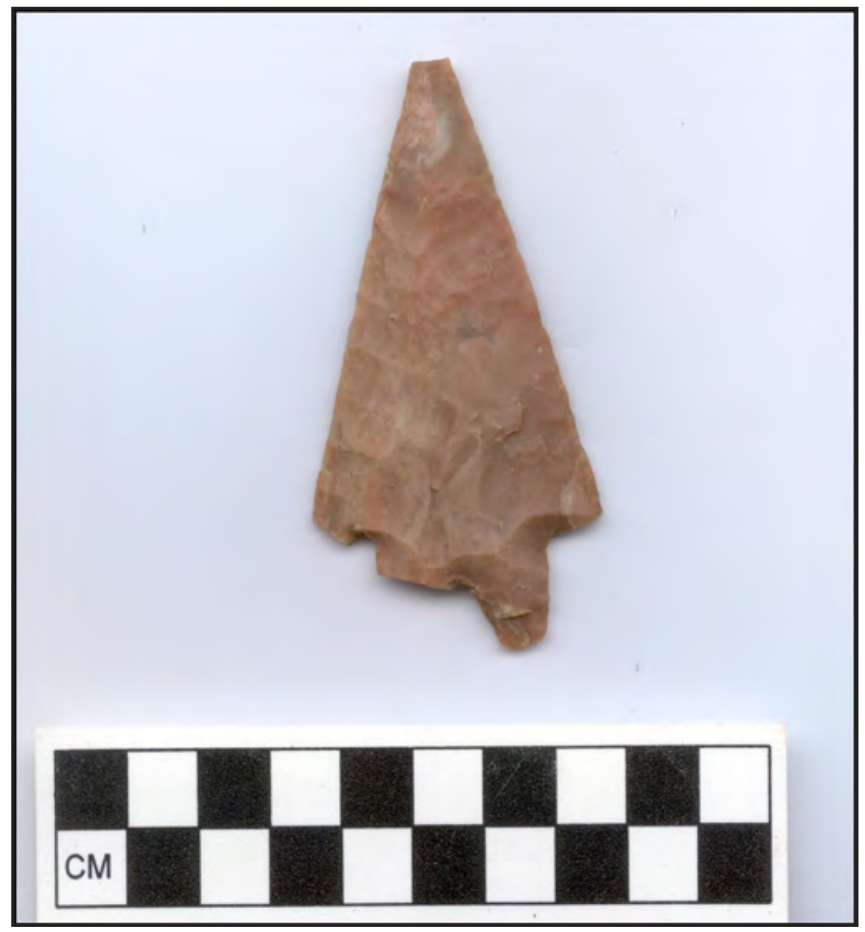

Figure K-5. Pedernales dart point from the Granberg I, 1962 excavations.

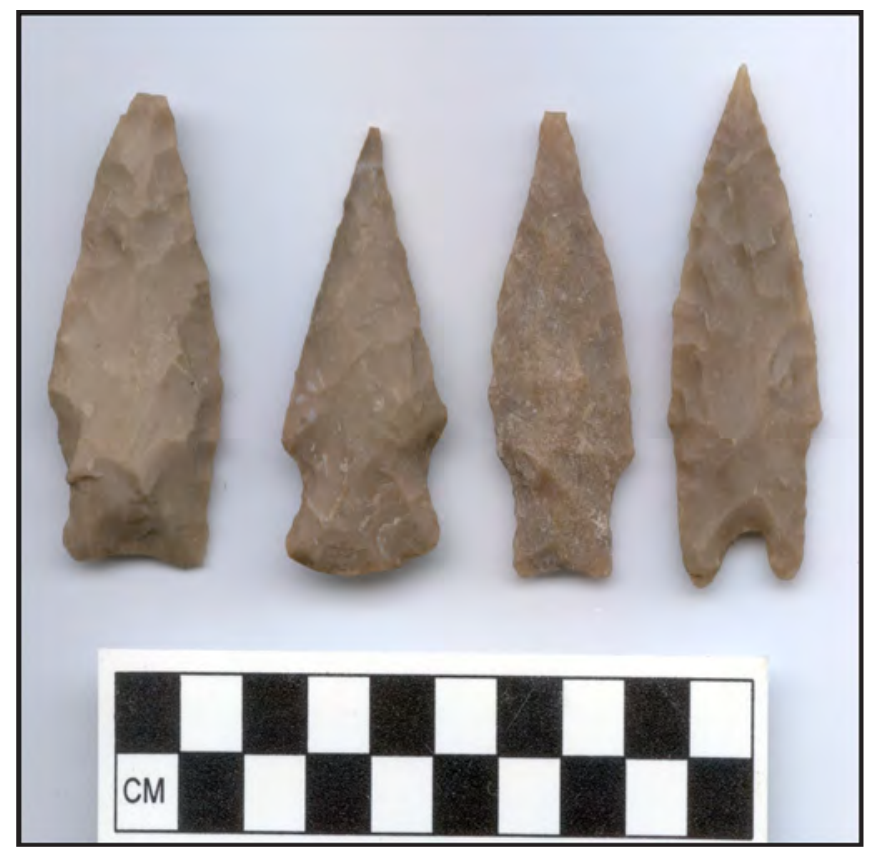

Figure K-7. Selected artifacts from the Granberg I, 1962 excavations.

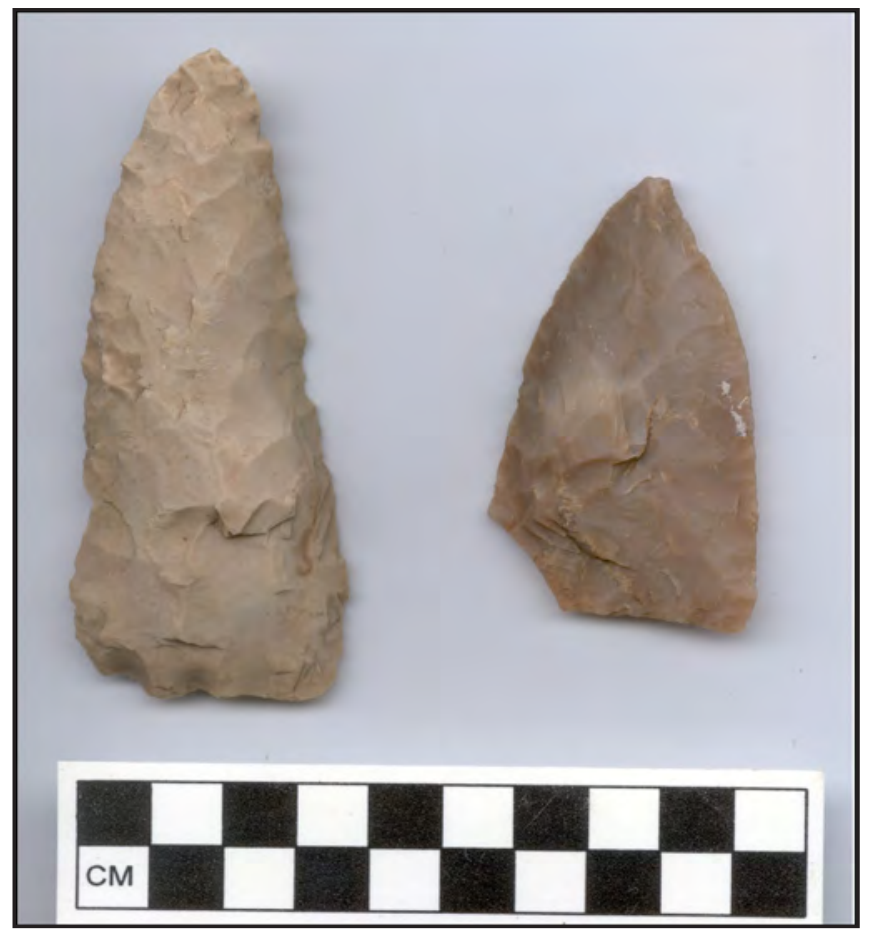

Figure K-6. Selected artifacts from the Granberg I, 1962 excavations.

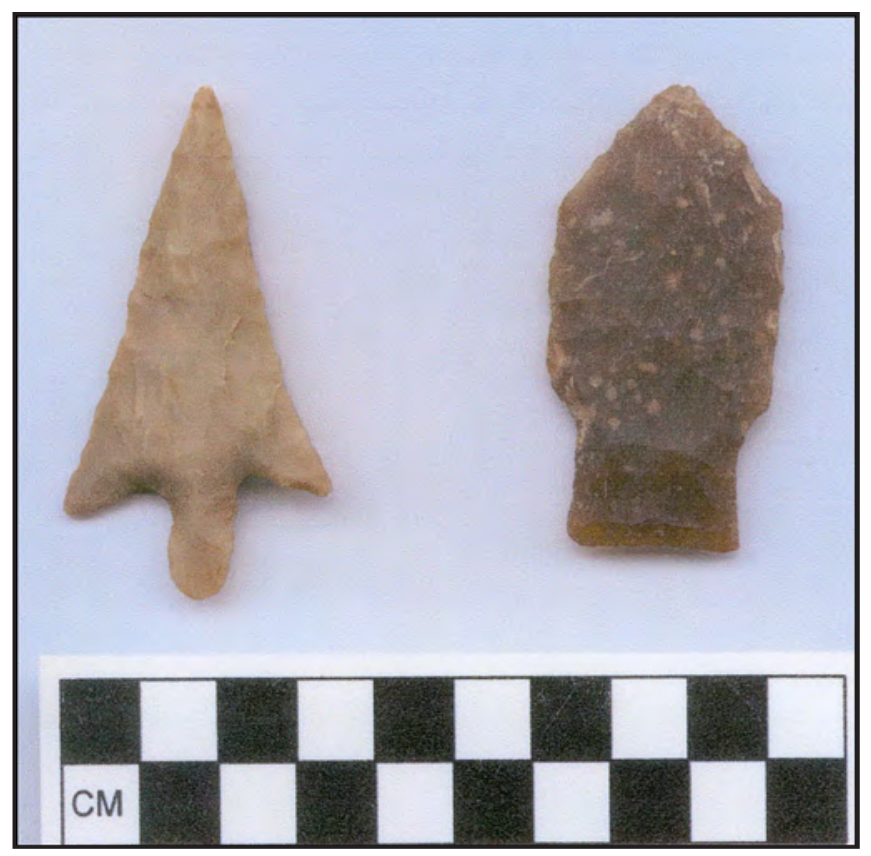

Figure K-8. Selected artifacts from the Granberg I, 1962 excavations. 


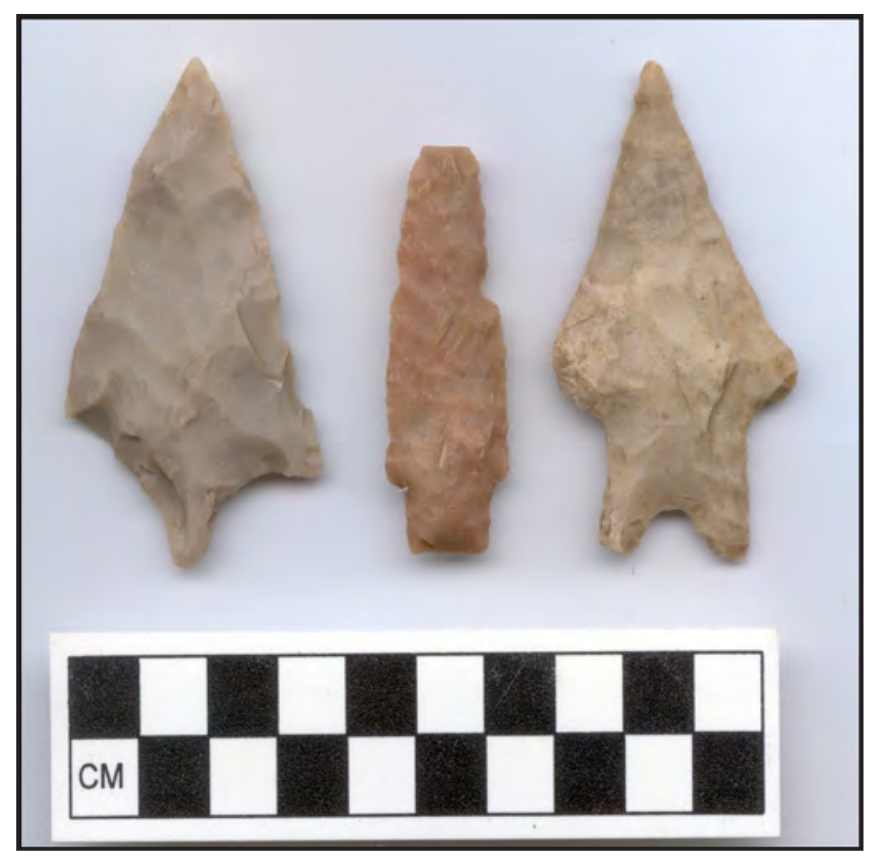

Figure K-9. Selected artifacts from the Granberg I, 1962 excavations.

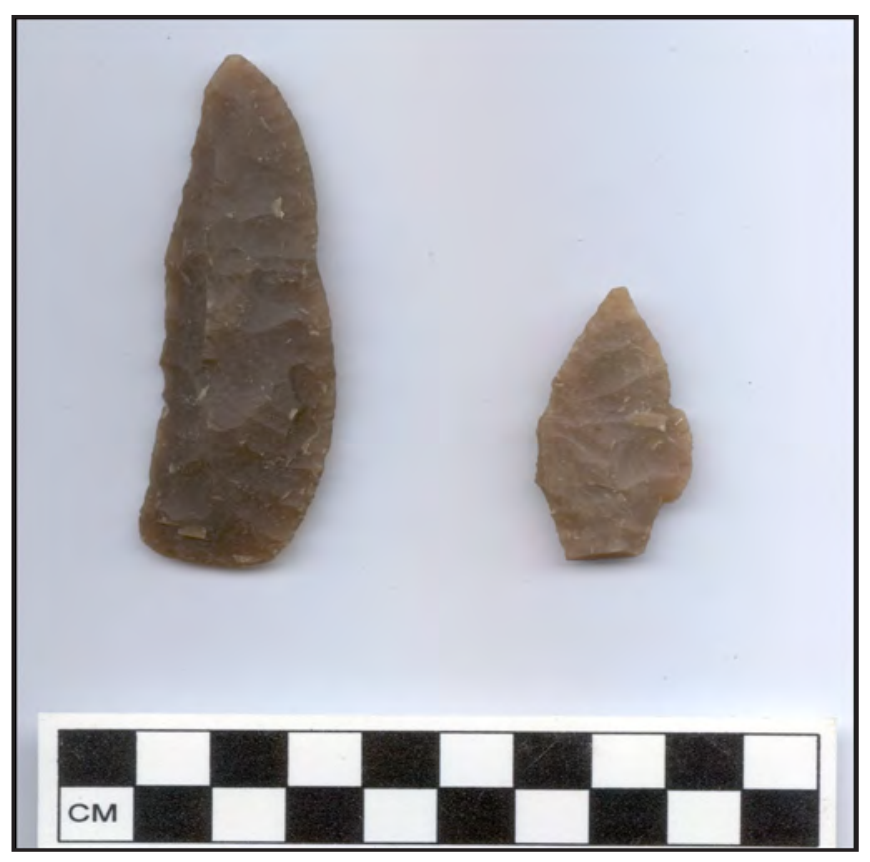

Figure K-10. Selected artifacts from the Granberg I, 1962 excavations.

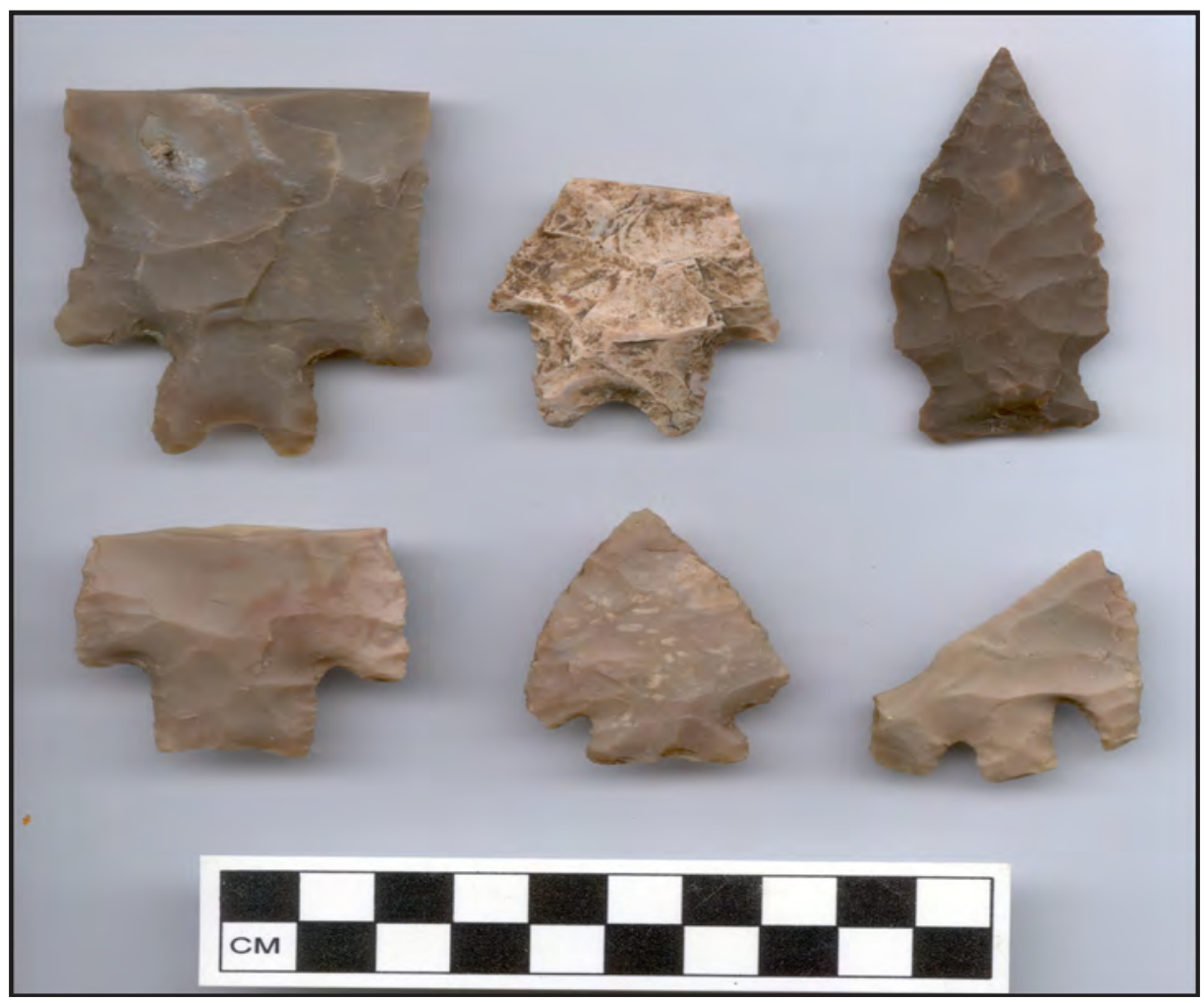

Figure K-11. Selected artifacts from the Granberg I, 1962 excavations. 


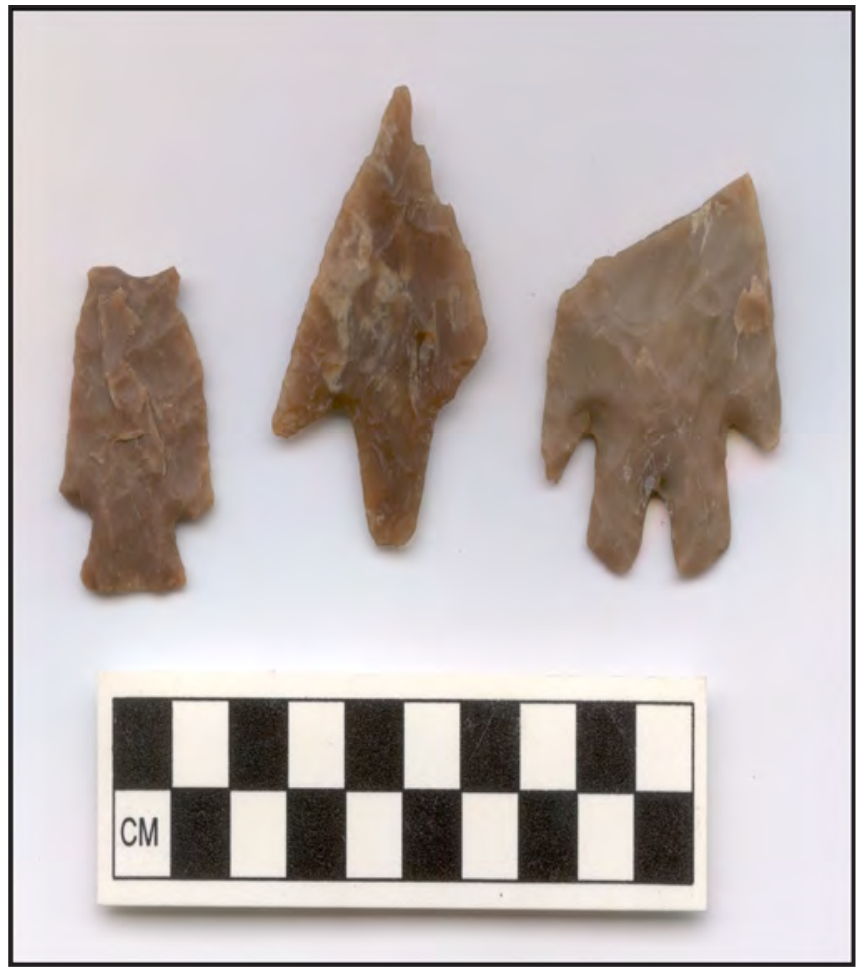

Figure K-12. Selected artifacts from the Granberg I, 1962 excavations.

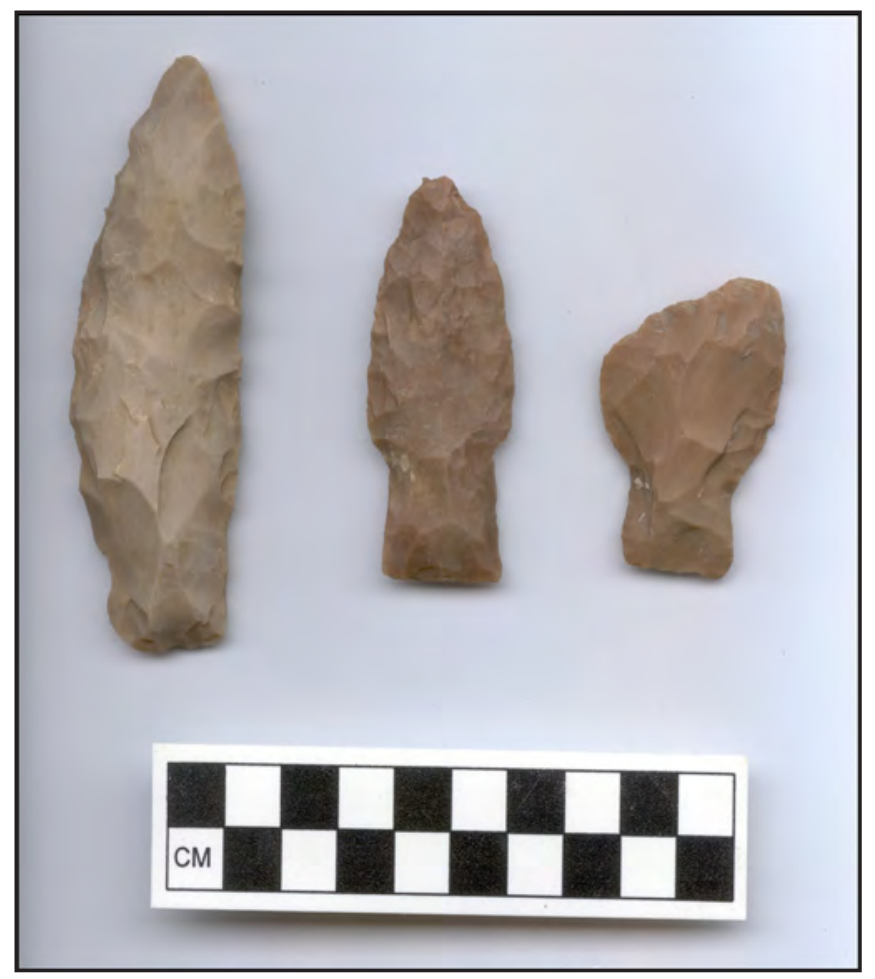

Figure K-13. Selected artifacts from the Granberg I, 1962 excavations.

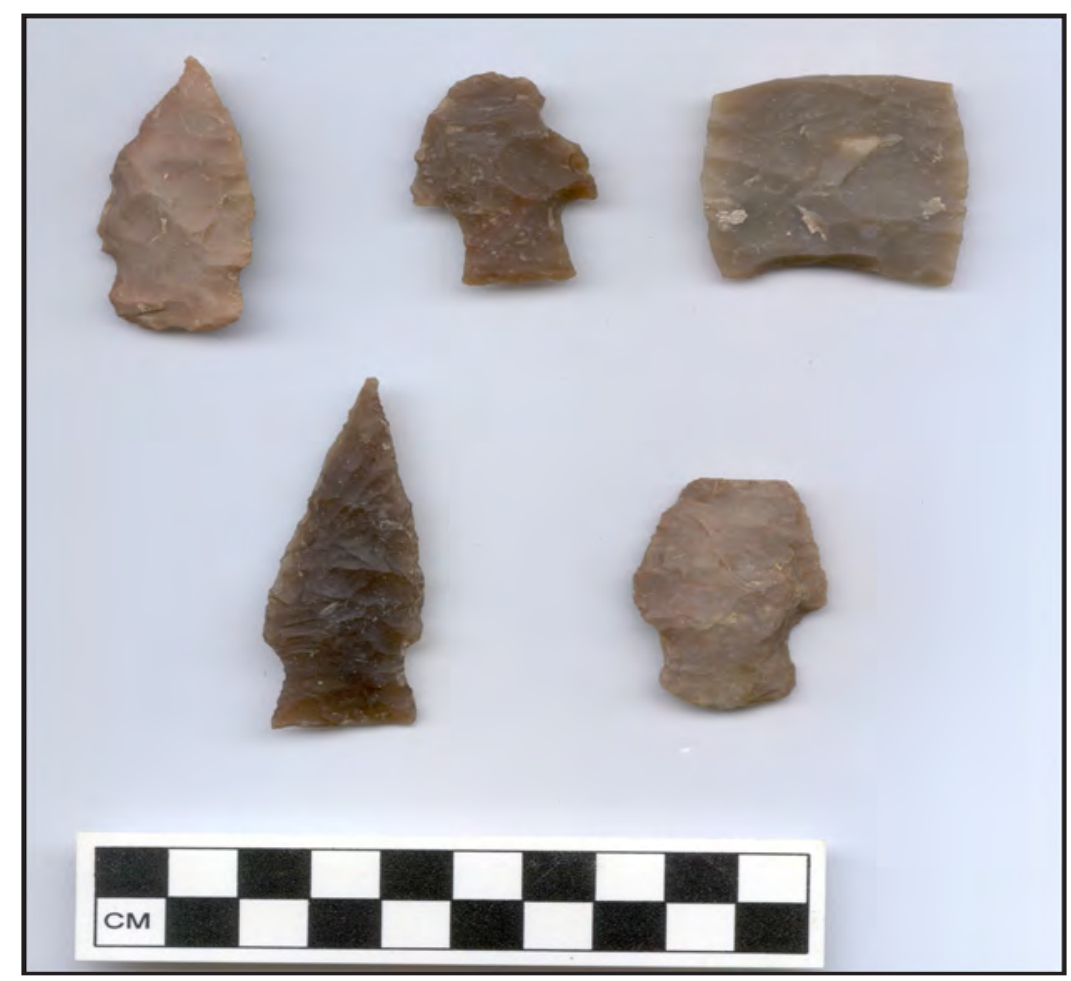

Figure K-14. Selected artifacts from the Granberg I, 1962 excavations. 


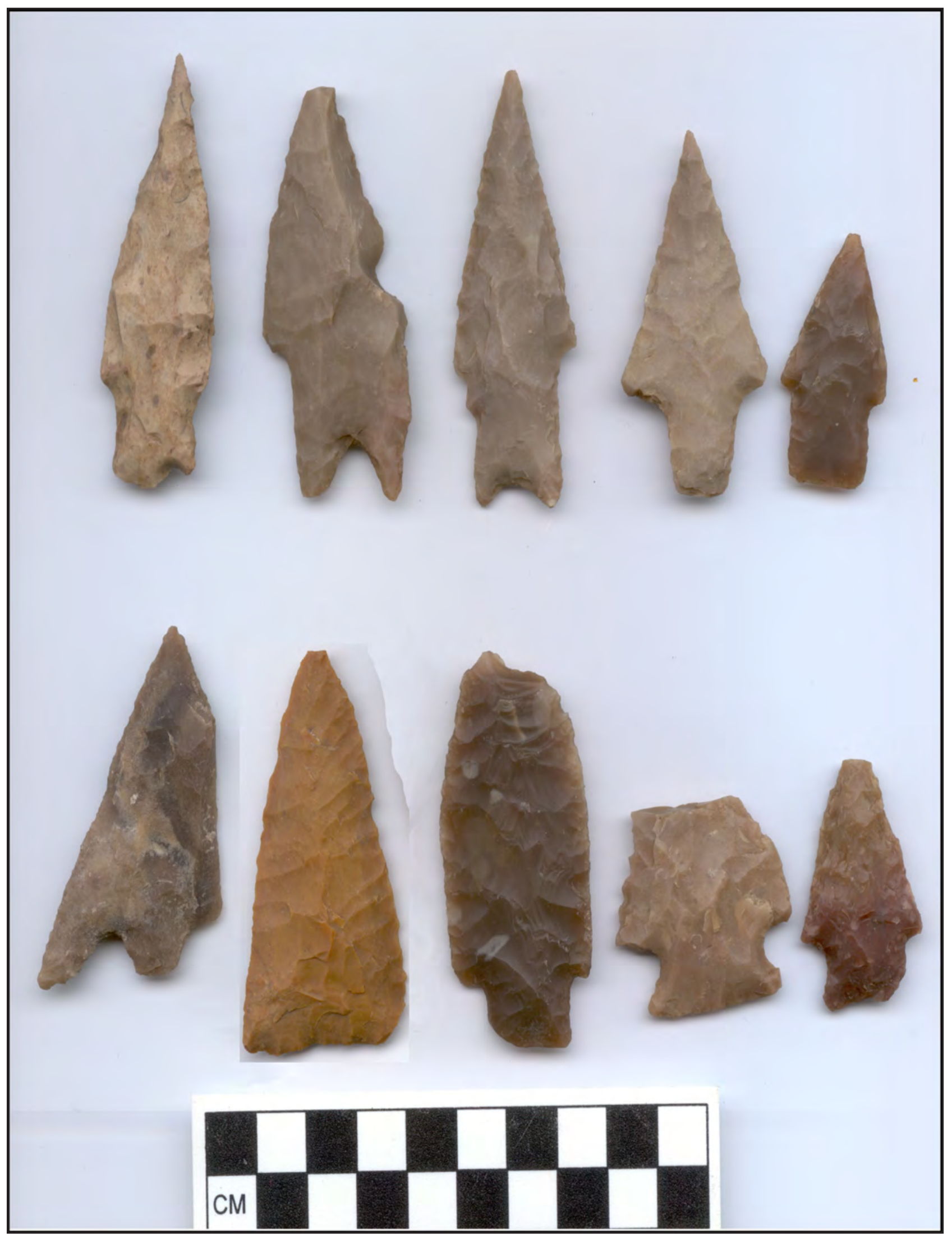

Figure K-15. Selected artifacts from the Granberg I, 1962 excavations. 


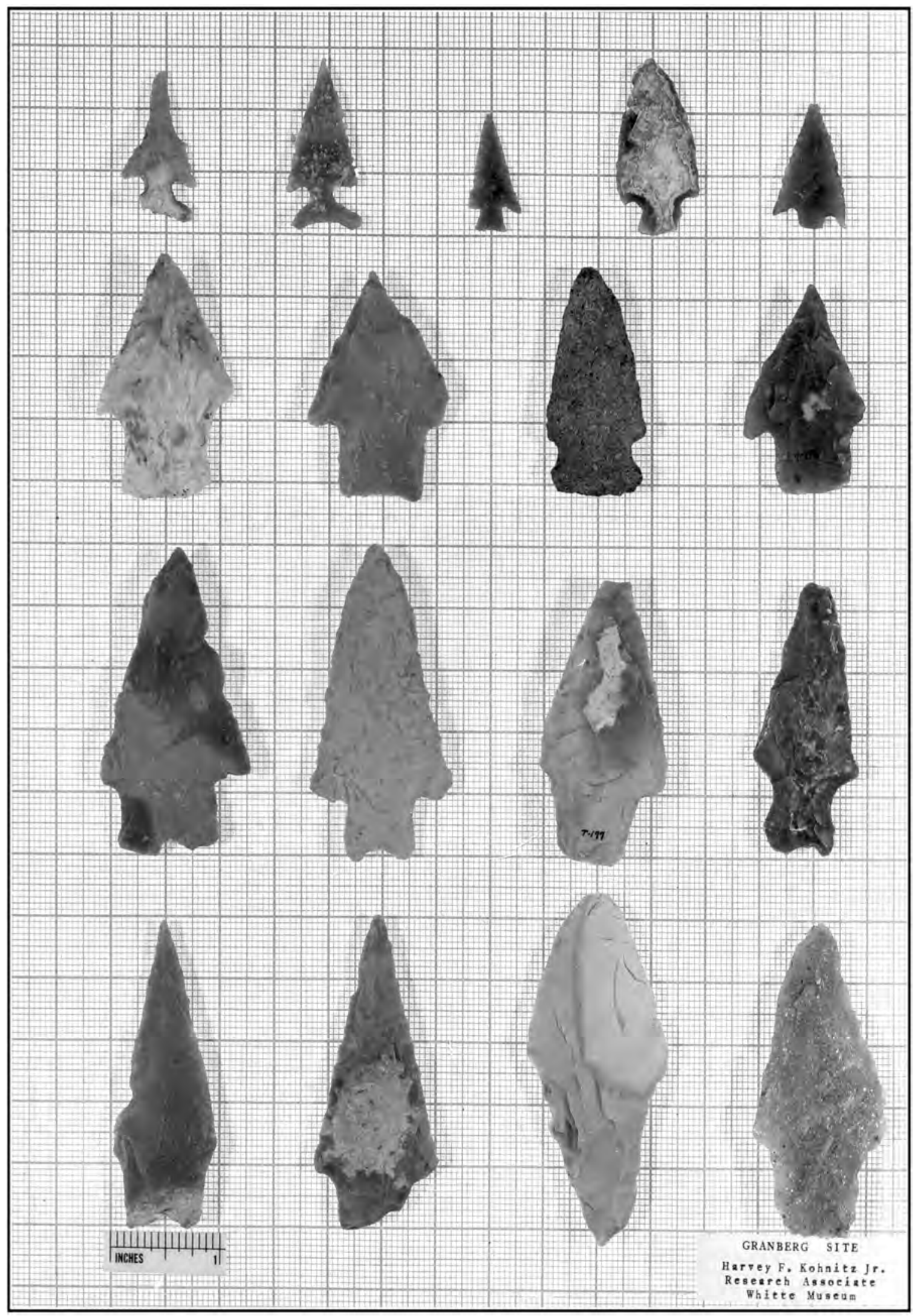

Figure K-16. Scan of photograph of selected artifacts from the October 1962 excavation of the water trench immediately prior to the Witte 1962 excavations. 


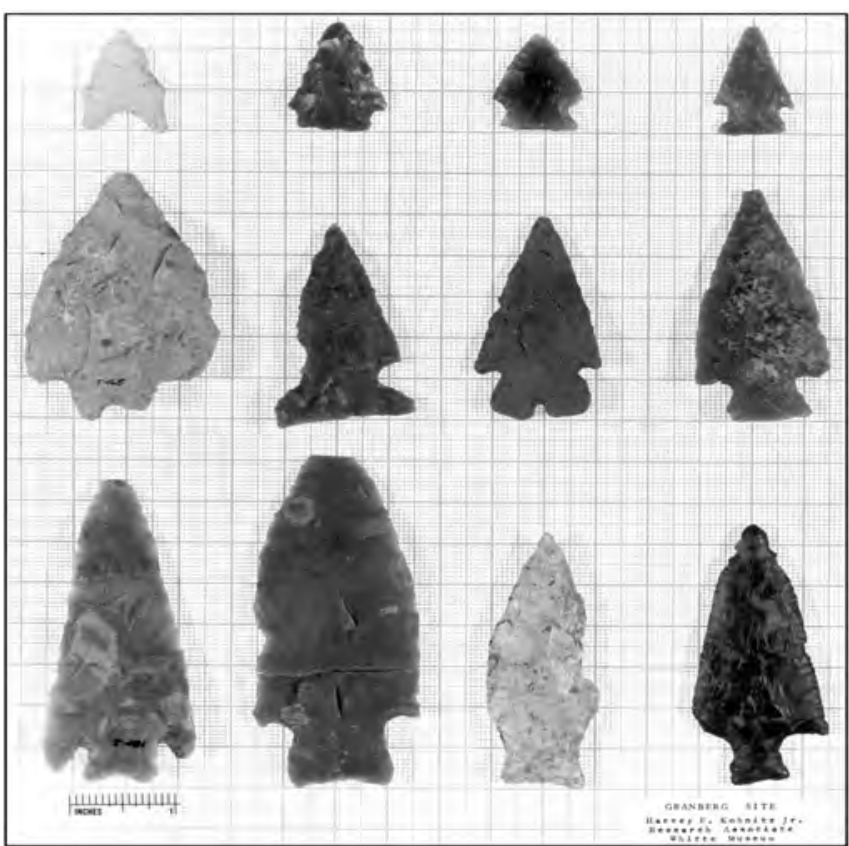

Figure K-17. Scan of photograph of selected artifacts from the October 1962 excavation of the water trench immediately prior to the Witte 1962 excavations.

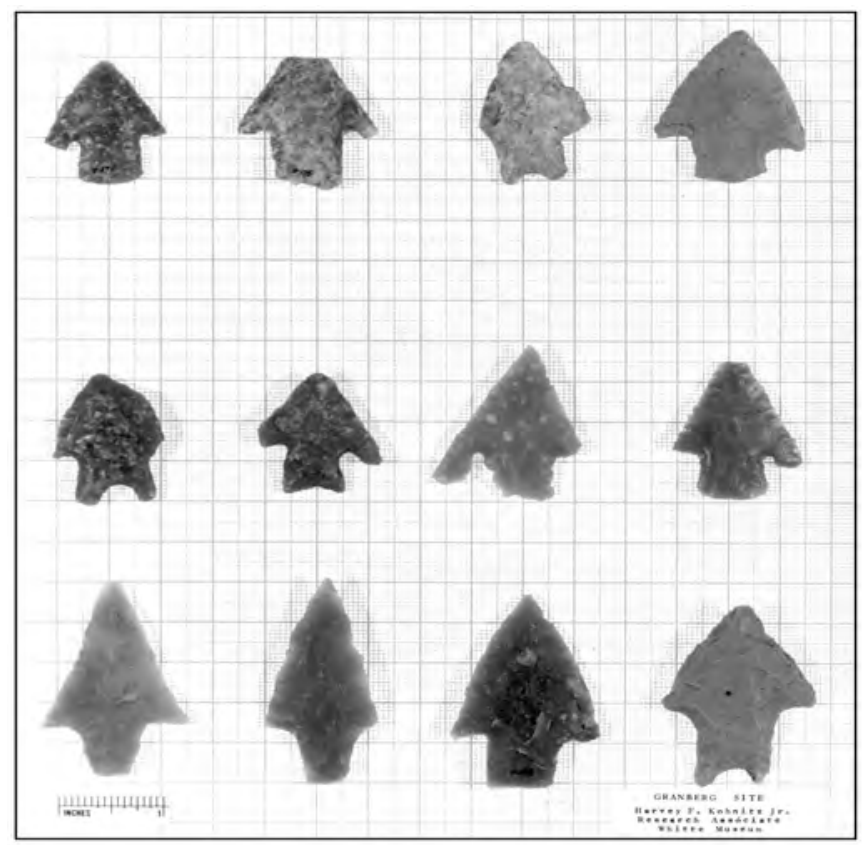

Figure K-18. Scan of photograph of selected artifacts from the October 1962 excavation of the water trench immediately prior to the Witte 1962 excavations.

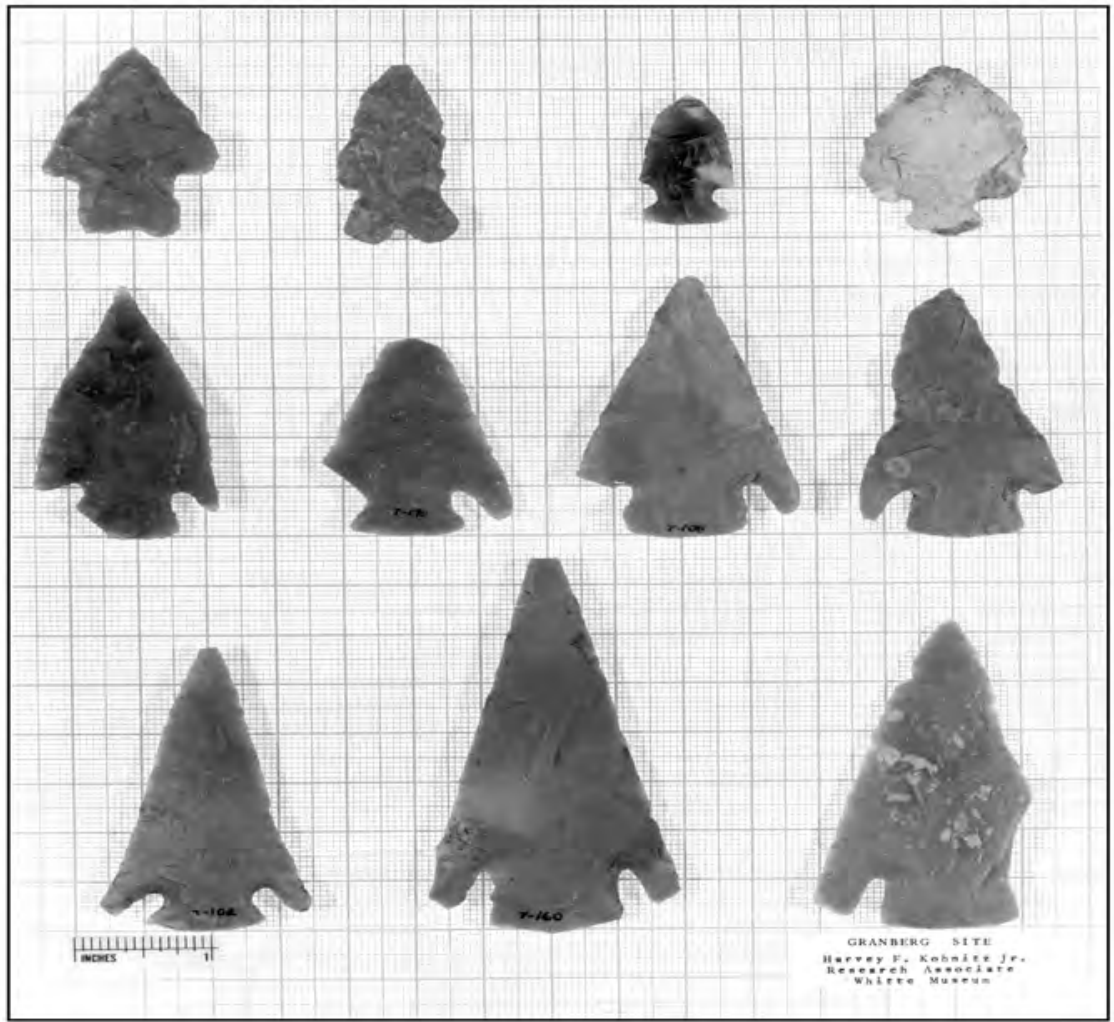

Figure K-19. Scan of photograph of selected artifacts from the October 1962 excavation of the water trench immediately prior to the Witte 1962 excavations. 


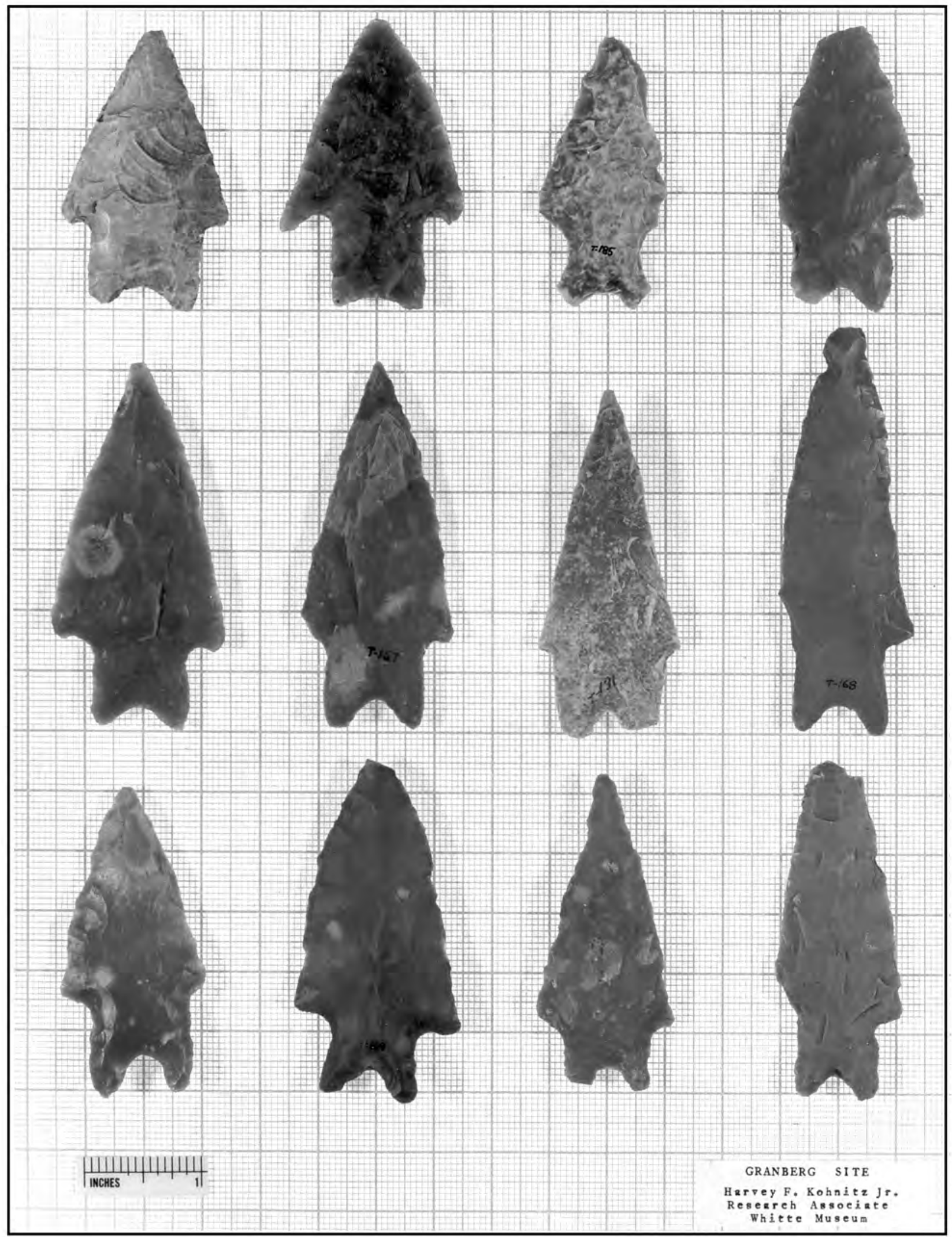

Figure K-20. Scan of photograph of selected artifacts from the October 1962 excavation of the water trench immediately prior to the Witte 1962 excavations. 


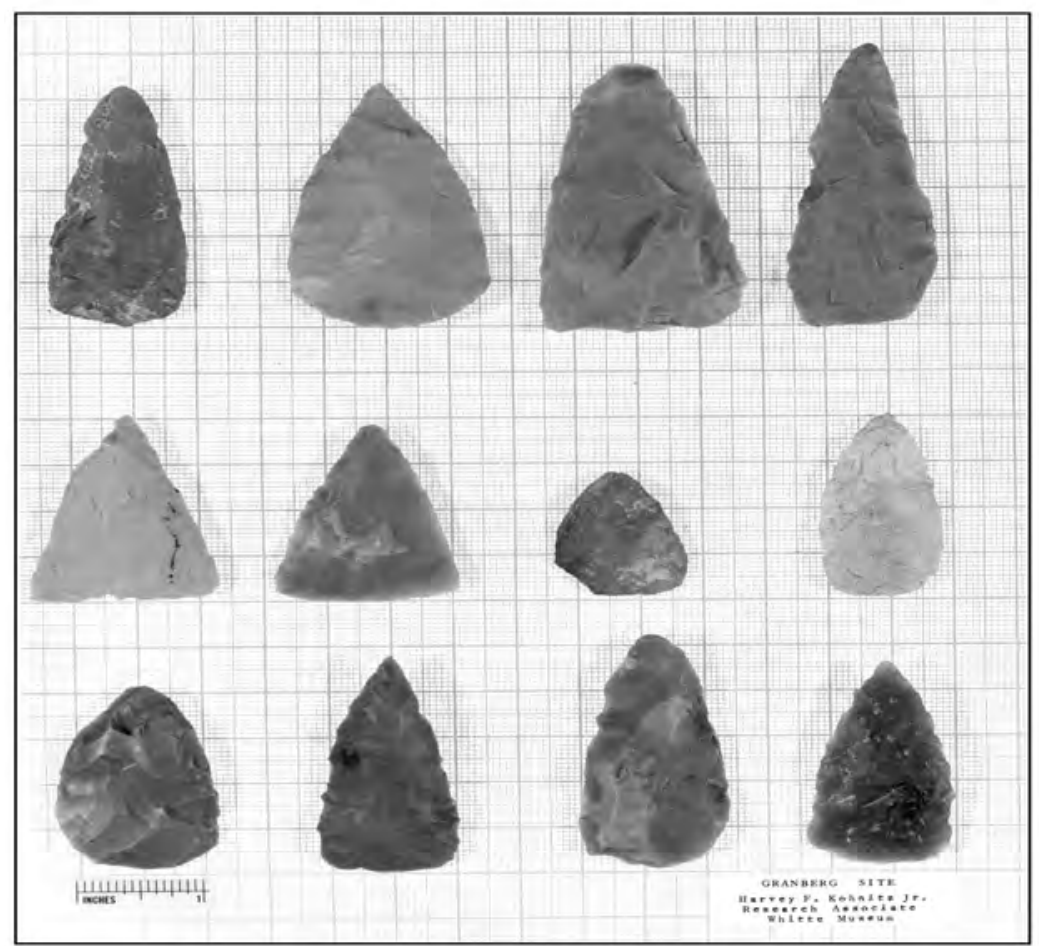

Figure K-21. Scan of photograph of selected artifacts from the October 1962 excavation of the water trench immediately prior to the Witte 1962 excavations.

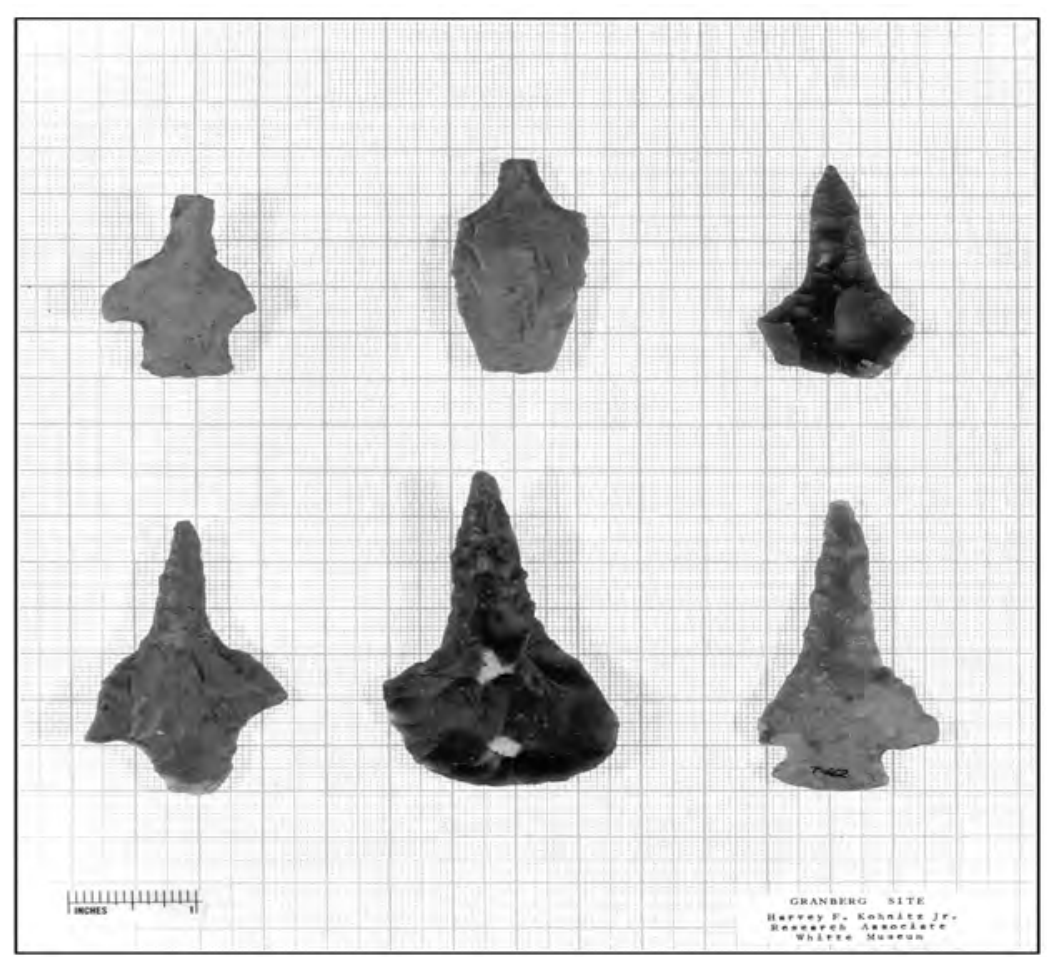

Figure K-22. Scan of photograph of selected artifacts from the October 1962 excavation of the water trench immediately prior to the Witte 1962 excavations. 


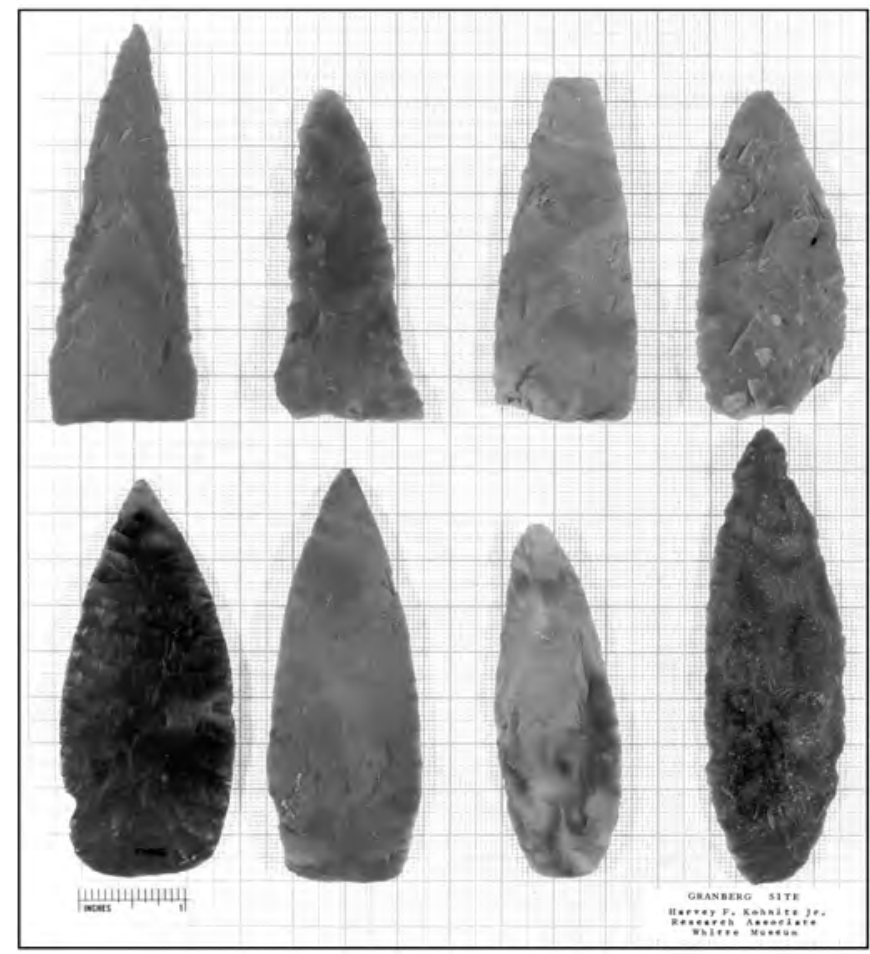

Figure K-23. Scan of photograph of selected artifacts from the October 1962 excavation of the water trench immediately prior to the Witte 1962 excavations.

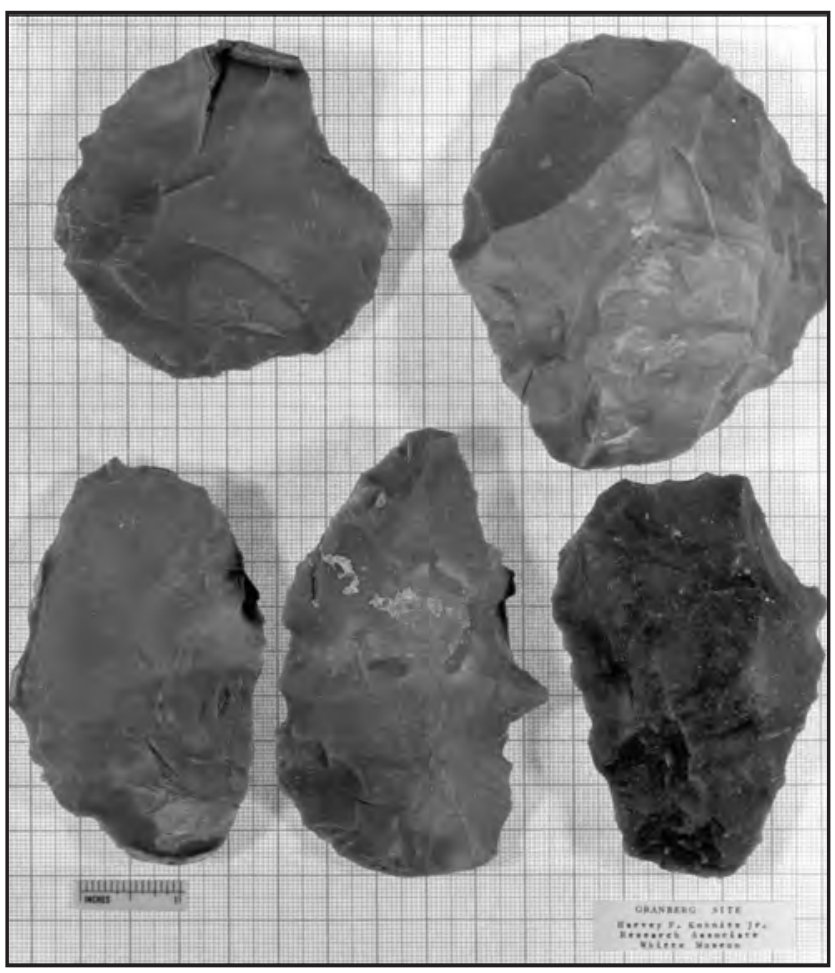

Figure K-24. Scan of photograph of selected artifacts from the October 1962 excavation of the water trench immediately prior to the Witte 1962 excavations.

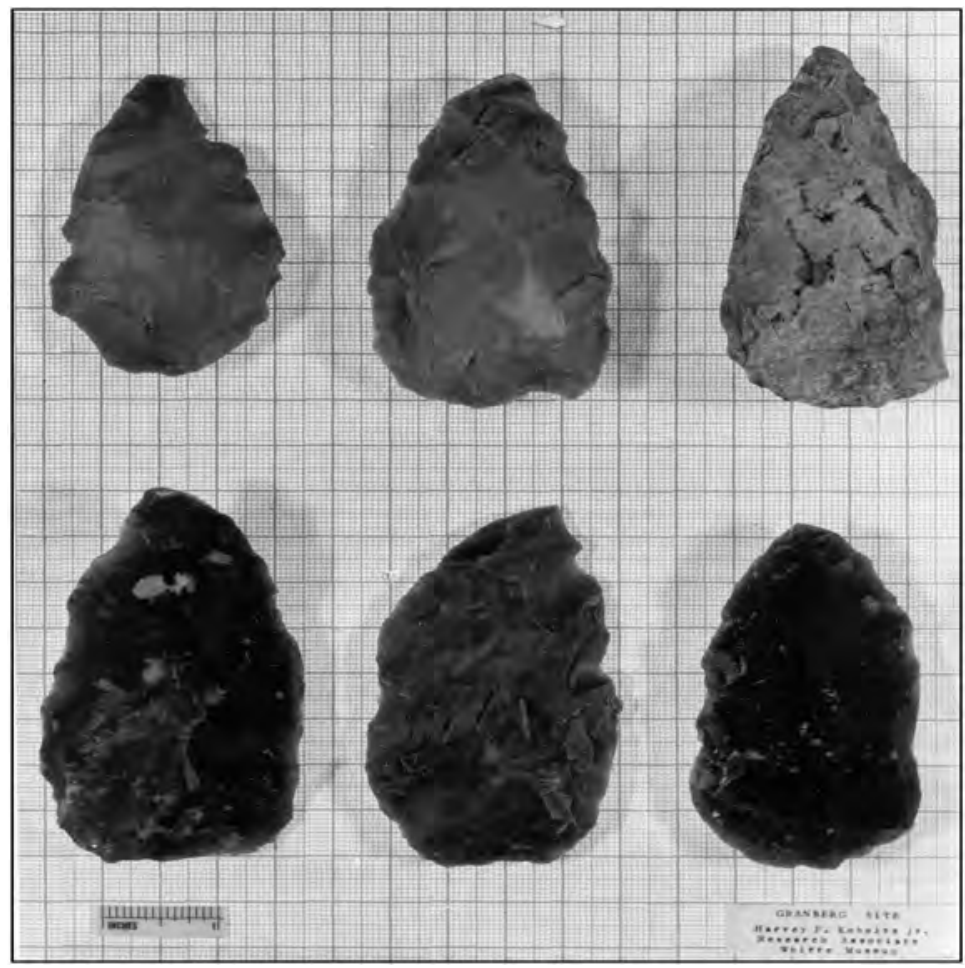

Figure K-25. Scan of photograph of selected artifacts from the October 1962 excavation of the water trench immediately prior to the Witte 1962 excavations. 


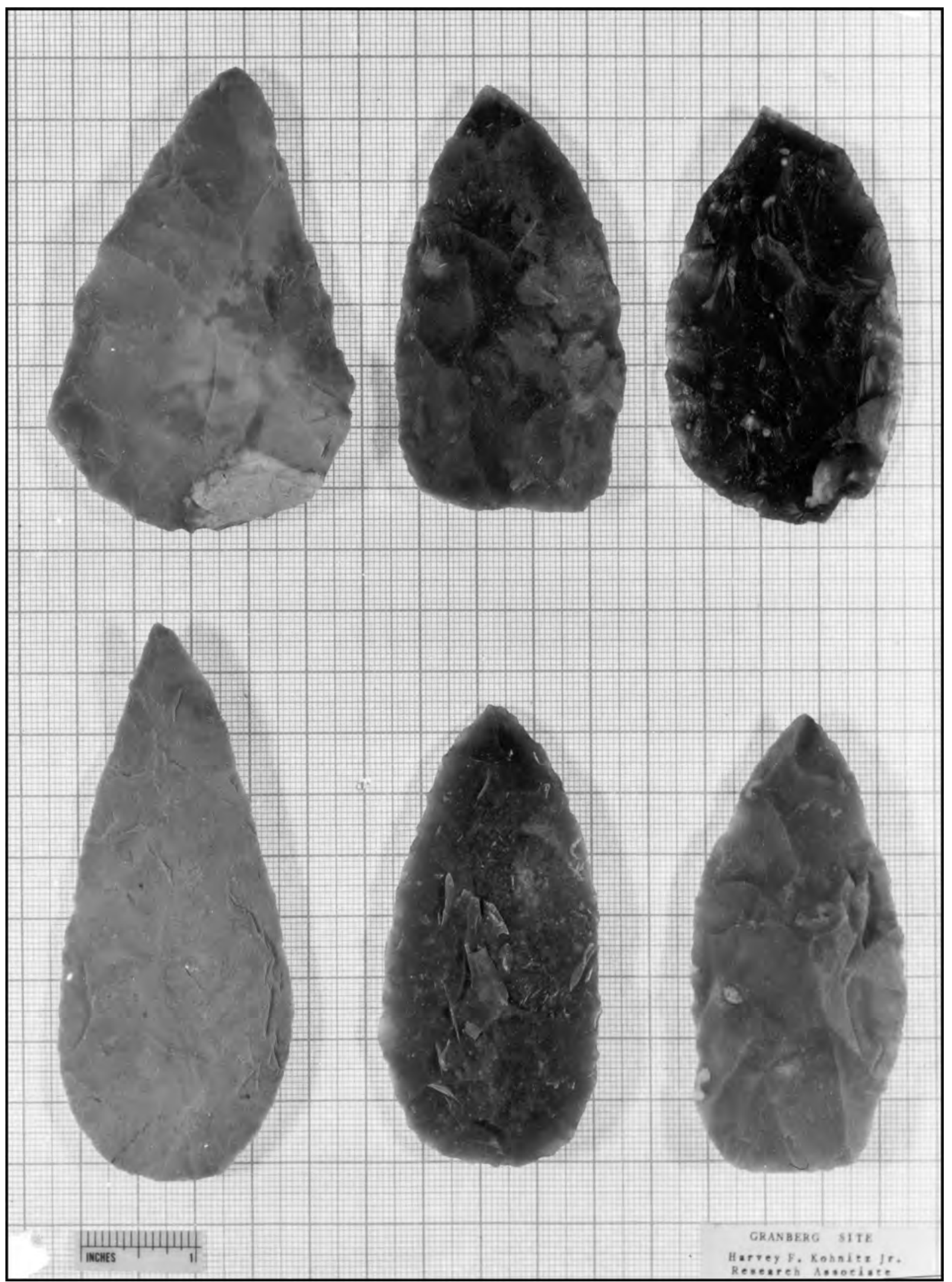

Figure K-26. Scan of photograph of selected artifacts from the October 1962 excavation of the water trench immediately prior to the Witte 1962 excavations. 
Appendix L:

TxDOT Review of National Eligibility Recommendation for 41BX17/271, the Granberg Site Loop 410 and the Salado Creek, San Antonio

Al McGraw 



\title{
Appendix L
}

\section{TxDOT Review of National Eligibility Recommendation for 41BX17/271, the Granberg Site Loop 410 and the Salado Creek, San Antonio}

\author{
Al McGraw \\ Environmental Affairs Division \\ Texas Department of Transportation
}

Introduction

\section{Site 41BX17/271 and the Proposed Undertaking}

The area of potential effects of an undertaking involving the proposed reconstruction of a segment of Loop 410 West in the City of San Antonio, Bexar County, includes a portion of a previously recorded and investigated prehistoric occupation archeological site, the Granberg Site, 41BX17/271. Recovered archeological materials indicate periods of prehistoric huntergatherer occupation from approximately 4100 to $2000 \mathrm{BP}$ with no indication of affiliation with any federally recognized tribe. First discovered in 1962, the site contained the remains of prehistoric hunter-gatherer campsites consisting of stone tools, lithic debris, burned limestone rock in the form of remnant campfires, a possible burned rock midden, and what was estimated to be the partially disturbed or fragmented remains of up to eight prehistoric burials.

The proposed reconstruction of IH 410 will occur within existing previously disturbed right-of-way including access roads and the divided main lanes of an interstate highway. Although the archeological site was severely impacted by long-term natural and modern disturbances, TxDOT determined in 2005 as part of a Section 106 review of the area of potential effects of the undertaking that the locale of the archeological site should be re-investigated. Although proposed work would be limited to the existing previously disturbed ROW, TxDOT considered that subsurface investigation was warranted in the form of intensive archeological testing including nine backhoe trenches and 17 cubic meters of hand-excavated units to determine the current subsurface condition of any remaining archeological deposits, identify the extent of disturbances, verify the presence or absence of any prehistoric interments, and establish the extent of any further work.

In compliance with the requirements of Section 106 and the Antiquities Code of Texas, all work was conducted under the terms and conditions of the Programmatic Agreement and First Amended Programmatic Agreement (2005) among TxDOT, the SHPO, FHWA and the Advisory Council on Historic Preservation; the Memorandum of Understanding between TxDOT and the Texas SHPO; in consultation with federally recognized tribes and; under Texas Historical Commission Antiquities Permit No. 4010.

Following a review of background information and the completion of field work in the form of extensive archeological testing, TxDOT concluded that the collective severity of previous impacts compromised the integrity and intactness of that portion of the site remaining within the ROW. No human remains were found during testing. While remnant deposits containing lithic material and stone hearth features were found and documented in a portion of the site, these remaining elements could not be clearly linked to former living surfaces or activity patterns of the former site area. While TxDOT believed that the remaining archeological deposits should be properly sampled, documented and reported, neither the presence nor content of the features could contribute new and important individual site information to the significance or understanding of the archeological property type.

Based upon the conclusion of field work that documented the extent and severity of previous disturbances and the results of multiple radiocarbon assays that did not reflect an intactness or integrity of remnant prehistoric archeological living surfaces, TxDOT determined that the remnant portion of the prehistoric site within the ROW was not eligible for listing on the National Register nor warranted designation as a State Archeological Landmark. TxDOT recommended that the undertaking proceed to construction under the conditions and recommendations that are discussed below. Section 106 consultation for the undertaking and site eligibility determination was sent to federally recognized tribes and received SHPO concurrence in April, 2006. 
Following the conclusion of Section 106 consultation, TxDOT's archeological contractor, the University of Texas at San Antonio, as part of interim requirements for site documentation and reporting under the THC antiquities permit, recommended reversing TxDOT's earlier recommendation of site non-eligibility. Based on their subsequent post-field review of the remnant features and lithic materials, UTSA recommended that the presence and content of the site's remaining lithic materials and hearth features warranted consideration for the site's eligibility for listing on the National Register under Criterion D (see enclosed report).

After a considered review of UTSA's recommendation, it is TxDOT's conclusion that UTSA's discussion does not provide sufficient justification to warrant a revised determination that the archeological property is eligible under Criterion D. This conclusion is based on the same factors and elements as stated earlier for non-eligibility during previous Section 106 consultation and thus TxDOT's determination and recommendation of non-eligibility status remains the same. A detailed explanation of TxDOT's determination including a discussion of significance, required elements of eligibility for this prehistoric archeological property type, a review of site condition, UTSA's interpretations, and a summation of TxDOT's over-all recommendations are presented below.

\section{Site Background}

Site 41BX17/271, is a prehistoric terrace multi-component occupation site located partially within the existing right-of-way (ROW) of Loop 410 West in a highly urbanized portion of northeast San Antonio, Bexar County, Texas. It was first discovered in 1962 during utility relocation for the construction of Loop 410. Because the period predated modern federal and state historic preservation laws, early and extensive site salvage excavations were conducted by the Witte Museum with the approval of the highway department. The prehistoric terrace site is located on the south or left bank of Salado Creek with the northern portion of the site extending into the highway ROW.

Investigations found that the site (then known as 41BX17) consisted of a prehistoric encampment characterized by numerous south-central Texas Archaic Period stone tools, lithic debris and burned rock hearth features and probable burned rock midden. The disturbed skeletal remains of an estimated eight prehistoric Indian burials were also found. Based on the relative age of chronologically diagnostic stone tools and several subsequent radiocarbon dates, the period of site occupation ranged primarily from the Middle Archaic through Late Prehistoric Periods (approximately 4150 to $2000 \mathrm{BP}$ ). The date of interments could not be determined but were estimated to be during the Late Archaic or Late Prehistoric time periods (500 BC to AD 1200+). Due to their association with prehistoric deposits, the disturbed burials were not originally and are not currently thought to be affiliated with any federally recognized tribe.

Before, during and after the 1960s, the site was extensively disturbed by a number of impacts including the Witte excavations, illegal relic collecting, underground utilities and subsequent highway and bridge construction. Reports from the Witte Museum also noted probable earlier disturbances affecting the integrity of deposits presumably from natural sources such as bioturbation, natural erosion and possible prehistoric cultural impacts such as former pits or deliberately dug holes during prehistoric occupations.

In 2005 as part of a Section 106 review of the area of potential effects associated with proposed reconstruction of Loop 410 West, TxDOT determined that the locale of 41BX17 should be revisited. Although proposed work would be limited to the existing previously disturbed ROW TxDOT considered that subsurface investigation was warranted in the form of archeological testing to determine the current subsurface condition of any remaining archeological deposits, identify the extent of disturbances, and verify the presence or absence of any prehistoric interments.

This work was initiated by the Center for Archaeological Research, The University of Texas at San Antonio on behalf of TxDOT beginning with a review of available background information. As a result of UTSA's background work, the site's boundary within the ROW was more clearly defined and shifted slightly eastward. In addition and because of this shift, the prehistoric Early Archaic archeological deposits (ca. 3200 BC) of a nearby site on adjacent private property designated as 41BX271 appeared to be a continuation of prehistoric occupations in the area and thus the over-all site location was redesignated as 41BX17/271. 
After the background review, UTSA performed field work in the form of archeological testing within accessible portions of the ROW under THC Antiquities Permit No. 4010. The CAR-UTSA conducted intensive archeological testing in a portion of the previously recorded prehistoric archeological site 41BX17/271 within the ROW from late January to April 8, 2006. UTSA's The recent field work did not find any evidence of human remains but did find that a large portion of the original cultural deposits within the ROW was truncated by former construction, replaced by modern fill, and disturbed by buried utilities.

Utilizing mechanical trenching, hand augers and controlled hand units (see attached photographs and figures), the purpose of this work was to: (1) identify the extent and current condition of the archeological deposits; (2) confirm the overlapping site boundaries of the previously recorded adjacent locales of 41BX17 and 41BX271 as estimated from a background review; (3) verify the absence of human remains within the ROW and; (4) systematically collect basic site data that was not recorded or otherwise absent from previous investigations and that is necessary to complete a current final report. The last item, the collection of supplemental information, included geoarcheological data, radiocarbon assays, documentation of disturbances, small burned rock features, and the horizontal and vertical distribution of deposits.

In summary, the work by UTSA has found that the previously recorded sites of 41BX17 and 41BX271 once comprised a single prehistoric activity area extending into the southern ROW of Loop 410 along the right bank of the Salado Creek. The portion of this activity area within the ROW of Loop 410 West consisted of a multi-component middle to late Archaic Period campsite sporadically occupied from about 4150 to $2000 \mathrm{BP}$.

A remnant of former prehistoric campsite deposits generally similar to those described in the 1960s was found in an area approximately 12 meters wide x 30 meters long between the eastbound access road and the westbound main lanes. The vertical extent of archeological deposits in this locale varied significantly although the presence of small burned rock features and chronologically diagnostic horizon markers initially suggested a relative vertical sequence. Subsequently, a suite of six radiocarbon assays from the archeological deposits collected from within the ROW did not support the assumption of intact deposits or the integrity of an undisturbed chronological sequence. In contrast, the dates indicated a subsurface vertical displacement of datable charcoal because some of the older dates were redeposited above younger samples (see attached chronometric information sheet). While these radiocarbon assays indicate a lack of integrity and intactness of former living surfaces, this locale became the focus of controlled unit investigations for the reasons listed in item (4) above.

Based upon the field results of intensive testing, the documented extent of previous disturbances, and the results of multiple radiocarbon assays that did not reflect an intactness or integrity of remnant prehistoric archeological deposits, TxDOT determined that the remnant portion of the prehistoric site within the ROW was not eligible for listing on the National Register nor warranted designation as a State Archeological Landmark and recommended that the undertaking proceed to construction under the conditions and recommendations listed below. It was also TxDOT's recommendation that the additional data collection from recent field investigations was necessary to provide the documentation for the completion of a final report as required by the THC Antiquities permit.

TxDOT also included additional recommendations for on-site archeological monitoring during construction as a condition to proceed with the undertaking in currently inaccessible areas in the vicinity of 41BX17/271. A small portion of the site within the ROW lies beneath existing pavement and could not be investigated prior to construction. Although no significant archeological occupational deposits were anticipated, TxDOT considered that the former evidence of human remains required on-site systematic monitoring to identify and appropriately address any prehistoric human remains in the event of a post-review discovery. General notes and requirements were added to the construction plans to allow for the implementation of monitoring. Any post-review discovery would follow a treatment plan of human remains previously established during consultation with the SHPO and federally recognized tribes that was included in the earlier scope of work for testing.

In summary, based on the resulting information, it was TxDOT's determination that the proposed undertaking would have no effect on an archeological historic property and that the project may proceed to construction under the conditions and recommendations listed above. In the unlikely event that buried archeological deposits are discovered during construction, work in the area of discovery would cease and post-review procedures would be implemented under the requirements of Section 106, 36 CFR Part 800, and the terms and conditions of the programmatic agreements among TxDOT, FHWA, the SHPO, the Advisory Council on Historic Preservation and those of certain federally recognized tribes. TxDOT's findings and Section 106 consultation for the undertaking and site eligibility was sent to federally recognized tribes and received SHPO concurrence in April, 2006. 


\title{
Discussion of the regional property type: The Granberg Site as an example
}

\author{
The south-central Texas prehistoric multi-component burned rock midden stream terrace site
}

Prior to long-term natural and modern impacts that have affected site condition, the prehistoric campsite of 41BX17/271 once contained the abundant remains, mostly in the form of stone tools, lithic debris, and fire-fractured rock, that regionally characterize intermittent but repetitive central Texas Archaic Period hunter-gatherer occupation sites.

Regionally, this type of prehistoric multi-component site is broadly characteristic of prehistoric Archaic Period huntergatherer campsites commonly distributed along stream and river terraces. The natural landscape setting provided access for the exploitation of both riparian and nearby upland resources. The intensity of occupation and size of these repetitive temporary occupations vary greatly and generally date between about 4000-500 BC, often overlain with traces of subsequent Late Prehistoric Period hunter-gatherer activities (AD 500-1200+). Common features of this Archaic Period type campsite include clusters of fire-fractured rock in the form of small campfires; often a floor-like thin horizontal scatter of burned limestone covering a broad surface; one or more burned rock middens, a dense accumulation of burned rock used for recurrent baking and cooking; and an abundant collection of stone tools and debris from tool manufacture.

\section{The Granberg Site as a member of a local archeological property subtype; the context of the escarpment site clusters (prehistoric sites along the upper Salado Creek)}

Bexar County is one of the more archeologically studied counties in Texas with over 2000 recorded historical and prehistoric archeological sites. Many prehistoric sites, including the Walker Ranch National Register Archeological District, are located along the Salado Creek drainage of northern Bexar County. As noted earlier, this setting, like other counties that lay along the Balcones Escarpment separating the central Texas plateau from the rolling prairie of the Gulf coastal Plain is an ecotone that includes abundant natural resources including major springs, multi-kilometer exposures of chert for stone tool making and a concentration of floral and faunal resources within the riparian zones and in adjacent uplands.

The density and concentration of prehistoric sites along the Salado drainage of northern Bexar County is reflected by the former presence of individual sites such as 41BX228, 41BX229, 41BX300, 41BX338, and the Walker Ranch National Register Archeological District located along and near the forks of Salado and Panther Creeks a few miles north of 41BX17/271.

In the early $20^{\text {th }}$ Century, the drainages were simply known as the forks of the Salado,[a.k.a., the wet and dry forks] (Ganahl Walker, personal communication). The district has been the focus of repeated archeological investigations since the 1970s. Although the district's boundary is limited, the lessening distribution of other repeatedly occupied prehistoric sites continues a few miles downstream. Sites 41BX17/271 and the nearby Paleoindian site of 41BX228 are located on the southern margin of this occupational pattern, southwardly overlooking the relatively flat prairie and basin that form the environs of modern San Antonio.

The cluster of prehistoric sites along the Salado Creek drainage also seem to indicate that the intensity of site occupations are relative to the predictability of critical resources such as water in inter-drainage and trans-physiographic patterns of movement.

An important element of the unrecognized archeological context of the local area is the significance of stream valleys that cut through the rugged relief of the Balcones Escarpment (once called Lomeria Áspero, or rugged hills). These valleys acted as natural corridors for travel through the difficult terrain. The natural passes used for travel through the escarpment were historically known as puertas and form a unique, significant aspect of the regional cultural-historical and archeological record. The significance of these natural features, recognized by their individual names in the cultural landscape such as Puerta Viejo, Puerta Pinta, and Puerta Helotes appear to have not only determined routes of local and inter-regional travel but influenced the selection and location of campsites for thousands of years. In short, the predictable character of prehistoric site clusters along the base of the Balcones Escarpment is closely linked to drainages such as the Salado and adjacent Leon Creeks that contain convenient permanent water sources along narrow, historically definable corridors of movement and travel. 
An important local example of this type of site in San Antonio is 41BX52, a prehistoric multi-component occupation along Leon Creek at a pass of the escarpment formerly known as Puerta Viejo. The site, like others nearby, was impacted by long-term mixing of cultural deposits ranging from the Paleoindian through Archaic periods. Its unrecognized significance even after extensive archeological studies was as a contributing element in a pattern of the cultural landscape that spanned thousands of years. The same route through the escarpment was a documented historic Indian Comanche trail, a route of Spanish exploration of the central Texas Hill Country, the trail of $19^{\text {th }}$-century German immigration into the Edwards Plateau and today, the intersection of two interstate highways. The name of the pass originated from the Spanish Colonial road (the Camino de Casas Viejo) leading from San Antonio to a mid-1 $8^{\text {th }}$ century mission on the San Saba River in central Texas.

Although northern Bexar County was intensively exploited in prehistoric periods as evidenced by the density of sites concentrated along the stream terraces, the stream terraces themselves were continuously subjected to recurrent and catastrophic episodes of seasonal flooding. From a local perspective that includes the upper Salado Creek drainage, previous archeological investigations for several decades have found that the dynamic nature of the environmental setting is not generally conducive to the preservation of prehistoric archeological sites.

The force of these flooding sequences often redeposited thick layers of early Holocene calcareous gravels and cobbles tens of feet thick along the stream channels. Direct flooding sometimes accompanied by lateral shifts of a drainage channel recurrently scoured portions of adjacent terraces. The dynamic nature of seasonal and/or catastrophic flooding often removed, truncated, or replaced earlier natural and cultural deposits throughout the area along stream terraces. The magnitude and cumulative effect of the catastrophic flooding episodes are visible as thick beds of exposed interbedded gravels and cobbles in the flood plain of streams along the mouth of the escarpment and may be in excess of 20 feet thick. The same processes that affected the stream terraces along the escarpment also were responsible for transporting lighter materials downstream with their subsequent redeposition in and as part of massive river fluvial flood plains in the adjacent south Texas coastal plain.

Ancient flooding episodes are clearly associated with such factors as the escarpment's abrupt topographic relief that creates a temperature gradient inducing seasonal flash flooding. However, the severity and cycles may be related to broader, unaddressed and important questions of regional prehistoric climate change and cultural responses. The implications and applicability to research themes of the historic context are further discussed below in a subsequent section of this paper.

In summary, under certain conditions and with examples discussed below, individual sites associated with this property type have the potential of contributing new and important information to the understanding of prehistoric peoples and their lifeways in the local and regional archeological record. As important, the physical characteristics of the cultural and natural deposits of such sites also commonly reflect elements that have limited and continue to comprise aspects the research and interpretive potential of the property type. These limitations are thought to be applicable to site 41BX17/271 as representative of the property type and are also discussed below.

\section{Previous Research Directions}

The focus of research and resultant significance of such sites has shifted through decades of study. Prior to the 1970s, most of the reporting was descriptive in nature but in more recent years has invariably coalesced on issues of lithic technology (quantification of lithic debris), subsistence (i.e., cooking features and evidence of food), and chronology, mostly in the form of chronologically diagnostic projectile points. There has been an extensive collection of regional excavation reports spanning over five decades that describe the nature of these sites including several previous full-scale excavations locally in Bexar County. Collectively, former investigations have identified the complexity of these sites, occasionally proposed consistent strategies and methodologies for investigation and considered the problematic nature of their archeological context and shortcomings of interpretive data.

\section{Data Limitations of the Property Type Identified From Previous Regional and Local Investigations}

The problematic nature of the archeological deposits in prehistoric central Texas Archaic Period multi-component terrace sites is often characterized by the mixing or turbation of both cultural and natural deposits. While a general chronological sequence can be established by the relative age of stone tools as horizon markers, mixed deposits compromise the integrity and intactness of individual occupational episodes and former living surfaces. The common causes for this mixing are multiple and include 
both natural and human related effects. Through time, the cumulative impacts of this turbation result in the discontinuity of spatial occupational patterns, i.e., living surfaces, and the disruption or dissolution of identifiable synchronic and diachronic chronological episodes of activity. This has resulted in and increased the difficulty of refining research foci and addressing the property type's significance in the regional archeological record.

A reoccurring pattern of human activity associated with the property type is the repeated prehistoric occupation of the same locale for thousands of years including activities that disrupted previous surface and subsurface deposits. The construction of multiple pits or basin hearths across a site area and the widespread reuse, rebuilding or salvaging of stone hearth or midden cooking features are examples of common campsite activities that result in the mixing or a reversal of natural stratigraphy and the chronological order of cultural deposits. In addition, unexpected and unpredictable spatial occupational shifts across a site area can result in the inability to identify the former living surface of an occupational level [unless broad horizontal areas of the site are available for excavation]. Katz $(1987: 178-179,187)$ believed that this occurred at 41BX300 during the "elusive" Middle Archaic Pedernales-associated occupation whose presence was distinguished only by secondary poorly defined midden refuse deposits containing a number of chronologically diagnostic projectile points.

Sites often contain burned rock clusters as features in varying conditions of intactness. Because of their rock mass they are more resistant to pressures of displacement that affected adjacent smaller lighter archeological materials and their surrounding matrices. The identification, documentation, content, and analysis of such features using soil samples and floatation to recover identify floral and faunal remains have been a primary focus of previous studies of excavated sites in the local area. Such work constitutes well-documented discussions and descriptive lists of floral and faunal contents in published site and special reports. This includes reports from previously excavated sites near 41BX17/271 in northern Bexar County; 41BX228, figures 49, a-d; 50, 51; 52 and with accompanying special studies Black and McGraw 1985); 41BX300, Description of Features, pp. 140-169 and Figures 32-44 (Katz, 1987); 41BX126 pp. 49-90, Figures 6-3 to 6-36, Chapters 9 and 10, Plant and Vertebrate Remains, (Nickels et. al, 1998) and; 41BX52, Chapter 8, the Archaic Pavo Real and Figures 8-10 to 8-54 (Collins et. al., 2003). Burned rock midden and hearth features are also extensively discussed in Black's two-volume study of sites associated with regional Archaic burned rock midden sites (Black et. al., 1997).

The long-term effects of natural disruptions are equally important factors affecting the integrity of archeological content of the property type. While some of these effects such as animal burrows and tree root growth displacing archeological materials have been well-documented, other natural effects are recognized more by their results than an understanding of their causes. There are two major examples of such effects; one appears to commonly affect the archeological deposits of the property type regionally while the other effect is sub-regional or local, partially induced by, and amplified by the unique character of the local environmental setting of Bexar County, the Balcones Escarpment and the surrounding area.

In both cases mentioned above, major natural influences that have affected the integrity and intactness of buried archeological deposits appear to be related to the long-range effects of the region's changing environmental/climatic patterns as well as local short-term weather conditions. Regionally, historical climate patterns are associated with broad intervals of wet and dry periods in the archeological record. There is some evidence from local prehistoric sites that indicate these periods triggered, were associated with or contributed to the long-term stability of former living surfaces and/or erosional cycles of former terrace surfaces. Archaic Period terrace sites seem to reflect buried but stable, deflated living surfaces within occupational episodes and this is characterized by materials of chronologically separate cultural levels that become compressed or mixed with earlier cultural levels.

A previously excavated archeological site along the Salado creek drainage site that contains apparent evidence of buried deflation is the prehistoric campsite of 41BX228, located approximately seven miles north of 41BX17/271. A portion of Early Archaic and later transitional Archaic campsite activities were sealed by a more recent and overlying burned rock midden feature. Originally, excavators assumed this setting would enhance the preservation of the earlier materials and living surfaces but subsequent systematic map plotting of individual artifacts indicated a horizontal pattern of deflated materials moving across a colluvial surface.

A more recent example investigated by UTSA in neighboring Comal County documented similar prehistoric time periods at 41CM111 Mahoney et. al.,2003). Overlain for the most part by sterile deposits that precluded the mixing of later cultural deposits, archeological stone tools of the prehistoric site dated from about 4000-2500 BC Containing campfires and materials 
from an upper Middle Archaic and two undifferentiated lower cultural intervals, the site was summarized as forming on a stable land surface ca. 5000 BP by slow rates of deposition and a tendency for admixing of otherwise temporally distinct materials (i.b.i.d.: 90).

\section{What does an individual archeological site need to contain to be eligible under Criterion D, e.g.; to contribute new and important information to the significance/ understanding of the property type?}

\section{Eligibility Considerations for the Property Type}

Based on the short review above on the significance and limitations of the archeological data associated with the property type, there are four general considerations for determining National Register eligibility of an individual property. The first three considerations determine whether the individual property contains the basic requirements that collectively or as a partial group have the ability to contribute new and important information to the significance of the property type. These are listed below:

1. The demonstrated integrity of cultural and natural deposits of the property as a whole or for individually identifiable episodes of occupation. If only a portion of the deposits reflect integrity, these must contain evidence of broad, discrete, horizontal and vertical integrity.

2. Intact cultural levels with identifiable separable living surfaces. These must contain substantive evidence of individual occupational episodes, associated features and chronologically diagnostic materials within definable horizontal and vertical boundaries of the property. This requirement is necessary to provide an assessment of eligibility of the property and determine the scope of valid sampling.

Clearly the conditions of this second consideration are more likely to be present when the entire or most of the boundary of the property is available for investigation, as in the case of TxDOT undertakings that contain large areas of new previously undisturbed rights-of-way. Such highway projects including a recent example discussed below as 41KR621, provide the best opportunity for an accurate determination of eligibility and allows a cost-effective strategy for the recovery of information. A shortcoming of most TxDOT projects however is the linear not areal nature of the undertaking that contains only a portion of the site area for evaluation and investigation.

The nature of linear projects confines most TxDOT evaluations to investigating a narrow line through a portion of a discovered archeological property. The alignment of the investigation is arbitrarily and often pre-determined by engineering design or an existing roadway and not by the site's information potential. Subsequent sampling is often conducted in previously disturbed sediments containing limited information potential which may not reflect the character, content, or former significance of the prehistoric site as a whole.

In contrast to data recovery, the investigation of archeological sites within such linear undertakings often lends itself instead to a robust and intensive period of testing that details the content and character of remnant deposits and features, documents the extent of disturbances, and reports this information in the context of the local archeological record. In such cases, the presence and reoccurring content of multiple features such as hearths are not considered as contributing elements to a site's eligibility if: (1) these features are individually isolated within the cultural matrix; (2) cannot be associated with preserved former individual living surfaces or broad intra-site activity patterns and; (3) contain repetitious or redundant information. Intensive archeological testing of such features provides the mechanism to allow the necessary and appropriate documentation, analysis, and reporting of their content but does not provide justification for eligibility of the property.

3. Consistent, multiple and reliable 14-C data associated with definable occupational episodes, living surfaces and diagnostic materials.

4. The formulation of explicit statements relating to the historic context and significance of the property type. An individual property must demonstrate the ability to contribute new important information that address these statements. 
The fourth consideration is the necessity and formulation of research themes relating to a stated historic context that focuses and directs the interpretations of recovered data. Research topics or questions relating to the context must be expressed explicitly and contribute to the understanding and importance of the property type in regional or local archeological record. Collectively, the presence of all four considerations demonstrate the potential of new important information within a site or its well-defined portions (i.e., living surfaces or cultural episodes).

The absence or only partial presence of one or more of these four elements compromises the ability of an individual property to contribute to the understanding of the broad patterns of prehistory and the unique character of the property type.

\section{In Contrast: A Recent Example of Site Eligibility: The Prehistoric Site of 41KR621}

The prehistoric site of 41KK621 is located near the upper Guadalupe drainage in Kerr County, central Texas. Discovered in 2004 during an archeological survey for a proposed new roadway and river bridge, the prehistoric multi-component Archaic period site was subsequently found to contain cultural materials and a number of features predating bout $4000 \mathrm{BC}$ to AD 1200 . The presence of new right-of-way 75 to 100 meters in width allowed the majority of the site area to be initially investigated by a variety of techniques including systematic mechanical augering, mechanical trenching and controlled hand excavations. Initial investigations found that while the site was located along a major river terrace and subjected to the effects of a dynamic fluvial system, an additional unique condition of the natural setting provided the means for rapid and long-term preservation of individual occupational episodes. Situated at the toe slope or base of a hill at the edge of the flood plain, long-term colluvial slope wash precipitated by storm water run-off from the hill slope contributed to and accelerated the rapid burial of occupational debris. Preservation included the demonstrated vertical separation of occupational episodes and precluded their horizontal disturbance and scatter by later activities.

Prior to full-scale excavation, access to a large portion of the site area allowed horizontal stripping to expose the distribution and intra-site patterns of buried features and living surfaces. In addition, this methodology revealed the presence of horizontally discrete and chronologically distinct, living surfaces that were spatially separated by tens of meters. Based on the exposed pattern of broad activity areas, multi-block excavations subsequently and selectively investigated the contents of the former living surfaces.

These activity areas dated to the prehistoric Early Archaic and transitional early Middle Archaic cultural intervals. Although these episodes are commonly found as components within the region's archeological sites they are poorly understood or documented in the regional archeological record due to the disturbed mixed nature of deposits. In contrast, the presence of intact activity surfaces at 41KR621 supported by a range of occupational data and reliable multiple 14-C assays allows a more holistic description of the character of prehistoric Archaic lifeways not only at the site location but reflective of Archaic period exploitation of the upper Guadalupe River drainage. As a result, this will provide a currently missing body of information for comparison and contrast of these same prehistoric lifeways in other inter- and intra-regional settings. The over-all research themes and the nature of preservation may also address the broader environmental mechanisms, causes, and effects that influenced the lifeways of peoples reflected in this regional property type.

\section{Summation and Discussion of UTSA-CAR's Recommendation of Eligibility for 41BX17/271}

As noted earlier, it is the view of TxDOT that the former buried archeological deposits at 41BX17/271 both within and adjacent to the right-of-way has been subjected to extensive and severe long-term natural effects as well as decades of modern disturbances. These include common natural sources such as erosion, root and animal turbation as well as a series of man-induced impacts including recurrent prehistoric activities, modern land clearing, highway and bridge construction, buried utilities corridors, and previous archeological block and trench investigations that employed machine excavations. Additional ground-disturbing activities include UTSA's recent work of nine backhoe trenches and 17 cubic meters of hand-excavated units. 
This view is in contrast to UTSA-CAR's summation of eligibility and designation as a State Archeological Landmark that is based on the site's data potential that, "...has yielded, and is likely to yield data significant to Texas prehistory... [because] these data include human burials, hearth features, stone tools, ethnobotanical remains, and well-preserved faunal remains." This is based on: (1) distribution of materials; (2) site stratigraphy and; (3) radiocarbon dates. These items, their validity, and their applicability are discussed below.

\section{General Comment}

An evaluation of eligibility of an archeological site is based on the (1) stated significance of the defined historic property type and its ability to provide new important information relating to explicitly stated research themes, topics, and questions derived from a formulated historic context. UTSA in its discussion of eligibility does not state explicitly what research themes, topics, or questions may be addressed other than the data can address broad unstated important questions about Middle Archaic huntergatherers. In comparison to the eligibility requirements discussed previously in section III above, the unstated questions also are not linked to a statement of historic context of a property type nor is the property type defined or its data limitations discussed as in the earlier section of this paper.

Following a statement of significance, the eligibility of an archeological property requires a demonstration of integrity and intactness of deposits. UTSA notes that these are represented by the distribution of materials, stratigraphy and radiocarbon dates. In addition, UTSA noted that the presence of former burials recovered in 1962 also contributed to the site' eligibility.

In considering the first of UTSA's items, the distribution of materials includes a number of small burned rock features described as hearths or burned rock clusters [although in reality, the former is a subset of the latter]. Several radiocarbon dates and chronologically diagnostic projectile points indicate these features are associated with Middle and Late Archaic campsite activities.

As discussed earlier in section III.A.2 above, TxDOT believes that such features should be thoroughly sampled, documented, analyzed, and reported. However, and it is restated here, “... the presence and reoccurring content of multiple features such as hearths are not considered as contributing elements to a site's eligibility if: (1) these features are individually isolated within the cultural matrix; (2) cannot be associated with preserved former individual living surfaces or broad intra-site activity patterns and; (3) contain repetitious or redundant information. Intensive archeological testing of such features provides the mechanism to allow the necessary and appropriate documentation, analysis, and reporting of their content but does not provide justification for eligibility of the property."

The archeological deposits described by UTSA also include a variety of Middle and Late Archaic period projectile points that appear to indicate the integrity, intactness, and research potential of the cultural zone as a whole with deposits up to ca. one meter in thickness but usually ca. half of that due to the modern disturbances that truncated upper cultural deposits and underlying stream gravels. The presence or variety of these horizon markers do not convincingly demonstrate any of the above as these artifacts also indicate recurrent activities and occupations of the same small area and within a relatively compressed, mixed or sometimes truncated vertical sequence of deposits. The extent and variety of stone tools recovered from various site investigations should also be described in the compilation of a final report but because of the limited or non-provenienced nature of much of the material, the archeological context is limited and final reporting may focus on the artifacts as a descriptive collection rather than analytical lithic assemblages.

The estimated integrity and intactness of the Granberg Site's cultural deposits and stratigraphy was also commented on previously by Mardith Schuetz (1966:66) in her report of the Witte Museum's excavations in 1962 within the highway rightof-way. Although not widely distributed, Schuetz's work is a commendable and substantive body of information regarding the content of the site, as well as the complexity and hardships of the accomplished work. While noting the variety of stone tools and features, her concluding observations made prior to subsequent additional impacts were, There is undoubtedly much mixing of material in all of these [type of] sites. Johnson has pointed out the fallacy of equating all artifacts found within a seemingly homogenous level. The instability of the living surface, rodent and root action, and digging by the occupants themselves are listed as causes for mixing material (Johnson 1964: 86). This is particularly true in a site such as the Granberg which appears to have be occupied almost continuously with no sterile levels allowed to accumulate. 


\section{The Importance of Radiocarbon Assays}

As noted by UTSA, the collection of six radiocarbon dates from 41BX17/271 initially appear to cluster well in the Middle Archaic range. TxDOT has also conducted an initial review of these dates and their position is shown as yellow circles placed on a regional prehistoric chronological sequence as illustrated in Figure L-1.

The dates range from 1990 to about $4150 \mathrm{BP}$ with four of six samples between 3600-4150 BP. Time frame is Middle Archaic and should include horizon markers such as Bulverde, Nolan and Travis. The more recent dates, 1990 and 2510 BP are central Texas Late Archaic although the earlier of the two dates may be transitional Middle Archaic.

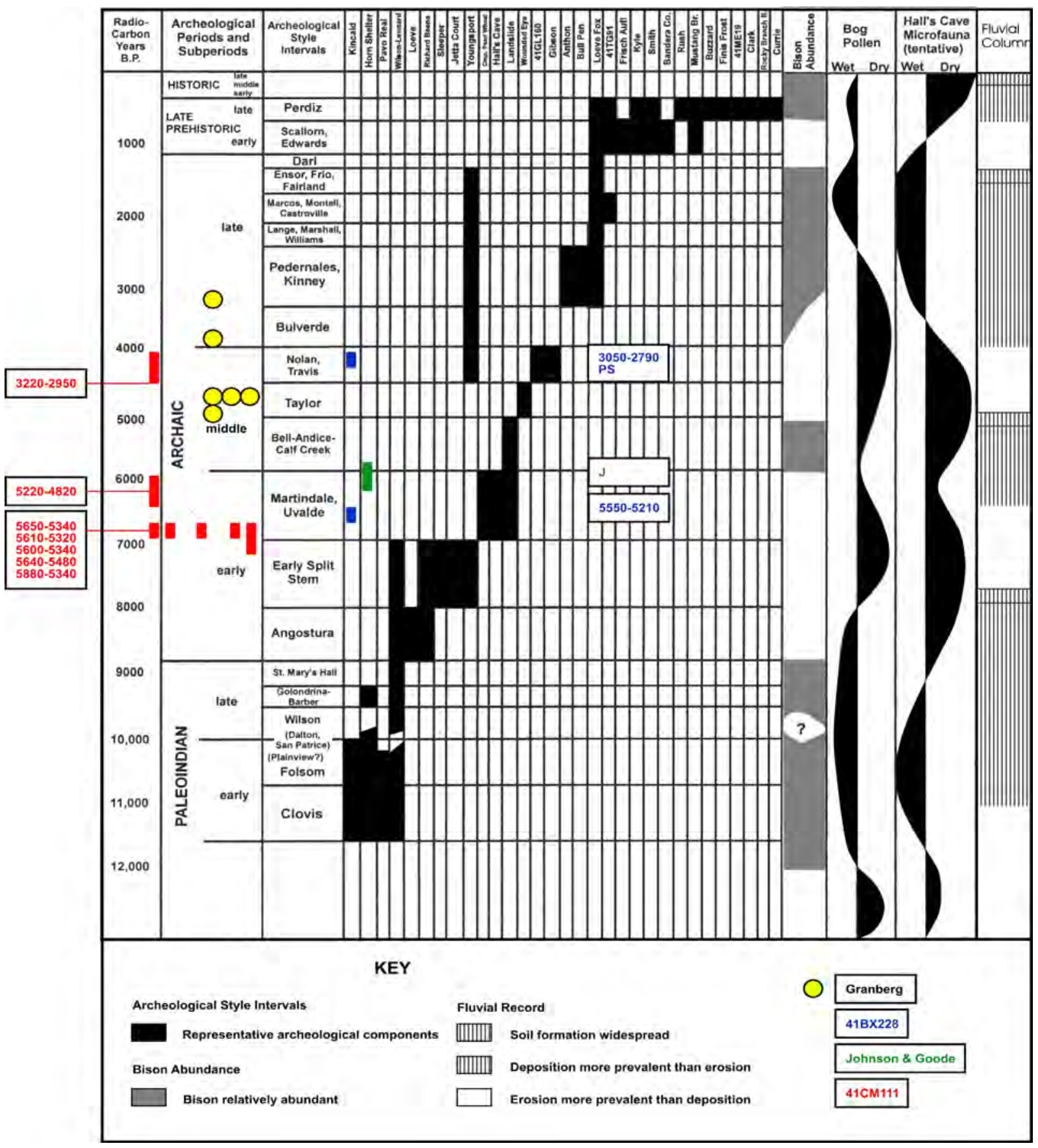

Figure L-1. Synoptic archeological and environmental sequence for Central Texas (modified from Collins 1995). 


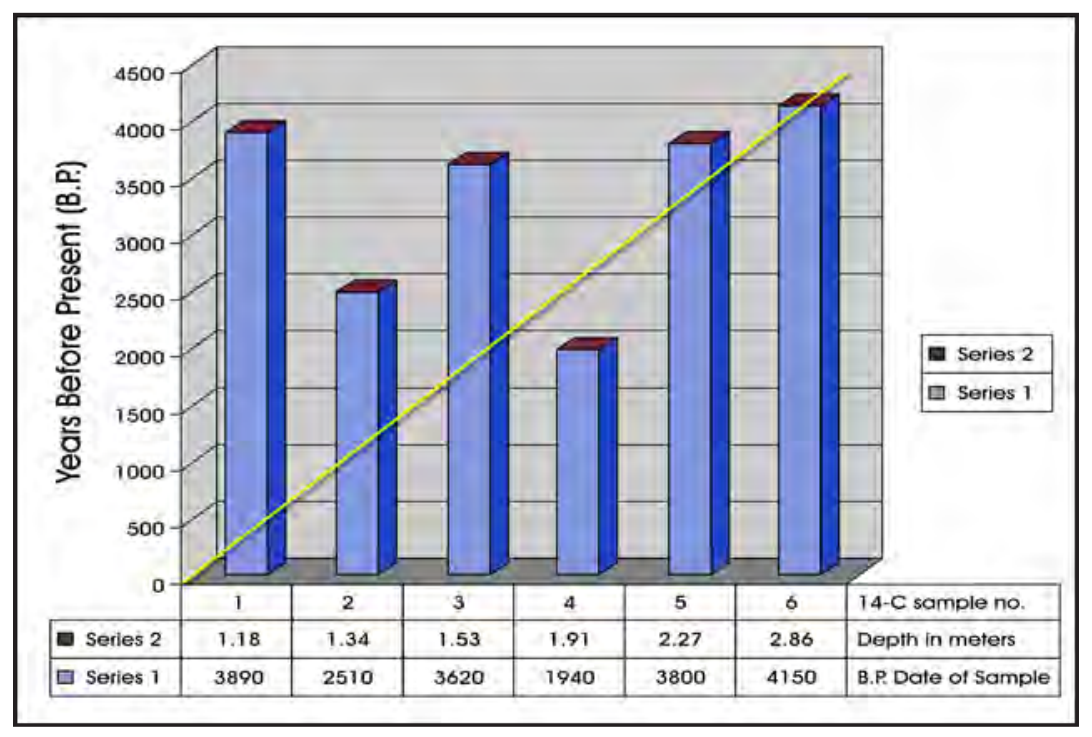

Figure L-2. Radiocarbon assays from the Granberg Site, Loop 410.

When these radiocarbon assays and their corresponding depths below the surface are compared as a group, the intactness of their cultural association or surrounding deposits becomes more problematic. As shown in Figure L-2 that compares a sample's age with its depth below the surface, the chronological ages of the first four samples do not match a normal sequential vertical deposition; that is, older samples do not correspond with increasing depth. As examples, samples 2 and 4 which are younger in age underlie the older dates of samples 1 and 3. This may be due to highly undulating buried surfaces or long-term vertical mixing of deposits from buried living surfaces. This implies that it is not safe to assume the age of a feature or its adjacent association based on depth below the surface unless dated or correlated by unambiguous composite profiles. The earliest date is also younger by $1500-2000$ years or more than anticipated.

\section{The Presence and Importance of Ethnobotanical and Faunal Remains}

In general, the presence of floral and faunal remains from similar-aged prehistoric sites have been recovered from previous full-scale excavations in the local area and these are discussed above in section II.D. of this review. Like the presence of burned rock features their presence at the Granberg site warrant thorough sampling, documentation and reporting. It is not clear why the collection from 17 cubic meters of hand-controlled excavations during testing did not recover an appropriate sample. Also like the presence of burned rock features, it is unclear and UTSA does not explicitly state what new, different or important information is anticipated. As such, the presence of such material warrants a detailed description to describe the archeological content of the site but does not in itself offer a justification of eligibility.

\section{The Former Presence of Prehistoric Burials and Site Eligibility}

It has been and is TxDOT's position that if intact prehistoric human remains are found during the course of archeological investigations or subsequently during monitoring, this will require a reevaluation of site eligibility and reconsultation of Section 106 with the SHPO and federally recognized tribes. TxDOT recognizes the sensitivity and cultural importance of human burials and has included a treatment plan currently in effect for the discovery of such remains throughout the period of the undertaking. This was initiated prior to the UTSA field work.

No human remains or related evidence were found during the recent extensive testing conducted by UTSA. In the light of TxDOT's position above and its willingness to reconsider eligibility if intact human remains are discovered, it is not clear why the existing negative evidence should provide a justification for eligibility. Schuetz's report (1962: 71-72, 81-84) also presents some information on the remains found in 1962 including an initial osteological report by The University of Texas with comments by an orthopediatrician from Baylor University Hospital, Dallas. The fragmentary remains of eight individuals dating to the estimated prehistoric Late Archaic period were in poor condition due to modern construction impacts and longterm root actions and displacements. In general, the remains discovered in 1962 were of a fragmentary nature, lack detailed 
provenience data and appeared to have limited research value. To date, there is no evidence that any human remains in 1962 were affiliated with any federally recognized tribe.

\section{Additional Eligibility Considerations Not Addressed by UTSA}

According to the previous work by Mardith Schuetz (1966), the Witte Museum's investigations in 1962 were the first full-scale scientific excavations of an archeological site on TxDOT (then known as the State Highway Department) roads. The work, largely precipitated by utility construction preceding and occurring because of highway construction, was both difficult and highly public due to the presence of spectators, the destructive effects of illegal rampant relic collection and vandalism, and issues of security and safety. The resulting public and agency outcry created the first emergency preservation law in the state.

The difficulties encountered by both the Witte Museum and the Highway Department, especially by the on-going threat of vandalism eventually resulted in a departmentally supported effort for state legislation to prevent any future occurrence of such vandalism and trespassing. This resulted in Senate Bill No. 242 of the $58^{\text {th }}$ Congress that enacted law for the protection and preservation of archeological, paleontological and cultural features on lands owned or controlled by the State. It also created penalties for their disturbance or destruction. This law in its changing evolution is still in effect today as V.T.C.A. Penal Code, Title 7, Section 28.03, 28.04 and Natural Resources Code Title 9, Sec.s 191.171-174.

The emergence of this state law in 1963 predated the implementation of Section 106 of the National Historic Preservation Act of 1966 and the Antiquities Code of Texas of 1969. In addition, the state highway department also began the slow process of lobbying for and developing an archeology section of the highway department to respond to and address archeological sites found within the rights-of-way. This was later established in the 1970s in response to the newly created state and federal laws.

The law of 1963 was a landmark change in the state's history of historic preservation and site 41BX17/271 is closely associated with that event. As such, the archeological site in an unusual fashion must also be evaluated under eligibility criterion a; that is, associated with an event that has made a significant contribution to the broad pattern of history. As a further consideration of eligibility, however, the associated property must still retain and reflect elements of its original setting and sense of place. Given the extensive physical changes both within TxDOT right-of-way and in the adjacent properties reflecting intensive urban development in the form of commercial businesses, urban residential neighborhoods and high-rise structures, the site's former setting has changed drastically from it's earlier undeveloped setting. For this reason, while it should be documentarily recognized for its former influence in 1963, 41BX17/271 is not considered eligible under criterion a.

\section{Conclusion of Eligibility Review}

Following a review of background information, a discussion of archeological property types, considerations for eligibility, and a considered review of UTSA's recommendation, it is TxDOT's conclusion that UTSA's discussion does not provide sufficient justification to warrant a revised determination that the archeological property is eligible under Criterion D. This conclusion is based on the same factors and elements as stated earlier for non-eligibility during previous Section 106 consultation and thus TxDOT's determination and recommendation of non-eligibility status remains the same as does TxDOT's previous commitments for archeological monitoring during construction.

It is also TxDOT's recommendation that the archeological site information including its available material collection, data on features and archeological content warrants the publication of a detailed published report that identifies the site's place in the local archeological record. This would follow the completion of other commitments of the undertaking including monitoring during construction, an appropriate level of any feature documentation and other requirements necessary for the completion of the final report. TxDOT will ensure the publication of a full detailed report for professional and public dissemination of all previous and current work since no information has ever been produced. This is to describe the available archeological site information within the local archeological record.

As stated previously, it is also TxDOT's intent to review the eligibility status of the archeological site in consultation with the SHPO and federally recognized tribes if the presence of human remains are discovered during the course of the undertaking or if new information affecting the local or regional archeological record is uncovered. 


\section{References Cited:}

Black, Stephen L., L. W. Ellis, D.G. Creel, and G.T. Goode

1997 Hot Rock Cooking on the Greater Edwards Plateau; Four Burned Rock Middens Site in West Central Texas. Studies in Archeology Report No. 22. Texas Archeological Research Laboratory, The University of Texas at Austin. Texas Department of Transportation Report No. 2.

Black, Stephen L. and A. McGraw

1985 The Panther Springs Creek Site: Cultural Change and Continuity Within the Upper Salado Creek Watershed, South-Central Texas. Archaeological Survey Report, No. 100. Center for Archaeological Research, The University of Texas at San Antonio.

Collins, Michael B., Dale B. Hudler, and Stephen L. Black

2003 Pavo Real (41BX52): A Paleoindian and Archaic Camp and Workshop on the Balcones Escarpment, South-Central Texas. Archeology Report No. 41. Texas Archeological Research Laboratory, The University of Texas at Austin. Texas Department of Transportation Report No. 50.

Johnson, LeRoy Jr.

1964 The Devil's Mouth Site: A stratified Campsite at Amistad reservoir, Val Verde County, Texas. Department of Anthropology, Archaeologial Series, No. 6, University of Texas, Austin.

Katz, Paul

1987 Archaeological Mitigation at 41BX300, Salado Creek Watershed, South-Central Texas. Archaeological Survey Report No. 130. Center for Archaeological Research, The University of Texas at San Antonio.

Mahoney, Richard B., Harry J. Shafer, Steve A. Tomka, Lee C. Nordt, and Raymond Mauldin

2003 Royal Coachman (41CM111) An Early Archaic Site along Cordova Creek in Comal County, Texas. Archaeological Survey Report, No. 332. Center for Archaeological Research, The University of Texas at San Antonio. Texas Department of Transportation Report No. 49.

Nickels, David L., C. Britt Bousman, Jeff. D. Leach, and Diane A. Cargill

1998 Test Excavations at the Culebra Creek Site, 41BX126, Bexar County, Texas. Archaeological Survey

Report, No. 265. Center for Archaeological Research, The University of Texas at San Antonio. Texas Department of Transportation Archeological Report No. 3.

Schuetz, Mardith

1966 The Granberg Site: An Archaic Indian Habitation in Bexar County, Texas. Witte Memorial Museum, San Antonio. Report on file, Texas Department of Transportation. 



\begin{abstract}
Appendix M:
Summary of Archeological Monitoring, 41BX17/271 along Storm Sewer Line Adjacent to Eastbound Access

Road and East of Salado Creek Bridge

Al McGraw
\end{abstract}





\title{
Appendix M
}

\section{Summary of Archeological Monitoring, 41BX17/271 along Storm Sewer Line Adjacent to Eastbound Access Road and East of Salado Creek Bridge}

\author{
Al McGraw \\ Environmental Affairs Division \\ Texas Department of Transportation
}

Archeological monitoring of a linear strip of ROW not previously accessible for archeological investigation due to roadway pavement and safety issues occurred discontiguously from December 4, 2006 to May 10, 2007. This work was conducted by TxDOT archeologist A. McGraw during utility construction within existing ROW for the installation of a buried storm sewer line parallel to the south ROW of the existing eastbound access road of Loop 410 (Figure M-1).

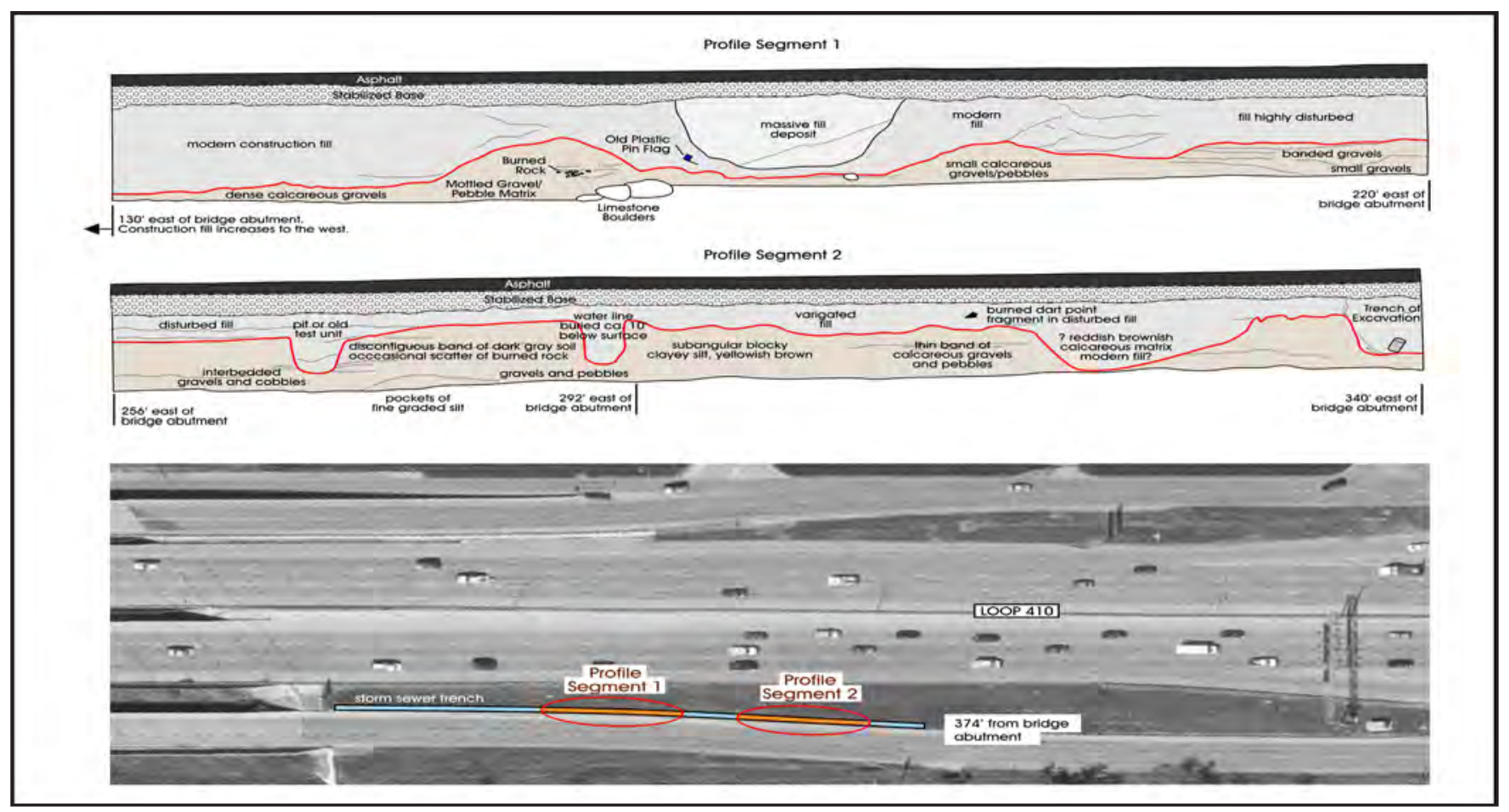

Figure M-1. North wall profile of two segments of storm sewer line excavated parallel to the south ROW of the existing eastbound access of Loop 410.

On-site monitoring for utility excavations occurred eastward from the intersection of Ira Lee road and the access road west of the creek. East of the creek, monitoring occurred from the bridge abutment on the right bank of the creek eastward ca. 376 feet to a depth of sterile caliche and/or calcareous gravels at ca. 10 feet. The linear extent of monitoring east of the drainage was longer than the known site length and extent of site 41BX17/271 within the Loop 410 ROW.

Monitoring at the east terminus also included the examination of a separate construction pit required for underground mechanical boring and second, a small utility pit immediately adjacent to the new waterline at the north ROW fence line. Located between the eastbound access road and the main lane the first pit was used to install a mechanical boring equipment to bore a new water line under the main lanes to the west ROW. The pit was ca. 14 feet wide, 10-14 feet deep, and ca. 40' in length. The size was required for OSHA standards as the depth of the pit required a 5' step safety step. 
The west margin of this utility pit was located ca. 380 feet east of the access road bridge abutment and adjacent to the eastern linear terminus of the monitored storm sewer trench. Subsurface deposits at this locale were dominated by an exposure of a buried modern fill from previous construction including asphalt and concrete fragments to the floor of the pit, partially burned tree branches, modern charcoal, a broken fence post, and rusted metal.

The small utility trench about 10 feet wide along the north ROW was excavated to expose existing buried water lines and to connect the new water line with those running parallel to the north ROW. This later pit was excavated on January 22, 2007 to a depth of ca. 12' or $370 \mathrm{~cm}$. Modern construction fill was noted to a depth of 190-220 cm. The truncated remnant of a cultural deposit consisting of burned rock fragments, and several fragments of undiagnostic lithic debris were observed from ca. 220$240 \mathrm{~cm}$ below the surface along the north wall adjacent to the ROW fence line. Given the lack of material in adjacent subsurface exposures, it was likely that additional cultural deposits extended beyond the north ROW in private property.

In summary, monitoring consisted of over 375 linear feet of storm sewer trenching with an additional adjacent 40' length of a utility pit excavated for underground mechanical boring. Documentation included contiguous profiles and photographs along the entire length. Examination of vertical profiles consistently reflected modern fill to a depth of 5-6' that had truncated or replaced original cultural deposits. Fill was the result of previous construction activities as well as the refilled portions of previous 1960s archeological excavations. In small areas, shallow deposits of disturbed remnant features of burned rock and lithic debris were noted.

Subsurface remnants of truncated archeological deposits were exposed in a relatively small area along the length of the long utility trench beginning ca. 303 feet north of the right bank of the creek and extending for ca. 50 feet eastward. Additional scattered material was noted further eastward but in a highly disturbed subsurface context due to previous construction and earlier archeological excavations. No intact features, burials, or other significant archaeological deposits were observed. 